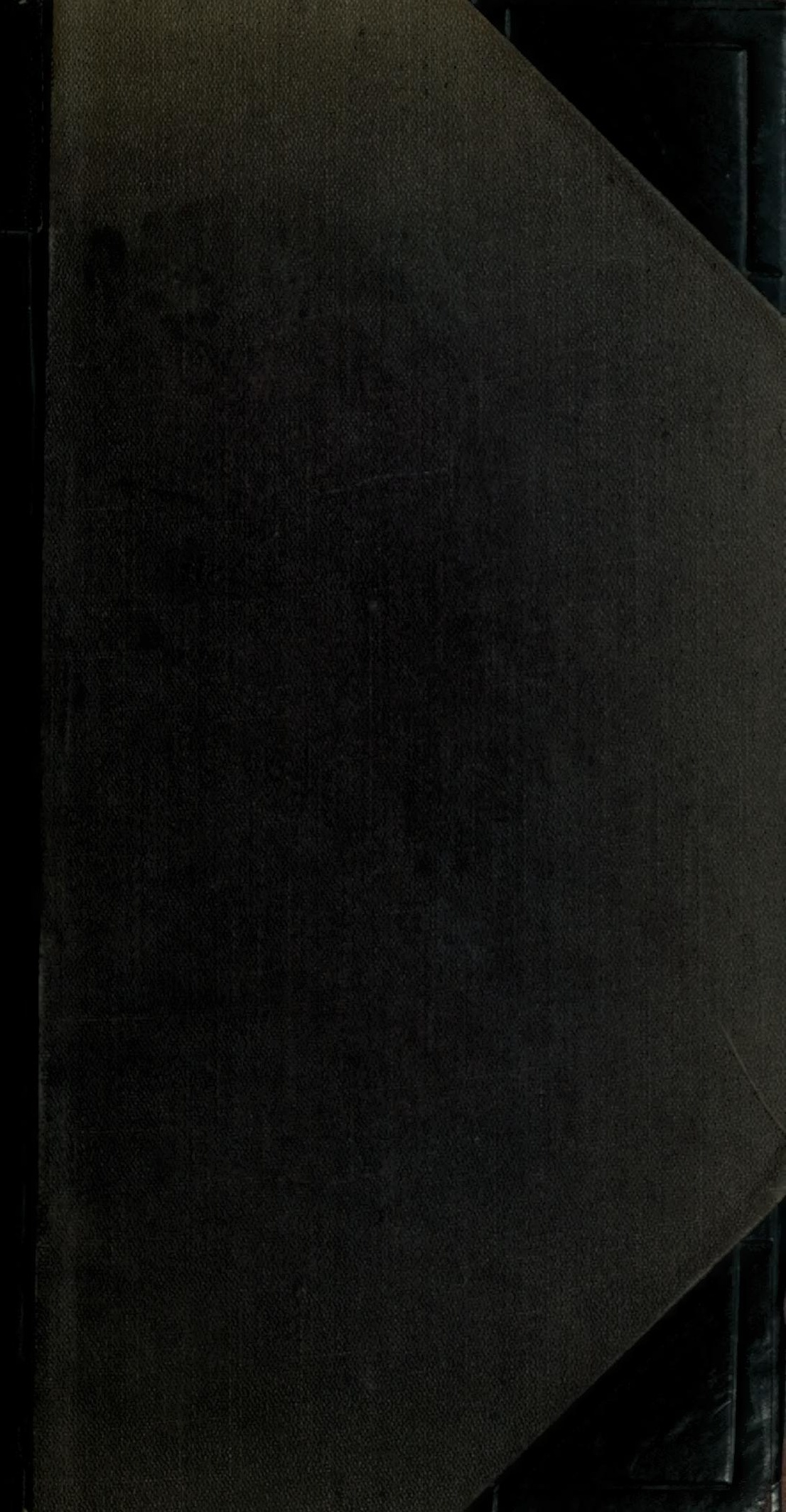





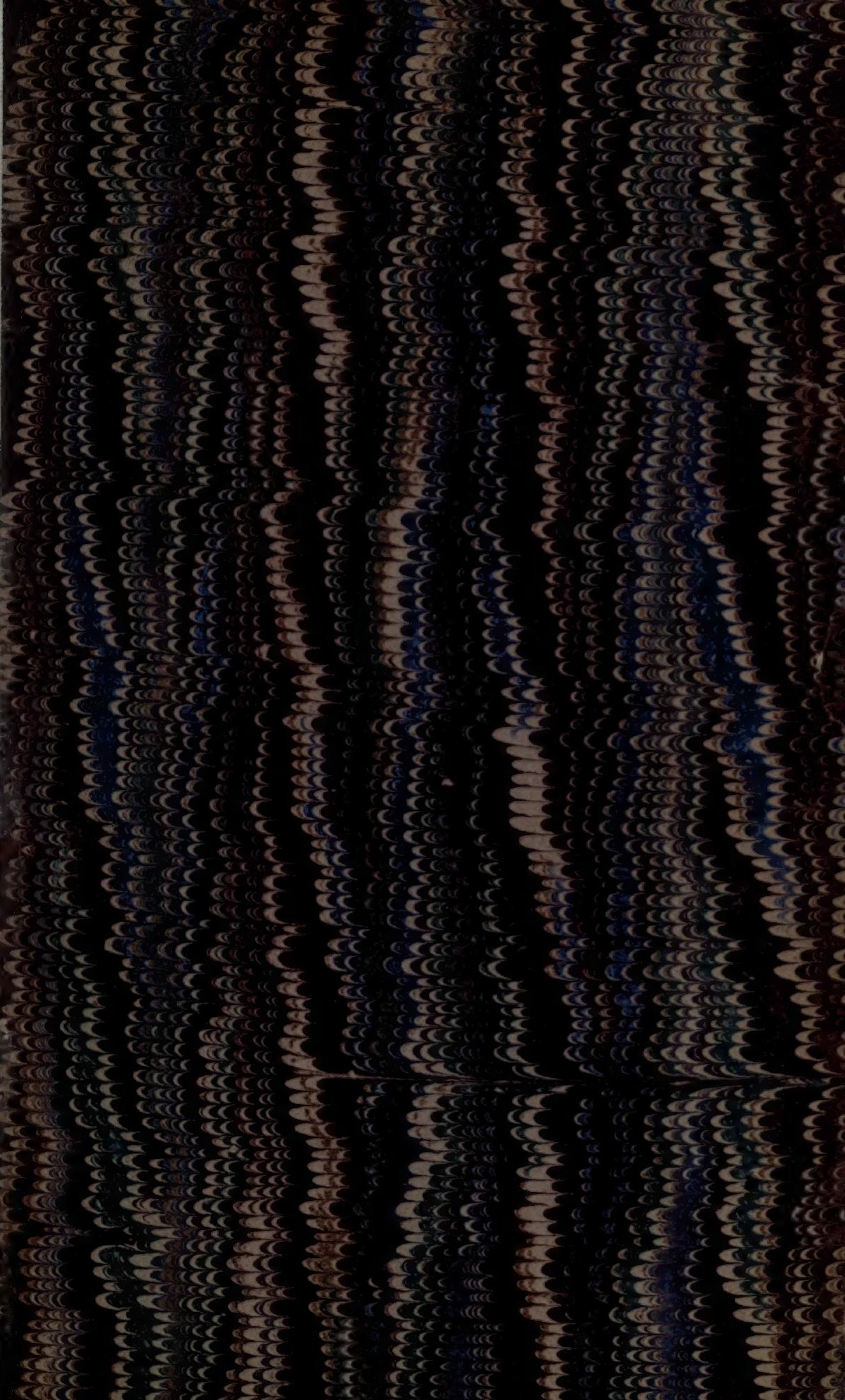




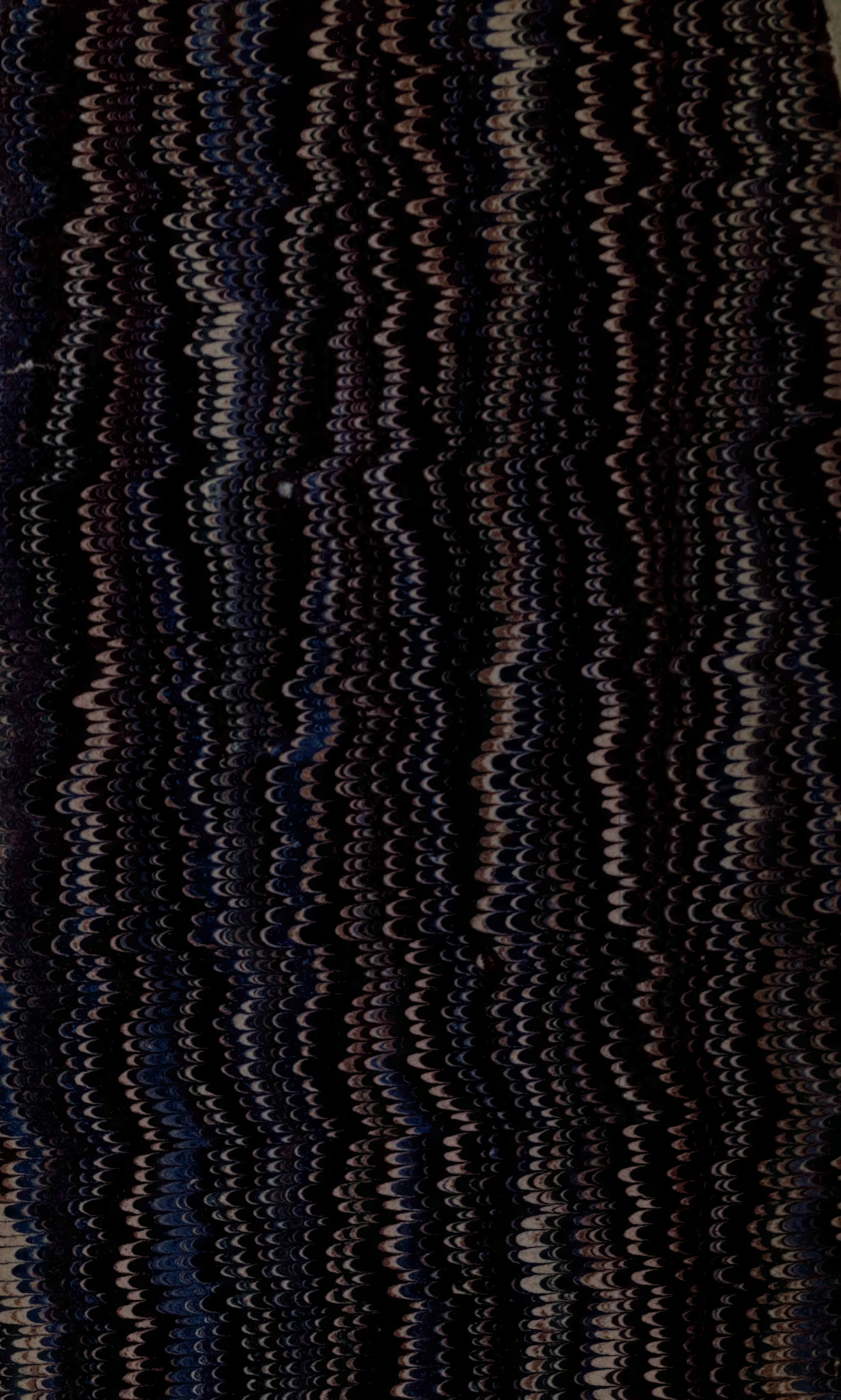




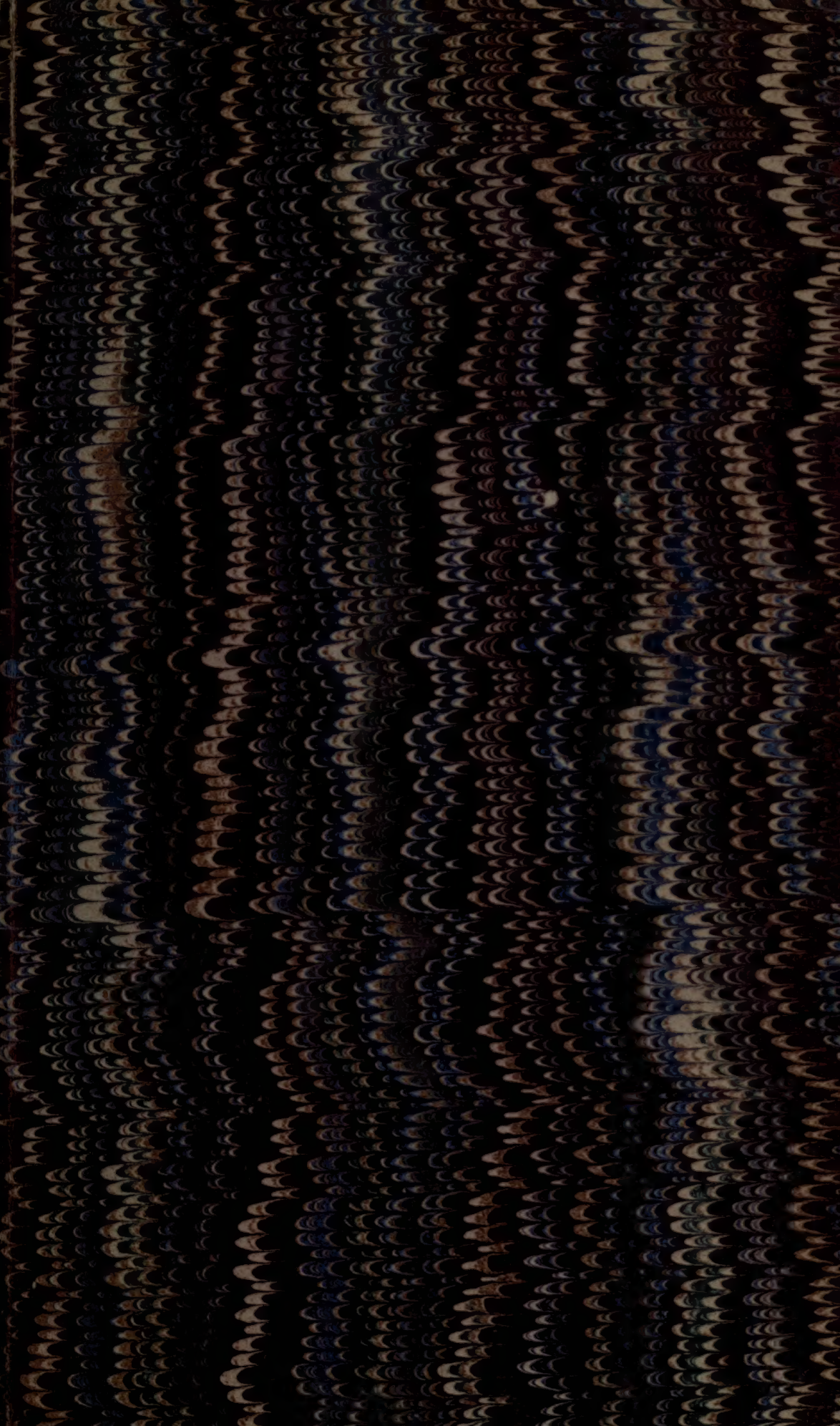




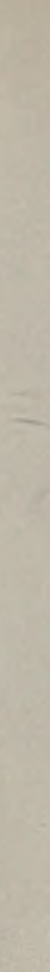

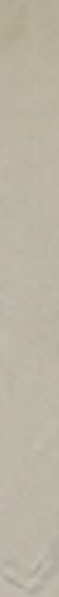




\section{A TOUR}

THROUE

\section{NORTH AMERICA;}

тосктнв พIтม

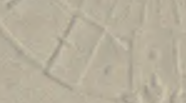

A COMPREHENSIVE VIEW

or тнг

CANADAS AND UNITED STATES.

AS ADAPTED FOR AGRICULTURAL EMIGRATION.

By PATRICK SHIRREFF, Farmer, MUNGOSWELLS, EAST LOTHIAN.

\section{EDINBURGH :}

PRINTED BY BALLANTYKE AND COMPANY, PAUL'E WOIK, CANONGATR.

PUBLISHED BY OLIVER AND BOYD, EDINBURGH; SIMPKIN, MARSHALL, \& CO., LONDON; DAVID ROBERTSON, GLASGOW; AND WILLIAM CURRY, JUN. AND CO., DUBLIN. 


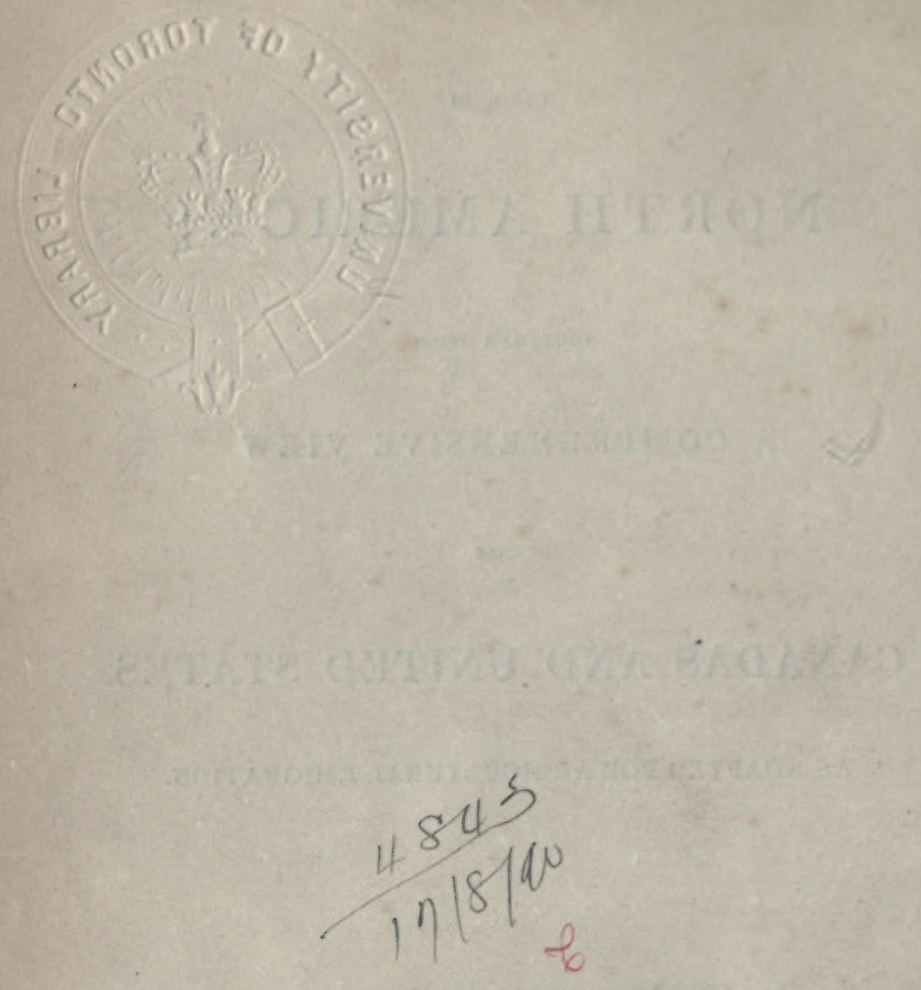




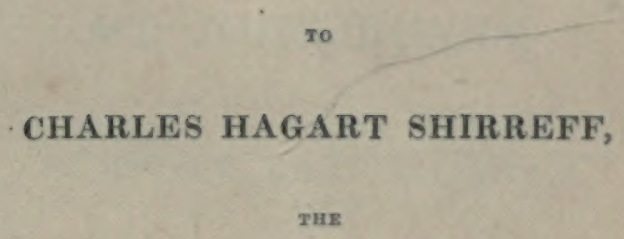

FOLLOWING VIEW OF THE CANADAS AND UNITED STATES

IS INSCRIBED

BY

H IS ВНОТнЕR,

THE AUTHOR. 


$$
=
$$

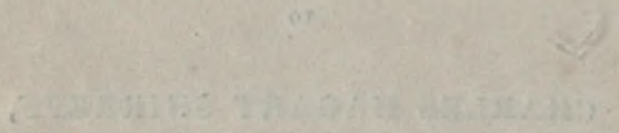

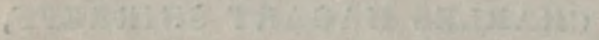

(1)

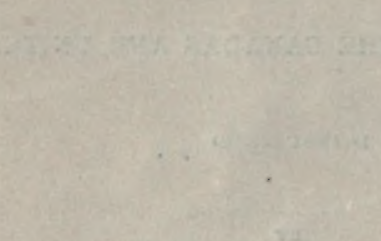

$$
\begin{aligned}
& +4
\end{aligned}
$$

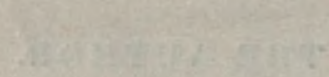

$$
\begin{aligned}
& 13 \\
& \text { s. }
\end{aligned}
$$

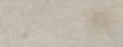

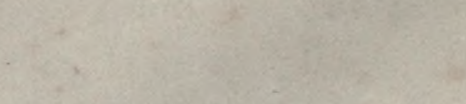




\section{MR JOHN DEANS,}

PENSTON, EAST LOTHIAN.

My dear Deans,

I DEDICATE the following tour to you, who had an opportunity of judging of many of the scenes and occurrences which I have described. Your candour and honesty have long been known to me, and I hope the sentiments and the feelings expressed in the succeeding pages, will be found to accord with your own character.

It has been said that I was appointed by a party of East Lothian farmers to visit and report on the Canadas and the United States; but nothing could be more unfounded. A younger brother having expressed a wish to try his fortune as an American farmer, I resolved to explore the country for the purpose of enabling me to give an opinion on the step which he contemplated. With this single object in view, my Transatlantic excursion was originally planned, and 
afterwards performed, unfettered and unassisted by any party whatever.

Having been led to travel from a sense of fraternal duty, I would have willingly remained satisfied with simply accomplishing the object of my journey, being aware how recently some individuals of the highest attainments had published works on America, and how ill qualified I am, in some respects, to convey an accurate impression of a country and people so interesting. But the solicitations of friends induced me to give my opinions to the public, and the rosult will, perhaps, prove their partiality to have been greater than their discernment.

Having passed much of my time apart from fashion and politics, the position which I occupied in the world may not have been favourable to an impartial view of all which came under my notice. My acquaintance with agriculture enabled me, however, to judge of American farming without relying on the opinions of others, and, while listening patiently to much which was told me, I drew conclusions only from what I saw.

In measuring the advantages of the different parts of the country by the standards of nature, and the reward of agricultural industry by produce, I hope to have departed from custom without having been led into error. Nature is the most general and invariable of agricultural tests. 
Want of information is a complaint which has been brought against treatises on emigration, and the charge in all probability arises from diversity of human character"; one mind being incapable of furnishing all requisite information to another, without previously knowing what is required. 'The first part of this publication is intended to show the opportunities which I had of seeing the country, and the second part to aid in forming an opinion of the different places of settlement. I have aimed only to impress the understanding of the reader, and should any of my representations and conclusions be found to differ from reality, I shall regret having written a word on the subject.

The common currency of the United States and the Canadas consists of dollars, expressed by the character $S$, and worth about four shillings and threepence sterling. The dollar is divided into one hundred cents, of about the value of a British halfpenny each. In the State of New York and Upper Canada the dollar is divided into eight shillings, or sixteen sixpences currency. In Lower Canada the dollar consists of five shillings currency. The dollar of Illino is is divided as in the State of New York, but the shilling is often called a "bit" and the sixpence a "piccryune."

I was not aware of any circumstance which could possibly influence my judgment in favour of one portion of America more than another, until I heard that my brother Charles had fixed on Illinois as his place 
of residence. Like myself, he had seen Upper Canada before visiting Illinois, and his preference of the latter district may be regarded by some individuals as corroborative of the opinions which I have expressed, and by others as the cause of my partiality. But since an inducement to praise Illinois may exist, my statements regarding it ought to be carefully examined.

Being a farmer in the strictest sense of the word, and having written the volume at intervals snatched from professional duties, I make no pretensions to correctness, much less to elegance of composition. My only aim has been to state plainly and freely what appeared to be truth, and I trust this will be received ths an apology for any inaccuracies of style which may be discovered, and for such dogmatical and homespun expressions as may be considered inconsistent with good taste.

PATRICK SHIRREFF.

$\left.\begin{array}{l}\text { MUNaoswells, } \\ \text { 10th January, 1835. }\end{array}\right\}$ 


\section{CONTENTS.}

\section{TOUR IN NORTH AMERICA.}

CHA P. I. - Journey to Liverpool-Lady and Child-Dine at LaneasterInpostors at Manchester-Kailway-Lateness of the ceason-Deserration of the Sabbath-Agrieultural detaily-Napoleon packet-ehip-Cemetery-Mr Huskinson, ..................................................

Crux. 1I. - Vuyage frum Liverpool to New York-Sea-sickness-CrewPassengers-Details-Approach to New York_Wabington Hutel,.... Сва P. III. - Theatre-Mrs Trullope's Work-Custom-huuve (PficerRace-course-Details_-Westhouses Breeding Stud-Thunder-stormReturn to the Hotel-Exeursion to Long Island-New-town-Flushiug -Agriculture in the Neighbourhood of New York,.................... Cri A. IV.-Journey from New York to Philadelphia_-Steam-buat-Railway Coach-Militia Muster-American and British soldiers-Characters of Travellers - Mansion-house Hotel-Funeral-Exeursion to Holmsburg - Hotel-keepers in Ameriea and Ireland-Mr W * - Mr F - - Sir John Sinelair of America_Fair Mount-Naval YardPhiladelphia-Return to New York-Face of the Country-Agrieultural Details, .....................................................

Cha ₹. V. - New York-Damakk hair-eloth manufactory-Dr H • • President Jackson, and Black Hawk-Hyde Park-Residences in America and Britain-Taste for Flowers-Cattle and Sbeep-Seenery of the Hudson and Clyde_Fast Eating-Albany_Coach Paseengers-Women working in Fielde, .......................................................

Crap. V1,-Journey from Albany to Boston-New Lebanon-Pittsfield -Roal Repairing - The Features of the Country-RhododendronsNorthampton-Mr Stuart's Description of Northampton-Stage Passengers-Mode of Courtship_Villages-Agricultural Notices,.........

Cruar. VII. Journey from Boston to Lowell-Lyun-Salem-Newburghport-Female waiters, or helps-Agricultural Notices-Stage pasengers-Lowell_Manufacturing Females_American and British manufacturers-House building-Benevolent Societies-Water Power - Manufacturing power of Britain and the United Staten-Notices of Nature, ................................................................ 
Cira s. VIII. - Journey from Lowell to Saratnga-Keene-Bellows Fall Townsend-Arlington-Driver at 'Tuble-Landlord and Driver-I'ansage of the Green Mountains - Stage Coach practicen of America and Britain - Passengers and Travellers - Juvenile politenens - Agricultural Notices-New England Villages-Free School Eilucation unfairly entimated by British travellers-Ealucation of Scutland and the Cinited States-l'ublic Schools_Fagging in the Seminaries of Britain-I'rin. ciples of Education

Cим P. IX. - Company at Saratoga-Fast Fating - Notices of Buel Farm -Mr Buel-New York-_State Agricultural Society-Advantagen of a young country-Farmers of Brituin and the States-British Agricultural Societies,.........................................................

Cin p. X.-Jourbey to Geneva-Sehenectady_Quention Asking-Stage Driver-Valley of Muhawk-Agricultural Duties-Vtica-Attention to Females-Marcellus_Skeneatiles-Cayuga Britge-Dinner Party -Dumfries-shire Farmer-Sheep Ilusbandry-Condition of Animals -Farms_-Geneva,...........................................................

CHa P. XI. - Journey from Geneva to Lewistown-Land offered for Sale - Canandaigua-Genesee Country-Variations of temperature-Agricultural Notices-American and Scotch notions of Reverted WheatGenesee Flats_Mr Wadesworth-Avon-Wood Bridges_-Girdling Trees-Falls of the Genesee-Rochester-Ridge Road-Face of the Country,....

Char. XII. - Niagara River and Falls-Carving-Entrance to Canada -Cavern beneath the Falls_Rapids_City Building_Stage Pansenger —General Brock's Monument_Letters_Maps_Queenstown and Nia. gara - Agrivultural Notices - King — Old Settlers - Disappointment with Canada, ...................................................................

Char. XIII, - Baffled in reaching the Western States-Buffalo-4th of July_Oneida Indians_Fort Erie-Early Marriages_David BaxterPetersburgh - Separate from Companions - Musquittoes - Settlers around Dunville-Earing of Wheat-Dunville-Face of the CountryNotices of Nature-Breaking Fruit-trees_Bar-room Group -Junction with Companions_Visit a New Settler-Politicians-HamiltonYork,

Chap. XIV._Excursion to Lake Simcoe-Hope-David Willson-Meeting-house-Tenets of the Children of Peace-Northumberland Farmer -Soil_Notices_Excursion to Niagara_Scenery of Lake OntarioReturn to York,........................................................

Chap. XV._Journey from York to Coburg-Mail Waggon-Mr Somerville-Agricultural Notices_Clay Kneading-Female Helps seating themselves at Table-Port Hope-Coburg-Agricultural Notices_Fast Eating-Excursion to Peterborough-School. Fellow-PeterboroughRice Lake-Notices of Nature and Agriculture - Settlers-High Price of Land_Injudicious Settlement_-Bay of Quinte_Indian SettlementCanada Thistle_Kingston-Storekeepers and Store-pay_Grasshoppers -Lake of the Thousand Isles _ River St Lawrence,.................... 
Cuar. XVI. Excursions around Montreal_Townehip of Hiachinbrooke -River Chateauguay_Kinds of Houses_Bushmen and FarmenSquatters_Price of Land_Flag Staffs_Huntingdun-Isle Buurdeaux -Face of the Country around Montreal-Farming of old SettlereFrench Canadians-Laprairie-Wheat Fly_Cheap Purchase Cham. by_Cheap Education-Mistake Ruadz-Horse Ferry-boat_Starving out_Mountain_Race Course-State of Agriculture around Montreal

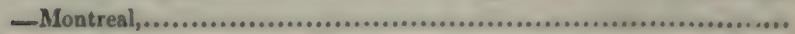

CHAr. XVII._.Juraey from Montreal to Ilamilton-Separation of Friends-Rideau Canal_Enigranto passing up the St LawrenceMassena-Waddington-Ogdensburgh_Lake of the Thousand IulesAndrew Dinwoodie, a Farmer from Dumfries-shire-Live-stuck from England-Innkeeper of Kingston_Great Britain Steamer-Emigrant Passengers_Juhn By Steamer,

C'HAP. XVIII.-Journey on the Banks of the Grand River-Corduroy Roads_River-side Vegetation_Cradling - Settler from EdinburghReserve of the Six Nations_Nullis Settlement-Indian Notices-Settler from Perthshire-First Settlers-Gentle Childrea-Agricultural Notices-Great Heat-Drinking Water-Raisiug Bee-BrantfordOak Openings-Paris_Galt_Guelph_Waggoner at Talle_Face of

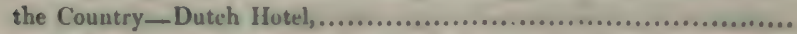

CHAP. XIX._Journey from Galt :o Goderich-Farmer from Roxburghshire-Female Worth-Improved Healch of Scotch Farmers-Visit Captain A * "-Humming-birds-London Family is the BushGuides-Avon Accommodation-German Settler- Notiees of Nature,

Cinap. XX._Goderich Hotels-Eagle's Nest-Doctor Dunlop_Cheap Dinner-Seareh for an East Lothian Farmer-Guderich-Poverty of Settlers-Canada Company - State of Guderich Settlement - Juurney to London_Mr T * - Aux Sable Creek_Ship builder from EssexNegro Settlement-Notices of Nature-Robinson Hutel-Mode of Travelling-Huron Track Roads_London_St Thomas-Port StanleyEmigrants from Argyleshire-Dirty Beds_Agricultural Notices,.......

Cual. XXI. - Culonel Talbot's Revidence-Caup-meeting-Barn-Mrs Aldgeo-Moravian Indian Village-Cheap Fruit_Runsway SlaveeExcursion to Bear Creek-Mr Goose-Soil_Agricultural NoticeeRiver Thames-Unhealthy Appearance of Inhabitants-Chatham Plains_John Macdonald_Colborne Furnace-Neighbourhood of Amherstburgh-French $I_{n} n$,

Cuar. XXII._Horse Hiring-French Inn-Negro Family-PrairieSupplied with Oats_Mouth of the Thames-Elephant-Yorkshiremen-Want of Cunveyance-Old Settler-Prairie_Face of the Country and Soil-Notices of French Inhabitants, and their AgricultureHuron Indians and their Agriculture-Royalists and their AgricultureNotices of Nature-Detroit River-Amherstburgh_-Sandwich_Ferry -Detroit,...........................................................

Cuap. XXIII._Journey from Detroit to Chicago_Thrashing Machine -Face of the Country in Michigaq-Prairie Hen-White Pigeon Prai- 
rie_Travelling Party - La Porte - Cuoking Breakfant_Jaded Hormes Thunder Storm-Huvel on the Shore of Lake Michigan-Fare of the Country - Notices of Nature-Chicago - Indian Treaty - Hurne-racing -Intuxication-Fair-Oceurrences at Chicago, .........................

Сиян. XXIV._Journey from Chicago to Springfield-Oak PlaineTravellers_Crowded Houne-Du Page-Benighted-Clatterman'hOttawa-Family from New England-Travellers-Gouging - Slenoping Accommodation-Peoria_Pekin Storekeeper-Salt Cremk_Ilonpitality of Inhabitante_Springfield_-Prairies-Nutices of Nature-Face of the Country - Soil-Agricultural Noticen,.............................

CuAp. XXV.-Journey from Spring gield to St Louis-JacksoovilieEmigrant from Edinburgh-Beds-Face of the Country-Alton-Mis. sissippi-Luxuriant Vegetation-Bottoma-Mamelle Prairie-Mr Fliat -St Charleg- Hiver Mlissouri-Notices of Nature-Indian Antiqquities -St Leuis, ........................................................

Crap. XXVI. - Voyage from St Louis to Cincinnati-Minsinsippi-Ohio - Falls of the Ohio-Passengera-Details of the Voyage-Nutices in Natural History-Vessels on the River-Louisville-Hotel_Steamboato-Inquisitive Irishman-Tobacco-squirting American-Advanta. ges of Shabby Attire to Travellers-Mr Hamilton's Account of Men and Manners in the Western Steam-boats-Cincionati-Agricultural Notices........ g...................................................................

Crap. XXV1I._Journey from Cincinnati to Detroit-Macadamized Road-Lebanon-Passengers-Agricultural Notices-Pawpawn-Cider-making - Hotels of the United States-Customs of the CountryColumbus - Details to Sandusky - Mr Hamilton on the Proepects of the Union-Sandusky_Cider-making - Perrysburg-Mamee-Ohio-Mi-

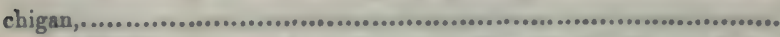

Char. XXVIIL._Journey from Detroit to New York-Western Lakes which form the River St Lawrence-Cleveland-Erie Canal-Cold Weather-Canal Packets-Sabbath School Children at RochesterBlack Children-Slavery in the United Statea-Agricultural NoticesWashington Hotel-Transition from Rudeness to Refinement-Travelling-Cheap Land_State Election-Inhabitants Consulted in Political

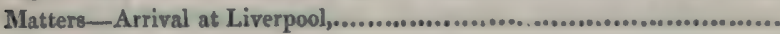

A VIEW OF THE CANADAS AND UNITED STATES, AS ADAPTED FOR AGRICULTURAL EMIGRATION.

Crap. 1. - System of Nature Reproductive and Progressive, when aided by Man-Soil is a Workshop-Nature and Man manufacturing Produce -East Lothian Agriculture-Corn Laws-Leases-Competition for Land-Situation of Tenants-Situation of Hinds-Prospects of the People connected with Land, 
Chap. II.-Persons engaged in American Agriculture-American and British Agriculture - Applieation of Capital and Labour to Cultivation -Rent-Price of Land-I'ruportions of Nature-Capital and I.ubuur in the Production of Farm Produce, and their Distribution in Britain and America-Capital requited to Stuck a Farm in both CountriesUnhealthiness of America-Climate-State of Society-Situation of Young Men without Capital-Choosing America or Britain.

Chap. HI. - Lower Canala_Inhabitants_('imate-Soil_Mode of Sell. ing Land-Productions and J'rices_Farming near Montreal-Climate affecting Agriculture and Farmers,...................................

Chax. IV._-Upper Canada-Iuhabitants_Climate-Suil-Mode of selling Land, and Prices_Bad kiffects of Selling on Credit_-Situation of Settlers without Capital-P'rice of Land in Cipper Canada, and the Western United States_Price of Lanul, and Mode of Setthement Injurious to the Province $\rightarrow$ Singgestions for Improving the State of the Coun-

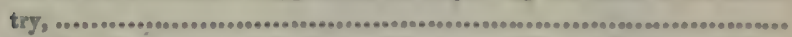

Сиar. V._Productions-Agricultural Sucieties-Want of Paoturage - Progreas of Forest Settlenuent-First Crops on Forest Land-Worn-out Soil_-Mildewed Wheat-Misrepresentatious of ('anada-Mr Fergusen' b Statement_- Townohip of Nichul-Praises and Detractions - Cheusing a Situation-Advantages and Disadvantages of ( pper (anada for difierent Emigrants_-state of the Inhahitants-Constitution-Game,.............

Char. V1. - I'nited States-Climute-Diseases-Pruduetions-Aerieulture East of the Alleghany Mututains-Agriculture West of the Munutains-Wages - Chwice of Residence-l'rugress of Wealth-Wages of the United States and the Canadas-Profits of Capital,..................

Снар. VII. - Wealth and Refinement of Ditterent Parts-Writers on American Manners-1'lainness-Civility-New England CharacterUnfair Dealing-Emigrant's Situation and Character-Civvernment-

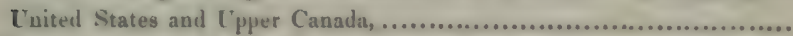

Chap. VIIl. - Illinois-Climate-Face of the Country-Prairies-Sivil -Salt_Lead-Iron_Coal_-Water Communieation-History-Town -Government-Education-Kintucky Population-Now Ringlanders -Pioneers-Manners aud Custums,.................................

Cuar. IX.-Productions-Animals - Fowls-Country for SportingMode of Selling Laud_Cnsolil Publie Land_Number of Indians_Government P'olicy tuwards the Indians- War with Indians-Decrease of Population-Agriculture-Wages of Labour-Illinois and Cpper

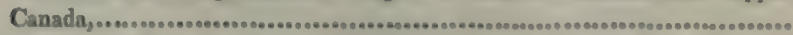

Chap. X.-Prairie Agriculture-Capital Required-Crops and PricesWages of Labour Compared with Land and Produce in Illinois and Britain-Future Prospects_-Sheep Husbandry - Illinois and C'pper Canada_-llinois and Britain-The Canadas and Illinois estimated by the standard of Nature-Emigrant Information, 


\section{TOUR IN NORTH AMERICA.}

\section{CHAPTER I.}

Journey to Liverpool-Lady and Child-Dine at LancasterImpostors at Munchester-Railway-Lateness of the seasonDesecrution of the Sabbuh-Agricultural Details-Napoleon packet-ship-Cemetery-Mr Huskisson.

I LEFT Mungoswells on the 20th of April, 1833, and proceeded from Haddington to Edinburgh by the Earl Grey stage-coach, drawn by a pair of thoroughbred bays, in charge of Quinten Campbell, a most excellent driver, who landed us at the end of the journey, a distance of seventeen miles, in less than an hour and a half, without an application of the whip.

After spending a few hours in Edinburgh, two friends, who intended accompanying me on a transatlantic tour, and myself, were seated in a Manchester coach, and we arrived at Carlisle about five in the morning of the following day.

During a few minutes' delay which occurred in changing coaches at Carlisle, a waiter at the inn asked us to partake of breakfast; and resented our declining to do so, by saucily refusing to exchange small silver-money for a half-crown piece. My friend and I here agreed to take an outside place alternately, to accommodate a lady and child with an inside one. In course of the day I learned from the lady that she was booked as a passenger from Dumfries to London, and had, to her regret, been detained a whole day at Carlisle. It was 
evident that this unprotected female and her innocent charge had been imposed upon, and her escape from a second day's detention was entirely owing to the little concession of iny friend and self in her favour.

Breakfast was served at Penrith, and the party complained loudly of the fare placed before them. 'The stage passengers were joined by other travellers at Lancaster, where eighteen in number dined together, carving for themselves, and several partaking of hot punch, in the space of twenty minutes, which was the whole delay at Lancaster.

We reached Manchester a little after nightfall, where we spent the evening; and one of my friends not having sufficicut change to settle with the guard and driver of the coach, he soon afterwards paid them in the coffeeroom. Next morning two different individuals presented themselves, as deputed by guard and driver to receive their allowance. My friend goodhimouredly rallied the impostors on the hopelessness of their attempt, and they seemed to feel the force of his satire more than they perhaps would have done a scolding. I have noticed the treatment of the lady and child at Carlisle, as wcll as the impostors at Manchester, in consequence of a lecture from a fellow-passenger on Yankee knavery, and a well-meant advice to guard myself against American duplicity. Without meaning to impeach the character of my fellow-countrymen, I may remark that the natives of Britain need not illustrate moral delinquency by examples from other countries. Mankind seem to be, nationally as individually, sensible of the faults of others, although, at the same time, they are blind to their own.

We travelled from Manchester to Liverpool by the railway, on the morning of the $22 \mathrm{~d}$, and accomplished a distance of thirty miles in an hour and a half. Several miles were performed in two minutes, according to my stop-watch. At the request of a friend, I occupied a place on the outside of a way coach, and was much annoyed by the current of air and coke from the engine. My eyes did not recover the effects of the coke for forty-eight hours afterwards.

On the east coast of Scotland the season had proved to be one of the wettest and latest on record. At the time of our de- 
parture the vegetable kingdom had scarcely responded to the vivifying influence of spring - the buds of the hawthom and the larch were expanding only in sleeltered places. England did not present a more advanced vegetation. We were fortunate, however, in olstaining the first good weather of the scason for our journey; and, notwithstanding the bleakness of nature, the ever varying scene afiorded many olijects fitted for contemplation. We crussed the line separating lingland from Sicotland early on Sunday morning, and for many miles afterwards the roads were covered with herds of cattle and flocks of sheep, travelling towards the south. This was a novel sight to a scotsman; such practices on Sabbath being prohibited by the laws of his country. The deseeration of the Lord's day may, perhaps, to a certain extent, be traced in the customs of every Cloristian country, but in no ease whatever ought appearauces to be regarded as she measure of religious feeling, the seat of which is hid from human eye. Without assigning to my countrymen purity and intensity of religious emotion, I may be permilted to say, a Scuttish sabbath is marked throughout by a still, quiet, external decorum, seldom met with in other parts of the worli, which fusters piety, and checks an open display of profarity. I trust her inhabitants will ever respect and preserve its solemnity of cinaracter.

The land from Canlisle to Manchester seemed, generally, poor and indiflerently cultivated. The enclusures are small in size, often surrounded by irregular fences, formed and maintained at a sactitice of suil and labour. Many of the grass fichls were studhed with lean young horses and cattle, inclustrivusly secking a repast which nature still sparingly supplied. Betwixt Manchester and Liverpool, much of the grass lands had been ploughed with a furrow slice, only two and three inches in depth. Three stout horses yoked in line, the first of which was led by a boy, were seen dragging a small harrow, kept on a narrow convex ridge, by means of a man with a rope operating like a rudcler, and he was apparently the only severely worked animal engaged in the operation. The agriculturists of Britain being deemed enlightened, and her soil not producing a suficient quantity of foud for the popu- 
lation, it was painful to witness land so mismanaged and labour so misapplied. This anomaly may, perhaps, be accounted for, by the genius of the inhabitants of this district having long been successfully applied to manufactures; and neither soil nor climate being congenial to agriculture; together with entails, tythes, and corn laws, checking the devotion of skill and capital to cultivation. Chatmoss, through which the railway passes, seems, however, an exception, and I regretted time did not permit an examination of the interesting management it is under, with which I had become acquainted by means of periodicals devoted to rural affairs.

On reaching Liverpool, our first proceeding was to search for a conveyance to New York, which we obtained in the Napoleon packet-ship; the commander, Captain Smith, resigning his cabin to my friend and me, the other berths in the ship having been previously engaged, with exception of one which was required for our companion.

Part of the 22d, 23d, and $24 \mathrm{th}$, was spent in viewing the attractions of Liverpool, the chief of which, in my estimation, is the cemetery. This repository of mouldering humanity has been recently formed, and its numerous beauties have not been matured or mellowed by time. Trees, shrubs, and flowers, were diminutive, and generally in their winter garb, which fully displayed the memorials to the gaze of visitants. The cenotaph to Mr Huskisson stands near the centre, and can seldom fail of fixing for a time the attention, and exciting the sympathies of his countrymen. The world is now enjoying the green fruits of his genius, with prospect of increasing and lasting supply, while the laurels of contemporary warriors are barren and fading. So long as the principles of free trade are cherished and acted on, the memory of Huskisson will endure. 


\section{CHAPTER II.}

Voyuge from Liverpool to New York-Sea-sichness-Crev-Passengers-Detuils-Approach to Wew York-W'ashington Hotel.

Ar noon, on the 24th April, the Napoleon got under weigh, and was towed down the Mersey by a steamer, in consequence of an adverse wind. In little more than an hour from the time of sailing, I became sea-sick, which afflicted me severely for nearly thirty days, and frustrated the little plans of recreation and amusement which I had formed on shore. Although appearing only once or twice at table, the attention of friends, and the situation of my berth, enabled me to know much that was passing on board. I shall not, however, chronicle many events which took place during the voyage, which some of my shipmates will readily pardon.

The establishment of the Napoleon consisted of about thirty, embracing men of every country and of every clime. There were eighty passengers in the steerage, and thirty in the cabin, eight of whom were ladies. England and Scotland furnished each five gentlemen, cabin passengers; Ireland, two ; and the United States of America, three, one of whom had been naturalized from Ireland. All the individuals from England and Ireland, one from Scotland, and two from America, smoked. In some cases, the use of tobacco was immoderate, one gentleman smoking a hundred and fifty segars in fourteen days; the saliva in many parts of the vessel was copious and disgusting. Some of the passengers seemed to spend much of their time in sensual gratification, there being little reading or card-playing indulged in. Breakfast was served at eight o'clock, luncheon at twelve, dinner at four, and tea at eight. The first dinner course occupied about an hour, the second fifteen minutes, and dessert about the same length of time. The cabin, in some respects, resembled a British inn, the 
passengers drosing as they chose, and at all times calling for what they wished, champanne, secmingly, being the only wine restricted, and which was presented at dinner twier aweek. 'Th those not of fastiolious taste, the Napoleon offered a fit opportunity for indulgence, the table being enpionsly stored with substantial food and a variety of liguids. The noise of calling the steward, and drawing of corks, succeseded each other at short intervals throughout the day, and generally formed my morning and evening salutations. The quantity of good things which some individuals stowed under their helte, appeared excessive. Man is apt to despise what he cannot enjoy, and sensual indulgence never appeared to me so unworthy of regard. Champagne, sparkling in the wine-cup, did not afford a thousandth part of the pleasure I had often derived from the dewdrops glancing in the morning sunbeam, and when presented to my fevered lips by a most friendly hand, I envied my pretty Ayrshire cow, Salina, the privilegre of quaffing the cool and limpid fount at Mungoswells.

On 20th May, $40^{\circ} 30^{\prime}$ north latitude, 5.3' west longiturle, and 950 miles from New York, Mrs —, a cabin passenger, gave birth to a female child. In compliment to the ship, this little nymph of the sea was to be christened Josephine : a name memorable for conjugal affection, and the poor return such a virtue will sometimes receive.

Our commander, Captain Smith, was an American by birth, and part owner of the ressel. He was indefatigable as a seaman, spending successive nights on deck, and seldom concluding a meal without satisfying himself, by occular demonstration, that all was right aloft. To the passengers he was attentive; and, considering the situation in which they occasionally placed him, also forbearing. Individually, I found him courteous and gentlemanly in a high degree.

The wind continued adverse for the first twenty-five days; and sometimes blew tempestuously. The weather moderated for the last eight days of the voyage, and the bar at New York was made on the morning of the 29th May, which a dense fog prevented us crossing without a pilot. The vessel stood off and on during the day, and towards noon, six gentlemen, accompanied by the letter-bag, set out in a 
fishing-boat for New York, where they landed in safety a few hours afterwards. The fog increasing as the day advanced, deprived the passengrers of the hope of reaching shore until next day, and all their stock of patience was required to withstand the disappointment.

Next morning I was early on deck. The fog of the preceding day had disappeared in course of the night, and the sun shone brilliant in a sky of cloudless blue. A bracing and favourable breeze filled our canvass, and hastened on their voyage a thousand vessels around us, which had been detained by the previous unfavourable weather. Land was seen on both sides of the channel, but too distant to render oljects on its surface distinctly visible. At a quarter before eight, a pilot stept on board, under whose guidance the Napoleon proceeded merrily on her way.

Under the combination of advantages we now enjoyed, our detention on the previous day seemed a fortunate occurrence, without which we should have been landed at New York, insensible of the beauties of its approach.

Having been nurtured in the country, and by profession and taste brought into fellowship with the regetable kingdom, I anticipated much pleasure on my first introduction to America. This feeling led me on deck early in the morning, and, with telescope in hand, I watched with anxiety our approach to the shore. My situation was like that of a famishing person with food in view, intense desire without gratification, and brought to feel enjoyment by gradual participation. At first the country appeared a mass of uniform vegetation; by and by, the green broke into different shades, forest could be distinguished from cultivated field, kinds of trees and crops became visible, but I strained my eyeballs almost to blindness without being able to mark the minute characteristics of individuals. The general effect imparted delight, which was heightened, perhaps, by my having left home at the termination of a tedious winter, and crossed a wide waste of waters; the green mantle of nature never appeared to me so rich and fascinating.

The general aspect of the scenery, on approaching New York, is beautiful; consisting of hill, wood, water, island, town, villa, and hamlet, in every combination which can im- 
part pleasure. But blue mountains, so prominent in the landscapes of Scotland, and so dear to her children, are altogether wanting, and the eye searches in vain for an object of sublimity.

An inspecting surgeon came on board at the quarantine station, who examined the passengers and crew. On comning to anchor in the river, near the wharf, a custom-house officer sealed up the luggage in the berths, and the cabin passengers were landed by means of a steam-loat.

On reaching shore, we learned there was a scarcity of lodgings at this season of the year, when the inhalitants of the Southern States travel northwards in quest of health. Our charioteer, after two unsuccessful attempts to find accommodation, landed us at the Washington Hotel, kept by Mr Ward, who kindly supplied us with every thing we could desire. 


\section{CHAPTER III.}

Theatre-Trollopes-Mrs Trollope's Work-Custom-house Officer -Race-course - Westhouses Breeding Stud-Thunder-storm -Return to the Hotel-Excursion to Long Islund-New toun - Flushing-Agriculture in the neighbourhood of New York.

Miss Fanny Kemble taking her benefit on the night of our arrival, it was determined that we should visit the Park theatre. We found the house well attended, the ladies greatly outnumbering the gentlemen in the boxes, while the pit contained males only, apparently belonging to what is known in England by the operative classes, amongst whom people of colour were seen. Having peeped into Mrs 'Trollope's work on the Domestic Manners of the Americans, and its illustrations of those witnessed at the Cincinnati theatre recurring to memory, I watched the behaviour of the audience.

At the end of the second act, I observed a gentleman in the second tier of boxes in an indelicate posture in front of the box. Three were similarly situated, at the end of the third act, when several voices in the pit called out, "A Trollope, a Trollope," and a general hissing and hooting from the same quarter had the effect of inducing the offenders speedily to withdraw.

This incident at the theatre, amusing in itself, afforded me pleasure, by exhibiting the operatives in the pit enforcing chaste manners on those considering themselves higher in the scale of humanity; and proving that Mrs Trollope's remarks had not been altogether lost on the Americans.

The clever, and to some people, amusing work of Mrs Trollope, will have different effects from what its admirers in Britain contemplate. The many sketches of low and incidental character which the book contains, and given as belonging to the people generally, wounded the feelings of the inha- 
bitants of the United States; and hy drawing attention to bal practices, led to the inprovement of the people reviled. From much I saw and heard, the keen satire of this authoress is likely to produce, in a few years, the usual improvement of a century. On the other hand, her caricatures of manners and institutions fostered the prejudices of many of the inhalitants of Britain, and engendered dislike to political changes taking place in that country, more likely to be accelerated than retarded by intemperate opposition. When indelieacy flows from the pen of a female, though veiled by effusions of poetic fancy and garnished by wit, it is highly dangerous to youthful innocence, and the popularity of Mrs 'Trollope's work may be regarded as evidence of want of discernment, if not of vitiated religious and moral feeling, in a portion of the reading population of Britain.

The piece of the evening was "The Wonder," in which Miss Kemble did not appear to advantage. Having formerly seen her at Edinburgh in the play of the "Hunchlack," the contrast on the present occasion was painful. Whether my disappointment arose from the difference of character she represented, or a change of feeling on my part, cannot be determined, but I left the house long before the conclusion of the piece, for want of interest.

Next morning we applied at the customhouse for our luggage, and, on paying a trifle, obtained a permit for its inspection. The officer on board performed his duty in the most gentlemanlike manner; and in less than five minutes from the time of going on board, our luggage, under charge of a porter, was on the way to the Washington hotel.

The New York races take place on the Union Course, Long Island, twelve miles distant from the city, and this being the last day of them, we were anxious to embrace what we conceived so good an opportunity of seeing the different ranks of society. Accordingly, we crossed the river at Brooklyn ferry, and engaged a light four-wheeled waggon drawn by one horse. The individuals proceeding to the course in vehicles, and none were observed on foot, seemed under a racing mania, and rattled along the road expeditiously, many of the horses trotting in admirable style. On approaching the 
course, our horse and waggon were put into a court, and we proceeded on foot.

The Union C'ourse is private property, and completely shut against the public by a fence of strong upright posts, or stakes, enclosing a considerable space of more ground than is occupied by the course. For a considerable distunce on each side of the winning post, the exterior fence consists of strong boards impervious to vision, on the top of which are stands capable of containing many thousand people. The interior margin of the raceway is fenced by a low open paling, except opposite the winning-post, where high upright stakes are substituted. A portion of ground including part of the raceway is thus enclosed for the accommodation of the horses, and those more immediately interested in them, by the stinds on one, and close upright stakes on three sides, with larye gates crossing the raceway, which are kept open during the time of running. A quarter dollar was exacted on passing the outer barrier of the course, on entering which, we found the first race concluded. Inheriting a smack of the jockey, my first object was to obtain a view of the horses; and on applying for admission into the enclosure where they were walking, I learned a ticket was the only passport; but preparations for starting commenced, and the first two-mile heat was run, accorling to my watch, in three minutes and fifty-seven seconds. My anxiety for a sight of the horses increasing, I applied to a gentleman, seemingly of importance in the racing circle, to be allowed to approach them, and was informed that on paying three dollars, $12 \mathrm{~s}$. 9d. sterling, I would obtain a ticket of admission into the enclosure. The terms on which I could come near the horses appearing extravagant, I contented myself with peeping through the stakes at a distance. It would be unfair to attempt a minute description of the animals, under the circumstances in which I was placed, but they seemed not quite so strong as English race-horses, though more sprightly and graceful in the mode of carrying their heads and tails.

There are few finer sights in England than a well-attended race-course in good weather. All ranks, from the king to the beggar, male and female, assemble in their best equipages 
and gayest attire. Splendour and beauty seem to regard the occasion granted for display ; and the more immediate actors in the scene harmonize with the general pageant, a well-trained horse and his rider being a perfect model of chaste neatness. All is, however, different at New York. In the interior of the race-course, there were a limited number of people, few equipages, and a total want of finery or display of any kind. The stands were crowded, but amongst the assembled multitude I could not have numbered more than thirty females who, from their appearance, had no pretensions to the epithet of lady. The jockeys were of all hues, generally coloured boys, whose black faces appeared very grotesque under their brightcoloured, ill-fitting dresses. One jockey, of small size and tender years, was clothed in shabby leather trowsers, which had formed knee-breeches to their original possessor; and a second had his spindle-shanks in old boots of the largest dimensions, with strings below his knees to prevent his trowsers and boots parting company. Bridles and saddles were covered with mould and rust, and in one instance a pair of stirrup-irons were warped with rope, to fit them for a little tawny foot. On coming up to start for the second heat, the horses displayed much impatience, being, generally, led by one, and sometimes two men on foot, as motley and grotesque in appearance as the riders. Two false starts were made; and at the time of finally getting away, one horse had his tail in the direction of the others' heads. 'The jockeys rode all in the same style, their toes being placed near to the nose of the horse, and their heads inclining back above the tail. The second heat was run in three minutes and fifty-five seconds, after which I withdrew, disappointed at what I had witnessed.

On reaching a foreign land for the first time, a person is apt to judge every thing he sees by the standard of his own country, until the home-rust, which more or less accumulates on every one, is rubbed off, and a consequent expansion of mind takes place. At first it appeared to me illiberal to exclude the poor from seeing a race, and sordid to exact money from the rich who witnessed it, particularly in a reputed free country like the United States of America. On reflection, however, I could not see any impropriety in 
making those who enjoy the amusement of horse racing pay for it, more especially when the government does not squander public treasure on such an object, and where the course is private property. I could not ascertain if the course is lucrative, but the funds arising from the following sources, which are extracted from a race bill, must be considerable.

Members and their (immediate) families, to pass free.

For every two-horse four-wheel carriage, with not more than

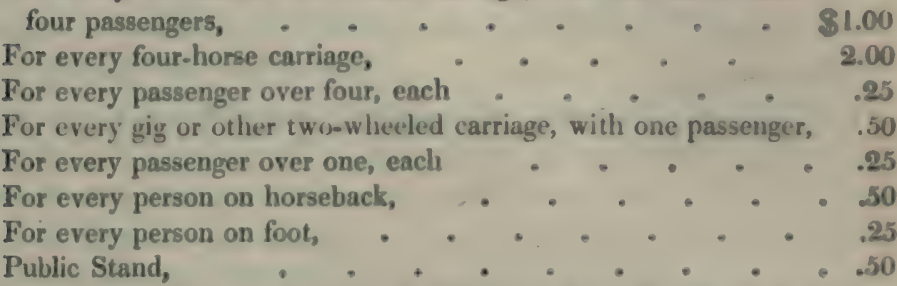

15. No person but a Member, or a resident of another State, invited by a Member to purchise a 'Ticket, ean have access to the Members' Stand. Any non-resident of New York, so invited, by paying three dollars, may procure a Ticket, for the week, of admissiun to the Members' Stand.

The Pavilion will be set apart for Ladies, Members of the Club, and such Gentlemen only as have Tickets to the Members' Stand.

** An efficient Police is provided to preserve order, and see that the Rules are strictly adhered to and enforced.

The next day we were accidently carried to the farm of Westhouses, where we saw an extensive breeding stud of thoroughbred horses, amongst which was a sister to Eclipse, the most celebrated horse in the States, and Henry, next in fame to Eclipse. The gentlemen of the turf consider their horses superior to those of England, equal distances being run in less time; but the style of running is, however, different, the weights of America being lighter, and the horses pushed from the starting-post.

We experienced a most severe thunderstorm while at tea, but the young ladies of the party did not seem to concern themselves about the war of elements, the most vivid lightnings flashing without remark. We travelled a few miles after the storm abated, and daylight had disappeared. The calls of toads and catydids were deafening, and innumerable fire-flies illuminated the face of nature, and lighted our way. The wetness of the evening induced us to remain for the night at the house of a friend, instead of returning to New 
York. Next morning I was awoke from a sound slecop) by a loud knocking at my bedroom window, and on answering the call, my disturber asked the hour. After looking at my watch, I answered, twenty minutes past three o'clock, and adcled, he had surely made a mistake in coming to me. He sharply answered, in a disagreealole nasal twang, "I have slept too long, that is all the mistake, I guess." In a few minutes afterwards, all hands, including several of the fanily, were engaged in milking cows; and the produce of about twenty was despatched for New York lefore five o'elock, under charge of the person who awoke me, and I learned that he had contracted for the milk during the season. We breakfasted at six o'clock, and were immediately afterwards drawn to the city by a pair of handsome chestnut geldings, at the rate of eight miles an hour, and which would have graced any barouche in Britain. Our vehicle was the common fourwheeled waggon of the country, with two deals across for temporary seats, and it was to return loaded with seed-potatoes. We drove smack up to the Washington Hotel, one of the most fashionalile houses in the most celelorated street in New York; and in course of our progress I was amused at the uneasiness of my friend, one of the best and plainest of men, at being carried to our residence in such a mean-looking carriage. During his short residence in the States, he had not learned to shake off that aristocratic feeling which so generally pervades human nature, and has produced much misery in the world.

After changing our linens, we set out in a gig for Long Island, proceeding by way of Flushing, and returning by the beautiful village of Jamaica. Long Island has been termed the garden of the States-a name which it may well merit from its numerous orchards, but certainly not from the fertility of the soil, or the management which it is under. The land is generally of light texture, requiring constant supplies of manure, and a considerable part of it is sand of the poorest quality. The enclosures were small, the fences bad, and every description of crop inferior. Parts of the surface were covered with thriftless brushwood, and there were numerous pools of water which might have been easily drained. Many of the houses were composed of brick, others of wood, resem- 
bling the country-seats or villas of England. As a protection from the sun's rays, windows were generally provided with green Venetian blinds opening on the outside. Grave-yards, or private burying places, were innumerable, and like the flower plots and gardens, kept in an untidy mamner.

On passing the village of Newtown, celebrated as the place where the delicious apple bearing its name was first discovered, we drove into a shed, a convenience attached to every country place of entertainment in the eastern United States, and after giving orders for the tending of our horse, applied at the bar of a respectable-looking hotel, if we could have dinner. A thin vixen-looking woman peeped from behind a door, and whispered something to the landlord, who immediately told us, in a civil tone of voice, he could not comply with the request, as they were engaged in cleaning the house. There was no alternative but to proceed, and on reaching a good-looking hotel at Flushing, about one o'cluck, we learned that the dinner hour was at two, but no uljection was made to accommodate us immediately. 'lable was prepared by a pretty young woman, called, in this part of the world, a hired girl; and in less than a quarter of an hour from the time of our arrival, dimer was set before us. 'The same person, whom I consider entitled to the name of lady, being neat in dress, easy and polite in manners, waited during dinner in a standing position. She conversed fretly and semsibly on different subjects, without forwariness or levity of conduct, and apologized for part of our fare not heing so nice as it would have been, had time been allowed for preparation. On paying the bill, a gratuity was not proffered for her services, nor did she seem to expect it. 'The hostler, however, made a demand, and told us he did not receive wages from the master of the house, but depended entirely on travellers for remuneration.

The nurseries of Messrs Prince, the most extensive in America, are situated at Flushing, and were visited by us. The grounds, compared with such places in Britain, and some others which I saw in America, seemed badly kept, being full of perennial root-weeds of the most troublesome description, as well as those of annual growth.

Agriculture being little known as a science in any part of America, and but imperfectly understood as an art, the same 
diversity of opinion, and mode of management, prevail as in Britain, with greater difficulty of becoming acquainted with them. 'The following particulars relate to the neighbourhood of New York.

Grass crops are mown for hay five or six years in succession, without being top-dressed or manured in any way-the aftermath, which is seldom abundant, being depastured. Five pounds of red clover, and half a peck of timothy seeds (I'hileum pratense), are sown on an acre; and also, occasionally, small quantities of herd-grass and redtop, two kinds of poea. I believe the red clover lives longer than it cornmonly dues in the cultivated fields of 13ritain, having seen many plants after five successive crops of hay. 'The grass, on being ploughed, is followed in the first year by Indian corn without manure, by potatoes with manure in the second year, and, if early, they are followed with buck-wheat; barley is taken in the third year, and in the fourth, oats accompanied with grassseeds. Potatoes are grown in drills as in Britain, and sometimes in hills three or four feet distant, formed by the surface being marked into squares by the plough. A whole potato, or three cuttings, are placed above the manure, and both covered over with earth by the spade. Disease in the potato was said to be unknown. The fruit crop is often injured by spring frosts, and wheat by mildew. Swede turnip is sown in August, and stored before winter. Geese are plucked three times a-year-Jive goose feathers being a general article of commerce.

Farm labourers, or helps, get from ten to twelve dollars amonth, with bed and board, including washing, and a deduction is made for sickness or voluntary absence. A married man is allowed from ninety-five to one hundred and twenty dollars a-year, instead of board; and pays from twenty to twenty-five dollars for house and garden rent. The hours of labour are from sunrise to sundown, without a specified time for meals, to which they are commonly summoned by sound of horn. Hired men do not consider themselves bound for any length of time, and occasionally absent themselves for a day or two without giving notice of their intention. Hired spademen get seventy-five cents, or three-quarters of a dollar per day, without board, all the year round. 


\section{CHAP'TER IV.}

Jo:rney from New York to Philadelphia-Steum-bout-Ruilucay Coach-Militia Muster-American and British SoldiersCharacters of Tratellers-Munsion-house Hotel-FunerulExcursion to Holmshurg-Hotel-keepers in America and Irelund -Mr W**-Sir Joln Sinclair of America-Fair MountNaval Yurd-Philadelphia-Return to New York-Face of the Country-Agricultural Details.

WE left New York in a steam-boat, a little after six o'clock in the morning, and reached South Amboy, on Rariton bay, a distance of twenty-eight miles, at half-past eight. From Amboy we travelled on a railway to Bordentown, distant thirty-four miles, in carriages drawn by two horses, which were changed three times in four hours, and thence down the Delaware river, by steam, to Philadelphia, where we arrived at three o'clock.

The passengers breakfasted and dined on board the steamboat, paying half a dollar (2s. $1 \frac{1}{2} \mathrm{~d}$.) for each meal; no difterence in charge or accommodation being made, and smoking in the cabin or after-part of the vessel was prohibited. There is a bar on board, at which liquors, segars, maps, \&c. \&c., may be obtained. American steam-boats have been compared to flourishing hotels, a term not sufficiently comprehensive, as they contain barbers, commodities of different kinds for sale, and often horses and carriages. They are floating cities.

Soon after leaving New York, the passengers were warned by bell to purchase breakfast tickets, and some time afterwards to identify their luggage, when all belonging to those proceeding to Philadelphia was placed in a large crate, which was lifted from the steamer to a carriage, and again to a steamer, by means of cranes, without its contents being moved. The railway carriages rest on four wheels-are divided into three compart- 
ments, each containing six persons, many of whom are provided with tickets for their respective places before leaving the vessel. The horses were placed in sheds, ready harnessed, at the different changing places, for greater expedition in attaching them to the carriages. Every arrangement in this line of travelling is excellent.

In passing along the railway, the train of carriages stopped for a few minutes, which afforled us an opportunity of seeing a militia muster, which some writers have humorously described. The dresses of the men consisted of all hues and shapes, there were hats with and without feathers, and some garnished with roses. The guns consisted of single and double barrels, with not a few rifles amongst them. Many of the corps were seen approaching the muster ground on horseback, and others in light waggons drawn by beautiful horses. The soldiers were, generally, small, thin, miserable-looking creatures, and such as would not often have been enlisted in the British army. A young gentleman, lately arrived from England, and a fellow-passenger in the Napoleon and railway coach, was quizzing the mean appearance of the militiamen, when a blithe, jolly-looking fellow from Baltimore good-humouredly remarked, that such men as these beat off the English at New Orleans; and some conversation on the relative merits of American and British soldiers took place; the citizen of Baltimore was drawn into the question.

Whether American or British soldiers are the best, will, I trust, long remain undecided by actual trial. There is, however, no doubt, that the British are apparently more muscular than the Americans, and I imagine also more capable of enduring fatigue and privations. But large men do not load muskets faster than those of smaller dimensions, while they are more easily hit by a bullet. My ingenious friend W-, residing in the neighbourhood of Philadelphia, is of opinion, that the best fed army will always prove conquerors, and attributes the success of the American army and navy, last war, to the circumstance of the Americans having been better fed than the British. The influence of food in imparting strength and courage to animals is well known, and, under a parity of circumstances, the best fed army will prove victorious. But my 
friend's argument, to be of weight, requires the British to have been under-fed, a circumstance not likely to have occurred; but in American warfure, when men are often armed with rifles and masked by trees, strength and courage are not brought into play. While the Americans fight in their own country, in defence of wives, families, and property, notwithstanding their liberty and equality notions, and want of discipline, they will always prove an overmatch for hireling soldiers of any nation. But place them in a foreign land, amidst pestilence and privation, with no incentives to exertion but a miserable pittance called pay and frivolous glory, I doubt if they would display deeds of greatness and valour as Britons have often done.

We had not been long seated in the railway coach, when the Englishman became the butt of some Americans, who crammed him with such alsurdities, that he must have returned home, which he shortly intended duing, with very erroneuss ideas of the States; and the quickness with which his charatter was discovered by the Americans did eredit to their discrimination. 'The tenor of a foreigner's conversation with the natives on his first arrival is an index to his understanding, and the information he receives is often made to accord with his eapacity and feelings instead of truth. Without sound judgment to discriminate and appreciate information, the gleanings and impressions of a traveller must be as apt to mislead as instruct others, and his lucubrations will often be found more illustrative of his own character than of the preople and country he visits. We took up our residence at the Mansionhouse hotel, Philadelphia, kept by Mr Head; but it did not seem to warrant the praises bestuwed on it by some travellers, meal hours not being regularly kept; and the bed of my friend was preoceupied by a set of mischievous natives, which fortunately in no instance paid their respects to me.

While walking after tea, a funeral passed by, which was the first I had seen on American soil. A hearse moved slowly along the side of the street, accompanied by about thirty men walking two and two on the pavement, dressed in coloured clothes, without crape on hat or arm; then followed six or seven females, each supported by a gentleman, and both sexes were dressed in black garments, and seemed to be near relations of 
the deceased; then came forty or fifty men and women in pairs, partly in black and partly in coloured clothes, which closed the procession. I afterwards observed a funeral train at New York, composed entirely of men, chiefly in coloured clothes, arranged in pairs. The custom of attending funerals in coloured clothes is said to be of recent introduction; and as grisf springs from the heart, and cannot be expressed by hue of garment, this innovation on old custom is creditable as well as advantageous to the people.

Wishing to visit a gentleman residing fourteen miles from Philadelphia, to whom I had letters of introduction, the proprietor of the hotel demanded five dollars, $21 \mathrm{~s} .3 \mathrm{~d}$., sterling, for a carriage to convey us to the place and back again by midday. The charge appearing unreasonable, I made application at several quarters, and at last engaged an Irishman on the street, who undertook the journey for three dollars, and he fulfilled his engagement to our perfect satisfaction.

Next morning, we left Philadelphia at an early hour, and on reaching Holmsburg, were refused breakfast at an unpretending hotel, without a reason being assigned. On applying, however, at another hotel on the opposite side of the street, we were more fortunate, and had every thing set before 'us which could appease hunger or gratify the palate. 'The refusal of breakfast reminded me of being in Ireland in 1830 ; on which occasion I was accompanied by a friend. We travelled from Drogheda to Kells, in the county of Meath, in a common car of the country, exposed to a burning sun, and choking dust. On reaching that lovely village, and alighting at an inn, we were told the Marquis of __ was momently expected, on which account we could not be accommodated, and at a second inn experienced the same disagreeable reception. I exerted the little eloquence with which Nature has endowed me to obtain a single room, and after despairing of success, I petitioned for a stall in the stable. The heart of mine hostess was so far overcome as to provide tea, and allow us to wash in a dirty miserable-looking room. I here des'patched a card to a landed proprietor in the neighbourhood by an errand-boy of the house. This circumstance changed 
the state of affairs all of a sudden; but I withdrew to the house of my friend in the country. The great man did not make his appearance that evening; yet the mere expectation of his arrival deprived us of food and shelter. What a miserable state of society !

The tavern-keepers of Ireland, and those of Newton and Holmsburg, seem to have been actuated by very different motives. Both were culpably unaccommolating; but those of America, probally, acted from saucy independence-those of Ireland, from greedy and needy dependence. P'addy wishcd to fawn on the rich man, and enjoy the crumbs which fell from his establishment; while Jonathan indulged his own humour, and disregarded crumbs of every kind.

Just as we approached $\mathrm{Mr}$ W__ 's, rain began to fall, and prevented our examination of his farm, which I much regretted. Our stay, however, was prolonged till after dimer, having been fascinated by the sentiments of his powerful and original mind. Besides acquiring much useful information regarding the Enited States generally, I learned the advantages of introductory letters, which i too lightly esteemed, from the circumstance of having, when a young man, travelled over a considerable portion of England without such credentials, and obtained access to whatever interested me, by stating, either verbally or in writing, the olject of my visit. Mrs II-_- asked me if I had a friend named Flanagan, and on being answered in the negative, added, that a person, passing by that name, introluced himself to her husband as my bosom friend, and in consequence received considerable attention for seven or eight months, at the end of which he decamped, without paying his debts. On reflection, I recollected having received and answered two letters from a person of that name in the north of Ireland, which formed the extent of our intercourse. Introductory letters have become so common of late years, that in many quarters they are treated with neglect. They are perhaps unnecessary to liberal-minded men, and only useful to guard against imposition.

Returning to Philadelphia in the afternoon, I delivered an introductory letter to an eminent individual, who had been described to me as the Sir Jolun Sinclair of America, which 
appeliation I found he well merited. A dirty-looking girl opened the door of a house in one of the principal streets, and clesired me to occupy a seat in the passage until came down stairs. The passage was about five fect wide by forty in length, and so dark that objects were not distinctly visible in the lightest part of it; and in this hole, on a plain woolen chair, I sat for upwards of a quarter of an hour before the gentleman made his appearance. During this interval of suspense, I debated with myself the indignity offered me according to British notions, and whether I ouglit to leare my dungeon in disgust; hut on reflection I resolved to sulimit to any thing, short of insult and imposition, that might come in the way, whilst amongst the Americans, for the double purpose of seeing character aud ensuring personal comfortknowing how disagreeable it would be to act at variance with the manners and customs of a nation, and vain to expect to bring the population to my way of thinking on such matters. The gentleman at last made his appearance, and conducted me to a room, without saying a single word about the delay he had occasioned, or the situation in which I had been placed; and from his manners being easy and polite, I was led to conjecture that sitting in the dark lobby was a common occurrence with his visitors. My reception was flattering, his offers of service extensive, and conversation, which was chicfly agricultural, more fluent than profound.

Rain continued to fall in torrents during the night and next day, which prevented us visiting the celebrated botanic gardens belonging to Colonel Ker, to whom we had letters. With the aid of a street coach, we, however, reached Fair Mount, where public works which supply the city with water are situated. The machinery is propelled by water from the river, part of which is raised to an elevated reservoir, from which the city receives a copions supply for every purpose. The reservoir is surrounded by a pale fence, enclosing wellkept walks, accessible by flights of steps. The beauty of the spot and surrounding scenery deserve a visit from every person of taste, even although they disregard the machinery of the works.

From Fair Mount we drove to the Naval Yard, which we 
reached just as the workmen were leaving it to dine, during which time visitors are excluded. The sentinel on duty enquired if we were foreigners, and on learning that we were, conveyed information to his superior in command, but on his return informed us we could not be admitted. While we lamented being too late to see the Naval Yard, the justness of our exclusion was fully admitted.

Philadelphia contains about 170,000 inhabitants, is the second place in population and the fourth in shipping within the United States, and forms the depoit to a county yearly increasing in population, wealth, and extent. It is situated on the west bank of the Delaware river, which is navigated by vessels of the largest size. Many of the streets are shaded with trees, and all of them remarkably clean and well paved, running parallel and at right angles to each other. The houses are generally built of red brick, those of some of the principal streets having the basement, steps, door, and window sides of white marhle. 'The doors are in general painted white, and have silver handles and knockers. Houses of this description have a chaste and pleasing appearance. Many of the public buildings are elegant, and composed of white marble. The city is generally considered regular, to a fault-the inhabitants the most wealthy, fashionable, and polished in America.

The weather continuing wet, we left Philadelphia for New York at three o'clock in the afternoon, passing the night at Perth Amboy, where we paid a charge of threepence sterling for cleaning boots, and reached New York next morning. The railway from Amboy to Bordentown passes chiefly through Middlesex county, state of New Jersey. The soil is absolutely drift sand, and, according to my present notions of farming, unworthy of eultivation. The crops consisted chiefly of rye and Indian corn, and were uniformly bad. Clovers and timothy grass are seldom sown. In several instances lime and gypsum had been applied where Indian corn was growing, having been carried to the field in waggons, and spread thinly over the surface. In one instance farmyard manure was being applied in imperfectly formed drills, which I supposed were destined to receive potatoes. Women were seen hoeing Indian corn in the fields, but I could not discover whether they 
were white or coloured. The cattle grazing on the scanty herbage appeared mere starvelings, and smaller than some of the Ilighland cattle of Scotlaud. The sheep were even more miserable-looking than the cattle, and many of them retained their winter fleece. P'igs corresponded with the sheep and eattle; the horse alone forming an exception to the general wretchedness, some nohle animals of this species lreing met with. Many orchards, consisting chiefly of peach-trees, the fruit of which is distilled into brandy, had been lately formed, and seemed the only thriving thing on the surface of the earth. The men seen at the militia muster, already noticed, are inhabitants of this district, and appeared to partake of its character.

When passing along the railway, I was much struck with the beauty of a plant, bearing a profusion of pink-coloured flowers, which the rapidity of motion prevented me seeing distinctly; and on asking its name, one pasienger guessed it to be lauristinus and another hawthorn, but which I soon discovered to be rholodendron. This plant grows in great profusion along the road, and more especially around the seat of Joseph Bonaparte, near Bordentown.

The country around Philadelphia through which we passed, forms a striking contrast to that of New Jersey; its general aspect resembling, in all respects, the finest parts of the south of England. Many of the fences consist of well-kept thornherlges, studded with wide spreading trees; and many of the crops were excellent, although the soil is not generally in a high state of cultivation. The trees were covered with massy rich foliage, superior to any thing I had ever witnessed befure-the effects of which were heightened by the season of the year and prevailing weather, which was warm and moist. Here and there a few pollard trees were seen raising their thin tops and branchless trunks amidst the glorious exuberance of nature; and when viewed in the landscape with the weeping willow, queen of American vegetation, the tendrils of which, clothed with shining leaves, hang in graceful festoons thirty feet in length, show how destitute of beauty are the works of man when compared with those of nature.

Men assisting at farm-work, in the neighbourhood of Philadelphia, get from ten to twelve dollars, with maintenance, 
per month, and they are not easily obtained to attend regularly at work. Young men and women of the industrious classes in the country dress in fashionable clothes of the finest fabrics before marriage, after which, the wife becomes a lady, and generally engages a hired girl or help. 'Thrashing machines are common, but not good; and when the flail is used, barley and oats cost three cents, rye seven cents, and wheat twelve and a half cents per bushel, when found,-that is, food provided for the workmen. From the high price of human labour. compared with the price of food, Indian corn is often trod out by oxen. Craddlers generally mow round the field when the crop admits of doing so; and stop only when the scythe requires to be sharped. Hay costs in cutting from one to om and a half dollar per acre. Mr W - pointed out a field of rye which was a good crop, and which he had a few days before let to be craddled at seventy-five cents per acre, without board or any other etcetera. The craddler not being permitted to sit at table with the family, and disliking to eat in the kitchen, had agreed to board with one of Mr W-_'s labourers for forty-five cents per day, and would be thus fed, viz. breakfast at seven o'clock, on wheat-bread, rye-bread, fish, cheese, butter, and coffee; luncheon at ten o'clock, on cold meat, pickled pork, cheese, butter, pickles, bread, and coffee ; dine at twelve, on every thing that is good and substantial; at five is served coffee, with bread, butter, fruit, and fruit-pie. Occasionally supper is taken at seven, but this meal is considered superfluous. Mr W - thinks Americans perform a great deal more work than Englishmen, which he attributes to their being better fed. At the conclusion of my transatlantic tour, my opinion is, the inhabitants of America do not work near so much as those of Britain throughout the week or year, although they may, perhaps, do more in a day. The strength and expertness of workmen seems a favourite idea-those of every district which I have visited being accounted by the inhabitants the best in the world. But the climate of Lingland being better fitted for exertion than that of America, and the apparent health and strength of Englishmen superior, I can discover no reason why they should do less work than the Americans. Men and animals may be considered machines 
capable of manufacturing or yielding labour according as they are fed, provided their powers be not weakened by excess, or other circumstances affecting health. 'The half-starved, potatofed Irishman could no more keep pace during a day's work with the meat-eating American, than the grass-fed steed with one trained on corn and hay. It is shortsighted policy in a master to pinch his labourer of food, when he reaps thefruits of his exertions.

In the neighbourhood of Philadelphia, land of fine quality and in high condition, may he had from 100 to 120 dollars per acre. Produce of all descriptions is high, and the straw of a wheat crop has been sold at thirty dollars per acre. Wheat is often mildewed. I saw several fields of a newly introduced grass, called Andes grass, said to have been lately bronght from the range of hills in South America bearing that name. On examining the plant in the fields, and the seed in the shops, I think it is identical with the small-bulbed oat-like grass (Holcus avenceus of Sinclair) indigenous to Britain, and which I afterwards observed growing in a state of nature in different parts of New York State. Much has been said and written in exaggeration of $\mathrm{Mr}$ W__'s system of farming; and he seemed highly amused when told of their nature. He grows excellent Swede turnip after his wheat crop, and this is the only succession of crops he gets in one year. His system is to plough in green vegetable matter, such as clover aftermath, French beans, and Indian corn, for manure to other crops. Horses and cattle are soiled with green food in summer, farming operations appeared to be well executed, and every thing connected with the establishment was in good order. Mr W. takes charge of agricultural pupils for 300 dollars a-year; and, from my visit to this gentleman, I think him eminently qualified for imparting knowledge to them. Young boys are often apprenticed to farmers for four years, with a stipulation of getting a quarter's schooling each year of their apprenticeship. 


\section{CHAPTER V.}

New'York-Damesk hair-cloth munufuctory-Dr H_, President Juckson, and Bluck Hauk-Myde Purk-Residences in Americu and Britain-Taste for Flouers-Cattle and Sheep_-Scenery of the Hudson and Clyde-Fust Euting-Allony-Couch I'assengers-Women working in Fields.

Several days were spent in viewing the beauties of New York and its neighbourhood, which the works of recent travellers render unnecessary for me to describe at length. This eity is the first city in the Union, both as to shipping and population, which does not perhaps fall much short of two hundred and forty thousand. It is situated on an island separated from the mainland by a small ereek passing betwixt the north and east rivers, which some individuals failed in converting into a canal. From the site of New York as an emporium of trade, there seem to be no limits to the extension of the city and its suburbs. It is already the chief outlet of much of the produce of the eastern parts of the New lingland states, part of Pennsylvania and Ohio, and almost the whole of New York State. When the canals and railways now in progress are completed, it will also become the depot for part of the produce of the states of Indiana, Illinois, and the unsurveyed country to the west of Lake Michigan, traversed by the rivers Mississippi and Missouri; and, in the course of events, Upper Canada may be added to the list. The mouth of the Mississippi seems the only outlet, calculated by the extent of inland navigation, to vie with New York; but the warm and pestilential nature of the climate unfits it for the reception of produce, and the residence of man. The public and private buildings vary in size and elegance; and the inhabitants are justly proud of Waverley and Lafayette Places, the houses of the latter being decorated with immense 
Corinthian pillars, and the whole fronts and steps consist of marble. The strects are not so clean as the inhabitants wish strangers to believe; but as swine seem, in part, intrusted with the charge of removing the filth, they are in as good order as might be expected. The strects appear to be thronged at all hours, noise and uproar prevailing when I retired for the night; ladies and gentlemen on horseback, and the industrious on foot, were bustling forth at five in the morning when I arose. Einblems of aristocratic pride and shitmeless mendicity occasionally met the eye, in the red rests and peculiar cut coats of serving men standing at the back of luxurious carriages, and in the extended hat supplicating charity. Like other large commercial and manufacturing town, activity characterises the inhabitants by day, dissipation by night.

At Johnston and Green's manufactory I saw a newly invented fabric of great beauty - damask hair-cloth, consisting of different patterns, the raised figures being sometimes of silk and sometimes of linen. A patent has been obtained for making this stuff, both in the States and in England. It forms a beautiful covering for sofas and chairs, and is said to be durable. I paid one dollar for the linen, and two for the silk damask, per yard, in small quantities. About two hundred people are employed at the manufactory, and, at the time I saw them, they all appeared happy, healthy, and clean. Young women, when weaving by the piece, earned three dollars (13.8.1.) per week; small boys, six and seven years of age, one dollar; the hours of labour being from six in the morning to seven at night, with intervals of half an hour for breakfast, and an hour for dinner.

Having forwarded an introductory letter to Dr $\mathrm{H}-$ who, on my arrival at New York, was at his country-seat, I had intimation of his return to town a week afterwards. On calling upon the Doctor at his friend's house in Street, I was ushered into the drawingroom by a tawdrylooking girl, without announcing my name. My reception was all I could have wished; and on learning my intended movements, he expressed regret at not being able to be at — by the day mentioned, and expecting General 
Jackson, the President, to visit in course of his tour, already commenced, proposed that I should wait and form one of the party. 'There is no ruler of any portion of the earth I would so soon associate with as a President of the United States of America, chosen by a free and enlightened people, to administer their laws; but the task which 1 had imposed upon myself did not warrant delay in an indulgence of feeling, -forming part of the President's tail, being unconnected with the objects of my excursion. I had no reason to regret this act of self-denial, the conduct of the people and President during the tour being such as I could not admire.

General Jackson having resolved to visit the chief towns in the northern parts of the Union, he got as far as Buston, when he was compelled by fatigue to return to Washington. In every town his deportment and reception seemed an imitation of the rules of despotic countries-a spectacle to the crowd, and an object of extravagant devotion. An Indian chief, named Black Hawk, who had been taken prisoner the preceding year, in a war to the west of Lake Michigan, and who was carried through some of the great towms, with a view of impressing him with the power of the States, preparatory to his liberation, arrived at New York the clay after the President, and divided public attention. The ladies declared in favour of Black Hawk, some of them actually kissing him, which, it is said, affected the old President's health. The chief of the white men, and the chief of the red, were alike objects of curiosity ; the President holding a levee by day, the Hawk by night, in Niblo's gardens. Had a mam-moth or elephant appeared, the mighty ones of the earth would have been eclipsed in public favour,

We left New York early in the morning, by the Albany steam-boat, for Hyde Park, after viewing which we returned to the landing-place on the river Hudson, and, at half-past twelve at night, stept on board of a steam-boat which landed us at Albany a little after seven next morning. I got on deck at four, when passing the town of Hudson; the wind was blowing high from the north, and piercingly cold.

Hyde Park, the seat of Doctor Hosack, is the most cele- 
brated in America, and which Mr Stuart describes as being "embellished as a fine residence and fine grounds in lingland." The house is situated some hundreds of feet above the level of, and at a consilerable distance from the IIudson, the intervening grounds being finely undulating. In front of the house there is a road, leading from the landing-place on the river, along a small stream, over which there is an elegant wooden bridge, and several artificial eascades have been formed in its channel. The house is composed of wood, as well as the offices and lodges, painted white, and are very neat of their kind. The conservatory had been dismantled a few days before our arrival, by placing the plants in the open air; the collection seemed extensive and well kept. The flower garden is small, the walks limited, and both destitute of beauty. I am aware that most of the evergreens which impart loveliness to the residences in Britain cannot withstand the rigours of an American winter, but this circumstance is no excuse for the nakedness of Hyde Park walks, the aid of many native plants having been disregarded. 'The matchless beauties of the situation have not only been frequently neglected, but destroyed by stiff, formal, naked walks, and the erection of temples resembling meat-safes, without a climbing plant, which the country produces in endless variety, to hide their deformity, and harmonize them with the surrounding scene. In short, while I greatly admired the situation of Hyde Park, I do not recollect having seen a celebrated place where nature had done so much, and man so little, to render - beautiful. The embellishments at Hyde Park, contrasted with those met with every day in Britain, place American landscape-gardening immeasurably behind, if it can be said to exist.

The progress of a people in refinement and taste, manifested in a combination of nature and art, is commonly the work of time, and the decoration of grounds an unproductive investment of capital. Thus the residences of England having descended for ages in the same line, without the power of possessors changing their destination, may be said to represent the accumulated savings, labours, and tastes of many genera- 
tions. In America the country has not been long possessed by the present owners, and property does not necessarily descend in the same line; and if to these causes be added the high price of labour, and the scarcity of capital, the state of the residences will be sufficiently accounted for. Dr Hosack has great merit in what he has accomplished, but it is mockery to compare his grounds, in point of embellishments, with the fine places in Britain, which have originated from circumstances which America is not likely soon to experience.

Throughout the whole of my transatlantic tour, the inhabitants of the country manifested perfect indifference to the beauties of nature. It was rarely $I$ could learn the name of a plant, with the exception of trees. Nurserymen, seedsmen, and farmers were, generally, unacquainted with varieties, and, with exception of two or three individuals, no one seemed interested in the matter. Rhododendrons grow as plentifully in many parts of the Eastern States as furze in Britain, yet 1 saw vast numbers of this plant shipping at Liverpool fur Philadelphia, although millions of the same variety could have been obtained for the trouble of lifting, at no great distance from the eity. Gardens and nurseries were overrun with weeds, and did not display beauty either in decoration or arrangement.

Hyde Park is also celebrated for its agriculture, which I found under the charge of a gentleman from Fifeshire, Scotland, a person on excellent terms with himself. The farm offices, which are extensive, would be considered good in most situations, and were the best I saw in America. There was a young hawthorn hedge, well kept, and in a thriving state. The cattle consist of imported short-horns, or their descendants, and one or two of the best cows were tolerable specimens of that breed. The sheep were said to be a mixture of the Leicester and Cotswold breeds ; the pure blood of the former not having been found to answer. The flock was miserably low in condition, and the ewes were followed by large, though not fat-looking, lambs.

Ilowever well the short-horned breed of cattle, and improved Leicester sheep, may have been found to answer in some parts of Britain, it is doubtful if the farmers of the State 
of New York will benefit themselves by introuluring them. The one is remarkable for lack of dairy produce, and the other for inferior quality of mutton ; and both for heing unprofitable, unless liberally supplied at all seasons with nutritious food. The population of the eountry cannot well dispense with any part of their present dairy produce, and do not require an increase of quantity at a sacrifice of quality of mutton, while the present state of agriculture does not furnish a sufficiency of food for the health and growth of short-horns and Leicesters during winter. I imagine smalles and more hardy breeds, of both kinds of stock, will be found more profitable for general purposes.

During my residence at New York, I attenderl the cattle market, which was stored with moderately fatted cattle, many of which had been worked. I also witnessed a herd of two hundred passing along the streets, said to have come from the state of Kentucky, forming part of four thousand which had been bought by one company, and brought forward in weekly supplies. They bore some resemblance to the Hereford cattle of England-were four and five years old, of excellent quality, and were estimated to average eighty stones dead weight, of $14 \mathrm{lbs}$, to the stone.

The scenery of the Hudson did not realize my expectations on first view, an occurrence which frequently takes place when much has previously been heard in praise of objects. Every person of observation must have remarked how different scenery appears under a change of circumstances. The weather being cold and raw during the passage, affected, perhaps, my feelings; and it was not until the objects had been seen a second time in the beginning of November, that I became sensible of their beauties. The Palisadoes, a line of rocks extending for twenty miles on the west side of the river on leaving New York, are of moderate height, with their base covered with stunted trees, and convey nothing of the sublime to the beholder. The objects became more interesting on approaching the high lands where Anthony's nose is situated, and forms the most prominent and beautiful feature. The channel of the river seems to have been produced by a mighty convulsion; the banks being destitute of soil, and the islands 
masses of pure rock, which strikingly display the economy and beauty of nature - the islands, without a particle of soil or blade of grass, being thickly studded with healthy, though small trees, while the perpendicular rocks on the banks, from the water's edge to many hundred feet in height, were adorned with blossomed kalmias.

The margins of the river Hudson, and islands in its course, assume a different character on approaching Albany; the islands being depositions of mud, susceptible of cultivation, and the banks rich soil, bearing good crops, and adorned with pretty houses.

The tide flows up the Hudson to Albany, distant from New York 144 miles, admitting vessels of considerable burden, and sloops of small size penetrate much farther up the river. 'The waters of the Hudson, passing through a rich and popu. lous country, forming the outlet of the Lrie Canal, present a never-ending scene of pleasing industry. At all times innumerable sailing vessels, with extended cotton canvass, whitened by a bright sun, and pure air, float gracefully to and fro. Steam-boats, crowded with passengers, pass with rapidity, while cock-boats, loaded with fish, poultry, and fruit, rest in quietness. Sloops carrying well-formed hay and straw stacks, glide towards New York, while steam-boats tow canal barges and vessels of every description, up and down the river. The surrounding country is also full of interest, abounding in thriving villages and towns, each forming a depot to the country in their rear; besides villas, academies, hotels, prisons, and forts without number, associated with the history, literature, and improvement of the country. To a citizen of the States, the Hudson is the most interesting, beautiful, and important river in America, and no foreigner of taste can be insensible to its charms.

The scenery of the river Clyde, in my native country, is of a different character. In vegetable decoration, the banks of the Clyde are greatly inferior to those of the Hudson, as well as in soft and picturesque beauty, although some sweet landscapes, such as the bay of Rothesay, are found on the former. But the Hudson is altogether wanting in the rugged blue mountains, so conspicuous from the Clyde, which are the 
most noble and awe-inspiring objects of nature. I know not whether it is taste or prejudice which makes me prefer the scenery of the Clycle to the Hudson.

On reaching Albany, the bustle and confusion on board the steam-boat, with passengers landing, and porters scrambling for the luggage, was excessive; and there was some difficulty in preserving unauthorized hands from carrying away our effects. We reached the Columbian hotel rather late for breakfast; after which we walked about the town. Things appeared very different from what New York presented : carts, waggons, and carriages, as well as the animals harnessed to them, were greatly inferior. 'The population did not appear so active, and the eye looked in vain for those ladies whose fashionable attire, interesting countenances, and elegance of feet and ankles, delight the beholder. Our dinner party consisted of upwards of sixty. One gentleman dined in five minutes, reckoned by my stop-watch; the ladies rose from the table at the end of twelve; dinner and dessert occupied about fifteen minutes. The affair seemed an eating race, and my companions not being aware of the rapidity of the pace, were sadly behind. I was amused at a little jockeyship displayed in the contest. An individual, as soon as he seated bimself at table, emptied a dish of green pease on his plate, to the evident disappointment of a gentleman on his right hand, and when a fresh supply appeared, he performed the like feat a second time, although part of the first seizure was unconsumed. Few of the party drank wine during dinner, and very little of the brandy which stood on the table, for the use of the company, was used. At tea, a gentleman removed from table in four minutes, but the party generally sat as long as at dinner.

Albany is the capital of the state of New York, containing about twenty thousand inhabitants, and has lately been made a port of entry. From being situated near the outlet of the Erie Canal, which is the channel of commerce with the country to the west and north, and on the line of railway now in progress, which will soon connect Boston with Lake Erie, it is almost certain to rise into importance. It is at present a place of considerable trade, being the seventh or eighth in the union. 
Betwixt dinner and tea I took an opportunity of delivering a letter of introduction to a gentleman residing a little to the north of Albany, availing myself of a railway coach proceeding to Schenectady. I chose part of an outside place behind, sufficient to accommodate five individuals of ordinary size, and which was occupied by two beings, half-men, half-boys, sitting cross-legged, and who, by their position and expression of countenance, seemed resolved not to admit a third person. After waiting for some time without speaking a word, I made preparations for taking a place between them; and at last their legs were only withdrawn to escape the weight of my body. I notice this circumstance, trivial in itself, as being the only instance where rudeness, or want of an accommodating spirit was manifested by travellers in the course of my American tour. The gentleman I called on being from home, I returned by the fields to Albany. On my way I saw a grey coloured fox, which appeared larger, and not so active as the red fox of Britain. I observed several women engaged in the fields in weeding, cutting, and planting potatoes, and none of them seemed in poverty, or tinged with black blood. Mr Stuart, in his " Three Years' Residence in America," says, women are not allowed to work in the fields, without saying whether the prohibition arises from custom or by law. Women are actively employed in different occupations when their services are wanted, which does not, however, often occur. 


\section{CHAPTER VI.}

\section{Journey from Albany to Boston-New Lebanon-Pillsfield-Road Repairing-The Features of the Country-Rhododendrons- Northampton-Mr Stuart's Description of Northumpton-Stage Passengers-Mode of Courtship_Villages-Agricultural No- tices.}

MY companions and I having left Scotland without fixing on a route by which we were to proceed, I consented to visit the New England States, in order that I might claim their company through the Western States, to which they expressed an aversion. Accordingly we left Albany at two o'clock in the morning, by a stage which carried the mail-bag, crossing the Hudson in a horse ferry-boat, and reaching Nassau, by five, where we breakfasted on indifferent fare. Shortly afterwards we passed New Lebanon, finely situated in a lovely valley, surrounded by picturesque hills, a great part of which belongs to the religious sect denominated Shakers, whose principal establishment is here, and whose garden seeds are justly esteemed throughout North America. New Lebanon is celebrated for mineral waters, chiefly used for bathing; and the hotels afford ample accommodation for visitors. Nine miles beyond New Lebanon is the village of Pittsfield, a clean and beautiful village, reposing in a charming valley. The houses form a spacious square, in the centre of which is a tall aged elm, seemingly a remnant of unsubdued nature. There are several churches and hotels. Here the members of the Berkshire Agricultural Society, the oldest in America, hold their meetings, the first show of which took place in 1807, and consisted of two Merino sheep. We dined at Peru, a miserable country hotel, where bad fare was washed down by worse tea, the first time such a beverage had been presented to us during dinner, and is presented only in inferior 
hotels. We reached Northampton about six in the evening, having travelled seventy-seven miles in sixteen hours.

This day's travelling afforded opportunities of seeing the American system of road-mending, or more correctly speaking, road-destroying. A plough, drawn by four, and oceasionally six oxen, with two drivers, one man holding by the stilts, and another standing on the beam, is passed along the margins of the road, turning every fifty yards. 'The loosened earth is then moved to the centre of the road, by men with shovels, or by a levelling-box drawn by oxen, the stones, great and small, being first carefully removed from amongst the earth, and in many instances more were thrown aside than sufficient to Macadamize the road.

The country from Albany, has not an agricultural feature worthy of notice, the soil being chiefly poor sand, interspersed with rocks and innumerable stones. The crops were truly miserable, and the pastures thinly clothed with sheep and cattle, which were invariably lean. Some beautiful cows were seen at Northampton, apparently descended from the North Devon breed of England.

The road in several places was so hilly that the stage passengers walked on foot, which afforded an opportunity of examining much that was interesting. 'This was one of the happiest days of my life, almost every moving and stationary thing on the earth's surface being new to me, and the weather fitted for displaying them to the best advantage. Strawberries of different kinds were gathered, tasted, and their seeds preserved. Shrubs and flowers were culled and compared. Insects and birds seemed to vie with each other in displaying brilliant colours; squirrels and woodpeckers of every hue were sporting around the trunks of aged trees, and the snakes were basking in the glorious sunbeams. Nature seemed in jubilee.

The forests through which the road led were strewed with decayed and decaying trees of former ages, and at the same time exhibited living specimens of each variety in every stage of growth, from the seedling budding into. existence, to the aged pine, bearing the white and flowing tresses of Spanish 
moss, so emblematical of hoary and declining man. The flowers of rhododendrons and kalmias were unexpanded on the highest ridges, and opening into beauty in the valleys below, illustrative of the effect of elevation on climate. 'These plants were growing in all situations, on rocks, deep rich soil, beneath trees, and on exposed banks of rivers. The kalmias with bright red flowers, and white and pink blossomed varieties of rhododendron, were mingled in pleasing groups.

Near Northampton some snow-white rhododendrons, twelve feet in height, rich in blossoms and foliage, were shading cows browsing on the banks of the river, where decaying trunks of pine-trees stood in picturesque combination, like ruins of an ancient castle. After partaking of tea at an excellent hotel, we walked forth to survey the village, which is reckoned the most beautiful in New England. Northampton is extremely irregular, branching into roads leading in all directions. The houses are composed of wood painted white, with green Venetian blinds. 'The congregational church is a handsome structure, of the same hue and materials as the houses, and cannot fail to attract the notice of strangers, being one of the best specimens of wood and paint that the United States afford. The ranges of houses are enveloped in trees, amongst which are many magnificent elms, members perhaps of the original forest, reducing modern vegetation to insignificance, and affording umbrageous shelter to the inhabitants. The village stands in the rich valley of the Connecticut, and is surrounded by hills rising nearly 1000 feet in height, wooded to the summit, the chief of which is Mount Holyoke.

My impressions of this village, which must be attractive at all times, were perhaps heightened by the circumstances under which it was viewed. A delightful day's travelling had terminated at a comfortable hotel. The air was luxuriously balmy, and a cloudless sun, on the eve of setting, imparted a rich mellow tint to the face of nature, with which every person of observation, leading a country life, must be familiar, and have experienced how decorative it is to vegetation, and soothingly gratifying to human feelings. The houses, decked in white and green colours, which harmonize in rural scenery, 
and are associated with purity and shade, so desirable during an American summer, were in keeping with the landscape. In seeking for a comparison to Northampton, memory suggested the village of Dirleton, near to my native place in Scotland. But Dirleton, although associated with some of my best cherished recollections, and containing a picturesque ruin shrouded in ivy, and adorned with shrubbery of unrivalled sweetness, yielded to Northampton in situation, buildings, and vegetable beauty.

Having carried Mr Stuart's work, " Three Years' Residence in America," with us, as a kind of guide-book, for which it is recommended in the author's preface, we experienced considerable disappointment at being unable to corroborate his description of Northampton. Instead of finding that " much of the pavement and steps are of white marble," we could only observe a small portion which consisted of red brick. I shall not, however, take upon me to say there is no white marble pavement or steps in the village, but three of us walked about for an hour and a half without discovering a single stone of white marble; we did not, of course, approach villas remotely situated from the public roads, with a view of gratifying our curiosity, but every street, lane, and walk which promised gratification, were explored. His allusions to the vegetable beauties are also unhappy, when he says, "if a traveller in Britain were to stumble on such a place as this, he would not fail to enquire whose great estate was in the neighbourhood, and attribute the decorations of shrubs, flowers, \&c., which adorn even the smallest habitations here, to the taste of a wealthy neighbour, or his being obliged to make them to promote electioneering views." In the streets of Northampton, we numbered three or four bushes of lilac and white pipe, and a few roses, as the amount of shrubs adorning the foreground of houses, and flowers of small size were equally rare. The spaces were generally unmown grass, and in several instances luxuriant thistles and docks excluded light from the apartments. At the back part of the hotel in which we lodged, there was a garden, surrounded with a low ugly wooden fence, and crowded with the gaudiest of flowers, but our general impression was, that the gardens are ill kept, void 
of beauty, and unworthy of the place. I would require no better illustration of the small progress the inhalitants of the United States have made in gardening than Northampton, where man hath long resided, and done so little to improve the exquisite beauties of nature.

We left Northampton at three o'clock next morning, and passed the bridge and valley of Connecticut hefore daylireak, breakfasting at Balchertown, and passing through Ware and Brookfield to Worcester, where we dined, and reached Boston Tremont hotel in the evening.

The stage passengers, in course of the day, were intelligent, communicative, and agreeable companions, polite during meals, and frequently asking others to partake of the dishes they distributed. A gentleman asked me if the old mode of courting in Scotland was still practised-when, after the consent of the lady's parents had been obtained, she was mounted on horseback, and her suitor placerl in a similar situation, and if he could not overtake the fair one, it was considered a refusal. I laughed heartily, and assured him it was the first time I had heard of such a custom existing in my country, which, in all probability, never existed there, and could not now, as most of the youth of both sexes were denied the luxury of riding, by a heavy tax on saddle-horses. He rejoined, with an air of astonishment_" What! horses taxed! Does any thing escape government? Would a man having a nose longer than his companion's be taxed for it?" I answered, "if he filled it with snuff-a practice very common amongst my countrymen - he would be taxed."

The villages through which we passed presented the same characters-white wooden houses with green Venetian blinds, and every thing wearing the appearance of cleanliness, order, and comfort.

The use of wood for fuel, the machinery of the manufacturing villages-and all of them may be termed suchbeing propelled by water, and the absence of coal smoke, contribute, in no small degree, to the external cleanliness of the houses and garments of the inhabitants. Manufacturing establishments were conspicuous in every direction, and innumerable bundles of rye straw were bleaching around the cottages 
-the manufacturing of straw hats to an immense extent being carried on in this district.

We passed the workmen employed at the Boston and Worcester railway, at present in progress, and which, it is said, will ultimately be extended to Albany. Agriculture furnishes little of interest, the soil is poor, and the crops partaking of its character-rye being the prevailing crop. Small patches of Indian corn were observed, nearly destroyed by frost ; and the pastures were inferior. In the neighbourhood of Worcester, many of the fences consist of stone walls. Within a few miles of Boston five or six men were engaged in throwing peats out of a bog, seemingly for the purpose of fuel.

The horses observed on the roads were lean and inferior. Draught oxen seemed in good condition, and of large size. Many of the cows were finely formed, of a deep red colour, with dark faces. Barberry, elder, and aller were growing plentifully in a state of nature. The rhododendron seemed to occupy the place of furze in Scotland-the kalmia that of heath. 


\section{CHAPTER VII.}

Journey from Boston to Lowell-Lynn-Salem-Newburghport - Female waiters, or helps-Agricultural notices-Stage passengers-Lovell-Manufacturing females-American and British manufacturers-House building-Benevolent SocietiesWater power-Manufacturing power of Britain and the United States-Notioes of Nature.

Having had my eyes injured in travelling from Albany, I was unable to enjoy the sights of Boston-accomplishing only, with the aid of a shade, the delivery of a letter at 50, North Market, where there is an extensive assortment of agricultural implements, meriting the notice of farmers.

Next day we left Boston for Newburghport, a distance of twenty-four miles, travelling by way of Lynn and Salem, the latter containing about 13,000 inhabitants, many of whom are extensively engaged in the Indian trade, and the former containing 4000 souls, is celebrated for the manufacture of ladies' shoes.

Newburghport is situated on the banks of the river Merrimack, three miles from its mouth, over which there is a suspension bridge of six arches, 350 yards in length. It possesses considerable trade, and contains a population of about 7000 souls. In our progress through the New England States, attendants at table, except in cities, were chiefly females, more especially during tea, which is invariably served out by them. The female waiters at Newburghport were ladylike in manners and appearance, and politely opened the door on our retiring from meals. In every case that came under our notice, their . demeanour was prepossessing, and such as would command respect from gentlemen. Having been unaccustomed to such attendants, I felt disappointed at the manner in which their services were received at table-a polite or kind expression 
never being addressed to them, and their assiduous attentions unacknowledged. In no instance did I observe a female attendant seat herself at table, nor even in the room with the guests of a hotel, and only on one occasion, in a private house, a help of slender years occupied a seat in a dark corner of the room during tea, when her assistance was not required. I do not see why a belp of low or high degree should not seat herself when her services are not wanted. There are many anomalies in human customs. In Asiatic countries, the slave is required to bend himself almost in the dust, while in Britain the superior exacts homage in an erect posture.

Remaining for the night at Newburghport, we hired a gig for the purpose of visiting a farm fourteen miles distant, belonging to a gentleman residing at New York, to whom, for his polite and friendly attention, I am much indebted, and should feel pleasure in having an opportunity of expressing my gratitude by deeds. We returned by Newburyhport, in time for dinner, after which we proceeded by stage to Lowell, along the banks of the Merrimack by Andover.

The country from Boston to Newburghport and the interior, which we visited, is low and marshy, with a poor soil and inferior crops. The pastures appeared in most cases suffering from want of drainage and previous management. In the eastern States of Ameriea, and more especially in those of New England, hay is the best paying article of farm produce, which induces farmers to mow their grass lands when first sown down, year after year, so long as the herbage ean be collected with the scythe, after which it is converted into pasturage. Grass land so treated eannot fail of yielding a poor return in pasturage in any country, and more especially in the States of New England, where there are few natural grasses, the soil poor, and where the husbandman does not assist nature by a judicious supply of seeds. Many of the enclosures consist of stone walls; and in one instance, near Boston, I observed an excellent thorn hedge. On the farm which we visited, there was a good short-horn bull, and a thrashing-machine. The wheat straw of the preceding year was sadly mildewed. In one instance I observed meadow 
foxtail grass growing in a situation which induced me to think it was indigenous.

The surface of the country along the banks of the Merrimack, after leaving Newburghport, is fincly undulating, and several sweet lakes were seen. 'The soil, on passing Andover, was of the worst description of sand, bearing crops truly wretched. A few patches of hops were seen in the fields.

The stage from Newburghport to Lowell was crowded with well-dressed females, unemlarrassed in manner, untainted with forwardness or vulgarity, and who evidently had not been accustomed to high life. On our arrival at Lowell, we observed several stages deposit loads of the same sex, which circumstance was accounted for by the extensive cottonmanufactories situated in the immediate neighbourhood. There is a constant succession of females departing from, and arriving at, Lowell; the high wages of those attending the factories' attract such as particularly want a sum of money, after obtaining which they return home.

Lowell is the chief seat of cotton manufactures in the Lnited States; was formerly a section of the town of Chelmsford, and derives its name from Francis Lowell, who introduced the manufacture of cotton into the States. It is situated at the confluence of the rivers Merrimack and Concord, and has risen into manufacturing importance of late years. The source of its riches and power is the water of the Merrimack, which is conducted to the town by a canal, one mile and a half in length, eight feet deep, and sixty wide, distributed by lateral branches, and again discharged, either into the Merrimack or Concord; the fall being thirty-two feet. Lowell communicates with Boston, from which it is distant twenty-five miles, by a canal, and a railway is now forming.

The manufactures comprehend those of cotton, and woollen of various kinds, gunpowder, ale, \&c. The chief manufacturing company is the Merrimack, which, in 1832, employed four hundred males and nine hundred females, with one thousand looms and twenty-six thousand spindles at work.

By the census of Lowell for January, 1828, the total population was 3532, of which 2190 were females. On 12th June, 
1830 , the population was 6477 , whereof 4085 were females. The following is the census on lst June, 1832

\begin{tabular}{llr|llr} 
White Males. & & \multicolumn{3}{c|}{ White Females. } \\
10 (under) & - & 703 & 10 (under) & - & 771 \\
10 to 20 & - & 563 & 10 to 20 & - & 1,465 \\
20 to 30 & - & 1,996 & 20 to 30 & - & 2,735 \\
30 to 40 & - & 720 & 30 to 40 & - & 638 \\
40 to 50 & - & 208 & 40 to 50 & - & 233 \\
50 to 60 & - & 62 & 50 to 60 & - & 83 \\
Above 60 & - & 27 & Above 60 & - & 52
\end{tabular}

Grand Total, 10,254.

The females engaged in manufacturing amount to nearly 5000 , and as we arrived at Lowell on the afternoon of Saturday, we had an opportunity of seeing those connected with some of the largest eotton factories retiring from labour. All were clean, neat, and fashionably attired, with reticules hanging on their arms, and calashes on their heads. They commonly walked arm in arm without displaying levity. Their general appearance and deportment was such that few British gentlemen, in the middle ranks of life, need have been ashamed of leading any one of them to a tea-party. Next day, being Sunday, we saw the young females belonging to the factories yoing to church in their best attire, when the favourable impressions of the preceding evening were not eftaced. They lodge, generally, in boarding-houses, and earn about 8s.6d. sterling per week, independent of board ; serving girls earn about 4s. 3d.

The recent introduction of large manufacturing establishments, thin population, and ample reward of labour, account for the apparent comfort and propriety of the Lowell young women. The situation of the manufacturing class in Britain is very different : nurtured amidst poverty and vice, they toil in crowded and unwholsome factories from infancy, often disregarded by parents and employers, and attaining maturity ruined in constitution and in morals, with few of the sympathies of humanity.

The factories and dwelling-houses at Lowell are mostly composed of brick, although good building stone is to be had 
everywhere. The people seem to be influenced by halit in house-building at Lowell; a wooden dwelling-house was being erected where rock, which had been dug from the cellar, was obstructing its progress, and thousands of loads of stones quarried in forming a railway, were lying at not more than one hundred yards distant. Here I saw a stone arch building across a lateral branch of the canal, which was the only bridge of that material I saw-wood generally being used for their construction. Many large sized $\mathrm{d}$ welling-houses and factories were in the progress of erection.

Lowell is connected with the village Belvedere by a bridge over the river Concord, the water of which is also employed in propelling machinery. In Lowell there are seven newspapers published, one of which is a daily paper. There are no less than forty religious and benevolent societies-a magnitude of number, owing, perhaps, to the many religious sects wishing to equal each other in good deeds. This village may be taken as an instance of the giant strides by which the United States are advaneing to greatness, and the immeasurable water power nature has lavished on them. The canal supplies more water than the present machinery requires; and, after inspecting the surplus in the canal and rivers, I am of opinion, there is water enough to propel nearly one hundred times the machinery at present employed, and which might employ a population of above a hundred thousand souls.

Britain is said to owe much of her greatness to the supply of coal with which she has been blessed; but however extensive and available it may be, the water power of the United States will excel it in cheapness and magnitude. The price of labour is, and will likely continue, much cheaper in Britain than in the United States, which seems the only circumstance that can ultimately give a superiority to the manufactories of the former.

The strawberry plant was met with in every direction throughout our excursions, and the fruit was found to be of superior quality on very poor soil on the banks of the Concord. In one instance I removed a plant from the earth, the leaves of which did not cover three-fourths of an inch in dia- 
meter, bearing two ripe berries and one unripe. The appletrees from Boston to Lowell exhibited leafless trunks; and, on inspection, I found the cankerworm which was said to have destroyed them had disappeared.

At Newburghport the noise of toads and land turtles, in the evenings, was deafening. At Lowell we first became acquainted with the call of the bull-frog, which in loudness and expression strongly resembles the note of the English bull. 


\section{CHAPTER VIII.}

Journey from Lowell to Saratoga-Keene-Bellows Fulls-Tounsend-Arlington-Driver at Table-Landlord and DriverPassage of the Green Mountains-Stage Coach practices of America and Britain-Passengers and Travellers-Juvenile Politeness-Agricultural Notices-Nevo England Villages - F'ree School Education unfairly estimated by British travellersEducation of Scotland and the United States-Public SchonlsFagging in the Seminaries of Brituin-Principles of Education.

WE left Lowell on the morning of the $2 \mathrm{~d}$ June, passing through Gorton, Townsend, New Ipswich, Jeffrey, and Keene, a pretty little town with a neat square, in which there is a church with a handsome spire, and many of the houses are composed of brick. The situation is an extensive plain surrounded by well-wooded hills, but the beauty of the place is injured by the want of trees and grass in front of the houses in the square. The population amounts to about 2500 souls. There are two glass manufactories-two for cotton, and one for woollen are about to be erected.

Bellows Falls are romantically situated on the river Connecticut, the approach passing round the base of a beautiful mountain, and over a bridge across the rapids of the river. The manufacture is paper, the machinery propelled by water obtained from a canal half a mile in length, and there is a vast unemployed power.

Townsend is a small village lying in the bosom of a sweet amphitheatre of hills of limited extent. Its general effect is somewhat destroyed by a glaring church spire, the basement of which is painted white, the middle part pea-green, and the top a chocolate colour. 
Arlington consists of a few houses; it has a stone church, finished with turrets of wood work, a combination of materials in the exterior of buildings very common in the United States and the Canadas.

At New Ipswich, the driver of the stage seated himself at table with the passengers, which was the only instance of the kind that eame under my observation. Some of the passengers were of the most genteel description, and the driver conducted himself with propriety.

On arriving at Bellows Falls, the landlord of the hotel saluted the stage driver with "How do you do, captain?" and he answered-"Quite well, major-this is a cold morning." The major in question ushered us into the breakfast room, where he presided with a suavity of manner that would have done credit to a Frenchman; and I considered this individual the most courteous I met with in the course of my tour. The hotel-keepers of the country are the noblesse of the district, and are generally chosen, by the people, officers of the militia. Captain is a general title for stage drivers; and I found, both in the States and Upper Canada, that military titles of high sounding were often used as nicknames. I did not enquire if our driver was actually a military captain, but so far as appearance entitles a man to rank, he might have been a field-marshal.

The road from Jeffrey to Arlington is through a poor hilly country, abounding in scenic beauty of infinite variety, which afforded me more pleasure than the banks of the Hudson. From Bellows Falls to Arlington we passed over what, in common parlance of the country, is termed a new built turnpike, leading through the Green Mountains, which had been only a few weeks open to travellers, and some parts of which were almost impassable. Twenty miles of this road is through a dense forest, quite impervious to the sun's rays; and for five or six miles on the other side of the Green Mountains towards Arlington, in a deep narrow ravine, the rocks and hills being finely wooded to the summit. The country opens up into picturesque views towards Sunderland, which is a few miles from Arlington.

Passing the night in a crowded hotel at Arlington, we 
proceeded next morning to Saratoga, by Union Village and Schuyler-ville, where the stage stopped a little after twelve, to afford two passengers an opportunity of dining, who did not take breakfast at Arlington, although only twelve miles distant from Saratoga, the end of our journey. This accommodating spirit of stage-conches stopping whenever passengers choose to feed, and calling for or setting them down at their respective residences in towns, seems at variance with the character of the people, and is somewhat trying to the temper of a newly-imported traveller. In Britain travellers must wait for the coaches which arrive and depart from each place at specified houns, with perfect punctuality. In America the coaches wait for the travellers, and the consecpuent irregularity is such, that if a coach is said to reach a given place by twelve, there is an equal chance whether it does so by twelve at noon or midnight.

The road from Arlington passes for many miles along the river Battenkill, the banks of which aftord good sheep-pasturage, and some fine grain-growing districts were seen near Cambridge, before reaching Union Village.

From Schuyler-ville to Saratoga, the soil is of the quality of drift-sand. A fence of considerable extent was observed on the wayside, composed of pine-tree roots adhering to the trunks, and placed close to each other, so as to form an effectual barrier against ordinary intruders. This was the most picturesque fence I ever beheld.

The stage passengers and other travellers we came in contact with throughout our excursion in the states of New England, were chiefly mechanics, unobtrusive in manner, intelligent, and free from vulgarity. They conversed on every subject connected with their own and other countries, and betrayed none of that question-searching curiosity imputed to the population. They seemed to possess a general knowledge of British literature, and more especially of the works of Sir Walter Seott and Robert Burns. They are also familiar with the works of Captain Hall and Mrs Trollope, and occasionally asked if I found the people of the States as inquisitive as represented by those writers. The proceedings and success of Dr Franklin were often quoted; 
and the life of that great man seems to have had no small share in stamping the character of this class of the population.

The external appearance of the houses after passing the Green Mountains became gradually less attractive, till at last they were little better than mere log-houses.

Primary or State schoolhouses were frequently seen, and I regretted not having an opportunity of examining the proficiency of the pupils. The little boys attending the schools were often going without stockings or shoes, and the girls generally wore flowing trowsers to their ankles. On one occasion, in passing through the state of Vermont, I observed four little girls and two boys going to school, dressed in clean clothes, with nice little baskets over their arms, which I conjectured to contain their dinner. When the stage passed by them, the misses curtsied, and the boys bowed to the passengers. I was much gratified at this voluntary and unexpected display of juvenile politeness, and repeatedly kissed my hand in return; but recollecting they might not understand such a mode of acknowledgment, I leant my head out at the coach window and bowed familiarly, when they seemed delighted at my interchange of civilities, and smiled to each other.

A valued friend, residing in the neighbourhood of Montreal, informed me he was visiting at Rochester, in the state of New York, in 1831, when a plain-dressed little girl approached the window of a cottage at which he was seated, on a fine summer evening, and curtsying, asked him for a rose, a flower which was growing profusely round the cottage. He told her to help herself to the prettiest she could find, but being afraid of injuring the bush, she returned, asked the use of his knife, which being granted, she departed with the object of her affections.

The surface of the New England States is often hilly, always highly undulating, and the soil generally rocky, and of the most inferior description of sand. The staple crop appeared to be rye; and we did not observe fifty acres of wheat throughout a journey of 400 miles. The grass was scanty, and seemingly incapable of fattening oxen, from its 
inferior quality. The cattle, as already stated, were of a good breed, but often remarkably lean. Sheep were inferior, and so also were horses used for farming purposes. 'The mode of farming did not meet my approbation; but perhaps bad land, like bad wives, can be managed by every one but by those who possess them ; and a foreigner unacquainted with the peculiarities of the district cannot be an infallible judge of such matters. It appears to me, however, impossible that the New lingland States can furnish food sufficient for the population; and the time is perhaps near at hand when the whole produce will not do more than maintain the agriculturists, and supply the manufacturers with dairy produce, leaving their butcher-meat and bread to come from other districts. 'The present farmers find difficulty in earning a subsistence, and any thing paid in the name of rent must be truly insignificant.

The villages of New England are uniformly clean, airy, and neat, with spacious openings near the centre, in which churches form the most prominent feature. Indeed, a village is seldom seen without having two or three churches of considerable size, composed of wood, painted white, and surmounted with a spire, and generally flanked with a considerable extent of shades for waggons and horses belonging to people coming from a distance. The houses are, in some instances, built of brick, but more frequently of wood, painted white, with green Venetian blinds, opening to the outside. Both churches and dwelling-houses seem to be painted annually; at least, they are never seen in the slightest degree dingy coloured. The houses of every size and fabric, have a light appearance from the number of windows they contain, the legislature not taxing the inhabitants for enjoying air and light through the medium of windows as in Britain. The houses seldom indicate either extensive wealth or poverty of the inmates; and although the architectural decorations are often in bad taste, and the materials of which they consist associated in the mind of the Europeans with instability, yet the general effect is highly pleasing, and the villages want only the judicious aid of flowers and shrubs to render them absolutely beautiful. 
The system of Free-school education in the Eastern States does not appear to have been fairly estimated by some British travellers. Mr Stuart, in chapter xiv. of "Three Years Residence in America," states, "the general plan of education at the public Free-schools, is not confined to merely reading, writing, arithmetic, and book-keeping, and the ancient and modern languages, but comprehends grammar, mathematics, navigation, geography, history, logic, political economy, and rhetoric; moral and natural philosophy; their schools being, as stated in the printed regulations, intended to oceupy the young people from the age of four to seventeen;" and in chapter xvi. he takes the same view when conversing with President Jackson. Captain Basil Hall and Mr Hamilton seem to consider them charity-schools, and consequently objectionable to an independent people.

The public Free-schools, or what are called "common schools," and maintained by public funds, are managed in each district by twelve directors, chosen by the people, at which children are taught gratis, the parents furnishing books. 'The funds being inadequate to provide teachers during the whole year, men are engaged to teach in winter, and women, who are engaged at a cheaper rate, to teach during the summer. The period of teaching varies according to the extent of funds, which are managed with economy, and seldom exceeds nine months throughout the year, and in some States only six months. In one or two States, there is also a Free grammar-school in each county town.

It has been formerly stated, that an opportunity of examining the common schools of New England did not oceur. I, however, saw the scholars of upwards of twenty of them in the school-houses, and on the play-ground. I also saw several of the teachers. None of the scholars, who, in summer, are chiefly girls, seemed above twelve years of age, and the teachers were invariably females. From this circumstance, it appeared to me that Mr Stuart had confounded the district common schools with the grammar-schools of the county towns; and many of the natives, to whom I showed his account of the schools, readily agreed in this view. Indeed, to state that little children and female teachers in the woods of America 
should be engaged in logic, rhetoric, and navigation, is taring eredulity too far.

The funds, remunerating teachers of common schools, being provided by the State, for general use, not only removes from the inhabitants any feeling of degradation or dependence, in the education of their children, but renders it their duty to prefer such seminaries, when the teachers are equally good. It is singular that Captain Hall and Mr Hamilton, both Scotsmen, should consider these schools eleemosynary and degrading, when the religious establishment, as well as the schools of their own country, are similarly situated. The inhabitants of Britain do not consider themselves partaking of charity when listening to teachers of religion, or preachers in connexion with establishments, nor when educating their children at public seminaries, the teachers of which are almost always in part remunerated by public funds, and the fees consequently lower than they would otherwise be. In private tuition the teacher has, in most cases, received his education in part from public funds, and, in consequence, is a cheap source of instruction. The principle of public education in Scotland and the United States is the same, and if at all eleemosynary, the degree is less in the American States, where the inhabitants generally have a voice in levying and disposing of the funds. The Scotch system of schools is, however, preferable, by guarding against a change of teachers, frequently injurious to the progress of those under tuition-the appointment of parochial teachers being for life, or during good behaviour; and each session continuing throughout the year, with the exception of two or three weeks' vacation. The schools are not like those in the States, free; but in consequence of the teachers having a fixed salary, the fees may be said to be half-price, which operates on the diligence of the teachers, and is a considerable boon to the inhabitants. In some of the States, where common schools are open half the year, the expense to parents is nearly the same as in Scotland, where the parochial school is open throughout the year at half-price, without, however, the pupils having a chance of making the same progress.

Public schools are founded on the principle of diffusing 
knowledge amongst the people, thereby raising the standard of morality-by which crime is prevented, and good government secured. Simple, and in some respects defective, as the American common school system is, it has, nevertheless, succeeded well, and seems suited to the present wants of the people.

Reading and writing, with the elements of arithmetic, which can he attained in a few years, enable those to improve themselves by application who are at all desirous of acquiring knowledge. Indeed, the learning generally obtained at school may be regarded as but a foundation to build on in after life : and therefore the schools of the U'nited States and Scotland supply, alike, the primary means of ultimate improvement. A longer and severer course of mental study than afforded by these institutions often converts weak minds into polished nothings, without adding to the usefulness of the man.

The system of fagging, so generally introduced into the higher seminaries of England, and which may be described as each of the senior members holding a junior in slavery, requiring not only the discharge of menial services, such as brushing clothes, and cleaning shoes, but often the performance of criminal and immoral actions, is altogether unknown in the States. Fagging is so complete and systematic in many of the English schools, that the junior boys have not the power of resisting the commands of their seniors, and must lie or steal at their nod. Such a system inculcates passive obedience in the weak, and absolute power in the strong; the ductile youth, after being corrupted by vice, and degraded by offices of slavery, becomes, in turn, slave-master, when recollections of his former sufferings leats him to exercise his power with more zeal, and when so trained, he is sent forth to play his part in the world. Powerful minds occasionally overcome the effects of this pernicious education, but ordinary ones are unable to do so. It is chiefly the aristocracy of Britain who are reared under the fagging system, and it unfortunately too often influences their conduct in after life. A law prohibiting fagging in seminaries of youth would be a blessing to Britain, where man too often fags his fellow-creatures.

Fagging has found an eloquent advocate in Mr Hamilton, 
in his work entitled "Men and Manners in America," wherein he seems to consider its menial duties as tending to overcome pride of birth and station. But even in this narrow view fagging must be condemned, as the menial offices are forcibly imposed, and flow not from philanthropy of feeling or legitimate authority, but from usurped and overpowering tyranny. Menial offices in the seminaries of England are the means of corrupting, not of improving youth, and fagging fosters the worst of human vices. If pride of birth and station is to be corrected, public schools where fagging is unknown, and where all the pupils are placed on an equality, will best attain the object.

Mr Hamilton treats of fagging as if it were general in England, whereas it exists only in the higher description of schools, and is, I believe, altogether unpractised in scotland. When lately discussing this point, a friend stated that fagying existed at the academy of 1 ollar in Scotland; and on applying to my brother Charles, who was educated at that seminary, if such was the case, I learned that he himself was the only instance of an attempt of the kind, a big fellow having claimed such a privilege on his first arrival, and which was frustrated by Willse $\mathrm{M}$ _ and he joining and beating the tyrant well. Very few Scotch boys would feel inclined to fag their companions, and still fewer to submit to such a bondage.

The education of youth ought to embrace all that is necessary for discharging the duties of life, and is most effectual when combining industrious and moral habits with the highest degree of mental cultivation-on such a principle some of the schools of continental Europe are founded, and it is also acted on in one or two instances in the State of New York. 


\section{CHAPTER IX.}

Company ut Saratoga-Fust Eating-Notices of Buel Furm-Mr Buel-New York-State Agricultural Society-Adecuntuges of a young country-Furmers of Brituin and the States-British Agricultural Sacieties.

We reached Saratoga, the most celebrated watering-place in America, about two o'clock, and found accommodation at Congress Hall, the principal hotel in the village, and capable of accommodating 300 individuals. On retiring to prepare for dinner, $m y$ friend and $I$ debated the nature of the attire in which we should appear-he conceiving it unnecessary to change our travelling garb, and I thinking it proper to assume full dress, in expectation of meeting the gay, wealthy, and polished of the land. We soon found ourselves seated at a second dinner table, consisting of a numerous company, which the railway coaches had just brought from Albany. The party displayed few symptoms of refinement. A gentleman on the opposite side of the table deliberately folded up the sleeves of his coat before commencing dinner, planted both elbows on the table, and swallowed his food voraciously, without once looking to the right or left. I felt, and perhaps looked, disappointed at the hurried manner in which the party dined; and on the company leaving table immediately afterwards, my friend enjoyed his triumph of opinion, and quizzed my shoes and stockings, as a marked singularity which both of us were anxious to avoid. Tea was served at seven o'clock, and, as usual, the repast was a regular feeding race. Business may have originated, but it cannot always excuse the practice of fast eating; and the inmates of Congress Hall were in perfect idleness. 
In the industrious and lower ranks of life I observed slower mastication, and greater politeness and attention to each other at table than what is generally met with at fashionable hotels. The former frequent boarding-houses, not very plentifully supplied with waiters, or female helps, and they consequently assist each other in carving, and other duties of the table, while they have fixed hours of relaxation from business, affording ample time for eating, whereas commercial men, and other people who are not laboriously employed, eat at table with numerous attendants, and at short intervals snatched from business. Therefore, the traveller in America who draws an inference from what he witnesses at the public tables of hotels, unfavourable to the manners of the lower ranks of the inhabitants, does them injustice.

At Saratoga we tasted the different mineral waters, so deservedly celebrated, and next morning travelled to Albany by the railway. The soil over which we passed was unproductive sand, with exception of the banks of the Mohawk, in the vicinity of Schenectady. Betwixt Schenectady nd Albany, the plains of the railway exhibited sand of fifty feet deep, having a thick covering of small pine-trees.

I was fortunate in finding Mr Buel at home, so well known as a farmer throughout the Union. I walked over this gentleman's grounds on my first visit to Albany, and enjoyed the same privilege a third time in October. The surface is highly undulating, the soil inferior sand, and extremely wet, though capable of being drained. Notwithstanding these disadvantages, some good crops were seen, more especially Indian corn and Swede turnip, the latter having been sown after a hay crop, with bone manure, manufactured by Mr Buel himself; and the state of the farm is, perhaps, one of the most striking instances in America of man overcoming the sterilities of nature.

Some attempts had been made at enclosing with hedges, consisting of American and British thorn, as well as locust. The hedges were not of sufficient age to enable me to judge of the fitness of the last-mentioned plant for farm purposes; but I certainly did not augur favourably of it, from the specimen before me. The American thorn was preferred by 
Mr Buel to the British; and, perhaps, indigenous plants will generally be found superior to foreign ones. In the present instance, however, the soil was not such as I have found congenial to the British thorn, and the management of the fences had not been unexceptionable. A few days afterwards I had a proof of the growing powers of British thorn at Geneva, where I cut a growth of the season on the 24th of June, from the hedge of Mr W__ 's garden, three feet in length. This, joined to the fine hedge of $\mathrm{Mr} \mathrm{F}$ - of the same place, establishes the fitness of the British thorn for the climate of America. The American thorn has very broad leaves, large fruit containing several seeds; and when growing in single trees, has horizontal branches, few prickles, and is apparently more dwarfish than the British species, which possesses pendulous branches, with numerous prickles. The British thorn has the property of growing throughout spring, summer, and autumn, which, with its numerous and strong prickles, eminently fits it for a fence plant.

Although Mr Buel's farm is much celebrated, it presents few attractions to any one couversant with British agriculture. He is himself, however, an object of interest to the farmer of any country who has studied his profession. His conversation on a variety of subjects amply unfolded to me the treasures of an enlarged and well-stored mind, and I was delighted to find his views of improving agriculture harmonize with what $\mathbf{I}$ had long advocated in my humble sphere. At separation he presented me with the printed proceedings of the New York State Agricultural Society, of a considerable portion of which he is the author; and I imagine a day spent with Mr Buel one of the richest agricultural treats that can be enjoyed in North America.

The New York State Agricultural Society was incorporated by act of the Legislature, on 26th April, 1832. A Report, recommending a Legislative grant, was approved, at a general meeting of the Society, in February, 1833, and in all probability the grant has been obtained before this time. I extract the Report, as conveying, in the general remarks, with a few exceptions, my own sentiments. 
"Report of the Select Committee on the Memorial of the New York State Agricultural Society.

"Mr Sudam, from the select committee to which was referred the memorial of the New York State Agricultural Snciety, praying for the establishment of an Agricultural School,

"Reported:- That they have had under their consideration the subject submitted to them, accompanied by a report made, during the present session, to the New York Agricultural Society, and on which their memorial to the I.egislature is predicated.

"It will be conceded that there is no portion of the community more entitled to the fostering care of the I.egislature, than the tillers of the soil. The farmers of the State of New York are a class numerous, wealthy, industrious, patriotic, and above all other classes, from principle, devoted to our republican institutions, and cherishing with a holy spirit the union of our States. Their political exertions are not called forth by a desire of any great portion of their own body for legislative honours, or for those of the minor judicial situations in the State; but to maintain and preserve inviolate that sacred trust which has descended to them by the revolutionary efforts of their fathers, the full protection of life, liberty, and property.

"When a storm arises in the horizon, and danger awaits us from abroad, or when crazed ambition at home drives the frenzied passions of men to madness and all its excesses, it is in the farming interest of the country that you find the steady hand which holds the balance of political power, and by its strong arm repels the foe, or by its electoral voice annihilates the unjust hopes of the aspiring ambition of profligate politicians.

"It may be said by your committee, (without the imputation of a State vanity,) that New York holds a high rank by her munificent endowments of colleges, academies, and common schools. We, knowing their extent, need not elaborate on them in this report. Still it is but just to say, that she is already cited in Europe as a signal instance of what may be 
done for the education of every class of society, under the soft and benign influence of a free government, and that her motto is, ' Knowledge is wealth.'

"In her enterprise, by facilitating intercourse between the different sections of her State and the waters of the Atlantic, she is as unrivalled in conception as she has been successful in execution. Not content with this, it is an admitted fact, and worthy of all honour, that she has carried into effect the most perfect prison discipline in the world ; and we have already witnessed the wise and the humane of Europe resorting to her shores to ascertain the art of subduing the rebellious passions of the worst of our race, without the aid of those sanguinary punishments which have so long disgraced the Old World.

"Thus she has expended millions of her money, and already has she erected a monument to the wisdom of her statesmen, more durable than any ever dedicated to the victor of a thousand fields.

"Who are they who have contributed so freely, so generously to expenditures calculated to immortalize the State, and to establish its glory on so pure a foundation? Mainly the farmers of your country, the yeomen of the land, the tillers of the soil. Freely have they given, and joyfully have they paid, and most rich results have been the consequence of their enlightened liberality.

"Is it then unfair to ask, what has been done by the legislature for a class of its citizens so numerous, virtuous, and meritorious? The stranger, when he sojourns in our land, and views all that has been done for the cause of science, for education in the higher branches of literature, for your common schools, for the reformation and punishment of erimes on a scale superior to any State in Europe, naturally enquires: Show me your agricultural school. You are essentially an agricultural people; a class of society who have aided so liberally to the institutions of your State, must have received the constant and peculiar care of legislative protection and patronage, by forming their minds, their habits and their tempers to become the patrons of the noble monuments already erected, and which, while they shed lustre on our State, have placed her first among her sisters in the Union. 
"Shall we any longer be compelled to answer? We have no such institution; we have provided an ample revenue for all but a complete course of practical instruction in agriculture. In almost every State in Europe, the attention of despotic governments has been called-nay, seriously and sedulously directed to the formation and endowment of schools of this description. There it is admitted the motive to a certain extent may be mercenary - to provide food for taxation. Here it is a debt due from the State to a class which, before they asked for themselves, have contributed to all others.

"It is conceded by your committee, that to a certain extent farmers are not fond of innovations. If experiments are tried, they are too often limited to one or two. If they fail, it is condemned. That prejudices of this description are fast wearing away, we admit; but that they still exist, to a considerable extent, there can be no doubt. And a gentleman farmer is generally at hand, as an instance of a poor farmer. But it is not the intention of the committee to endow an institution to rear up and educate persons in the mere theory of husbandry. It is to combine practice with science; and if it should be said that this would be a school only for the children of the more opulent, the unanswerable argument is, that it is the same in regard to your colleges, and must be so of necessity. Still the results of such an education, practised upon in all parts of the State, must and will lead to the most beneficial results. A good example is worth a world of mere speculation.

"In a school of this kind, under competent managers, there may be concentrated the best models of practice, in rural labour, known at home or abroad. The various breeds of domestic animals, the varieties of garden and orchard fruit, and the implements of husbandry, may be here satisfactorily compared, and their relative merits and advantages determined. Diversified experiments may be made in the various departments of husbandry, calculated to instruct and improve us in practice. Mechanical science, particularly what is denominated The Mechanics of Agriculture, may be illustrated and taught in the best manner, in the shops, and on the farm. The application of science to the mechanic and manufacturing arts, 
has, in a wonderful degree, simplified their manipulations, abridged their labour, and rendered their results more certain. From what has already been done, we are not permitted to hesitate or doubt but science will prove equally beneficial to agriculture. There is no business which embraces a wider range in natural science than this.

"The laws which govern organic and inorganic matter, which influence the economy of the animal and vegetahle kingdoms, it cannot be denied, have a controlling influence in the operations of the soil, and in the business of raising animals and plants. Education (practical education) is nowhere calculated to diffuse a more benign influence in society, than when bestowed on the farmer. He neither elaims nor can exercise a monopoly. His improvements and his knowledge diffuse light around him, and are beneficial to all within the sphere of their influence.

"Your committee feel assured, that if put into operation, this school will become, not only popular, but highly useful. To the pupil it will aftiord the most important advantages, besides instruction in the principles and practice of rural labour, which, of itself, confers the power of ereating wealth. It will afford him the advantages of a literary school, qualify him for the higher duties of eivil life, and give him withal, what is seldom acquired but in youth, habits of labour and application to business; calculated alike to promote his individual happiness, and the good of the State.

"With such an education, combining personal labour for a practical knowledge of all the instruments of husbandry, and the mode and manner in which it is to be prosecuted, those scientific pursuits will be prosecuted with a certainty that the foot of labour is guided by the unerring results of experience, founded in and regulated by the laws of nature.

" This school is intended to be purely agricultural. But in saying this, it will be necessary to open a course of instruction, combined with labour, which your committee venture to say, will be as interesting, and to the State, as valuable, as that which may be acquired in any other seminary. The different qualities of soil, as fitted for the various products of the earth; the use of compost and manures, as applicable to 
soils : the seasons for planting the rotation of crops, and the vast mass of practical information which enables man to transform a wilderness into a paradise, is worthy the pursuit of the richest as well as the humblest of the land.

"Again, the importance of procuring, at all times and at fair prices, prime stock, of the best breeds of cattle, ought not to be omitted, either as an inducement to the Legislature, or as of the first importance to the people.

"'The question is, shall we endow a school, to which many would desire to send their children for the purpose of prejaring them to depend in future life on one of the most certain, and therefore the most happy of human pursuits; combining in itself all the elements of constant, regular, and sagacious employment; and freed from the cares and corroding recollections, present or past, of the pursuits of a political life?

"It is evident that law, divinity, and physic, are overstocked. The pursuits of commerce are laborious, and do not very often yield a return to persons of a moderate fortune and liberal education: as now educated, they are not fitted for farmers; so tenaciously do those early halbits adhere to them, that the attempt at agriculture is generally a failure. Your committee propose to give them a school, to which resort may be had for the cultivation of the mind, and the improvement of the person: Laying the foundation for future toils and pleasures, (for toils in agriculture are pleasures, when conducted to a successful result,) for future health and happiness, and preparing them to rear up a race, fit to transmit to posterity the liberties we so highly cherish.

- 6Y Your committee do not, in this report, enter into a detail of the expenditure necessary for this school. That is so fully treated of in the annexed report to the Agricultural Society, that they could only repeat what is there stated. But they cannot close without remarking what must be obvious to all, how much skill and science may effect in agricultural pursuits.

"Is there one of our body who has not seen, and remarked, the difference in adjoining farms, where nature had made no difference in the soil? It is this practical skill, this science, combined with labour, that they desire, (most anxiously 
desire, to bestow on a rising generation; and they deem it their duty, most earnestly, to press it on the consideration of the Legislature, as called for by every consideration due to the public welfare, to the true and lasting interests of the State; and as the last, but most substantial pillar in the varied edifice of her public institutions.

"Impressed with this belief, and that the school recommended will, in many ways, prove highly beneficial to the community, and persuaded that the state will ultimately be fully indemnified for her advances, your committee have prepared a bill in conformity with the prayer of the petitioners, which they have directed their chairman to ask leave to present."

\section{"Report of the State Ayricultural Society, Alluny, February 14th, 1833.}

" The committce appointed at the first meeting of the Society, to report a plan for an Agricultural School, with an estimate of the expense necessary to estahlish and put the same into operation; together with their views of such an establishment, beg leave to submit the following report :-

"The main ohjects of the proposed school are, to impart to agriculture the efficient aid of the sciences, and to furnish it with the best models of practice; to teach, simultaneously, in the period of youth devoted to academic studies, the practical operations of husbandry, and such branches of useful knowledge as may tend to elevate its character and increase its products. The plan, therefore, should embrace,

"1. A Farm, of sufficient extent to afford room for the diversified operations of tillage, cattle and sheep husbandry, and of orcharding and gardening-on a scale that will admit a fair comparison being made of crops, of breeds of cattle and sheep, and of the varieties of hardy fruits ; and sufficiently diversified in soil and surface as to admit of satisfactory experiments :

“2. A Farm House and Farm Buildings, which may serve as models of convenience, taste and economy, and accommodate the head farmer and his assistants :

"3. A School Building, for the accommodation of teachers and scholars : 
"4. A Library and Philosophical Apparatus :

"5. Sitock and Implements for the farm : and,

"6. Shops for the construction of farm inplements and machinery, for the use of the farm, for the illustration of mechanical science, and to afford practical instructions to the pupils in mechanics.

"These items of expense, which may be considered preliminary and permanent, together with the cost of the furniture required for the school building, are estimated at $\$ 7,500$.

"1. The plan of elucation might embrace: practical instructions in the various operations and labours of the farm, the garden, the orchards, and the shops : and,

"2. The study of the natural sciences generally, mathematics, mechanics, chemistry, and drawing, so far as these may conduce or become subservient to agricultural improvement: together with such other branches of knowlerge as will qualify the students for the higher duties of civil lifesuch as will fit them to become independent electors, discreet jurors, faithful magistrates, and wise legislators.

"As prerequisites to admission to the school, the pupils might be required to possess a good common school education, to be at least fourteen years of age, and of good moral character. Four years might constitute a course of studies ; and the internal regulations and police of the school might be conformed, in a measure, to those of our military academy.

" A department of the farm should be set apart for experiments in husbandry, and the details and results of these experiments accurately registered. The garden and the orchard should contain all the good hardy fruits, and specimens of all hardy plants, that may be useful on the farm, in the arts, in commerce, or that are ornamental - in order that the relative value of different species and varieties may be determined, and their mode of culture and process of curing taught to the pupils, and the approved kinds furnished for public distribution.

"To put the school into operation, there will be required -a principal, professors, and teachers-a steward and servants, for the school:

6 A manager, labourers, and assistants, for the farm: 
"Machinists and assistants for the shops : and,

"A practical and scientific manager for the garden and orchard.

"The number of officers and assistants which will be required, must depend upon contingencies : and of course the committee do not pretend to state with precision, in their estimate, the amount of their salaries and pay.

"The proceeds of the school and the farm may be expected to increase for some years, and will materially depend on the terms of tuition. The committee have assumed, as reasonable data, that the number of pupils would average 200 , and the average produce of the farm amount to $\$ 4,000$ per annum, for the first four years. Upon the assumed data, then, the estimate would exhibit the following result :-

Preliminary Espenses.

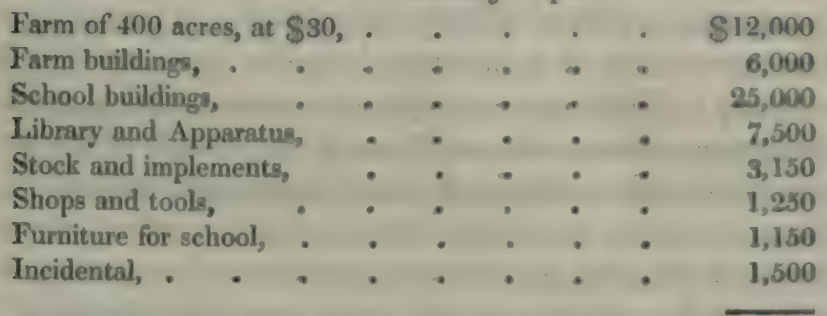

Total preliminary expense, . . . . . . $\$$. $\$ 57,350$

Anural Expenoe.

Salaries of officers and teachers of the school, . $\quad \$ 5,100$

do manager and labourers on fiarm, . . 1,000

do machinists, : . . . . 600

do gardener, . . . . . 300

Expense of boarding 200 pupils, at $\$ 1,50$ per week, $\quad 14,400$

Servants for the establishment, . . . . 2,000

Estimated annual expense,

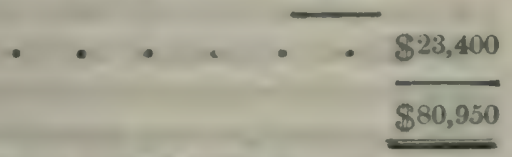

The Annual Receipts are computed as follows:

Board and tuition of 200 pupils, at $\$ 150$ per annum, . $\$ 30,000$

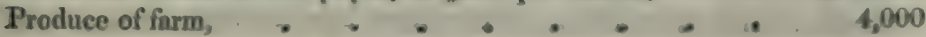


"Thus the total expense of establishing the school, and of maintaining it the first year, is estimated at $\$ \times 0,950$, and the income, after the first year, it is believed, will be amply sufficient to defray all expenses. Fet to meet contingencies that may occur, and to make up for any deficiency in the entimate, the committee think that an appropriation of $\$ 100,0000$, the surplus to be invested for the benefit of the institution, will ensure usefulness and permanency to the school, and prove amply sufficient to meet all its wants. This sum, if equalized among the population of the State, would operate as a tax of about fire cents to each inhabitant.

"Your committee have thus complied with the reouisitions of the society, in submitting the plan of an Agricultural Sichool, and an estimate of the expense necessary to establish and put the same into successful and permanent operation. It only remains for them to state their opinion of its utility.

" The agriculture of a country affords the best criterion of - its prosperity. Whether we compare kingdoms, states, counties, districts, or farms, the condition of this branch of labour, which they severally exhibit, is a sure index, not only of the pecuniary, but of its moral condition. It is no less an axiom founded in truth, that agriculture prospers or languishes, in proportion to the science and skill of the men who manage its labours. - It is not the natural fertility of the soil, so much as the intelligence and industry of those who till it, which gives to husbandry its interests and its rewards. The man who devotes the energies of a highly cultivated mind, to the improvement of this primitive and all-important branch of labour, is a public benefactor. Cincinnatus did more to immortalize his name, and to command our applause, by his love of rural labours, than by his military exploits. Washington, amid all the honours thatirradiated his,brow, sought his highest pleasures in the business and retirement of the farm. And it was the first remark of our present chief magistrate, to the writer, after introduction, that he would not forego the pleasures of the farm for all the honours and emoluments that this nation could confer upon him. Education enables man to appreciate the wonderful provisions which God has made for his happiness in rural life, and imparts to him the ability of diffusing instruction and happiness to multitudes around him. 
"It should be the policy of government, therefore, winch watches over the interest of all, to infuse into the labours of husbandry, all the lights of science and knowledgre-to take care to expand and elevate the minds of those who are to give it efficiency and character, and to call forth skill and industry by proffered rewards. With us these considerations possess peculiar force. Our population and business are emphatically agricultural, and every aid which is extended to this class benefits, indirectly, every portion of the community. Agriculture constitutes the fountains of the thousand rills, which, swelling and traversing every part of the state, propel the spindle and the hammer of the artisan and the manufacturer, and finally, by their union, make up the mighty stream of eommerce which unceasingly flows into the Aclantic.

"That our agriculture is susceptilse of improvement-that the products of its labours may be doubled, nay, quadrupled, must be apparent to those who have compared our husbandry with that of some liuropean countries, or who have contrasted at home the well-cultivated district or farm with those which are badly managed. How is the desired amelioration to he effected? How can a better husbandry be so well promoted, as by teaching it to our youth? By sowing our seed in the springtime of life? Prejudice nowhere retains a stronger hold than among farmers who have approached or passed the meridian of life. While some retain old practices, for want of confidence in their knowledge to guide them in better ones, others lack the first requisites to improvement-a conscionsness that their system is not the most useful; while not a few are influenced, in their hostility to public means of improvement, by the desire to keep things to their own level. If we would efticiently improve this great branch of business, and elevate its character, as well as the character of those who are engaged in its operations, we must do what universal experience has shown to be the only sure method. We must lay our foundation in the rising generation-we must teach the young idea how to shoot-we must instruct the head to help the hands. Our physical and mental powers are twin sisters; they lighten each other's labour, and mutually impart a zest to each other's enjoyments. And as it is becoming common to 
introduce manual labour into literary schools, it is courteoum that literature and science should requite the civility, by associating with the inmates of schools of labour.

"Agricultural schools, although of modern date, have nevertheless been established in most of the states of Furope, and their utility has been fully demonstrated. Who has not heard of the school of Fellenburgh, at Hoffwyl, or of Von Thayer, at Moegelin-to which young men are sent from every part of Europe, and even from America? In France and Prusmia, agricultural schools have been founderl and maintained by the governments. If they are found to be beneficial, and worthy of governmental support, in countries where power is vested in the few, how much more salutary must they prove herewhere our institutions receive the impress of their character from the many, and where the perpetuity of these institutions depends emphatically upon the intelligence and virtue of the agricultural population. Despotism will never flourish in American soil, but through the ignorance, and, we may say, consequent depravity of its cultivators.

"Your committee recall to recollection, with feelings of pride, the munificent benefactions of the Legislature, to advance the literary character of our State; and the fact, that comparatively nothing has been done, legislatively, to improve our agriculture, which employs five-sixths of our population, can be ascribed to the fact, that nothing has been asked fornothing thought of. Our public colleges and academies, for literary instruction, are numerous and respectable. They meet our eye in almost every village. But where are our public schools of labour? Where is the head taught to help the hands, in the business which creates wealth, and which is the grand source of individual and national prosperity and happiness? Our literary and professional schools have been reared up and sustained by the expenditure of more than two millions of dollars from the public treasury, and they continue to share liberally of the public bounty. It will not, however, be denied, that the benefits which they dispense are altogether partial, - that the rank and file of society, destined by heaven to become the conservators of civil liberty, are virtually denied a participation in the science and knowledge, -in the means 
of improvement and of happiness which they are calculated to dispense. Is it not a mandate of duty, then, as well as of expediency, that the benefits of public instruction should be more generally dispensed?

"We hazard not the fear of contradiction in assuming, that if a moiety of public moneys, which have been appropriated to literary schools, had been judiciously applied, in rendering science subservient to the arts, and in diffusing the higher branches among the labouring classes, the public benefits from the appropriation would have been far greater than they are at the present day. How many hundreds may now be pointed out, of liberal education, who are mere ciphers in society, for want of the early habits of application and labour, which it is the object of the proposed school to form and infix! And how many, for want of these habits, have been prematurely last to their friends, and to a purpose of usefulness for which man seems wisely to have been created-that of doing good to his fellows.

"From a full conviction that the interests of the State not only warrant, but require, an appropriation of public moneys to this object, your committee bey leave to recommend to the consideration of the Society the following resolution:

"Resolved, That a respectful memorial be presented to the Legislature, in behalf of this Society, and of the great interest which it represents, praying that suitable provision may be made by law, for establishing a school of agriculture, on the plan recommended in the preceding report; and that the co-operation, in this application, of societies and individuals friendly to the object of the petition, be respectfully solicited."

The report is attributed to Mr Jesse Buel, and is a document creditable to its author and the society which adopted it. It advocates mental cultivation of furmers, as the best means of improving agriculture, and youth as the seedtime of an abundant harvest of human knowledge. Whatever diversity of opinion may exist in rural matters, every individual who has reflected on the subject, will admit the mind of the farmer is the chief implement of husbandry on which the agricultural system depends, and by which its advancement 
can be best effected. Man is the principal animal connected with the farm, and the amelioration of his mind more important than the improvement of brute formation. Mr Buel knows well the strength of prejudice exinting amongst farmers, the results of their isolated situation, and that youth is generally the only season when new impressions can be maule and acted on. In advaneed agriculture, the mind will guide the hands as well as all farm machincry, and science and art become blended togrether in the relation and loveliness of conjugal unity. Mental illumination of furmers is not merely calculated to advance agriculture, but to enable them to see, in their professional pursuits, the means of serving their fellowcreatures, and the exhaustless hounty of Ciod.

New York is justly considered the leading state of the Union, being celebrated for prison discipline, extensive canaling, common schools, and if Mr Buel's vigour is spared for a few years, it is also likely to be distinguished for its agricultural institution.

The United States possess great advantages, from being new or young countries, in which no class have exclusive privileges, and where the selfishness and prejudices of classes are seldom manifested. The inhabitants are a mixture of all nations, or the descendants of such, in which the fetters of old customs have been loosened perhaps by collision, and, in measures of general utility, they can at once adopt the wisclom of antiquity without its folly. Many of their public institutions are illustrative of this as well as Mr Buel's report.

How different is Britain and Ireland from the state of New York, where the "tillers of the soil" are regarded as the most patriotic class, holding the balance of political power, and alike ready in repelling foes and restraining profligate politicians. In former ages the cultivators of British soil were considered mere vassals, and termed villains. At present they are lightly esteemed by those who chiefly reap the benefit of their exertions; and although this is the age when the schoolmaster is said to be abroad, judicious steps have not been taken to improve their condition.

Agricultural societies are to be found in almost every county in Britain, but their proceedings seldom directly 
embrace the improvement of the moral condition of humanity. Indeed their proceedings have sometimes an opposite tendency, by seeking to maintain monopolies and duties on foreign produce, which cripple trade, curtail the field of inclustry, and enhance the necessaries of life, from all of which wretchedness and vice flow. But the population actively engaged in agriculture are also little cared for, and their condition seems declining comparatively with other classes. Such institutions too much overlook youth and moral agency in improving agriculture, and spend much of their funds and time on minor objects.

In making these observations on the agricultural societies of Britain, I am aware of some exceptions. 'The Liverpool society is a good institution, and a manufacturing district is the situation where an efficient society might be expected in Britain, as furnishing members liberal in mind, and comparatively free from agricultural prejudice.

The Highland society of scotland is also a good institution; its ample funds accomplishing much for the benefit of the country by giving premiums; but more advantage would result from their application in the improvement of youth, and in cultivating an experimental farm something analogous to what Mr Buel recommends. Edinburgh would form an excellent situation for such, where there is already a University Professor of Agriculture. An experimental farm of sufticient size would furnish better results from systematic procedure and continued registration, than the efforts of isolated individuals. With such an institution, sons of landed proprietors might be instructed in the science and art of farming, and the management of property. Stock and seeds might be experimented with and improved; and by the sale of them the institution would support itself. 


\section{CHAPTER $\mathrm{X}$.}

Journoy to Geneva-Schenectudy-Question Asking-Singe Driver-Valley of Mohauh-Ayricultural Duties-Citicu-Auention to Females - Marcellus _. Skeneutiles_Caynga BridgeDinner Party-Dumfries-shire Farmer-Sherp HusbandryCondition of Animals-Farms-Geneva.

We left Atbany in the morning, and breakfasted at Scheneetady, which contains about 5000 inhabitants, and from its situation on the Mohawk, the union of the Erie Canal, and railway from Albany and Saratoga, it is likely to rise in importanee. From Schenectady we proceeded, by stage, along the valley of the Mohawk, on the north side of the river, to Utica, where we arrived about two in the morning, the state of the roads being bad.

The temperature was unpleasantly warm throughout the day, and the stage crowded with passengers, who were generally agreeable companions. One of them, a gentleman in dress and manners, while conversing with my friend, enquired what country he came from, and immediately apologized for so doing. It is but justice to the people of America to say, this was the first question put to either my friend or me evincing curiosity, and considering conversation had been previously continued for hours, it was not altogether inexcusable. Travellers from a foreign land generally ply with questions the natives they come in contact with, and thereby lay themselves open to questions in return.

The driver who carried us to Utica behaved improperly towards my friend, regarding his luggage. He was a saucy fellow, and spouted what he perhaps considered wit, and others insolence, with every person who spoke to him. In fact, he was the only insolent driver I met with in the United States, this class of men being generally civil and accommodating to their passengers. He treated all travellers alike, and when told by an American he had taken four hours 
to drive fifteen miles, answered it was just an hour less than he intended to have taken. The drivers receive no gratuity from passengers, and can only be acted on by civility.

The state of the weather and stage-coach conveyance prevented our enjoying the scenery of the valley of the Mohawk as I expected; and after passing Little Falls, I exchanged places with a friend on the box seat. The object appearing, when the sun was approaching the horizon, was the German flats in the neighbourhood of the Herkeimer. But the shortness of twilight soon shut the landscape from my sight, and the brilliancy of the fire-fly alone remained to attract attention.

I again passed through this part of the valley of the Mohawk, in the end of Oetober following, when the weather was fine, in a canal packet, which afforded a better opportunity of seeing the scenery than travelling by stages, as on the former occasion. There is no part of America which I visited so interesting as this valley, which happily combines the beauties of nature with the comforts of man. The Mohawk is a moderate sized stream, according to the conceptions of a Briton, and wends its way gently through a valley, bounded by verdant hills, adorned with an infinite variety of vegetable productions. The road and canal in many places approach the verge of the river, where the scenery assumes the boldest character, and the different objects around Little Falls have few equals in any part of the world. 'The bottom of the valley affords evidence of successful cultivation, and its beautiful sloping sides are thickly covered with cattle and sheep browsing on the herbage. The country around the Herkeimer, near which the West Canada creek joins the Mohawk, as seen from the canal, is truly fertile, and the inhabitants of the valley apparently wealthy and happy.

In New England States, I observed a few plants of a class known to British farmers as wild mustard, chadlock, \&c. \&c., and which appears to me raphanus raphanustrum, but not in such numbers as to injure the crops.

On entering the State of New York, the raphanus was common, and methought I could distinguish the wild turnip from the stage-windows. Between Scheneetady and Little Falls, 
these weeds, in one or two instances, were choking the crops. The wheat crops throughout the valley of the Mohawk were good; the Indian corn had suffered severely from frost and the overflowing of the river, which hat, a few weeks before, attained a most unusual height, and imparted a disigreeable appearance to much of the land, which was little elevated above the river.

Utica is situated on the Krie canal, and is a handsome, thriving place, containing about 10,000 inhabitants, and became a city in 1832. We again, after a few hours' rest, proceeded on our journey, and reached Auburn, where we stopped for the night.

At Maulins we dined with a large party of travellers, who arrived by different stages, and afforded several marked instances of cooing, which the newly-married people of this country seem to indulge in. During this day's travelling, and on other occasions, the behaviour of such people appeared, to our British notions, verging on indelicacy, and completely at variance with the general opinion of English writers, who suppose that the females of the C'nited States are treated with neglect. Jurlying from what, of this nature, came under my notice in different parts of the country, I was led to think the American hushands attentive in the highest degree, and some of the ladies absolutely spoiled by too much attention. In almost every hotel chairs at the head of public tables are reserved for ladies, and they invariably occupy the principal seats in stage-coaches.

This day (21st June) the weather was warm, the thermometer in the stage, which is open on each side to the free admission of air, indicating 82 degrees at five P.M. Fortunately, myself and two friends were the only passengers after dinner, and we enjoyed a rapid drive through a fine country; there being no regularity with regard to time, the speed of the stages is often in the inverse ratio of the number of passengers. The prospect from the village of Onondaga-hill, which has two churches, is beautiful and extensive, embracing Onondaga lake and the villages of Syracuse and Salina. Beyond Onondaga-hill is Marcellus, which reminded me of the villages of New England, and is the prettiest place 
seen to the west of Albany. A farther drive of six miles brought us to Skeneatiles, situated at the foot of the lake bearing the same name, which, unruffled by the wind, and gilded by the rays of the setting sun, was sleeping in bright tranquillity. Skeneatiles is more beautiful than Marcelluscontains about 1200 inhabitants, and every thing in the village and neighbourhood indicates wealth and prosperity. At seven in the evening we reached Auburn, the seat of a stateprison, where the system of prison discipline, so justly celebrated, was first introduced.

Early next morning, the 22d June, we pursued our journey, passing over Cayuga lake by a remarkable wooden bridge, upwards of a mile in length. The lake is here very shallow. The bridge rests on posts, and was in a dangerous state for want of repairs. A new bridge was being formed, adjoining the old one, and seemingly of improved construction. Seneca falls and Waterloo are thriving villages, through which we passed, and reached Geneva in time for dinner. We stopped at the Franklin hotel, kept by Mr Mann, a most obliging individual, and where we found a large party, consisting chiefly of travellers. The table was well stored with brandy, which, with exception of water, was the only liquid; and my friend, who is well known for sobriety of character, drank more of it than all the rest of the company put together.

Having letters to several people in Geneva, induced ine to remain some time. Next day we attended divine worship at a Dutch reform church, and every thing which came under notice at Geneva, showed the Sabbath to be observed with propriety. Monday, the 24th June, proved wet, and so cold, that fires in the public rooms of the hotel were courted for their warmth. 'The rain ceasing about noon, we walked after dinner round the north end of the lake, to visit a farmer from Dumfries-shire, Scotland.

Mr J_ possesses strong natural parts, and is an instance of what energetic and persevering industry is capable of accomplishing in this country. On his first arrival he was very poor, and often employed himself in earrying wheat for hire. One year he raised by his own labour 900 bushels of wheat, with only the assistance of a small boy in harrowing, while he him- 
self was engaged in sowing. His farm is now his own property; and this season he has sixty acres in wheat, equal to any crop of similar extent I ever exanincd. His system is to sow clover amongst wheat, which affords good pasturage in autumn, and is fed off in the following spring; the land is ploughed in the end of June, and after an imperfect fallowing, sown with wheat in autumn. The Dutch farmers in the neighbourhood also sow clover with the wheat crop, which in spring is ploughed down for manure, without being fed off. This shows how much nature does for the farmer, - one year providing manure, and in the next a wheat crop. Skill might improve the system followed, but the period of introducing advanced agriculture into the United States has not yet arrived. Mr J_ applies fifty heaped Winchester bushels of lime to an acre, which costs nine cents, or $4 \mathrm{fd}$ sterling, per bushel. Gypsum costs fifteen cents per bushel, and is only used for clover and Indian corn. 'This being the season of applying it to the latter, people were carrying it in baskets, and putting a pinch on each hill or cluster of plants. Half a bushel is sufficient for an acre, and imparts an improved appearance to the crop in four days, except on black soft land, where it has little effect.

Mr J_ feeds labourers on the best of fare, and finds no want of them at any time. His wheat crop is cut with the cradle scythe at \$1 a-day and found, that is boarded-and two binders follow the cradler at $62 \frac{1}{2}$ cents. Wheat is cradled at $\$ 1 \frac{1}{2}$ per acre, and grass at $\$ \frac{7}{3}$, labourers finding themselves - and the work well done in both cases. Amerieans, Dutch, English, Irish, and Seotch, he finds work equally well. All his crop, including hay, is housed, and he considers a dollar per bushel a good price for wheat.

A good many sheep were shown us, a mixture of Saxon and Merino blood, which are not anointed with any kind of liquor or salve, and never stricken with fly. They are kept in courts during winter, fed on hay, and lamb betwixt 20th April and 20th May. Mr J___'s flock was in better condition than any yet seen, though poor, and the lambs were starvelings, compared with those reared in the cultivated parts of my native district. He says his sheep seldom die, having 
only lost two out of five hundred in the course of two years, and the mortality amongst lambs was not much greater. The price of his ewes, when the lambs are weaned, is \$3, and that of two-year old wedders, $\$ 2$ and $\$ 2 \frac{1}{2}$. Fleeces weigh $3 \frac{1}{2} \mathrm{lb}$., and his wool at present is worth 60 cents per $\mathrm{lb}$. We examined a large collection of wool belonging to Mr $\mathrm{R} \longrightarrow$, which was of fine quality. He told us one of his yearling wedders, weighing $291 \mathrm{lb}$. yielded 2lb. 90z. of wool; and the small size of this sheep induced him to think an acre of ground would yield as much fine wool as coarse. But the data furnished by this animal are not satisfactory, as its wool and carcass, in all probability, bore a different proportion in the preceding autumn; since which, the latter may have decreased, and the former increased. The carcass of a live wedder, weighing 29lb., must have consisted only of bone and sinew; and the weight of wool, compared with that of the sheep, may be held as evidence of wretched condition, and not of superiority of wool-yrowing.

Mr J__ 's cows were beautiful animals, and very fat. For some days past a great improvement in the condition of cattle had been observed, arising, perhaps, from better pastures, and the advance of the season. There was also an obvious change in the inhabitants, having seen more corpulent men since leaving Schenectady than in all our previous wanderings in America.

Mr Stuart, in his " Three Years' Residence in America," remarks, there are few lean animals; but observation leads me to a different conclusion_cows, sheep, and pigs, taken collectively, being apparently the leanest and most neglected creatures $I$ ever saw in any country. The condition of the horse is greatly superior to that of other animals, yet many are met with on the Erie canal equal in wretchedness to the most overwrought animal in Britain. Combining the price of the animal and of food, the daily expense of a horse is much higher in Britain than in the United States, while the wages of his driver are proportionally lower; hence a poor, weak, lame horse may be an object of profit in the one country long after he ceases to be so in the other, and the fatness 
of the American horses is not owing to abundance of foor in the country, or humanity in the people.

We examined a farm within three quarters of a mile of (ieneva, belonging to $\mathrm{Mr} \mathrm{W}$ _, consisting of 280 acres, 200 of which were cleared, fenced, and sublivided, with good dwelling-house, two servants' houses, suitable offices, and a large productive orchard, for which he asked \$ 35, or L.7, 5s. 10d. sterling per acre. 'The public burlens affecting the property were eighteen days' lahour of a man yearly for road-making, and $\$ 2$ for school-tax. There is a flour-mill on an outlet of the lake, propelled by an endless screw lying horizontally in the stream, which, for want of fall, is unsuitable for any common machinery. A steam flour-mill had been set a-going in the village a few days before our arrival.

Geneva is situated on the west sille of lake Seneca, near its northern extremity, commanding a view of the lake, which is the most beautiful sheet of water in America. There is a college, forr churches, a bank, and other public builclings. The chief part of the village consists of a square, and a street of neat villas ruming parallel to the lake, on which a steamboat plies daily to the extremity, distant thirty-five miles. 


\section{CHAPTER XI.}

Journey from Genevu to Leniston-Land offered for SuleCanundaigua-Genesee Country - Vuriations of Temperuture -Agricultural Notices-American and Seoteh notions of Reverted Wheat-Gevesee. Fluts-Mr Wudesurth-AvonWood Bridges_Girdling Trees_-Fulls of the Genesee-Rochester-Ridge Roud-Fuce of the Country.

We left Geneva in the morning by a stage-coach, and after travelling through a country of clay soil, badly farmed, but bearing excellent wheat crops, arrived at Canandaigua. Having a letter to a scotch gentlemin residing there, I discovered him by his national appearance when riding on the street. I was gratified at visiting him, and in viewing his new house and fine garden, one of the rarest sights in America. 'The necessity of proceeding with the olject of my tour, prevented me sharing his sincere hospitality, and I returned to Blossom's Hotel, and dined in an excellent room of large dimensions. In the afternoon we walked four miles in the direction of Mills, to view some lands for sale, and found the soil and wheat crops on the road generally good. For finc cleared land $\$ 25$ per acre was asked; and a person accosted me on the road and offered his farm of 100 acres, and his father's of the same extent, with suitable offices, at \$28 per acre. Almost every farmer in the eastern States who has a family, or is in straitened circumstances, is willing to sell his land and move to the western States, where he can obtain soil of equal quality, and in a finer climate, at a twentieth part of the price; and foreigners, who are easily known, and supposed to be in search of land, are constantly asked to purchase farms.

Canandaigua is situated near the outlet of the Lake of the 
same name, which is navigated by a steam-boat. The principal street extends back on rising ground nearly two miles, and consists of separate villas, as white and clean as paint can make them, with green Venetian blinds, situated at some distance from the street, and surrounded with umbrageous vegretation, which at this warm season imparted an appearance of coolness and luxury. Bevides a garden in front, crowiled with rose bushes hearing a profusion of flowers, many villas have a considerable extent of ground behind, capable of maintaining animals, and sfforling every family convenience. The buillings and beauty of Canandaigua surpass any place I have seen out of New England; and the wealth and comfort of its inhabitants may be owing to its early erection and situation in the Genesee country, the most celebrated wheat district in America.

The Genesee country was sold by the State of Massachusetts to Messrs Gorham and Phelps, who obtained 6,000,00() acres, at about eightpence sterling per acre; but finding difficulty in fulfiling their bargain, the land passed into other hands, and part of the country now belongs to the Pulteney family of England.

We left Canandaigua by a stage-coach at three o'clock in the morning, and suffered considerably from cold. When day dawned, a little after four o'clock, my thermometer, exposed on the outside of the stage, indicated $43^{\circ}$, and at Allanshill, on the outside of the hotel window, $45^{\circ}$. On different occasions I experienced inconvenience from variations of temperature in America, which are greater and as frequent as those of Britain. We reached the village of Genesee early in the forenoon, and from the courts being then sitting, could not be received where the stages stopped. The landlord and driver were not accommodating, but we soon found a very attentive hotel-keeper in a different part of the village.

The surface of the country, from Canandaigua to Genesee, is undulating and picturesque, but ill cultivated. The wheat crops generally good, and a considerable extent of ground preparing for fallow, by breaking up grass land which had been depastured. In some cases, four oxen and a horse were dragging a plough, a boy ridinz the horse in front, and a 
driver to the oxen. In every case, a driver was employed with oxen, and horses generally riden by boys when in the plough, which, I supposed, was owing to their being little accustomed to this kind of labour.

I had observed the wheat crops of America abounding with a species of grass passing by the name of chess, which I imagine to be the Bromus secalinus of botanists, and which I have seen in the wheat crops of Surrey, lingland, and south of Ireland. A passenger between Canindaigua and Genesee, stated, that chess was reverted wheat, and originated from an inclement season, or bad seed, an opinion which I found pretty general in the States and Canada. This doctrine was made known to me by letters in the Genesee Farmers' newspaper, published at Rochester, numbers of which I received in Scotland, but it is so different to my observation and reflection, that I told the passenger, I would as soon expect a horse to become a pig, as wheat chess. From extensive olsservation in remote parts of America, I have not a doubt of chess being indigenous to the soil, and henee its growth amongst wheat crops, where the farmer did not sow its seeds.

Akin to the notion of wheat reverting to chess, is that of the same grain changing to darnel (Lolium temelustum), lately advanced in Scotland, where the plant is provincially called sleepies. Botanists assign original types for cultivated plants, but farmers seem not to be agreed ahout that of wheat. Americans may arrange themselves on the side of chess, Seotchmen that of darnel, without throwing light on the subject. A plant cunnot change from one species to another, or the veyetable kingdom would pass into confusion. Wheat, chess, and darnel, are distinct species.

Having heard much of the Gienesee flats, I proceeded to call on their owner, on arriving at Genesee. Mr Wadesworth had gone to a distant part of the country, one of his sons being the only member of the family at home, and who had rode out after breakfast. On calling a second time, the young gentleman pointed out the way to the flats, where he said he would join us in an hour afterwards.

The Genesee flats belonging to $\mathrm{Mr}$ Wadesworth, are rich alluvial soil, ornamented with aged trees, deposited in 
groups and at intervals ; and perhajes no gentleman's park in Britain equals them in fortility and beauty. They dotier from the rest of the surface in this part of the country, hy having heen cleared by nature, and are chicfly in grass, atforling the richest pasturage I ever saw, with exceppion of some fields in the neighbourhood of Boston, Lineolnshire, England. On examining some parts which had never been suljected to the plough, red and white clovers were particularly abundant, also timothy grass (I'heum pratense), aml several kinds of poea. Cocksfoot was less common, and a few spikes of tall oat-like grass (Holcus arenurens). Ryegrass or yellow-flowering clovers were not visilsle. A field was pointed out which had been mown for hay thirty-five successive years, without top-dressing, and the grasses were still in vigour of growth, interspersed with red clover nearly thirty inches high.

The young gentleman joined us on the flats, and pointerl out every thing deserving of notice. The sheep were a mixture of Merino and Saxon breeds, and not fat looking. There was a fine shorthorn bull, intended to improve the dairy stock, which I did not see. This contemplated improvement originated from perusing the writings of the Rev. Henry Berry of England; and I took the liluerty of advising the cross to be tried on a small scale, believing the shorthorns the worst milking breed in Britain. This opinion was new to the gentleman, who said he would keep it in view, and proceed cautiously in intermixing the breeds. The grazing cattle were extremely numerous-four-year-olds, which had been bought in spring, and kept on hay till the arrival of grass, on which they are to be fatted. Mr Wadesworth intends to cultivate wheat extensively; and one enclosure, as a beginning, was bearing an indifferent crop. I have often observed wheat not succeed well on very rich ground, and that, in Britain, the United States, and Canada, soils which have been long under cultivation, yield the best crops of this grain when properly managed. There was a variety of implements which brought to recollection those at Holkham, Norfolk, England. Amongst others, a mowing machine was exhibited and descanted on. We were shown a fine oak-tree 
growing on the banks of the river, and said to be twenty-four feet in circumference.

We passed the evening at the house of Mr Wadesworth, in agreeable and instructive conversation with the young gentleman, whose acquirements and intelligenee were of a superior description. He expressed regret at the necessity of leaving home next day, but offered to place at my disposal his father's carriage, horses, and driver, with introductory letters to his friends in the neighbourhood, and said he himself would show us the country on the day fullowing. Time would not admit of embracing the kind offer, and I notice this attention as creditable to a person of the highest influcnce and station, on whose good offices I had no claim. It has been my fortune to experience attention from eminent agriculturists in all ranks of life in Britain, and while the heart must be held as the seat of kindness, I can bear testimony to having foumd true agricultural knowledge, distinguished from what is empirical, connected with expansion of mind and liberality of sentiment.*

Next morning we left Genesee and passed through Avon, frequented for its mineral springs, and beauty of situation. While the horses were changing, we found many people indulging in copious draughts of water, which I prevailed on my friend I) — to taste, when he amused the bystanders by making a wry face, and exclaiming in a serious tone of voice, "Do people really drink that for health?" We dined at a stage house, and were much annoyed by a tipsy person whose impertinence called for an exercise of patience. He was descended of Irish parents, said to possess property, and seemingly an

- The following extract is from a letter addressed to me, and dated with June, 1834.- "I called on Mr Wadesworth, Genesee. 'The cldest of the brothers died last year, leaving lauched property to the amount of about a million and a half of dollars. The remaining brother, a man about seventy, inherits it all. His family consists of two suns and a daughter, the eldest of the sons was on his marriage jaunt. Immediately after introduction I was placed on a good horse, and directed down to the farm, of about 1:000 acres, where I found your friend amongst the cattle, without his coat, and I could not help smiling as I contrasted him with our frivoluus game-preserving lairds at home. With a mind infinitely superior to most of them, and the most unexceptionable manners, he considered it no disgrace to be actively engaged in business. I found him agreeable and communicative." 
excellent customer to the har-room. On reaching Rochester, I remarked to the driver, that he seemed to be traversing the same street twice in setting down passengers, and learned that he was afraid to cross a certain bridge, through which one of his horses fell a few days before and broke a leg. Few things in America appear more striking to a Briton than the wretched state of the wooden bridges, a material which he does not associate with strength or durability. We took up our quarters at the Eagle tavern, the landlord of which was attentive and accommodating.

The soil from Grenesee to Rochester is chiefly clay, bearing excellent wheat, and nineteen-twentieths of the land in crop was producing this grain. I observed a good wheat crop amongst girdled oak-trees, in a field of considerable extent. Girdling is effected by cutting a ring through the bark round the tree, which does not again put forth leaves, by which sun beams and air are admitted to plants on the surface of the earth. This mode of improvement is only followed amongst oaks, the roots of which strike perpendicularly into the earth, and consequently are favourable to the progress of the plough; but the trees become more obdurate, and girdling is only excusable in the first operations of a new settler.

We lost no time in viewing the sights of Rochester, the chief of which is the fall of the Genesee river, ninety-seven feet in height, and celebrated by the ill-fated leap of Sam Patch in 1829. We enjoyed a walk down the banks of the stream on a lovely evening, but the scenery in the neighbourhood of the fall has been injured by the erection of machinery propelled by the water. The flour mills are numerous, and on the most extensive scale, said to be capable of manufacturing 12,000 bushels of wheat in twenty-four hours. There is an arcade, extolled by the inhabitants, but possessing no attractions to individuals who have seen those of other countries. Rochester is one of the many places illustrative of the growing wealth arid population of the United States, and which some English travellers ridicule for want of antiquity, on the principle a withered old beau affects to despise the freshness and elasticity of youth. The first settlement took place in 1812 , and the population is now estimated at about 14,000 . The 
situation of the town, communicating with Lake Erie, and the extensive waters to the west, by means of the Erie canal, which is carried over the river in the middle of the town by an aqueduct of free stone, 800 feet long-with Lake Ontario by a railroad-with Montreal by the St Lawrence, and with New York by the Hudson, together with its splendid water power, renders its increase of wealth and population almost without limits.

Next morning we set out for Lewistown by way of Lockport, travelling on what is termed the ridge-road, a natural formation extending round the south end of Lake Ontario, at a distance of eight or ten miles from the present waters, and nearly a hundred feet higher. It is from twenty-five to fifty feet wide, fifteen to twenty feet above the surrounding country, and composed of sand and gravel. The road is supposed to have formed the margin of the lake at some remote period of the world, but I had not sufficient opportunity to form an opinion on this point.

The country through which we travelled, after leaving Rochester, is more recently settled than any yet seen, the fields being thickly covered with black stumps overtopping the wheat crops ; and the felling and buruing of trees was going on in all directions. The houses were mere log-huts, and wanting in external comforts. The warm state of the weather induced the inhabitants to throw open the doors and windows, affording an opportunity of seeing the internal arrangements, and I can testify to their well-stored tables and general neatness. The crops were bad, and much of the soil so inferior as not likely to repay those engaged in clearing it of timber.

After a fatiguing ride, we reached Lewistown, a thriving village, at midnight, and found the bar-keeper and porter of the hotel intoxicated, which was the only instamce of the kind I met during my transatlantic tour. By this time we had learned to take things as we found them, and in a few minutes our baggage and selves were in bedrooms without assistance. 


\section{CHAP'TER XII.}

Niagara River and Fulls - Carving-Entrance to CanadnCinvern beneath the Fulls - Rupids - C'ity Building-Singe Pussenger - Gieneral Brock's Monument - Letters - MripsQueenstoun and Viagara-Agricultural Nolices-King-Old Selters-Disappointment with Cunadu.

Aware of being near the Niagara river, which connects Lake Erie with Ontario, and which forms the St Lawrence, my first proceeding in the morning was to obtain a sight of this stream, from the window. 'The sun shone brightly, and displayed to advantage the white painted houses and endless forest, but there was no feature indicating a river. On walking a short distance from the hotel I unexpectedly found myself on the banks of the Niagara, moving in the midst of a flat country, betwixt low woodless banks void of beauty. On the opposite side lay Upper Canada; the village of Queenstown was seen in the distance, over which Sir Isaac Brock's monument was towering. I looked on the scene with feelings of a British subject, and, with a thousand associations rushing on my mind, anticipated new enjoyment from mingling with the inhabitants.

After breakfast we were seated in a stage on the way to the Falls of Niagara, winding up a steep hill, corresponding with elevated ground on the Canada side, called the heights of Queenstown. From the summit, the passengers expatiated on the extent and beauty of the prospect, but being unfortunately seated between two stout individuals, I was deprived of seeing objects at a distance. I could, however, perceive that the banks of the river, along which we travelled, underwent a change on reaching the height, being rocky, precipitous, and deep. It is conjectured, and appearances support 
the theory, that the cataract of Niagara once poured its torrents over this spot, and that it has receded to its present position, seven miles distant, by the gradual wearing of the rock. The soil from Lewistown, along the river, is inferior, bearing bad crops.

On reaching the village of Manchester, situated on the rapids of the river, we instantly sallied forth to view the Fulls of Niagara, which I had long considered the most wonderful sight in the world. A remarkable and fragile-looking bridge leads across the rapids to Goat island, and we soon stood on what is termed the American falls, formed by that part of the river passing on the south side of the island.

I know not whether it was owing to unreasonable expectations, or the magnitude and sullimity of the object, that I feit disappointed on first viewing the falls. Instead of being riveted to the spot in breathless agitation, and soul-thrilling delight, a feeling of uneasiness stole over me, from which I sought relief by culling a variety of plants from the eige of the cataract. But every sight afforded additional pleasure, and hours flitted away in gazing on their endless beauties.

On returning to the hotel, a large and good establishment, numerous visitors of the falls had assembled for dimer, to which they did justice, thinking, perhaps, the grosser senses entitled in turn to gratification. Guests are not expected to carve, waiters either doing so, or carrying dishes to those wishing to help themselves. The numerous company induced me to cut up a joint, and having served a dozen of individuals, I was about to help myself, when the fragments were expeditiously carried off and placed before a gentleman at the extremity of the table. Amused at the way I had been treated, I resolved to involve a companion in the disappointment, by asking him to help me to mutton. He complied, and no other person was so honoured during his tour. Foreigners may well be excused carving, their utmost exertions being required to finish meals with the natives.

Immediately after dinner we set out for the Pavilion House, a celebrated hotel in Canada, a porter conveying our luggage in a barrow to the ferry, which we reached by descending a wooden spiral staircase. The river is 1200 yards broad. The 
agitated state of the waters conveys an idea of danger, and we were landed safely on the opposite beach in 14 minutew, having been drenched in crossing by the spray of the fulls. Mr 1) remained with the luggage, while we went in search of assistance to transport it. 'T'wo men of colour were met carrying trunks to the ferry, who brought ours on their return.

On the Canada side of the river, a wide road winds up the steep bank, at the top of which were carringes of different descriptions, and people walking to and fro. The ascent being long and difficult, afforded time for observation. Banks, rocks, trees, carriages, and people, appeared like those I had been accustomed to of late, and no important object indicated a change of territory. But characters of countries and individuals may sometimes be learned from trifles. On walking up the banks of the river, an elevated board attracted notice, containing the following inscription :- "All persons found on these grounds will be prosecuted." This was so unlike any thing I had seen in the States, that it impressed me with an idea I had left the land of liberality, if not of liberty, and recalled associations connected with notice-boards of Scotland regarding steel-traps, spring-guns, and prosecutions according to law, which deface the country, and exhibit the characters of those who erect them.

The banks of the Niagara from the ferry to the Pavilion is the loveliest and most interesting portion of the globe. At the point where the footpath diverges is the Table rock, aftording the best view of the Horse-shoe fall, one of the most splendid earthly objects the eye of man can behold. We reached the hotel in time for tea. Our bedroom windows overlooked the cataract, whose murmurings soon lulled us to repose.

Next morning, when the sun was peeping above the horizon, and ere the vapour had melted before his rays, we were at the Table rock, gazing with increased pleasure at the Horse-shoe fall, preparatory to entering the cavern below it: In a small shanty we changed our elothes for sailcloth dresses kept for visitors, and, laughing at our grotesque appearance, descended a spiral stair to the level of the river. The guide led the way, and after a considerable battering of spray and wind in passing the verge of the cataract, the interior of the 
cave was comparatively serene. We penetrated 153 feet to the 'Termination rock, where we conversed without difficulty, in a peculiar greenish light, the sun being distinctly visible through the falling sheet of water. The pathway is strewed with loose stones-the debris of the falling rock-and unpleasantly narrow. 'The guide seemed impatient to regain the outside, and I experienced no difficulty in breathing, or uneasiness of any kind. Next day I repeated my visit, when the spray and wind were much more powerful. On this oceasion, $\operatorname{Mr~C~}-$ and I were preeeded by three Yaukee youths, two of whom lost courage on encountering the spray, and nearly overturned us in their hurried retreat. There is little danger in a pilgrimage to the Termination rock, and nothing to affect the nerves of an ordinary person, or to reward him, beyond the glory of having made it, and enjoying the finest of shower-baths, formed by the spray of the falling water.

'The currents of air acting on the soft under stratum in the cave, is the primary eause of the lime rock giving way, over which the water pours, but how they should vary so much is not easily accounted for. At both visits the external atmosphere was still, but I did not remark the direction of the wind, or revolve the matter in my mind. Air mingled with water will at all times pass over the cataract, and the current in the cave may either proceed from the agitated water below being incapable of containing the same quantity of air as that above, or from wind passing through the falling sheet, as sunbeams do through glass.

At my first visit to the cave I lifted an eel about the centre, and restored it to the water. A toad was near the falling sheet, in full vigour of life, and on my second visit there was one near the same spot. In the channel of the river, and amidst the thickest vapour, swallows were whirling at all times, and occasionally seemed to pass within a few inches of the surface of the most impetuous part of the Horse-shoe fall. 'The suction and danger of the falls seem to have been exaggerated, and the noise and terror said to be experienced on viewing them, either do not exist, or my feelings were insensible to them.

At twilight of the evening of Ist July, I walked up the 
Niagara to deliver an introductory letter, when I was so much gratified with a sight of the rapids, that my friends accompanied me next night at the same hour. No person who has not seen the rapids can form a just estinnate of the quantity and force of water descending the cataract. When standing at the verge of the river, a hundred yards below the grist mills, and looking up the stream, the most obtuse feelings cannot fail of being touched with the spectacle. Such is the breadth and descent of the river, that the water forms the visible horizon ; and the mighty stream, in waving folds, seems issuing from the firmament. 'The sun had sunk to rest; the evening was soothingly still ; the thin clouds of vapour rising from the falls curled gracefully over Goat island, and were lost in the distance. The agitated rapids formed a contrast with the serene sky emblematical of troubled earth and calm heaven.

Conscious of my inability to do justice, in the way of description, to the Falls of Niagara, when so many higher-gifted individuals have failed in the attempt, the works of travellers must be consulted by those interested in the matter. They will find descriptions, like the actual falls, abounding in so many beauties, that readers, like visitors, may select what is suited to their taste. Visitors, however, ought to perambulate the banks of the river and islands in the neighbourhood of the falls, and begin with the American or Canadla side, according to their temperament. As few seem capable of appreciating the magnificence of the sight at first, it will generally be found the best policy to begin with the American side, which affords opportunity of seeing both falls; while the Horse-shoe and rapids from the Canadian side, the sublimest objects of the scene, are reserved for the last.

Two rival companies have commenced building villas on the Canada side of the Niagara, and in all probability will lead to the embellishment and improvement of the banks in the vicinity of the falls. The period has not yet, however, arrived for the population resorting to villas in Canada for a few months in summer; and city building at the falls seems as visionary an undertaking as could at present be entered into. 
On the morning after our arrival at the Pavilion, we entered a stage for the village of Niagara, formerly Newark, distant twenty miles, and found a passenger railing at delay. His dialect marked him from the north of Scotland; he could not be made to comprehend the distinction between the rivers Niagara and St Lawrence, and amused us by some remarks on different subjects. The beef of Canada, he said, was so tough that teeth could not chew it; and on being reminded his might not now have so keen an edge as when in Seotland, replied, there could be no great change on them, as he came to this country last fall; but when in the old country he only got beef once a-week on Sunday, here he had it three times aday. 'The road is full of interest, from recent historical events, and was fringed with various kinds of fruit-trees, bending under an abundant crop. On reaching the heights of Queenstown, five or six individuals left the stage and went to the top of General Brock's monument, erected hy the (iovernment of Upper Canada to commemorate the services of that officer. who fell in the moment of victory during the last war with the States. The heights afford a sweet view of the junction of the Niagara with lake Ontario, and the surrounding country ; the monument commanding a wider range of landscape, without diversifying the scene, and certainly does not reward the labour of reaching the summit. The party joined the stage at Queenstown, and soon reached Niagara, having deposited a passenger at the steam-boat on the river before entering the village.

My friend D_ found letters at the post-office of Niagara, but the like fortune did not attend me, although our letters are said to have been put into the same post-office in Scotland, and similarly directed. I did not receive a letter from Britain while across the Atlantie, but my communications regularly reached their destination in Scotland. The post-office of the United States seems well conducted, but I experienced proofs to the contrary with that of Canada.

Few countries are better provided with maps than the United States, pocket ones being everywhere to be had, and the walls of hotels covered with them and information regarding stages and routes. We could not obtain a map of 
Canada, the booksellers of Niagara informing us a pocket one of the country never had been published, and almont nothing could be learned about mails and stages, which nearly placed us in the situation of pursuing our route blindfold. Dining at the village, we returned to the Pavilion in an extra, which corresponds to the post-chaise of I3ritain; and I took an opportunity of delivering some letters by the way. Queenstown and Niagara are mean dirty-looking villages, apparently without trade, and very unlike the clean bustling places on the opposite side of the river. The bar-rooms of the hotels we entered were filled with swearing tipsy people, and the establishments badly conducted, from the stage-cosach to the presenting of butter; which, instead of being, as in the States, hardened by means of ice, was an unclean liquid.

Between the falls and village of Niagara the soil is partly clay and partly sand, both seemingly of indifferent quality, and bearing bad crops. The farm-houses are untidy, and the fences look old and dilapidated. No trace of recent improvement could be discovered, and the state of agriculture seemed stationary.

I had a letter to $\mathrm{Mr} \longrightarrow$, whom I was requested to visit, as he had been nearly half a century in Canada, and possessed some fine farms in the neighbourhood of the falls. On enquiring at the landlord of the Pavilion, if he knew any thing of the gentleman to whom the letter was addressed, I learned he was a little king in this part of the world, with whom the landlord himself had served when a boy. Impressed with the rank of the person, I asked if I might venture to breakfast with him next morning. Yes, was the reply, you will be sure to get every thing of the best. The import of my question being misunderstood, I was told it was unnecessary to announce my visit beforehand. I requested an extra to be in readiness to carry us to ——, and retired to rest, meditating on the treat expected from walking over some of the finest farms in Canada, in company with King Next morning rain fell in torrents, which detained us till after breakfast, when we travelled by the way of St David's, and at length the extra drew up at the door of a small wooden cottage. No time was lost in delivering and reading the 
letters; and I regretted to observe a restraint in the family, arising, perhaps, from the extra, which probably was the ouly one that ever approached their dwelling. When engaged in putting questions regarding farming, in presence of father and son, the old gentleman said he would send for his man Peter, as best qualified to answer me. Peter was from stirlingshire, Seotland-had been several years in the country, and possessed more information and address than any of the roygal family. He told me farm-labourers receive $\$ 10$ a-month when engaged by the year, with board. In winter, labour can seareely be obtained at $\$ 6$ a-month, and boys sometimes engage for their food. Canadians drink less spirits than they did at one time, and they are not now served to labourers in the fielt. King —_ and Prince —_ boasted of making their furm implements, which a mechanic could have done at half the labour, and of treading out the wheat crop with horses. The day continuing wet, prevented a walk over the dominions, and we returned to the Pavilion in time for dinner, to the expressed regret of $\mathrm{Mr} \longrightarrow$, who was as kind as possible; but a prolonged stay might not have been agreeable to either party. The interior of the house presented few marks of comfurt, according to my notions at the time, although after experience in Canada enables me to say it was respectable in this view.

The old settlers are evidently the least enterprising class. Having come to the country uncultivated themselves, and ever since living without intercourse with the world, they seem content with the necessaries of life, which are easily obtained. Their descendants imbibe the same sentiments and habits; and before the first settled portions of Upper Canada can be farther improved, the present farmers must either sell to others of more enterprise, or another generation arise with new opinions.

I could no longer conceal the disappointment experienced with Canada and its inhabitants. The Pavilion House, so much praised by travellers, lately purchased by a company, and puffed off by advertisements, was greatly inferior to the hotels in the States. The manners and customs of the peopie were essentially Yankee, with less intelligence, civility, and 
solriety. 'The houses and fences were inferior to those of any district yet seen, and instead of the youthfulness and never-ceasing activity of the States, there seemed the listless repose of doating age. 'The brute creation partork of the change-horses, cattle, sheep, and pigs, being inferior to those on the opposite side of the frontier. If such was the state of things in Niagara district-the paradise of Upper Canadalittle could be expected from other parts of the province. My friends, at first, scemed to regard my opinions as more the result of prejudice than observation, lut in a few days after, they drew a contrast less favourable to Canala than I had done. No unprejudiced traveller can spend a few hours on either side of the frontier line without remarking the difference of the two countries, and as the people, soil, and climate, were originally alike, the circumstances in which the inhabitants have been placed must alone account for the dissimilarity. If governments affect the state of countries, politicians would do well to visit both sides of the river Niagara. 


\section{CHAPTER XIII.}

Baffled in reaching the Western Stutes-Buffulo-4th of July -Oneida Indiun-Fort Erie-Liarly Marriuges-1)urid Buter-Petersburgh-Separute from Companions-Musquittoes-Setters around Dunille_Euring of Wheat-DunilleFace of the Country-Notices of Nuture-Breuking Fruittrees-Bur-room Group_Junction with Compunions-Visit a New Séttler-Politiciuns-Humilton-York.

As it was my intention to visit the Western States of the Union, my friends aureed to aceompany me round the north side of Lake Erie, and cross over to Cleveland, proceeding down the Ohio canal and river, passing north, through Illinois and Michigan, east by Upper and Lower Canada, and to Britain hy the St Lawrence. We could not get information regarding roads or conveyances at the Pavilion, which we left in a stage for Buffalo on the morning of the $3 \mathrm{~d}$ July, to push our way in the best manner we could, having forwarded our heavy luggage to York. The day being fine, the drive was delightful up the banks of the Niagara; here a broad smooth flowing stream, divided by islands, and a few feet below the surrounding country. The river does not at any time overflow its banks, seldom varying ten inches in depth, a peculiarity arising from the lakes, through which the waters flow, acting as reservoirs. The soil is clay of good quality, badly fenced, without indication of recent improvements, and appearances did not bespeak wealth or industry in the inhabitants. At the village of Waterloo, we crossed the river in a four-horse ferry-boat, and after passing through a country of recently cleared and inferior soil, reached the lagle tavern at Buffalo in time for dinner, served in a well-lighted room, 93 feet long, and crowded with company.

Buffilo is situated in the extremity of Lake Erie, at the mouth of the Erie canal, and is the depôt of commerce pass 
ing between the Eastern and Western Sitates. In 1814, the village was reduced to one house, having been hurned by the enemy. Now it contains many brick houses of large size; and I was struck with the stores, or warehouses, at the wharf, and the immense quantity of merchandise they contained. It is the chief port on the lake for steam-boats-a daily line sailing for Detroit, one of which, in course of the season, was said to have left the pier with 800 passengers on hoard. The Americans have fifteen steam-boats on the lake, many of them of the largest size, and four are building. The British had not one at this time-two small boats having heen launched in course of the season, were undergoing repair, after having made a trip or two. American steamers do not touch at any port on the Canada side of Lake lirie, with exception of Amherstburgh, on the river Detroit.

'The 4th July is a holiday over the U'nion, heing the anniversary of American independence, and was ushered in at Buffalo with firing of guns, and other demonstrations of joy. All was again quiet by breakfast time; and a procession was to take place at noon. Approving of keeping such a day in remembrance, as impressing the mind of youth with love of liberty, I felt inclined to witness the proceedings, but the necessity of continuing my journey induced me to abandon the idea.

After breakfast, we got on board a miserable steamer of eight horse power, which landed us at Fort Erie in Canada. On the wharf at Buffalo we saw a number of the Oneida tribe of Indians, on their way to Greenbay, a branch of Lake Michigan. This tribe having sold their lands in the state of New York, government was conveying them to their new possessions. The poor creatures were standing in groups, dressed in their best attire, and many young and old of both sexes stupified by intoxication. I particularly remarked a grey-haired aged female, with a countenance of the deepest suffering, bearing in her arms a child of spurious origin. These descendants of the original owners of the soil have been gradually deprived of their birthright; and although Greenbay is 1000 miles from their old habitations, the white man in progress of time will envy their new possessions, and the poor 
Indian will retire still farther to the west, if drunkenness, and other vices aequired from the whites, do not exterminate the race.

On landing at Fort Erie, consisting of four or five houses, I was disappointed at finding that a gentleman, to whom I had a letter, resided three miles from the fort, and that it was doubtful if we could make our way round the south side of the lake, there being no regular conveyance of any kind; but I flattered myself if we could reach Gravelbay, at the mouth of the Welland canal, all difficulty would be over; and after some little enquiry, we succeeded in engaging a farmer to drive us there in his waggon.

I delivered letters, and dined at Fort Erie, where a pretty little miss, when enquiring about her friends at Eilinburyh, said her cousin, Mrs —, was old when married. On replying I did not think so, she alded, "O yes-quite old; she was six-and-twenty." 'This lady's opinion of marriage was pretty well expressed, and I hope she may not be disappointed in her own fate. 'The people of America marry early. When at Montreal, a couple was pointed out, the lady being only thirteen years of age.

The waggon arrived soon after dimer, driven by its owner, Mr David Baxter, so much improved by change of dress, that I had difficulty in recognising him. He was son of a captain of militia, farmed 100 acres, and owned 200 more in the London district, yet he readily left his employment, and engaged to carry us nineteen miles for $8 \mathrm{~s} .6 \mathrm{~d}$. sterling. The horses were excellent, and he said to them a thousand times, " Jim and Jerry, go-a-long; bid you both; what-you-bout? wheel-away ;" and being good-humoured and intelligent, time passed pleasantly in the waggon.

For eight or nine miles the shores of Lake Erie resembled the beach of the sea. The country at some distance was wet and partly newly cleared; the ridges eight or ten feet wide; crops, with exception of some wheat-fields, indifferent, and included a considerable extent of peas. Houses were mean; the inhabitants ragged and dirty. Cattle were small and lean. Many pigs were pictures of starvation; and on the 5th July their winter hair was hanging on them in matted masses, like 
the wool of sheep. At dusk, we reached a few log-housers, called Petershurgh, on the Welland canal, where we had one bed assigned to three of us, which was occupied by two, the third reposing on a chest, with a great coat below, and a cloak above him.

We rose at four o'elock next morning, and walked down the banks of the canal to its junction with the lake, and some miles to the west, to see a property for sale belonging to $\mathrm{Mr}$ _. for which \$10 per acre was asked. After breakfast, we expected a waggon and a pair of horses to take us to Dunville, but the waggon being engaged in carrying hay, a small boat was provided to carry our luggage up the canal to the junction of the feeder from the grand river, in hope of getting a conveyance to Dunville. On learning the passage-boat was expected from, instead of going to Dunville, my compranions became angry, and announced their intention of returning to Britain without loss of time, by way of the St Lawrence, a piece of intelligence not altogether unexpected. The luggage was the chief obstacle to our progress; and if it could have heen dispensed with, they might have been induced to persevere. It was arranged that they should proceed down the canal to St Cathrine's, and wait my arrival at Hamilton.

I proceeded on foot to Dunville, distant eighteen miles, dining on poor fare at Marshville. On passing Cranberrymarsh, I was attacked by musquittoes, which clustered chiefly behind my ears, and defended myself for two hours by waving the branch of a tree in each hand, reaching my destination after nightfall, having walked fifteen hours in course of the day. My repose was disturbed by the nibbling of musquittoes; and on rising at day-break, I found vegetation most copiously covered with dew.

In the course of the day I visited settlers in the neighbourhood of Dunville, resident from a few weeks to three years, and found them leading lives of privation and hardship. In every instance, they were cheerful and looking with confidence to futurity ; but it was evident to me they, generally, had entangled themselves with an extent of possession far beyond their means of paying for, and at a price so much beyond its real value, that accumulation of interest on the purchase money 
would ultimately weigh down the utmost industry. I felt for their situation; but the morning of first settlement shone so brightly, that prognostics of a coming storm would have been disregarded, and considered unkind. First crops on small clearances were half suffocated for want of air, and what came under notice, satisfied me that a settler in the forest, trusting alone to his own labour, will have difficulty in raising sulficient food for a family during the first three years.

The wheat crop of Upper Canada is sown in autumn, termed fall in this part of the world; that of the Lower l'rovince in spring. I was informed fall-wheat sown in spring does not put forth the ear until that time twelve-months, while the wheat of Lower Canada produces a good crop in August following; and in corroboration was shown, on the 7 th July, a crop of wheat just coming into ear of the spring wheat of the country, while one from seed, brought from Roxburyhshire, Scotland, sown under a parity of circumstance, was only a few inches high, without indication of shooting into ear. This appearing inexplicable, induced me to bring home samples of fall and spring wheats, the plants from which were destroyed at Mungoswells by hares. I found, however, plants from Scotch wheat sown in the garden did not show a disposition to ear when sown in the middle of May. 'The effects of cimate on the non-earing of wheat seems the same in Britain as in Upper Canada.

Dunville is situated on the Ouse, or Grand River, four miles from its mouth, and where the feeler of the Welland canal branches off, by means of a dam eight feet high. There are about twenty small wooden houses, a grist and saw-mill. The river is navigable to the lake, and it is said to be in contemplation to render it so as far as Brantford by means of locks. Dunville may increase in progress of time; at present it stands amidst stagnant waters, and is a perfect bullfrog and musquitto nursery.

It was my intention to have walked up the river, and across the country to Hamilton, but learning that a friend, whose dwelling I had passed, resided near the Falls of Niagara, induced me to change my route. I left Dunville at five in the morning, 
passing along the feeder and canal to Port Robinson, and from thence by Lundyslane to my friend's house.

The country at the junction of the Welland canal with Lake Erie is little cleared, and few habitations or traces of cultivation are met with on the banks or feeder. Many trees have perished, from stagnant water, on the margins of the feeder, and impart a gioomy aspect to the scene. Part of Cranberry-marsh is seen on the banks of the feeder; the soil is peat-moss, thickly covered with stunted larch-trees, ten to twenty feet high; and the water is yellow coloured, but not unpleasant to the taste. A plough, drawn by four oxen, was turning over part of the marsh bearing grass twenty inches in height, and five or six Irishmen planting it with potatoes on 6ith July. The country improved on descending the canal, and the banks of the Chippeway were well cleared; the soil is dry, and some good crops of wheat and grass were seen. Cattle and sheep were in considerable numbers; the inhabitants seemed wealthy, and resided in good houses.

When near Dunville I saw, for the first time, wood-pigeons and humming-birds, also a few carrion crows and herons, similar to those of Britain, and different kinds of hawks. On the south from the canal, annual thistles and wild mustard were growing; and on the north bank of the feeder red and white - French willow, the latter having afterwards been seen only in one situation.

After an agreeable visit my friends drove me to St Catherine's next day, to get the stage for Hamilton. On the way we met an Irish funeral, accompanied by waggons filled with both sexes, who, on approaching, descended, and broke immense branches from cherry-trees, loaded with ripe fruit. The owner of the trees halloed to the depredators in vain, and I felt indignant that they should composedly take the fruit, and destroy the trees. I was told it is customary for the people of the country to help themselves to peaches and other kinds of fruit in the same way.

While waiting for the arrival of the coach, I strolled into the bar-room of the hotel, which would be better named bearroom, and witnessed a group deserving the pencil of Cruikshank to immortalize them. The landlord, a little, spruce, 
talkative Yankee, was swinging in the chair, with his legs on the table; another individual was sitting with his face to the back of the chair, a third stretched at full length on the table; and one occupied two chairs. The forms were adorned in a similar manner, and there was only one person sitting in an upright position by the wall, fast asleep, in a state of intoxication. The subject of discussion was a riot on the 4 th July, the anniversary of North American independence. Some boys of the village were innocently firing guns in the morning in rear of the hotel, with which they had no connexion. The landlord being a Yankee, the firing was considered insulting to the British government : a multitude assembled, broke the windows, and attempted to set fire to the hotel. The mob was said to have been headed by a justice of the peace. My friend, who drove me to St Catherine's, said a travelling trunk had been found open in a wood a short time ago, in the Niagara district, containing a few articles marked with initials. The owner was supposed to have been robbed and murdered, yet the circumstance had passed unnoticed.

The stage arrived with one passenger, tipsy, who placed his head on one side of the coach, with his feet out at the opposite one, and snored loudly. Next stage the driver was intoxicated, and I began to ruminate on the possibility of the horses participating in the common vice.

I reached Hamilton at one in the morning, and after a few hours' sleep, took my friends out of bed in another hotel. At separating on the banks of the Welland canal they despaired of getting a conveyance to Port Robinson, and accepted the offer of a furmer to accompany him to his house on the Chippeway in the evening, and be taken in his waggon next day to Hamilton. They were much pleased with the farmer and the country which they travelled through.

On learning that a relation, who left Britain in March, was residing in the neighbourhood, a waggon was obtained, in which we rode out to breakfast. The waygons of America are light, uncovered, four-wheeled carriages, used for carrying goods or human beings, and almost the only vehicle in the country. We passed the Albion mills, situated in a romantic glen, where a rock was pointed out, over which a young woman 
threw herself some years before. Being deserted by a lover, her mind gave way under the shock her feelings sustained, and the spot where she sought relief from her sufferings will long remain associated with human frailty, and the perfily of man. The family with which my relative resided were about to sit down to lreakfast, and I tasted, for the first time, mash, or Indian corn meal porridge. Mr C__ had only been ten days on his farm, having judicionsly purchased a moderate extent, including live stock and growing cropss. He converted what had been erected for a barn into a tolerable dwellinghouse; and, with solviety and industry; will have little difticulty in bringing up his family.

A gentleman of Hamilton, to whom I had a letter of introduction, remarked, in course of conversation, he was a Whig at one time, and had lately changed and opposed the mol, as there was no end to innovation. I replied, most people do so after sharing the pickings of 'Tory governments, not being aware at the time that he himself had lately obtained a government situation worth L.300 a-year. A feeling of toryism pervaded most people in the Canadas I came in contact with, more especially those lately arrived from Britain. Whig and Radical in the mother country, after becoming possessed of a few acres of forest in Canada, seem to consider themselves part of the aristocracy, and speak with horror of the people and liberality. Politicians are too seldom influenced by patriotism and philanthropy; changing opinions as they do garments, according to fashion and interest.

Hamilton is situated within half a mile of Lake Ontario, and at a short distance from an elevated rilge passing round the head of the lake. The houses are chiefly of wood, forming a broad street, resembling some of the villages of the States. It is in the midst of a beautiful country, and forms one of the cleanest and most desirable places of residence in Canada.

From Hamilton we proceeded to York at 10 P. M. by the mail stage, the evening being cold with bright moonshine, and the passengers walking up and down hills in crossing several oreeks to ease the horses. When objects became visible by return of day, the country seemed partially and recently cleared, and the inhabitants far from wealthy. The soil clay 
and sand, the former yielding good wheat and grass; the latter prevailed on approaching York, where we took up our residence at the Ontario house.

York is situated on Lake Ontario, and is the seat of government of the province from which it derives its chief importance. Steam-boats arrive and depart almost hourly, and the inhabitants amount to about 8000. The progress of American cities in newly settled districts seems to be uniform; -at first mean wooden houses, which, as wealth increases, gradually give way to better ones of the same material, and ultimately to those of brick or stone,-clay for making the former being almost everywhere to be had. The houses of the principal streets of York are passing from wood to brick, and in no place, during my tour, did I see more brick erections going forward. 


\section{CHAPTER XIV.}

\section{Excursion to Lake Simroe-Hope-David Willson-Meeting-house -Tenets of the Children of Peuce-Northumberlund Farmer- Soil-Notices-Evcursion to Niagara-Sicenery of Lake Unlario -Return to York.}

Nexr day my friend D _ and I set out for Lake Simcoe by the Newmarket stage, passing along a road called Younge street, a small part of which was Macadamized, in the vicinity of York. At Richmond hill, our dinner consisted of roast beef alone, so tough that my friend remarked the animal must have died in the yoke from distress. Human teeth could make little impression on it, and I satisfied hunger with bad bread and water, thankful that keenness of appetite exceeded my nicety of palate. At Newmarket we were disappointed at learning the steam-boat, passing round Lake Simcoe once aweek, had left Holland-landing shortly before our arrival, and there was no other possible mode of conveyance; I therefore committed letters to people residing on the margin of the lake to the post-office.

In the morning we were conveyed in a waggon round the neighbourhood of Newmarket, our first stage being the village of Hope, known also by the name of Davidstown, the residence of a religious sect called the "Children of Peace," founded by.David Willson. It is upwards of four miles from Newmarket, and consists of sixty or seventy houses scattered up and down. Not finding Mr Willson at his house, where we saw his wife, a thin yellow sickly looking person, we proceeded to the counting-room, a fanciful building, which was open, and no one within. Mr Willson being pointed out on the street, I introduced myself as a stranger anxious to see his place of worship, to which he dryly assented. He asked if I belonged to government, and on learning the object 
of my tour, and place of residence, two men who accompanied him enquired anxiously about Scotland, and the state of the working classes there. On entering the building we took off our hats, placing them on a table, and were told we might walk round the house.

The building is of wood, painted white externally, seventy feet high, and consists of three stories. The first is sixty feet square, with a door in the centre of each side, and three large windows on each side of the door. On two sides there is a representation of the setting sun, and the word "Armageddon" inscribed below. The second story is twenty-seven feet square, with three windows on each side; and the third story nine feet square, with one window on each side. The corners of each of the stories are terminated by square lanterns, with gilded mountings, and the termination of the building is a gilded ball of considerable size. The interior was filled with wooden chairs placed round sixteen pillars, in the centre of which is a square cabinet of black walnut, with a door and windows on each side. There was a table in the centre of the cabinet covered with black velvet, hung with crimson merino and fringe, on which was deposited a Bible. On the four centre pillars were painted the words "Faith, Hope, Charity, and Love;" and on the twelve others, I believe, the names of the Apostles. The centre pillars seemed to support the second story, and at the foot of each was a table covered with green cloth. The house was without ornament, being painted fawn, green, and white, and had not a pulpit or place for addressing an audience. It is occupied only once in a month for collecting charity, contains 2952 panes of glass, and is lighted once a-year with 116 eandles.

There was a cold suspicious reserve in Mr Willson's manner, which prevented me at first engaging him in conversation. After fruitless attempts I remarked the temple was a handsome building, and he muttered in satirical sounds, "we did not wish to raise a temple, it is only a meeting-house." I said the interior of the building was tastefully finished, and asked if the design was his own,- when he repulsively replied, "Did you ever see one like it?" On answering in the negative, he said, with a great deal of self-complacency, "That is the work of the mind." I had now a key to his good graces? 
which was used, and he conversed freely on a variety of subjects. I had a publication in my pocket, entitled " (anada as it is," wherein he was mentioned; and on reading the particulars, he emphatically said, " $\mathrm{P}$ art is true-but threefourths are lies." From seeing Mr Owen's name in the bosk, he said he had his writings, and asked how he got on in Scotland. I stated shortly his late career, and he seemed pleased at hearing of the breaking up of New Harmony.

David Willson seems about 65 years of age, and is a middle sized, square built man, wearing his hair over his forehead, and squints considerably. He reminded me of my early friend and preceptor, Edward Irving, but the association, in all probability, arose more from semblance of character than of feature. He was dressed in a short brown cluth jacket, white linen trowsers, with a straw hat, all perlaajs horne-made. Originally from the State of New York, he had resided thirty years in this country. 'The number of his followers is unknown, but all offering themselves in sincerity are accepted, as he dislikes sectarianism, and has no written creed. He seems to act on Quaker principles, assisting the flock with money and advice. The produce is sent to York market weekly in common, yet individuals are left to guide themselves. There is a school for teaching young women to be industrious, whether they join the sect or not. Most people in the neighbourhood say the "Children of Peace" are good people, but scandal has been busy with their leader.

On leaving Mr Willson he presented me with a small tract, which may be regarded as the tenets of the family, to the following effect.

\section{Matthew, Chapter xxy. Verse 34.}

"Then shall the King say unto them on his right hand, Come, ye blessed of my Father, inherit the kingdom prepared for you from the foundation of the world for $I$ us an hungered, and ye gave me meat; I was thirsty, and ye gave me drink; I was a stranger, and ye took me in; naked, and ye clothed me."

"I make use of this text to explain the purposes of a building erected at the small village of Hope, in the county 
of York, and province of Upper Canada.-We who are distinguished from other worshippers, of our country, by the name of Peace, which name we have given to our place of worship, here insert singular purposes, not generally known to our friends abroad; we esteem all such who are not our enemies; these latter, in a literal sense, cannot be our brethren or our friends.

"The world is in a singular system to us, as we can be to them; that is, that they are in a state of servitude to a set of Christian priests, since Christ eame to liberate the eaptives. The objector may say, they are in no servitude on the clisssical plan, but what is voluntary. I answer, a child should be directed in his choice, and a disciple taught to pray. We confess the people are directed in their choice, and invited to be baptized, join society, and partake of the holy ordinances. If we may give the ancient names to the present apostles, Peter saith come, for this is the way, and I ean prove it by scripture; Paul saith come, for I can condemn the very creed that Peter approves, and justify mine own to an extreme. Now, we are of the mind to leave the creeds of the Christian Apostles of this age (of which they have no scant number) and take into a simple way, in which there can be no dispute, and which, we think, will outwit the priests of the Christian church to condemn. We take the words of Christ our Saviour for truth, but to believe in all the contradictions of the ace, is to us impossible. Priests quarrel now for titles; the printers print them, and sell them to the world, and make barter of priests' disputes; and the clashing of creeds has become a popular trade, and brings in a considerable wealth to the craftsmen that have set up selling these tales from their refined presses, which makes religious disputes and new occurrences subjects of detail.

"We publish these lines, and refuse for a considerable time to publish any more. We give them gratis, because the Lord hath given to us; not that which is the form of others, but of our own that we may rejoice in his favours, and envy not. Our form or ceremony is not in contradiction to any religious creed, and will therefore admit of no dispute; and with us, we intend that religious arguments shall come to a close. 
6" The Son of God hath plainly shown us how we shall gain ardmittance to the blessed purposes of the creation, for this is the kingdom prepared from the foundation of the world.

"We have built a house for the purpose of offering to Gind Israelite fashion; we purpose to commence the last Saturday in October, at twelve o'clock, and continue to offer to (iod for the purposes contained in the text, once in the month throughout the year, and so on successively until the year we die, leaving this example and precept to our children always; this we perform without the direction of a priest, or any officer in the church, for we are brethren.

"6 'Then shall the King say unto them on his right hand, Come, ye blessed of my Father, inherit the kingdom prepared for you from the foundation of the world. Then he begins to justify, showing cause of merey and of favour; (and when the harvest is ripe, and the wheat shall be gathered, and the tares burned;) I was hungry and ye gave me meat; here is the power and glory of religion, here teaching comes to an end. Can a priest preach to a man, when his heart is to do the deeds justified of God? As a doctor to a man in good health, so is a literal teacher to these. I was thirsty and ye gave me drink; various favours continue from the human mind, throughout all the excellent deeds contained in the text; the whole amount is this; Loving God, and the salvation of the world. (We have no written creed, and therefore we have no image to quarrel about, or literal rule to argue for, we are against nobody, but for all.) The answer of these souls shall be this, When saw we thee an hungered, and fed thee; or thirsty, and gave thee drink? When saw we thee a stranger, and took thee in; or naked, and clothed thee? Or when saw we thee sick, or in prison, and came unto thee? And the King shall answer and say unto them, Verily I say unto you, inasmuch as ye have done it unto one of the least of these my brethren, ye have done it unto me.

"I now leave the text, and turn to the practice of 'life, to show cause for a change of system; and we are required to give a reason for the hope that we possess. The priests are as despotic in their several congregations, as the potentates 
of the age; not all, I should say. I will say that all are above their brethren, and press subordination to their written creed, or line of doctrine. If a stranger comes to him of another creed, will he take him in as himself, or one of his religious kinsfolk? No; like the Almighty setting bounds to the sea, hereunto thou mayest come, but here thy freedom and thy liberty shall be stayed. As for me, I am numbered with the impostors, and am so contented with the name, I forgive all my accusers; but tell them how they use their creed, brethren, who can equally prove themselves as right as they are. How do we of the latter named class use each other? I confess upon an equal plan. You sell each other's failings for money, through the means of the press, and electioneering converts by public arguments, and send them round sea and land to proselyte the world. And what are they when they are gained? We will impartially own the good with the evil. It puts away some rough and profane language, and some extreme immorality, a work glorious in its place. Do we not teach them to pray? To an extreme, but not how to receive. Do we not teach them the way to embrace society ? Yes, a hundred ways. Christ said, I am the way, and that way through preaching is perhaps divided into a hundred parts; the number of sects in the Christian name, I know not; but I know that priesteraft hath done this, and with us it is coming to an end. It is not the one way, Christ the hope of glory, that hath divided the whole world, and produced vain argument to such an unlimited degree as it is now extended, from priest, pulpit, and press, and it is chiefly sold to the poor inhabitants of the world. And some extol themselves to be of high value, for they take shameful sums for doctrine, and the divines are more extravagant than the apothecaries. But a man cannot have soul or body mended now, but at dear cost. In the days of Israel, productions of this kind were cheaper, in the days of Christ, without money or price; a happy day for poor souls when Christ preached the gospel to the poor, and healed the sick without cost. The text suffers no man to go in distress, and binds us to use lawyers, doctors, and priests well; when we see them hungry 
give them meat; if thirsty, drink; if naked, clothing ; if they are in a strange place, show friendship, take them in, they are our brethren; if they are sick or imprisoned, go to them, they cannot come to us; and as we use this part of the creation, so do by all other classes, for they are our brethren ; if we do it to the least of these that hope for salvation in Christ, we do it unto him, for this hope is the gift of (iod ; and him that practises, doeth the will of Cod, the same is my mother, my sister, and my brother. Do the sects use each other as brethren, or doth not the priest use the common people, in many instances, as his footstool? Amongst the liberal kind, they only take the liberty of sect abusing sect, and priests liberally quarrelling with each other, which hath been operating in penmanship, ever since the dark ages of the world, that succeeded the apostles. Can you tell me, contending priests, how many quarrels will make a millennium? If you cannot, quarrel no more; for common people are laughing at such barter as this; selling priests' quarrels at the printer's office; dividing the world into unnumbered parts; and by example and precept, inviting divided proselytes to follow you ; this is the practice of sects. But there is a practice between the priest and his brethren I think worthy of note, for the information of those more ignorant than ourselves in our home capacity, if it is possible that any such there be.

" The priest gets on a stool or pulpit, and preaches over what is already spoken, which is well done, and cannot be bettered. The potters prepare men for this purpose, take them in, passive as clay, and make of them what they will. It is far from me to speak against learned men; but rather note a little of the principle by which education is used. Literal education is no distinguishing mark of an apostle, for or against the service of God. Why, then, are learned men so highly extolled above their brethren, and sold at the highest price at market, like the best beef? The son of God equalizes, and owns all equally his brethren, that are for God and his righteousness. But some classes are taught by these self-thinking superior qualities, that an unlearned man should not be heard; if he comes to their house, the sentence is this, Be off with the 
goats, on the left hand; ye are fit for nothing, but to be convieted for ignorance; but ourselves for learning and oflice, are worthy of thousands a-year for preaching scripture creeds to the people. Poor people: little is obtained for your money, for you are not taught that equalization is man's right, and that the poor are the heirs of the tribute in a Christian Church. Christ united Jew and Samaritan, and remnants of every kind to himself, and gave them the name of brethren; he is the pillar of a glorious Millemium. And when priestcraft is fulfilled, and God hath said it shall come no farther, it will come to pass. The priest is heir of the big sum-other churcil officers of less, whether according to their righteousness, what they do, or what proportion of learning it takes to fulfil their respective offices, I do not know; but this I know, the high priest first puts his head in the purse, for he is a general of an army, and holds subordinate titles under him, like military order, not equalizing his brother with himself, but astep lowe: on the righteous stairs that reach from earth to heaven (like Jacob's ladder), he holds the chief power of putting in and putting out of office-of calling one a sheep, and another a goat-taking in and casting out of the church. This last prerogative descends quite down to the foot of the stairs, and they have got the world divided indeed; and one priest will eall his neighbour's sheep goats, and keep them on his left hand, because his creed is not written in their foreheads. But there is another dark class called sinners, and they are not fit for any body's building materials, and have no mark upon them but the black mark, unworthy or uninformed. I belong to these, and I am resolved never to wear a priest's creed on my forehead; for if I do, I am sure I will despise my neighbour or brother, and will not account him equal with myself. I am on the goat side of the question-the priests have put me there; but I mean to prove that such judges as ours may be in error, for these that some call goats, others call sheep. 'This judgment cannot be correct, and wants amendment. Christ hath passed the sentence, and it needs no alteration, and the priests need not preach any more about the matter.

" If men are generous, hospitable, and kind to all people 
in necessity, the Son of God hath justified them; he hath taken away their melfish and proud heart, and given them a generous one, equally wishing salvation to all the world, dividing their crumbs equally to those that stand in need. 'This is the glory of God, and power of religion. Where is the priest's office here? 'The Sion of God saw it would come to an end, when the hearens were preached or couverted into the practice of the text.

"We have built a house to sacrifice to God, feed the hungry, and clothe the naked. Any stranger may come in and sacrifice with us, without giving us money or price. It is for the various purposes of Giod's glory, the end of doctrine, and the perfection of the world. We are not perfect; but the system adopted by us is justified of God in Scripture, and draws the soul near unto God and Christ. It is beyond all creeds and sectarian plans, and is with us the end of craft. We lament the divisions of the world, and the pride of the people, the superiority professed by priests, and the tribute paid to them. Therefore, in adopting this plan, we expect to employ them no more.

\section{"David Wiligos.}

"We now commence a building of a different structure, and for a different purpose from the other. We hold that doctrine is good for the soul, as the physician is for the sick; but the above-written purpose is the end, when the soul is restored from selfish delights and purposes, and prefers the will of God before his own, he is as the patient healed. But this doth not constitute him to be an idle creature the rest of his days. What shall he do? Do as the sick man healed of God; devote his strength to praise, vocal and instrumental, that the harp of David, and the hymn sung by the apostles, may be united together. He shall not be idle with his hands, nor still with his feet; he shall not be redeemed from hearing the widow cry, or her offspring mourn; his eyes shall not be closed from seeing the hungry naked soul; he will take his burden upon him, and lighten his grief; he shall till the field, or improve the mechanic's shop, and the widow and the fatherless shall rejoice in the works of his hands; and his soul shall 
rejoice before the Lord, because he shall dwell with Christ; for he hath said unto this description of people, Come, ye are blessed of God. 'This is riches indeed, of which we have reason to believe that very few high-priests enjoy; for they bear away the widow's crumbs, and deprive their offispring of a garment. They are so greedy and selfish, the world mourns under the burden of these practices, and the very earth groans for relief.

"As for the purpose of our contemplated building, it is to prepare the heart for such a mansion as we have already. And as for our public friend, he is growing old, and seems hastily preparing to die, and he has enabled us in the hand of God to see as we saw not, and to liberate our hands from priests' wages, lawyers' fees, and the judge's sentence at court. He will give way for nothing but civil power; to such we esteem him as a true subject, and not of the alien kind. Church matters with him are voluntary; he is bound to none, and refuses the control of creed or priest in the service of God. We rejoice in his labours; they make glad the heart for the exhibiting of such liberal and generous doctrines as hath so far liberated our hands and feet from a kind of veiled Christian slavery. We build a house where we intend they may be handed down after his death to our children, and the succeeding ages of the world. We covet craftsmen no more. Our adviser prefers his brethren before himself, and will not enter the peaceable mansion with us where we sacrifice to God. He saith he hath sacrificed his own interest, and received the liberal abuse of the sects, and gave up his family to provide for themselves. He tells us that the priest's oltice is below ours, and that he, by appointment, is not worthy of that title that is justified of God; for you observe in the text, that a priest is not set above his fellows - that justification belongeth to brethren, those that love God and the salvation of the world. We cannot persuade his feet to enter there. He saith his eyes are forbidden to see the quiet place, but his children and his grandchildren may see it after him. He hath given us exact orders to perform by, and put a new song in our lips. We esteem him as a brother indeed, but he is not always used as such amongst us, but that amounts to our shame, and 
not his. Ilis works, we trust, through the blessing of Civol, will speak for him for ever.

"We purpose not to open our present building but once in a month, commencing the last Saturdiny in Octuleer, and so on in succession, as time and (iod may permit. We refuse (n) open to every visitor. We are not indubted to the publie for money, nor Parliament for ground; and a little dust on the floor from the feet, and a dry compliment for turning the key, will not pay the cost of leaving our labour-the work of our hands are for better purposes than these. If far distant strangers should come unto us, we may open unto them, and all our neighbours and friends once in a month. We think ourselves done with the sectarian plan of worship-rather the principle than the plan. We think that no priest can preach us to a better end than the purposes of our present house, and that no doctrine can lead us to better purposes than these. Therefore, we embrace our own, and set the dividing plan, of converting into a hundred divisions, free, and give this testimony to the world, that if our testimony in public doctrines is unworthy, not to suffer them into your houses, for we do not covet that yours should be offered unto us.

" Signed on behalf of the brethren by

\section{"Merdoch M·Leod. \\ "JOHN DOan. \\ "Ebenezer Doan."}

After perusing such a production, many will wonder at the number and prosperity of David Willson's flock, and the influence he has attained, which results from shrewdness, and not genius.

On leaving Hope, we proceeded north to Lake Simcoe, and returned by another road to Newmarket, being engaged to dine in the neighbourhood with $\mathrm{Mr} \mathrm{H}$ farmed in the north of England, and has been several years in his present farm, which he rents. He manages 120 acres of cleared land, free from stumps, and none of it in pasturage, with two horses and two oxen. The potatoes and turnips were drilled, and howed in good style. Cattle and sheep are fatted, and, in common with those in almost all parts of America, 
get salt once a-week. Labourers can be had at all times, getting $\$ 10$ a-month in summer- $\$ 5$ in winter. Thrashing with the flail, one-ninth of the quantity ; carriage, or teaming, from Newmarket to York, $7 \frac{1}{2} d$., Halifax curreney, per bushel.

Timber around Newmarket is of the largest size, and the expense of obtaining the first wheat crop was stated by Mr $\mathrm{H}$ - thus-

Purchase money of wood land, Under bushing and chopping,

Logging, burning, and fencing,

Seed and harrowing, -

Carting and harvesting,

Thrashing and teaming,

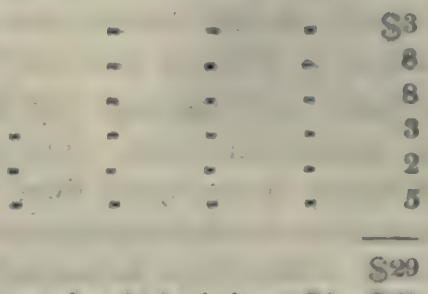

Produce estimated at 25 bushels, at $\$ 1=\$ 2.5$

The country from York to Lake Simcoe is, generally, well cleared and settled, the soil being chiefly loam, carrying excellent wheat crops, and seems fitted for almost any kind of husbandry. It is difficult to classify the soil around Newmarket, which seemed well fitted for turnip growing, and such as would be considered of too soft a texture in the place of my nativity, yet it was producing wheat crops, with stiff straw and large ears. The farm-houses seem comfortable, and the stumps are chiefly removed. The surface is undulating, and free from stagnant water.

For the first time, we saw small flocks of wood-pigeons, collected after the breeding season, and people shooting them.

The bar-room of the Newmarket hotel was filled with drunkards of the lowest class, part of them in rags, and swearing in a disgusting manner. Before the arrival of the coach which carried us to York, we examined a large flour mill, and many samples of wheat it contained, not all of fine quality, and partly much sprouted. There were handsome iron ploughs, made by George Gray, Uddingstone, Ayrshire, Scotland, selling at \$30, while wooden ones, of Canadian make, were \$18. I observed a lime kiln, formed in a bank of clay, by excavation, without building materials, and which seemed to have been used for some time.

Our luggage, which Mr Chrystler, the landlord of the 
Pavilion house at Niagara falls, assured us had heen despatched for York before we left his house on the 3d July, had not reached its destination, and not having received an answer to a letter written to him on the subject, I resolved to enquire personally. Next morning I got on board the steam-boat, King William the Fourth, for Niagara.

'The scenery, when sailing up Lake Ontario, is uninteresting. Dark coloured monotonous forests fringe the low shore, on which, at different intervals, are the meanest hahitations of civilized men; and now and then a puny vessel, with dirty sails, appears in view. On approaching Hamilton, the landscape is more varied from the heights and little lake, twelve miles in circumference, on which the village is situated, and divided from the main lake by a stripe of land eighty yards wide, through which there is a canal lined with wood. When going through the canal, the rope passing from the helm to the wheel in the forecastle, where the pilot of all American steamers takes his station, gave way, and the vessel narrowly escaped destruction. Six hours were spent in landing and shipping merchandise at Hamilton on Sunday. Many of the steerage passengers were tipsy, and some quarrelling. I walked into the woods to escape the scene. The stillness of a Sicotch Sabbath is better appreciated after sojourning in a foreign land.

The steamer reached Niagara at ten o'clock. At four next moining I proceeded in an extra to the falls, which were visited before breakfast. Mr Chrystler assured me the luggage had been despatched as stated at the time; and on my return I discovered it in the lobby of a hotel at the village of Niagara, where it had arrived from the Pavilion house the night before. At noon I got on board the daily steamer for York. The day was so cold that people clothed themselves in great-coats in crossing the lake, and many became sick from the agitation of the waters.

On 14th July I found some wheat crops near Niagara almost ripe, the cherry-trees stript of fruit, and the graceful blossom of the sweet chestnut fading. 


\section{CHAPTER XV.}

Journey from York to Coluorg-Mail Waggon-Mr SomervilleAgriculturcal Notices-Cluy Kinecuding-Fenule Helpo seating themselves at Tuble-Port Hope-C'aburg-Agriculturul Notiees -Fast Eating-Excursion to Peterborough-Sichool-fellowPeterborough-Rice Lake-Notices of Nuture und Ayriculture -Settlers-High Price of Land-Injudicious Settlement-Bay of Quinte-Indian Settlement-Canada Thistle-KingstonStorekeepers and Store-pay-Grasshoppers-Lake of the Thowsand Isles-River St Lawrence.

Mr friend D_ and I left York at 5 P.M., on 16th July, by the Kingston mail, an open waggon, drawn by two horses, and reached Windsor, a distance of twenty-nine miles, at two in the morning. The roads were worse than any yet travelled on, and a driver stopped two hours at a hotel notwithstanding our anxiety to get him away.

The soil, for ten miles down the margin of the lake, is poor sand, covered with pines, until passing some ridges, where there are good farms; here night shut out the face of nature.

From Windsor, in the township of Whitby, we set out on foot, after breakfast, to visit Mr W $\longrightarrow$, to whom we had a letter, and found him suffering under ague at Mr Somerville's. r I was anxious to see Mr Somerville, from having heard his letter, which appeared sometime before in the Edinburgh Quarterly Journal of Agriculture, censured by my latelyimported countrymen, and his establishment and prospects ridiculed. He received us kindly, and after walking over the farm, we returned in time for an early dinner.

On entering the house it was necessary to go one by one, as the door opened so as to close up the passage leading to the kitchen, through which we entered to the sitting-room, where we dined. Both apartments were small, elean, and crowded with old-country furniture. The house was a log 
one, but a better was soon to be built. The dinner consisted of fried pork, the standard dish of the country, eggs, new potatoes, and pancakes. Homely as the fare may be considered, it has seldom been my fate to rise from table more gratified with a repast, each dish being excellent in its kind, and the entertainment seasoned with the good sense, contentment, and manly feeling, of our host. Miss Somerville, like all my countrywomen met in Canada, was active and in good spirits; but her piano had remained untouched in the corner of the room since her arrival in the country, the churn being now her favourite instrument.

Mr Somerville told me his letter was not written with a view to pullication, and it appeared in the Quarterly Journal without his knowledge. Cnder these circumstances it would perhaps be unreasonable to hold him responsible for its contents. Not having read the letter since the time of publication, I cannot say if it is a just representation of his situation, but I can testify to the good quality of his soil, which he says no visitor ever examined minutely but myself. His pasturegrass was truly excellent; wheat and oats of medium quality; potatoes and Indian corn well cultivated, and promising crops. He had let twenty acres of forest land to clear and fence, at $\$ 12$ per acre, which he says is the common cash price of the country. Labourers have difficulty in getting employment during winter; and on the morning of our arrival Mr Siomerville engaged a first-rate hand for his aguish friend at $\$ 80$ per annum, and ordinary people may be had for $\$ 72$; wages paid in cash. Boys fit for farm work, and women servants, get $\$ 4$ a-month. Farms in the township, two-thirds cleared, with suitable buildings, may be had for $\$ 12$ cash, and $\$ 16$ credit. Bricks are \$5 per thousand.

The soil of Whitby is rich, and not much inferior to that around Newmarket, being free loam, and occasionally approaching to sand. The vegetable mould in Mr Somerville's forest was five inches deep.

Immediately after dinner we joined a waggon, by appointment, on the Coburg road, and by which we travelled to the Darlington hotel in the village of Bowmanville, passing over 
a poor sandy soil, of which the township of Darlington seems to consist.

On our journey we saw two oxen employed in walking round a pit, kneading clay for hrick-making, which appiared cruelty, and wasteful of animal labour, the poor animals walking up to the bellies in mud, with erect tails and extended tongues. The common mode of preparing clay being with a tree drawn by a horse or ox round a pivot, the lopped branches kneading the clay. An elm-tree, twenty feet in height, was growing from the heart of one of rotten button-wood, ten feet from the ground. A plantation of hops, in Whitby, was luxuriant and healthy.

On stepping out of the waggon at Bowmanville, we walked over a farm which I had been requested to value for a friend, and we sprung a woodcock in a wheat-field, a bird that is said to breed regularly in the district. Woodpeckers, rolins, and blackbirds, of the country, were devouring cherries so greedily, that a gun was fired at them to little purpose every five minutes. Two wrens were seen in Whitby similar to those of Britain.

In the United States and Canada tea and coffee are not prepared or poured out by travellers, but by the landlady or a female help. In no part of the United States did a female help, at a hotel, seat herself during meals; and I observed the practice only upon one oceasion in a private house. 'The maid-servant at Bowmanville seated herself during tea in a corner of the room, and the like occurrence took place at Newmarket during supper. In Britain servants stand while assisting at table, and they also do so in Canada; the differcnce of attitude taking place when their services are not required. For my own part, I would much rather see a young waiting-maid seated, when not required, than standing perhaps painfully erect; and, in:many instances, when taking tea or coffee, during my tour, I put it in the option of the helps to leave the room, which they generally did. There seems no general rule for attitude, as inferring respect. In some countries attendants almost humble themselves in the dust in presence of employers, and in others they are required to carry themselves erect. 
We left Bowmanville at seven in the morning, by the mailstage, which had taken fourteen hours to come forty-three miles; and my friend left my ouly thermometer at the door of the hotel. A few miles from Port Hope our waggon was changed for a small neat eoach, which we found an agreeable alteration, and soon reached Coburg.

Port Hope is prettily situated near Lake Ontario, at the mouth of a small stream, murmuring over a rocky bottom, and well ealculated for propelling machinery. There is a pier, and general appearances betoken prosperity.

Coburg is also situated near Lake Ontario, and much larger and more advanced than Port Hope. It has much trade with the country across Rice Lake.

There is a considerable extent of cleared ground from Bowmanville to Port Hope; the soil poor and ill managed. Near the latter it improves, and towards Coburg are some good farm-houses and offices, around which the fields are well cultivated and fenced.

Around Coburg the vegetable mould in the woods was three inches deep, and the soil sandy loam. The greater part of the soil we have seen in America is of soft texture, and easily laboured. Here we learned plough irons are only repaired twice a-year. At Newmarket a plough was pointed out, the irons of which had not been at the smithy since the previous Oetober, and were still in tolerable order. Mildew was seen on wheat at Bowmanville and Coburg. A limekiln was preparing building-lime on the shores of the lake, and stones of the same rock were quarried for building.

We found the young men swallowing their food at the table of the hotel as fast as those of Albany did. It is almost a universal practice in the States and Canada to board men, such as clerks and shopmen, in hotels. A large bell or horn is sounded half an hour before meals, and again when served up. Hence the rush to table, and expeditious eating.

Next morning we set out in a waggon for Sully on Rice Lake, a steamer carrying us across the lake and up the river Otanabee to Peterborough, the head of navigation, where we found aceommodation at Macfadden's hotel.

When about to sit down to breakfast, I was introduced to 
Colonel B_, a Scotchman, who, when seated at table, stated he was from East Lothian. Knowing almost every individual in the district, I said in a tone of surprise, "Are you serious?" and scanned his features very closely. Answering in the affirmative, $\mathrm{I}$ asked if his name was Robert, if he had a brother, and immediately introduced myself as a class-fellow at the school of Iladdington in 1806, not having since met or perhaps heard of each other. We talked over old stories, and I was delighted to find my friend possessed of one of the neatest and most comfortable cottages in the finest situation in Peterborough.

Peterborough is on the Otanabee, and likely to become a place of some importance. At present there are a number of mean houses scattered over a considerable extent of surface, and the population is stated at $1000 \mathrm{souls}$, although I would not have rated them near so high. It is said to contain a number of military and naval half-pay officers of Britain, and the society to be the most polished and aristocratic in Canada.

In the forenoon we walked up the left bank of the river to visit $\mathrm{Mr} \mathrm{T} \longrightarrow$ whom we met by the way, accompanied by his lady, who continued her journey on horseback, and he returned with us. In the evening we walked up the river side, passing an excellent mill-site, on which grist and sawmills were being erected, until we reached a string of lakes, through which the Otanabee flows. The road up the banks of the river was just opening, the trees had not been felled the length of $\mathrm{Mr}$ ' $\mathrm{T} \_$s, and in our evening walk some parts of the tract could only be erossed by leaping, like squirrels, from trunk to trunk of fallen trees. On one occasion my friend 1)__'s feet slipped, and he fell on his face, with both arms fixed in the mud.

We left Peterborough for Coburg on 22d July, by way of Rice Lake, and remarked that two-thirds of the people seen on the road were tipsy. This was a painful sight, which the heat of the weather did not soften or justify.

Rice Lake takes its name from the quantity of rice floating on its waters ; it is surrounded by gentle rising banks, and contains several small islands. The lake is formed by the waters of the Otanabee, which, from the lake to within a short dis- 
tance of Peterborough, forms an uninteresting sail, being a dense forest on both sides, with three or four log-huts in the course of sixteen miles. Above the rapids, at Peterborough, the river runs with considerable impetuosity, the banks be. come diversified, in size equalling the largest river in Britain, and its water-power, if properly developed, of considerable magnitude.

The surface, from Coburg to Rice Lake, is highly undulating, and, if cleared, would perhaps be picturesque; the soil gradually falling off, becoming poor sand, with timber of inferior size, and all kinds of crops had. For miles, before reaching the lake, the road leads through thinly scattered oak trees, called plaines, or oak oprenings, covered with stunted underwoor, with external indications of extreme sterility; hut farther experience enables me to say, the appearance of the plaines is not owing to quality of soil, but to the herbage being annually burned.

To the west of the Otanabee, and on the banks of the lake, is a considerable clearance formed by government for the Massagur tribe of Indians, and called Indian Village, adjoining which is the residence of Captain Anderson, prettily situated.

The soil of the small clearances on the Otanabee, ahove Peterborough is not of very fine quality, and mingled with large stones, but seemed to improve on receding from the river. On cleared ground there was scarcely a plant of clover, or even of grass, with the exception of timothy, the seed of which had been sown. At the time of visiting this district I was inclined to think unfavourably of the soil from the want of clovers and grasses, but extended observation convinced me this circumstance had no connexion with the quality of soil, and would not operate unfavourably against the prosperity of these plants when their seeds are sown.

Near the banks of the Otanabee, a dark-coloured caterpillar had devoured some fields of timothy grass, with exception of the culms, and the insect had extended its ravages partially to Indian corn and wheat, but red clover was untouched, growing amongst timothy which had been entirely consumed. I could learn nothing of its natural history; but its attacks 
were said to have been felt in 1825; and accounts from distant parts of the north spoke of its attacks this year as highly destructive.

While delayed at Sully I strolled into the forest, and, on the margin of Rice Lake, found a solitary plant of red elover, having about fifty flower-stalks from one root, measuring five feet in height, and neither soil or situation seemed favourable to luxuriance. There were three heads faded, which I collected, and afterwards lost to my regret. On the plains there were many flowering plants and grasses, and I remarked triticum repens, the thick-rooted couch-grass of Britain, which is found over many parts of Canada. Gooseberries covered with strong prickles, which soften as the fruit ripens; and black currants, with prickly and unprickly fruit, were growing in the woods; and hazel loaded with nuts on open places.

Wages of farm-lahourers in the neighbourhood of Peterborough were stated at $\$ 10$ per month by the year, and at $\$ 12$ in part of summer. A respectable settler in Smithstown told me he had offered $\$ 115$ in eash per annum, to be paid when a crop was reapod from the labour. In all cases produce or store pay seems to be given, unless by special agreement to the contrary. Cash is a scarce commodity, and could not be obtained for wheat at the present time.

In course of my short exeursion I had seen some bush life of individuals formerly moving in a higher grade than those on the Welland canal. The general impression was not favourable, and after farther experience of such life, many things appeared exceptionable. In particular, ardent spirits were too frequently used, mingled it is true with water, which perhaps did not mitigate their effects. A cask of spirits, with a crane, often stood in the corner of the room, and $\mathrm{Mr} \mathrm{D} \mathrm{D}_{\mathrm{r}}$ informed me $\mathrm{Mr} \longrightarrow$ had a bee a few weeks before, which lasted two days, and at which eighty gallons of spirits were consumed.

The Newcastle district has been a fashionable place of settlement of late years, more especially around Peterborough; and I was soon aware of the means taken to induce people to settle in it. Before leaving Scotland $\mathbf{I}$ had seen a catalogue 
of a most extensive sale of land purporting to take place in course of summer, and which contained a chart of the district in which the lands lay. 'The chart formed our only map, and was studded with villages, \&c. In particular, Ciambletown was marked on the chart with numerous houses, as if a place of considerable size; and on sailing up the Otanabee, on which it is situated, I expected a thriving village; but on stopping to obtain a supply of firewood, what was my disappointment at only finding two log-huts, one of which was unoccupied ! Accounts of the value of land appear exaggerated. Uncleared forest land had, it was said, been sold at some distance from Peterborough at S\& per acre, and some people wished me to believe all land bore a relative value. A gentleman estimated his property at $\$ 20$ per acre, while I was offered the adjoining back lot of better soil at \$6, and I have no doubt could have got it for $\$ 4$ cash. A property has been said to yield annually L.500, which is very near the sum I valued it at in perpetuity after examination.

On the morning of the 23d we left Coburg for Carryingplace on the bay of Quinte, which we reached before dusk, having passed over an undulating surface, the soil of which, with exception of part near Carrying-place, was sandy and stony. Crops of all kinds inferior. A field of rye had been cradled, and one of wheat was sufficiently matured for the operation. This line of road illustrated the evils arising from want of knowledge of soils in new settlers. Much of the soil was drift sand, and would not repay the expenses of cultivation, cheap as those in Canada are. Several farms seemed to have been deserted after having been some years occupied; and unacquaintance with land, and other parts of the American continent, can alone account for human beings having wasted their labour in clearing such unfruitful soil.

Next morning we left Carrying-place at four for Kingston, where we arrived at nine P.M., having passed Trent, Belville, Sophiaburgh, Hallowell, and Bath.

The bay of Quinte is a branch of Lake Ontario, and a sail on its waters perhaps imparts as much pleasure as any in Canada. Numberless islands, bays, and promontories of every size, shape, and aspect, together with ever-varying 
shades of vegetation, delight the eye. In many places the margins are low, but for miles, on both sides of Hallowell, the banks are of considerable height, well clothed with wood and adomed with houses. In the distance was an island with a considerable sized Indian village, said to contain 600 souls. The white-washed cots had a fine effect in passing down the bay, while the inhabitants fishing in their fragile canoes, and gliding to and fro on the unruffled waters, aclded interest to the scene. On the mainland, opposite to the island, is an Indian reserve, on which is a church, lonely situated near the margin of the bay, and very unlike the worshipping places of more civilized men. But the half-naked Indian, in recesses of the forest, may offer homage to the Author of the Universe, with as much sincerity and hope of acceptance, as the purple-clad in the glittering temples of the city.

The shores of the bay of Quinte have long been settled, and a considerable extent of surface freed of wood. Wheat appeared nearly ripe, and in a few instances cradling had commenced. Crops were inferior and crowded with thistles, apparently the common perennial way-thistle of Britain. My friend D__ and I, walking on deck, remarked a field bearing a dense-looking crop with purple coloured flowers, which one pronounced clover, the other pease, but on nearer approach it was seen to be pasturage intermixed with thistles. This was an unfortunate mistake for those having some pretensions to a knowledge of practical agriculture, and perhaps the thistle-grower may esteem our diseernment as lightly as we do his management. This species of thistle is known in the States by the name of the Canada thistle, and some proposals have been made in the State of New York, to legislate to prevent its increase.

Kingston is finely situated on a bay of Lake Ontario, over which there is an excellent wooden bridge, perhaps the best in America, connecting the town with the fort and naval yard. Most of the houses are of stone or brick, and the inhabitants estimated at 6000 souls. It enjoys a considerable trade, which is likely to be greatly augmented by the opening of the Rideau canal, which here enters the lake.

We examined the barracks, most substantial erections, also 
the fort and naval yard; the former is renewing with the best materials; the vessels in the docks are hastening to decay. Regarding war in every case an evil, and its engines tor often misapplied, the rotting vessels excited more pleasing ideas than the rising fort.

We learned masons employed at the fort got SI a-day, without finding or boari; and in town conviderably more, when store pay is given. One gentleman said lre would rather give $\$ 120$ store-pay than $\$ 100$ eash; and a worhman said he preferred S!) cash to $\$ 12$ store-pay. I could not learn that employer and store-keeper unite for the purpose of plundering workmen. At present store-keepers constitute the most wealthy and powerful class in the community, landowners and workmen being generally indelsted to them, hence enormous profits. The common per centage on retailing provisions at Kingston, being stated at 70 per cent, dry goods 100 . Potash sells at Montreal for I..24 a-ton; the farmer at Kingston gets L.17 store-pay, equal to L.12 cash.

In the neighbourhood of Kingston grasshoppers wer. numerous, many of them having wings, and flying a considerable distance. This insect is numerous throughout America, and sometimes seriously injures grass crops. As cultivation extends, its numbers are likely to decrease.

Having perambulated Kingston and the surrounding country, the soil of which was inferior, with limestone everywhere protruding, we got on board a steam-boat for Prescott, where we arrived at midnight, and again sailed for Longsault in the Iroquois steamer, a light vessel with parldles in the stern, built for navigating the rapids of the St Lawrence, and which has been found to answer well. From Longsault we passed to Cornwall by a stage, and again by a steamer to Coteau-delac, where we got into a stage to Cascades, and by steam to Lachine, and from thence by land to Montreal.

On leaving Kingston I anticipated much pleasure in sailing through the Lake of the Thousand Isles, which forms the passage of Lake Ontario into the river St Lawrence, but the curtain of night fell before we had well entered, and the light of the moon did not render objects distinct. There was a pleasing novelty in the lake from the number of low islands like tufts 
of regetation sleeping on the surface, and glistening with the fires of the wood-choppers. 'The moon's shadow in the ripple of the waters was particularly beautiful, and some hours might have been passed pleasantly on deck but for a cold, damp atmosphere.

The St Lawrence being the first river of magnitude I had sailed on, my preconceptions of its effects on the senses were quickly dispelled; the objects on its level banks being indistinct and soon lost to the eye. The associations suggested by the endless and ever-varying objects, successively and vividly impressed on the mind's eye in passing down a river in Britain, are altogether wanting. Fertility, shelter, health, and peaceful retirement, so dear to a Scottish farmer, and almost invariably the attributes of the streamlets of his country, belong not to the st Lawrence in this part of its course, where the low lying, and in many places reed-growing, margins suggest pestilence and privation. The immensity of fresh water hurrying towards the sea fills the mind with wonder.

Around Cornwall, and more particularly from Coteau-duLac to the Cascades, much excellent wheat was growing on clay soil formed into very narrow ridges. Other crops were indifferent, and nearly choked with perennial thistles. From Lachine to Montreal we observed many wild oats (Avena fatua) for the first time in America. 


\section{CHAPTER XVI.}

Excursions around Montreal-Township of Hinchindronke-River Chuteanguay-Kinds of Houses_Bushmen and F'urmersSquatters-Price of Land-Flag Sienffis_-IIuntingdon-Isle

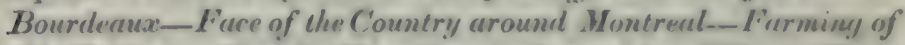
old Setters-French Cunudiums - Laproirie-Wheat FlyCherep Purchase-Chumbly-Cherup Educution-Mistuke Rouds -Horse Ferry-bort-Starving Out-Mountain-Race Course - State of Agriculture around Montreal-Montreal.

In the town of Montreal and its neighbourhood reside several old friends, by whom we were kindly welcomed, and in whose company we experienced so much pleasure, that I shall ever look back on the time spent amongst them with delight. The town was soon explored, and became the centre of several excursions to the arjoining country.

On the second day after our arrival we set out for the Township of Hinchinbrooke, travelling by stage to Lachine; from thence by steam across the St Lawrence into the river Chateauguay to the head of its navigation, twelve miles from its mouth, where we got a stage to the village of Huntingdon. We dined at a hotel kept by Mrs Love, and walked up the banks of the river to the residence of $\mathrm{Mr}$ _ met by the way. Next forenoon was spent in walking over the farm, and after dinner we visited $\mathrm{Mr}$ _ , who arrived in the country a year ago, and who was erecting a good stone house. Early next morning, Mr__ and I walked over the country, crossing the river Hinchinbrooke, passing up Oak or Mud creek, and down Trout river to the village of Huntingdon. Here we met, by appointment, a party of friends, and examined a farm which $\mathrm{Mr}$ __ had bought a few days before. Next day we travelled by stages and steam-boat to Montreal.

During this excursion I experienced much pleasure at find- 
ing my friends and former neighbours possessing so many more old country comforts than the backwood settlers in Upper Canada, and all enjoying good health and spirits. This is quite an East Lothian colony; four farmers who have settled here dined with us, and there are blacksmiths, tailors, \&c. \&ce. without number in the village. The township of Hinchinbrooke is a thriving settlement, and in point of climate perhaps the best in Lower Canada.

The river Chateauguay is of small size, its banks have long been settled by French Canadians, and for twenty miles alsove its navigable point is almost a continued village, the mode of French settlement being to place houses on each side of a road or street, with narrow parallel portions of land attached to each, extending a mile or two back. 'The farms are generally free of wood, and the banks of the river, consequently, without beauty. Towards Huntingdon there are few Lirench settlers, and above the village the banks are wooded, and some good farms are seen. Here the Chateauguay is joined by the Hinchinbrooke, Trout river, and Oak creek, the banks of all of which are settled, and abound with good situations.

The soil on the banks of the river occupied by the French is strong clay, bearing alternately wheat and thistle pastures, with occasionally a few oats, big, peas, and potatoes. The houses are generally brick, and a few are of stone. Boys were seen playing at ericket.

For several miles below Huntingdon the soil is very inferior, but improves in the neighbourhood of the village. (On the small streams above the village the soil embraces every description of clay, loum, and sand. This tract has been recently settled, chiefly by British emigrants, and when the forest is subdued, likely to become valuable. Corn crops do not occupy much extent of ground at present. Grass was in many situations excellent, red and white clover abounding without having been sown. In two instances I saw wheat crops which had been sown in autumn, and neither were good; if such a crop succeeds any where in Lower Canada, it must be in this district. The houses consist of wood, and are $\log$, block, or frame, according to the wealth or taste of the owner. A log-house consists of rough logs or unbarked trees, piled 
alove each other, dove-tailed at the comers of the walls, and the intervals betwixt the logs filled up with clay or other materials. A block-house is composed of logs squared so as to class on each other. A frame-house is sawn boards, nailed on a frame, with lath and plaster inside, and corresponds with the wood barracks in Britain. There is another description of frame-house in Upper Canada, which has slender lath on the outside, simply rough-cast with lime and gravel, like stone houses in Britain, with common lath and plaster inside. Houses have pitched roofs, covered with thin pieces of wood, called shingles, resembling and answering the purposes of slate. A shanty differs from a log-house only in wanting a pitch roof, and having bark or hollow trees in place of shingles.

During this excursion, the cause of bushmen or pioneers moving from first settlements to more remote parts of the forest, became obvious. The destruction of forest, and management of cleared land, are evidently different departments, the latter requiring more capital, and a higher degree of knowledge than pioneers generally possess; and in Canadian farming, the wood-chopper and husbandmen stand to each other in relation of mason and joiner in British house-building, the one forming a rude outline, which the other polishes, and may be instanced as illustrative of the advantages of a division of labour. In several instances I saw families of first settlers possessing a considerable extent of excellent cleared land, without the knowledge or means of rendering it productive, and they certainly would benefit themselves by disposing of their properties, and adopting another mode of life. Living almost in idleness, they cultivated, in the most negligent manner, only so much wheat and potatoes as was judged sufficient for home consumption, relying on the hay crop for procuring what necessaries they did not themselves produce, and appeared so encrusted with sloth, that they were likely only to fire a gun with the view of obtaining food, and to cut down a tree for the purpose of cooking it.

Amongst the numerous calls I made, was one on Trout river, at the house of a Yankee squatter, who was from home. Mrs C__ was also a Yankee, a good-looking buxom dame, with two or three young children, and a help of small 
size. She spurned the idea of assisting her husband to cut down his wheat crop, but said she would join him in eating itnever worked in the fields herself, and her girls should not; men must work for her girls, she did not think females were made for working. In all probability she was the daughter of a wood-chopper.

Lands in the district of Hinchinbrooke are held by Einglish tenure, and sell moderately. A friend bought 200 acres last year, with a $\log$ and frame-house, for $\mathbf{L} .270$ currency. 'This year another bought 300 acres, with 90 cleared, for $\mathrm{L} .327$ currency. The inhabitants did not appear so much addicted to ardent spirits as those of some parts in Upper Canada.

In passing up the Chateauguay, many flag-staffis or poles were observed, which owe their origin to an old law, requiring captains of militia so to distinguish their residences. My friend $\mathrm{Mr} \longrightarrow$, residing near the frontier line, was appointed captain of militia some years ago, and erected a pole in front of his house. In the States similar poles are used for hotel sign-posts. The Yankees not being aware of this old custom, used to call at my friend's and ask for brandy, \&c. He was much annoyed by such visitors, and while deliberating one day on the mode of restraining them, a spruce fellow walked into his parlour, and asked to be shaved. The pole was instantly stretched on the ground.

The village of Huntingdon consists of 30 or 40 wood houses, with grist and saw mills ; paper, and hat manufactory, and a post office. There is a school, and a church was soon to be erected.

On 2d August, $\mathrm{Mr} \longrightarrow$ and I, in his gig, friend $\mathrm{D}-$ _ with a driver and hired calash, left Montreal, passing down the banks of the river, by Long Point to Isle Bourdeaux, situated. at the confluence of the St Lawrence with the north channek of the Ottawa, which forms the Island of Montreal. Isle Bourdeaux was understood to be for sale, and is one of the most celebrated spots for situation and soil in the Lower Province. Here a place was pointed out from which clay had been dug, and burned for manure some years ago, and which failed, as in other parts of the world.

After dinner, we crossed by the ferry to the opposite side of 
the Ottawa, passing up the banks of the stream by 'Terre Bonne, and reached St Therese in the morning. Karly next day, we examined a property for sale, and after breakfast proceeded in a northern direction twelve or fourteen miles, and returned to St Therese. Here we changed our horses for those brought with us the day before; and after crossing a branch of the Ottawa by Porteous' Bridge to the Isle of Jesus, and over a second branch of that river to the Island of Montreal, we reached our destination by six in the evening, having encountered several thuuder-storms in the course of the journey.

The face of the country on the banks of the Ottawa, in the neighbourhood of 'Terre Bonne, St Therese, and from thence by St Rose and St Martin's, to Montreal, is truly beautiful, and the softness of the scenery is in many places heightened by the small wooded islets, encompassed by the smooth gliding branches of the Ottawa. The scenery increases in interest on approaching the mountain over which the road passes by a kind of glen, clothed with fruit and other trees. From the brow of the hill passing to the south, the majestic St Lawrence, flowing in broad expanse down Lachine rapids, bursts on the view, and the declivity of the mountain, adorned with villas, and the city of Montreal lying at the foot, with shining tin-roofed houses, giving it the appearance of a distant camp, form a scene seldom equalled in America or any other part of the world. The general aspect of the country from St Therese to Montreal, closely resembles that of some of the finest parts of England.

The soil from Montreal to St Therese, a distance of nearly forty miles, by the banks of the St Lawrence and Ottawa, is strong clay, and I do not recollect of having travelled over the like extent of continuous good wheat soil in any part of the world; but the management which it was under is wretched in the extreme, although the crops in many parts were good. Pasture and spring sown wheat succeed each other, year after year, almost unaided by manures, with one ploughing previous to wheat sowing. Clover seeds are never sown, yet cow grass and white clover everywhere abound, and often attain the utmost luxuriance. Heaps of manure 
were seen dissolving into earth on the way sides. Manure is, occasionally, deposited thickly in heaps on pastures in the early part of summer, where it remains to be spread by the cattle and pigs. When manure is applied to the potato crop, which is very limited in extent, it is spread on the surface after the crop is above ground Cattle and sheep are small, lean, miserable looking creatures, and their pastures as bare as possible. Fully one-third of the sheep are black coloured, the wool of which is useful in forming the grey cloth which almost the whole French population wear, and saves the expense and trouble of dyeing. Neither sheep nor cattle resemble any of the breeds I am acquainted with, and in all probability both are descended from those of France. The horses are small, and coarse-looking-mere ponies, though said to be active and hardy. 'The fences are invariably post and rail. Wild oats were particularly numerous in all crops.

The French Canadiaus, of the ordinary classes, almost invariably live in block-houses, with large windows, and seem ill constructed, externally and internally, for economizing heat, which the nature of the climate, and scarcity of fuel, render so desirable. They have a clean appearance, being often white-washed with lime, and the window-boards and roofs are occasionally painted of different colours, and selelom harmonize with the house. A tree or slurub is never found in their gardens, and an orchard, except in the neighbourhood of the mountain, is almost unknown.

The wealthier French Canadians are ambitious of having stone-houses, which are very awkward erections, and so ill built, that my friend D__ said the work looked as if it had been done by ploughmen between yokings.

The inhabitants are rather under-sized, broad-shouldered, and athletic-looking men, with swarthy complexions. They generally bowed to us in passing, and the boys invariably did so. The little creatures had a most grotesque appearance, decked in very broad-brimmed straw hats, and a flowing shirt being their only covering.

Contemplating a tour into what are called the Eastern Townships, and which have since become the scene of operations of a new land company, I was obligingly furnished with 
instructions and letters by $\mathrm{Mr} \mathrm{R} . \mathrm{A} \longrightarrow$, who had passed through them a few weeks before, and on whose attentions I had not the slightest claim. We arranged to leave Montreal by the mail stage, on the afternoon of the 5 th ; but receiving a eall from $\mathrm{Mr} \longrightarrow$, whom I had met with in Scotland, and who once farmed in the neighbourhood of Edinlsurgh, it was agreed that we should accompany him to his residence on the opposite side of the St Lawrence, and be driven in his waggon a considerable part of our route, next morning. Accordingly, we crossed to Laprairie in a steamer, at ten A.M., and proceeled on the road to St Philip's three or four miles, till we reached $\mathrm{Mr} \longrightarrow$ 's residence.

Laprairie is a small mean-looking village, inhabited almost entirely by French Canadians, and deriving its chief importance from being the entrance and depot of farm produce from the States to Montreal, and from its inhabitants enjoying the privilege of an extensive grazing common, which was part of the Jesuits' confiscated property.

This part of the country differs from any we had yet visited inhabited by French Canadians, having many single trees interspersed over the surface, and a few on creek banks. The soil is invariably clay of the strongest texture, in bad condition, and stands much in want of draining.

In this neighbourhood I observed wheat ears exhiliting ravages of wheat-fly, and on examination found many capsules filled with shrivelled grains, or altogether empty. 'The maggots having left the ears and descended to the earth, I was unable to determine whether this insect is identical with the wheat-fly of Britain; but the collapsed state of the chaff presented the same appearance as the crop in East-Lothian when injured by fly, while spider-webs on the ears contained fragments of flies resembling ichneumons. I was told the French inhabitants around St Philip held meetings and processions a few days previous, for staying the plague of worms in wheat ears, and I have no doubt they were delighted with the apparent success of their measures; knowledge of the habits of the insect would, however, have taught them the futility of their attempts at so late a period of the season. The same insect caused extensive injury in $\mathbf{1 8 2 5}$. 
After dinner, we walked with $\mathrm{Mr} \longrightarrow$, to call on his neighbour ——, who once farmed in my native district, and whom we found engaged in hay-making. He had lately bought a farm, subject to an annuity on the lives of an old lirench Canadian and his wife. He was in good spirits, and had lost none of the rotundity of form earried from Scotland.

Feeling a desire to examine a bull-frog, a reptile which abounds in a pond in front of $\mathrm{Mr}$ _ 's house, I found them large, of a dirty green colour, with a remarkably large mouth, and in formation similar to the frog of Britain.

$\mathrm{Mr}$ _ 's farm is not of great extent, and, considering the excellency of his dwelling-house, was a cheap purchase. In an enclosure in front of the house, grew some hickory-trees, the nuts of which are held in esteem by the population. 'The first year of his purchase, these trees bore a great crop, while there was a failure of this nut generally; and he told me the value of his nuts actually amounted to the interest of the whole price of the estate.

Next morning, Mr $\longrightarrow$, Miss $\longrightarrow$, my friend and I, set out at five o'clock, in a four-wheeled waggon, drawn by a strong little Canadian horse, and arrived at Chambly in the midst of a thunder-storm and rain, which detained us during the day, by rendering the roads impassable. The soil in this part of the country is clay, of the most adhesive texture, and the roads being without stone, the clay became so waxy after the rain, as to remind me of bird-lime. Our horse would have had difficulty in pulling the empty waggon along the road, and I found walking on foot a very slow and arduous mode of proceeding.

'The rain having abated, we walked out, after dinner, to view the village of Chambly, which is situated on the river Richlieu, in a fine bay or basin, three miles wide, and at the head of the navigation. At present there is a canal forming, to connect the waters of Lake Champlain with Chambly basin, and which is expected to be completed in course of next year. The village contains several churches and mills, and is celebrated for seminaries of education. Here young ladies are taught the French and English languages grammatically, arithmetic, writing, and drawing, for \$5 a-month, or about 
21s. sterling, finding themselves with books, bed-clothes, and washing. Cientlemen are elucated for 1.20 a-year, including all branches of education, board, and washing. Some excellent stone barracks are in the village, which is reckoned an important post in approaching Quebee from the States. 'They were unoccupied, and in good order. The river above the village forms a continued rapid for a mile or two, and affords ample power for propelling machinery.

The state of the weather and roads induced me to abandon the plan of visiting the Eastern Townships, and we agreed to pass down the banks of the Richlieu to Sorrel. We obtained a cart, in which a seat was placed for my friend $\mathrm{D} \_$__ and me; and we set out, driven by a boy who was said to know the road well, followed by Mr___ and Miss __ in the waggon we all four occupied the previous day. A more wretched equipment than the one furnished us seldom appeared. A ragged boy drove a small lean Canadian mare, which hopped on three legs; and the ill fitting wheels of our crazy cart besmeared us with mud, and creaked so loud, that we could scarcely hear each other speak, while almost every passenger cracked a joke on our musical vehicle. After jogging on for more than an hour, it was discovered we were on the road leading to Montreal, instead of that to Sorrel. A council was held-we determined to continue the route, and Mr and Miss _ returned. We soon reached Longueil, and crossed the St Lawrence in an awkward-looking ferry-boat, propelled by horses. This horse-power differed from that we had seen used in the States for similar purposes, by the horses walking round a circle instead of remaining stationary. The machinery of the boat was fitted up for twenty-two, although only fourteen horses were attached, and the poor animals were unmercifully goaded by two ruffian drivers. On landing on the opposite side of the river, we walked to Montreal in time for dinner.

The soil, from Lapraire to Chambly, and around the village, is strong clay, varying considerably in quality, and uniformly ill managed. Parts of the canal channel, forming near Chambly, showed no change of soil at the depth of ten feet. The soil also from Chambly to Longueil was clay, and part of 
the country was flooded by the rain of the previous day. The whole surface bore evidence of want of draining, and how essential knowledge is to improved agriculture. In many instances, soil of the best quality did not yield more than two seeds of wheat, while the crops were intermingled with truly luxuriant indigenous tares, thistles, and white clover. I had often heard of the French Canadians clinging to their farms until starved from them-that is, till the soil did not yield them food to subsist on, and I had here evidence of the process and result of such an agricultural system. The ravages of the wheat-fly were everywhere evident.

The appearance of the population, houses, and gardens, resembled that of 'Terre Bonne, excepting that the floors of many dwelling-houses were raised two or three feet above the ground, the result, doulhtless, of the wetness of their situation.

After dining at Montreal, we visited the nursery grounds of Mr C_ of any we saw in America, on our way to the mountain. 'The mountain is about 700 feet high, situated at a short distance from the town, and one of its chief ornaments. From its summit is seen an immense extent of diversified country, together with the waters of the St Lawrence and Ottawa flowing in their various channels-those of the latter, by dividing, form the islands of Montreal and Jesus. The mountain is altogether destitute of public walks or carriage drives, although admirably adapted for both, being covered with trees, and aftording some truly interesting views, which change at every step.

Next morning, in company with our kind and attentive friend, $\longrightarrow, \mathrm{Mr} \mathrm{D} \longrightarrow$ and I rode in a gig round the country lying to the north and west of the mountain, calling on different individuals, and examining several farms for sale. During our drive, we visited the race-course at St Pierre, where we saw three horses belonging to $\mathrm{Mr} \longrightarrow$ get a gallop. One was particularly small, and none of them seemed to possess racing merit. On leaving the race-course, we drove to Lachine rapids, and returned by the river side to Montreal, much gratified with our excursion.

A young thriving hedge of English thorn was observed at 
a village on the north side of the mountain. Bushvetch, vicin caraca, and yellow clover, were growing plentifully, and I also met with the latter at Chamlly. Mildew was seen on wheat where the crop was strong, and the ravages of the fly generally traced, though they did not exist to the same extent as on the sonth side of the St Lawrence.

The soil of the island of Montreal, about seventy miles in circumference, is variable, including gravel, clay, sand, and peat; the two former preponderating, and a great part of all requires draining. Limestone is ahundant, and on one farm I found marl, which we tested with vinegar. The land is held by French tenure, and divided, in the French manner, into long narrow portions of from 70 to 220 acres. The agriculture cannot be said to have been reduced to system, if we except the alternation of wheat and thistle pasture, alrealy noticed. A better state of things is, however, about to dawn-several British farmers having commenced operations near the town of Montreal, and are draining, liming, and manuring freehold as well as leasehold properties. At present, the most lucrative department of farming is raising vegetables for the market, and from the cheapness of manure, the limited extent of free dry soil, the skill requisite for producing market stuffs, and the prospect of increasing population, this description of husbandry is likely to continue profitable for a great length of time. Manure during part of the year is obtained without price, and it rarely exceeds sixpence a cart-load. Vegetables are extravagantly dear at all times. My friend, Mr —, while I was with him, sold a considerable extent of potatoes at L.35 per acre.

Hay fetches a high price at Montreal, more especially that of timothy grass for horses. Clover hay is only bought for the use of cows. Two Scotch farmers, in the neighbourhood of Montreal, sow from two to three lbs. of red clover seed to an acre; and I doubt if it is economical to do so when hay is grown for sale, as clover is more than one penny a-stone cheaper than timothy hay. A milch-cow ean be grazed during the season for \$1, and near Montreal, for \$2, or 8s. 6d. sterling for a season.

The price of land on the island is from L.10 to L.20 per acre, according to quality, situation, and buildings. Labour 
is moderate, in the American sense of the word. Mr D had let the cutting of his barley crop, which was good, and the work well executed (to both of which I testify) to French Canadians, at 7s. 6d. sterling per acre, without food, or any etcetera. $\mathrm{Mr} \longrightarrow$, near Laprairie, paid a stout active Last Lothian ploughman by the year, L.15 Halifax money, $6 \frac{1}{2}$ Lothian bolls of oatmeal, 3 bolls potatoes, 2 bushels peas, and a month's meat in harvest, a cow's keep, a house and garden, with 10 cords of firewood. A second servant got the same wages in kind, with L.12 in money. $\mathrm{Mr} \longrightarrow$, also, near Laprairie, paid his servant \$8 per month, and his second, \$7 both found, or L.20 sterling a-year, with bed and board.

The city of Montreal is situated on an island of the same name, on the north bank of the St Lawrence, and at the head of the ship navigation of the river. 'The houses consist chiefly of stone, and are disposed in narrow streets. The prineipal building is the Catholic ehurch, a capacious builting, not quite finished on the original plan for want of funds, and said to be capable of holding nearly 10,000 souls. The population amounts to about 30,000 souls, and the trade is most extensive. While Upper Canada, and the western part of the Lower Province, continue to prosper, limits cannot be set to the increase of Montreal, which is at present the most important place of trade in the British American possessions. Should manufactures ever flourish in Lower Canada, Lachine rapids could supply Montreal with an unlimited water-power. 


\section{CHPATER XVII.}

Journey from Montroul to Hamilton-Sipuration of Friends - Rideau Canal-Eimigrants pressing up the St Laurevece-Massene -Waddington-Ogdevashergh-Lake of the Thousand IslesAndrew Dinuoberlie, a Furmer from Dumfries-shire-Live-stock from Enyland-Inskerper of Kingaton-Cireat Brituin Steumer - Eimigrant I'assengers-Jolen By Stecomer.

Having long made up my mind to visit the western parts of Upper Canada, and the confluence of the Mississippi and Missouri, it was necessary to separate from my companion, in whose company I had spent so many happy hours, and to whose disinterested friendship I owe more than it will ever be in my power to repay. It was arranged that he should take my trunk and portmantean to New York, to wait my arrival there, having experienced the inconvenience of attempting to take luggage through a thinly-peopled district. I reserved a plain suit of clothes, which had already become shabby. Packing two shirts of cotton, and one of flannel, five collars, five pair of cotton stockings, and a dressing-case, into a small leathern cloak-bag which my friend had used for buckling behind his saddle in Scotland, I left Montreal on the 18th of August; having arranged to be at certain places on fixed days, so as to reach New York in the first week of November. My friend left Montreal some hours before me, on a visit to New Glasgow, and, after seeing Quebec, travelled by Lake Champlain to New York, and reached England on the 17th September.

I was anxious to pass along the line of the Rideau canal, so much praised by engineers, and sneered at by utilitarians, and which nine-tenths of those best capable of judging of its merits condemn as a lavish misapplication of national expenditure; but the irregularity of the conveyances by this route, and my limited time, induced me to ascend the St Lawrence; 
and, by way of varying the scene, I took the American line of conveyances-travelling by stage to Lachine, and from thence to Cascades by steam, from Caseades to Coteau du Lac by stage, and again by steam to Cornwall, which we reached by 2 A.M. of the 11 th.

The waters of the dark-coloured Ottawa, and limpid St Lawrence, formed a striking contrast on the way to Cascades, situated on the former. The hanks of the St Latwrence were ohserved in some places to consist of elay twenty feet deep, without any admixture-some excellent soil was seen above Cascades-the wheat crop from Montreal upwards was perfectly ripe, and barley in some instances carried.

At Coteau du Lac our steamer took seven batteaux, or open boats, in tow, in one of which I counted 110 emigrants, of all ages, who were doomed to pass the night on board. Men, women, and children were huddled together as close as captives in a slave-trader, exposed to the sur's rays by day, and river damp by night, without protection. It was impossible to look upon such a group of human beings witheut emotion. The day had been so intensely hot, that the stuutest amongst them looked fatigued, while the females seemed ready to expire with exhaustion. Conversation was carried on in whispers, and a heaviness of heart seemed to pervale the whole assemblage. Never shall I forget the countenance of a young mother, ever anxiously looking at twin infants slumbering on her knee, and covering them from the vapour rising from the river, and which strongly depicted the feelings of maternal affection and pious resignation. Night soon veiled the picture, and, I fear, brought no relief to the anxious. mother. The navigation up the St Lawrence in batteaux is accomplished by propelling them with poles, and is necessan rily tedious. The accommodation is so wretched and irksome, that the emigrants' privations of transport may be said only to commence at Montreal, where they perhaps expected them to end, and when their spirits are ill fitted to bear up against them. Steam conveyance of late must have shortened their sufferings.

On reaching Cornwall I immediately proceeded on board. the American steam-boat Dalhousie, which conveyed us across: 
to IIongdensburgh ly six A. M. From thenee we were conveyed to Ogdenshurgh hy land, passing through the villages of Massena and Waddington. We breakfasted at Massena springs, the waters of which possess medicinal qualities, and are pleasantly situated on a branch of the Racket.

The thriving village of Waddington is on the St Lawrence, and opposite to which, on an island in the river, is situated the handsome residence of (iovernor Ogden.

The country in this part of the state of New lork is of indifferent soil, and very partially cleared; the farm-houses are of the meanest description, and there is no appearance of wealth or comfort amongst the rural population. In many instances farmers were engaged in securing their hay crops on the Sabbath, and much wheat was standing in a state of over-ripeness. The previous state of the weather may, in some measure, explain both proceedings.

We arrived at Ogdensburgh shortly after night-fall, at an excellent hotel, which seemed filled with people. 'Tea, or, in common parlance of the country, supper, was soon provided for the stage-passengers, who did ample justice to the viands. On learning a steam-boat was to sail next morning at daybreak for Kingston, I retired to a double bedroom, in company with $\mathrm{Mr} \mathrm{M} \longrightarrow$, a north country S'cotsman, who had just arrived in the country, and was travelling to York. The landlord of the hotel showed us personally to our bedroom, and also conducted us to the quay in the morning.

Ogdensburgh is situated at the confluence of the Oswegatchie river with the $\mathrm{St}$ Lawrence, and is the lower termination of American navigation on Lake Ontario. It has many appearances of prosperity, and contains a population of nearly two thousand souls.

At five in the morning the United States steam-boat left Ogdensburgh, calling at Morristown on the American side of the lake, and on the British one at Brockville and Kingston, where I remained for the evening. Darkness prevented me seeing the Lake of the Thousand Isles, on my way down to Montreal, and I was not fortunate in passing up during day. The Lake of the Thousand Isles takes its name from the number of islands which it contains, and is about 
forty miles in length ; forming the termination of Lake Ontario, and commencement of the river St Lawrence. The islands are generally small rocks, a few feet above water, covered with stunted trees, standing as close together as curling-stones on a rink of ice in Scotland, and completely excluding a sight of the mainland. The weather was unfavourable, a drizzling rain having set in, which perhaps affected my feelings, and increased the sombreness of the scenery, which it all times possesses little interest from the want of life. So much is this felt, that a gentleman of my acquaintance, passing up the Lake of the Thousand Isles a few weeks before, was sitting by a traveller engaged with his note-book, when a crow came in sight. He interrupted the writer, and begged he would notice the crow, as it was the only moving thing he had seen during three hours' sail.

On board of the United States I had a long conversation with a fellow-passenger, Andrew Dinwuddie, from Dumfriesshire, in Scotland, and I hope he will pardon me mentioning his name. Andrew was an excellent specimen of his cautious countrymen, and showed credentials highly honourable to his honesty and integrity. He had come to America in spring, accompanied by two brothers, who had purchased land near Prescott, paying L.300 for 200 acres, seventy of them being cleared. Andrew was unmarried, and determined to look about him before sitting down for life. After assisting his brothers to plant their potatoes, he worked with an English farmer in the neighbourhood of Ogdensburgh for a month, and was now on his way to Geneva and Canandaigua in the state of New York, at which places he intended to work for some time. Andrew seemed to have belonged to what is called in Seotland the class of small farmers, and was much pleased with the change of country he had made; having assisted at the Englishman's hay and wheat harvest, for which he got $\$ 8$ a-month, working moderately, and messing with his employer on the best of fare. He had found no difficulty in mowing during the warm weather ;-and greatly preferred American butcher-meat three times a-day, to the oatmeal porridge, barley bread, and sour milk of Scotland.

While at Kingston, ten short-horned cattle, nineteen South- 
down sheep, and a lot of swine, came to the yard of the Kingston hotel, at which I lodged, on their way to the county of Dumfries, Upper Canada, direct from England. They were objects of interest to many of the inhabitants, and were seemingly in excellent health and condition.

I left Kingston about dusk for York, in the St Gieorge steam-boat; one of the shafts broke when opposite the Bay of Quinte, and we returned to Kingston about noon next day. Another vessel was immediately expected to carry us on our voyage; and, in the meantime, the captain refused the passengers dinner; and four of us went on shore to dine, in order to be in readiness. We called at the Commercial Hotel, esteemed the first house of entertainment in Upper Canada; and, on an application at the bar, were told a joint could not be prepared for us until four o'clock. Having stated it was possible to dine without a joint, and we soon expected a steamboat to take us to York, a mutton-chop was promised in half-an-hour. We had not, however, retired to the parlour five minutes, when a spruce waiter entered, and told us $\mathrm{Mr}$ Macdonald would not give dinner. I could not help contrasting this treatment with what we experienced at Ogdensburgh; and if Mr Macdonald's behaviour passes for British manners and hospitality, they have not improved by transportation to Canada.

The Great Britain, one of the largest vessels on Lake Ontario, was laid alongside of the St George, and all hands employed in transferring the cargo of the one to the other. A passage was made from the upper decks of both vessels, along which the passengers passed to and fro; and as they came crowding up stairs for hours together with their luggage, reminded me of bees entering a hive laden with pollen; it was eleven o'clock before the bustle was over, and the vessel under weigh. I observed a quantity of gunpowder conveyed from the St George to the Great Britain in the most careless manner, and locked in the captain's room. The owner of the Great Britain, $\mathrm{Mr}$ _, was on boand at the time, and must have sanctioned the transport of this dangerous commodity.

The night-scene on board the Great Britain formed a counterpart to that of the batteau on the St Lawrence, almost 
every inch of surface being crowded with reposing individuals; the lower decks and passages were crowded to excess, and a great part of the upper deck, which is uncovered, was also occupied. The aged and infirm sought shelter below; the boys clustered round the chimney stalks for heat, while the more hardy stretched themselves on the upper deck without almost any covering, surrounded by forms, or under lee of large packages. Near the stern of the vessel a young woman, perhaps with a view of avoiding danger, placed three infants on her outspread mantle, with their innocent faces towards heaven; and as they gradually sunk to rest, the motion of their slumbering eyelids seemed mimicry of the twinkling stars in the firmament.

The Great Britain reached York about six P.M., previous to which the passengers were mustered on the upper deck, and paid their passage-fares on going below. Many of the emigrant deck-passengers had not, or affected not to have, money; and I saw two middle-aged respectable-looking females place part of their wardrobe in pawn for their fares, and luggage had been credited from conveyance to conveyance all the way from Montreal, with the fares of its owners. Steam-boat proprietors do not lose much in this way, as the friends of emigrants generally relieve the pawned effects.

The meeting of emigrants and their friends at York was an interesting sight. In particular, a group of Scotch Highlanders, consisting of old women and half-a-dozen of innocentlooking girls, incapable of speaking the English language, appeared in ecstasy at joining their friends on the pier, who seemed to have arrived in the country some time before. They laughed, embraced, and saluted each other on the cheek, which is rarely witnessed in America.

To accommodate a gentleman, I lodged in the Steam-boat Hotel at York, which I found an indifferent establishment in the sleeping department. I could not have remained a second night, or gone to bed the first one, had light enabled me to see the actual state of things.

A friend having agreed to accompany me in a tour through the western part of Upper Canada, and who was waiting my arrival, we left York together, in the John By steamer, for 
Iamilton, where we arrived at eleven o'clock. The John By had been constructed to ply on the Rideau canal, with paddle wheels in the stern-the worst sailing and ill-constructed boat in Canada. 'The engine was high pressure; and if a ressel was to be built for roasting passengers, the John IBy might have furnished useful hints. She was soon afterwards wrecked.

We could not gain admittance into any of the hotels at Flamilton, except one, on account of the lateness of the hour. The beds were all occupied before our arrival; but the barkeeper said he would place one on the floor, where $\operatorname{Mr}$ C and I were soon stretched side by side, and soon afterwards some indivicluals, similarly situated, were admitted to share our bed. On awakening next morning I missed Mr Cfrom my side, who was lying in a distant corner of the room; and he afterwards told me, that disliking the company which joined us, he slipped from bed so soon as he could do so unnoticed. 


\section{CHAPTER XVIII.}

Journey on the Banks of the Grand River-Corduroy RoudsRiver-side Vegetation-Cradling-Settler from EdinturghReserve of the Six Nutions-Nellis Settlement-Indiun . Vicices - Settler from Perthshire-First Settlers-Gentle ChildvenAgricultural Notices-Great Heat-Drinking Wuter-Ruising Bee-Brantford_-Oak Openings-Paris - Galt_CiuelpleWaggoner at Table-Face of the Country-Dutch Hotel.

WE rose very early next morning, and rode in a hired waggon to a friend's near Albion mills, where we breakfasted, and set out for the Grand River, accompanied by a third person, to whom I had written to hold himself in readiness for the excursion. The road was tolerably good, until within four or five miles of the river, which then consists of almost one unbroken line of corduroy, on reaching which we returned the waggon, and walked the remainder of the journey. A corduroy road, or, in the language of the country, crossway, is formed of the trunks of trees, laid close to each other, so that animals and carriages may pass without touching the ground. It is formed wherever the soil is wet, and may be considered log pavement. We came in contact with the river at Brant's tavern, where a wooden building was erecting of some pretensions, and continued our walk down the left bank, where $\mathrm{Mr}$ W resides, about two miles below the tavern.

The soil from Hamilton to the Grand River is chiefly clay, of good quality, and well settled, with exception of the Indian reserve on the banks of the river. From Brant's tavern to Mr W__'s, the road is beautiful, the banks of the river being fringed with plum, cherry, apple-trees, and hawthorn, encled with the wild vine, the foliage of which was particularly rich. I have often remarked the luxuriance and beauty of river-side vegetation, and more especially in America, which, no doubt, is in a great measure owing to the copious supply 
of moisture afforded the plants by evaporation, and which is the more abundant on moderate-sized rivers in a country like America, where the temperature of day and night varies considerably.

The greater part of the crops had been carried, and those of wheat remaining in the field appeared particularly shabloy, compared with those of Britain, being thin on the ground and short in the sheaf. I examined a cradler at work in an oatfield, who was making good work, cutting low, and laying down the ears with regularity. The implement is brought round with a full and awkward-looking sweep, nine or ten feet wide, and jerked so as to throw off the stalks, the whole of which are collected in the cradle. By this mode of operating, the cradler supports the weight of the crop collected in the sweep on his arms, and receives no relief from any part of the cut crop, or implement resting on the ground, as in the case of mowing grass with the common scythe of Britain : a heavy crop of grain must, therefore, be particularly fatiguing to the cradler.

We found Mr W_ at home, who had been expecting us for a day or two, in consequence of having been written to. He had been known to us all when in Edinburgh, which he left in the previous month of March, and had only been a few weeks in his present situation in the Nellis Settlement on the Grand River. He had purchased six or seven hundred acres, about seventy of which were cleared, and there was a good house, in the Canadian sense of the word, on the property. For some time after the purchase, he resided with the former proprietor, who only left the house a few days before our arrival. His household establishment consisted of a newlyimported Scotch ploughman; and as our host had not himself been accustomed to house-keeping at any period of his life, the house may have justly been termed Bachelor Hall. The evening was spent in walking over the property, and admiring the beauty of the situation. Next morning Mr W_- explained the peculiarity of his circumstances with regard to household matters, which were temporary, and excited in all of us mirth instead of regret. The breakfast table was laid out with the only animal substance in the house, a large bone 
of mutton, the fragment of a joint which had been prepared for us three days before, and now produced to show we would have fared better had we kept our appointment. I had made up my mind to try if there was flesh on the bone, which could not be ascertained without using a knife, but unfortunately a large dog scampered off with the relick before our eyes. Mr $\mathrm{W}$ - at this time was in the kitchen, infusing tea, and, when informed of the catastrophe, promised to reward with a swing in a rope the poor dog, which had no master, and had taken up its quarters with him a day or two before. A consultation was held about obtaining a substitute for the bone, when two of us went in quest of hen-eggs, a nest of which was found in the barn, containing a great supply. On searching for the means of cooking them, we could only find a boiler with a hole in the side, which seemed to serve for general use. Into this vessel part of the eggs were put, but it was impracticable to make the water boil, as it would have escaped through the hole. On removing them, they were found sufficiently done, and formed an excellent repast in connexion. with the best wheaten bread I ever met with, and which had been baked by the lady of the former proprietor.

I have noticed these particulars in $\mathrm{Mr} \mathrm{W}$-'s household, from being amongst the first real Backwood scenes we had met with, and which his kindness and good-humour would have rendered agreeable under any circumstances. He had been accustomed to move in the best society in Edinburgh, and the facility with which he accommodated himself to his altered situation, was deserving of praise. It has been said, the circumstances of his household were temporary ; and I have since learned he soon afterwards married a young lady, whom I saw on the banks of the Grand River, and trust he now enjoys that degree of happiness he so well merits, and which I sincerely wish him.

In the forenoon of the day after our arrival, Mr Wdrove my two friends, $\mathrm{C}$ the river, I riding on horseback, in company with $\mathrm{Mr}$ W. $\mathrm{N}$ - The banks form what is called the Reserve of the Six Nations, which extends from the mouth of the river on Lake Erie to Brantford, a distance of about fifty miles, and 
embraces three miles on each side of the river. The Indians granted part of their lands, upwards of fifty years ago, to individuals chiefly of Dutch extraction, who then settled on them, and whose descendants are still resident. The land so granted is called the Nellis Settlement, and is one of the most beautiful spots in Upper Canada. The poor Indians of the Six Nations, like every one of the many tribes in America which have come in contact with white men, have greatly decreased in numbers, and have recently sold to the British Government fourteen miles in length of their Reserve from the mouth of the river, and which has been surveyed, and was brought into the market a few weeks after my visit there. To see this district was the object of our excursion, but which the state of the roads and want of time prevented our accomplishing. We retraced our steps, after passing about half a mile into the newly ceded territory.

A number of well-dressed Indians of both sexes were passing up and down the banks of the river on horseback, with good saddles and bridles. In one instance, an Indian and his wife, or squaw, as they are called in the language of the country, were riding together, she after the manner of Englishwomen, with a child sitting behind, and the husband had a child before him.

In going down the river, we called on an Indian of reputed wealth, named Fish Carrier. $\mathrm{He}$ is a stout middle-aged man, with a wife and family. His log-house had an appearance of comfort, having two large well-glazed windows in front, a door with veranda to the back, and a stone chimney stack. The family seemed to have finished a repast shortly before our arrival, - a good table being covered with plates, knives, and forks, recently used. There were two four-posted beds in the room, five or six chairs, a cat, and several dogs. There were horses, cows, and pigs in the woods. Fish Carrier could imperfectly understand, but was unable to speak the English language, and Mr W. Nbeing similarly situated with the Indian one, the conversation of the parties was short and unsatisfactory.

Some distance below Fish Carrier's is the Council-bouse of the tribes, a long narrow wooden building, with an upper 
and lower range of benches round both sides, on which the senators recline during counsel. It is kept by two old women, who cook on days of meeting. At the time of our visit they were in the act of churning, and I sipped a little of the buttermilk. The butter was particularly white in colour. I also partook of bread made from Indian corn meal, mixed with a few unhusked French beans, which looked like raisins in a cake. The bread was soft and damp, and seemed to have been prepared by boiling. To me it was unpalatable, although some of my friends did not dislike it. The roof was hung with ears of Indian corn, considered public property, which are contributed by individuals in years of abundance, and reserved for times of searcity. The Council-house is also used for dancing, and contained a number of ornaments worn on such occasions, consisting of strings of bones for fixing on different parts of the body, and prized for the clattering they make when in motion.

On our return, a young Indian, of fifteen or sixteen years of age, shot a small bird with an arrow from a common bow, and on being requested to try and strike the bird when dead, he placed it on the trunk of a tree, and missed it twice. Five small boys were shooting birds with a blow-gun, and amused me by their manner of stealing up to the object of their attack. The blow-gun is a long narrow wooden tube, with a small arrow, on the end of which is a quantity of thistle down neatly dressed, and which fills the tube, so as to give effect to the arrow, which is discharged from the gun by the breath of the sportsman. It is little better than a child's toy.

Having a desire to see the lands which Government had obtained from the Indians, Mr C - and I set out next day at seven A.M., furnished with horses, through the kindness of friends, to visit Mr B__. We had not, however, gone far when his horse became so lame that he returned, and I proceeded alone, down the banks of the river, which I lost sight of, and after a long ride came to a settled part of the country, where I found myself on the road to Cranberry, and four miles from the river. On learning the direction of the river, I entered the woods with a tired horse, which I led in my hand, and after a tedious walk, gained the river two miles below where 
the object of my search resided, and which I reached at two P.M. After resting the horse some time, I returned up the river, and in two hours got over a distance which in the early part of the day occupied seven hours. Many adventures are related throughout Canada of people having lost themselves in the woods; and there is so much danger in a bush excursion, that people unaccustomed to follow tracks in the wilderness, ought never to incur the hazard. A stubbomness of disposition led me to make an attempt to regain the river without a compass. Guiding my course by the sun, my success was complete, but had clouds arisen to obscure it, $\mathrm{my}$ situation would have been unpleasant.

On introducing myself to $\mathrm{Mr} \mathrm{B} \longrightarrow$, he said he had heard of my arrival in the country, and welcomed me kindly. He had only been settled a few days, and was engaged in improving his house, with the assistance of an Indian, who understood cabinet-making. The Indian was preparing a duck for dinner, of which I partook, sitting on a chest, and having another for a table. The duck might be a canvassback, but I made no enquiry on the subject, and it was without feathers, by which alone I could have determined the species. No food could be more grateful to my palate, and I rejoiced at so opportune an arrival. Mr B with the understanding of Government, purchased the Indian improvements, that is, paid them for the house and cleared land; and was to pay afterwards the ordinary price of land to Government. He was said to have farmed in Perthshire, Scotland, and resided some time in the state of New York before coming to Canada. Mentioning to him that $I$ had been told of his leaving the States in disgust with the people, he assured me such was not the case, as he felt ashamed of having left his acquaintance there, who had shown him the utmost kindness, and whom he respected and loved.

On my return to the Nellis Settlement, I passed one or two habitations of white men on the river side, and seldom enjoyed a more agreeable ride. The sun was low in the horizon, and gilded every object with a rich and soothing hue, so different from the fierce rays of summer noonday, that an admirer of nature seldom loses an opportunity of viewing 
its loveliness. A romantic fancy may suppose this tint of the setting sun an affectionate evening adieu to nature; and such are its effects on vegetation, that I have seen the Scottish farmer stalk forth, and gaze on the beauty of his crops, although perhaps insensible of the cause of his pleasure. The unruffled waters, beneath a cloudless sky, reflected objects on the surrounding banks; while Indian cots, situated on the most prominent points of the terrace, occasionally met the eye. When contemplating a landscape, where several small islands seemed reposing on the surface of the river, and on which grew luxuriant Indian corn, overtopped with magnificent sunflowers in full blossom, gentle ripples issuing from beneath a bush on the bank of an island, led me to expect waterfowl, but a squaw, standing erect, came gracefully paddling a canoe filled with children, who had been cultivating the sunflower. Swan never guided her brood with more majesty and care than this female did her offspring.

I met some Indians, and a plain-looking white woman, with fair hair, dressed in Indian attire, and carrying a child of Indian hue. She was said to be a native of Ireland, and a solitary instance of a white female living with the Indians.

My friends were at a loss to conjecture the cause of $\mathrm{my}$ absence, as I engaged to dine at Mr N__'s, where I joined them a little after seven o'clock. Next day we dined with Mr W. N_. These invitations came opportunely after the loss of the mutton bone; and I have no doubt were the means of saving the lives of several of Mr W__ fowls. It was gratifying to see the old settlers so attentive to $\mathbf{M r}$ W__ on this emergency, and I was glad of the opportunity of witnessing the manners and customs of the descendants of the first inhahitants of this part of the country. $\mathrm{Mr}$ $\mathrm{N}$ __ is pretty well advanced in life, a shrewd and wellinformed person, and has let his farm in shares to an Englishman. Mr W. N- is a very active middle-aged person, with a wife and family, and cultivates his farm personally. He lives in a small frame-house, with plain furniture, and every thing we saw was plain and neat. Mrs W. N__ was also a native of Canada, cousin to her husband; had four or 
five children; and was, I believe, without a female servant or help. The children were thus the third generation which had been reared in comparative seclusion on the hanks of the Grand River. The softness of manner, ease, and goorlhumour of the children, appeared equal to families in the better ranks of life in my native country, and I was anxious to ascertain if this gentleness of manner was real. With this view I romped, fondled, and teased, within and without doors, the small hoys, without ruffling their tempers; and trust my little friends Hamilton and Nielson will in age display matured fruits of their sweet and early blossoms. Manner, like the disposition of children, is, to a certain extent, the gift of nature; but the example of parents deeply affects families, more especially when shut out from society. This family unquestionably owed much to the good sense and conduct of both parents, and ought to go far in satisfying people in Britain that their children will not necessarily become savages by being removed to the woods of Canada, if they themselves lead proper lives, which they ought to do for their children's sake, if not for their own.

I have already mentioned a dam across the Grand River at Dunville for supplying water to the Welland Canal, and which throws back the water in the channel of the river for nearly twenty miles, until it reaches the Nellis Settlement. The beauty of the river has been injured below this point by the stagnant water having covered the low lands, destroyed the trees, and imparted a marshy and gloomy character to the banks. In the Nellis Settlement, the river possesses much of its original character, and is truly fine, gliding around some fertile and beautiful islands, while the rich flat lands on the banks extend a considerable distance back, and terminate in an undulating surface. The low land on the banks of the river is what is termed bottom, or interval land, in some parts of America, and is a fine rich loamy soil. The undulating ground is clay of good quality, and has not been cleared to any extent. The low lands are altogether cleared, though adorned with single and wide-spreading trees; and it is here most of the settlers reside. If the Grand River is rendered navigable to Brantford by means of locks, as is talked of, the charms of the 
Nellis Settlement, one of the most beautiful spots in the province, will be destroyed by the submersion of the islands and flats. The soil of the Indian Reserve, including what was sold to government, as seen by me on the east side of the Grand River, is chiefly clay of medium quality, with very little vegetable mould on the surface. In a distance of nearly twenty miles, I observed only one or two streamlets joining the river, which does not augur favourably of the lands abounding in water, unless the springs flow in a westerly direction towards the Welland or Chippaway River. The prevailing wood is oak.

The agriculture on the Grand River embraces the cultivation of wheat, oats, clover, and Indian corn, by the white population, the Indians confining their attention chiefly to Indian corn, and occasionally a little wheat. The female Indians bestow considerable attention on the cultivation of Indian corn, which is planted on the best of land by the river side, and infinitely surpasses any thing I saw belonging to the white population. In many cases the crop was eight feet high, and almost always has intermingled with it a few plants of the sunflower, still more luxuriant than the corn, the large yellow flowers of which bending towards the sun, impart a high degree of richness and beauty to the crop.

At eight A. M. on the 21 st August, the party at $\mathrm{Mr}$ W__ 's broke up, Captain A__ on horseback for Blenheim, Sand the mutton-bone stealer for Hamilton, and $\mathrm{C}-$ and $\mathrm{I}$ on foot for Brantford. The morning was fine, and the road being through the Indian Reserve on the banks of the river, we enjoyed our walk for some time. But towards noon the powerful rays of a vertical sun shone on us, while the banks and trees excluded every breath of air, and we suffered considerably from heat. My friend on two occasions petitioned for a few minutes' rest, when we reclined under a tree to cool, almost naked. We reached Brantforl to dinner, a distance of twenty-four miles, and learned the thermometer stood at ninety-four degrees in the shade. In the evening we walked around Brantford, having quite recovered the fatigue and broiling we underwent in the early part of the day.

People frequently speak of the danger of drinking cold 
water in Canada, and recommend a mixture of spirits as a safeguard, a convenient doctrine for such as delight in stimulants. Having at every period of my life indulged in the use of cold water when thirsty and taking exercise, I saw no reason for a change of system while in America, which Mr C also followed. In walking through the Indian Reserve, we became thirsty, and being unable to discover water, we approached the dwelling of an Indian, in the hope of obtaining a supply. A well-dressed interesting young squaw was sitting under a wooden shade, with a deer-skin, the embers of a fire, and cooking apparatus before her, apart from the house, to avoid heating it. I asked for a drink, and on observing that she did not comprehend the import of my words, motioned the action of drinking, when she instantly glided into the house, and brought a snow-white bowl, which she presented with water. We made a second application at an Indian habitation, but our eloquence and gestures were unavailing, as the inmates did not seem to wish to afford us relief. My friend now contrasted the soft black eye and henevolent countenance of the squaw who supplied water, with the dirty sordid looking creatures who denied it; and while we were engaged in debating whether the different appearances of the individuals really existed, or arose from our associations connected with them, we suddenly beheld an interesting and extensive view at a bend of the river, lying 200 feet below; and in the foreground, at a few yards distance, a limpid fount bubbling forth from the hollow trunk of a tree, at which we quenched our thirst.

In passing from Nellis Settlement to Brantford, two Indian school-houses were observed, and we intended calling on their religious instructor, Mr N_, who was from home. The Indian houses were similar to those on the river below, with glazed windows, verandas for excluding the rays of the sun, and a ladder on the roof for reaching the chimney-top. We several times pulled excellent apples, and passed one tree of remarkable size, loaded with fruit, surrounded by a fence, and its branches supported by props.

The soil on the banks of the river was generally clay, though in some places sand, and there was a tract of five or six miles 
of excellent loam. The wood was chiefly oak, with here and there a few pines, which on the west side seemed to prevail to the water's edge. There is little agriculture on this part of the Reserve of any kind. At the Indian's dwelling, where we obtained the drink of water, there was a good crop of wheat, well stacked, a waggon for carrying home the crop, and a good barn. This day I commenced a collection of seets, by selecting six species of wheat, three white chaffed varieties having red-skinned grain, and three red chaffed varieties having very white grain.

While at Brantford, we observed a raising bee, that is, raising the frame of a house by a collection of people. The frame had been constructed, and the parts fitted before-hand, and the company had only to put them together. The process was expeditiously effected, the largest timbers being hoisted to their places by long sharp-pointed poles. The power of brute-furce was displayed; yet three men, with the aid of mechanical power, might have accomplished the labour of thirty.

Brantford owes its name to the celebrated Mohawk Indian chief, Brant, and is situated on a high bank on the east side of the Grand River. It is a growing place, containing six hundred souls. There is a new bridge erecting over the river, forming the great thoroughfare to the London and Western districts; and it is said to be in contemplation to render the river navigable to this point. On the opposite side of the river, there is an extensive rich-looking flat country, a part of which is occupied by Europeans on lease from the Indians.

Having experienced the inconvenience of walking in warm weather, we debated whether to pursue the remainder of our journey on horseback or in a waggon, and determined on the latter, which was engaged at $\$ 3$ per day, the driver finding himself and horses.

Next morning Mr W—, Captain A—, my friend, and I, left Brantford early in the morning, on our way to Galt, and stopped to breakfast with a $\mathrm{Mr} \mathrm{C} \longrightarrow$, a successful farmer, residing within seven miles of Brantford. The farm consists of what is called oak openings or plains; and, on examination, I found the soil consisting partly of clay and partly 
of sand. The crops had been pretty goml, expecially a field of oats. The straw of wheat in the barn showed no traces of mildew, and the grain was equal to any I had met with in Ainerica, a sample of which I preserved. Oak openings or plains consist of stunted oak-trees, thinly scattered over the surface, so that the plough may frequently enter without further obstruction than what arises from the roots of bushes. It is quite certain that fire passes over the plains every year or two, and destroys all tender vegetation. 'The effects of fire, I have no doubt, also prevents the growth of the trees, which are sometimes pretty thick, and in other places several acres are found without any. Oak openings are free of vegetable mould, or even live vegetation of any value; the soil is commonly light sand, and a superficial observer is apt to think nature hath pronounced the curse of sterility on such spots. But part of Mr C___'s soil convinced me the thinness of the trees, and thriftless vegetation is not an effect of the nature of the soil, which is often much under-rated. ()ak openings may be cultivated by girdling the trees, and ploughing with six oxen, and fallowing the ground two years.

Mr C__ speaks in high terms of his oak openings, only a small part of which, in my opinion, merited praise. He estimates the expense of raising the first wheat crop on such soil, including the price of land, and two year' fallow, at $\$ 20$ per acre, and the return of the first crop at twenty bushels. The price of wheat, last year's crop, 1832, was $\$ 3$. Gypsum, or plaster of Paris, he invariably applies to clover. Labourers are always to be had at from $\$ 10$ to $\$ 13$ a-month in summer. Winter lasts six months. I was pleased with my visit to $\mathrm{Mr} \mathbf{C} \longrightarrow$, and on parting expressed myself so to him.

After breakfast we proceeded by way of Paris, so called from its quarries of gypsum, or plaster of Paris, situated on the Grand River, eight miles from Brantford, and one below the Forks, at which there is mills. We soon afterwards reached Galt, also situated on the Grand River, over which there is a bridge. It contains a church, grist, saw, and pail mill; and several buildings are of stone. My friend had a letter of introduction, which he had brought from Edinburgh, 
to a gentleman in Galt, whom we understood to be in the haljit. of receiving the bearers of such letters coolly. In order to guard against apparent disappointment, we delayed calling with the letter till after dinner, and gave instructions for the horses to be put to the waggon before we left the inn. Our reception was, however, all we could have wished, being asked to take wine, and tea, both of which we declincd. In conversation, we learned he had left his own residence to avoid company, and building-lots in the village were not sold, for creating opposition to $\mathrm{Mr}$ — 's store. 'The prospcet from Galt is pine forest of stunted growth, with a few straggling cedars on the margin of the river. We left Galt in the afternoon, and reached Guelph at eight P.M. Next day we rode into the township of Lramosa, and returned to Guelph in time for dinner, and reached Galt in the evening.

Guelph is finely situated on the river speed, a branch of the Grand River, and is well supplied with water from springs as well as the river, which drive's mills, and over which there are two bridges. There are about fifty houses in the village, only one of which is of stone. There is a market house of wood, roughly finished, and without a stall or a frequenter of any kind. Three considerable sized churches of different sects, Catholic, Episcopalian, and Presbyterian, are being erected. Three weeks previous to our arrival, a range of six or seven wood houses had been burnt down, the brick chimneys of which were standing.

This village could boast of ruins, if not of antiquities. The bridges over the Speed at Guelph, and the corduroy, were decayed, and in a shameful state of neglect, alike marking the worthless nature of the wood and insufficient road-way management of the district.

The inn at Guelph is a good establishment for the country, and greatly superior to that at Galt. Our waggoner brealifasted and dined at the public table, in company with two gentlemanly-looking persons, lately from England, without any explanation from the landlord. The waggoner was a Lower Canadian, of French descent, and strongly resembling in size and feature the common description of Scotch peasantry. He 
spoke the linglish language in a broken imperfect manner, and was an unassuming obliging person. This was the second time drivers had appeared at table since reaching the American shore, and I did not experience inconvenience of any kind on either occasion from their presence, both having conducted themselves with the utmost propricty. A meal in the United States and Canada is simply a feeding, and not in any degree a conversational meeting; and ability to pay is therefore considered the standard of admission to public tables. Britain and America are similarly situated in this respeet, but in Britain the facilities of getting private tables, and various degrees of entertainment, completely separate travellers into different grades. Viewing meals as social meetings, texture of coat or profession ought not to gain or deny an individual admission to table; and wherever the inhabitants of a country have not been brutalized, true politeness at a public table never fails to check vulgarity and impudence, as well as to impart pleasure.

The surface from Brantford to Galt, by way of Paris, is andulating, chiefly oak openings, consisting of dwarfish decaying oak-trees, with a good deal of underwood, and scarcely a plant of grass or clover interspersed. In some places a good deal of pine is seen, but every description of tree, including lareh, is small and stunted looking.

From Galt to Guelph, and in the neighbourhood of the latter, the soil is light, composed of sand or gravel, bearing inferior crops, and, judging from the way sides, calculated to produce excellent pasturage. The wood is small sized; and the district abounding with limpid streams. Annual thistles were growing in vast numbers, and where cleared land had been neglected, were occupying the entire surface. The clearing of land was going on to a considerable extent.

The wheat was much mildewed, and some fields we examined nearly destroyed by it. Sleighs, mere arms of trees, were passing along the roads, drawn by two oxen, on which were small bags, seemingly going to the grist-mill, and under guidance of a stout man, who could have carried "the bags on his shoulders. Such a misapplication of ox labour arose, I fear, from laziness. 
A considerable part of the country between Guelph and Galt is settled by Dutchmen, many of whom have cleared farms of considerable size, with good houses and barns. There is a respectable hotel within a few miles of Galt, at which we intended to stop for the night. On entering the bar-room, in which were ten or twelve people, the landlord was scolding his wife in high Dutch; and as he continued deaf to our enquiries, we left the house. 


\section{CHAPTER XIX.}

Journey from Gialt to Goderich-Farmer from RoxluryhshireFemale Worth_Improved health of S'sotch Farmers - Visit Cruptrin A - -Humming-birds_London Fiumily in the Bush_Guides-Avon_Accommodation-German Selter-Notices of Nature.

Having letters from some friends in Scotland to a relation of theirs near Galt, who had formerly farmed in Roxburghshire, I was anxious to deliver the letters personally, and set out at six o'clock in the morning in search of his residence, which was difficult to find, from not being named. (On enquiring the way at an old man on the road, we got certain information in broad Scotch; and in the course of conversation, he told us he thought Canada a rough bit at first, but he now liked it. Calling at a house to ask the way, a man said it was one thing to put a question, and another to answer it. Seeing the indiviclual was in a state of brutal intoxication, I walked to the waggon, followed by the poor wretch, vociferating disgusting oaths, who seemed exasperated by the silence and contempt with which he was treated. I afterwards learned he had a short time before beat his wife out of the house, and was considered on the high road to ruin.

We at length found the object of our search, Mr 'Twalking in his fields with $\mathrm{Mr} \mathrm{R}$ _ Kingston. Mr T__ had only reached Canada the year before, and was not perhaps fairly set down. The farm he had purchased was mostly cleared, and he was summer fallowing a considerable extent of land, which was well ploughed, and laid off into regular ridges. He had bought all the manure in the neighbourhood at about sixpence per load, and was laughed at for having done so. The house was built of wood, and two beds were standing in recesses in the apart- 
ment where we breakfasted. Mrs T__ apologized for the mean appearance of her house, which I assured her was unnecessary, as I found few in the country so good, and its shining cleanness imparted more interest to me than the highest glitter of British fashion. She was in excellent spirits, and entertained us with many particulars of her journey from Scotland. Arriving at Montreal when cholera was raging in a dreadful manner, and her husband being in a delicate state of health, no time was lost in pursuing their route. In passing up the St Lawrence with her family and luggage, the boat admitted water so freely, that she was forced to walk by the river side with an infant on her back. The population being panic-struck at the havoc cholera was making, shut their doors on emigrants, who, they imagined, had introduced the disease into the country, and she was under the necessity of baking bread for her family with her own hands, and firing it under a tree. After relating many particulars of their first settlement, she concluded by stating, that in Scotland she had three maid-servants constantly at her own command, here she had no servants, and was happier without them. On remarking it delighted me to find her in such excellent spirits and pleased with her situation, as the change from the old country to Canada appeared more trying for ladies than gentlemen, she replied with animation, " $\mathrm{O}$ no, sir, ladies can manage their own department here, but gentlemen require assistance in theirs." Mrs T___ spoke with so much good-humour and feeling, that it would have been rudeness to have maintained an opposite opinion; and without investigating which of the sexes in the middle ranks of life undergo the greatest privations at first settlement, observation convinced me females get sooner reconciled to their duties, and discharge them with better effect than males. Much as I have ever esteemed my countrywomen, they never appeared to so much advantage as in Canada, where their energies had been fully called forth and developed by the new circumstances in which they were placed, and their exertions induced me to regard many of them as heroines. Emigrants are desired to bring out wives to Canada, and I add my testimony to the justness of the recom. mendation. In almost every case that came under notice, $m$ 
country'women appeared calculated to stimulate their hushands to industrious exertion, and some, under divine Providence, seemed to owe almost all they possessed to their fair partnens.

One great source of rejoicing to Mrs T- was her husband's improved state of health since his arrival in Canarla, which she attributed to climate. But were I to judge of the matter, I would assign his change of circumstances as the more likely cause of his better health. Land in Scotland is almost always occupied on lease of 19 years' endurance, and perhaps there is no situation more trying than a tenant with an over-rented farm. In nine cases out of ten he cannot get quit of his lease, or a modification of rent; if he rise early or toil late, the fruits of his labour go to the proprietor of the land, and year after year he finds his funds diminishing, with ultimate ruin in prospective. Under such circumstances I have known individuals become druakards, others gamblers; some have sunk into a premature grave, and but few minds remain in full tone, and still fewer constitutions. To escape from such a situation, and reach Canada, where the present may be said to be without care, and futurity so brilliant, must be a perfect Elysium and restorer of health. It is but justice for me to say, that I am altogether unacquainted with the circumstances in which $\mathrm{Mr}$ T_ was situated in Scotland, but if like many of his profession, his improved health may be regarded as an effect of his improved prospects.

We reached Captain A__'s, in the township of Blenheim, in time for dinner, having passed through miles of forests, in which a track could scarcely be recognised. The general appearance of the place had an air of neatness, although it was only fifteen months since the first tree was felled. He had already cleared about 30 acres, and reaped a luxuriant, though mildewed, wheat crop. Oats, potatoes, and Indian corn, were advancing towards maturity. Here, for the first time in Canada, I saw crops injured from luxuriance, and only two or three instances of such afterwards came under my notice.

The residence of Captain A_— was within 50 yards of a rivulet which joined the Nith, the space between the house and the stream being occupied as a garden, in which the taste of the family had begun to be displayed in cultivating flowers. 
The house was a log cottage of considerable dimensions, one longitudinal half of which was occupied by a kitchen and sitting "room ; the other half consisted of sleeping apartments, which I did not number. The door opened into the kitchen, in which every thing was clean and neat, and which communicated with the rest of the house. The interior walls consisted of unbarked trees, against which an extensive library was placed, occupying one end of the sitting room. When retiring for the night, we were conducted up a stair into a kind of garret, where we were told we must sleep. At this time I had not seen much Backwood life, and my looks, perhaps, betraying astonishment, Captain A__ laughed heartily, and reconducted us to an apartment below, where I reposed for the night, on a more comfortable bed than any I afterwards met with in America.

Next morning, I arose before any of the family, and while walking up the banks of the stream, ere the sun had peeped over the forest, enjoyed an excellent opportunity of observing the humming-bird of the country. Upwards of a dozen of these lovely creatures were feeding on the blossoms of a plant growing near the river, the celerity of their movements in examining and passing from flower to flower excited admiration, and when moving to a distance, the eye could not follow their rapidity of flight. A copious formation of dew had taken place in course of the night, which draggled their beautiful plumage in fluttering amongst the leaves, and they frequently retired to a fallen tree to trim their feathers. They seemed regardless of my presence, and plied their task within a few yards of me. They do not, like the bee, rest on a plant when examining a flower, but thrust their long bill into the heart of the blossom when suspended in air, and in this position excite the noise from which they take their name.

Captain A__'s family consisted of eleven children, the eldest of whom seemed about seventeen years. He had moved in the best society of London, and in consequence of a sudden reverse of fortune, came to his present situation, and at once placed his family in the bush, without a servant or any one to assist them, and they bake, cook, wash, and do every thing for themselves. Mrs A- is a sensible woman, 
reconciled to her situation ; and her household and family matters testify to her excellent management. Two sons, handsome, gentecl-looking youths, about fifteen or sixteen years of age, chop trees, and perform all sort of furm work. The young ladies seem equally active in their department. I was anxious to see the cows milked, but unfortunately they had strayed in the woods, and could not be found while I was there. It requires a considerable degree of heroism in people like Captain and Mrs A_- accustomed to the gaieties and luxuries of London life, retiring to the woods of Ciunada without a servant or any thing like their former notions of com. fort, and whatever may have been the impelling motive for the step they took, their perseverance merits applause. It was an interesting sight to see a young and genteel family so situated and happy in their new position, and the pleasure experienced during my visit at Lamotte, was an ample recompense for crossing the Atlantic.

In my progress through Canada I had witnessed female devotion of the most exalted character, which circumstances prevent me noticing, but the same reasons do not apply to the youths of this family, and I trust they will pardon the liberty I take with them. Two slender and accomplished boys, in a part of the world blighting to their first budding hopes and enjoyments, inuring themselves to the hardest manual labour in support of their parents, and infant brothers and sisters, is a picture of disinterested virtue worthy of being delineated by an abler pen. I trust their exertions will be crowned with success, and that a portion of time, which can be spared from furnishing food, will be devoted to the moral improvement of the younger branches of the family. What a source of comfort these youths must be to their parents, whose precepts must have had no small share in forming their character, and their conduct may be instanced as illustrative of the advantages of parental care, in a selfish point of view, where nobler motives do not exist. Their mode of life may be different from that of their schoolfellows in England, but in mature age they will look back with delight on their past labours, and in all probability, great will be their reward in this life, and greater in that which is to come. 
After partaking of breakfast, we bade adieu to Lamotte, when the little members of the family clusteringar ound, reminded me of the humming-birds seen in the morning, and I could not refrain from stealing a kiss from a curly-headed child, whose soft blue eyes were innocently fixed on the departing strangers. On our way to the Goderich road, we were accompanied by Mr 'T. A—, mounted on horseback, with an axe over his shoulder, to act as guide, and cut a way for the waggon. As he rode before us, with his slender figure dressed in a clean neat jacket and trowsers, snow-white shirt, with exposed collar and broad-brimmed straw hat, I would at one period have thought him ill-adapted for a Backwoodsman, but having, in course of my wanderings in the wilds of Canada, witnessed the advantages of cultivated minds and habits, his appearance was a source of pleasure, while I meditated on his probable career in life. We fortunately did not require much of his axe services, and parted with him at the end of five or six miles, where the road was good. About two miles farther, the road seemed to terminate at a log-hut, the inmate of which told us a waggon had never penetrated beyond his dwelling, and would have difficulty in reaching the Goderich road, distant four miles. He offered to be our guide, and provided himself with an axe to clear the way. We had before this time commenced walking, from the badness of the roads, and found considerable difficulty in getting the waggon through the bush, when at length its progress was arrested. In this dilemma a person approached, and said it was impossible to proceed in our present route, and offered to show us through the only passage. We were conducted many miles of foot-path, till we at last reached the wished-for. road. I felt pleased with our bush guides, one of whom was from Yorkshire, the other from Ireland; they did not take advantage of our situation by stipulating for reward, but seemed to act alone from friendship, and I bestowed on each a trifling gratuity.

We dined at a tavern on Smith's Creek, newly erected, good of its kind, and a little after nightfall reached one on Avon Creek kept by an intelligent Irishman. On retiring for the 
night, we were conducted to a shanty thirty or forty yards from the tavern, consisting of one apartment, containing three beds, one of which was already occupied, another was destined for our waggoner, and the third for my friend and self. This hovel did not even contain a seat, or any kind of furniture, except the fore-mentioned beds, and the door was without a fastening; the roof was of bark, and the rays of the moon shone through it and the sides of the building, which bore a stronger resemblance to a bird-cage than a human habitation. 'The beds were boughs of trees, put together in the manner of a camp stool, with a netting of bark connecting the frame-work. The feeble glimmer of a small candle fixed near the door, prevented me seeing the bed-clothes, but the bed feit as rough and hard as the corduroy roads over which we had travelled in course of the day. On lying down for the night, the farmer's saying to Mr T. A $\longrightarrow$, this is a rough country for a gentleman, recurred to my memory; and in a few minutes the chirping of a thousand crickets lulled me to repose.

Next morning I called our waggoner at daybreak, and, while the horses were attaching, examined a grist and saw mill which were erecting by the river side. We breakfasted on very poor fare at a tavern kept by a German, who was one of the first settlers on the road, having been five years in his present situation. He expressed himself satisfied with his lot, having 1000 acres of land, and had only sixteen in his own country. I remarked that he perhaps held too much land; when he told me he had nine sons, to each of whom he meant to give 100 acres, and retain the same extent for himself. His wheat crop this year consisted of sixteen acres, and was almost entirely destroyed by mildew. We dined at Van Egmont's tavern, which is a wealthy-looking place for the country, containing a store of miscellaneous goods, large barns, and a tolerably good garden. We travelled five 'or six miles after nightfall to Goderich.

From Smith's Creek to Goderich, a distance of about sixty miles, nearly two-thirds of the road is corduroy or crossway. Occasionally a tree has been left standing in the centre of the road, as if for the purpose of attracting notice. These trees 
are generally rock-elm of the finest description, but as others equally good could be found a few yards from the road, those on its centre ought to be removed as interruptions.

The soil of Captain A__'s farm in Blenheim is a rich soft loam of easy cultivation. The land of this township, and the adjoining one, Wilmot, which we passed through, is loam of excellent quality. 'The wood is chiefly maple, interspersed with elm, oak, cherry, and beach. On our way from Lamotte to the Goderich road, we saw what is called a wind-fall in the forest, or havoc of a whirlwind, where the decaying trunks of trees were scattered in wild and mutilated confusion. Many single trees were lying up and down, with large masses of earth raised by, and adhering to, the roots, termed cradle-knolls, which, in some places, were so numerous as to resemble graves in a churchyard. 'The soil in the township of East and North Hope seems considerably inferior to that of the two mentioned, and a great deal of bad land is afterwards met with, consisting of swamp and wet elay, covered with stunted wood of various kinds, and partially settled by poor looking people, lodged in miserable hovels. I was grieved to see human beings had set themselves down on bad soil, while so much of good quality remained unoccupied, and which would have better rewarded them for the labour of clearing. It is perhaps the policy of some to fix settlers on bad soil, in the first instance, as the good will be sure to attract others. One person told me, with seeming self-satisfaction, that his consisted of an inch or two of black mould on top and fine white clay below.

Chess was plentiful in all situations on the Goderich road; timothy the prevailing grass, a few plants of cocksfoot, with narrow leaves, and white clover, were occasionally seen.

A deer was observed standing on the road for some time, at no great distance from the waggon, and suddenly bounded off into the forest. 


\section{CHAPTER XX.}

Goderich IJotels-Eagle's. Vest-Doctor Dunelop) - Chertp DinnerSearch for an Eust Lothian Farmer_Cioderich-Porert!l of Setelers-Canada Company-State of Goderich Sitllement-

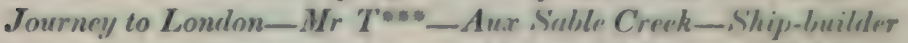
from Essex-Negro Setlement-Notices of Niture-Robinson Hotel_Mode of Travelling-Huron Track Roads-London- St Thomas-Port Stunley-Emigrants from ArgyleshireDirly Beds-Agricultural Notices.

ON arriving at Goderich, we could not get admittance to Reid's hotel, unless my friend and I would occupy half a bed, which induced us to drive to that of $\mathrm{Mr}$ Fisher, where we slept uncomfortably on the floor, the landlady telling us, while preparing the pallet, that Goderich was a poor place. While partaking of tea, served up after the fashion of the States, I imagined the sugar had been put into the pot, as there was none visible in the apartment, but next morning I discovered it was mixed with the cream. Fisher's hotel was crowded with workmen of all descriptions, and by way of kindness, I suppose, we were invited to breakfast with the family. My shoes had long remained uncleaned, and I got them blackened here by paying $3 d$. sterling, which was unprofitably spent money, as a few minutes' walking in dewy grass rendered them as brown as before.

After breakfast, we walked in the direction of Dr Dunlop's new cottage, on the north side of the river Maitland, and named the Eagle's Nest. The situation seems happily chosen, and the name is characteristic of the owner. We spent a considerable time in examining the vegetable productions of the large islands formed by the river, which, at the time we saw it, was a mere brook, until overtaken by a shower, which compelled us to return to Goderich without reaching the 
Nest. I understood the islands at the mouth of the Maitland and the adjoining banks, had been granted as a common to the inhabitants of Goderich. The grass was very limited in quantity as well as variety of species, but tall growing weeds of great beauty covered the surface. I do not know whether these plants flavoured dairy produce; but the butter we got at Goderich was so nauseous, that neither my friend nor I could eat this substance for some days afterwards. The butter of Upper Canada was generally of the worst quality.

On returning from our walk we called on Dr Dunlop, at the office of the Canada Company, who introduced us to his brother the captain, recently arrived in the country. I had been furnished with an introductory letter to the Doctor, from a well-known character, both in Scotland and Canada, and which I left with Mr Jones at York. The Doctor seemed busy, and our conversation was limited, which I did not much regret, as I visited America with a determination to judge of matters more from what I saw than what might be told me, and there appeared nothing in the circumstances of the Goderich settlement requiring much explanation.

As Mr Fisher's establishment did not appear of the first order, we determined on dining at the principal hotel, where we were admitted to what Mr Reid termed a family dinner. The table seemed surrounded by all the irmates of the house, twelve or fourteen in number, including boarders and travellers of all descriptions. Mr Reid presided, and amused me by distributing a tureen full of Scotch broth, with a tea-cup for a divider, and from the shortness of the handle, his fingers were immersed in stirring up the liquid. The entertainment was poor enough, and cost the moderate sum of sixpence sterling.

Having promised, on parting at Montreal with Mr D_, to endeavour to visit, if possible, a friend of his in the neighbourhood of Goderich, who once farmed in one of the finest situations in East Lothian, I felt anxious to witness the proceedings of an East Lothian farmer in so new a settlement as this; and immediately after dinner set out in search of Mr $\mathbf{K} \longrightarrow$, who, we were told, lived about four miles from Goderich, on the shores of Lake Huron. We at first attempted to walk along the margin of the lake; but the quantity of drift and fallen timber which lined the shore, joined to the surge 
which was rushing from the west with the violence of a tempestuous ocean, rendered this route impracticalle. On regaining the banks above the lake, I approached a cottage, and enquired the way. A young gentleman asked me to walk into his house, and he would furnish a hand-sketch of the road. Ile was employed in mapping for the Canada Company, and his productions did him eredit. He told me he was from Edinburgh, and brother to _-, a well-known engraver there, and whose name was quite familiar to tme. On enquiring the way a second time, a mile or two farther on, I was astonished at a gentleman mentioning my name, when he said he had seen me in Edinburgh, where he was a brasfounder in the Grassmarket, and had only been a few weeks in the country. Notwithstanding the assistance of a sketch of the road, and minute directions received regarding it, we eould not find the object of our search, and must have passed the night in the woods, had not the light of the moon, which was fortunately within a night of being full, enabled us to reach Goderich. The road on which we travelled is termed a coneession line, and was marked by a blaze or are-chip on the bark of trees. From this concession line, the difierent lots of property diverged, and were distinguished by marks which old countrymen could not readily notice; and I have no doubt we passed over the property of $\mathrm{Mr} \mathrm{K} \longrightarrow$, without discovering the tract leading to his abode. The concession line, a mile from Goderich, was almost an undistinguishable path, on which a horse or sleigh seemed never to have travelled. The cleared spaces on the different lots seldom exceed a few acres; and while conversing with my friend, I compared our route throngh the forest to a hare-path in an East Lothian wheat field, and the openings around the dwelling places to the forms of that animal.

Goderich is situated on the margin of Lake Huron, at the mouth of the river Maitland, and consists of about forty mean wooden houses, scattered irregularly over a considerable space. With exception of half-a-dozen of houses, near what is termed the pier, the rest of the village is about 200 feet above the level of the lake, partly on a cedar swamp, through which there is a street of corduroy. The Maitland river, when seen by me, on 28th August, was incapable of floating a canoe, 
and a vessel, a few tons burden, could not enter the mouth of the harbour.

I found the Canada Company very unpopular at Goderich, although Dr Dunlop is a favourite amongst the settlers, who are of the poorest class, and seemingly without industry or energy of any kind. Indeed, when men despair of overcoming their pecuniary difficulties, which must have been the case with most of the first settlers, they are apt to become both indolent and dissipated. The Canada Company charge 7ః.6d. per acre for land, payable, with interest, by instalments ; and when a specified extent is taken, part of the settler's travelling expenses are allowed him out of the second instalment. This is a most disadvantageous regulation for emigrants, being a premium to purchase beyond their means of paying, and an unprofitable locking up, or perhaps rather transfer of capital, which cannot by possibility fail of ending in ruin, as it hath been proved by the whole history of American wood gettlers, that they find it difficult, for the first three years, with the utmost industry, to do more than maintain their families. In this case, the interest on the unpaid instalments is more than the cleared part of the farm will yield of profit at the end of five or six years, where a person trusts alone to his personal labour for improving. When all the instalments are duly paid, the price of the forest land, which seldom yields a blade of grass, and is totally unproductive, remains an overwhelming burden on what is cleared. Dr Dunlop told me, that only one of the original settlers continued to hold his land at the time of my visit to Goderich, and alluded to a cause for their removal, which I did not think likely to have produced the effect. The first settlers at Goderich were people of limited means, the majority of them paupers, and they soon became so involved to the Company, as to induce them to leave the district. Many of the recent purchasers, perhaps forty or fifty of them, were working on the Company's roads while I was present, which the Doctor told me was the only means by which they could render payment.

It seems bad policy in a nation overflowing with population to sell a large though distant tract of land to speculators, like the Canada Company, who must seek immediate gain, with- 
ont regard to the ultimate welfare of settlens, and only pursue revenue without aiming to develope the permanent resources of the district. Such an extent of territory as the Canada company possess, gives a monopoly of land, and a power of enhancing price, operating on the emigrant as a tax, which is transferred to the shareholelers in England, instead of being employed on the spot. The affairs of the Company are not likely to be soon wound up, as the lands of insolvent purchasers will, from time to time, return to its management, and the price of land will be raised beyond the demands of the population, as well as let on lease. 'The political power of the Company will soon be felt, and its minions thrust into the legislature of the country, to the retarding of every local improvement affecting the financess of the Company. The shareholders will ultimately occupy the position of absentee landlords, and become the most avaricious of taskmasters.

The first settlement in the Huron tract having been marle in 1829 , it would be unreasonable to expect any thing like luxury or old-country comfort in the neighbourhood of Gorlerich. The habitations of the farmer are generally of the meanest description, and often quite equal in wretchedness to the worst hovels of Ireland and Scotland, and perhaps the notions of many of the settlers lead them to desire no better accommodation. It has already been noticed, that only one of the original farmers retains his possessions, and their successors are an improved race. A change proceeding in this manner may have benefited society, but at present there is a coarse rawness about men and things at Goderich which I felt far from being agreeable:

- We left Goderich at seven in the morning of the 28th of August, and about seventeen miles distant, met $\mathrm{Mr} \mathrm{T}-$ and his friends journeying to Goderich, and resting on the wayside till their horse had fed, and I enjoyed highly a piece of bread which he presented to me. This gentleman had one of his horses stolen by an Indian the night preceding, and which was seen by us grazing with a halter on its head a few miles distant. I had become acquainted with $\mathrm{Mr} \mathrm{T}-$ in travelling from Montreal to York, and we regretted missing 
him at Goderich, where his local knowledge, joined to his sound sense, would have rendered him a most desirable companion.

It had rained pretty heavily in the afternoon, and we reached an inn at Aux Sable creek, hungry and wet. In a miserable log-house of two apartments, ten travellers passed the night, partly in beds and partly on the floor. The door was a collection of open boards, and the walls and roof admitted air and light in all directions. The bed which I occupied, in common with my friend, was hard and uneven, and I arose from it unrefreshed. The morning was so cold that I could hardly warm myself by walking, and the rays of a cloudless sun were courted for warmth at mid-day. After travelling nearly seven hours we made seventeen miles, at the end of which I enjoyed the company of an old Irishwoman, cooking pork, potatoes, apples, and tea to breakfast, for a party which had travelled together from Aux Sable creek. 'This old lady and her husband had been thirteen years on a farm of 150 acres, eighty of which were cleared, and every thing around them looked comfortable. I joined two reapers, and cut a few sheaves in a very fine field of oats, which I was told had been cropped for twelve successive years without an application of manure. After resting the horses, we proceeded on our journey to London.

About noon of the preceding day, I had some conversation with a shipbuilder from Essex, in England, settled on the London road in the Huron tract, and at whose dwelling I made an unsuccessful application for something to eat. Like most settlers, he was full of hope, and extolled the fertility of his soil. On remarking to him that his wheat crop, which had been sown in spring, was destroyed by mildew, he reluctantly admitted the fact, and acded that he was assured mildew did not visit the district above once in twenty years; not perhaps being aware that I knew the district had only been inhabited three or four years, and not even visited by a white person more than six years previous to the time of our conversation. Some of this person's family had a sickly appearance, and on questioning him if any of them ever had 
ague, he told me several caught the complaint while reniding at Hamilton, on Lake Ontario, but it was quite unknown in his present situation. I record these anecilotes as two of the thousand instances which occurred, of settlen lessening the evils, or rather magnifying the arvantages, of their situation, and how necessary it is to sift, by reflection, the grain from the chaff of common convensation.

On the boundary of the Huron tract, next to the London district, we passed a negro settlement. The houses of the coloured people appeared of a particular construction, having the chimney-stack on the outside of the log-house, and which stack is composed of thin sawn timber, placed borizontally, and mixed with clay. Their chief crop was Indian corn, well cultivated. Before my departure from Britain, I had heard this settlement instanced as a complete failure, and used as an argument against the emancipation of slaves, then a general topic of conversation. The houses, barns, fences, and general appearances of this settlement are certainly mean enough, but $\mathbf{I}$ considered it in most respects equal, and in some superior, to settlements of whites in the Huron tract of the same standing of three years. But admitting, for argument's sake, that this negro settlement had been a failure, the circumstance could not form a good reason of expediency against emancipation generally. When individuals attain maturity in a state of slavery, they will become so demoralized as to be incapable of acting with the feelings and aspirations of freemen and moral agents, and it is the rising and not the risen generation that much improvement is to be expected from. Perhaps the neglected and depressed state in which the poor Irish are reared in their native country is the chief cause of their making improvident settlers in Canada, and continuing hewers of wood and carriers of water over so great a portion of the globe.

The land in the Huron tract is truly excellent, with exception of a few miles around Goderich, which is sandy or gravelly, and some small cedar, ash, and larch swamps, being fine clay with a covering of black vegetable mould. The soil on the road leading from Van Egmont's tavern to London, is particularly fine clay, especially near the Bayfield river, and 
the whole surface is perfectly level, with exception of the margins of the creeks. The London district is gently undulating, the soil greatly inferior to the Huron tract, and near the village becomes barren sand.

The wood on the road from Goderich to London is chiefly maple, interspersed with beech and elm, the latter being of considerable size. White clover is seldom seen on the waysides, red never, timothy plentiful, and a few plants of cocksfoot. Alder was growing in every place where the forest had been cut down, and put forth shoots of uneommon luxuriance, which seemed to die yearly, as I never observed a trunk or branch of a former year's growth. The species appeared the same as that common in Britain, and perhaps the young shoots cannot withstand the rigouns of a Canadian winter.

I observed a wasp-nest in the ground on the Goderich road, where swarms of the insects were passing out and in. They appeared similar to the wasp of Britain ; but my friend was not philosopher enough to be prevailed on to try their stinging powers.

On reaching London we stopped at the Robinson hotel, christened a few days previous to our arrival, in compliment to the chief justice of the province, who had honoured the house by his presence while on the circuit. The landlord told us the dinner was over, but that he would prepare something for us immediately. In the meantime we retired to wash, and at the end of an hour and a half discovered it was intended to put off our eating till the arrival of tea hour. We had been treated in the same manner at Brantford; and after remonstrating with the landilord on the impropriety of promising dinner without furnishing it, we removed to the Mansion House hotel, where we experienced civility and attention.

This evening we parted with our waggoner, Francis Packet, who had brought us from Brantford. Unlike his countrymen, he possessed little wit or humour, but he was very goodnatured, strictly sober, accommodating, and an excellent driver. He seemed disposed to accompany us throughout the remainder of our tour, and I confidently recommend him and his chestnut horses, John and Charlie, to all who may require their services. Francis was seldom disposed to talk 
much, but he invariably accosted every person on the road, by saying, in broken linglish, "How far tavern?"

At Brantford we engaged a waggon in preference to horses, under an idea of its being an easier mode of conveyance, but I am now satisfied our opinion was erronecous, as horseback would have been more expeditious, and less fatiguing than our waggon, over such roals as we travelled. The roads formed by the Canada Company in the Iuron tract have been styled good by the lackwoodsmen, and so puffed off in every British newspaper, that linglishmen may be apt to imagine they are Macadamized. They are simply straight lines, formed by felling trees, the branchess and trunks of which have been hurnt, or formed into corduroy, and the stumps, from two to three feet in height, left standing. I have already alluded to the extent of corduroy, a description of roads which most travellers speak of with horror, and, without meaning to praise it, I must say it was by far the best and smonthent portions of the Goderich roads. The roots projecting from the stumps in a slanting direction kept the wheels and axles of our waggon moving up and down with the regularity of the beam of a steam-engine, and were alike annoying to us, and fatiguing to the horses, and more especially when travelling between Van Egmont's tavern and London. In the neighbourhood of Goderich people were engaged in burning out the stumps, and throwing the earth from the sides into the middle of the road, giving it a convex form, which, in American phraseology, is called turnpiking, and this operation will be extended in time, if settlers have not cash to discharge their engagements to the Company.

London is situated at what is termed the Forks of the Thames, and when the forest is a little more cleared away than at present, few situations will be accounted more beautiful. At present a number of houses are being erected, and the village is rising rapidly into importance. It contains three or four large hotels, many well-filled stores, and a court house, of which the inhabitants feel proud.

On the 30th August we left London for St Thomas and Port Stanley, in a waggon belonging to $\mathrm{St}$ Thomas, and enjoyed our drive after the jolting snail pace we had expe- 
$\checkmark$ rienced on the horrid roads of the Huron tract. Dining at St Thomas, we walked to Port Stanley, where we remained for the night. Next morning we returned to St Thomas, in the midst of a heavy rain, which confined us to the house for the greater part of the day.

St Thomas seems healthily situated on a bend of Kettle creek, about 200 feet above its waters. Three years ago it consisted of thirteen houses, now there are about fifty. Mr Gregory, at whose hotel we stopt, then had four beds, now he has twenty-five, and is engaged in enlarging his house to twice its present size. There are other two good hotels in the village.

P'ort Stanley is situated at the mouth of Kettle creek, and has a tolerably good harbour, formed by wooden piers jutting into the lake. 'This is almost the only port at present on the north side of Lake Erie, and from its proximity to London and St 'Thomas, its trade will greatly increase. A steam-boat commenced this season to ply regularly from Buflalo, by which a number of British emigrants reach the London district by way of New York and the Erie Canal. Steam-boats also touch in passing from ('hippaway to sandwich and ('hatham.

Kettle creek is a small stream running in a deep channel, the banks being clay, and nearly 200 feet high at its mouth on the shores of the lake, from the bosom of which we saw the moon rise majestically, while examining the banks. On Kettle creek there is a carding, grist, and saw-mill, a distillery and brewery, situated between St Thomas and Port Stanley.

At Port Stanley I conversed with a party of emigrants encamped on the wharf, from Argyleshire, Scotland, who had come by way of New York, and seemed in comfortable circumstances. The males of the party had gone into the country in search of relations, who had settled some years before, and the females were anxiously looking for their return. Several women, apparently on the verge of seventy years of age, and infant children, were amongst the number. A middle-aged woman complained to me of the dirtiness of the beds at Port Stanley, and the extravagance of the charges. On the preceding night she had been charged 1 s. for a bed. Water to wash her children's faces could not be obtained, and the party 
preferred lying in the open air to the nasty beds. This was a sensible and well-informed woman, although she had not got quit of her home prejudices in some little matters. The difficulty of obtaining water to wash her children might soon have been got over, by going for it herself to the lake or creek, neither of which were seventy yards distant; and if a vessel for holding water had been denied her, she might have taken the children to the water. People brought up in an artificial state of society must often wonder at their own helplessness on first arriving in Canada. I quite agree with my countrywoman in the dirtiness of the beds in some parts of western Canada. My friend $\mathrm{C}$ - much oftener slept on the floor than in the beds; but long before this time my notions of delicacy in this respect had been overcome by reflection, if not blunted by habit, and I reposed as soundly while in Canada, as ever I did in the most luxurious night of my life.

The surface between the village of London and Lake Erie is undulating, varying from clay to sand, and a very small portion can be termed rich. Three miles from Port Stanley the soil is oak openings of the poorest sand. There is a scarcity of running water, Kettle Creek being the only instance seen in a distance of thirty miles. Many orchards are to be met with, and soil and climate seem highly congenial to the apple-tree.

The settlers on what is known by Talbot road, running through St Thomas, and at no great distance from Lake Erie, live in mean log-houses, with miserable barns and fences. The clearances extend from thirty to sixty acres, and improvement of every description seems at a stand amongst them. Labourers' wages were stated at $\$ 120$ a-year, with bed and board. Wheat, crop 1832, was 2s. 9d. cash, and 3s. sterling, storepay, per bushel. Mr Gregory told me he had purchased good wheat at St Thomas at 1s. 9d. per bushel, and it has been known as low as 1s. sterling. 


\section{CHAPTER XXI.}

Colonel Talbot's residence-Camp-meeting-Barn-Mrs Aldgeo -Moraviun Indian village-CKeap fruit-Runaway slanesExcursion to Beur Creek-Mr Goose-Soil-Agricultwral Notices-River Thumes-Unhealthy appearance of inhabitants -Chatham-Plains-John Macdonuld-Colborne FurnuceNeighbourhood of Amherstburgh - French inn.

IN travelling from London to St Thomas, we were told of a Methodist camp-meeting in the neighbourhood; and as I had long been anxious to see one, we ayreed to attend on the Sunday, when the meeting would be fullest. Early in the morning, people, in waggons and on horseback, were streaming in crowds through Sit 'Thomas towards the meeting, and as I was atraid of losing patience before evening, when the richest scene is said to take place, we embraced an offer of going to Colonel Talbot's in the forenoon, distant about twelve miles west from St Thomas. The colonel's residence may be described as a cluster of mean wooden buildings, consisting of dwelling-houses, stables, barns, pigstyes, and cattle-shades, constructed and placed seemingly without regard either to convenience or effect, commanding a view of Lake lirie, from which it is distant about 200 yards, and at the mouth of Ottar creek, a small brook, with clay banks of considerable height. The clay banks behind the colonel's house have a barren and naked appearance, while the lake in front is too near. The situation, nevertheless, has capabilities to make a fine place, when taste shall build a habitation. 'The garden, which was badly kept, contained some fine apple and pear trees, which we viewed from the outside of the fence. There were a few weeping willows, the first I saw in Canada, and which raised the colonel considerably in my estimation, as they are not, I believe, indigenous to the country. 
The cleared ground may extend to about 200 acres, and is partly clay and partly sand. The fences and general appearance of the place seem to mark the Colonel as an indifferent manager, both with regard to neatness and profit.

On the creek there is a site of a mill, which was burnt down by the Yankees during the war, and which remains unrepaired. The colonel is said to have narrowly escaped being captured at this time, by a party of Americans, who came intentionally to take him prisoner. The colonel, at the time of their arrival, happened, it is said, to be occupied in milking cows in the fields, and thereby escaped detection till he reached the woods.

It was my intention at one time to have introduced myself to the colonel, who was observed standing at his door, when we were only a few hundred yards distant; but the accounts received in the neighbourhood induced me to think there was very little chance of our interview being attended with pleasure, and I withdrew without making his acquaintance.

We returned to St 'Thomas, which we left at half-past four, in a waggon, for the camp-meeting, and on our way met multitudes of people on their return home. It now became evident we had been too late in visiting the meeting, to see the greatest assemblage, but consoled ourselves that the most fervent worshippers would be more readily distinguished. Our waggon was left within a mile of the meeting, and we proceeded on foot through the forest. The ground in the midst of the forest had been prepared for the occasion, having had the brush or underwood removed, and trees laid in parallel rows, by way of seats, for five or six hundred people. On entering a square, formed by tents, in which the people reside for four or five days together, I was disappointed at the smallness of the assemblage, which did not exceed three hundred souls. Many people were walking up and down, engaged in mirthful conversation, and five or six small groups were standing in different parts, singing hymns in a low tone. At this moment I observed a comely young woman in front of a tent, laughing and nodding familiarly to a numerous acquaintance, which induced me to think she might be engaged in attending a tent for entertaining the company. She bore a-striking 
likeness to a valued friend in Scotland; and while engaged in tracing the resemblance, feature by feature, she and a younger companion jumped into a waggon, and seated themselves in a conspicuous situation, as if wishing to attract attention. On walking round the square, I was riveted to the spot by the sweetness of a young lady's voice, dressed in white, with a very broad gipsy straw-bonnet, and black veil hanging over her shoulder. Her figure was above the middle size, slender and graceful, her features expressive and handsome. She was accompanied by another lady, wearing a bounet and veil of the same description, and a gentleman, seemingly her sister and brother, and all were engaged in singing. From the appearance of things, I concluded the people had a short time before been engaged in taking tea.

A little while after entering the square, five or six old men placed themselves in front of a rude platform erected for the preachers, and commenced singing in a loud strain, on hearing which the different small parties came and joined the old men. The singing lasted about ten minutes, when praying succeeded, and each individual pronounced a different prayer aloud. At this time a minister placed himself on the platform or pulpit, and in a stentorian voice, ejaculated an impassioned prayer, which, by degrees, excited the feelings of the people below him, and when they reached what he, perhaps, considered the proper key, he descended and joined them on his knees.

I was standing close beside the worshippers, on a trough used for collecting the juice of the maple in spring, leaning my back against a tree, and gazing on the extraordinary scene. Many individuals of both sexes were bellowing at the utmost pitch of their voice, and clapping their hands in seeming transport; others were whining supplicatory strains, and wringing their hands in despair. The comely young woman and her companion, formerly noticed, joined the group in a standing position in the first instance; they soon became bathed in tears, and ultimately joined in prayer in a state of high excitement. A very emaciated old woman, with dishevelled locks of silvery whiteness, shrieked so loud and piteously, that the minister's voice became unheard, and something 
like a thrill of uneasiness vibrated on my nerves. Such was the confusion and discord, that I was unable to collect two connecting sentences from the prayer of any individual. When the devotees had seemingly reached the highest pitch to which their foelings would strain, the lady with the gipsy bonnet stepped forward near to where I was standing, and commenced singing in the most soothing and mclodious tone. She was joined by her sister and brother, and soon afterwards by all the sect. In this manner prayer and praise succeeded each other, during which the feelings of the wonhippers were alternately excited and lulled by minister and nymph, like ocean by tempest and calm.

Many bystanders were laughing at the exclamations and postures of the worshippers; others were reading newspapers, or carelessly engaged in conversation. One individual, more prominent in his ridicule than the rest, was rebuked for his conduct by one of the sect, when a controversy ensued between the parties, who were listened to by a crowd collected around them. On approaching the disputants, one was openly avowing his unbelief in the Bible, and the other, without meekness, condemning his sentiments and conduct; but neither possessing the power of arranging an argument, I left them engaged in the hopeless task of trying to convince each other.

There was something so different in the impassioned supplications of the minister, whose aim seemerl to be to rouse the feelings, without impressing the minds, of his audiencein the time, place, and manner of addressing the Supreme Being, so different to what I had been accustomed to in the Presbyterian worship of Scotland, that at first I could not believe the sect was addressing the same Deity. The earnest, excited, I may say hysterical, devotions of one party, the indifference and unrestrained scoffing of the other, gave rise to such conflicting emotions, that I arranged to meet my friend in half an hour, and retired from the multitude.

In the meantime, fires had been lighted up on the ground in different parts of the square, one six feet high near the platform, and a few candles were glimmering in the tents. The foliage of the maple and oak, so remarkable for richness and variety of autumnal tints, formed a beautiful canopy over the 
heads of the people, and, when gilded by the flames of blazing fagots, and intermingled by rising sparks, had a supernatural and solemn effect. Could I have alone contemplated nature unconnected with the part humanity was acting, my enjoyment might have been great, but the wailings of fellowbeings, and the shouts of boys on reaching the ground, disturbed returning repose.

On again approaching my friend, a preacher was thanking the Almighty for the manifestations of his goodness since they had met together, and concluded by requesting all who desired to be released from their sins, to accompany hin to another place, and a procession to the place ensued. This consisted of a small enclosure, formed by a single rail of saplings, nailed to the standing trees, in the centre of which were two branchless trunks lying parallel to each other, and is perhaps what is termed the pen. Here the preacher again requested all who earnestly desired to be relieved from their sins, to come within the lines which had been prepared for them.

The whole devotees then prayed promiscuously aloud, and when at the height of exeitement, the nymph of the gipsy bonnet commenced singing, standing on the outside of the enclosure, and was joined by the people within.

When the singing ceased, it was announced that Brother Fraiser was to preach, and the people assembled around the shade on the seats prepared for them, after being repeatedly requested to do so. At the conclusion of praise and prayer, a text was given out, and sermon commenced. Mr Fraiser now discovered that he was hoarse, perhaps from previous exertion, and in the midst of his apology to the audience, I took my leave at half-past eight o' clock.

The devotees were few in number, perhaps not more than sixty, and almost either old men or young women, the Irish brogue being conspicuous amongst the former. They seemed of the lowest elass, not more than half-a-dozen of well-dressed people being amongst them. There were four ministers.

I could not divine why the pretty creature with the gipsy bonnet did not join in prayer, and commenced singing at the proper time. Could her bonnet and elothes be too fine for 
kneeling and tossing on the ground like others, or had she a part to act?

At the time of my departure, there might be nearly three hundred people on the ground, including all descriptions, amongst whom were fifteen or twenty females, unconnected with the sect, and a great many boys. On walking from the meeting, many youths were met on their way to it.

It is but justice for me to say, that I did not witness any act of impropriety or indecency by the attenders of the camp-meeting ; but whether this arose from the character of the people, the time of night, or my want of discernment, others may determine. The meeting was, however, a small one, and in a part of the country not likely to have furnished many examples of disregardless profligacy. Whether camp-meetings are favourable to the cause of genuine religion, is matter of dispute, and the greater part of those whom I heard speak on the sulject, supported the negative side of the question. Perhaps the matter is oftener determined by feeling than reason. It would be presumption to give a decided opinion on so serious a subject, with such limited opportunity of judging ; but something extraordinary will occur to induce me again to visit a camp-meeting. This may be prejudice.

On leaving the camp-meeting, we proceeded to a tavern five miles distant, on reaching which we learned that the beds and floors were so oceupied, that we could not gain admittance. We, however, obtained permission to lodge ourselves in the barn, which, on scrambling over several rail fences, we found open, and occupied by human beings snoring in full chorus. 'The mows of grain being of different heights, we ascended to the attics, where we passed the night. The grain seemed to have been lately carried in, its upper surface being moist from sweating, which, joined to currents of air passing through the openings in the roof, rendered me so cold, that I had recourse to my flannel shirt for the first and last time between leaving Montreal and New York. Next morning I awoke from a sound sleep, and, like a dog, put myself to rights by a shake, shouldered my knapsack, and took the road at half-past four o'clock, in as good walking trim as at any former period of my life. 
The day proved hot-we dined at Delaware, a village of seven or eight houses, situated on the Thames, over which there is a bridge, and the road passes to the north side of the river. I was anxious to be present at a sale of Crown lands, which was to take place at Chatham next day, but we could not obtain the means of transport, and no alternative remained but jogging along on foot. We called at the land-office at Caradoc, and reached Mrs Aldgeo's tavern an hour after nightfall, where we found two gentlemen who had passed us on the road in the afternoon, and one of whom I had seen at York. 'They were going to the sale of C'rown lands at Chatham, which one of them did not reach in time, and the other remained at Mrs Aldgeo's, having been slightly injured by a fall from a waggon.

Mrs Aldgeo's tavern is a log-house of mean appearance, hatving two apartments-a kitchen, and room for all purjoses. It is, however, the most comfortable house of entertainment in this part of the country, owing to the excellent management and good-humour of the hostess. Four individuals slept in the same appartment, in two clean beds, in which we were told, by way of recommendation, the Chief-Justice and Atturney-General had slept a few nights before.

The next morning proved wet, which enabled me to see a little of the economy of the establishment; and I particularly remarked a poor fowl very unceremoniously knocked off a rail fence with a stick, and in the space of twenty minutes presented at table in the shape of an excellent stew. Mrs Aldgeo is a genuine Irish lady, from the old country, and her kindness and loquacity during breakfast, which she served out, were unbounded. She did not always wait for an answer to her questions; and with a few pauses, held forth in the following manner:-

" I was married at the age of twenty-four to Aldgeo, then eighteen and a-half, and the finest-looking man in the world. I lost him six years ago, God rest his soul! it was a sad loss to me as-but of this no more. Yes, my poor dead husband left four horses, fifteen sheep, twenty cows, forty hogs, ox chains, auger, gimlet, and other furm utensils. Will you take something more, $\mathrm{Mr}$ _ ? I will helpyou to a little more of the fowl; 
you must eat while under my charge, and not hecome thinthere, take an egg. Here is an elegant potato from the gar den, where they are planted for the old woman, as she has not time to go to the fields. My boy will sometimes say, ah, mother, leave the gentlemen to themselves; but I like to press old-country gentlemen, when not proud. I never press Yankees; them boys help themselves. Yankee women are lazy good-for-nothings, eating cake and sucking sugar all day long. I attend to man and beast. Yes, there is no one to assist me in the house, and I look to the fowls, hogs, and cows ; in the evenings, my feet are like to drop out of my shoes. Do you see that field on the opposite side of the roarl? - my hands burnt all the brush on that field. Do take some of the bread baked by the old woman; I hake some every afternoon-that is handsome bread. The Scotch lawyer below, with the wooden leg, and angel children, brought his pretty little wife here to learn to make bread. I use no barm, but mix two parts of milk and one of water together, add a spoonful of salt, a little flour, and let them stand ten or twelve hours by the fire. Then make the bread with milk, as water gives it a black colour. I make my own soap_oh, darling soap_and never boil it. My boys have not taken wives, but my two eldest daughters are married. Did you observe an elegant store at the corner of __ in London? that belongs to my daughter's husband. My youngest girl is at a boarding-school in London, where two ladies from England have lately commenced, and I pay for my girl \$39 a-year."

The rain ceasing about noon, we left Mrs Aldgeo's, and reached Howardbridge to tea, where the road passes to the south side of the Thames. The roads were fatiguing in consequence of their wetness, and we gladly accepted of an offer, made by two gentleman in a waggon, to carry our knapsacks, and in whose company we next day travelled to Chatham, where we spent the night. Some time before reaching Chatham, I obtained a draught of water from a young girl on the banks of the Thames, to whom I proffered a piece of money, which she declined, saying, she never accepted money for such things. At this time my British habits were not altogether laid aside. The soil on the banks of the Thames, from the point where 
the St Thomas road joins that from London to Sandwich, is oak openings, seemingly of inferior quality, all the way to Delaware, and from thence, to six miles below Mrs Aldgeo's tavern, poor clay, with small stunted wood. From this, passing through the site of the old Moravian Indian village, the soil is poor sand, and a little farther on, becomes loam of the best quality.

The Moravian Indian village is situated on a bend of the Thames, and the surrounding lands were bearing luxuriant crops of Indian corn. The old village was burnt by the Americans during the last war, and on its site, a mile to the north of the present one, some fine apple-trees are standing, the fruit of which we found agreeable as quenching thirst. Here I observed, for the first time, a species of hawthorn with glossy leaves, of a smaller size, more numerous prickles, branching, and of taller growth than the common hawthorn of the country, and apparently a better hedge-plant. (On the banks of the Thames, above Chatham, (Celestina Scandens,) a climbing plant, with beautiful orange-coloured berries, was first observed growing luxuriantly on many trees, entwined with the vine. Apple-trees are numerous near the river, and the crop so abundant, that they were breaking under their load. I was offered any quantity of fruit at $1 \frac{1}{2} \mathrm{~d}$. sterling per bushel, gathering it myself. The peaches were also a great crop. $\mathbf{A}$ pear-tree was seldom seen.

In the evening, we walked down the banks of the Thames, for the purpose of procuring horses for an excursion, and succeeded in our mission. In returning, we observed two men of colour crossing the river in a canoe, and leading a horse, which was swimming. On entering into conversation with them, I learned they were brothers from Kentucky, and both farmed on lease, one of them renting 190 acres on the banks of the river, fifty of which were cleared, for $\$ 20$ per annum. On asking if they had run away from Kentucky, one of them answered in the affirmative, and replied, laughingly, I suppose you have also run away. A great many people of colour are settled in the Western parts of Upper Canada, almost all of whom are runaway slaves from the United States.

On the morning of the 5th September we left Chatham for Bear creek, under the guidance of Mr John Goose, who own- 
ed a property on the banks of the 'Thames, four miles below Chatham, inherited from his father, who was one of the original settlers. Mr Goose was a sensible, well-informed man, of a weakly constitution, and had let his farm on shares to a Yankee, by which he obtained half the produce for his labour. Mr Goose rode a brown mare, with a filly foal running at her feet, in the language of the country styled a colt, a term applied to the young of the mares, without regard to sex. My friend C _ and I rorle chestnuts, or sorrels, without shoes, the reins were stout ropes, and the saddles without panels or girths. On, however, we jogged up the Thames, and crossed over to lBear ereek, which we reached about four o'elock, and got some refreshment at the house of Mr Cinose's brother-in-law, whom we found sowing wheat. The ostensible olject of our journey was to examine some lots of land which had been offered us by letter in the township of Dawne, and regarding the situation of which we could not obtain information till arriving on the creek, when we learned it was in the opposite direction where we were, and so swampy that no person could live on it. We then commenced descending the stream, and passed the night with $\mathrm{Mr} \mathrm{B} \_$, friend to $\mathrm{Mr}$ Goose, sleeping soundly on the floor. Next morning, we descended the creek four or five miles below, where its waters are on a level with those of Lake St Clair, and crossed over to the Thames, which we passed below Chatham in a canoe, swimming the horses by its side. Here we parted with Mr Goose, much pleased with his conduct, paying him $\$ 4$, or 16 s. $8 \mathrm{~d}$. sterling, for the services of three horses and himself two days.

The soil, on the banks of the Thames, varies from soft sand to strong clay, and may generally be termed heavy loam. Our first and most easterly line from the Thames to Bear creek was poor sand, gradually improving to fine loam on approaching the creek. The banks of the creek showed the richest description of sandy loam; and much of what is termed bottom land, more especially above $\mathrm{Mr} \mathrm{B}$ __'s property, is perhaps too rich for first crops. This richest of land, extending to both sides of the creek, and containing a thousand acres, was unoccupied, for sale, and could have been bought at about 
\$3 per acre. Our lower line, from Bear ereek to the Thames, was invariably fine loam.

I consider the soil on the banks of the Thames, around Chatham, superior to what I saw on Bear creek, from containing a greater portion of clay; both are, however, excellent, and objectionable only on account of their lowness, and proximity to the marshy plains around Lake St Clair, though only ten or twelve feet above its waters, yet twenty miles distant from its shore. The forest exhibited few cradle knolls, which proves the soil of stronger texture than that of Blenheim, Wilmot, or the neighbourhood of Goderich, cradle knolls being a sure indication of sand, except where trees are prostrated by a whirlwind or hurricane.

The agriculture of the Thames and Bear ereek do not merit much notice. Bear creek, and the country between it and the 'Thames, is very thinly settled, and the clearances of small extent. 'The habitations are mean, and the inhabitants seemingly poor, and without enterprise or industry. The chief market has hitherto been Detroit, and the population have, in a great measure, been shut out from the rest of the world. Mr B_ told me thirty bushels of wheat have been given for a bushel of salt-now five is the price. I did not see a clearance of any extent going on, while some portion of rich cleared soil had been abandoned or neglected; and when overgrown with weeds, and destitute of grass, exhibited complete sterility. Natural elover of any kind was not visible, nor had the seeds of any been sown. 'The settlers had never applied any manure, and seemed to lead easy lives. The wheat harvest was gathered previous to my visit. Buck wheat was uniformly a poor erop, being injured by drought, and in many cases also by frost. Indian corn was by no means good. A field of barley on Bear creek, as the first crop on bottom land, was destroyed by mildew. A portion of millet on the same field was uninjured, and the only instance in which I have seen such a crop.

Bear creek is a small stream, about half the size of the Thames, and propels two grist mills, and a third at Mr B__'s is being erected. We examined the lowest mill; the 
water-power was not economically applied; the house without a door; the machinery entirely of wood; and the whole erection a bauble of the worst construction. There were perhaps fifty small parcels of wheat for grinding in the mill, and six or seven people were waiting to carry away their flour. This mill cannot make marketable flour at present, and its undurable construction may be considered fortunate for settlers. Girist mills are much wanted in the country, none being effective on the Thames, and I was told wheat has actually come from Michigan to be ground at this wretched mill.

The river 'Thames, the letters of which are invariably pronounced soft by the inhabitants of the eountry, is of small size, incapable of moving machinery for want of fall, and when seen by me, perhaps not more than equal to the power of a grist mill with one good pair of stones, if fall could be obtained. The banks are low and uninteresting. The water is on a level with Lake St Clair, and is navigable five miles above Chatham.

Having entered the houses of many of the settlers on Bear creek and the Thames, and observed the countenances of hundreds of people seen on roads and in fields, I was particularly struck with the sallow, dried, and sickly appearance of the inhabitants. Perhaps, in the course of three days' travelling, I did not meet half-a-dozen of healthy-looking individuals; - a recently-imported old-countryman could always be distinguished by his complexion, and often, also, by his pertliness of figure. While speaking on this subject, $\mathrm{Mr}$ Goose did not like the chuncky (stout) appearance of Britons, and could not comprehend why the skin of their faces seemed to creep like Muscovado sugar. Ague was evidently not a stranger to the country; and a lodger in the tavern at Chatham was suffering under the complaint.

Chatham is on the south bank of the Thames. Twelve months ago it was said to contain only five or six houses; now there are nearly twenty. It is visited by steam-boats; and from being situated at what may be termed the head of the Thames navigation, it is certain of rising at no distant day. There is a rumour of making Chatham, instead of Sandwich, the seat of the district courts, which would be a 
more convenient situation; but the growth of Chatham seems to be independent of this alteration.

After parting with Mr Groose, and dining at Chatham hotel, kept by Mr Cartier, a French Canadian, and who was enlarging his house from an increase of business, we engaged Israel Williams, a man of colour, who owned an excellent farm in the vicinity of Chatham, to earry us with a waggon and pair of horses south to Lake Erie, and round the lake and Detroit river to Sandwich.

Two roads led to Lake Erie, one by what was called the town line, and another across the plains. Having heard much of the plains from Mr Croose, who said all the farmers in the neighbourhood cut hay from them, and that a squatter had been successful in growing crops, although considered barren, I was anxious to see the plains; and accordingly took them on our way to the lake, although Israel Williams had never travelled the road.

We left Chatham about half-past nine, and soon reached the plains, two miles north of Chatham. At the east end, where we passed through, they consist of an area between two and three miles wide, and as far as the eye could reach to the westward, destitute of trees, except small spots here and there, bearing shrubs and stunted trees of various sizes, and which resembled islands in a lake. A number of dwarfish willows were growing in most places, and the grass consisted chiefly of two species, which oceasionally reached the horses' ears. A number of beautiful flowering plants adorned the plains, but being thoroughly wet, and rain falling heavily at the time, my botanizing zeal abated, and I contented myself with adding the seeds of four or five to my collection, gathered without descending from the waggon. Williams missed the tract leading into the forest on the south side of the plains, which we perambulated for upwards of an hour, till reaching a house, containing a ragged, dirty, and miserable looking family, a boy of which acted as our guide till entering the forest. We reached what the people of the country call Frogmore-street, a newly opened road leading from Sandwich; from which we were directed to Lake Erie, but missing our way a second time, it was about sunset hefore we came in 
sight of the lake, having been nine hours in travelling a distance of twelve miles.

When emerging from the woods on Lake lirie, we passed a camp-meeting of the Jacksonite Methodists, which I filt no inclination to visit. On enquiring to be directed to the nearest tavern, I was told there was not a tavern on the road for thirty miles, but that almost any farmer would receive us for the night.

Our first three or four applications for accommodation were unsuccessful, the houses being filled with the attendants of the camp-meeting; but we at last gained admittance to the house of John Maedonald, from Appin, Argyleshire, Scotland. Application had in this solitary instance been made by Williams, and John reluctantly consented to receive us, under the impression we were people of colour like Williams. John was surprised to find us of the same complexion as himself, and still more so when I said he must be a countryman of mine, from his dialect as a Scotchman. Ile put a thousand questions about my visit to the country and the state of Scotland, and when satisfied that I was not an impostor, his joy seemed unbounded. John was a true Scotch Highlander in every respect, and spoke the English language in the comic purity, if I may use the expression, of his countrymen, - his phrases of "her nainsell," and "gosh, man," being as fresh as if from Appin the day before. I enjoyed his originality, and admired his warmth of heart, amply displayed in aneedotes of his past life, which he continued to relate long after we went to bed.

Next morning I walked over John's farm, consisting of 200 acres of most excellent land, forty of which had been cleared in fourteen years, during which he had not applied any manure, and which I testify had not accumulated to an inconvenient degree. His Indian corn was about the best crop I saw in Canada, with exception of some belonging to the Indians on the Grand River. The quality of his wheat was excellent, and part of his farm carried this crop and peas alternately; the extent of wheat being limited to the assistance he could obtain during harvest. John had two sons on adjoining farms, in the same state as their father's, and a third 
who had lately married, lived with him. John had twelve acres of good land, which had been gradually cleared in obtaining timber for different purposes, and which a week's work of his son would render fit for cultivation; yet it had remained for years in a state of comparative unproductiveness. He wondered at me not having tasted unripe Indian corn, on which every creature, he said, lived in this country, as they did on herrings in the west of Scotland during the season; and he roasted two ears for me, which I did not highly relish. John's house was very mean-looking, and he accounted for it by the want of saw-mills in this part of the country, which rendered boards dear.

We left John Maedonald after breakfast, and travelled to Colborne Iron-works, in the township of (rossfield, and had a late and uncomfortable dinner where the workmen board. A bed was obtained fur us at the house of Messrs Calhoum and Field, proprietors of the works, - which was a log-house of recent erection, plain and rough, externally and internally.

The furnace had been burnt down a few weeks before our arrival, and all hands were engaged in reconstructing it. The whole erection, with exception of the fire-place and chimneystalk, was composed of wood, and one of the most temporary buildings it is possible to conceive. The bed of ore lies in a marsh a mile and a half distant, and is what is called bog-ore, one or two feet thick, with six inches of peat-earth on the surface; and I was assured by Mr Field that the earth thrown aside two years ago was now fruitful of ore. The iron-work is expected to consume the coke of nearly 200 acres of forest yearly; and the company would clear any farmer's woodland for the coke it produced. 'This may be worth the notice of settlers, and is given from Mr Field's statement.

We examined some land for sale in the neighbourhoor of the iron-works before breakfast; after partaking of which, we travelled a few miles south, to the shores of Lake Erie, round which we passed to Amherstburgh, which we reached in the evening.

Williams had at one time resided at Amherstburgh, and 
landed us at what he considered the best house, kept by Mrs Drake, which was a large old dingy uninhabited looking tenement. Mrs Drake was seated with Mr M _ at tea, or supper, as it is generally called, on our arrival, which suited us well, as we had not dined, — a brace of roasted ducks being on the table.

After tea, we walked down the banks of the Detroit river and Lake Erie four or five miles, and retumed through the fields, at some distance from our former line. The evening was clear, calm, and delightfully cool; the still glasey lake adomed with beautiful wooded islands, the American steamboats, with music playing and unfurled sails, majestically ascending the limped and smooth-gliding Detroit, together with the gracefulness of vegetation and richness of soil, so enchanted us, that we resolved, contrary to our original intention, to devote another day to the neighbourhood of Amherstburgh.

Next morning, Williams drove us up the banks of the Detroit, till we reached the bridge crossing the Canrad, where we parted with him. Ascending the Canrad a little way, we turned to the right, up a flat piece of ground, in the centre of which there is a small brook, and where we spent some hours agreeably in examining plants, and adding to our collection of seeds. We returned through the lands belonging to the Huron Indians to Amherstburgh, and in the evening extended our walk in the direction we had passed the night before.

We left Amherstburgh soon after sunrise, to walk by Sandwich to the town of Detroit, and breakfasted by the way at a small inn with a French sign. The innkeeper had very little English, and we found some difficulty in understanding each other. Our fare consisted of poor green tea, bad butter, and worse bread. There was a fireplace in the kitchen, which was without furniture, except a table and chairs. 'The room was well lighted, and separated from the kitchen by a partition of lath, without plaster of any kind. There were two beds in the room without top or posts, with fine rich old printed bedcovers 'and pillowslips of the same, clean and neatly arranged. The upper story was accessible by a ladder. The father told me 
his family consisted of six children; the mother and two children had died a few weeks before. The children are at school; the masters seldom remain long, being too fond of whisky.

We arrived at the ferry opposite to Detroit about noon, which we crossed by a steam-boat of small size which plies every quarter of an bour, and took up our abode at an excellent hotel. 


\section{CHAPTER XXII.}

Horse Hiring-French Inn-Negro Fumily-Prairic-Supplied with Oats-Mouth of the Thames-Elophant-YorhshiremenWunt of Conveyance-Old Setter-I'rairie-Face of the Country and Soil-Notices of French Inlabitunts and their Agrientture-Huron Indians and their Agriculture-Royalists and their Agriculture-Notices of Nature-Detroit River-Amherstburgh-Sandwich-Ferry-Detroit.

Mr friend C__ sailed from Detroit for Buffalo on the 12th September, and next day I commenced a tour into the Western United States, from which I returned again to Detroit, and spent a few days in Canada.

With a view of keeping a connected account of Canada, I shall take up my proceedings on the 18th October, on the morning of which I crossed from Detroit to the British side of the river, on which there is situated a good many houses of different descriptions, with the view of obtaining a horse to proceed to Chatham on the Thames, a distance of fifty miles. Being refused by three different people who kept horses for hire, on what appeared to me frivolous pretences, and thinking they might be afraid of me leaving the horse, and escaping to the States, I offered to deposit the value of the horse with the owner before setting out on the journey. To this arrangement one individual out of the three consented, but demanded for the use of his horse the same hire as if he himself and a pair of horses had accompanied me, as he could not employ himself and the other in my absence. Under these circumstances I returned to Detroit, where I readily obtained a horse, which I entered at the customhouse before setting out on my journey, and again on my return, or rather paid the fees at once. I am not sure if it is absolutely neces- 
sary to enter a horse at the customhouse on crossing the Detroit river; and at the time suspected it was as much with the view of obtaining the fees, as complying with law, the owner of the horse requested me to apply at the customhouse with which he was connected.

'The road from the town of Detroit, or rather Sandwich, which is on the Canadian side of the river Detroit, to Chatham, passes along the margin of Lake St Clair and the river 'Thames, and is the chief line of communication with the most westerly and other parts of Canada; yet except in the neighbourhood of Detroit and Chatham, I could not obtain oats or Indian corn to feed my horse. My first applieation was at the door of a newly erected house on Lake St Clair, in which $I$ observed two young men through the window, and a voice answered to come round to the other door, on tapping at which I was told to come in, and on lifting the latch I found three men and two women, none of whom rose from their seats, or could tell me where my horse could be fed. At length I came to a house near the mouth of the 'Ihames, with a French sigupost at the door, where I stopt for an hour, my horse getting only coarse marsh hay.

This inn is situated on a ridge of sand thrown up by the lake, and about two feet above its waters; the surrouncing country, for miles on all sides, being a marsh and destitute of inhabitants, another unoccupied house being a few hundred yards distant. Here a Canadian Frenchwoman of prepossessing appearance resided, and who spoke the English language tolerably well. Her husband died the previous year of cholera, and a young man who assisted her since, died a week or two before my arrival, of small-pox, and two girls were then just recovering from the same complaint. She told me a travelict had scarcely entered her door for seven weeks, and there was no one to fetch her oats and other necessaries. My poor horse, which was the roughest-motioned creature I ever bestrode, became tired, and I was anxious to shorten his journey as much as possible.

I called on Mr John Goose, with whom I travelled to Bear creek a month before, and who resided on the 'Thames, four miles below Chatham. He was in the woods bringing home 
fire-wood, and was momentarily expected, so I gave my horse some of his hay, and walked ont to meet him. Mr (joose readily recognised me; and on learning my intention of wishing to pass the night at his house, on account of the tired state of my horse, was informed, he himself would be happy to receive me, but his wife was not fond of seeing strangers at present when small-pox were rife in the country, his family never having had the disease, or been vaecinated. Knowing the situation in which $I$ had been a few hours before, I did not urge the matter with Mr Goose, although not a thorough disciple of the school of infection, and taking my wearied horse in my hand, proceeded onwards.

I called on Israel Williams, in whose stable I left my horse, and walked on to Mr Cartier's inn, Chatham, where I passed the night. On enquiring for Israel's horses, Pape and Jerry, which carried me round Lake Erie last month, he told me, that, when swimming Pape across the 'Thames about ten days ago in a canoe, he sunk like a stone, and remained under water two hours, having been, he supposed, seized with cramp. Williams was a runaway negro from the State of Virginia, a smart, active, stout little fellow, in good circumstances, having several stacks of wheat, and six or seven horses of different ages. I was asked to go into his house and see his wife Juliana, who was as stout and glossy black as any negro could desire. They had five or six fine curly-haired children of the same complexion as themselves, none of whom had been at school, as the teacher could not receive children of colour without displeasing his white employers.

Next morning, immediately after breakfast, I rode to the plains which I formerly crossed in a waggon, and, under the guidance of the squatter Mr Cass, had an opportunity of giving them a hurried examination. The plains of Chatham are, beyond all doubt, prairie, extending from Lake St Clair on both sides of the Thames. The east end of the prairie, next to Chatham, is variable soil, embracing sand of different colours, and clay of all textures, generally wet, and seemingly capable of being drained into the river. The wood islands are small, the grass in some parts very luxuriant, and several of the plants similar to those on the Michigan prairies. 
On advancing westward, the soil improves, and some parts are clay of the first quality. The grass on much of this prairie is four feet high, and as thick as it can stand ; no part of Illinois seems richer.

No part of this prairie is cultivated; it is so little above the level of Lake St Clair, that it is doubtful if it can be drained, and much of it at present indicates wetness. I was anxious to ascertain the practicability of draining the prairie; but well-informed people at Sandwich and Detroit told me, instruments for levelling could not be obtained nearer than New York, and all streams being dry, there were no means of approximating the point. Some of the farmens on the Thames maintained there was no difficulty in the matter, and all mentioned Lake Lirie, and not St Clair, as the outlet. I had no opportunity of forming an opinion on the subject, but if the drainage can only be effiected by Lake Erie, the undertaking will be far too expensive for a private individual; and, in the present circumstauces of Canada, not likely to repay a company for the outlay.

Lake St Clair, and the other lakes connected with the river Sit Lawrence, do not rise and fall by floods and droughts like ordinary collections of water in other parts of the world, yet it is subject to variations at distant periods; and this, I believe, has not been satisfactorily accounted for. The Frenchwoman who keeps the inn at the mouth of the Thames told me the lake was lower now than she had ever kwown it, and had been falling for years past. She said it contimued to rise for years formerly, and drove people from the houses she pointed out, at some distance on the prairie, and thought it now eighteen inches below its highest level. 'This change of elevation on the lake might affect the prairie, even when drained.

The grass on the margin of the prairie near the Thames, and more especially in the neighbourhood of French church, six or seven miles from the junction of the river with Lake St Clair, is of the richest description, having a large portion of white clover, and cropped as short as teeth could make it. Yet the animals of all descriptions roaming on it were small, lean, stunted-looking creatures. This, in some 
measure, may have been owing to their respective breedn, but I could not resist auguring unfavourably of the land from the poverty of the animals grazing on it.

On leaving the prairie I found my horse getting tired; and on applying to a farmer on the banks of the 'Thames, he readily consented to furnish oats, for which he would not accept of payment. I also was asked into his house, and partook of his hospitality. I could not with propriety enquire the gentleman's name, but learned his farm was Lot tenth, of Concession first. I need not, through this medium, ask him to accept of my thanks, however grateful I may feel, as there is little chance of his seeing or hearing of my lucubrations. I reached the inn at the mouth of the Thames, where I remained for the night, getting a clean and good bed, fried pork morning and evening, and acting as my own ostler. In the morning I walked over a considerable extent of the shores of Lake St Clair, and the mouth of the Thames. The soil is exceedingly poor, and so wet that animals cannot walk over much of it. Here I saw the Thames steam-boat coming down the river from Chatham, which had a singular appearance when viewed from the prairie, the river being about two feet below the surface, the ground so perfectly level, and without an object of any kind, that the vessel seemed gliding on land.

I left the inn after breakfast, and reached Detroit in the afternoon, with my horse nearly done up. By the way I met an elephant walking on the road towards Chatham, covered with canvass, and attended by two men on horseback. A waggon led the cavalcade, in which I was told there was a lion and some other animals. The exhibiting of animals must yet be an indifferent trade in Canada, when population is so thin and poor.

I met many old-country Yorkshiremen at Detroit. The ostler who received my horse was from that county; a flash fellow, strutting the streets with a scarlet frock coat, collar and pocketlids of black velvet, with top boots and buckskins, was a Yorkshire tailor; and a Yorkshireman was entertaining many listeners in the bar-room of the hotel while dinner was preparing for me, having arrived after the regular 
hour. This character was dressed in his smock-coat, with tight lacing boots and leggans, as if from his native country a minute before, and was telling cock-and-bull stories about his shooting feats with Lord Liverpool and other great men, as their companion. His language, dress, and appearance formed a striking contrast to the grave, thoughtful-looking Americans, who did not make a remark or alter an expression of countenance indicating their opinion of Yorky; yet they seemed to be eyeing him with a keenness, as if measuring the strength and depth of his character.

After partaking of dinner, I recrossed the river to the Canadian side, walked over some French settlements, and passed the night at Sandwich. The hotel was a poor, dirty, illfinished place, and more especially the sleeping part of it. Here I met with two gentlemen of the village, whose conversation was of consilerable use to me.

Next morning it was my intention to have risited a new settlement, four miles to the east of Sandwich, but I was unable to obtain a horse or conveyance of any kind in this metropolis of Western Canada. The people of the hotels do not in the least degree interest themselves in the proceedings of travellers, and knew of no one likely to hire his horses or waggon. I, however, applied to several French inhabitants without effect; and the day being wet I had no alternative but to walk down the banks of the river to Amherstburgh, where, - with the assistance of Mrs Drake, I got the use of a pony from Mr Obrion at a dollar a-day.

Nothing could exceed the wreteherl equipment of the pony, which was a good one if it had been in condition. But it had run on the common and in the wood until caught for my use ; its mane was almost a solid mass of burs, and its hairs so covered with eggs of the bot-fly, that they almost changed the colour of the animal. It was without shoes; the saddle, without girths, was held in its position by a belt passing over it; the stirrups and bridle harmonizing with the saddle.

In the first instance I rode over part of the Huron Indian Reserve with Mr Clark, who had married a squaw of the Huron tribe, by whom he had a family, being originally an American, and having lived in comfort, since the time of his 
marriage, on the Huron lands. Returning again to Amhenstburgh, I rode down the shore of Lake Erie, after dinner, to Mr _ 's, where I arrived about dusk. There was no stable for my pony, and it was turned into a field to shift for itself. $\mathrm{Mr}$ was unfortunately from home, and not expected for some days. I found this old settler, who had been born in the country, living pretty much in the style of those who had recently set themselves down, and I partook of homely fare, and slept on the floor. Here I met with a military gentleman of intelligence, whose name is connected with a beautiful island on Lake Simcoe, and who was in search of a desirable lot of land to fix on, to which he was entitled by his services. He expressed a wish to have my assistance in the selection, and offered such terms, that nothing but want of time, and the advanced period of the season, prevented my accepting.

Next morning I rose by daybreak, and caught my pony, on which I rode to the hotel at the shipping place of Colborne iron works, kept by Mr Faux, from whom I hired a horse, to save my pony, for returning to Amherstburgh in the afternoon. I rode on Mr Faux's horse to a prairie some miles to the east of the iron works, which $I$ had heard spoken of in high terms, and which I observed at some distance a month before. This prairie was understood to be for sale, and $I$ called on the proprietor, who was a kind, well-informed old gentleman, showing me personally over the land, and regretting my inability to dine with him.

I found the prairie in question to consist of peat earth, about a foot in thickness, on a wet sandy subsoil, intermingled with marl, which I was able to distinguish by the aid of a spade, and test by vinegar. It was of small size, very picturesque, and not likely to repay the expense of draining.

I again mounted the pony at Mr Faux's hotel, and reached Amherstburgh in the evening, having examined four farms that were for sale in course of my excursion. Time was now pressing me; and being anxious to see an individual in Sandwich, and a farm in the neighbourhood, I engaged Mr Obrion to take me early in the morning to Sandwich in a cart.

I called Mr Obrion out of bed some time after the hour he 
appointed to meet me, and he was so long in getting every thing put to rights, that I walked over the common on foot. He, however, soon overtook me; but declining to go beyond a pace faster than I could walk, I leapt from the cart, and proceeded on foot, breakfasting at a French inn, stopping at Sandwich two hours, and bidding adieu to Canada, by crossing over to Detroit about noon.

Having, on my different visits to Canada, passed completely round the peninsula formed by the Thames river, Lake St Clair, Detroit river, and Lake Erie, I shall describe the face of the country through which I passed.

On leaving Chatham for the south, the soil from that place to Lake Erie, with exception of the plains already noticed, was clay of excellent quality, the surface level, and apparently wet near the margin. In passing up the shores of the lake, the soil was variable, being sometimes clay, and sometimes sand, the latter greatly preponderating. Siome parts of the lake shore were unsettled, and scarcely a recent clearance was discernible. In the townships of 'Tilbury and Marsea, some farms had been deserted, which had a most barren aspect, being overrun with weeds, and scarcely producing a blade of grass.

The surface in the township of Grosfield, near the ironworks, differs from any seen in the peninsula, being undulating, and, in the language of the place, a handsome country. The land is not of the best quality, and for the first time in Canada, I walked over a gravelly soil.

The townships of Colchester and Maldon are not much above the level of the lake, and the road passes through a sandy soil generally, and sometimes thin clay of bad quality. In the former there are oak openings, the soil of which is poor sand. The soil of Maldon seems superior to that of Colchester, and improves, on approaching Amherstburgh, to the finest quality. In both townships there are a good many people of colour, who generally rent the farms on which they reside, or obtain so many years' possession, on condition of clearing a certain extent of wood. A considerable quantity of tobacco is here grown, chiefly by the black population.

The country from Chatham to Lake Erie in the township 
of 'Tilloury, and round the lake to Amherstburgh, seems badly watered, not having seen alove two rills passing into the lake. In Colchester and Maldon, there are occasionally stagnant branches of the lake, like canals or channels of a stream, jutting into the land to a considerable distance, and which I was told terminate in swamps, and prove the greatest, if not the only, natural oljection to the country.

About a mile from Amherstburgh, on the river Detroit, commences a tract of country known by the name of the Iluron Reserve, extending seven miles along the banks of the river, and seven miles back from it.

For the first four miles of this Reserve, in passing from Amherstburgh, the river, which is here perhaps the most beautiful in the world, is upwards of twenty feet below its banks, the soil a rich crumbling clay, and is one of the loveliest spots in Canada. Above this, the banks sink to the level of the river, and there is an extensive tract, six or seven miles in length, and two or three in breadth, covered with tall aquatic plants, which impart a pestilential aspect to the country, and must form one of the best nurseries in the world for ducks and mosquittoes. On approaching Sandwich, the banks again rise aloove the river, and maintain their elevation until a little above the ferry at Detroit.

From the termination of the Huron Reserve to Sandwich, the soil on the river is inferior, and the road, on entering the village, passes throngh what has originally been an oak opening of poor gravelly soil, and is still covered with oak bushes, intermingled with inferior pasturage. Above Sandwich the soil is good on the banks, and continues so as long as the elevation above the river is maintained. This part of the country is inhabited by the descendants of the French, and not a trace of the original forest remains.

A mile or two above the ferry at Detroit, and approaching Lake St Clair, the banks are low, and tracts of marsh fall back into the country. Around Lake St Clair there is some tolerable soil, elevated about two feet above its waters, and a small wet prairie or two, besides that at the mouth of the Thames. There are few settlers, scarcely a vestige of cultivation, and one or two recent clearings of insignificant extent. 
The banks of the river Thames are nearly on a level with the waters of Lake St Clair, and gradually rise on approaching Chatham, where they are fifteen or twenty feet high. They have long been cleared of the forest, descendants of French settlers residing below, and those of British Loyalists above. Both classes of inhabitants seem to cultivate only what is necessary to supply their wants, and have made no introads on the forest or prairie for many years. The extent of cultivated land is limited, and everywhere celebrated in Canada as the best in the worll. 'The soil on the south banks of the Thames, from Chathain to its mouth, varies from the finest brown-coloured loam to indifferent sand, the former being of limited extent. I do not mean to damn this favourite spot with faint praise, but while $I$ admit there is some loam as good as man could wish, I contend it is not generally of such a description. No competent judge of soil need remain long in doubt on this point who visits the situation, and I shall only particularize a field above Mr John (ioose's house, which was being fallowed when I was there, and which I pronounce not grood soil. 'The state of the erops might be adduced in evidence of my opinion, especially that of Indian corn, which was not equal to that on some parts of the shore of Lake Erie, more especially that belonging to John Maedonald.

Of the land in the interior of the Peninsula, I am un. able to speak, with exception of what was seen passing from Chatham to Lake Erie, and which I found of superior quality. I have already noticed that few running streams join Lake Erie, and the same remark is applicalble to Detroit river and Lake St Clair. Several rivers are laid down on maps as flowing into the south side of Lake St Clair, but at the time of my visit the mouths of all of them, with a single exception, were closed with sand on the margin of the lake; and I could not determine whether their waters filtered through the sand bars into the lake, or those of the lake into the channels or canals running into the land.

The greater part of the inhabitants in and around Amherstburgh and Sandwich, the banks of Detroit river, Lake St Clair, and the mouth of the Thames, are descendants of the 
French, who settled in this part of the country about the year 1670. They still retain the language, appearance, and many of the customs of their ancestors. Like the Lower Canadians, they seldom engage in commerce or manufactures, and settle together on long narrow lots of land, in strects or villages, and cut down every forest tree. In lower Canada the French population have no orchards, except on the sides of the mountain at Montreal, but here almost every settler on the Detroit river has an orchard. I did not olsserve in the gardens of the French a single pear, plum, or peach-tree, but apples were very abundant, and cider-presses frequently met with. The inhal,itants do not seem so light-hearted or polite a people as those of the lower province. They do not notice strangers in passing, and I only observed two boys bow to me at Sandwich, while every man, woman, and child does so in the neighbourhood of Montreal. The houses are generally brick, and occasionally frame, but seldom with the stone basement of the lower province. The beds of the inhabitants are sometimes without, and sometimes with, posts and curtains, and, in every case which came under my notice, very clean.

On some parts of the river Detroit, Lake St Clair, and on the Thames, many people reside literally amongst water, passing to and from their houses on planks.

The French Canadians are said to be averse to clearing forest land, and perhaps as population increases, they prefer occupying swamps to clearing dry land. The appearance of the inhabitants residing in such situations was unhealthy. Around Lake St Clair, the inhabitants seem to be employed in preparing firewood for the town of Detroit.

The French inhabitants have a great dislike to service of any kind, and more especially to females going out as cooks. The women seem industrious, and often drive the produce of the farm to market in carts. Some children were seen running about in their shirts, as in Lower Canada, even when the weather was cold.

The French seem to have little system in their farming, growing wheat, Indian corn, and grass. They plough with 
oxen and a driver. The sheep are similar to those of the lower province, many of them being black-coloured, with a little white on the face and neck. The oxen are of different colours, somewhat larger than those of Lower Canata, and many of them are without horns. The horses are small, and perhaps not equal to those of Montreal.

In several instances I examined a machine with which the French inhabitants were thrashing out grain. This was a beam twelve or fifteen feet in length, with projecting spars like the spokes of a wheel, resting on the groumel at one end, and rising with an elevation to suit the draught of a horse at the other. The lower end of the beam was without spars, which increased in length according to the elevation. As the horse moves in a circle, the beam revolves, which brings the spars successively in contact with the grain spread on the floor, and by which means it was beat out from the straw.

This mode of separating grain from straw is evidently the first step from treading it out by animals, and is, perhaps, as old as the flail. An economizer of labour would have strewed the gangway of the horse with grain, so that it might have assisted in the operation, by treading with its feet. I have not been able to learn if this plan is known in France, or any other part of the world. It has not heen adopted by the Americans or British Canadians, although it must be an assistance to, if not calculated to supersede, the treading of animals.

The Huron tribe of Indians, residing near Amhersthurgh, are few in number, extending only to ten or twelve families, and from their long intercourse with Europeans, most of the present generation seem to have a mixture of white blood in them. They have long been Christians in connexion with the Catholic church, and have adopted most of the habits of civilized life. They have orchards, numerous herds of cattle, horses and pigs; the cattle being the best I saw in the western part of Canada, and which I attribute to the superiority of the pasturage. On the 24th October, I observed a Huron Indian harrowing sown wheat with a triangular harrow on as well formed ridges as any $I$ saw in Canada.

The Huron Indians were understood to have sold part of 
their reserve in the neighlonurhood of Amhersthurgh to the British Government. Mr M- had been appointed to survey the purchase, and with this view was residing at Amherstburgh during the time of my first visit. The Indians, under some pretext, would not, however, allow the measurement to proceed, and Mr M- got orders from York to delay the survey.

The inhalitants of Amherstburgh are anxious, almost clamorous, to have the Huron Reserve, in the vicinity of the village, exposed for public settlement, which would, in all probalility, promote its increase and prosperity. It is not ray intention to enter into the merits of the puliey of removing the Iluron Indians from their situation on the southern part of their territory. But in the event of the lands falling into the possession of the present inhabitants of Amhersthurgl and its vicinity, I question if the change would be for the better, as the landholders seem incapable of managing or appreciating the great advantages nature hath placed within their reach. The white man strongly displays the frailty of his natue in envying this remnant of his copper-coloured brother's inheritance, while so many millions of acres in Canada are unoccupied.

A considerable portion of the inhabitants on Lake Frie, in the townships of Maldon, Colchester, and the banks of the Thames, are descendants of the Royalists who left the States at the time of their becoming independent, and who olstained grants of land in Canada from the British Government. Like other colonists in this vast continent, who have been shut out in a great measure from intercourse with the world, they have been content to live without an apparent desire to improve their condition. Their extent of clear forest is limited, and few additions have recently been made. The dwelling-houses and farm-offices are of the shabbiest kind, and only two brick houses were seen in a distance of twenty-seven miles, passing from Amherstburgh round Lake Erie. A brick house is also a rare sight on the Thames, wood being almost the only building material.

In this part of Canada, farming is as low as in newly settled districts, and embraces the cultivation of wheat, oats, peas, 
Indian corn, and tobaceo-wheat and Indian corn being the chief crops. In many instances wheat had been sown amongst growing Indian corn, and ploughed in between the drills. This is an excellent plan, the wheat being well advanced when the Indian corn is reaped. Oxen are employed in ploughing generally, and all operations are performed in at superficial manner. I observed a crop of buck-wheat lsing carried in the township of Gosfield, on 24th Oetoler. Two horses were attached to a sleigh, and two men on the ground were building small sheaves on the sleigh with their hands, neither of them having a pitchfork. A trifling load was taken off the field, attended by the two men already mentioned; and after being upset, a man and two boys placed it in the barn. 'The carrying of this crop would have been effected at one-fourth of the labour in scotlind, where the division of farm labour is properly understuod. Lxtensive orchards are everywhere met with, and the crop of apples was immense, so much so, that they sometimes remained ungathered. 'The horses, oxen, sheep, and pigs in this part of Canada are all inferior in kind; and if such a thing as a good sized horse can be found either for the saddle or draught purposes, which I very much doubt, it must have come from the States.

The implements of husbandry are such as are common to the country. Several grist-mills are propelled by oxen walking on an inclined plane, and are very poor machines. A good many grist-mills are also propelled by wind, chiefly amongst the French inhabitants on the shores of Detroit river and the lakes, and also some by oxen or horses attached to a large wheel, moving horizontally a few inches from the ground. I was given to understand a steam-power grist-mill was about to be erected at Sandwich, by a capitalist lately arrived in the country, and I imagine will be chiefly employed in grinding wheat from the States.

The trees do not materially differ from those in other parts of Canada, with exception of sweet chestnut being common on the shores of Lake Erie. This tree is generally found on poor sandy soil, and seems to occupy the place of the pine in the districts to the north and east. In passing round Lake 
St Clair, I thought I observed the pawpaw growing near the commencement of Detroit river, but the plants being small, I could not determine their identity. Future travellers may be better able to settle this point, as I seattered some seeds of the pawpaw, which were in my pocket, and which I gathered in Ohio a few days before.

The turkey is said to inhabit this district in considerable numbers, and the boy who conducted us out of ('hatham plains told me he had come on a hen and her brood a short time before, but this bird was not seen by me. The pheasant and quail are numerous, and so tame that you may approach within a few yards of them on open ground. Ducks of various kinds inhabit the waters, and more especially I)etroit river, in vast numbers; and many of the species are so tame, that, schoolboy like, I pelted them with stones in open water without their taking wing. Several kinds of geese also frequent the waters, but it is only in autumn, when they and ducks congregate in such numbers, preparatory, perhaps, to moving south for the winter.

Birls of prey are numerous. Near the mouth of the Thames I observed a bald eagle perched on a decayed tree, and which was the only one I saw in Canada. Buzzards were seen frequently, gliding gracefully in circles, and in company, though at considerable distances from each other. Many hawks of different sizes, and small eagles, were observed on the shore of Lake Erie, sitting inactive on trees, or fighting with each other about a favourite resting-place. On one occasion, near Chatham, a hawk singled out a small bird for its quarry which frequents the banks of the Thames, without the power of swimming. The little creature was above the centre of the river when attacked, and aroided a death-blow by diving under water with a shrill cry. It no sooner, however, left the element than the hawk made a second swoop, which was again aroided by going under water, and by a succession of dives and flights, it at last found shelter amongst some bushes on the banks. There are vast numbers of what are here called blackbirds, consisting of two kinds, and both highly destructive to the farmer, devouring almost every species of produce, and especially Indian corn; they breed 
amongst reeds, and find the marshes of the Detroit an excellent cover. 'There are squirrels of various kinds, striped, black, and brown; the former live in the ground, and the two latter are occasionally shot and used as food. Racoons are often hunted, and valued on account of their skins.

The river Detroit issues from Lake St Clair, and falls into Lake Lrie, after a south-west course of about twenty-eight miles. The waters of the greatest lakes in the world, Superior, Huron, and Michigan, pass through the channel of the Detroit, which, at the narrowest point, is about 800 yards wide, and above as well as below this place, expands several miles in breadth. 'The current seems to run at a rate of between two and three miles an hour, and the water is as limpid as that of the purest spring, except when slightly tinged with earth, eaused by the waves during a tempest. The largest steam-vessels pass up at all times, and navies might contend on its waters.

The village of Amherstburgh is situated near the confluence of Detroit river with Lake Erie, opposite to a small island, between which and Amherstburgh the main body of water passes. 'The houses are almost entirely of wood, arranged into streets at right angles with each other, and almost all bespeaking poverty and meanness. There are Catholic, Episcopalian, and Preslyterian places of worship, besides schools, and the population is about 500. Most of the inhabitants are of French descent. Trade is very limited, and thought to be declining. Lvery vessel passing up and down the Detroit comes within 100 yards of the pier, which is at all times accessible to the largest class. Fort Maldon, a paltry mud erection, is situited on the banks of the Detroit, about half a mile from the village, and the military reserve around the fort, which is the best of pasturage, is occupied as common. Amherstburgh is one of the oldest places in Canada, situated in its finest climate, the best British port on Lake Erie, and in beauty and healthiness of situation, inferior to no place in America; yet every thing, with exception of two handsome residences below the town, seems in a state of listless decay. I have no doubt there are better days in store for Amherstburgh. 
Sandwich is also on the Detroit, sixteen miles above Amherstburgh, and derives its only importance from being the county town. The houses compose an irregular street, running along the river, and chietly occupied by French. The trade of Sandwich is more limited than that of Amhersthurgh, and I do not think it has the sane chance of progressing.

About a mile and a half above Sandwich is the ferry at Detroit, at which there are fifteen or twenty houses on the Canadian side of the river, and several brick buildings were being erected at the time of my visit. This place will soon eclipse Sandwich, and may rival (hatham. Detroit is the great market of Western Canada, and the ferry possesses advantages, in proximity and aceess during winter, above every other situation. Since leaving Montreal, I had seen no place bearing the marks of age and wealth, and the town of Detroit, situated on the magnificent river of the same name, ranks next to that city in appearance; and in recalling old-country associations, forms a striking contrast to the poverty and lifelessness of Amherstburgh and Sandwich, on the opposite side of the river. Lofty spires and large brick buildings are seen in the distance; steam-vessels, and engine-stalks, employed in manufactures, on a near approach. A fine large steam-boat leaves Detroit daily for Buffalo, and smaller ones for less distant places on the north and south. Now and then a steam-boat plys to Chicago and other places on Lake Michigan, and in course of a year or two it is probable there will be a daily line of boats. There are three streets running parallel to the river, and many at right angles. The houses in the principal streets are of brick. The population exceeds 3000 souls, the greater part of whom are of French descent. 


\section{CHAPTER XXIII.}

Journey from Detroit to Chicago-Thrashing Machine-Face of the Country in Michigun-Prairie Hen-White Pigenn P'ruirie -Travelling Parly-La Porte-Cooking Breakfust-Jaded Horses-Thunder, Storm-Hovel on the Shore of Lake Michigan - Fuce of the Country - Notices of Nuture - Chicugo - Indiun Treaty_Horse-rucing - Intoxication-Fuir-Oceurrences at Chicago.

ON the 13th September, I left Detroit, early in the moming, in a stage for Niles, which was drawn ly four horses, and well filled with passengers. We breakfasted at the distance of twelve miles, the hotel being a sulitary house, the name of which has escaped my memory.

Here I examined a thrashing-machine, worked by four horses, attached to the ends of two rough poles moving two small horizontal wheels, a few inches from the ground, round one of which was a leather belt moving in a wood case, and connected with the drum or beater placed in the barn. The machinery in the barn consisted simply of a beater, without rollers, shaker, or fan. 'The board over which the grain slides to the beaters, had a few upright spikes, which formed the only detaining power to the grain while passing the beaters. This machine would not cost more than L.8 sterling, but its imperfections in shaking and faming, as well as in beating out the grain, which I discovered on examination, render the saving of first-cost injudicious.

Our roads, for the first stage or two, were very bad, and perhaps affected the passengers, eight in number, who did not exchange half-a-dozen words during the first day. In course of the second day, a few short questions were put and answered, and on our arrival at Niles, on the evening of the third day, nothing like familiar intercourse had taken place. 
Niles is a small place on the river St Josephs, and said to be twelve or fourteen miles from lake Michigan. In our route from Detroit, we had passed through the territory of Michigan, in a south-westerly direction, crossing most of the rivers, near their source, which flow into Lakes Lrie and Michigan; and I experienced considerable disappointment at the general aspect of the country, which, with the exception of about twenty-five miles next to Detroit, was found to consist of oak openings. The soil is chiefly sand, and exhibits few marks of fertility. The trees are stunted oaks, of aljout thirty feet in height, and so thinly scattered, that a man may frequently clear an acre in a day. The surface is gently undulating, and, from the thinness of the trees, and frequency of streams, lakes, and prairies, highly picturesque. 'The lakes sometimes assume the character of marshes, and many of them contained small eminences, or islands, covered thickly with trees of a different species from those growing on another, at a few yards distant, or on the margin of the marsh. 'The district is still very thinly settled; and in passing along, I wondered what had become of all the people who of late years have been pouring into Michigan from the eastern states, forgetting the extent of territory, and that it has become the common route for settlers moving to the fertile and extensive tracts lying to the south and west of Lake Michigan. The houses, with the cxception of those in villages, are mere log-huts.

We breakfasted at White Pigeon, on the third morning of our journey, at a well-regulated hotel, where some broiled ruffed grouse, called, in the language of the country, prairiehen, was presented at table, and in praise of which, some of our taciturn fellow-passengers became loquacious. 'The particulars of the discussion may have been highly valualle, but I was too busily employed in displaying $m y$ opinions by actions, to note down the conversation.

White Pigeon is a small pretty village, composed of wellpainted frame-houses, and in neatness and apparent comfort resembling some of the residences in New England. It is situated on the skirts of White Pigeon prairie, one of the most beautiful and fertile prairies in Michigan, and to which, perhaps, the whole territory is indebted for much of its celebrity. 
White Pigeon prairie is an interesting spot to those who have long looked on the interminable forests and small clearances of Canada, being a level surface of many miles extent, thickly interspersed with good farm-houses and barns. To me the change was truly gratifying, and gave rise to a thousand associations connected with other parts of the world. An old farmer from New Eingland, on his way to join a son in IIlinois, could not contain himself, and exclaimed,_- "Surely this must have been the place where Adlam and Eve resided."

On examining the soil of White Pigeon prairie, I found it composed of black gritty sand, thickly interspersed with glittering particles of spar. 'The inclosures were large, and without ridges. The crops had been gathered, with the exception of Indian corn, which seemed good. The weeds growing on the surface were of no great strength, amongst which were two kinds of grass. I did not olsserve sown grasses or clovers, and the latter does not grow naturally. It is said many English farmers are settled on White Pigeon prairie, who have good thrashing-machines. There is a small prairie to the east of White Pigeon, and a large one to the west, through both of which we passed. These prairies do not seem fully occupied, and the land is said to sell at from $\$ 3$ to $\$ 6$ per acre, government price being $\$ 1$ t

The ruffed grouse, or prairie-hen, abounds on White Pigeon and the adjoining prairies, to which some gentlemen resort for the purpose of shooting. This bird resembles in colour the female pheasint of Britain, and the black-cock in size and shape.

While walking in the garden of the hotel at White Pigeon, the experiment I wished my friend to try in the Huron tract at Goderich, was made on myself. A wasp stung me on the eyelid, and did not cause much pain, but $I$ cannot draw any inference from this regarding the properties of the American wasp, as a sting from such insects in Britain did not create inflammation at any period of my life.

At Niles we changed our stage-coach for an open waggon drawn by four horses, which was the first time a regular stage had passed from Niles to Chicago, the mail having hitherto 
been carried on horselack. 'The waggon and horses were to carry us through all the way, as proper posts and relays had not been established on the road. We breakfasted before setting out, and a guide was sent with our driver.

Our travelling-party was somewhat changed from that which had come from Detroit. Three of our original passengers remained; one an Englishman, $\mathrm{Mr} \mathrm{L} \_$, who had been twelve months in the western states, and now on his way back, after an excursion to the southern and eastern states of the Union, was accompanied loy Mr 1)___ a young gentleman, who, from his pronunciation of the English language, I imagined from Germany ; the third was W__- from Betroit, an officer in the United States army, and the most prim individual I encountered in the course of my travels. He seemed as if carrying the dignity and honour of the whole army on his shoulders, and I could not help remarking how very repulsive he was to his countrymen who ventured to address him. America may be the land of liberty and equality, but, personally, no one seemed equal to Major W__, and certainly liberty could not be taken with him. The rest of our passengers consisted of an old revolutionary soldier and his wife, on their way to join a son settled in Illinois, a Michigan farmer, myself, waggoner, and guide.

The farmer was originally from York State, now settled on Nottawa Sepee prairie, on St Joseph's river, and proceeding to Chicago, where an adjustment of Indian claims was taking place, in the hope of obtaining recompense for losses. I had not an opportunity of learning the result of his mission, but from his own statement, it did not merit success. He told us he intended to have made a great deal of pork this season, but on collecting his pigs from the woods, where they had run for five months, he could only number thirty-five instead of fifty-five. The Indians had been seen hunting pigs, and he expected to get payment from the government agent for twenty of his which were missing. In this manner the poor Indian is preyed on by his white frontier brother, and made pay for the ravages of disease, wild animals, and perhaps the dishonesty of white men. 
In our first day's journey we dined at La Porte, a small rising place, situated in a rich prairie country, and on the margin of Clear Lake, a beautiful and picturesque sheet of water, said to be eight miles from Lake Michigan. We stopped for the night at Clavering. The house was a mean log erection of two apartments, one of which contained five beds, in which nine travellers huddled together, and the other apartment, from the number of the family, must have been equally well filled.

Our party collected at daybreak, when we set out on our journey, the poor horses, not having got any thing but hayoats, or Indian corn, were not to be had. 'The road, leading through forests, was so heavy, that the poor animals could not go beyond a slow walk, and I proceeded forward, in company with the Nottawa Sepee farmer, with a view of orlering breakfast for the party.

On reaching a house, we were told it would be some time before breakfast could he prepared, as we had not been expected. 'The inmates of the house consisted of a fernale and her two young daughters, whom the farmer and I assisted in preparing wood for cooking. A kettle and two frying-pans were put on the fire, and two others over some ashes, removed from the general mass by means of a shovel, and placed on the hearth. Into one of these pans some small loaves were placed, which had been prepared beforehand, and covered with a lid, on which hot ashes were placed; and in the other, battercakes, called flap-cakes, were prepared. In one of the fryingpans on the fire bacon was dressed, and in the other potatues; so, in less than half-an-hour, a breakfast of the best the house could afford was prepared.

The horses again fared poorly, getting a few ears of green Indian corn, collected from the field, and we were told oats would be obtained at the end of six or seven miles. We accortingly found this to be the case, a small feed for each was granted, and a supply to carry with us clenied.

After breakfasting, a French Canadian from the Lower Province, engaged in trading with the Indians, joined us; and for five or six miles, before reaching Lake Michigan, the road was through undulating oak openings of loose heavy 
sand, over which I walked. We reached the lake to the wust of its most southerly proint, and distinctly saw the shore running north on each side of us. The beach along which our road lay was so soft, that almost all the party walked to ease the horses, who showed unequivocal symptoms of distress. It was now ahout nightfall, and our guide from Niles, who had carried the mail over the country, assured us we were twenty-eight miles from the nearest house. It appeared to me doultful if the tired animals could accomplish the journey under any circumstances, and hopeless to think of them doing so with all the passengers in the waggon. I therefore proposed to walk the distance, and set out with such a view by myself; but reflecting that I was altogrether unacquainted with the country, and might pass the resting-place without noticing it, I left the shores of the lake, and botanized on the sand hills until I could no longer distinguish plants.

On returning to the waggon, the party were all reseated, with the exception of the Nottawa Sepee farmer and Indian trader, and I could not refrain from remarking the want of feeling evinced by some of the gentlemen in oppressing the horses, then moving at the rate of three miles an hour, dead to the whip, and occasionally coaxed on with water in a pail. 'The evening was agreeably cool, the moon and aurora borealis shone in splendour, and the ripples of the lake, and the wheels of the waggon, passed without noise on the smooth beach. By and by, the sound of distant thunder was heard rolling - on the waters flashes of lightning could be distinguished, and at length the clouds from which both proceeded came directly over our heads, accompanied by torrents of rain. At this time the farmer and trader also betook themselves to the waggon, and I continued to walk on foot. It is impossible for me to convey in words a correct impression of our situation. Peal after peal of thunder followed each other for two successive hours. The lightning was so vivid, that every flash deprived me of vision for a few seconds, and, unable to see the way, I laid hold of the waggon with one hand. The horses seemed unwilling to proceed, and the guide was mounted on one of the leaders to urge them along. At this time the wind had sprung up, and the rain fell in such torrents, that, 
on turning my back to the storm, I distinetly felt water running in streams on the surface of my skin.

The horses at length stood still_no means could make them move; and all the passengers, with exception of the old soldier and his wife, descended from the waggon. Five of us, $\mathrm{Mr} \mathrm{L} \longrightarrow$ - Mr D——, the farmer, trader, and myself, resulved to make the best of our way on foot, and the others remained with the waggon. 'The gentlemen having had cloaks and umbrellas to protect them from the rain while in the waggon, were comparatively dry. The moon had set, and fortunately the night eleared up at the time of commencing our walk. Mr L_ - who was a tall athletic person, in the prime of life, led the way at an exterminating pace over the soft sand, followed by the farmer and others. It soon became evident to me, that no frame could last at the rate we were going. Mr D__ and the trater dropped astern, the farmer gave place to me, and at length $\mathrm{Mr} \mathrm{L}$ - proposed to breathe on the trunk of a tree. Mr I__ 's proposal was most agreealle to me, having walked.ten hours in course of the day before setting out with $\mathrm{Mr} \mathrm{L} \longrightarrow$; and I afterwards heard the farmer say, in conversation, that had it not been for the honour of his country, he would not have continued to walk with the Europeans. Mr D _ and the trader had not been seen for an hour before. We shouted to them in vain, and at the end of ten minutes continued the journey at our former pace. When resting a second time, $\mathrm{Mr} \mathrm{D} \mathrm{D}_{\text {_ }}$ and the trader passed us, both mounted on one horse, which they obtained from an Indian known to the trader.

At three in the morning, we observed a light, which, on approaching, was discovered to be a lantern, with which Mr D__ was gathering potatoes in a garden with his fingers, as the only means of removing them from the earth, and the trader was bawling in a hovel for whisky. On entering the hovel, two young girls and a boy, half Indian and half something else, were reposing in a corner, each wrapped in a blanket; and on seeing so many strangers, they all rose hurriedly and left the house. Some oats were sent off by the Indian who owned the horse for the waggon horses, and a small piece of bread and some whisky were obtained for ourselves. $\mathrm{Mr} \mathrm{L}$ 
Mr D_ soon took possession of the corner and hlankets, which the girls had abandoned; and I was anused to soe these individuals, who had evidently been long familiar with the luxuries and rofinements of liuropean society, accommodate themselves to circumstances, and take possession of a sleeping place, which, in cleanness and softness, was inferior to the bed of many an Last Lothian pig. The farmer and trader soon followed their example, and I was left standing by the fire drying my shirt, after accomplishing which, I stretched myscelf alongside of the trader, and was asleep in an instant.

- At five the waggron and the rest of the party arrived, and at seven we again set out, and reached Chicago in time for a late breakfast; the countenances of all bore evidence of the fatigues of the preceding evening, and my limiss felt them. The old soldier had drunk ton freely on his arrival at and departure from the hut, and his ravings while under intoxication in praise of republicanism and General Jackson, as well as in censure of England, were amusingly alssurd. I lis wife seemed to feel for her husband's conduct, and the influence both of the driver and Major W- was scarcely sufticient to keep him in order.

Soon after leaving Niles, we crossed by a ford the river St Joseph's, which seemed to me to contain rather more water than the largest sized rivers in Britain. For miles on both sides, the country is uninhabited, and seems to combine the features of forest oak openings and prairie, the trees being small, thin, and standing in groups, so as to produce the best effect, often reminding me of the finest English parks. Six or seven miles from St Joseph's river, the prairie country commences, and continues with little intermission to the westward as far as the country has been explored. On the southern margin of Lake Michigan, there is a range of sand hills, from 100 to 200 feet in height, apparently formed by the drifting of sand from the beach, and the same character is maintained up the west side of the lake, although the elevations are quite inconsiderable.

The country from the river St Joseph's, round the south side of Lake Michigan, with exception of a small spot, belonged, at the time of my visit, to the Pottowatamy tribe of 
Indians. This tract, extending to about $6,000,000$ of acres, was sold by the Pottowatamys to the United States Government a few days after I passed over it, and is now in the market.

The agriculture of the country from Niles to Chicago is limited to a few prairies in the vicinity of La Porte, on which wheat and Indian corn are cultivated in the most primitive manner. Here, as in the western part of Cinada, the farmers seemed contented to live. There were no barns seen any where; and at Clavering the wheat was thrashed in the open air, on the bare earth, and the fanners were standing covered with a little straw. The Indian corn was still growing. In one instance, I observed wheat newly sown, and a field of this crop above ground. The erop of the year was in sinall, ill-built, unthatched ricks, resembling in size and shape the hay cokes of Scotland. At Clavering I examined the prairie wheat crop, and found the ears small in size, the straw short and slender; the grain was particularly small, but of fine colour and appearance.

The wood is chiefly oak. The summits of sand hills on Lake Michigan are crowned with a few stunted pines, a tree which, I believe, is not to be found farther to the snuth of this point, or west of the grand river in Upper Canada, although abounding in some districts on the north-west shores of Lake Michigan. Nearer the beach, and at a lower level than the pines, dwarfish poplars grow, two species of bent grass, and a thistle. A few vines were also on the sand hills, and when not growing in very exposed situations, were lying on the banks as if trained on a wall; but after a diligent search, I could not discover fruit on them. The sand hills were thinly clothed with vegetation, and every plant, with exception of the grasses, seemed stunted like those exposed to the spray and storms of a British ocean. In this part of the country, I made a large addition to my collection of seeds, which were wrapped in small folds of paper, dried in my pocket, and afterwards transferred to my knapsack.

I observed no animals that appeared new to me. In some parts squirrels were particularly numerous, and exclusively of the black variety. 
While walking on the sand hills on the south point of Lake Michigan, I observed a small hawk pursue a bat, similar to that of Britain. The bat dexteronsly avoided three swoops of the hawk, seemingly without much exertion or concern, and both were hid from vision behind a bank in the fourth attack. I had frequent opportunities of seeing birds of prey attack their game while in America, without witnessing a successful effort.

Chicago is situated on Lake Michigran, at the confluence of Chicago river, a small stream, affording the advantages of a canal to the inhabitants for a limited distance. At the mouth of the river is Fort-I)earborn, garrisoned by a few soldiers, and one of the places which has been long held to keep the Indian tribes in awe. The entrance from the lake to the river is much obstructed by sand banks, and an attempt is making to improve the navigation.

Chicago consists of about 150 wood houses, placed irregularly on both sides of the river, over which there is a bridge. This is already a place of considerable trade, supplying salt, tea, coffee, sugar, and elothing to a large tract of country to the south and west; and when connected with the navigable point of the river Illinois, by a canal or railway, cannot fail of rising to importance. Almost every person I met regarded Chicago as the germ of an immense city, and speculators have already bought up, at high prices, all the building-ground in the neighbourhood. Chicago will, in all probability, attain considerable size, but its situation is not so favourable to growth as many other places in the Union. The country south and west of Chicago has a channel of trade to the south by New Orleans; and the navigation from Buffalo by Lake Huron is of such length, that perhaps the produce of the country to the south of Chicago will find an outlet to Lake Erie by the waters of the rivers Wabash and Mamee. A canal has been in progress for three years, connecting the Wabash and Mamee, which flows into the west end of Lake Erie; and there can be little difficulty in connecting the Wabash with the Illinois, which, if effected, will materially check the rise of Chicago.

At the time of visiting Chicago, there was a treaty in pro- 
gress with the Pottowatamy Indians, and it was supposed nearly 8000 Indians, of all ages, belonging to different tribes, were assembled on the occasion, a treaty being considered a kind of general merry-making, which lasts several weeks; and animal food, on the present occasion, was served out by the States government. The forests and prairies in the neighbourhood were studded with the tents of the Indians, and numerous herds of horses were browsing in all directions. Some of the tribes could be distinguished by their peculiarities. The Sauks and Foxes have their heads shaven, with exception of a small tuft of hair on the crown. Their garments seemed to vary according to their circumstances, and not to their tribes. The dress of the squaws was generally blue cloth, and sometimes printed cotton, with ornaments in the ears, and oceasionally also in the nose. The men generally wore white blankets, with a piece of blue cloth round their loins; and the poorest of them had no other covering, their arms, legs, and feet being exposed in nakedness. A few of them had cotton trowsers, and jackets of rich patterns, loosely flowing, secured with a sash; boots, and handkerchiefs or bands of cotton, with feathers in the head-dress, their appearance reminding me of the costume of some Asiatic nations. The men are generally without beards, but in one or two instances I saw tufts of hair on the chin, which seemed to be kept with care, and this was conspicuously so amongst the well-dressed portion. 'The countenances of both sexes were frequently bedaubed with paint of different kinds, including red, blue, and white.

In the forenoon of my arrival, a council had been held, without transacting business, and a race took place in the afternoon. The spectators were Indians, with exception of a few travellers, and their small number showed the affair excited little interest. The riders had a piece of blue cloth round their loins, and in other respects were perfectly naked, having the whole of their bodies painted of different hues. The race-horses had not undergone a course of training. They were of ordinary breed, and, according to British taste at least, small, coarse, and ill-formed.

Intoxication prevailed to a great extent amongst both sexes. When under the influence of liquor, they did not seem unusu- 
ally loquacious, and their chief delight consisted in venting low shouts, resembling something between the mewing of a cat and the larking of a dog. I olserved a powerful Indian, stupified with spirits, attempting to gain admittance to a shop, vociferating in a noisy manner; as soon as he reached the highesst step, a white man gave him a push, and he fell with violence on his back in a pool of mud. He repeated his attempt five or six times in my sight, and was uniformly thrown lack in the same manner. Male and female Indians were looking on and enjoying the sufferings of their countryman. 'The inhuman wretch who thus tortured the poor Indian, was the venter of the poison which had deprived him of his senses.

Besides the assemblage of Indians, there seemed to be a general fair at Chicago. Large waggons drawn by six or eight oxen, and heavily laden with morchandise, were arriving from, and departing to, distant parts of the country. There was also a kind of horse-market, and 1 had much conversation with a dealer from the State of New York, having serious intentions of purchasing a horse to carry me to the banks of the Mississippi, if one could have been got suitable for the journey. The dealers attempted to palm colts on me for aged horses, and seemed versed in all the trickery which is practised by their profession in Britain.

A person showed me a model of a thrashing-machine and a churn, for which he was taking orders, and said he furnished the former at $\$ 30$, or L.6, 10s. sterling. There were a number of French descendants, who are engaged in the fur-trade, met in Chicago, for the purpose of settling accounts with the Indians. They were dressed in broadcloths and boots, and boarded in the hotels. They are a swarthy scowling race, evidently tinged with Indian blood, speaking the French and English languages fiuently, and much addicted to swearing and whisky.

The hotel at which our party was set down, was so disagreeably crowded, that the landlord could not positively promise beds, although he would do every thing in his power to accommodate us. The house was dirty in the extreme, and confusion reigned throughout, which the extraordinary circumstances of the village went far to extenuate. I contrived, 
however, to get on pretty well, having by this time learned to serve myself in many things, carrying water for washing, drying my shirt, wetted by the rain of the preceding evening, and brushing my shoes. The table was amply stored with suistantial provisions, to which justice was done by the guests, although indifferently cooked, and still more so served up.

When bed-time arrived, the landlord showed me to an apartment about ten feet square, in which there were two small beds already occupied, assigning me in a corner a dirty pallet, which had evidently been recently used, and was lying in a state of confusion. Undressing for the night had become a simple proceeding, and consisted in throwing off shoes, neckcloth, coat, and vest, the two latter being invariably used to aid the pillow, and I had long dispensed with a nightcap. I was awoke from a sound sleep towards morning, by an angry voice uttering horrid imprecations, accompanied by a demand for the bed I occupied. A lighted candle, which the individual held in his hand, showed him to be a French trader, accompanied by a friend, and as I looked on them for some time in silence, their audacity and brutality of speech increased. At length I lifted my head from the pillow, leant on my elbow, and with a steady gaze, and the calmest tone of voice, said,"Who are you that address me in such language?" The countenance of the angry individual fell, and he subduedly asked to share my bed. Wishing to put him to a farther trial, I again replied,_- "If you will ask the favour in a proper manner, I shall give you an answer." He was now either ashamed of himself, or felt his pride hurt, and both left the room without uttering a word. Next morning, the individuals who slept in the apartment with me, discovered that the intruders had acted most improperly towards them, and the most noisy of the two entered familiarly into conversation with me during breakfast, without alluding to the occurrence of the preceding evening.

On arriving at Chicago, I learned there was a mail-waggon which passed down the Illinois river once a-week, and had set off a few hours before, and was the only conveyance in that direction. I could not think of remaining a week waiting for the waggon, and not finding a suitable horse to purchase, I deter- 
mined on walking. The passengers who had travelled together from Niles, lodged at the same hotel, with exception of the Major, who perhaps found shelter in the fort. 'The old soldier seemed to have commenced a regular fuddling fit; and his wife, who was a prudent sensible person, was in great distress, being thirty miles from the residence of her son, and her husband quite uncontrollable. Finding the destination of the old lady lay no great way out of my route, I hired a waggon to take the old people and myself there next morning, the soldier having been easily coaxed into the arrangement, and for which his wife expressed thankfulness. On the waggon reaching the door of the hotel, its owner, who was of French descent, insisted that he had only bargained to convey two, and that unless he received $\$ 2$ from me, I must remain behind. After a noisy altercation on both sides, he offered to accept of $\$ 1$ extra, but feeling indignant at his attempt at imposition, I shouldered my knapsack, and trudged off on foot. I have often looked back with regret on this proceeding, as it was improper to leave the old lady without seeing her fairly on her journey, and silly to have exchanged high words with an individual who would altogether disregard them. This was the only instance which occurred to me in the States, of experiencing an attempt at imposition, or which was calculated to ruflle my temper. 


\section{CHAPTER XXIV.}

Journey from Chicago to Springfield-Oak Plains-TranellersCrowded House-DuPuge-Benighted-Clutterman's-Ottanous -Family from New England-Truevllers_Gouging - Sleeping Accommodation-Peoria-Pekin Storeheeper-Sultcreek-Hospitality of Inhabitants-Springfield-Prairies-Siotices of ' $\mathrm{Na}$ ture-Fice of the Country-Soil-Ayricultural Notices.

I LEFT Chicago at ten in the morning of the 19th September: rain having fallen, rendered the prairie difficult to walk on, especially when the soil was wet. A number of Indians were travelling in different directions, and also heavy waggons, some of the attendants of which carried guns for the purpose of shooting on the journey.

I dined twelve miles from Chicago, at a hotel on the river Oak Plains, a stream on which people were engaged in erecting a mill, and the waters of which were competent to propel machinery of moderate power. On asking the workmen if the stream flowed into Lake Michigan, they answered, "It joined the Illinois, although in time of high freshets it sometimes crossed the plains to the Chicago concern." This is evidence of the level surface of this part of America; the river Oak Plains, after running in a southerly direction for half a degree of latitude, takes a westerly course at a point twelve miles from Chicago, and only a few feet above the level of Lake Michigan, and its waters join the sea at New Orleans, while those of the lake flow into the Gulf of St Lawrence.

When crossing the Oak Plains, five or six geese alighted in the stream, and I stood and saw a young man shoot one of them, who pointed out the proper road across the prairie, which had become doubtful by two or three diverging in different directions. While in the midlle of the prairie, two Indian men and a boy, the former with guns over their shoulders, 
and the latter with a bow, perfectly naked, with exception of a piece of blue cloth round their loins, and a few quills twisted into their hair, approached me, and whom I saluted with a nod of the head. They spoke in a language which I did not comprehend; they seemed equally unsuccessful with me; and we parted, smiling at the fruitlessness of our attempts. When nearly across the prairie, after passing the river, a waggon overtook me, in which were two young men, who offered me a seat, which I readily accepted. On learning the route $\mathbf{I}$ had travelled, they particularly enquired about the waggons I had passed between Detroit and Chieago, as they expected their parents to be then moving from New England to join them in Illinois, and were anxiously looking for their arrival. After riding about a mile we came to a tavern called the 1)octor's, inhabited by a practitioner of medicine, getting the appellation of Doctor, although in all probability not holding a diploma.

The Doctor, on our arrival, was drawing water from a well built with stones, which is uncommon in this part of the country, few people taking so much pains to keep their water free of mud. The travellers acted as their own ostlor. On entering the house, which was a small $\log$ hut of one apartment, I found a wife, four or five children of different ages, and two travellers, one of whom was called squire, which is, I believe, synonymous with judge, and corresponds with justice of the peace in Britain. For some time I was puzzled to conceive where we were all to sleep, and at length four of us were shown up a ladder into a garret, or cock-loft, in which there were two beds. I took possession of one in partnership with the squire, who told me, before going to sleep, that he had lately suffered much from fever, and finding himself unwell, he had stopt here for the night, instead of proceeding to Chicago. On rising at daybreak, I found two travellers sleeping on the floor at the foot of the ladder. The Doctor, his wife, and two children, lying in bed in the ordinary way, and other two children lying across their feet. After seeing the exertions made by this family to accommodate strangers, and the consequent uncomfortableness of their own situation, I felt thankful for the poor half bed allotted me, 
and in course of my travels duly appreciated the most homely fare and accommodation, when it was the best my entertainers could supply.

The inhabitants in this part of the country reside on the skirts of the prairie, for the convenience of obtaining fire and fencing timber, and I felt hungry befure getting across a large one, after setting out from the 1)octor's. Here, as in sume parts of Canada, there are few taverns, but almost every inhabitant entertains travellers for payment. On entering the first house I reached, two well-dressed, genteel-luoking women were sewing at a window, one of whom said she could not furnish breakfast without some inconvenience, and on apologizing for mistaking her house for a tavern, she directed me to one about a mile distant, near the banks of the river Du Page. After partaking of breakfast, I examined a mill on the river, and again faced a prairie, the limits of which were beyond the reach of vision. 'The day was extremely warm, and I sauntered slowly along, collecting seeds of the various plants, and washing my feet in the different streams I had to wade without my stockings and shoes, by way of excusing myself from exertion under so hot a sun. At length I met two travellers in a vehicle, who asked me how far they were from the next house. After replying, I put the same question, and was told twenty-five miles. At this time the sun was sinking towarls the horizon. I had no alternative but to push on, and as evening approached, got into my best pace. Night, however, set in before I could discern the forest at the termination of the prairie, and while ruminating on the still seclusion which surrounded me, I was cheered by the faint barking of a dog. The road diverged into two lines, and darkness prevented me selecting the most beaten path, when the appearance of a light in the distance decided the choice. I was now in high spirits at the near prospect of terminating my walk, and disregarded getting off the tract I had chosen, still keeping straight on the light, which recalled to memory the song of "the Beacon light" I had often heard sung by my youngest sister. Whatever may have been the degree of interest excited by scenes and occurrences in a foreign land, the associations connected with my 
birthplace never failed to impart the most grateful and soothing emotions, and I had seldom been placed in circumstances so favourable to such enjoyment. "The Beacon light" suggested a thousand recollections which thrilled upon my soul; and as they flitted across my memory, I proceeded with an elastic step, whistling the air to which the words of the song are set, when I suddenly found myself up to the middle in water. There was sufficient light to enable me to see my situation was not attended with danger; and after wading for a hundred yards or two, and scrambling over a rail fence, I found myself on dry land. On applying at the house, the light of which had long attracted my notice, I was received for the night, and found three or four waggoners sitting down to supper, of which I partook without much solicitation. The travellers slept in a different house from the family, and each had the luxury of a single bed.

Next morning I breakfasted before setting out, and assisted my host, of the name of Clatterman, to brand sorne oxen, of which he had nearly forty, with a proportionate share of other agricultural wealth. In the middle of the prairie I met about a dozen of horses, in charge of three individuals, one of whoin was particular in his enquiries regarding Chicago, to which he was journeying to dispose of his horses. Like most traffickers, he lost no opportunity of attaining his end, and asked me to purchase one. Having walked upwards of forty miles the previous day, under unfavourable circumstances, and not feeling in the least degree fatigued, I determined to persevere walking for some time longer. Coming in contact with the river Illinois, about half a mile above its junction with the Fox river, I waded across a channel of free-stone, where there was a considerable sized island of the same rock, covered with wood. On reaching the south side of the river, I walked down the banks, and dined at Ottawa, a place of three or four houses, a little way below the mouth of Fox river, and likely to grow into a city, from being at the head of the navigation of the Illinois. Pursuing my journey until nightfall, I made application for a bed at a house which was filled with travellers and fever patients, and the owner recommended me to proceed four miles further on. By the light of 
the moon I was enabled to cross the river Vermilion by a sort of embankment for changing the direction of the stream for mill purposes, and got under the roof of a New Englander, who had lately come to this part of the country. The family consisted of the old pair, two handsome young women, and a male visitor, whose bed in the garret I shared. Every thing in the house was particularly clean and neat. The manners of the inmates were calm and dignified, a smile never playing on their countenances, or an emphatic sound proceeding from their lips. For tea, bed, and breakfast, the charge of $18 . \frac{1}{2} \mathrm{~d}$. sterling, was made.

Next day I applied for dinner at a house where a poor man was suffering much from sickness, and medical assistance had been called in. The family were about to sit down to a good dinner, of which I partook, paying $6 \frac{1}{4} \mathrm{~d}$. sterling. Night closed on me while in the middle of a prairie, and I felt some apprehension of passing the cottages, which are not easily discovered in a faint light, being almost invariably situated a few yards in the forest, and of the same dark shade. A breeze, highly tainted with the scent of fried pork, led me to expect a house, and to which a light, proceeding from a half-opened door, served to guide me. I found four travellers, the landlord, and his wife, assembled in a poor habitation, lighted by what they termed a string, or piece of twine, dipt in tallow, and which gave a glimmering light, so that we could scarcely distinguish objects. 'There seemed to be only three tea-cups in the house ; the party had, consequently, to feed by turns, and, being a stranger, I was requested by all to seat myself at the first table, an honour to which my appetite led me to make no serious objection.

One of the travellers was descended from the original French, a little merry fellow, speaking indifferent English, and two others consisted of an old man and his son, originally from Kentucky. Both of these individuals differed in their language and manners from most of the people I had come in contact with since leaving Canada. The old man spoke a good many words according to negro pronunciation, and both were addicted to swearing. The son, about thirty-five years of age, was one of the best-looking and finest formed men 
I met in America. I soon discovered he was slightly intoxicated, and a most profligate character. Being anxious to shun conversation with him, I was annoyed at his placing his chair beside mine; and as there was neither another house nor apartment to retire to, I endeavoured to make the most of my situation. Having replied to his encuiry what countryman I was, by asking him to guess, he suceessively said, Dutchman, German, Englishman, and Irishman, and fearing he might lose patience, I at last told him a Scotchman. He had never heard of Scotchmen before, and insisted I must be one of the Scotch-Irish, which I afterwards learnt means, in this part of the world, the inhabitants of the north of Ireland. The discussion about Scotch-Irish suggested the proudest feat of his life. He said Jim Partridge was an Irishman, ahle to whip any man in America, and who must have been heard of in my country. He had a whipping-match with Jim, who fell, and was in act of being gouged, when the bystanders lifted him off Jim, who, seizing a stick, cut his head with it in a dreadful manner. Gouging is performed by twisting the fingers into the hair of the victim, and with the thumb forcing the eye out of its socket. This savage act has long been known in Kentucky and some of the western states, and was often resorted to when parties quarrelled. It is now, however, confined to the lowest blackguards, and of rare occurrence. The eyes of the wretch sparkled with delight when relating the prostrate situation of $\mathrm{Jim}$, and the prospect of gouging him, and he explained his brutal attempt by placing his fingers in my hair and on my face, when I could scarcely trust his intentions. He also insisted that I should feel the indention made by Jim's stick, and I thought his skull must have been as hard as his heart to have withstood such a blow.

The house was in all respects a mean one, containing little furniture, and two beds, from one of which rose an emaciated person, labouring under aberration of mind, and to whom the house and lands adjoining belonged. I began to feel uneasy about the sleeping accommodation, as both beds would be required for the family, and there was no garret apartment. The landlord at length drew forth from the corner of the room a dirty tick and covering, which were 
placed in the middle of the floor, and formed the sleeping place of five individuals, who arranged themselves latitudinally on the pallet. I was anxious for an outside berth, in order to have sea-room in case of accident, but the complaisance of the gouger deprived me of this position, and I found myself placed for the night between the old man and his son. None of the travellers thought of unrobing; and after putting off my shoes, 1 laid my head on my knapsack, which was the only thing in shape of a pillow to be had. My situation was far from enviable ; fumes of whisky and squirts of tobaceo juice assailing me on every side, and I considered the partner of my bed more savage than the wolf of the forest. Speedily falling into a profound sleep, from which I was awoke at daybreak by the Frenchman searching for his saddle, the horrors of my situation flashed on my mind, and I stealthily crawled from the bed, my movements being accelerated by the gouger muttering an ugly oath.

On gaining the outside of the door, the freshness of the air was delightful. The sky was cloudless, and in walking through the trees, the paroquets fluttered from their restingplaces with a shrill cry. On reaching the opposite side of the wood, herds of cattle were seen streaming from the forest, and the smoke of the morning fires astending in graceful columus, undisturbed by the serene atmosphere. The prairie-hen rose from the pathway with a purring noise, and the little gophers stood on end, and seemed to regard me as an intruder. The sun peered above the prairie, as if rising from the ocean, and gidled the nodding sunflower, whose brilliancy was heightened by dewdrops sparkling on the blossom leaves, and with which I washed my face. Nature was decked in a wimning garb, and the events of the previous evening were forgotten in wooing her beauties.

On entering a house at the end of the prairie, I found every thing neat and elean, and two well-dressed females cheerfully provided breakfast. One of them was in delicate health, and had lately come from the Du Page, where she left a coloured man in charge of her establishment, about whose health she felt anxiety, as almost every one on the river had been afflicted with fever. It so happened that I 
had ealled at this lady's house for the purpose of encquiring the way, which was pointed out by the coloured man, who was then in good health.

When about to partake of breakfast, I was joined by a traveller in a light car, who passed me on the previous evening, and he expressed surprise to find me before him, having gone a mile off the direet road to eseape passing the night in the house in which I loriged. He resided at Pekin, and had come direct from Chicago, which he left about six houns after me, and had travelled at what he considered a grood pace. He asked me to take a seat in his car, and we travellerl together twelve or fourteen miles on the wooded banks of the Illinois till opposite Peoria, when we crossed the river in a ferry-boat, leaving the horse attached to a tree.

Peoria takes its name perhaps from the tribe of Indians called Peorias, and which is now almost extinet. It is situated on a lake, or an expansion of the river, two miles wide, and four or five in length, at some elevation above the water, and commanding a view of the lake and fine wooded banks on the opposite side.

The village exhibits marks of considerable age, but none of prosperity. I found the dinner hour past, and fared indifferently. There being nothing to attract attention at Peoria, I recrossed the ferry, where the horse was still standing, and bent my way to Pekin, which I reached a little before sunset.

Pekin, sometimes called Pekin-on-the-hill, is situated on the Illinois, and is progressing rapidly. The hotel was filled with permanent boarders, who seemed to be engaged in the different mechanical arts. The landlord was erawling abont the house in a debilitated state, and evidently a fever patient. The people assembled at table addressed me by the name of stranger, and showed considerable attention; a female, as usual, filling out tea.

For three days past I had been without shoe-ties, both having broken after leaving Chicago, the bark of trees having since then been substituted. I made application for a supply at different stores in Pekin, without success. In one instance I found the storekeeper stretehed at full length, with his back 
on the counter, and his feet touching the roof. At first I did not observe him, as the light from a candle was faint, and I was surprised at hearing human sounds proceeding from such an unseemly thing. He answered my enquiries regarding shoe-ties dryly, without altering his position. On retiring I purposely left the door of the store open, with the view of rousing him from his unelegant posture. My stratagem did not, however, succeed, and I begran to think the individual might be a philosopher engaged in study, instead of a demisavage, which his behaviour at first led me to suppose.

On retiring to bed, I was deposited in a pretty large apartment, containing seven or eight beds, some of which were occupied by sick people, and others were passing to and fro, at all hours of the night. I rose early in the morning, and bent my course towards Springfield, in Sangamon county, leaving the river Illinois to the westward. I applied for breakfast, at an early hour, at a solitary house, which an overgrown young woman readily supplied, baking bread and stewing a fowl in a very short space of time, for which she charged well. In course of conversation, I learned her husband was from the State of New York, and had lived sometime in Indiana. Her children were evidently unhealthy, and she said sickness was no great misfortune, as it was so easy to get a living in the country. After breakfast I passed several small prairies and the river Mackinaw, when I entered on a large and uninhabited one, sixteen miles across. 'The day being very warm, I felt a good deal fatigued, and was anxious to obtain dinner and shelter from the sun, but on gaining the only house on the road, I was told the whole family were sick, and it was impossible for me to obtain dinner. I proceeded to a hotel on Salt creek, which I reached with scarcely suffi. cient light remaining to distinguish the house.

The landlord of the hotel, Mr Music, was from home, and two daughters and a son did the honours of the house. These people seemed in good circumstances, having a well-stocked farm and abundance of Indian corn. On my arrival, I was asked whether I would have bread of Indian corn or wheat, and all seemed surprised to hear I had never tasted the for- 
mer. Two other travellers on horseback arrived, and bread of both kinds was presented at table.

One of the travellers was on his way to Galena, for the purpose of getting payment of horses he had sold some time hefore. He was originally from Kentucky, and now resided in the neighbourhood of Jacksonville. His manners were somewhat rough, and with this individual I had much conversation. At first he was most anxious to engage me as a farming-help, admitting that he himself had become too lazy to work hard, and pressed me again and again to name my terms. To him and others who wished my assistance as farminghelp, I uniformly expressed thankfulness for their kindness, and assured them that circumstances did not adunit me to reside in the country. Before separating, he offered me a letter to his wife, who would give me free hoard at his house till he returned, and his sons would drive me over the arljoining country. I took down his address and left him, with a promise to visit Mrs 'Taylor if time permitted me.

The travellers breakfasted at Salt creek hefore setting out on their journey, which is goorl policy in thinly settled districts. 'The day was excessively warm, and I suffered considerably from thirst. On passing a cottage, before reaching Sangamon river, a girl was drawing water, from whom I asked a drink; she went into the house and brought a tumbler, which she filled with indifferent water, and handed over the rails. When about to dejart, a woman of prepossessing appearance came to the door, and asked me to enter the house and shelter myself from the sun. I thanked her, and in return, said I was anxious to reach Springfield in time for dinner. She told me her husband, who was sick, liked above all things to converse with travellers, and hoped for his sake I would enter the house. There was something so earnest in the woman's manner that I would have found difficulty in resisting her entreaties at any time, and on the present occasion my inclination yielded a willing assent.

The husband was stretched on a clean uncurtained bed, and appeared in a most debilitated state. He brightened up by degrees, and showed he possessed a good deal of information. 
He was particular in his enquiries about Ottawa, on the river Illinois, to which he had some thoughts of removing, as he had resolved to leave his present situation, where he had resided for six years, on account of the scarcity of water. His health and that of all his family had been good until the jresent time, when he was seized with fever, which he thought the doctor had broken. He regretted that his weakness could not stand cooking meat in the house, but if I could partake of other food, his wife would place it before me. A suowwhite cloth was spread on the table, followed by bread, milk, butter, and preserved fruits of excellent quality, and to which I did justice. On departing, I received an invitation to call at the house if ever I passed in the direction. Soon afterwards, crossing the Sangamon river in a boat, although the stream was not more than eighteen inches deep, I reached Springfield about two o'clock.

Dinner was readily promised at the hotel, although past the regular hour, and in the meantime I prepared to wash and shave. On asking for a bedroom, the landlord personaily brought water, and on a second application, soap and a mirror. I had now discovered that I also wanted a towel, and at last, conscious of the impropriety of keeping the master of the house rumning up and down stairs on my account, I moved off to the pump-room and apologized for my past conduct, on the score of being a stranger in the country, and unacyuainted with its customs. I had no cause to regret this proceeding, the landlord being remarkably attentive during my stay, pointing out what was worthy of notice, and offering his horse to visit them.

In the evening I passed two individuals conversing on the prairie, to whom I nodded, a practice universal in all country places of the States I visited. After proceeding a short distance, one of the persons overtook me, and commenced conversation. "Sir, you are a European?"-_ Yes."-". And an Lnglishman?"-" No; I am a Scotehman."-" You are at a great distance from your own country?"- "I am, but the sight of this beautiful one has repaid me for the journey." - "You are a mechanic?"-_"No; I have been a farmer from my youth upwards." - What induced you to come 
here?"- "We farmers in Scotland, finding ourselves uncomfortably situated, desire to emigrate to this country, the accounts of which being contradictory, I resolved to see it personally." The old gentleman descended from his horse, with sparkling eyes, shook me by the hand, saying, "In me you have found a friend." 'There was something in the man's expression and warmth of manner so unexpecter in this part of the world, that I asked if he was from scotland. He said his name was Humphries, originally from Pennsylvania, his parents being of Welsh extraction. I was pressed to pass the night at his house, and on declining to do so, agreed to breakfast with him next morning.

I found the old gentleman, and what I supposed two danghters, expecting my arrival. The house contained several apartments, in one of which were some dozens of hooks on a shelf. Mr Humphries appeared verging on seventy. We walked over the farm, and after partaking of excellent melons, I took leave about noon, much gratified with my visit, and with the kindest invitations to visit him or his family at a future period.

On arriving at the hotel, I learned that two Seotchmen had called for me, Mr D__ and Mr B__ and I rode across a prairie, after dinner, to see $\mathrm{Mr} \mathrm{D}$ __ at his steam saw-mill on the Sangamon river. On my return to Springfield, I spent the evening in company with two ladies from New England, and one from Scotland. They agreed in thinking Illinois a hard country for women and cattle, as helps could not always be had. My countrywoman smiled at my oljections to the slave states, and maintained the coloured population were not human beings, but inferior animals created for slavery. It was painful to hear a lady advance such opinions, who in youth must have imbibed very different sentiments and principles, and I attributed the change she had undergone to her residence in a slave state, and affording in herself an instance of the evils of slavery. Her observations required from me a reply; and the subject dropt, on my remarking there were many white slaves in the world, some being slaves to their passions, and others to their prejudices.

Springfield is an irregular village of wooden houses, con- 
taining about 1200 souls. It is three miles from Sangamon river, which is only navigal,le for small boats at the meling of the snow in spring. 'There are good stores of all descriptions in the village.

The word prairie is derived from the French, and signifies meadow. In America it means grass-land naturally free from timber, and is used in this sense by me. Prairies have not been found in the eastern parts of North America, and many conjectures exist regarding their origin in the west. The general opinion is, they originated from, and owe their continuance to, the agency of fire. It is quite certain fire sweeps over them, at present almost every autumn, destroying the entire vegetation on the surface; but whether proceeding from human or natural agency remains unsolved, and it probably arises occasionally from both. The burning inust destroy secdling-trees, which would otherwise perhaps occupy the whole surface by the wafting of seeds; and the continuance of prairies may be, in many instances, owing to fire, lut after having seen them in all situations, it does not seem to account satisfactorily for their origin. Prairies of a few yards' extent are found in the midst of dense and extensive forests, and rows of trees jutting miles into the open country, without visille agency to account for their preservation. Fire cannot be supposed to have originated the first case, nor the alssence of it the last, as it is seldom so partial in its effects. I have no theory to offer instead of fire for the origin of prairies, which seem productions of nature. The localities of plants are often found to be partial, and Britain exhibits furze, heath, grasses, and different species of trees, exclusively occupying the surface of certain parts as natural productions. In America, trees vary in number on a given space, from the dense forest to the oak opening, with half-a-dozen of trees to an acre. Unless it be maintained that nature has allotted a certain number of trees to a given extent of surface, it will be idle to deny her handiwork in having formed oak openings and prairies, which are met with in all situations, and which often seem to merge into each other.

My friends in the Canadas used every argument to dissuade me from journeying to the junction of the rivers Mississippi 
and Missouri. They represented the eountry through which $I$ intended passing as a pestilential swamp, inhahited by demi-savages and dangerous animals. If, perchance, I escaped disease and enemies, I would become low-spirited in the wilderness, and to procerd alone and unarmed, would be little short of insanity. But how different was the result ! With the companionship of nature, and the God of nature as my protector, want of company and fear were unfelt, and I regard my wanderings on the prairie as the most pleasing and instructive period of my existence.

Having reached Chicago with an unsocial party of travellers, and gradually passing from the forests and oak openings of Michigan, it was not until after crossing the river Des Plaines that I became fully sensible of the heauty and sublimity of the prairies. They embrace every texture of soil and outline of surface, and are sufficiently undulating to prevent the stagnation of water. 'The herbage consists of tall grass, interspersed with flowering plants of every hue, which succend each other as the season advances. The blossoming period was nearly over at the time of iny journey. Sunflowers were particularly numerous, and almost all the plants had yellow blossoms. Every day brought me in contact with species formerly unobserved, while others with which I had become familiar, disappeared. Occasionally, clumps of trees stoorl on the surface, like islands in the ocean. 'The hounding forest projected and receded in pleasing forms, and the distant outlines appeared graceful. I had no time for searching ont and studying scenery, and perhaps conceptions of beauty and grouping of trees, formed in the artificial school of Britain, are inapplicable to the magnificent scale on which nature hath adorned the country between Chicago and Springfield. 'The works of man are mere distortions compared with those of nature, and I have no doubt many prairies, containing hundreds of square miles, exceed the finest English parks in beauty as much as they do in extent. Sometimes I found myself in the midst of the area without a tree or object of any kind within the range of vision, the surface, clothed with interesting vegetation around me, appearing like a sea, suggested ideas which I had not then the means of recording, and which 
cannot be recalled. The wide expanse appeared the gift of God to man for the exercise of his industry ; and there being no obstacle to immediate cultivation, nature seemed inviting the husbandman to till the soil, and partake of her bounty. Mr Malthus's doctrine, that population increases faster than the means of subsistence, appeared more than doubtful, and involving the unhallowed thought of a Being of infinite goodness and power leaving man, a favoured object of creation, without the means of subsistence. If a considerable portion of mankind ever are in want of food, the eause will be found to arise from human agency, and not from nature refusing to do her part. I felt grateful at beholding a field so well titted to relieve the depressed and starving population of Great Britain and Ireland, while the conduct of their lamd-owning and tithe-eating legislators, in restricting the circulation of nature's bounty, appeared sinful.

It has already been observed, that fire passes annually over the prairies, which may perhaps account for the alssence of clovers and fibrous-rooted grasses, the herbage consisting chiefly of three or four tall growing species, the creeping roots of which escape destruction, and continue to exist without renewal from seed. At this advanced period of the season, the coarse withered grass seemed unpalatable to animals, and the cattle were, generally, browsing on parts which had been burned, with a view of affording a succession of nutritious food. I collected the seeds of many plants without knowing any thing of their usefulness or beauty. On the banks of Meadowcrow creek, a small tributary of the river Illinois, I first met the indigenous hop, apparently identical with that of England, and from the Sangamon brought the leguminous and earth seeds of Glycine Monica, a species of hazel exceeding four feet in height, and indigenous to the whole extent of country through which I travelled on the American continent, and which commonly fringed the prairie, and graduated the change from forest to open plain. 'They were loaded with small nuts, which sometimes satisfied my hunger.

The most numerous of birds were the ruffed grouse, or prairie-hen already described. They frequent roads, particularly in the morning, perhaps to escape from the effects of 
dew, and with the aid of a gun, I might have shot many hundreds of them without leaving the pathway. On the skirts of the forest around Springfield, quails, or partridges as they are called in the language of the country, are abundant, and so tame, that they might have been killed with stones. Notwithstanding the number of such hirds, Illinois cannot boast of gamekeepers, and I only observed one individual shooting grouse. Many cranes, swans, ducks, and wild-geese, were seen hovering above the prairies, and on different occasions I disturled owls reposing amongst withered grass. The forests abounded with green coloured paroquets, which fluttered about with a disagreeable noise, in flocks of six or seven.

Deer were frequently seen bouncling across the plain, and prairie wolves skulking amongst the tall grass. The prairie wolf is a small animal, not much larger than the for of Britain, and whose habits are not widely different. In forests on the banks of the river Illinois, grey coloured squirrels were extremely numerous, and seemed actively engaged in collecting nuts, with which the ground was strewed. Near Pekin I walked a mile or two with a person returning from shooting squirrels, and who bestowed four or five on a woman who asked them for a sick boy. In Canada, the colour of the squirrel is red; in Michigan, black; and in Illinois, grey. The gopher is a red-coloured quadruped, in size and shape resembling the weasel of Britain. It burrows in the prairies, forming passages, and throwing up earth like the mole. It subsists on vegetables, and is sometimes a source of annoyance to the farmer. I was told it is furnished with pouches for carrying earth from its excavations.

The wild bee was the most numerous of insects, and crowded the few remaining blossoms of the sunflow: $r$. The live in the hollows of decaying trees, and a considerable quanti $y$ of their honey is collected by the inhabitants. In the Canadas, the maple-tree supplies saccharine matter, and in Illinois, where this species of plant is rare or unknown, the bee forms the chief source of this commodity. Thus, the maple, bee, and cane, contribute the same ingredient to man, and are illustrative of the economy and diversity of nature.

The country from Chicago to Springfield, through which 
I passed, may be termed prairie, the portion of forest land being quite inconsiderable. In the immediate neighbourhood of these villages, the surface is nearly level, and in the intermediate space, sufficiently undulating for usefulness and beauty. The forest trees on the margins of the prairie are of small size, and chiefly oak ; those on bottom, or interval, land, on the banks of rivers, are of immense size. Forests generally clothe the banks of streams, but sometimes prairies descend to the water's edge, on both sides, and no general rule can be laid down for the prevalence or want of timber. After crossing the river Des Plaines, there was no indication of marsh or wetness of soil, and I only observed one lake, of very small extent. Rocks were not seen protruding above the surface, although stones of considerable size were observed on the wayside. The beds of the rivers Des Plaines, Du Page, and Vernillion, at the places where I crossed, were strewed with stones. The freestune rock, seen in crossing the Illinois, and of which a considerable sized island was composed, was observed for several miles below in the channels of tributary streamlets. I examined seams of coal on the banks of the river Sanganon, in the vieinity of springfield. My view was imperfect, as the seams had never been worked. They appeared about two feet in thickness, of bituminous quality, and fifteen feet above the level of the river. A contract was entered into at the time of my visit, to furnish coal, by removing the incumbent earth, at three cents per bushel.

The soil of this distriet embraces almost every description, from poor sand to rich clay of strong texture. It is of all colours, and generally of superlor quality. The poorest soil was on the banks of the Sangamon, the richest on those of the Illinois. The black sand, of which the prairies are partly com. posed, seems of a penetrating nature, and adheres to the skin like soot. Before being aware of this circumstance, I marvelled at the filthy appearance of some of the inhabitants, who did not wear stockings, and at evening I sometimes found my feet and ankles coated with black dust, after having been washed half a dozen times, in course of the day, in wading streams. The burning of the herbage prevents the accumulation of vegetable matter on the soil, and the creeping- 
rooted grasses, with which it is occupied, perhaps exhaust rather than enrich it. First crops are seldom too luxuriant, and land is said to improve after the breaking up of the prairie.

Agriculture embraces the growth of wheat and Indian corn and the rearing of live stock; but, from the limited number of inhabitants, the cultivated fields form a mere speck on the surface of the prairie. 'The wheat stubbles in the neighbourhood of springfield betokened luxuriant crops, and the height and thickness of Indian corn filled me with amazement. At the date of my visit, 231 September, most of this crop had heen severed from the earth, and was standing in conical piles on the field, where it remains during winter, or until such time as it is wanted. 'There are many kinds of Indian corn, differing widely in habits of growth, and I was unable to determine whether the uncommon luxuriance of that in this district was owing to a particular variety, or congeniality of soil and climate, but I supposed the latter.

The herhage of the prairie, consisting of strong-rooted grasses, is difficult to plough for the first time, and is commonly accomplished with the aid of six oxen. The first ploughing is sometimes performed by contract at $\$ 2$ per acre. 'The plough for breaking up the prairie is furnished with a broad share, and cuts a turf seventeen or eighteen inches broad, by two or three in depth. Indian corn is dropped into every third furrow, a bushel being sufficient for ten acres, and covered with the next cut turf. This crop receives no farther cultivation of any kind, is termed sod corn, and said to yield fifty bushels per acre. A wheat crop follows without a second ploughing, the soil being simply harrowed, receiving half-abushel of seed, and yielding twenty-five bushels per acre. When Indian corn is grown on land not newly broken up, it is commonly planted on hills four feet square, and four seeds are allowed to each hill. The grasses do not appear amongst sod corn, and annual weeds are not often troublesome, until after four or five years' cultivation.

I witnessed the process of seeding land with wheat, during my visit to Mr Humphries. Four oxen were dragging a small harrow, driven by his son, who left them standing while he 
sowed ridge by ridge, and he was the only individual engaged in the operation. The previous crop had been Indian corn, and the land had not been ploughed since its removal. Dung is not applied to the fields, though sometimes to the gardens, in which melons and potatoes are chiefly cultivated. At Springfield, the potato of Britain is not of fine quality, and passes by the name of Irish potato, to distinguish it from the sweet potato, a species of convolcolus. These potatoes seem not to be suited to the same climate. Here, and farther to the south, the sweet potato was of large size, and more palatalule than the Irish one, although not equal to this root when grown in a colder region. I observed a few plants of Gininea corn, which its cultivators said answered as a substitute for coffee, but none of them seemed to have given it a trial.

Clovers, or any description of herbage plant, did not come under my notice. 'The prairie grasses, when clusely depastured for a series of years, full off, and are said ultimately to disappear. 'This circumstance was a source of uneasiness to some settlers, who looked forward to the time when there would be a scarcity of food for cattle, and which seemed to me as irrational as the Canadian farmers' fears of wanting firewood.

I did not see breeding-horses or sheep in any part of my journey, although I have no doubt there are plenty of both in the country. 'The cattle were not numerous, but of good size, and in tolerable condition. The prairie herbage was so completely withered, that I could not form an opinion of its feeding qualities in spring. What had been burned to afford a fresh supply, was so closely cropt by the cattle, that its reproductive properties could not be estimated. In some situations near Springfield, where stock is pretty numerous, and the prairie has been cropt by them for years, the herbage appeared thin and unnutritious. Pigs were frequently seen running about the forest, and were, like all others seen at large in course of my tour, perfect starvelings. 'The acorn season had arrived, and I was amused at the pigs scrambling for this fruit. They ran grunting from tree to tree, and the noise of a falling acorn was the prelude to a race and fight.

The inhabitants are thinly scattered over the country, and chiefly settled on the skirts of the forest, the middle of prai- 
ries being altogether unoccupied, and I was told untaken-up land, or such as had not been bought from government, existed within a mile of Springfield. Proximity to forest is chosen for the facility of obtaining building, fencing, and fuel timber; and a settler regards the distance of half a mile from forest an intolerable burden. The dwelling-places are log-houses, larger than those of Canada, and somewhat better finished. Frequently a nail or piece of iron is not used in the whole erection, the door is without lock or latch, and the beds in the cock-loft lighted by chinks in the walls. In such places, the owners of hundreds of acres and scores of cattle reside. How powerful is habit and fashion in all things! Labour is scarce and highly remunerated. A good farming help obtains \$120, and an indifferent one $\$ 100$ a-year, with bed and board. A female help receives in private families a dollar a-week. The hotel-keeper at Springfield pays two female helps each $\$ 2$ weekly in cash, and told me if it were not for a desire young girls have for fine clothes, he could not get one on any terms. Board, at the hotel, with bed, is $\$ 3$ for short periods, and for long periods $\$ 2 \frac{1}{2}$ per week.

In the Springfield market, butter is worth eight cents per pound, and eggs six cents per dozen. Beef, in small quantities, is worth three, and pork two cents per pound, respectively, and much cheaper by the carcass. Wheat sells for thirty-seven and a-half, oats eighteen, and Indian corn ten cents per bushel. Good muscovado sugar costs ten, and coffee twenty cents per pound. 


\section{CHAPTER XXV.}

Journey from Springfield to St Louis-Jucksonville-Emigrant from Edivburgh-Beds-Face of the Country-Alton-Mississippi-Luxuriant regetution-Bottoms-Mumelle Pruirie-Mr Flint_St Charles-River Missouri-Notices of Nature-Indian Antiquities-St Louis.

DuRING my excursion from Chicago, I was fortunate in weather, which was dry and moderately warm. The temperature increased on the day of my arrival at Springfield, and became so hot on the following day, that I resolved to wait for a mail stage to convey me to the Mississippi ; I accordingly left Springfield, about nine o'clock in the morning, in a small stage, which reached Jacksonville about sunset. A very heavy shower of rain fell soon after setting out, and covered the roads four or five inches deep with water, the level surface and want of ditches preventing its escape. The passengers dined by the way, and chiefly consisted of clerical students, on their way to Jacksonville college. From their conversation with each other, I learned they had lately been engaged in teaching in different parts of the country, and felt much anxiety about speeches they were soon to make, and which were already written, and had been revised by friends. They were plain in dress and in manner, bordering on what is called homespun in Britain; and they sung most beautifully while in the coach.

Jacksonville contains about the same number of souls as Springfield, but is superior in buildings, arrangement, and situation. Many of the houses consist of brick, and the hotels are large and commodious. The country in the neighbourhood is consilered populous in this part of the world, and has been settled for a considerable length of time. I was anxious to see the farm of some Englishmen, whose skill I had heard extolled, but want of time and light denied me this gratification. 
I had been intrusted with a letter to a gentleman in the vicinity of Jacksonville, who formerly resided near Edinluurgh, and which I would have delivered persomally, had I not heen informed, when approaching springfield, that he had lately moved from his first situation into the territory of Arkatnas. On this intelligence, I put the letter into the post-office, and a few minutes afterwards learned, from unquestionable anthority, that my first intelligence was incorrect. Fincling the stage did not leave Jacksonville until two o'clock in the morning, I resolved to visit the gentleman, who residerl about three miles from the village. The moon being nearly full, I had little difficulty in reaching his dwelling. It was late before Mr $\mathrm{L}$ __ male his appearance, who happened to be dining with $\mathrm{Mr} \mathrm{K} \longrightarrow$, but the interim passed pleasantly in the company of Mrs L_, whom I had seen in East Lothian, and a sensible Irishman, who had settled himself about a hundred miles higher up the Mississippi. The house was a log erection of two apartments, and the family seemed to possess every necessary of life. Want of light prevented me seeing the farm, and forming an opinion of the prospects and circumstances of this emigrant.

On returning to Jacksonville, I found some of the stagepassengers partaking of coffee before setting out on the journey. The vehicle was well filled, and contained a young married woman labouring under ague. Some of the passengers were agreeable and communicative. We passed through Carlton, dined at a solitary log-house, and reached Alton sometime after night-fall. The hotel being crowded, there was difficulty in accommodating the passengers, and I was asked to take half a bed. I assented to this arrangement, but added I was a foreigner, and not likely to make the most agreeable companion to a native, on which account I would feel obliged to have, were it possible, a bed for myself; the landlord indulged me. By following this policy, I invariably obtained a whole bed in hotels, and it was only in the huts of the remote parts of the country, where beds could not be obtained, that I did not sleep alone.

The misrepresentations of American character, in connexion with beds, are frequently met with in Britain, and of which the 
following anecdote, related by one of my friends, may serve as an illustration. 'Two Englishmen, travelling in a hired carriage, reached a lonely inn at a late hour, to which they got admittance, and, after much solicitation, at length each took possession of a bed. In a short time afterwards, the driver wished to share one of the beds; an altercation ensued with the first possessor, who reluctantly yielded, in preference to maintaining his position by animal strength. However much the brutality of the driver may appear to be set forth in this anecdote, the traveller was the more culpable of the two. In such a climate as that of the C'nited States, where people can move from place to place in carriages of any description, every body will prefer the whole of a bed to a part, and the cireumstance of the driver wishing to lie down beside the Englishman, is evidence that a third bed could not be olstained. In all probability, the customs of the district and sentiments of the driver, placed both individuals on a footing of equality, and it was unreasonable to attempt to exclude him from a share of comfort, and more especially if the family put themselves to inconvenience in furnishing the beds. If the Englishman disliked nestling with the driver, he might have crept in beside his friend, or quietly betaken himself to the floor. I remember arriving at a large and well-conducted inn at Melrose, Scotland, on the evening preceding an annual lam? market, and learned that on such occasions travellers could only have half a bed. In course of the evening, the water whispererl that my companion wished to retire for the night, and pointed him out on the opposite side of the table. Hie was a profligate and well-known character, and nearly intoxieated to insensiluility. 'To have shared his bed was an idea revolting to my feelings, and, after requesting that he might be shown to a room, I stretched myself on chairs for the night.

'The two foreign gentlemen, in whose company I travelled from. Detroit to Chicago, earried along with thein a bed tick of air-tight eloth, which was occasionally filled, and reposed on by one of them. This is a very portable hed, and will be found agreeable to travellers frequenting the wilds of America, who do not dislike being encumbered with luggage. A robust 
person who dreads such aceommodation as the country affords, will do very well with the aid of a clock to wrap himself in during the night.

The country from Springfield to Alton, by way of Jackmonville, is a succession of prairies of a different character from those formerly seen, their surfuce being almost perfectly level, and in many parts indicating wetness. The soil did not always appear rich, more especially towards the conclusion of the journey. Darkness prevented me seeing much of the country around Jacksonville, but I saw a small patch of clover, which was the ouly instance I observed this plant in Michigan, Indiana, Illinoiz, and Missouri.

Alton stands on the east bank of the Mississippi, about one mile above the junction of the Missouri, and sixteen below that of the Illinois. It consists of two irregular villagres, called Cpper and Lower Alton; the population is stated at about 700 souls. This place is likely to become the chief port of Illinois on the Mississippi, and is already the seat of considerable trade.

On leaving my bedroom, on the morning after arriving at Alton, the Mississippi was seen flowing before me at a few yards' distance, and my first proceeding was to fetch part of its water in a jug for morning ablution, the number of travellers in the house rendering some exertion necessary to get washed and shaved in time for breakfast. On leaving the hotel, I walked down to the junction of the Missouri, and returned to Alton, where I crossed the Mississippi in a horse ferry-boat. The stream is more than a mile in breadth, flows at the rate of one or two miles an hour, and is slightly turbid. The situation of Alton, from the opposite side of the ferry, is beautiful. An island divides the river, which, being land-locked above and below, has the appearance of a lake. The western bank is low, the eastern high and rocky, terminated by wood on the summits of the bluffs, as the projecting knolls or hills on the banks of some American rivers are called. The rocks are partly sand and partly limestone.

Here I observed a steam grist-mill; the under part of the building was composed of stone, as high as the water of the river would reach in floods, the upper part being of wood. 
The building was founded on rock, and stones might have been had for the upper stories, by laying a plank from the building to the rock on the rising bank.

The purpose of my present excursion was to view the prairie in the neighlourhood of St Charles, at the foot of the Mamelles, so beautifully described by Mr Flint, whose account is given as a quotation in Mr Stuart's "'Three Years' Residence in America." The description excited my imayination at the time of first reading it, and was imprinted on my memory till effaced by seeing the olject hefore me. St Charles is about twenty-six miles from Alton, and as there was no regular conveyance between the places, I did not regret the necessity of walking, which would afford me an opportunity of travensing the narrow neck of land, separating two of the largest rivers before their junction in the most fertile and extensive valley on earth, as well as of examining the modern paradise of my imagination.

'The road from Alton to St Charles passes up the west bank of the Mississippi for above a mile, and fur ten or twelve through its densely wooded bottoms, at no great distance from the river before the prairie is reached. On attaining the opposite side of the ferry, the exuberant and varied vegretation excited my admiration, and far surpassed every thing $\mathbf{I}$ had seen on the banks of the Illinois and its tributaries. The height and circumference of the trees are immense, and such was the rankness of vegetation, that I culled several leaves from young shoots of the button-wood two feet in length. The climbing plants were in proportion to the rest of the vegetable family, reaching the summits of the most gigantic trees; sometimes three species were clinging to the same trunk, and seemed vying with each other in richness and beauty. The vines particularly attracted my notice. This plant is common in most parts of North America, and its foliage is beautiful in the neighbourhood of Montreal. Here the stem of the vine was occasionally seen nearly a foot in diameter, issuing from the earth twenty or thirty feet from the root of the tree which supported its branches, and stretching seventy or eighty feet before coming in contact with the trunk, forming, together with its supporter, a striking representation 
of a massy flag-staff. I had difficulty in accounting for the form which the vine presented. Both plants may be considered corval, and their boughs to have extended in unison. fome tender twigs of a vine were observed climbing and twining around its aged stems, leading to the supporting tree, which seemed to me illustrative of maternal affection, and of the hackneyed phrase, "teaching the young idea how to shoot." There were some trees of diminutive growth-overhanging the river, from the tops of which the tendrils of the vine hung in graceful festoons, as if wooing the water. From such I collected fruit, and discriminated several varieties by the form and flavour of the grape.

At first the clear and wide-spreading prairies delighted me from their novelty, and the contrast with the dense and interminable forests of Upper Canada, and I now enjoyed the umbrageous regetation of the Mississippi bottom, after having become familiar with the nakedness of the prairie. All the rivers of magnitude in the valley of the Mississippi seem to have occupied, at a remote period, higher elevations and wider channels than they now do, called first and second banks, and the flat space on the margins of their present channels passes by the name of bottom, which generally consists of alluvial depositions, annually augmented by the overflowing of the waters at the melting of the snow. 'This bottom of the Mississippi was undescribably rich, and I was so engrossed by the wonders of its shadowy vegetation, as to be insensible of the approach of rain and thunder, until torrents fell around me. Shelter was obtained from the inclining trunk of a large tree, and the foliage of many of the climbing plants formed vegetable umbrellas.

The soil of the bottom is of considerable tenacity, and the rain rendered it unpleasant and fatiguing to walk on. The road diverged from the river at an uninhabited brick house, and I did not see a human being for eight or ten miles. Some of the houses seemed to have been deserted, and no recent settlement made. In one situation there was a large and well-grown orchard, from which I gathered most excellent apples. There were few traces of cultivation, and Indian corn was the only agricultural production on the soil. 
Weeds, which in other situations were observed of diminutive size, here attained magnitude, and I estimated the height of some Indian corn at twenty feet; amongst this crop purple coloured convolvoluses were twining, the seeds of which were added to my collection. On examining some wheat ricks, I found the straw covered with mildew, and the grain shrivelled skins. Fertile as the Mississippi bottom appeared, it bore no traces of human enjoyment.

On entering the prairie, which is clevated a little above the bottom land, two lines of road diverge, and I was directed on that leading to St Charles, by two men of colour chopping firewood in front of a house, who, in all probability, were the first slaves I had ever seen, Missouri being a state in which slavery is tolerated, and in which I had travelled since crossing the Mississippi. My way, for a considerable distance, was over a waxy soil covered with water, the road being bounded with tall grass, over which I could not see. (On attaining a higher elevation, the rank grass disappeared, the soil became dry, and for miles was of poorer quality than any I had seen since leaving the shores of Lake Michigan. The soil, which was worn into inequalities by the action of wind and travellers, was repeatedly examined, and the opinion which I formed was corroborated by the thriftless and stunted vegetation on its surface. On leaving the bottom there were some spots covered with clover, and the finer descriptions of grass, closely cropped by cattle, which formed the only verdant palsturage I had met with since leaving Amherstburgh in Cinada. My progress over the wet roads had been slow, and I felt fatigued and hungry. On applying for bread at a log-house, the inmates cheerfully oftered to prepare some for ine, but I departed after quathing a glass of water. 'The soil improved, without becoming very rich. Some people were engaged in sowing wheat, and several herds of cattle were observed. On the left-hand side of the road there was a narrow and extensive sheet of water, covered with weeds and water-fowl, and seemingly connected with the Missouri. Light disappeared before I reached St Charles, and several miles were traversed in darkness.

I did ample justice to the viands set before me at St Charles, 
sitting at table with the landlord and his wife, and tencled by a female slave, who was addressed by all in terms of civility. The landlord was a Virginian, and had lately commenced hotel-keeping at St Charles, in consequence of having been unfortunate in another calling in the place of his birth. I found him kind and gentlemanly in manner, and communicative and intelligent on a variety of subjects. He presented me with a glass of wine, as made from the grape of the country, and which I considered good.

In course of conversation I learned the landlord intended going to St Louis next day, immediately after breakfast, and he agreed to give me a seat in his waggon on the same terms as the regular conveyances carried passengers. Before groing to bed, it was arranged that I should visit the Mamelles in the morning, and at daybreak I found a horse waiting for me, which proceeded over the ground at a rapid pace. 'The road leading from St Charles to the prairie passes through a rich and beautiful country, something like a narrow valley, with swelling heights to the west, the opposite side forming good farms. I followed a diverging pathway leading up the ascent, and soon found myself on the brow of an eminence, commanding an extensive view of the prairie, over which I had travelled the preceding evening. The scene was so different from the conceptions I had formed of it, that I fancied myself occupying a wrong position, and seeing a cottage on the plain below, I descended to ascertain the point. On asking for the Mamelles, a person pointed to a bluff a few hundred yards distant, forming the termination of the ridge I had just left, and considerably more to the east than the spot where I had been. Leaving my horse attached to a railing in front of the cottage, into which I was invited, I ascended the Mamelle on foot, from the top of which the scene was unvaried from that I had seen before, with exception of the addition of part of the small valley running towards St Charles, and which seemed the most interesting part of the landscape. Strong indications exist of the Missouri and Mississippi having once united their waters at this spot; and if such was the case, the prairie must then have formed the bottom of a lake, and become dry when the rivers assumed a lower level. The prairie 
is bounded to the west by the ridge of bluffs, of which the Mamelles form a part; and to the east by the forest on the Missouri and Mississippi bottoms. On the north the Mississippi curves gracefully round the margin, and its bold eastern bank forms a beautiful outline. The centre is monotonously that ; and at no great distance from where I stood were two insignificant clumps of stunted trees, which aftorded no relief to the eye, and excited ideas of sterility. Excluding the pretty valley stretching towards St Charles, and which cannot with propriety be considered as forming part of the prairie, half-adozen of hamlets could not be numbered, and there was a total absence of animated life. The rich blossoms of the various plants which impart delight to a lover of nature, had yielded to the influence of the season, and autumn had seared vegetation. The long narrow stripe of stagnant water which I had skirted the night before was a conspicuous feature, and suggested ague and pestilence. The view from the Mamelle was found to be extensive, but not pleasing; and, hurrying from my elevated position, I scampered off for St Charles.

Mr Flint, in speaking of this prairie, says, "It yields generally forty bushels of wheat, and seventy of com, to the acre. The vegetable soil has a depth of forty feet, and earth throun from the bottom of the wells is as fertile as that on the surface. Here are 100,000 acres of land of this description fit for the plough."

I am of opinion there is not a square inch of such soil as $\mathrm{Mr}$ Flint deseribes. But in differing with him on the merits of this prairie, I must not forget that the impressions of a scene are always affected by the circumstances under which it is viewed, both with regard to nature and the individual himself. The weather was unfavourable at the time of my visit, which was on the 1st of Octoher. Thick clouds obscured the sky, and were scudding before a cold and tempestuous west wind. The ground was drenched by rain which had fallen in course of the evening, and strewed with leaves and branches torn from the trees by the violence of the storm. Personal circumstances were more favourable than those of the weather for forming a just estimate. Having already traversed part of Michigan, Indiana, and Illinois, 
the novelty and excitement at iny first introduction to prairie scenery had sulssided. I enjoyed the highest degree of mental and bodily vigour, was at peace with the world, and favourably predisposed towards the object. Mr Filint was differently situated. But perhaps an American poet and a Scottish clodpole will ever view things through a different medium. 'The means which I had of forming an estimate of this prairie were anple, and the simple fact of it being still almost uninhabited, while thousands of settlers have passed over it to more distant locations, may be taken as proof that my estimate is substantially just. Having spoken of $\mathbf{M r}$ Flint as a poet, it is but justice for me to say I have alone formed my opinion of his endowments from the account he has given of this prairie, which seems to have been written with poetic license. "The prairie itself," he says, "was a most glorious spectacle, - such a sea of verdure, in one direction, extending beyond the reach of the eye, and presenting millions of flowers of every scent and hue, seemed an immense flower-garden." 'This is a description of a prairie, in lat. 3!?, in the month of September, when the luxuriance and brilliancy of vegetation is past. But it was "the first prairie of any" great size or beauty" he had seen. To me, who had alrearly become acquainted with the fertility of such places, and formed opinions of their utility in relation to civilized man, the scene was associated with the disease and destruction of the human race, and not their enjoyment and support.

Had the season of the year and state of the weather been more favourable for viewing this prairie, I might have admircl its beautiful outlines; but under no circumstances would it have possessed the interest of the landscape seen from the heights above Ottawa on the river Illinois. Here extensive prairies are seen stretching on every hand, with beautiful undulating surfaces, and adorned with masses of forest of every shape and size. The junction of the Fox River with the Illinois is in the foreground, and their banks are either forest or prairie, in keeping with the surrounding surface. Both rivers are of moderate size, and the flowing of their limpid waters imparts life to the landscape, which combines all the soft beauties of prairie scenery, and excites associations 
connected with human happiness. Settlers are yearly taking up their residence in this quarter, and the junction of the Illinois with Lake Michigan, by means of a railway or canal, which the state has undertaken to construct, will insure its early settlement.

St Charles is one of the many places in the Western States, founded by the French, which they partially explored in the early part of the eighteenth century ; and the descendants of the first settlers are still met with throughout the course of the St Lawrence and the valley of the Mississippi, possessing the language, manners, and customs of their forefathers. 'The population is stated to be above 1200 , and to consist of nearly equal numbers of Americans and descendants of the French. It is washed by the Missouri, and has increased considerably in wealth and population of late years.

Immediately after breakfast the landlord of the hotel, whose name has escaped my memory, conducted me over the rocky banks of the river to the horse ferry-boat, on board of which was his waggon and handsome pair of horses. The boat proceeded up the north bank for nearly a mile before crossing the stream, and the horses by which it was propelled were considerably distressed, and generally blind and in low condition. The Missouri possesses a difterent character from any river I had seen before. Here its breadth is about half a mile, the waters running impetuously between wooded banks, and so turbid as to exceed in muddiness the water of British streams after the most copious rains. The islands and banks seem to be constantly changing, and strewed with fallen trees, having their tops in the stream, and their roots on land. The water of the Missouri is said to undergo little change in consistency or colour, which is whitish, except during severe frost, when it contains less mud. The state of the waters of the Missouri is thought to be owing to the washing away of the banks, and it is difficult to account for it on other grounds. The course of the river before reaching St Charles is not much short of 3000 miles, and I have not been able to learn the state of the waters towards its source, or that of its tributaries at the places of junction.

On reaching the opposite side of the Missouri, we travelled 
over two miles of bottom resembling that of the Mississippi opposite to Alton, but not quite equalling it in vegetable luxuriance. The surface was wet from the rain that had fullen, and the only inhabitant seen was so feeble and emaciated, that his life was likely to be of short duration. On passing the bottom, we had about twelve miles of highly-undulating surface, consisting of red-coloured clay, of fertile quality, thinly wooded, and partially settled. For nearly six miles, before reaching St Louis, the road passes through a prairie country of undulating red clay, and apparently speedily getting into forest. The landlord told me he had visited this district many years before, which was then without a tree. 'There is a race-course within three miles of St Louis, which appears well frequented.

I had hitherto observed the vine growing chiefly by the sides of lakes and rivers, but here it was growing on the highest and most elevated situations, loaded with fruit. The prevailing tree on the partially wooded part of the road was oak. I first observed the catalpa-tree in the streets of St Charles, and the persimon, in travelling to St Louis. 'This fruit was disagreeable to my palate, and did not improve on a second trial some days afterwards.

Throughout my tour in the States of New England and Upper Canada, I had found the soil of all districts where the surface was considerably undulating, uniformly of inferior quality. Michigan presented the same appearance, and on a few of the prairies I fancied I could trace the same feature. I had considered the subject on different occasions, and began to draw a general conclusion, which this day's experience completely upset. Here the surface was one of the most undulating I had travelled over, and uniformly of fertile clay. I afterwards found some of the swelling grounds of Ohio of this character.

We met and conversed with the members of several families moving into Missouri, with the view of settling in the remote parts of the state; and I met one before crossing the Mississippi, on his return from it, in consequence, he said, of its unhealthiness. Local attachments seem to be the sheetanchor of man, and when they are once broken, or exist weakly, he becomes restless, and unhesitatingly follows any 
ignis fatuus that may dance before his imagination. From this source the erratic habits of the American population may perhaps arise, as well as many of their peculiarities of manners and customs. But without pursuing this subject into its various ramifications, I may remark that the temporary houses, fences, and generally uncomfortable nature of a Western American farmer's establishment, may be the result of constantly looking forward to departing from his residence, and seeking to have little property but what can be easily transported.

On reaching St Louis, I found the hotels crowded; my first two applications for accommodation being unsuccessful, I at last gained admittance into a secondary hotel, to which I was recommended by the landlord from St Charles. I slept in an apartment containing two beds, which were occupied, and the arrangements and customs of the hotel were similar to those I had hitherto frequented. Two days were spent in St Louis and its neighbourhood, on both of which I examined some mounds, or tumuli, of a former race of people, some of which are on the north skirts of St Louis, and many more on the opposite side of the river.

These mounds are found over the whole of the valley of the Mississippi, and many conjectures exist regarding their origin. They are found of all sizes and shapes, from the finished pyramid to the perpendicular square, a few feet in height. Suon after my arrival at St Louis, I found one in the town, of an oblong shape, fifty yards in length, and finished with a regular pitch of about forty feet in perpendicular height, while another, at a short distance, with sloping sides, had an unfinished top thirty-four by forty-four yards. Some tumuli have been examined, and found to contain immense quantities of human bones and broken pottery, which has given rise to a general opinion that they were the burying-places of former ages. Besides tumuli there are other antiquities of forts, camps, or towns, the best specimens of which are in Ohio ; and a fort in the neighbourhood of Newark, in that state, contains forty acres within its walls, which are about ten feet high. The Indiaus of the present day in the northern and middle parts of the valley of the Mississippi, are neither sufficiently numerous 
nor skilful to erect such works, from which some people argue the antiquities belonged to a different race, which precerled the Indians. It is of no consequence to the existing portion of the human race by what beings these remains were erected; and the grounds for believing the Indians to have decreased in numbers, and retrograded in civilisation, are much stronger than those for conjecturing them to have been preceded by a distinct and more skilful people.

St Louis stands on the west bank of the Mississippi, 1200 miles above its junction with the sea, 200 alove the confluence of the river Ohio, and 18 miles below that of the Missouri. Its situation is sufficiently elevated above the river, the banks of which are limestone. There is a row of stures fronting the river, built of stone, and the town consists ehiefly of two streets of brick-houses, running parallel to the river, the outskirts being mean wooden houses. This is a place of extensive trade, being the chief depot of lead, which is furnished in vast quantities by the states of Illinois and Missouri. Grist-mills and other machinery are propelled by steam. I counted sixteen steam-boats on the river, exclusive of one plying as a ferry-boat.

The city was founded by the French in 1764, and about onethird of the inhabitants are their descendants. 'The American population now preponderates, but there are numbers of all nations, including many Spaniards. It is the chief place of wealth and trade on the Mississippi, with exception of New Orleans, and may justly be considered the metropolis of the valley of the Mississippi.

I visited the market night and morning, which was abundantly supplied with every necessary, brought forward by farmers from all parts of the country, and not retailed by stall-keepers. Many well-dressed white ladies, and blacks of both sexes, carried baskets over their arms, and were making purchases, but I did not observe a white gentleman. Here I first saw the egg-plant. For hen eggs $9 \frac{1}{2} d$. a-dozen, and for skinned squirrels $1 \frac{1}{2} \mathrm{~d}$. each, sterling money, was asked. 


\section{CHAP'TER XXVI.}

Voynge from St Louis to Cinciunati-Mississippi-Ohio-Fulls of the Ohin-Passengers-Detuils of the Vuyage-Dotices in Natural Ilistory-Vessels on the River-Louiseille-Hotel_- Steumbouts - Inquisitive Irishman - Toluecen-squirting AmerieunAdecuntages of Shubby Attire to Trueflers-.Mr Hamilton's Account of Men and Manners in the Western Steam-boutsCincinnati-Agricultural Notices.

Having made up my mind to pay a second visit to Upper Canada before returning to Britain, and wishing to take Cincinnati in my way, I hesituted whether to proceed by stages, through Illinois and Indiana to Louisville, or by a steam-boat down the Mississippi, and up the Ohio. Having more than once experienced the deceitfulness of information obtained from stage-office people in Britain, and disliking the information got at the oftices of St Louis, I determined on travelling by water, and, learning the Helen Mar was to sail in a few hours afterwards, I immediately secured a berth.

The Helen Mar was a boat of the smallest size, and on this account well suited for the voyage at this season of the year, when there is a want of water in the Ohio for vessels of the second class. She proceeded at a rapid rate down the current, and made the first stop at Jefferson Barracks, ten miles below St Louis, on the west side of the river, where we were detained until night-fall, by receiving on board some officers of the United States army, with their families and luggage. In course of the night, one of the shafts broke, and the vessel continued her voyage with one paddle.

I found the Mississippi a very different looking stream from what it was at Alton. Instead of being a placid river, gliding gently between beautiful banks, it had assumed the character of the Missouri, impetuosity, muddiness, and devastated margins. In sailing down the Mississippi below St Louis, we 
were said to have passed the most interesting scenery in the night, and there was little seen by me calculated to impart pleasure or relieve the eye. The dense, and at this season, gloomy vegetation on the banks and islands, reminded me of the Lake of the 'Thousand Isles, at the opening of the Sit Iawrence. The turhid torrent, boiling and whirling in a thousand directions, was washing away the banks at one place, and leaving depositions at another. Indian corn was seen falling with masses of earth, and mingling with the stream, and uprooted trees, suspended from the banks with their branches under water, as if experiencing suffocation. Everything suggested to the mind desolation, and led me to think this such a river as despairing man might choose for his last plunge. 'The whole day was spent on deck, and I felt my spirits sinking when we approached the mouth of the Ohio, which forms a striking contrast to the Mississippi. The Ohio at its junction with the Mississippi, called by the Indians "the Father of Waters," is broader than the parent stream, and after the junction of three such rivers as the Missouri, Mississippi, and Ohio, their mingled streams do not appear larger to the eye than any of them singly, which arises from the depth and rapidity of the united current. The same difference of colour in the waters which I had remarked at the confluence of the Ottawa and St Lawrence, and of Missouri and Mississippi, were here perceptible. The limpid and placid Ohio, dammed up by the larger stream, and resting without motion between smooth and verdant banks, resembled the stillness of sleep. The Mississippi was like maddened intoxication. Well might the French of old, after traversing the death-like Mississippi, and becoming acquainced with the Ohio, term it La Belle Riviere, the beautiful river, a title it justly merits. For some time the winding course and full stream reminded me of sailing on a lake, yet the banks are monotonous, being thinly settled, with the background hid from view, and but for the lovely tints which autumn had imparted to the foliage, would have been without much interest. On advancing up the Ohio, the channel became bound by sand plains, which are covered when the water is high, and many of the banks of the numerous islands showed, by the size of the trees, the successive 
depositions that are mate to them, and I was enalsled to count six rows of the same species rising in different gradations.

We at last reached what are termed the Falls of the Ohio, a name given to a succession of rapids, caused by a stratum of rocks crossing the channel of the river, and form the only obstruction to navigation in the whole course of the Ohio. The falls are about two miles in length, and the descent in that distance twenty-four feet. When the river is high, vessels pass up and down the falls, and when low, through a canal lately opened on the south side of the river, commencing a little below Louisville, and extending nearly two miles. 'The Helen Mar had some difficulty in getting over a bar and rapid below the entrance to the canal; on reaching which I walked forward to Louisville, over a verdant smooth turf, which I enjoyed greatly, after so long an absence from nature's best carpeting.

The water in the Ohio was still low, although our captain had often been told on the voyage the river had risen eighteen inches in course of a few days. The rising of the Ohio and most of the western rivers in uutumn is observed to take place annually, without a considerable fall of rain occurring in the lower part of their courses. This is generally accounted for by the diminished temperature of the atmosphere lessening evaporation on the earth's surface. In all probability it is more owing to suspended veyetation, the falling leaves and decaying herbage ceasing to throw off moisture.

In the course of our voyage from St Louis to Louisville, a distance of six hundred and thirty miles, passengers were received and landed at many intermediate places, but the majority of them continued the whole distance. My time being spent chiefly in viewing the different objects on the rivers and their banks, I did not become intimate with any individual, except one, Mr Gemble, with whom I afterwards travelled by stage to Columbus in Ohio, and met at the Washington Hotel, on my return to New York. In course of conversation I learned he resided at St Louis, had travelled in the Rocky Mountains, and was on his way to the eastern shore to visit an aged parent. We spent a considerable part of fourteen days in close conversation, without making the 
slightest enguiry into each other's birth, parentage, or past and present pursuits in life. On leaving St Louis, I observed him reading several books which he took from his portmanteau, and left exposed on his berth, as if to court others to read them. My only companion of this kind at the time was a small volume, entitled, "a View of the Vulley of the Mississippi," which I often referred to, and found useful, and which Mr Gemble asked me to allow him to look at, although travellers in American steam-boats generally seize on every book within reach, without obtaining the consent of the owner to peruse it. I had thus an opportunity of asking a return of the civility of Mr Giemble, which he readily granted, adding, "I would be happy to allow every person on board to read my vulumes." 'The first that I opened was one of small dimensions, entitled, "The T'imes of C'hrist," which the preface stated to be from the pen of the gifted Harriet Martineau, which appeared in England as the "Traditions of Palestine," and had been reprinted with a more suitable title, and the omission of some matter which the publisher did not consider in good taste with the rest of the work. The other volumes were of a religious nature, which might have led me to suppose Mr Gemble a spiritual teacher; but there was nothing in his conversation or deportment marking or violating this character. He was a tall, thin gentlemanly-looking person, well informed, and apparently possessing as much real philanthropy as any individual $\mathrm{I}$ ever met.

The other passengers consisted of both sexes, of all ages, and of different professions. The ladies were never seen but at meals, keeping their own cabin at other times. The gentlemen were well dressed, and invariably civil to each other, General A__ being the least polished in manners and appearance of any of the company. The captain was an unassuming person, whose voice was seldom heard, and never in connexion with an oath, either in the cabin or amongst the crew. There was only one cabin passenger addicted to swearing, who had formerly been captain of a steam-boat on the Mississippi, and was now engaged in trade at St Louis. The officers of the army, and one or two others, passed part of the evenings in playing cards, at a game which I did not under 
stand, and at which they did not seem to hazard high stakes. On such occasions, I was sometimes amused at the group assembled around the table. Military men of the highest rank, when eagerly intent on the game, were joined by the steward boys without their coats, familiarly seating themselves at table, and looking on the hands of cards. The chewing and spitting of tobacco were incessant, the carpet serving as a receptacle for the moisture, when boxes were not within immediate reach; and on some cold evenings the fire in the cabin was almost overcome by squirting of tobacco juice.

The comfort of the passengers was little attended to in the general arrangements of the vessel. Three times a-day, at breakfast, dimner, and supper, which also includes the repast known in the Eastern States, and in Britain, by the name of tea, the table was stored with supplies of animal food and vegetables, so very ample, that on one oceasion I numbered thirty-one dishes placed on the supper-table for twenty-two passengers, and, perhaps, in no instance was there ever less than one dish for each individual. The food was coarsely prepared, and all placed on the table at once, and nearly cold before the company sat down. 'There was always a second company, consisting of part of the boat's establishment, and such deck passengers as chose to pay for their food; and sometimes a third company collected, independent of the people of colour, servants or slaves to the passengers, and who satisfied their hunger on the veranda. 'The succession of companies received no additions to the fare originally placed on the table, and such an injudicious arrangement was the means of rendering it less palatable to all. 'The vessel called three or four times a-day at different places, yet, on one oceasion, bread could not be had for breakfast, and milk or eream were more than once awanting without any notice being taken of it at table. There was no water for drinking or washing but what the rivers supplied, and this was even the case on the turbid Mississippi, the water of which was allowed to separate from the sediment before being presented at table. The inhabitants of the Western States are considered by those of the Eastern ones as wanting in refinement, and the table being loaded with the substantialities of life, while good water 
and milk, two of the most desirable of liquids, and which might at all times have been obtained on shore, were awanting, appeared a strong indication of cuarseness. The pasmengens drank in the greatest moderation in my sight, only taking a tumbler of spirits and water oceasionally when playing at cards, and never tasting wine or any kind of spirits at table at other times. I did not ohserve a person of any description on board, during the voyage, that appeared in the least degree intoxicated. The water for washing was always fresh drawn from the river, and I thought the Mississippi more likely to stain than clean any face. Many of the gentlemen attempted to clean their teeth and mouths with such mud, which I did not pass within my lips. My dressing-case did not contain soap, which I thought an article likely to be had everywhere, but on application to the steward, I was told there was none on board. An application to the captain, or some of the passengers, would have procured me this commodity, at least for shaving with, but there was something so ungracious in the steward's refusal, that I was unwilling to hazard another denial. From necessity I had learned to shave without a mirror, while in the northern parts of Illinois, and now attempted the operation without soap, which I found so easy, that I continued the practice until reaching New York.

The cabin being in the stern of the vessel, I spent much of my time in the forecastle, for the purpose of seeing the scenery, which brought me in contact with the crew, and many of the deck passengers. In this class of people $I$ found a considerable change of manner from any I had formerly come in contact with. Many of them swore disgustingly, and possessed a general levity and coarseness of manner, but in no instance did I experience incivility.

I had witnessed a great many cases of fever in course of my journey, and the accounts received in Michigan, Illinois, and Missouri, represented the season as unhealthy, and the population suffering considerably from its effects. On reaching the Mississippi I learned cholera had scourged the inhabitants in a dreadful manner, in the course of summer, and had now subsided. Several cases of fever occurred amongst the deck passengers during the voyage, and a poor child sunk under its 
attack. A rude coffin was prepared by a person on board, and the remains of the little innocent were interred at Smithland, on the mouth of Cumberland river, Kentucky. On the third day of the voyage, one of the firemen, a man of colour, became unwell, and I olsserved him rolling about near the furnace, and suffering much, unheeded by those around him. At last the attention of the captain was called to him, and the services of a medical gentleman, who was a cabin passenger, were requested. He pronounced it a bad case of cholera, and the poor fellow was carried on shore soon afterwards in the agonies of death. The consternation on board was great, and many of the passengers deserted the vessel.

Towards the mouth of the Ohio, vast numbers of geese were seen sitting on the extensive sand bars. 'The deck passengers often fired rifles at geese and other birds without effect. 'I wo or three bald-headed eagles were seen quite near the vessel, and on Diamond Island five or six wild turkeys were observed running from the side of the river into the forest, and was the only time this bird was seen in a live state by me.

The vessels on the waters in the valley of Mississippi burn wood, and supplies are found everywhere on the banks of the rivers, which are speedily conveyed on board, with the assistance of the deck passengers, who are bound to aid in the operation. During the time of taking in wood, I almost universally examined vegetation on the banks, and obtained many new seeds by so doing. I also had an opportunity of conversing with the inhabitants, who, in such situations, depend chiefly on this trade for the means of sulisisting. = I was surprised at the vessels not using coal, which is very abundant in many places on the banks, and could be easily transported to places where it is not. I am satisfied coal would be found cheaper than wood, and if depots were formed, and provided with a crane to put the coal on board, the saving of timewould be considerable in course of the royage. None of "the furnaces are, however, at present constructed for burning coal, and a considerable time is likely to elapse before it gets a fair trial.

In coming up the Ohio, I observed a great number of boats, or rather boxes or arks, of various sizes and shapes, floating 
down the river towards New Orleans, filled with farm produce, including sheep. 'These arks are built of strong timhers, fitted up with apartments for the navigators, and sold on reaching New Orleans, the crews returning by the steamhoats. The numerous steam-hoats do not seem to have diminished this mode of conveying farm produce, and probably many of them are built on shallow streams in the interior of the country, where steam-vessels never can have access. 'These arks are simply kept in the current, which floats them down, and in this country, where the farmer has so much leisure time in autumn and winter, must be a cheap mode of conveying produce to market.

Louisville is situated on the south loank of the Ohio, at the mouth of a small stream called Bear Grass, in the State of Kentucky. It consists of several streets running parallel to the river, and the houses are composed of brick. 'I'here are many steam-engines employed in sawing wood, grinding wheat, and other purposes. Louisville is the most thriving place on the waters of the coast connected with the Misissippi, and contains about 14,000 inhabitants; it is 1448 miles distant from New Orleans by the river, and 590 from Washington.

On arriving at Louisville I could not obtain aslmittance into either of the two principal hotels, and afterwards had sufficient evidence to satisfy me the denial was entirely owing to my shabby appearance. My third application was at the American Hotel, a large and excellent establishment; and feeling somewhat annoyed at the manner of my previous refusals, I asked the bar-keeper if he would accommodate me for the night, and he answered in a smart tone of voice, "Certainly, sir; we are servants of the public, but I hope you will eat something." The inmates of the house were assembling for supper in the Exchange room, and on ringing the bell, the rush up stairs into the banquetirg apartment was excessive, there being nearly two hundred individuals assembled. The company were settled down at two large tables, and every thing passed off well, but not in the same quiet way I had observed at other large establishments.

The gentlemen were fashionably dressed, and several of 
them swore and stormed at the waiters in a manner I never witnessed elsewhere in America, which was perhaps owing to this being a slave state, and the individuals themselves slave owners. The waiters were chiefly people of colour; and much as I did feel disgusted at the language which in two or three instances was directed to them, yet I had often heard waiters in Britain similarly addressed.

My bed was in a small apartment, indifferently lighted, in which were two bedsteads. The Exchange-room was as well filled in the morning with expectants for breakfast as it had been in the preceding evening; and although Louisville is in a slave state, and the establishment of the hotel chiefly composed of such beings, a white person, well dressed and of good appearance, stood at the entrance of the house with the room, and brushed every gentleman's coat and hat who required his services.

Having seen the town before nightfall, I at one time thought of visiting the theatre, for the purpose of seeing Mr Forrest, a celebrated native actor, of whom the people of the States are extremely proud. On referring to the playbill in the Exchange-room, I observed a line in small type at the bottom, intimating that people of colour were not admitted. This appeared to me so alsurd, to distinguish human beings at a place of public amusement by their complexion, and so illiberal, that I altered my intention. In walking through the streets in the evening, I was surprised at seeing so few people, and so many rats. These creatures were swarming, and I saw more of them in half an hour than I had seen in the previous course of my life.

Next morning, I embarked on board the Champlain for Cincinnati, where I found Mr Gemble and another passenger from the Helen Mar. The Champlain was an excellent vessel, with the cabin in the bow, which is much more agreeable than when it is in the stern, by allowing objects to be seen when approaching, instead of receding from them. The steam-boats on the eastern waters of the United States, and the Canadas, have their cabins in the hull of the vessel like those of Britain, and a deck above where passengers sit or walk. A different arrangement is followed on the western 
rivers. The lower part of the ressel is allotted for stowing away heavy freight, and the boilers are placed in the low, with a cabin for the gentlemen behind, and one immediately above, for the ladies. The fore-part of the second deck is for the deck passengers. In other cases, the place for deck passengers is in the stern of the first deck, and the second one is divided, forming the ladies' and gentlemen's cabins. The Helen Mar was of the first arrangement, and the Champlain of the second. The size of the steam-ressels varies from eighty to five hundred tons, the smallest size being best suited for the summer months, when the rivens are low, and the largest ean only be used from November to July. They are narrow, and stand so much above the water, as to resemlile a floating-house. Almost all of them use high pressure engines, and are considered wom out in five or six years, except those made of live oak which last from eight to ten years. The perishable nature of the western steam-boat property is, no doubt, in part owing to the materials of which it is composed, and the navigation, which, from currents, sand-bars, and sunken trees or snags, is the most trying and dangerous.

In passing from Louisville to Cincinnati, a distance of 132 miles, the Champlain was well-filled with passengers, who landed and embarked at many intermediate places. The table was by no means so lavishly stored as that of the Helen Mar, and could not contain all the passengers, some of whom, after dinner, filled the berths of others without ceremony, stretching themselves at full length, with their boots on, and sleeping for hours. The deck passengers, being in the stern of the lower deck, were not seen, and the cabin ones exhibited a great diversity of character. I got into conversation with an Irishman, who resided in Kentucky, which had become his adopted country. He was plainly but respectably dressed, and evidently without much education. After stating the advantages of the States in many respects, and how determinedly all the inhabitants would fight in their defence, he asked me where I came from? On answering St"Louis, he rejoined, "where were you raised?" It was my" practice, while in the Western States, to answer readily every question 
that was put to me, for the purpose of ingratiating myself with the people, by which alone I could obtain information from them, and ensure personal comfort; and I must do them the justice to say, they seldom, in this respect, exceeded the people of my native country. On the present occasion there was something so prying in the Irishman's expression of countenance and tone of voice, that I resolved to teaze him a little, and to his second question answered, "in the East."
"What part of the East?"
s. Europe."
"What part of Europe?"
"Mungoswells."
"Where is that?"
" Near Haddington."
"In what country is that?"
"Scotland."

Here he told me that he was a native of Ireland; and I answered his language had made me aware of that the moment he entered into conversation.

"Where do you stay?"

"I am a wanderer on the face of the earth."

"What are you doing?"

"Following the course of the river."

"What would you do if you were on shore?"

"Follow my nose."

"What would you like to be employed at?"

"In moving from place to place."

"Where do you reside?"

" He had been told I was a wanderer, and might rely on what had been stated." During this conversation, he did not seem to feel the import of my answers, and continued in conversation sometime afterwards.

While standing on deck, near the chimney, around which many gentlemen were assembled, for the heat it afforded, a person who was chewing tobacco, sprinkled a mouthful of juice on the tails of my surtout, which happened to be waving in the wind. As soon as the accident occurred, he pulled out his handkerchief, and when wiping off the filth, apologized 
for his conduct. There was something so sincere in the gentleman's manner, and in his anxiety to remove the stain, that induced me to say, he could not have spit on any thing more worthless; and notwithstanding the nature of our introdnction, we continued on intimate terms for the remainder of the voyage. There was nothing in America to which I was so long of getting reconciled, as the copions spitting, and my repugnance was chicfly overcome by the accident to my surtout. The use of tobacco in every shape is, to a certain extent, an abomination, and the preference or dislike given to one mode of consumption over another, arises from habit. The smoking Dutchman, chewing American, and snuffing Secotchman, may be oljeets of disgust to each other, and all of them perhaps abhorred by a fastidious person who dislikes the use of tobacco in any shape.

I have already alluded to the shabbiness of my attire on leaving Montreal, and after having travelled so long and so roughly, often not unrobing for the night, my clothes had become literally threadbare. My hat was originally of white silk-web of bad quality, and now almost without wool. My appearance would have betokened mendicity in Britain, and procured pecuniary assistance from the humane; but in the countries through which I had latterly travelled, charity is never asked nor bestowed, yet my garb had its adrantages: It brought me in contact with all classes of the inhabitants, without exciting suspicions of any kind, and enabled me to see them in their real character. My unpretending appearance and deportment could not call forth the democratic rudeness which assumed or presumptuous superiority seldom fails to experience, in almost every portion of the United States; and the sycophant, if such exists in the valley of the Mississippi, had nothing to attract his notice.

The safety of my person and property may have been aided by the meanness of my dress, which possessed no allurement to the robber, thief, or swindler. My position as a traveller in the Western United States, and Upper Canada, differed from that of many British travellers who have visited the countries, and I shall leave others to judge if it was calculated to promote the object of my journey. 
In passing up the Ohio, the temperature of the atmosphere became so cold, that I deliberated on the propriety of adding to my clothing, which was the more necessary from having left my flannel shirt in Michigan. The matter was decided by my shoulders and elbows making holes in my coat; after leaving Louisville, and on reaching Cincinnati, I adopted winter clothing, and concealed my external infirmities with a coarse great-coat, which hath since amused my friends in Scotland, by the queerness of its shape, and passed by the name of Mrs Trollope.

The scenery of the Ohio above Louisville, possesses more interest than the lower part of the river, the hills on the banks being higher, and the country better settled. Some beautiful villas are seen on approaching Cincinnati, which we reached before noon.

When walking about Cincinnati, I observed, in several booksellers' windows, - "Men and Manners in America, by the author of Cyril 'Thornton," printed in large characters, and purchased the volume. Mr Stewart's "Three Years' Residence in America," and Mrs 'Trollope's " Domestic Manners of the Americans," had been sent to New York with my trunks, but as the walking part of my journey was over, Cyril 'Thornton's work was not expected to incommode me. I had heard of the publication being in the press before leaving Britain, and on opening the book, I naturally turned to the account of the country in which I was then situated. The description of the company in the steam-boats of the Ohio, was so different from what I had experienced, that I shall quote the author's remarks in passing down from Wheeling to Cincinnati:"These western regions are undoubtedly the chosen abode of plenty. Provisions are so cheap, that no one ever dreams of economy. Three times a-day was the table literally covered with dishes, wedged together as closely as a battalion of infantry in solid square. Though the passengers were only twenty in number, there was always dinner enough for a hundred. Joints, turkeys, hams, and chops, lay spread before us in admired confusion. Brandy bottles were located at judicious intervals, and porter was to be had on paying for it. J had asked for wine, but in vain. So, being at the luxurious 
city of Cincinnati, and tolerably tired of the poison called brandy, I sent for a bottle of champagne from the inn. The bottle came, but on being opened, the contents were much more like sour eider than champagne. In short, the stuff was decidedly too bad for drinking, and was accordingly punhed aside. But the appearance of this anomalous-looking tlask evidently caused some commotion among the passengers. The wine was probably one which few of them had tasted, and many of them were evidently determined to seize the earliest opportunity of enlarging their experience. 'I should like a glass of your wine, sir, if you have no objections?' said my old enemy the Virginian doctor. I immediately pushed the bottle to him, and he filled his tumbler to the brim. Observing this, the persons about him, without ceremony of any kind, seized the bottle, and its contents incontinently disappeared.

"In regard to the passengers, truth compells me to say that any thing so disgusting in human shape I had never seen. Their morals and their manners were alike detestable. A cold and callous selfishness, a disregard of all the decencies of society, were so apparent in feature, word, and action, that I found it impossible not to wish that their catalogue of sins had been enlarged by one more-hypocrisy. Of hypocrisy, however, they were not guilty. The conversation in the cabin was interlarded with the vilest blasphemy, not uttered in a state of mental excitement, but with a coolness and deliberation truly fiendlike.

"There was a Baptist clergyman on board, but his presence did not seem to operate as a restraint. The scene of drinking and gambling had no intermission. It continued day and night. The captain of the vessel, so far from discouraging either vice, was one of the most flagrant offenders in both. He was decidedly the greatest gambler on board, and was often so drunk as to be utterly incapable of taking command of the vessel. There were few female passengers; but with their presence we were only honoured at meals. At all other times they prudently confined themselves to their own cabin.

" One circumstance may be mentioned, which is tolerably illustrative of the general habits of the people. In every steam-boat there is a public comb and hair-brush suspended 
by a string from the ceiling of the cabin. These utensils are used by the whole body of the passengers, and their condition the pen of Swift could alone adequately describe. There is no tooth-brush, simply, I believe, because the article is entirely unknown to the American toilet. A common towel, however, passes from hand to hand, and suffices for the perfunctory ablutions of the whole party on boand. It was often with great difficulty that I procured the exclusive usufruct of one, and it was evident that the demand was not only unusual but disagreeable."

There is so much discrepaney hetween this account and what I experienced, that it may be difficult for some people to believe the same part of the world is alluded to. 'The time which elapsed between Mr Hamilton's visit and mine was a little more than three years, and in course of that time the manners and customs of the people must either have undergone an extraordinary change, or we must have viewed things through a different medium. It is far from my intention to charge that gentleman with exaggeration or intentional misrepresentation, but objects are so well known to be affected by circumstances, that it may be worth while to enquire how he was situated to enable him to see and judge impartially. With his career in life and the place he occupied in British society, I am utterly unacquainted, and unless he is something immeasurably above ordinary humanity, both would influence his opinions. But it appears to me unfortunate that a man of such powers, as he has proved himself to be possessed of, should have sought information regarding "Men and Manners," in a part of the world, accompanied by a servant, where he was ashamed to avail himself of his services. This circumstance of itself was sufficient to sour him with all the country contained, as well as to create in others an unfavourable impression towards himself. It was surely an odd proceeding to send "for a bottle of champagne from the inn," when he was on board a steam-boat. The reason assigned for having done so- "tolerably tired of the poison called brandy"-perhaps accounts for much he has written regarding Americaa potation of this liquid, followed by "champagne," being one of the most deceptious mediums which things can be viewed 
through, and I shall leave future visitants of the United States to determine whether much he has described was reality, or the fantasies of his imagination.

My situation was different from Mr Hamilton's, not having tasted any liquid but water and tea since my departure from Montreal, with exception of half a glass of spirits amongst water at Detroit, and the glass of wine at St Charles, formerly mentioned. I do not recollect of seeing brandy on the dimnertable of any steam-boat in America ; and feel quite certain that neither wine nor spirits of any kind were on the table of those of the Ohio and Mississippi. I did not see or hear of an intoxicated person on board of any steam-vessel but those of Lake Ontario. "A public comb and hair-brush, suspended by a string from the ceiling of the cabin," or placed in any other position in the vessel, was not observed by me in the steam-boats of America, and I am sure they did not exist in the vessels I sailed with. Afterwards, I olsserved a hair-brush suspended by a string in a passage-boat on the Lirie Canal, and they are oceasionally found in the har-rooms of inferior hotels. People are not, however, compelled to use them, and they are certainly an accommodation to some individuals. A tooth-brush was used by almost every passenger in the Helen Mar, and I remarked dozens of storekeepers at Detroit washing their teeth in the mornings at the door, and in one or two instances narrowly escaped being soused with superfluous water from tumblers they had been using.

The manners of the people at St Louis, and from that place to Cincinnati, are unquestionably different from the inhabitants on the shores of the Atlantic, being rougher in all respects, but I did not witness any thing approaching to rudeness or disgusting vulgarity amongst cabin passengers. - The firemen, engineers, and many of the crew of the steam-boats were habitual swearers, and so were many of the stage-drivers and passengers in travelling through Ohio. But this bad habit did not pervade the inhabitants generally with whom I came in contact.

On landing at Cincinnati, I entered an excellent hotel in a square fronting the river, the name of which I have forgotten. On applying at the bar I was requested, as usual, to enter my 
name; and on asking for a bedroom to wash, a bell was rung, and a man of colour, who answered it, was desired to conduct me to No. 23, and to see that I got every thing I wanted. 'This was before any alteration had been made in my dress, and water, towel, and soap, were supplied me. Indeed, water in my bedrooms was furnished everywhere in the United States, with the exception of that part of my tour from Detroit to Louisville.

I had time to examine the greater part of the town before dinner, after which I walked to the top of the hills on the east side of the city, and then to the west end. 'The situation of Cincinnati, as seen from the height, is singularly fine, being in the midst of a circle of hills, through the centre of which the beautiful Ohio flows. The diameter of the circle is about three miles, and the river is not seen beyond the circle. The city is on the north side of the stream, and on the south, or Kentucky side, stand the thriving villages of Newport and Covington, divided by the river Licking, which joins the Ohio. Cincinnati contains about 30,000 inhabitants, the buildings are of brick, and many streets run parallel and at right angles with the river. I found the market plentifully supplied with every commodity, in stalls and waggons, and the bustle and activity of the place was much greater than I expected to find in a city so remotely situated. 'The streets were clean at the time of my visit, and the general appearance of the place indicated considerable advancement in luxury. Cuals sell at ten cents, wheat at fifty-six, Indian corn at twenty-five, and oats at twenty-two cents per bushel. I shall quote a few particulars relating to Cincinnati, from a recent Philadelphia publication, entitled, a "View of the Valley of the Mississippi.",

"There are ten founderies, including a brass and bell foundery, and one for casting types.

" There are three or four cotton factories, about fifteen rolling mills, and steam engine factories, and shops.

"There are five breweries.

"There is a button factory, and a steam coopering estublishment.

"Two steam flour-mills, and five or six steam sau-mills. 
"There are probably not less than forty different manufacturing establishments driven by steam-power.

"The imports, of which dry goods are a principal item, exceed \$5,000,000. The exports, consisting of various articles of produce, of which pork is the chief, and of unanufuotures, of which iron articles, and cabinet furniture, are the chief, probably exceed the imports in value.

"There are two banks, and a savings' fund association; two museums, very interesting to strangers; and two hospitals.

"There is a company which supplies the city with water, which is elevated by steam power from the Ohio.

"There are several literary and scientific institutions, of which the Iyceum, Athenzeum-established by the Catholics, and which is really a college, and cost about $\$ 20,000-$. Medical College, having seven or eight professors, Academy of Medicine and Law, and Theological Seminary are the chice.

"In 1831, there were eighteen public schools, embracing 2,700 scholars, at an expense of $\$ 6,610$ for teachers' wages. This city is imitating the noble example of Boston, in establishing free-schools for the whole population. The number of private schools and academies is great.

st There are three library companies, which have, in all, nearly 10,000 volumes of books.

"There are thirty-four charitable associations, and twentyfive religious societies.

"There are six Presbyterian churches, five Methodist, four Baptist, two Episcopal, one Lutheran, one Associate, one Catholic, one Unitarian, one Friends' Meeting, one Swedenborgian, one Jewish Synagogue, one African, one Christian.

66 There are three daily, two semi-weekly, six weekly, (four of which are religious,) two semi-monthly, two monthly, and one quarterly, (medical,) publications-sixteen in all, issued in this city."

In four months, during 1831, there were issued from Cincinnati press, 86,000 volumes, of which 20,300 were of original works. In the same time, the periodical press issued 243,200 printed sheets.

Cincinnati is generally said to be in a declining state, but I could not discover evidence of decay. Houses were build- 
ing, and bricks manufacturing in all directions. Streets and roads were undergoing extensive improvement in and around the city, while villas were being erected on the surrounding heights. The ship yards were full of bustle, and craft of various kinds were rising into existence. At the close of the year 1832, one hundred and thirty steam-boats had been built at Cincinnati.

The city is built on the site of some Indian tumuli, one of which I saw, near the western extremity, in tolerable preservation. I hope the inhabitants will protect this monument of a former race, by enclosing it with an iron railing, and adorning the foreground with flowers.

I attended the theatre in the evening. Amongst the players were Sinclair, Thorne, Mrs Knight, and Miss Clara Fisher. The audience were numerous, and somewhat noisy in their plaudits.

The agriculture, seen from the waters of the Mississippi and Ohio, is very limited, and which I cannot well describe. Cultivation becomes extended on approaching Cincinnati, and fields of wheat were seen on the sloping banks. The hills, three or four hundred feet high, which I ascended, to the east of the city, were covered with verdant pasturage of grasses and clovers, on which excellent cattle and sheep were browsing. Waggon loads of pumpkins were passing into the town, and I observed many working oxen eating this vegetoble in courts. 


\section{CHAPTER XXVII.}

Journey from Cincinnuti to Detroit-Macudamized roud-Lelunon - Pussengers - Agriculural Notiess - Parqunus-Cider muking-Hotels of the L'nited States-Customs of the Country -Columbus-Details to Sundusky-Mr Humilton on the Prospects of the Union-Sundusky_Cider muking_PerrysburyMamee-Ohio-Michigan.

Ar two o'clock next morning, I was seated in a stage-coach, on my way to Canada, through the state of Ohio, and no less than two hours were spent in calling and waiting on different passengers, before getting out of Cincinnati. I was delighted to find $\mathrm{Mr}$ (iemble amongst the number who intended to have gone up the Ohio to Wheeling, by steam, but learning the water was too low to admit of vessels sailing with certainty, he was induced to proceed by land. When day dawned, we were passing through an undulating country, over an excellent macadamized road, newly formed by a company, in the most complete manner, to the distance of twelve miles. There was a toll-bar on the road, which is to be extended to Springfield, in the state of Ohio, and there communicate with what is called the National road. We passed through the village of Lebanon, the parent seat in this country of the religious sect of Shakers. The village is of considerable size, and the bar-room of the hotel was filled with a set of drunkards, which I had not seen any thing resembling since leaving Canada. Xenia, in Green County, is a neat place, and we reached Springfield after dusk.

Next morning we left Springfield at three o'clock with the same stage party that had come from Cincinnati the day before. When light appeared, the ground was thickly covered with hoar-frost, and ice was seen in several places. This was on the 12th October, in 40 degrees of latitude. Ten miles 
from Springfield the stage had to wait half an hour for a change of horses, the driver being in bed when we arrived. Here one of the passengers, a lady travelling with her husband, complained of being sick and cold. A cup of coffee was suggested to her. The hostess of the tavern, a very old woman, boiled water and prepared coffee with incredible despatch. I know not whether the beverage was good, but it was agreeable to see the old creature moving about like a girl in her teens, and manifesting anxiety to please her guests. The lady was from Baltimore, and had resided several months in the west, on account of her health. She had a most delicate appearance, a sylph-like form, regular features, and a lively manner. Notwithstanding the coldness of the weather, and her delicate state of health, she was dressed in silk stockings, and it was with reluctance she consented to draw a pair of worsted ones over her shoes, which her hushand purchased for her. Like many of her countrywomen, she had feet and ankles of exquisite formation, and perhaps in the display of this gift of nature, she made a sacrifice of her health.

We reached Columbus in time for dinner, where I remained for the night, the stage proceeding on with the party for Wheeling. I found myself pleasantly situated with the passengers from Cincinnati, who conversed sensibly on a variety of subjects, and made themselves agreeable to each other. On leaving Columbus, each of them came up, and bade me farewell. In particular, I regretted parting with Mr (iemble, whose moral worth and unobstrusive manners pleased me the more I was in his company.

The country from Cincinnati to Springfield, Ohio, was chiefly a good clay of a yellow colour. The surface undulating, and in some places picturesque. The farm-houses were of large size, and generally brick. The soil was dry, and where seen, in making the road, six feet deep, of yellow coloured clay. There were no furrows in the fields, and wheat was above ground, and well sown. Herds of cattle and flocks of sheep were seen browsing on pastures as verdant as if in spring. Numbers of handsome hogs were fattening, in enclosures of worm fence, on Indian corn, without straw to lie on. Hogs are generally fatted in the open air 
in America, and whether kept in enclosures or small pens $\mathbf{I}$ never saw one of them have straw, and they make their beds in mud or sand. The waggons seen moving towards Cineinnati were in charge of men who rode on the shaft-horse, whether the vehicle was drawn by two or more horses. The country for twenty miles east of Springfield is level, rather wet, and not so fertile as that from Cincinnati. After passing this distance, there are many small prairies, most of which are wet and uncultivated. This tract is thinly settled, the soil, clay of a dark colour, and inferior to the yellow tinged clay. The bottoms of the Scioto are fine rich soil.

After dining at Columbus, I strolled into the woods north of the village in search of the pawpaw fruit, which I had heard much extolled by some of my fellow-travellers. This plant grows plentifully as underwood on most of the rich soils in this part of the country. I found the fruit growing on slender trees or shrubs fifteen or twenty feet high ; it resembles, in size, shape, and colour, the jargonelle pear of Britain. I found them variable in quality, and the best might rank with a third-rate pear of Scotland. The forests were now clothed in the splendour of autumn, and the richness and variety of their tints was of the most pleasing description. The oak, maple, beech, and dogwood, seemed to vie in brilliancy, and I often observed many leaves on the same lateral branch, exhibiting every shade from vivid green to the darkest purple.

I found so much to interest me in the productions of the forest and its feathered inhabitants, that my walk was insensibly prolonged, till at length the declining sun reminded me of the necessity of returning to Columbus. On emerging from the forest, I observed people engaged in making cider, and walked towards them to enquire my way, having lost the direction of the city, by wandering in the woods. The apples were collected into an immense heap, from which two men were engaged in carrying them to a mill, consisting of vertical cylinders, turned by the power of two oxen, which reduced the fruit to a pulp. A shovel was used in removing the pulp, which, by means of straw and wattles, was piled above a reeeptacle for the juice, and pressed by a powerful screw. The 
people engaged in cider-making, asked me to partake of the expressed juice, and to fill my pockets with the choicest fruit. I learned from them cider was very plentiful this season, and did not pay much more than the expense of making, being delivered at Columbus for 75 cents per barrel of 32 gallons. Some forest land, of medium quality, in the neighbourhood, had lately been sold by public sale at $\$ 2 \frac{1}{2}$ and $\$ 2 \frac{3}{4}$ per acre. Wheat at the present time was worth 50 cents, and Indian corn 20 cents per bushel.

I found my distance from Columbus was five miles, and supper was over before I reached the National hotel. On stating to the bar-keeper I had been detained in the woods, he ordered me fresh tea; and although I mentioned to him it was not my practice to eat meat in the evening, a newly broiled fowl was placed before me, and a variety of preserves. Next morning, after the usual preparatory bell had tolled for breakfast, the landlord called me personally, stating, that as I was a stranger in the country, and might not be aware of its customs, the breakfast would be on the table in ten minutes. The waiters were all white people, smart in their calling, and attentive to guests.

I found the hotels gradually improve on leaving Springfield, Illinois, and many of those in the state of Ohio appeared to be every thing a reasonable person could wish, with the exception of the want of single-bedded rooms. Water was always placed for washing without being asked for, and a bell communicatid with each room. The waiters and helps of the States are said to dislike being summoned by the sound of a bell, and many travellers have assigned this as a reason for the want of bells. But such a feeling in all probability never existed, as the guests of every hotel are first warned, and afterwards summoned to each meal, by sound of bell, and it is preposterous to say waiters are averse to the like call. Meals are served at fixed hours, when all the company sit down together. In good establishments, the principal joints at dinner are carved by the landlord and waiters, often at side tables, and the company seldom assist in the office. Abundance of iced water is on the table during summer, occasionally cider, and very rarely brandy. Wine may be had for 
payment. The company leave the banqueting room when the meal is over, and do not gain admittance until summoned. A number of smart attentive waiters skip about the room, and often anticipate your wants. They are generally arldressed in a whisper, and in all the eastern states of the Tnion a loud tone is never heard at table. The conduct of some perple in Britain, who command attention by oaths and noise, does not suit this region of America, where the mild and unassuming are never neglected. A friend of mine, on his first entrance to the public tables of New York, spoke to the waiters in the strains he had unfortunately accustomed himself to in Britain; they pretended not to hear him, and he found difficulty in getting his plate changed; while his companions, by adopting a different course, had the waiters pressing them to the principal dishes on the side-table, and paying the most assiduous attention. Civility is at all times duly appreciated by the establishment of hotels, and foreigners will find much annoyance in attempting to dispense with it. The morning and evening meals are served with the same regularity, and ample attendance, as the dinner, \&c. A profusion of animal food is placel on the table, and the quantity increases in proportion to want of refinement in the people of the district. Bonts and shoes are deposited at night in a fixed place, where they are found cleaned in the morning. Slippers, and bedroom lights, are obtained at the bar. As a general rule, wants are stated at the bar, and from this place orlers are given to servants for supplying them. All the bells of the house communicate with the bar-room, and the bar-keeper sees that the call of a bell is attended to. Throughout the whole of my intercourse with hotels in the United States, I did not receive an uncivil answer, or experience neglect from any one connected with the establishment, and every request which I made was cheerfully complied with. The landlords are much less fawning in manner than those of Britain, but equally civil and anxious to oblige.

The hotels of America are such as might be expected from the state of the country. Servants being particularly expensive, and difficult to be had, is the cause for having fixed hours for meals, and one table for the company as well as for 
most orders passing through the bar-keeper. Were another system adopted, a greater number of servants would be necessary, and there would be more difficulty in obtaining them. The plain and meagre furnishing of the hotels may also be traced to expensiveness of servants, and so also may the number of people which frequent them. The furniture of the bedrooms, consisting of a bedstead, without posts or curtains, and counterpane of small size, washing-stand, and solitary chair, seemed to me admirably fitted for promoting a circulation of air, which was the greatest luxury during the season I was in the country, and I doubt much if bedroom furnishings will be more ample in summer, when the wealth of the population becomes greater than it now is.

The circulation of air, in connexion with shade from the sun-rays, will account for the use of the calash as a head-dress for females, so generally met with in the States of New England, and which I imagine to be the most agreeable summer wear that can be devised. On the same grounds may be justified the New England gigs with hoods, having an aperture behind; thus the customs of a country will generally be found to have originated from circumstances connected with it, and to be well suited to the inhabitants.

Columbus is the capital of the state of Ohio, and beautifully situated on the east bank of the river Scioto. The public buildings are extensive and good. The village having been founded in 1812, the buildings, which are chiefly of briek, are well arranged. The state prison is a new and substantial stonebuilding. The population is about 3000. A lateral branch of the Ohio and Erie canal communicates with Columbus.

Next morning, after breakfast, 1 left Columbus for Sandusky city, formerly called Portland, on Lake Erie, passing through Delaware, Marion, and Bucyrus. The first part of the road lay on the banks of the Whetstone, a small river with very little bottom land. The country was thinly settled; and the soil second rate. The night was passed in a very bad hotel at Marion, and by three o'clock in the morning I was again in the stage. When day dawned, the stage was passing through a country between oak-opening and prairie, seem- 
ingly wet and unsettled. A good deal of forest was also passed through, thinly peopled. I reached Sandusky a little after night-fall.

The stage was nearly empty all the way from Columbus to Sandusky. A young joiner travelled from Columbus to Marion. Two striplings rode a mile or two near the village of Caroline, who were rude swearing fellows, and smelling strongly of onions and whisky.

The hotel at Sandusky was small and crowded with passengers. I found myself ushered into a small bedroom, with two individuals, with a bed for each. One of the penons rose in the middle of the night, smoked tobacco, and made himself as disagreeable as possible. 'The other opened the window to admit air to purify the sty. This was the only unpleasant circumstance that occurred to me from sleeping in apartments with others, and sufficiently illustrates how disagreeable the practice may occasionally become

Sandusky city is a small village on Lake Lrie, containing perhaps five or six hundred souls, and has a considerable trade. There is plenty of stone in the immediate neighbourhood, and some of the buildings are of this material. I found the price of beef at Sandusky was from three to five cents per lb., and hind quarters of mutton four cents. Wheat was 75 cents per bushel.

It was my intention to have proceeded from Sandusky to Detroit by one of the steam-boats passing up Lake Erie, but tempestuous gales of wind a day or two before my arrival, having totally wrecked one vessel and disabled another, I was detained two days in suspense. I could not go far from the hotel during this period, lest a steamer should pass in the interval; and my time was in part occupied in reading $\mathrm{Mr}$ Hamilton's beautifully written work of "Men and Manners in America."

In the early part of my tour, I remarked that, without sound judgment to discriminate and appreciate information, the gleanings and impressions of a traveller will be as apt to mislead as instruct, and his lucubrations will often be found more illustrative of his own character than of the people and country he visits. When penning this sentence, I had not 
another individual in view than the one treated of, and it is, perhaps, fraught with more truth than may at first sight appear. The wielders of the pen and pencil seem to be fond of portraying their own likeness, and the narrative of most travellers will be found stamped with their character. Truth ought to be the first object with every writer of travels, and is perhaps, like beauty, "when unadorned, adorned the most," and wherever it is lost sight of, the highest endowments may become prostituted in misleading others. It must, however, be admitted, that the best intentioned writer may become the dupe of appearances, resulting, perhaps, from his own feelings and prejudices. There are also some writers who aim at producing an effect on their readers unconnected with the subject treated of, and in such cases a traveller's narrative frequently becomes absolute fiction. I shall not say in which class of travels "Men and Manners in America" may be ranked, or whether parts of the work appertain to different classes; but I do not hesitate in saying, that the author's conclusions did not always appear to me to be just or consistent with sentiments expressed in other parts of the work. This seemed to be particularly the case in some speciously written paragraphs on the political prospects of the Union, which many of the people in Britain, who read the work, did not perhaps observe.

"In that city (New York) a separation is rapidly taking place between the different orders of society. The operative classes have already formed themselves into a society, under the name of 'The Workies,' in direct opposition to those who, more favoured by nature or fortune, enjoy the luxuries of life without the necessity of manual labour. These people make no secret of their demands, which, to do them justice, are few and emphatic. They are published in the newspapers, and may be read on half the walls of New York. 'Their first postulate is ' EQUAL AND UNIVERSAL EDUCATION.' It is false, they say, to maintain that there is at present no privileged order, no practical aristocracy, in a country where distinctions of education are permitted. That portion of the population whom the necessity of manual labour cuts off from 
the opportunity of enlarged acquirement, is in fact excluiled from all the valuable offices of state. As matters are now ordered in the United Stateg, these are distributed exclusively among one small class of the community, while those who constitute the real strength of the country, have barely a voice in the distribution of those loaves and fishes, which they are not permitted to enjoy. There does exist, then, they argue, an aristocracy of the most odious kind, - an aristocracy of knowledge, education, and refinement, which is inconsistent with the true democratic principle of absolute equality. They plerge themselves, therefore, to exert every effort, mental and physical, for the abolition of this flagrant injustice. They proclaim it to the world as a nuisance which must be abated, before the freedom of an American be something more than a mere empty boast. 'They solemuly declare that they will not rest satisfied, till every citizen in the United States shall receive the same degree of education, and start fair in the competition for the honours and the offices of the state. As it is of course impossible - and these men know it to be so - to educate the labouring classes to the standard of the richer, it is their professed object to reduce the latter to the same mental condition with the former; to prohibit all supererogatory knowledge ; to have a maximum of acquirement, beyond which it shall be punishable to go.

"But those who limit their views to the mental degradation of their country, are in fact the Moderates of the party. There are others who still go farther, and boldly advocate the introduction of an Agrarian Law, and a periodical division of property. These unquestionably constitute the extreme gauche of the Worky Parliament, but still they only follow out the principles of their violent neighbours, and eloquently dilate on the justice and propriety of every individual being equally supplied with food and clothing; on the monstrous iniquity of one man riding in his carriage, while another walks on foot, and, after his drive, discussing a bottle of Champagne, while many of his neighbours are shamefully compelled to be content with the pure element. Only equalize property, they say, and neither would drink Champagne or 
water, but both would have brandy, a consummation worthy of centuries of struggle to attain.

"All this is nonsense, undoubtedly, nor do I say that this party, though strong in New York, is yet so numerous or so wiclely diffused as to create immediate alarm. In the elections, however, for the civic offices of the city, their influence is strongly felt; and there can be no doubt, that as population becomes more dense, and the supply of labour shall equal, or exceed the demand for it, the strength of this party must be enormously augmented. Their ranks will always be recruited by the needy, the idle, and the protligate; and, like a rolling snow-ball, it will gather strength and volume as it proceeds, until at length it comes thundering with the force and desolation of an avalanche.

"This event may be distant, but it is not the less certain on that account. It is nothing to say, that the immense extent of fertile territory yet to be occupied by an unborn population, will delay the day of ruin. It will delay, but it cannot prevent it. 'The traveller, at the source of the Mississippi, in the very heart of the American continent, may predict with perfect certainty, that, however protracted the wanderings of the rivulet at his feet, it must reach the ocean at last. In proportion as the nearer lands are occupied, it is very evident that the region to which emigration will be directed must of necessity be more distant. 'The pressure of population, therefore, will augment in the Atlantic States, and the motives to removal become gradually weaker. Indeed, at the present rate of extension, the circle of occupied territory must, before many generations, be so enormously enlarged, that emigration will be confined wholly to the Western States. Then, and not till then, will come the trial of the American constitution; and until that trial has been past, it is mere nonsense to appeal to its stability.

"Nor is this period of trial apparently very distant. At the present ratio of increase, the population of the United States doubles itself in about twenty-four years; so that in half a century it will amount to about fifty millions, of which ten millions will be slaves, or, at all events, a degraded caste, cut off from all the rights and privileges of citizenship. Be- 
fore this period, it is very certain that the pressure of the population, on the means of subsistence, especially in the Atlantic States, will be very great. The price of labour will have fallen, while that of the necessaries of life must be prodigiously increased. 'The poorer and more suffering class will want the means of emigrating to a distant region of unoccupied territory. Poverty and misery will be abroad; the great majority of the people will be without property of any kind, except the thewes and sinews with which God has endowed them; they will choose legislators under the immediate pressure of privation; and if in such circumstances, any man can anticipate security of property, his conclusion must be founded, I suspect, rather on the wishes of a sanguine temperament, than on any rational calculation of probabilities.

" It is the present policy of the government to encourage and stimulate the premature growth of a manufacturing population. In this it will not be successful, but no man can contemplate the vast internal resources of the United States, -the varied productions of their soil - the unparalleled extent of river communication-the inexhaustible stores of coal and iron spread even on the surface-and doubt that the Americans are destined to become a great manufacturing nation. Whenever increase of population shall have reduced the price of labour to a par with that of other countries, these advantages will come into full play; the United States will then meet England on fair terms in every market of the world, and, in many branches of industry at least, will attain an unquestioned superiority. Huge manufacturing cities will spring up in various quarters of the Union, the population will congregate in masses, and all the vices incident to such a condition of society will attain speedy maturity. Millions of men will depend for subsistence on the demand for a particular manufacture, and yet this demand will of necessity be liable to perpetual fluctuation. When the pendulum vibrates in one direction, there will be an influx of wealth and prosperity; when it vibrates in the other, misery, discontent, and turbulence will spread through the land. A change of fashion, a war, the glut of a foreign market, a thousand unforeseen and inevitable accidents are liable to produce this, and deprive 
multitudes of bread, who but a month before were enjoying all the comforts of life. Let it be remembered, that in the suffering class will be practicably deposited the whole political power of the state; that there can be no military force to maintain civil order and protect property; and to what quarter, I should be glad to know, is the rich to look for security, either of person or fortune?

"There will be no oceasion, however, for convulsion or violence. The Worky convention will only have to choose representatives of their own principles, in order to accomplish a general system of spoliation, in the most legal and constitutional manner. It is not even necessary that a majority of the Federal legislature should concur in this. It is competent to the government of each state to dispose of the property within their own limits as they think proper, and whenever a numerical majority of the people shall be in favour of an Agrarian law, there exists no counteracting influence to prevent, or even retard its adoption.

"I have had the advantage of conversing with many of the most eminent Americans of the Union, on the future prospects of their country, and I certainly remember none who did not admit that a period of trial, such as I have ventured to describe, is, according to all human calculation, inevitable. Many of them reckoned much on education as a means of safety, and, unquestionably, in a country where the mere power of breathing carries with it the right of suffrage, the diffusion of sound knowledge is always essential to the public security. It unfortunately happens, however, that in proportion as poverty increases, not only the means but the desire of instruction are necessarily diminished. The man whose whole energies are required for the supply of his bodily wants, has neither time nor inclination to concern himself about his mental deficiencies, and the result of human experience does not warrant us in reckoning on the restraint of individual cupidity, where no obstacle exists to its gratification, by any deliberate calculation of its consequences on society. There ean be no doubt, that if men could be made wise enough to act on an enlarged and enlightened view of their own interest, government might be dispensed with alto- 
gether; but what statesman would legislate on the probability of such a condition of society, or rely on it as a means of future safety?

"The general answer, however, is, that the state of things I have ventured to describe, is very distant. ' It is enough,' they say, 'for each generation to look to itself, and we leave it to our descendants some centuries hence to take care of their interests as we do ours. We enjoy all manner of freedom and security under our present constitution, and really feel very little concern about the evils which may afflict our posterity.' I cannot help believing, however, that the period of trial is somewhat less distant than such reasoners comfort themselves by imagining; but if the question be conceded that democracy necessarily leads to anarchy and spoliation, it does not seem that the mere length of road travelled over is a point of much importance. 'This, of course, would vary according to the peculiar circumstances of every country in which the experiment might be tried. In England, the journey would be performed with railway velocity. In the United States, with the advantages they possess, it may continue a generation or two longer, but the termination is the same. The doubt regards time, not destination.

"At present the United States are perhaps more safe from revolutionary contention than any country in the world. But this safety consists in one circumstance alone. The great majority of the people are possessed of property; have what is called a stake in the hedge; and are, therefore, by interest, opposed to all measures that may tend to its insecurity. It is for such a condition of society that the present constitution was framed; and could this great bulwark of prudent government be rendered as permanent as it is effective, there could be no assignable limit to the prosperity of a people so favoured. But truth is undeniable, that as population increases, another state of things must necessarily arise, and one, unfortunately, never dreamt of in the philosophy of American legislators. The majority of the people will then consist of men without property of any kind, subject to the immediate pressure of want, and then will be decided the great struggle between property and numbers; on the one side hunger, rapacity, and 
physical power ; reason, justice, and helplessness on the other. The weapons of this fearful contest are already forged; the hands will soon be born that are to wield them. At all events, let no man appeal to the stability of the American government as being established by experience, till this trial has been overpast. Forty years are no time to test the permanence, or, if I may so speak, the vitality of a constitution, the immediate advantages of which are strongly felt, and the evils latent and comparatively remote."

On re-perusing the quoted paragraphs, the love of champagne and brandy was conspicuous in the second one, and the whole of them seemed like a maudlin dream, in which truth and probability were altogether wanting, told in strains admirably fitted to delight the ear and obscure the understanding of the reader. To me, who had made an extensive tour in the territory of the United States, and from all I had seen personally, and learned from the best sources of information, concluded that nine-tenths of the surface are still unemployed in the production of human sustenance, the idea of an agrarian law was ludicrous in the extreme. Whether there is such a society as "The Workies," and my after enquiries while at New York rendered the point doubtful, did not seem to affect the matter, as the only legitimate inference that could reasonably be deduced from the sentiments which Mr Hamilton has imputed to its members, is, that America does not exempt humanity from aberrations of mind. This seems to be admitted in the third paragraph, where it is stated, "all this is undoubtedly nonsense," yet the dream which is confessedly founded on man's infirmity, has been received by a portion of the British public as infallible wisdom. The quotations being founded on " nonsense," do not admit of criticism. An ordinary mind, however, cannot fail of observing that in almost every paragraph, the author raises up and demolishes a fantasy, and turns from one position to another, like fevered excitement tossing on an uneasy couch.

The following quotations from "Men and Manners in America" are of a different tenor from the preceding ones. "It is the fashion to call the United States the land of liberty and equality. If the equality be understood simply as im- 
plying that there exists no privileged order in America, the assertion, though not strictly true, ${ }^{*}$ may pass. In any wider acceptation, it is mere nonsense. There is quite as much practical equality in Liverpool as New York. 'The magnates of the Frchange do not stand less proudly in the latter city than in the former; nor are their wives and daughters less forward in supporting their pretensions. In such matters legislative enactments can do nothing. Man's vanity, and the desire of distinction, inherent in his nature, cannot be repressed. If obstructed in one outlet, it will only gush forth with greater vehemence at another. The most contemptible of mankind has some talent of mind or body-some attraction-virtueaccomplishment-dexterity-or gift of fortune-in short, something real or imaginary, on which he arrogates superiority to those around him. The rich man looks down upon the poor, the learned on the ignorant, the orator on him unblessed with the gift of tongues, and he that is a true-born gentleman, and stands upon the honour of his birth, despises the roturier whose talents have raised him to an estimation in society, perhaps superior to his own.

"T 'Thus it is with the men, and with the fairer sex assuredly it is not different. No woman, conscious of attraction, was ever a republican in her heart. Beauty is essentially despotic -it uniformly asserts its power, and never yet consented to a surrender of privilege. I have certainly heard it maintained in the United States, that all men are equal, but never did I hear that assertion from the lips of a lady. On the contrary, the latter is always conscious of the full extent of her claims of preference to admiration, and is never satisfied till she feels them to be acknowledged. And what zephyr is too light to fill the gossamer sails of woman's vanity! The form of a feature, the whiteness of a hand, the shade of a ringlet, a cap, a feather, a trinket, a smile, a motion-all, or any of them, or distinctions yet finer and more shadowy, if such there beare enough, here as elsewhere, to constitute the sign and shib-

* " Not strictly true, because in many of the states the right of suffrage is made dependent on a certain qualification in property. In Virginia, in particular, this qualification is very high." 
boleth of her fantastic supremacy. It is in vain, therefore, to talk of female republicans ; there exists, and can exist, no such being on either side of the Atlantic, for human nature is the same on both.

"In truth, the spirit of aristocracy displays itself in this commercial community in every variety of form. One encounters it at every turn."

It must be evident to every person who has visited the United States, that wealth has already obtained a prominent place in many parts of the country. 'That there are distinctions and classes in society, will not admit of doubt; and from the constitution of human nature, it cannot be otherwise in a eivilized and numerous population. The wealthy, the wise, the proud, the profligate, the virtuous, and the vicious, will associate with people of the same character, in despite of every means that could be devised for their separation; and it is perhaps well for society that such is the ease. The vain and frivolous are harmless creatures. The proud man may puff himself into bigness, like the frog in the fable imitating the ox, and assume the emblems of luxury and pomp with impunity. The form of aristocracy meets the eye in all the social relations of life. There is no such thing as equality in the abstract sense of the term, with the political privileges of the inhabitants, the right of franchise varying in different States, and a qualification being requisite in all of them.

Liberty and equality, as understood in Britain, is not to be found amongst the inhabitants of the United States. The people must obey the laws, which impartially affect the whole population, except in the case of suffrage; a privileged class by inheritance, creation, wealth, or purchase, being unknown. The laws are founded on the principles of freedom, and the mass of the population may be said to be politically equal. Here liberty and equality of the United States is applicable only to the political condition of the inhabitants, and in this relation must be taken in a restricted sense.

Aristocracy seems inseparable from civilized society, and an individual, by attending to the communings of his own heart, will perhaps be convinced that its spirit pervades the life veins of humanity. In almost every quarter of the globe, it has at 
some period attained strength, and from the earliest ages, the earth has been watered with the blood of the best and bravest of mankind, in attempts to check the workings of its spirit. The form of aristocracy is alrearly raised in the United States, and many of the citizens, when conversing with me on the institutions and inhalitants of their country, strongly displayed a feeling of aristocracy. If there is latent danger to the constitution of the Union, in the present state of things, it is from the seeds of aristocracy.

Human nature is said to be the same on both sides of the Atlantic, and the population of the United States and Britain having sprung from a common source, and inheriting the same natural dispositions, the growth of aristocracy in the former might be inferred from the experience of the latter, provided all the circumstances affecting the inhabitants were similar. But history does not furnish a parallel to the United States, and the experience of past ages, and analogies of other countries, are inapplicable to them.

The United States were first settled by people seeking relief from religious persecution, who, in the neighbourhood of Boston, worshipped the Author of the Universe according to their conscience, which liberty had been denied them in England. It may, perhaps, not be going too far to suppose the finger of Providence pointed the way to the pilgrims, since which, many of the persecuted of the human race have found a sanctuary in the same territory. When the conduct of the mother-country goaded the colonies to rebellion, they shook off her yoke at an enlightened period of the world, with the history of past ages before their eyes, and almost without an obstacle to adopt the advantages, and shun the evils recorded. 'The career of the States is evidence of the judicious proceedings of the inhabitants, and the many privileges which they enjoy can only be lost by their own corrupt and sinful venality.

The United States having risen and struggled into existence in opposition to despotic power, a dislike of tyranny, and love of liberty, pervades the inhabitants, and the institutions of the country are calculated to nurture and retain such feelings. The unexampled and growing prosperity of the coun- 
try-the recent progression in the governments of almost all European states, and more particularly in Britain - the mot hercountry-will, doubtless, tend to strengthen the principles on which the Union has been formed. But human nature often departs from principle, and there cannot be a doubt that aristocracy, which is already deep-rooted and flourishing amongst the people, will, when aided by wealth and luxury, and their inseparable evils, destroy the Union. The whole history of mankind warrants such a conclusion. The event is certain, but many circumstances lead me to suppose it is yet distant, such as the want of entail laws, the extensive franchise, and the probability of institutions altering with the progress of the people. In the meantime, they have a constitution, "the immediate advantages of which are strongly felt, and the evils latent, and comparatively remote."1

Seeing no prospect of a steam-boat calling at Saudusky, I hired a horse in the afternoon of the second day, and rode to the village of Lime, where I obtained a seat in the mail-stage for Detroit.

Arriving at Lime some time before the stage, I walked a short distance to some people engaged in making cider. 'The fruit was not crushed, as in other instances seen in the country, but grated by a revolving cylinder, which seemed to be an improved mode of extracting the juice. The grating apparatus had been manufactured at Rochester, the other parts of the machine were erected on the day of my visit by a person in the village; and it is scarcely possible to conceive any thing more rudely and ill-constructed than they were. On admiring the beauty of the fruit, which was brought forward in waggon loads, Mr Russel, the owner of the orchard from which they came, offered me grafts of any kinds I chose to fix on. When he learned I was a foreigner on a tour through the country, he asked me to look at the orchard, and conducted me to it. He raised the trees from seed, and had planted 450 fourteen years ago, twenty-four feet asunder, and the branches now interlope. Many of the kinds bore delicious fruit, which was generally small in size, from the numbers on the

3 Men and Manners in America. 
tree, and many branches were broken with the weight of fruit. There seemed a demand for Mr Russel's cider, which he sold at $\$ 1$ per barrel, of thirty-two gallons, when newly expressed, and he was unable to satisfy some applications which were made in my presence. 'The orchards are numerous in all parts of America, and most of the trees having been raised from seed, it is probable many excellent varieties may be met with deserving of propagation.

From the village of Lime, which is situated on a ridge, by which name it is sometimes known, a beautiful prairie is seen, and which I believe is entirely settled. The soil appeared somewhat wet, which ditching would easily remedy, but this practice seemed altogether disregarded.

Soon after leaving Lime, light disappeared, and I was allowed to remain three or four hours in a most uncomfortable hotel at Lower Sandusky, situated on a river of the same name. When morning dawned, I was travelling through a thickly-wooded country, and over a road, on the surface of which lime rock was protruding in the manner of honey-comb. The coach in which I rode being of a particular construction, the roughness of the road rendered the journey disagreeable. My progress was like a funeral procession, thirty-one miles occupying twelve hours. The jolting of American stages, and more especially when passing over one or two logs lying across the road, is truly annoying, and sometimes dangerous, from contusions which may be received, but I had never experienced any thing like the motion on the present occasion. For the first time since reaching the American shore, I was slightly afflicted with headach, and felt the sensation of fatigue.

I breakfasted at a log-house on the banks of the river Portage, where I was struck with the florid complexion and robust figure of a young man employed in cutting pork into small pieces at the door, and which a girl, apparently his sister, was salting and packing into a vessel. On approaching him, I discovered he did not understand the English language, but one of the inmates of the house acting as interpreter, he told me he was from Hanover, and on his way to settle in Michigan, 
I passed through the village of Perrysburg, situated on the south bank of the river Mamee, which flows into the southwest point of Lake Erie, and is navigable to the village. It is a thriving place, and when the canal, now forming, which is to connect the waters of the Wabash and Mamee is completed, it will soon become a place of importance.

On the opposite side of the river, and a little higher up than Perrysburg, is the village of Mamee, consisting of fifteen or twenty houses, where I dined, and arrived at Munroe in the evening. Next day I reached Detroit, and travelled part of the way with an overgrown man, who wore a blue cotton frock-coat above his clothes, and a pair of doublebarrelled guns over his shoulders. He spoke the English language imperfectly, and stated he was from Saxony, and had just settled in Michigan. His family was at Detroit, and he expected ten thousand of his countrymen to join him next season.

The soil from Lower Sandusky, on the road by Perrysburg to Michigan boundary, is not of first-rate quality, though good. The surface is level, and thinly settled. Throughout the whole of my travels in the state of Ohio, the country was chiefly forest, and seemingly not more than one-sixth of the surface cleared of wood. Perhaps the other lines of road were still more thinly settled. The state contains above one million of souls.

The part of Michigan seen in passing from Mamee to Detroit is thickly wooded, wet, and very thinly settled. There is no part of the United States which disappointed me so much as Michigan. Having passed through its whole breadth from Detroit to Niles, and along the shores of Lake Erie, and the banks of the river Detroit, I met with more indifferent soil in these routes, than in all the other Western States put together. There may be much good soil in Michigan, which did not come under my notice, but I am quite satisfied its eligibility for settlers has been greatly overrated. An inhabitant of New England, who may have resided all his life on poor soil, thickly covered with forest, can hardly fail of being pleased with seeing the timbered land and oak-openings 
of Michigan, while the small and beautiful prairies will impart ecstasy, and it is, perhaps, to the accounts of such people that the territory is indebted for its celebrity. Michigan, compared with the New lingland States, is rich, and a desirable place of settlement, but in all respects inferior to districts laying to the south and west. 


\section{CHAPTER XXVIII.}

Journey from Detroit to New York-Western Lahes which form the River St Laurence-Cleveland-Erie Canal-Cold Weather-Canal Packets-Sabbath School Children at RochesterBlack Children-Slavery in the United States-Ayricultural Notices-Washington Hotel-Transition from Rudeness to Refinement-Travelling-Cheap Land-State Election-Irhabitants Consulted in Political Matters-Arrival at Liverpool.

AFter spending five days in Upper Canada, it became necessary to wend my way to New York. The weather for weeks past had been tempestuous. The trips of the steam-boats on the lakes had been interrupted, and the ferryboat at Detroit had, on more than one occasion, ceased to ply from the violence of the wind. Had there been a stage through Upper Canada, from Sandwich to Niagara, I would have preferred travelling to New York by land, but dreading the state of the roads, and length of journey in passing round the west end of Lake Erie, I decided in going from Detroit to Buffalo by steam. Vessels were still leaving Detroit for the Western Lakes, notwithstanding the advanced period of the season, and I saw the Michigan steamer sail for Green Bay, with troops on board.

Lake Superior is the most westerly and largest of the lakes which divide Upper Canada from the United States, and the accumulated waters of which form the river St Lawrence. Its length is about 360 miles, and its average breadth 109 miles. The outlet of the lake is the river St Marie, through which the waters flow, and are not navigable for sailing vessels from the strength of current.

Lake Michigan is stated to be 300 miles long, and 50 wide, branching off from the east end of Lake Superior, and their united waters pass into Lake Huron. On the west side 
of Lake Michigan, is situated the village of (ireen Bay and (hicago, to which steam-ressels ply occasionally from Detroit.

Lake Huron is 218 miles long, by 180 broad, and has several large branches rumning into Michigan and Canada. Michilimackinac, or Mackinaw, is an island on which there is a village of the same name, at the entrance of the lake, and Goderich is on the east shore.

The waters of the three-mentioned lakes flow through the river St Clair, and form a lake of the same name, which is about ninety miles in circumference.

From Lake St Clair issues the river I)etroit, which falls into Lake Erie, having the villages of Detroit, Sandwich, and Amhersthurgh, on its hanks. Lake Erie is stated at 290 miles long, and ahout 50 broad, and from the many thriving villages on its margins, has a most extensive and increasing trade. Its waters are much shallower than those of any of the other lakes, and more easily agitated, which renders the navigation dangerous in boisterous weather. From Lake Lie, flows the Niagara, in the channel of which are the celelirated falls of the same name, and empties itself into Lake Ontario, which is 171 miles in length, and 40 wide. The depth of water is said to be very great. On issuing from Lake Ontario, the waters assume the title of the river St Lawrence.

I sailed from Detroit on the morning of the 25th October, with moderate wind, which increased towards noon, and the vessel anchored under the lee of an island in Lake Erie during the night. Next day we put into Cleveland for an hour or two, and reached Buffalo towards the close of the third day.

Cleveland is in the state of Ohio, on the banks of Lake Erie, and at the mouth of the Ohio and Erie canal, which connects the waters of the lake with the river Ohio. It is a place of considerable trade, and rising with rapidity.

On reaching the Eagle hotel at Buffalo, I found three or four gentlemen who were known to me, and whose conversation on European matters I greatly enjoyed after my western tour. Next day, after breakfast, I took a canal-boat for Schenectady.

In passing down the canal, on the banks of the Niagara, 
several new houses were erecting on the Canada side, and as they were of large size, I considered the circumstance evidence of improvement.

The Erie canal connects the waters of the river Hudson with that of Lake Erie. It commenees at Albany, and terminates at Buffalo, the length being 363 miles. Besides the main cut, there are lateral branches intersecting the country in all directions. One branch communicates with Lake Ontario at the village of Oswego, and $\mathbf{1}$ believe another branch is in progress to communicate with one of the tributary streams of the river Ohio. The height of Lake Erie above the Hudson is 568 feet, and the lockage of the canal 688 feet. 'The breadth of the canal is forty feet at the top, twenty-eight at the bottom, and the depth of water four feet.

The Erie canal was formed by the State of New York, the operations commencing in 1817, and ending in 1825. 'The revenues of the canal are so ample, that the rates of charge were greatly reduced in 1833, and it is expected the whole debt will be discharged in 1838 ; after which, the charges will be diminished, so as the sum collected may be just sufticient to keep the works in repair. 'The canal is therefore like a public highway, from which no revenue will be exacted from the inhabitants, and is an instance of the advantuges they enjoy from the wisdom with which public matters are conducted.

The traffic on the canal is already so extensive, that the barges are sometimes detained a long time in passing the locks. In all probability it will be quite unable to convey the traffic in two years hence, although a double set of locks were to be constructed throughout the whole length of the canal. The enterprise of the inhabitants of this State is adequate to any emergency, and relief to the crowded canal will be found in a railway. There is already a railway from Albany to Schenectady, and in 1833 a railway was contracted for to proceed from the latter place to Utica, all of which are situated on the banks of the canal. A railway may therefore be said to be already formed on the banks of the eanal one-third of its length; and there is little doubt of its being speedily extended all the way to Buffalo, and ultimately 
along Lake Erie into Illinois. However alvantageous canals may have hitherto been found in the Lnited States, such a

- conveyance is incompatible with the order of things that is arising. The population is advancing so rapidly towarls the west, that the intercourse between the Eastern and Western States must enormously encrease, while canals are shut by ice for nearly five months in the year. In this view railways, which afford communication during the whole season, will be had recourse to, and are admirably adapted to the country and climate. There is abundance of iron and coal in the United States, and the substitution of railways for canals will be aided by the rapidity of conveyance, the application of steam power, and unobstruction from frost.

While passing down the canal, the temperature of the atmosphere became cold; on the third morning, snow covered the ground to the depth of three inches, which did not entirely melt by the influence of the sun; and although the canal was not frozen, in consequence of its waters being kept in motion by the incessant traffic, the pools on the banks were covered with ice several inches thick. On reaching Albany, I learned Fahrenheit's thermometer had stood twelve degrees below the freezing point on the 29th October, and at New York ten degrees.

The canal packets were crowded with passengers all the way from Buffalo to Schenectady, who made themselves agreeable to each other, and time passed as pleasantly as the nature of things would admit. Two of the gentlemen on board seemed to be clergymen, with whom I conversed a great deal, and was invited to spend some days with one of them. Few things in America seem more extraordinary than the sleeping accommodation of the packets. The seats on which the passengers sit during day, around the sides of the vessel, open out by means of hinges, and having the outer extremities supported by small ropes from the roof, form beds. A second tier of beds is formed by frames hooking to the sides of the vessel, and supported from the roof by ropes. The sleeping place for the ladies is separated from the gentlemen's by a curtain, and the two rows of beds around the sides of the packet have a close resemblance to shelves in a British 
shop. The passengers are sent on the roof of the packet while the cabin is altering from sitting to sleeping-trim, which does not occupy more than ten minutes, and the passengers, suspended in rows when in bed, look like strings of onions in a green-grocer's shop. The eating department was tolerably well managed.

There was a changing of packets three times in the length of the canal, and a delay of twelve hours at Rochester; during which I stopt at the Kagle hotel. When standing at the door of the hotel, after breakfast, my attention was attracted to a number of children walking in pairs along the parement, attended by a few grown-up people, and on enquiry I learned they were proceeding to church, to the amiversary meeting of the Sabbath schools. After many hundreds of both sexes had passed, attended by their teachers, I observed four black children forming the rear of a school division; and being anxious to see so interesting a sight as the assembled children, I followed the little blackamoors. Knowing the prejudice which white people have to the coloured race in almost every part of the world, I was disappointed at seeing the four black children separate from the others, and instead of entering the church they were conducted round the corner of a street into a building within a court. I still followed the blacks, but seeing none of the people entering the place where they were, I walked to and fro on the outside. At the end of two minutes, about twenty black children came out of the building, attended by five or six white men, and walked into the church amongst the rest of the children. I occupied a place in the gallery, and listened to a very commonplace address to the children, and the meeting separated without religious exercises of any kind.

The want of religious exercise appeared to me to arise from a desire of preventing any feeling of jealousy amongst sects regarding minute differences in forms of worship and creeds of faith; and if such was the case, the inhabitants of other countries would do well to imitate this conciliatory proceeding. I did not observe, after getting into church, if the black children were kept separate from the white; but the fact of this hitherto despised race attending Sabbath schools with 
white children, and being taught by white people, in the town of Rochester, was placed beyond doulst, and gave rise to pleasing anticipations for the improvement of their condition.

Slavery excites much interest in America, as well as in Britain, and is so repugnant to my feelings, that before setting out on my 'Trainsatlantic tour, I determined not to penetrate into the slave-holding states. 1)uring my short excursion into Missouri, extending to about fifty miles, and stay at St Charles, St Louis, and Louisville, occupying four days, I had little opportunity of judging of the effects of slavery on the white population, or of the state of the slaves themselves. I must, however, say, no instance of cruelty or harshness towards the black population came under my notice, and all of them appeared to be well clothed and fed. Slavery, as existing in the United States, seems not to be well understood in Britain; and I regret it is not in my power to communicate more information on the subject.

The United States were originally English colonies, and they inherited slavery from the mother country. This foul stain on their character may in fairness be attributed to Britain, and accounted one of the curses with which her misguided rulers have afflicted mankind. In 1703, the colony of Massachusetts endeavoured to restrain the introduction of slaves, by the imposition of a tax, and to prevent it altogether in 1767. The colony of Virginia, in 1772, petitioned the Parliament of Great Britain on the subject, without obtaining redress, and other colonies remonstrated at different times. In 1780, the state of Pennsylvania, while engaged in struggling for independence, passed an act for gradually emancipating the slaves; and since that time, eight out of the thirteen original colonies have abolished slavery.

The United States are composed of twenty-four distinct countries, each having a different republican form of govern ment, and the power of managing its own affairs-the general government legislating only in matters connected with defence, commerce, and taxation. At the time of the United States rising into existenee, slavery engaged the attention of the legislature, but the evil had already spread thickly over 
the Southern States, and the feelings and habits of the white population in this part of the territory being strongly in its favour, a separation and weakening of the Union would have resulted from then pressing the subject. It is a disputed point whether the general government can interfere with slavery-the Northern and Southern States taking different views. A law was passed prohibiting slavery in the district north of the river Ohio, and east of the Mississippi, before the territory was organized into states; but since that time, the state of Missouri, with all the evils of slavery, has been admitted into the bosom of the Union, which seems to determine the noninterference of the general government in the slave question.

Slavery is felt and acknowledged to be an appalling evil throughout the Union, and the most intelligent inhabitants of the Northern States are also aware of its sintulness. Here the prejudice against the sooty race is becoming less strong; and in one instance, at least, they have been invested with the rights of freemen. In the state of New York, men of colour exercise suffrage when twenty-one years of age, and the census of 1825 showed 298 of them qualified to vote." This act of wisdom and liberality on the part of the legislature, cannot fail of producing a good effect throughout the Union, and in all probability led to the teaching of the little children at Rochester already mentioned. I hail these advances of the coloured population with unmingled pleasure, as sure indications of improvement in the people of both complexions. Slavery exists by the cupidity of the white population; and in most cases it will terminate only by their moral enlightenment. However slow the progress of abolition may be in the United States, it cannot stand still. Justice, humanity, and religion are already enlisted on the side of the slave; and before the lapse of many years, his manacles will assuredly be loosened throughout the whole territory.

The world does not perhaps afford a more striking instance of human frailty, than the existence of slavery in the Southern States of the Union, where the white population, after having

* Description of United States ; published at New York, 1831. 
avowedly established governments in opposition to tyranny, and on the principle that all men are equal, continue to exercise the most inhuman oppression towarls their coloured fellow-creatures, who are treated like the brute creation. This anomaly illustrates how much man is the creature of circumstances; and that with all his boasted powers of intellect, he is unable to conquer the habits and prejudices of his youth, even when his conduct is at variance with reason, and the principles of the religion he professes to follow. Whether the slave-owner, who has been instructed amidst slavery, and whose moral pereeption has been blunted by education, be answerable for all the enormities which result from the system, may be left for casuists to determine; but those who have been more fortunately situated may well commiserate his fate, and judge charitably of his errors.

However instrumental, under Providence, the people of Britain may have been in obtaining freedom for the West Indian slave, they would do well to reflect on the slow progress the question made amongst themselves, and that many of their own countrymen connected with the colonies were opposed to the measure of relief. If, having lived apart from slavery, and its demoralizing effects, they claim merit for their exertions in behalf of the slave, let them not withhold what is due to the inhabitants of the States, who, while living amidst slaves, set an example of emancipation which has not yet been carried to the same extent in any British possession.

Some recent British travellers in America, in pandering to the depraved taste of a portion of their countrymen, will not allow merit to the states who have emancipated their slaves, on the ground that they did so only when slave labour ceased to be profitable, and that the step involved no sacrifice, as the able-bodied slaves were sold to the inhabitants of other states-the aged and infirm being alone set free. This is a most uncharitable judgment. I have not the means of ascertaining the number of slaves that were emancipated, but contend that other motives than selfishness must pervade some of the inhabitants of New York state, where the coloured population are invested with suffrages, and taught at Sabbath schools with white children. It is true, however, the negro race is 
the subject of deep-rooted prejudice, and the slave of opinion; but in what portion of the globe, inhabited by white people, is not this the case?

There are many pretended philanthropists in Britain, who feel keenly for the sufferings of the coloured people in distant countries, and do not sympathize with the unfortunate beings of their own complexion at home, who proclaim to the world the sinfulness of slavery, and yet strain every nerve to retain the unjust fetters of their own countrymen, and who lament the negro being an object of prejudice in the Lnited States, while they regard most of the white people around them with the same feeling. In America, the inhabitants of the Southern States talk of the tyranny of Europe and the degraded population of Ireland, while the sound of the lash, and the moanings of their own suffering slaves, ring in their ears; and in Britain, the cruelty of the American slaveholder, and the injuries of his oppressed slave, are descanted on by people who actively engage in withholding just rights from the lower orders of their own countrymen, and remain insensible to their base condition. Such is the shortsightedness and inconsistency of man over the world. At a distance, he sees oppression in others, and sympathizes with its victim, while insensible to his own tyranny and its effects at home. Almost all the evils which aftlict humanity, originate from the passions of man. Slavery in the United States, and the degradation of the Irish peasantry, sprung from the same source-the aristocratic feeling of the people of England.

On the packet reaching Shenectady, a stage-coach was on the banks of the canal waiting our arrival, into which I stepped, and soon afterwards found myself in Albany. My first proceeding was to obtain a new hat, and after dinner I waited on Mr Buel.

From some paragraphs I had read in newspapers while in Ohio, I learned an agricultural exhibition was to have taken place about this time at Albany, at which I was anxious to be present. It had, however, been held two days before my arrival, and I learned from Mr Buel it had not altogether come up to his expectation. A certain time must elapse before the public acquire a taste for such things, and I 
have no doubt Albany will, in this respect, set an erample to other places in the States. I had carried from Britain a few copies of the Agricultural Exhibition at Stirling, by Messrs Drummonds, which I left with some of my friends in the United States, and doubt not they will find them useful.

From Buffalo to Albany, by way of the canal, there is a good deal of fine land, and much of the foliage having dropt from the trees, afforded an opportunity of seeing the country. Indian corn was frequently seen on the ground, though in some instances the ears had been plucked from the standing stalks, and I was particularly struck with the puny appearance of the erops, compared with those of Illinois. Pumpkins seemed to have been frequently grown amongst Indian corn, and farmers generally engaged in carrying them home. This vegetable is given to oxen and cows. In most instances the wheat crop was above ground. Before reaching Utica, I observed a drain forming, at no great distance from the canal, which was the only attempt of the kind I saw executing on the American territory.

On the morning after my arrival at Albany, I set out for New York, and the day being particularly fine, I enjoyed the sail down the river. 'The trees presented a diversity of appearauce, some being without a leaf, and others in all the freshness of spring. The blue rocks were seen behind the fading foliage, a bright sun added to the brilliancy of the autumnal tints, and rendered the scenery more beautiful than I thought it when seen before in the early part of June.

On reaching New York, about eight in the evening, I bent my steps towards the Washington hotel in Broadway, and found my trunks and keys were in the possession of the landlord, Mr Ward. After having seen some of the most celebrated hotels in the States, such as the Tremont at Boston, and Mr Head's at Philadelphia, none of them pleased me so much as the Washington hotel. No individual could be more eivil, accommodating, and attentive, than Mr Ward, and all the arrangements of the house seemed to me extremely judicious. The tables were at all times served with the best of fare; the hours were kept with punetuality, and the waiters numerous and active. I cannot speak of the accommodation 
for people who have private parlours. Ladies never appear at the public table of the Washington hotel, although many. of them have private rooms in it. The traveller who dislikes the Washington hotel is more likely to find the cause of his dissatisfaction in himself than in the establishment.

As soon as $I$ ascertained my trunks were in possession of Mr Ward, I proceeded to call on Captain Smith of the Napoleon, who was to sail in a few days for Liverpool, and from whom I secured a berth. I was still in my travelling garb, my tattered garments being concealed by "Mrs Trollope." Captain Smith, in the warmth of his greeting, hurried me into his parlour before I had time to explain my situation; and never shall I forget my feelings on again finding myself seated on a luxurious sofa in a fashionable room. Since leaving Montreal on the 18th August, I had not seen a sofa, or a chair with a stuffed bottom, except one at York, nor a window-curtain, or carpet. The walls of the rooms did not support a painting or print of any description, and in all domestic arrangements there was a total absence of the elegances of life. I had become so much habituated to the state of things around me, that for the remainder of my days I would have been satisfied with bare walls and wooden-bottomed chairs, and regarded the gewgaws of refined society with contempt. It is not likely the impressions of my Backwood tour will be altogether effaced while the pulse of life beats true. I confess, however, the facility with which I adopted the refinements of New York, and the enjoyment they afforded, seemed to arise from something else than mere novelty. The venison at the table of the Washington hotel, served on plates with a flaming spirit-lamp underneath, appeared more palatable than the coagulating fried pork of Canada, and my head seemed higher than it had been for ten weeks before, from being surrounded with a collar of velvet instead of rags. Man may often learn humility from his own inconsistency and folly. I felt ashamed of my weakness.

Soon after my arrival at New York, I retired to bed. Next morning my trunks were ransacked, and I was mortified at finding I had outgrown my wearing apparel. Travelling may at all times be regarded as conducive to health, by 
affording mental and bodily exercise, apart from worldly cares, and more especially under the circurnstances I was situated, having had choice of time, route, and distance, without incumbrance of any kind.

For weeks together I seldom entered a house which was not the scene of human suffering. Associating with disease and pestilence, I conversed at the bedside of the fever patient, and rubbed the muscles of the victim of cholera. I had been exposed to the effects of solar heat, night-damp, rain, cold, hunger, and fatigue. Few people perhaps ever enjoyed so large a measure of health as fell to my lot during my wanderings in the western parts of inhabited America, and at no period of life did I possess so much mental and bodily vigour. While I gratefully acknowlerge my health and strength to have emanated from divine agency, I may state my habits were strictly temperate, having denied myself every liquid but water and tea. The trammels of society prevented me trying the effects of absolute temperance at an earlier period. They exceeded my expectations, and from experience, I recommend temperance to all who wish to enjoy life.

On the second day after my arrival at New York, I attended a sale of land by auction, which I had olserved advertised. An estate fifty miles from Albany, sold at about 7s. 6d. sterling per acre. Another, situated in St Lawrence county, state of New York, consisting of 25,000 acres, was knocked down, in one lot, at 1s. $1 \frac{1}{2} \mathrm{~d}$. sterling per acre.

On the same day, there was an election of members of Senate for the state. The legislature of the state of New York consists of a Senate and Assembly. The Senate contains thirty-two members, who are elected for four years, and vacate their seats by rotation, one-fourth yearly. The right of suffrage belongs to every white male citizen, who has attained 21 years of age, and who has resided six months in the state, and paid taxes. Men of colour are allowed to vote if they are 21 years of age, and have been citizens of the state three years, and possess a clear freehold of $\$ 250$.

On getting into the street after breakfast, I did not see any thing indicating an election, the people seemed going about in their ordinary way. There was not a crowd, or idler of any 
kind on the outside of the ballot-rooms, and on entering one of them, I found nine or ten people inside. There were two printed ballot tickets, containing a different list of candidates, and which were supplied by individuals near the door. The voters, on entering the room, were offered tickets, which they handed to people on the opposite side of a counter, appointed to receive them, and who dropt them into a box. The voter was asked his name and place of residence, and immediately retired. The business excited little interest, the voters almost never reading any part of the ticket handed them, and the secretaries seldom referring to the lists for the identity of the voter. I also entered a ballot-room in the suburbs. Here a good many vehicles were standing around the door, and the interior, which seemed the bar-room of a hotel, was filled with men who had evidently been drinking spirits. Printed tickets were also here received and delivered, as already described. Individuals may prepare tickets for themselves.

Independent of the election of members of Senate, there was a ballot for reducing the duty on salt, which the following circular, copied from a newspaper of the day, will explain. "To the Public. After a most thorough examination of the subject, and a full conviction of the injustice and partial operation of the existing tax on salt of domestic manufacture, the Legislature of this State, at their three last sessions, successively passed resolutions for an amendment of the Constitution, by which they would be enabled to reduce that tax or duty from twelve-and-a-half to six cents per bushel. Those resolutions are now submitted to the people for their approval, and are dependent for ultimate suecess on the votes that may be given in their favour at the approaching annual election.

"The words of the amendment are, "That the duties on the manufacture of salt, as established by the act of the fifteenth of April, one thousand eight hundred and seventeen, and by the section of the seventh article of the Constitution of the State, may at any time hereafter be reduced, by act of the Legislature of this State, but shall not, while the same is appropriated and pledged by said section, be reduced below the sum of six cents upon each and every bushel, and the said duties shall remain inviolably appropriated and applied as 
is provided by the said tenth section; and that so much of said tenth section of the seventh article of the constitution of this state, as is inconsistent with this amendment, be destroyed.'

" At a meeting, called for the purpose of considering and deciding upon such measures as might be deemed most proper for the occasion, the undersigned were appointed as a committee to correspond with their fellow-citizens in the different parts of the States and to take such steps to secure a favourable result in regard to the proposed amendment, as in their opinion circumstances should require. They, accordingly, ask permission to state some of the many important considerations which have a bearing on the question, and which, they trust, will satisfy every person, as they have the Legislature, of the propriety and obvious necessity of the intended alteration.

" 'The present duty, or more properly excise, is excessively disproportioned to the value of the salt at the works, varying from 100 to 200 per cent, and obliging the purchaser, when he sells at retail to the consumer, to charge an advance of profit on this as well as on the net cost. And the consequence is, that a bushel of salt, at the present time worth about twelve and a half cents at the works, must have the duty of twelve and a half cents and the profit of the dealer added, and altogether make the cost to the distant consumer, (independent of bills and transportation, from twelve to fifteen shillings per barrel, one-half of which, and sometimes three-fourths, arising from the duty exclusively, will be in a ratio corresponding with any reduction that may be made in the duty. Now, the reduction anticipated by the amendment will make a saving to the consumer of six to ten cents on the bushel, or 30 to 50 cents on the barrel, and to the state at large, exclusive of the extra price for foreign salt, an aggregate of $\$ 200,000$ per annum; and farther, both the manufacturer and the dealer will be relieved in part, from an onerous and troublesome exaction.

" As a source of revenue, the following brief exposé will exhibit the glaring impolicy and sinister effect of the duty. Suppose that the quantity manufactured this year is $2,000,000$ bushels. 
"The duty at $12 \frac{1}{2}$ cents would be $\$ 250,000$

" Less-interest on the amount expended for the pumps, with their necessary repairs and engineer's sulary, over and above the sum received for pumping, say

"Superintendents", commissioners", inspectors' fees, and the office, with other chargew, . . . . 10,000 5,000 15,000

"Balance to be paid into canal fund, . . . $\$ 235,1400$

"Suppose, again, that 1,500,000 bushels are annually consumed within this state, the duty would be . . . \$187,500

"The dealer's profit (to cover losses, \&.c.) will be 25 per cent, 46,575

"Amount paid on domestic salt by the consumers within the state,

"The consumers of foreign salt within the state owring to 234,375 this duty, are compelled annually to pay an extra price for that atticle, in the above proportion, and on 1,000,000 bushels, of $56 \mathrm{lb}$. each (the lowest quantity at which it can be estimated) is

\section{6,250 $\$ 390,625$}

"Thus the $\$ 234,375$ paid into the canal fund, costs the people, and they are principally the farmers and the labouring classes, $\$ 390,625$, or, in other words, they pay directly and indirectly more than two dollars for every one dollar that that fund receives from the duty —a fund, too, that does not need it, as may be seen by the report of Mr Stilwell to the Assembly in 1833, No. 268. If, instead of an insidious impost, the sum received into that fund were even paid by a direct tax, the cost to the consumers would not be one-fourth the amount that is now drawn from them.

"It can be satisfactorily shown, should the object in view be attained, that the immediate extension of the markets to vast districts of country, in Pennsylvania, Ohio, Michigan, Illinois, the Canadas, and some of the Eastern States, which have hitherto drawn their supplies from other sources, and the consequent enlargement of the manufacture, upon which about one-half of the duty would continue to be paid, with a great and certain increase of canal tolls, will preserve the canal fund undiminished, and probably exceed at once the sum that would be obtained by a continuance of the duty at its present high rate. 
" The salt-springe, judging from the consumption of brine for the last two years, each of which reguire from ninety to one hundred millions of gallons, and produced about $2,000,000$ bushels of salt, without any perceptille diminution, appear as inexhaustible as the Onondaga lake itself. And we may, of course, conficlently assume, as the state possesses unlimited control, that there can be no monopoly, and that an increase in the quantity made will establish a steady supply at the lowest prices, and be a security against any sudden and extravagant rise, which would otherwise certainly happen in the event of a war, or interruption of our intercourse with other nations.

"The subscribers would present herewith other statements and calculations, but for their great length, and a desire to avoid prolixity, which have appeared upon this question in the several reports to the Legislature, especially that of $\mathrm{Mr}$ Throop, made to the senate in 1831, No 56, and which most fully sustain these representations. The committee rely on the aid of the people at large for the accomplishment of the object in view ; and in order that you may be prepared to cooperate with them, send a quantity of ballots, to the distribution of which at the polls, to be held in November next, they solicit your attention.

"The following is the form of the ballot which the law prescribes for those in favour of the proposed amendment. - For authorizing the Legislature to reduce the duties on salt." "

I rode with a gentleman in his gig to a ballot-room in the suburbs of New York, and saw him vote for continuing the duties on salt. An immense majority, however, of the inhabitants were in favour of reducing the duties.

To the people of Britain it may appear somewhat strange, that the inhabitants of a country should be consulted on a political question, its supporters and opponents being ascertained by ballot, and the circumstance of universal suffrage and annual parliaments prevailing in the state of New York, will heighten the feeling. The followers of aristocracy may denounce the proceeding, and proclaim the people incapable of judging political matters, which are alone comprehensible 
to nobility. But whatever peculiarities may exist in Britain, experience in America has demonstrated that the powers of human intellect do not, in any degree, depend on hereditary title, texture of garment, or weight of purse; and that all matters connected with the domestic policy of a state, may be made comprehensible, and intrusted to its inhabitants. The intricacy of legislation has long been a favourite theme with the few who rule the many. But whatever may be the state of enlightenment regarding legislation, the people of every civilized country must be as competent to understand it as their rulers are, both parties having the same common sense, and against the dictates of which law-making should not even be attempted. Whatever is clearly understood by men in power, may be made manifest to the people, and safely left to their decision; and when such men wish to adopt measures without seeing their way, the people ought also to be consulted, both with a view of oltaining instruction and lessening the responsibility and odium of failure. These remarks are borne out by the proceedings of the state of New York regarding the salt question.

Nobility and mobility, or by whatever names the aristocracy and people can be distinguished, may each have their advocates; but the propriety of placing political power in either, must be decided by the effects produced. In measures connected with public interest, the state of New York is not surpassed, and perhaps not equalled, by any district on earth, and all of them originated from, and exist by, the power and consent of the people. How different is the state of things in $\mathrm{Bri-}$ tain, where the people have hitherto had almost no voice in political matters. If the legislation of Britain was to be regulated by collecting the opinions of the people by ballot, many important changes would soon take place. There is, however, much difference between the people of America and those of Britain. In the latter, a considerable portion of the population has been so debased by the effects of aristocracy, that they are ill qualified for discharging political duties. This is not, however, a just reason for withholding rights from any portion of the community entitled to them; and should excess arise amongst the people in obtaining or exercising their rights, 
the aristocracy who have neglected and degraded them, may be considered its real authors.

Before leaving New York, it became necessary to change my American money into that of England, which was easily effected. The chief currency of the United States is paper, and consists of one dollar bills and upwards. The currency passing at par in one state, is often at a discount in the adjoining one; and as the value of almost the whole paper currency is published weekly in the newspapers, little loss need arise. Travellers often complain of loss sustained on paper money in passing from one part of the country to another. I supplied myself with large dollar bills of the United States Bank, which passes current throughout the Union, and on changing which, the hotel keepers and coach-office keepers asked me the direction I meant to travel, and gave me silver eoin, or such provincial bills as they knew would pass at par. Throughout my whole tour, I did not lose a cent by depreciated paper currency.

Notwithstanding the coldness of the weather in the end of October, November commenced most favourably, being calm, with bright sunshine. The ladies thronged the streets of New York in summer attire; and in some cases fires were dispensed with. In several little excursions made in the vicinity of the town, I remarked the graceful weeping willow still in fresh and full leaf on the 7th November, although the thermometer a week before had stood at ten degrees below the freezing point; and a branch of considerable length which I pulled and brought to Scotland, still retains the leaves.

I left New York in the Napoleon on the 8th November. The vessel was towed by a steamer until reaching the Narrows; the day was delightful, and looked and felt like what has often been described as Indian summer. On the second day of the voyage the wind blew strong, and sometimes afterwards tempestuously. The passengers were most agreeable people, but sea-sickness prevented my enjoying their company ; and we arrived at Liverpool in sixteen days from the time of leaving New York. 


\section{A VIEW}

07 พน

\section{CANADAS AND UNITED STATES,}

ADAPTED FOR AGRICULTURAL EMIGRATION. 



\section{CHAPTER I.}

System of Nature Reproductive and Progressive, when aided by Man-Soil is a Workshop-Nuture and Man manufucturing Produce-East Lothian Agriculture-Corn Laurs-LeasesCompetition for Land-Siluation of Tenants-Situation of Hinds-Prospects of the People connected with Land.

From whatever sources arise the materials which compose and sustain organized bodies, no symptoms of decline can be discovered in them. Nature seems to be a system of continued reproduction, and, when aided by man, of progressive increase.

The quantity of matter which has been organized since the beginning of time must be immense. But whether the world is viewed in whole or in portions, nature has no appearance of decay, but seems a manufactory producing new fabrics, which are again reduced to their elements, in endless succession. Generation succeeds generation, and year after year furnishes sustenance. In the operations of nature there is no loss of materials - and when they are aided by human industry, she generously rewards man with an increase of her returns, and continues to reproduce the increase. The bounties of nature seem inexhaustible, and, in some measure, proportioned to man's industry.

The system of nature, such as I have ventured to describe, may be illustrated by the details of the farm. Pastures which have continued under the influence of nature, annually yield herbage without decrease. When they are stocked with sheep, man is rewarded with the increase of the animals, and the herbage is reproduced as before. If the pasturage is improved by draining and top-dressing, there will be an increase in the returns from sheep, and the improvement in the pasturage continues from year to year. When an improvement in the sheep is effeeted, there will be an additional return 
from them, which, by continued attention, becomes permanent.

When pasturage is superseded by grains and roots, their increased returns above pasturage is the reward of cultivation; and drainage, manures, and labours greatly increase the returns. In such a system of farming man acts a prominent part with nature, and skilful industry is required to continue the increase. Without skill and industry the returns from cultivation yearly diminish, and ultimately fall short of those from pasturage or undisturbed nature. In this case it is not nature but man which fails to do his part, and the decrease may be considered a just retribution.

A reflecting mind will discover much evidence of nature's economy throughout the universe- and the farm supplies familiar illustrations. Cows and sheep by consuming grass, yield butcher meat, milk, butter, cheese, and leather. 'These varied fabrics emanate from the same source, and when reduced to their elements, may again enter into the composition of grass. The straw of grain crops and other vegetable matter, after being eaten by or trampled under the feet of animals, decomposes and enters into wheat, barley, and turnip, or any other plant. In this manner the vegetable and animal kingdoms assist each other, and so perfect is the economy of nature, that none of her materials are lost in the intercourse.

By judicious management the fertility of a farm may be maintained, or its productions reproduced year after year; the produce usually disposed of being the reward of cultivation. If such produce was to be consumed on the farm, its fertility would be augmented, and the reproductive and progressive increase of nature, when assisted by man, exemplified. But the progression in fertility is checked by excessive luxuriance, which diminishes the returns. Thus lavish and niggardly cultivation are both punished, and illustrative of the maxim, to use the things of this life without abusing them.

Man seems to have been endowed with rational powers for supplying himself with the means of subsistence, which he accomplishes chiefly through the vegetable and animal kingdoms. Vegetables directly minister to his wants in va- 
rious ways, and indirectly through domestic animals, which are altogether dependent on them. The farm illustrates the direct supply in the production of wheat, potatoes, and flax, the indirect supply, in butcher meat and wool. In farm economy, vegetables and animals may be viewed as manufacturing machines, assisting man and each other, and the united results of which are necessary to the formation of certain fabrics, such as milk. From this source man is supplied with many of the luxuries as well as the necessaries of life. The results of the mulberry-tree, silk-worm, and cochineal insect, are united in some of the lustrous clothing of the fair sex.

The materials entering into organized life may be varied, and partly unknown to man. The most important elements of them, however, are to be found in air and water, and may, therefore, be said to pervade the universe. Should a difference of opinion exist regarding them, it is encouraging for the farmer to know that they abound every where within the sphere of his operations.

The localities for manufacturing sustenance are almost as varied as the machinery or plants. The sea, air, and exterior of every organized body are stations, but the surface of the earth or soil is the chief. The localities may be considered workshops, differing in merit, without generally contributing materials towards the manufactures. Sustenance manufactured in the sea and on the surface of the earth, equally sustain human life, and contain the same elements.

Soil is not often regarded simply as a workshop, although no other view of it accords with the operations of nature and of man. It does not in any case appear to contribute materially to the formation of plants, and is only useful to them by affording support to their roots, and holding their sustenance, being a receptacle of air, water, decomposing organized bodies, and mineral substances. Soil may be rendered fertile or unfertile by imparting or withdrawing whatever promotes vegetation.

In the preparation of human sustenance, then, soil is a workshop; air, moisture, light, heat, and decomposing organized bodies, raw materials; plants and animals, machinery; certain minerals and labours, oil for the machinery. In manu- 
facturing produce, nature supplies air, light, heat, and mois. ture; man furnishes organized bodlies, machinery, and vil, which may generally all be obtained by capital. 'The parts performed by nature and man vary according to the fabrie produced. In the case of pasturage, nature contributes the greatest share ; in cultivation the capital skill and industry of man is conspicuous. The neglected farm, incapable of producing turnip with a visible bulb, yields a full crop with a judicious application of labour and manure. The united exertions of nature and man ensure success. She accomplishes much when unaided by man, but he cannot obtain any thing without the assistance of nature. When she withholds heat or moisture, the manufacture is suspended, and she possesses the power of arresting or altogether destroying the machinery. Farmers combine nature's agency under the term climate, and they are familiar with the general effects of heat, frost, drought, and moisture. If given quantities of manure and labour were bestowed on equal portions of soil, similar in quality, situated in sicotland, on a level with the ocean, and the top of a mountain, the difference of produce would be the effect of climate.

Man has been doomed to earn his bread by the sweat of his brow. Experience confirms that the industry of an individual, closely applied to the cultivation of the soil in the temperate climes of the world, is more than adequate to supply sustenance to himself. It is a beautiful feature in farming, that agricultural improvements furnish additional food, increase almost every comfort, and ameliorate climate. The goodness of God to man is thus manifested, in providing him with the means of subsistence, and a reward according to his industry.

A person who intends emigrating ought to consider well what his prospects are likely to be in the country of his birth, and in the district to which he is to move, and be guided by a balance of their advantages and disadvantages. You have chosen the profession of farmer, and I shall, in connexion with America, direct your attention to a few particulars affecting East Lothian agriculture, the district in which you reside, and its state is perhaps not widely different from the agriculture of other parts of Britain.

The results of nature, capital, and labour, forming farm 
produce, it becomes desirable to ascertain the proportions which they contribute. It is impossible, perhaps, to fix on them with accuracy in any particular case, and their combinations are variable. Endeavour, however, to obtain a clear comprehension of the separate parts they perform in the manufacture of human sustenance. They deeply affect the question of emigration from Britain, the choice of locality elsewhere, and the employment of capital and cultivation generally. Farm economy is altogether depending on them, and the suecess or failure of operations intimately connected with their combinations.

The soil of East Lothian is owned in large masses by landholders, who seldom contribute much towards farming exeept building accommodation. The properties being secured to them and their heirs by laws of entail, their own imprudence cannot deprive them of the land, and not possessing the power of disposing of it, they have little inducement to improve it. Being, many of them, unacquainted with agriculture, they are incapable of managing their properties, which are, consequently, placed under the charge of agents, who are generally lawyers, residing in towns, without knowledye of farming. Landholders too often only interest themselves in land as shelter for game, and agents as the source of rent; the interests of both parties being temporary, they pursue their hobloy, regardless of ultimate consequences, and occasionally without sympathy for their fellow-creatures residing on the soil. There is sometimes a person under the agent, called Factor, who, from being the medium of communicating with the tenantry, possesses much influence, which is generally used, for good or evil, to please his employer.

Land is generally occupied on a lease, which endures nineteen years; and it is by the skill and capital of tenant-farmers that the soil is cultivated, and that almost all agricultural improvements have been introduced. The farmers employ yearly servants called hinds, a highly deserving class of operatives.

As the population and wealth of Britain increase, there is employment for a proportionate number of individuals in most professions-such, for example, as bakers and shoemakers 
It is otherwise with farmers, because the soil has long been entirely occupied, and it does not expand with an increase of population. Indeed an opposite rule seems to apply to this profession, skill and capital enabling an individual to manage a greater extent of land. These circumstances, joined to the natural desire mankind have to till the soil, have created much competition for renting land.

The corn-laws have been denominated a bread-tax, lut they ought to be named rent laws, as their practical effect lias been to raise the rent of land without benefiting any one engaged in agriculture, except a few farmers during an existing lease. They are a tax on the community for the benefit of landholders, so admirably devised, that it is levied without expense, farmers acting as gratis collectors, and paying the proceeds in the name of rent. Corn-laws have long given a fictitious value to farm produce, and created delusive hopes in farmers which led to their own ruin. At present they are injurious to the agricultural labourer and farmer, because while they continue and are subject to change, rational data for renting land and investing capital in its cultivation cannot exist, and their abrogation will sooner or later be effected by public opinion.

The present defective leases of farms continuing fixed for nineteen years, are injurious, by giving rise to an improving mode of agriculture at the commencement, a stationary mode in the middle, and a deteriorating system at the termination of the lease. Thus, the fertility of a farm fluctuates, instead of progressing unchecked till the end of time. A nineteen years' lease is often hurtful to a farmer, by binding him to a bad bargain for such a length of time, and involving his heirs in the difficulty which, in case of a young family, is a more serious step than binding himself. Leases have also tended to lessen the landlord's interest in his property, and estrange him from the tenantry. So much is this the case, that at the present time many landlords are altogether unacquainted with their tenantry, and a good feeling does not always exist between them. Were land occupied on proper terms, with a proper lease, the case would be different. The landlord would then have a direct interest in the cultivation 
of his property, in the management of his tenant, and in the welfare of every being residing on the soil. A worthless character, or bad farmer, would be got rid of, and the farm of a tyrannical or illiberal landlord soon abandoned. In short it would be in the option of the parties to separate at short periods, which would prevent jarring, and a community of interests would ensure the progressive productiveness of the farm. The idea of a copartnership of every individual engaged in cultivating the soil, would, in some measure, be realized, and good feeling maintained amongst them. In some parts of England where annual leases prevail, I have witnessed as good farming as I ever saw in Scotland, and perfect harmony existed between landlords and tenants, and the latter seemed to enjoy more of the comforts and luxuries of life than Scottish farmers. However advantageous leases may have proved in former times, when the tenantry were bowed down by oppression and poverty, their effects, of late years, when competition for renting land has been so great, and the value of farm produce retroyrading, have been injurious to the tenantry and the advancement of agriculture. The terms of lease seem only calculated for progressive prices of farm produce, and have proved ruinous during declining ones. It would be easy to remedy the defects of the present lease, but, under existing circumstances, visionary to expect their removal.

On the termination of a lease the farm is generally advertised to be let by receiving written offers on a mentioned day. The landlord and his agent knowing little about its value, a tenant is accepted after every attempt has been made to obtain rent above the written offers, by operating on the feelings and local attachments of the former tenant, which seldom fitil to ripen during a lease. From all parts of the country candidates of different descriptions appear. Men of sanguine temperament, without calculation, unacquainted with the peculiarities of the district, and looking forward to the prices of produce returning to what they were upwards of twenty years ago. Adventurers, trusting to get a reduction of rent after obtaining possession, and reckless of the consequence of the step they have taken, having perhaps little capital to 
lose, and content to live, year after year, dependents on the property, and with arreans of rent accumulating. People merely wishing a place of residence, and not calculating on profit from the farm, having the means of living from other sources.

Such is the state of East Lothian farmers, that during the last twenty years perhaps three-fourths of thein have not fulfilled their original contracts, and the funds that have been lost in cultivating the soil is incalculable. I have known a tenant rent a farm with a capital of seven thousand pounds sterling, consisting of about 400 acres, and remove from it before the expiry of his lease, with only five hundred pounds in his pocket, and in arrears of rent to his landlord the sum of three thousand pounds. Mr $\longrightarrow$ of our acquaintance, on a farm under 100 acres, incurred twelve hundred pounds of arrears, and got off by paying only two hundred of them. With such competitors, a young man who must live by his profession, can hardly wish to be successful. The obtaining of a lease at the present time may often be considered little better than the first chance of being ruined, and many tenants, after leading anxious lives, and exposed to the insults of rent exactors, may think themselves fortunate if they escape with a remnant of their fortunes.

The feeling that landholders, agents, and factors sometimes evince towards the tenantry is so hostile, that a small portion of the farmers originally connected with East Lothian obtain leases of late years, the new tenants generaily coming from other countries. So much is this the case, that $\mathbf{I}$ have sometimes regarded such tenants as a proscribed race, and thonght that the sooner most of them put their house in order for removal the better for themselves. It is of no consequence how respectable the old tenant may be in private life, or high in his profession. A promise of rent, although not likely to be fulfilled, is a never-failing recommendation to a stranger, when joined to subserviency, without which it is very difficult to obtain a farm on any terms. If a tenant has opinions, they must agree with those of agents or factors on the estate, or warfare ensues; and if he is an individual of talent or independent feeling, he is hunted with more zeal as a dangerous 
person, and every species of annoyance and persecution is hurled against him. A tenant of great enterprise, who had obtained a conventional reduction of rent some years ago, in consequence of a fall in prices, was lately called before an agent and questioned about his management. The tenant maintained his innovation on the common system to be an improvement, but was told by the agent that if it was found he had injured the land, damages must be paid, and if, as was alleged, a discovery had been made, it was fair the landholder should participate in the discovery, and no reduction of rent would be made in future, although prices had fiallen thirty per cent since the conventional reduction was granted. A bout fifteen years ago, eleven tenants resided on a certain estate, and since then the effects of ten of them have been sequestrated and sold at the instance of the landholder, and in all probability the remaining tenant will remove elsewhere in a few months. On a division of another estate, the tenants have all been twice changed in twelve years, and one of the farms in the same time has had four tenants, three of whom became bankrupts. With such examples before their eyes, tenants eagerly seek after farms at rents which cannot be realized from its disposable produce. Their case soon becomes hopeless, but, being bound for nineteen years, they are generally held until their funds are exhausted, when they are sacrificed, according to the partial laws of the country, to make room for a new victim. The original tenants of East Lothian have been accounted fine gentlemen-extravagant fellows, devouring so much of the produce of the soil that they scarcely leave any of it for the landholder-an allegation which is unfounded, and which has hitherto served as a pretext for harshness. It has been suggested that the managers of great estates are fond of power and adulation, and cannot brook the idea of farmens approaching themselves in the refinements of life; hence the harsh treatment of the tenantry and the success of subserviency.

There is a prevalent idea that small farms occupied by hard working men afford more rent than possessions of larger size, and on some estates small farms are forming. The effects of a division of labour, skill, and capital must be nearly the same 
in farming as in most other manufactories, and a very short trial of tenants without capital, however they may live, will prove this position by the altered fertility of the soil, which is illustrated by the state of Irish agriculture. In Ireland farm produce is the result of nature and imperfect labour ; but in East Lothian the results of capital, skill, and improved labour enter into the combination; and in the latter the produce of land is much greater than in the former. But the landholders of Ireland are perhaps more wealthy than those of East Lothian, compared with the people of the respective countries. A crowded and agricultural population will pay rent in proportion to its degradation, or, at least, afford in such a ratio influence and rank to landholders. This rule is not, however, applicable to Britain, where commerce and manufactures flourish, whose profits of stock and wages of labour ultimately affect those of agriculture, and the selfish attempts at degrading the farmers of East Lothian will recoil on their authors. For a time tenants without capital can pay high rents, by extracting from the soil the means of fertility imparted to it by others; but the deteriorated condition of the farm is ultimately a loss to the landholder and the community.

The capital which is required to put the operations of an East Lothian farm in full motion, the tenant maintaining himself and reaping a crop without the aid of credit, may be stated at seven pounds sterling, or nearly thirty-five dollars per imperial acre. The rent which is stipulated to be paid, and the capital expended in fertilizing the soil, renders the step which he takes a serious speculation. If a bad crop or two occurs at the commencement of the lease, the tenant will be unable to pay the rent, and he is then deprived of the lease, or allowed to continue a dependent on the estate. Being bound for nineteen years, he has not the option of removing from the farm, and is very seldom permitted to do so while a tangible farthing of his funds remain. At all times he leads an anxious life without bodily toil, and is seldom remunerated for his exertions and risk of capital. Industry and enterprise may enable him to struggle to the end of his lease. Should he die and leave a wife and young family, the unexpired years of the lease would in all probability ruin 
them, his funds being liable for the rent, and they would be incapable of managing the farm without incurring great loss. Two thousand pounds may be stated as an ordinary capital to commence farming with; and it is hopeless for a person without considerable funds to think of farming at all.

The hinds, or farm-servants of East Lothian, are, perhaps, the stearliest and most praiseworthy race of men in the world, and indifferently rewarded for the important part which they act in farm economy, living on poor fare, and in bad cottages. $\mathrm{Up}_{\mathrm{p}}$ to the present time, the best feeling has existed between them and the tenantry; and there are thousands of instances of men having died of old age in the service of their first employers, without an alatement of income having been made during sickness or infirmity. But a change is taking place in their condition, by the pressure on the tenantry weakening attachments, and forbidling an indulgence of generosity towards their faithful and proficient operatives. Mutual confidence and assistanee, in the diflerent classes engaged in farming, forms the strength of the East Lothian system of agriculture, and the true souree of happiness of all interested in it. Kindness and attention, on the part of landholders towards the tenantry, commonly radiates to farm-servants, from them to the animals under their chargre, and the happiness of all is thereby promoted. On the other hand, harshness and neglect shown by landholders to the tenantry, descends to servants and animals, and general uneasiness is the result. Some of the recently introduced tenantry bring all their operatives from other districts, and have commenced the Bothie system, which is highly demoralizing in its effects on the men who are subjected to it, although it is somewhat cheaper than the customary mode of treating the ploughmen. The prospect of this class bettering their condition is hopeless, and there is reason to apprehend their comforts will be curtailed.

The rural population of East Lothian appears to be undergoing an unhappy change. The management of landed property is almost entirely intrusted to agents, who, like the middlemen of Ireland, have no permanent interest in the soil, nor sympathy with its cultivators; and, like that country, East Lothian now suffers from the effects of absenteeism, so 
far as the interests and feelings of the rural inhabitants are concerned. The landholders and tenantry are unknown to ench other, and dislike may sometimes be traced in both parties. 'The tie of farmer and ploughman is waxing weak, and instead of the quietness of conduct which now pervades all classes, a very few years may develope the troubles of Ireland, and the south of England.

It has already been stated, that nature contributes much towards the manufacture of farm produce; but the fruits of her exertion do not benefit the tenant nor operative. The landholders receive as rent all that results from nature, and also a considerable portion flowing from the tenant's capitul and the operative's labour. 'The tax which the corn-laws impose on the unagricultural portion of the population, for the benefit of landholders, is collected free of expense by the tenantry. The ragged and half-starved peasant of Ireland labours amongst, and begs from, the people of Britain, and, on reaching home, gives his earnings to the owner of the soil, that he may be permitted to exist only on the potato he himself cultivates. The East Lothian tenant of the present day is often not more happily situated, gradually paying the landholder the earnings of early life, or inherited wealth, for the privilege of ocupying the soil, and returning its produce. It is fortunate landholders do not possess the power of preventing the population removing to other countries, and there growing produce for themselves.

There seems but little in the present constitution and state of agricultural relations to brighten futurity. An abrogation of the com-laws would ensure an extended application of capital to the soil, and create employment for operatives. Annulling the law of entail would produce landholders interested in agriculture and the people who follow it. But however beneficial might be the effects of such measures, the evil of a limited surface with a numerous population would remain. The landholder would perhaps be reduced to the necessity of superintending the cultivation of a part of his own soil, and generally interest himself in his estate. The situation of tenants and operatives would only be improved for a short while, as they would soon compete with each other as before. Nei- 
ther of them are at present adequately remunerated for their exertions. To expect much improvement in their condition while population is so numerous, seems hopeless; and individuals will require to exert themselves to maintain their present position.

I have treated generally of East Lothian agriculture, and the classes immediately connected with it, without nuticing examples of wisdom and generosity on the part of landholders, or of folly and worthlessness amongst tenants and operatives. My object has been to bring the unsound parts of the system under notice, in order that an estimate of future prospects might be formed. But all classes may be regarded as the victims of circumstances which have not perhaps been of their own creating, and they are more deserving of sympathy than censure. While what appeared to me to be the true state of things has been freely described, I disclaim feelings of bitterness or reproach towards man or things. 


\section{CHAPTEH II.}

Persons engaged in Americun Ayrisulture-Ameriocen and Brilish Agriculture-Applisstion of Capital and Lablour to Ciultiontion. -Rent-Pries of Land-Proportions of . Vuture-Cippital and Labour in the Production of F'arm Produce, and their distrilution in Britain and Ameriea-C'apilal required to stock a liorm in both Conentries-Unhealthiness of Americu-Climate-Sints. of Society_Sitution of young Hen without Capitul_Choosiny America or Britain.

Is North America, extensive landholders are not common in any of the districts which I visited; and where they do exist, a great part of their possessions are unproductive. 'The soil is chiefly cultivated by its owners, who, in sundry respects, resemble the tenants of Scotland; and they often perform a great portion of the manual labour of the farm. In many parts of the country, which has been long settled, the farmers are opulent, participating in all the conveniences of life ; and, without passing their time in absolute idleness, hire a good deal of labour. In the more recently settled parts, farmers have few of the elegancies and conveniences of life, with an ample share of its necessaries. They do not labour hard after the first three or four years of settlement, and seem to live without much care. Land does not invest its owner with any privilege or status in society.

Renters of land, or tenants, are common in many parts, and in all respects rank as landholders. The terms of rent are variable. Near towns, and in thickly-peopled districts, a small rent is paid in money, and a lease of several years taken. In remote situations, land is commonly let on shares from year to year. If the owner of the soil furnishes seed and labouring animals, he gets two-thirds of the produce, when on the field, and removed from the earth. If the tenant supplies 
animals and seed, the landowner gets one-third. But terms may vary according to situation, soil, and crop.

Farm-hired men, or by whatever other name they may be distinguished, are to be had in all old settled distriets, and also in many of the new ones. In most cases their reward is ample, and their treatment good, living on the same kind of fare and often associating with their employers. A great deal of farm labour is performed by piece-work.

The agriculture of a country is affected by local cireumstances, and farming in Britain and in the remote parts of America may be considered the extremes of the art. In the one country the farmer aims to assist, and in the other to rub nature. When the results of capital and labour are low, compared with the hire of them, they are sparingly applied to the cultivation of the soil, in which case nature is oppressed and neglected, if I may be allowed to use such terms; and when they are high, compared with their hire, she is aided and carressed. Both systems are proper in the respective countries; and, by assuming a fixed result for nature, they admit of arithmetical demonstration. Along the eastern shores of America, manures and a considerable portion of hired labour are applied to the cultivation of the soil ; but in remote districts manures are not used, and the smallest indispensable quantity of labour bestowed. In the eastern parts, the results of capital and labour enter into the productions of the soil ; in remote districts the aid of capital can scarcely be said to have been called into action, and in both situations nature is the chief agent.

The circumstances affecting the application of eapital and labour to the cultivation of the soil in Britain and America are as opposite as their systems of farming. In Britain, with her limited surface and dense population, nature's contribution towards the production of farm produce is given to the landholder as rent, and the rural inhabitants living near the starvation point, the price of provisions regulates in a great measure the hire of labour. Accordingly, the wages of agricultural labour in the different parts of the country are proportionate to the value of their produce; being lowest in the remote and inclement situations, and highest in the most 
favoured districts. In America, the extent of soil and thin population has not distorted effects, and nature's portion of farm produce is not absorbed by rent. The results of capital and labour being represented in quantities of produce, and their hire paid in money, it follows, that the eash-value of the former must generally exceed the latter, and that an additional application of capital and labour to cultivation is a consequence of produce being high priced compared with their hire. Accordingly, in all parts of the country where produce is high, labour is low, and where produce is low, labour is bigh.

In Britain, the hire of agricultural labour has been affected, and in all probability will continue to be regulated, by the wages of the unagrieultural part of the population. Without manufactures and commerce, the condition of her vural inhabitants would have approached the present state of the Irish people. In America, the returns of the agriculturist appear to regulate the wages of other classes. When they are high, other classes are attracted to farming; when low, farmers change their profession;-Americans generally being able to exercise two or three professions.

The origin and progress of rent seem to admit of easy solution. In the western prairies of America, where cheap and good cleared land is almost as abundant as air, rent is unknown, except in the neighbourhood of towns. In the eastern districts, where good cleared land is of limited extent, compared with the inhabitants, rent is paid. Thus, population is the origin of rent, which is the value of produce above what it hath cost in raising and carrying to market. At first, it consists of a small portion of the produce furnished by nature; with an increase of population the whole is absorbed, and ultimately also, parts of the results of capital and labour. Rent is also affected by the condition as well as by the number of the people; and, under a parity of circumstances, will be found to augment in the ratio of the number and misery of the agricultural inhabitants.

Until land yields rent, it is not worth purchase-money, and in proportion to a rise of rent its price will increase. Lands, therefore, sell at a considerable sum on the eastern 
side of America, and diminish in price to the westward, unless enhanced by localities of situation. As population increases in the west, and labour falls, land will rise in value, cheap land and cheap labour being incompatible with each other. But the investment of capital in the purchase and cultivation of land depends also on the profits of stock, or rate of interest in the country, the tangibility of the investment, and many other things.

From the high price of produce, and comparatively cheap labour and manuce in the eastern parts, capital, judiciously employed in cultivation, yields an ample return. But the low produce and high labour in the west renders it unprofitable to employ much eapital in cultivation at present in that situation. From the great advantages which the western districts possess over the eastern ones in cheapness and fertility of soil, and consequent reward of labour, population will flow into them, and render a rise in the value of land more probable there than in the eastern parts.

Having frequently allueded to the results of nature, capital, and labour, in the production of farm produce and their distribution, I shall endeavour to illustrate the subject hypothetically, for the purpose of assisting in forming an opinion of their general bearings. The results of eapital and labour employed in cultivation camnot always be separated, and perhaps they ought to be classed together. The assumed data does not include capital invested in the purchase of land, and I do not wish the accuracy of the statement to be relied on, although I think it approaches to correctness.

In Last Lothian produce, let nature be represented by 3

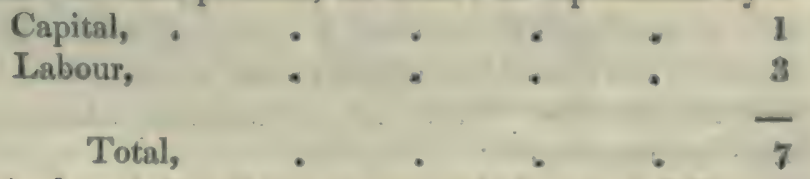

Nature's share being given as rent, and also part of the results of eapital and labour, the landholder perhaps gets a portion, expressed by $3 \frac{1}{2}$, leaving $3 \frac{1}{2}$ for the tenant, labourers, and all other expenses of cultivation. But the expenses of cultivation and rent must be paid under all circumstances, and frequently 
nothing remains for the tenant. 'This is particularly obvious in unproductive seasons when the diminished crop may be represented by 4 , leaving the tenant, after discharging taxes and some other things, without a farthing to pay rent. I myself have been so situated, and human means cannot prevent such visitations. Hence the speculative nature of farming, and the results which have flowed from it.

In American produce, let nature be represented by 3

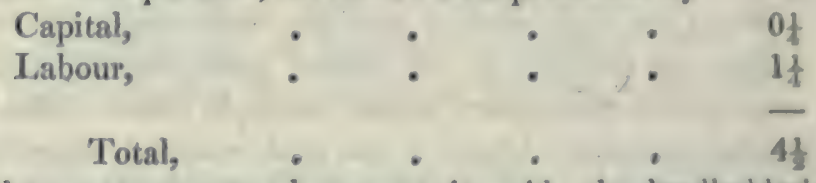

In the eastern parts where rent is paid, the landholder's portion may be 1 , leaving $3 \frac{1}{2}$ for the tenant and expenses of cultivation. In remote districts where capital is scarcely employed, the whole produce falls to be divided between the landholder and labourers, and the landholder enjoys it without division, when the labour is performed by his own hands. Although the divisible portion appears the same in both countries, the labour and capital employed in cultivation is perinaps five times greater in Britain than in western America. On a given surface the produce is greater in Britain, but in America the produce is greater in proportion to the labour employed in cultivation.

In East Lothian the farmer gives the fruits of nature and part of the results of capital and labour to the landholder as rent. In western America the farmer shares nature's bounty with the labourer, or enjoys it himself by labouring with his own hands. In East Lothian the farmer of the present time is in some degree the servant of the landholder. In western America the farmer has nature for his servant, or at least enjoys her labours. With such an assistant what industrious man can be poor?

In the event of death or old age, nature still continues her services to the American farmer, by furnishing grass and other commodities. A widow or young family, almost under any circumstances, could milk cows and plant potatoes. Bountiful nature would provide grass for the animals and mature 
the potatoes, on the produce of which the family might live. In Last Lothian a widow or young family, after being ruined, would be turned adrift on the world.

In the eastern parts of America land may be purchased and stocked for nearly the sum an East Lothian farmer expends in stocking and improving a farm, namely L.7 per acre. But if the land has great local advantages, the price will be considerably higher. In the western parts of the United States, prairie land of the best quality, without the least olstacle to cultivation, and to any extent, may be had. For the sum of three hundred pounds sterling a farm of 200 acres could be bought and stocked in the prairies of western America. In East Lothian farming is a hazardous calling; in America there is no risk attending it. In Last Lothian L.2000 is required to stock a farm; in the Western States L.300 will purchase and stock one nearly of equal size. In last Lothian a farmer has mental annoyance with bodily ease; in America he has mental ease with personal labour. In liast Lothian a young farmer commences his career in aftluence, and at middle age finds himself in poverty; in America he begins with toil, and is in easy circumstances by middle age.

But however favourable American farming may appear when simply viewing the quantity of produce, the country has many disadvantages deserving of consideration, and one of the most important is its unhealthiness. The whole of North America is liable to ague and fevers of various kinds, and the chief difference of situation in these respects seems to be owing to cultivation. 'The more cultivation is extended, the healthier the climate becomes, but occasionally ague and fever prevails in all situations. I found fever and ague at Hyde Park, on the banks of the Hudson, at Niagara, Whitby, and Chatham, in Upper Canada. The inhabitants on the prairies of Michigan, Indiana, Illinois, and Missouri, were suffering much from fever when I was amongst them. Almost every person you meet with in America tells you of the healthiness of his situation, and the unhealthiness of other parts of the country. The cause of ferer and ague in America does not appear connected with marshes or stagnant waters, as the inhabitants resiling on the dry open prairie of 100 miles in 
extent are not exempt from its attacks, but is thought to ariae from the miasms of decaying vegetation; and the rich bottoms, covered with rank vegetation, on the banks of rivers are the most unhealthy situations. While journeying over the prairies of Illinios after nightfall in autumn, when vegetation was decaying, the smell of fermenting grasses was unpleasantly strong, and reminded me of the odlour of a sweating hay-stack in Scotland. In almost every part of the world where the earth's surface is uncultivated and well clothed with vegetation, fever and ague prevails, and is found to abate as cultivation is introduced. 'Thus bountiful nature at once rewards the enterprising farmer with her fruits and a more salubrious atmosphere. What incentives to industry!

The climate of North America is remarkable for variations of temperature, and most situations seem alike in this respect. But the duration of winter increases, and length of summer decreases, with the latitude of the situation. 'The region of North America is not so congenial to human life as Britain, but far more so than the East and West Indies and many other parts of the world. In such a vast continent cultivation is alone wanting to render it healthy.

The state of society in America is very different from what it is in Britain, there being less refinement and fewer of the elegancies of life enjoyed. I am satisfied, however, from experience, that much of what is known by, and appreciated as, the comforts of life, arises from fashion and force of habit, and that a few weeks' residence will reconcile a reasonable person to the change. Throughout the greater part of the country, fashion has not established her empire, and there is little vieing amongst the inhabitants. The handsome bound volumes which adorn the drawingrooms of Britain, are not more instructive or amusing in consequence of their showy exterior; and the meagre furnishings of American log-houses, in the remote districts, meet the wishes of the inhabitants, and are found as useful as the most gaudy. Plain furniture is not despised where fine is never met with. In taverns, luxuries and refinements are common, and wealth may obtain them almost any where. Of the state of domestic society I am not qualified to speak from personal observation, farther than that 
the manners and customs of the people differ from those of Britain. In the eastern parts the distinctions of classes in society and elegancies of life approximate those of Britain, and both gradually diminish on proceeding to the westward. But in any part of America, where an emigrant may settle himself, he must lay his account with a change in the social intercourse of life. Some people are, however, incapable of altering their manners and customs, and such characters may live without society.

In the eastern parts of America the luxuries and conveniences of life are cheaper, and the necessaries dearer, than in remote districts. The east should therefore be the abode of the wealthy, refined, and luxurious; the west, of the persons who value the necessaries of life, and such as are not of fastidious habits. But in no part of the country will the fastidious find themselves happy.

The want of good assistants, servants, or helps, is ranked amongst American privations. In the east assistance can at all times be had, which is not the case in the west; but in most situations high wages and good treatment will obtain assistance. Female servants are very scarce, and said not to be good. To the wealthy and refined, who have resided in Britain, this state of things at first appears insupportable. They soon, however, learn to assist themselves in many things, and find their happiness increased by doing so.

The difticulty of obtaining servants arises from the ease with which individuals obtain a livelihood, every industrious and sober character having the means of purchasing a good estate in the west with the accumulated savings of three years' service. However much certain classes may feel and regret the want of servants, the extraordinary reward which they receive ought in fairness to be accounted the country's greatest blessing. In no other part of the world is industry, sobriety, and worth, so richly rewarded.

The influence which wealth has attained in Britain merits the consideration of all young men without capital. Personal exertion is often considered degrading, and visited with the contumely of former associates. To lose rank in society must be particularly galling to young men of spirit, and few in the 
middle walks of life can keep their place without capital. This is one of the many inconveniences attending a refined state of society, and is more likely to increase than diminish in Britain. In the remote parts of America wealth is not idolized. The industrious youth may there follow any oceupation without being looked down upon or sustain loss of r:ank, and may rationally anticipate raising himself. 'The plain style of buildings and household furnishings of such places are favourable to young people, and in almost every particular their situation may be said to be the reverse of what it is in Britain. A young man without capital and of good character, is almost sure to gain but cannot lose rank by emigrating to America, and will rarely maintain his rank by remaining in Britain.

In judging then of the step of becoming an American agriculturist, all may lay their account to undergo considerable privations at first settlement, and lead a different life from the farmers of East Lothian. The bountiful reward which industry receives soon enables good men to purchase land; and it is therefore often the unsteady and idle which hire themselves to farmers. On this account, it will be necessary to work personally, by way of example and active superintendence. Right thinking people consider it no disgrace to labour in any part of the world, and it is thought quite disreputable to be idle in America. East Lothian farmers often toil mentally without remuneration ; and the assurance that, while in America, all the fruits of a person's own labour, assisted by generous nature, accrues to himself, will nerve his arm and sweeten his toil. The division of labour so beautifully effected in some of the operations of East Lothian agriculture, and which I may be permitted to call professional luxuries, cannot be practised at present in America. The wooden dwelling-house and barns will at first perhaps appear revolting, and may induce some people to think, that, with the same privations and sacrifices, they would have been enabled to have lived in East Lothian. Such is not, however, the case; because the pressure on farmers arises from a competition of numbers, which would be increased by lowering the standard of living; and the only result of such policy would be to raise the rent of land, and degrade all engaged in farming. Let no one, 
however, from my representations of American farming, elltertain too sanguine hopes of success. Farming, in most parts of the world, ranks low in the seale of professional remuneration; and without virtue, persevering industry, and sobriety of character, people will not likely either become wealthy or happy. In nine eases out of ten, a man's suceess in life depends on his own exertions. America presents a fertile and extensive field, and whoever does not reap an abundant harvest, will, in all probability, find the cause of failure in his own character. I cannot hold out an immediate or ultimate prospect of great wealth, as the low price of produce and high labour renders this improbable. Every person may, however, obtain all the necessaries and most of the true comforts of life in the fullest abundance, unharassed by the cares of the present, or apprehensions of the future. The pleasures of society are not likely to be so much enjoyed in America as in Britain; but, on the other hand, its mortifications are escaped. In every part of the world, man ought to look to his family and himself, and not to society, for true happiness. If abundance of the necessaries of life do not ensure society in America, the want of abundance is almost sure to lose society in Britain. 


\section{CHAPTER III.}

\section{Lower Canada-Inhabitants-Climate-Soil-Mode of Selling} Land-Productions and Prices-Farming near MontrealClimate affecting Agriculture and Farmers.

Canada originally consisted of one country, and was divided into two provinces, Upper and Lower Canada, in 1791. It was discovered by Jacques Cartier, a Frenchman, in 1535, and continued under dominion of the French until 1759, with exception of a year or two, when it was ceded to the English.

The descendants of the French, after the eonquest by the English, were allowed to retain their laws and religion, which so attached them to the British government, that their fidelity remained unshaken during the war with the colonies to the south, which now form part of the United States. In the late war between Great Britain and the United States the population again continued faithful; and their antipathy to the inhabitants of the States seems to be unconquerable.

About two-thirds of the inhabitants of Lower Canada are descendants of the French, who speak the French language, and retain most of their old manners and customs. The rest of the inhabitants consist of all nations, and are chiefly descended from British subjects. The French Canadians profess the Catholic religion; and lands held by Catholics pay one twenty-sixth of the grain produce to the clergy. 'The exaction, however, seldom extends beyond the wheat crop; and the people of all religions represent the Catholic clergy of Lower Canada as the best disposed and most inoffensive class of men in the province.

The French Canadians are chiefly engaged in agriculture, and are a most unenterprising race of individuals, and lead the same kind of life which their forefathers did upwards of two hundred years ago. They appear to be poor, indolent, and a mirthful loving people. The commerce of the pro- 
vinee is carried on chiefly by British subjects. In politics, there is a French and British party. At present the French interest is the most numerous; it will, however, ultimately dwindle away.

The provinee of Lower Canada lies between forty-five and fifty-two degrees of north latitude, and sixty-three and eightyone of west longitude, from Greenwich. The climate of America is very different from places of the same latitude in Europe, the degrees of heat and cold being much greater. Although Jying considerably farther south than England, Fahrenheit's thermometer ranges between ninety and one hundred degrees in summer. In winter, the thermometer oceasionally indicates thirty degrees below zero, and for six months the surface of the earth is covered with snow. The St Lawrence, which divides the province, runs in a northeasterly direction, and the climate becomes mild as the river is ascended. In the western part of the province, spring commences a month earlier than it does at Quebec, the eapital of the district, and the climate is in all respects superior for agriculture.

The climate of Lower Canada is perhaps as healthy as any in America, which may be owing to the length of time the banks of the St Lawrence, where the population chiefly reside, have been cultivated. In newly settled districts, fever and ague, the scourge of America, is frequently known.

The soil, which has been surveyed, is estimated by Bouchette at about $16,000,000$ acres, and is said to be inferior sand in the eastern parts, and to improve to the westward. This gradation of soil seems to be pretty general in most parts of North America ; but soils of the most opposite character are to be found in all situations, and America is as variable in texture and quality of surface as Britain.

The greater part of the cleared land is occupied by the descendants of the French in narrow stripes, seldom exceeding 100 acres, and often extending miles in length. The tenures are of French origin, and it is difficult to get a good title to land, without it has been disposed of at a sheriff's sale. A considerable part of the land is held by English tenure, 
and to such there is no difficulty in obtaining good titledeeds.

A considerable extent of crown lands is still undisposed of, and they are sold by public sale on the first day of every month, in every township where an agent resides. 'The upset price of the lands varies from 2s.6ol. to $10 \mathrm{~s}$. Halifax currency, by which all land in the Canadas are sold. 'The following are the conditions of sale for 1834 :-

" 1st, The lands will be put up for sale in lots or parcels of from 100 (or a half surveyed lot) to 1200 acres (or six surveyed lots), as may suit the convenience of parties disposed to bid for the same.

" $2 \mathrm{~d}$, The lots will be offered at the upset price, as quoted above.

" $3 \mathrm{~d}$, The lots are to be taken at the contents marked in the public documents, without guarantee as to the actual quantity contained in them.

" $4 \mathrm{th}$, The biddings to be made in currency upon the upset price per acre.

" $5 \mathrm{th}$, The lots will be sold to the highest bidder.

" $6 \mathrm{th}$, The purchase-money to be paid by four annual instalments, without interest. The first instalment or depositmoney of twenty-five per cent at the time of sale, and the second, third, and fourth instalments at intervals of a year.

" 7 th, The instalments to be paid into the office of crown lands at Quebec, or the treasurer or receiver of rents on his half-yearly tour for the collection of rents.

" 8 th, If the instalments are not regularly paid, the depositmoney will be forfeited, and the land again referred to sale."

The chief productions of Lower Canada are wheat, barley, and oats, of inferior quality, which may be partly owing to the climate and the management which the soil is under. For nearly half a century, manure has not been applied to the greater part of the cultivated land, which, after being what is considered exhausted, is allowed to produce a natural sward of grass, on which animals browse during one summer, and it is again ploughed in autumn. Notwithstanding the natural goodness of much of the soil, the crops are of the worst de- 
scription; and when all things are taken into consideration, it is surprising to find them so good.

Much of the land in the neighbourhood of Montreal, unconnected with the island of that name, is of excellent quality, and, if properly drained and manured, might produce almost any description of crop.

The island of Montreal contains some good soil, of light texture, well adapted for market gardening, a department of husbandry at present highly remunerating. 'The French Canadians being unwilling to dispose of their lands in the neighbourhood of the town of Montreal, and not likely soon to change their present system of agriculture, the growing of vegetables will, in all probability, long continue profitable, even should high prices induce settlers up the St Lawrence to transmit produce when the communication with Montreal becomes improved, as it unquestionably will in progress of time.

Agriculture produce of all kinds fetches a high price in Lower Canada, which does not seem to afford sutticient food for the inhabitants, and more especially butcher meat. The following inland imports to Montreal are taken from the Commercial List.

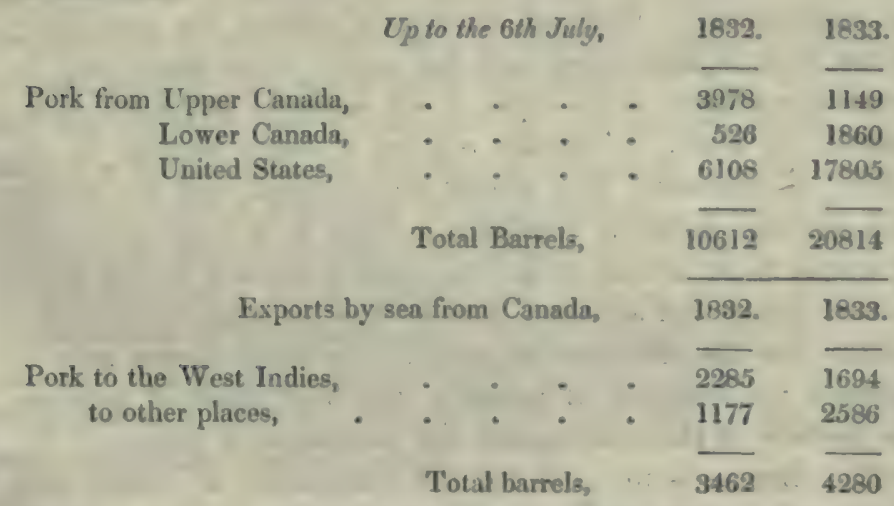

These lists, containing only the imports to Montreal and the exports of the whole province, show a considerable balance against the country, which would be greatly increased if the imports of the whole province were included. It is probable other articles would also show an unfavourable balance. 
The difficulty of raising produce is unquestionably the cause of its high price, which is not likely to be lowered loy other means than importing supplies. The French Canadians, having few wants and strong local attachments, labour cheaply rather than remove to a distance, which, joined to the influx of destitute emigrants from Britain and Ireland, renders wages lower perhaps than in any other part of the American continent. High prices and cheap labour are favourable to investing capital in cultivation; and a skilful and prudent farmer cannot fail of being successful in the immediate neighbourhood of Montreal. Here he will feel the change from Britain less than in any other part of America, with exception of climate, and even the length and severity of winter are said to be agreeable. A considerable extent of capital is required to purchase land in a good situation, which costs from L.10 to L.20 per acre. Land is also occasionally to be had on lease; and when a sufficient number of years, and proper terms are obtained, an outlay of capital in improving the soil would be profitable.

If soil is the workshop of the farmer, and animals and plants his machinery, the climate of Lower Canada is an impediment, seriously affecting plants, animals, and man, which cannot be removed. With six months of winter, the machinery of the farm is suspended half the year. Few plants can be properly matured, and erops, in all seasons, are liable to be injured by frost. Animals require a large supply of dry fodder, as succulent food cannot be provided, and the intense cold reduces them in condition. Man is so long prevented by winter from labouring the soil, and so hurried by the shortness of spring and autumn, that he has not time to prepare it suitably for the reception of crops. To these causes may be ascribed the leanness of animals, the high price of produce, the poverty of the people, and the cheapness of labour.

The climate is too cold for the cultivation of Indian corn, which only occasionally comes to maturity in the most favoured spots. Autumnal sown wheat is similarly situated, and the wheat of the country sown in spring is of the most inferior quality. Fahrenheit's thermometer having stood twelve degrees below the freezing point at Albany, in the 
state of New York, on the 29th October, 1833, the cold, in all probability, must have been greater in Lower Canada, which is several degrees of latitude farther north. Accordingly, a gentleman of my acquaintance, who settled in the township of Leeds, stated in a letter, "that misery and famine stared farmers in the face; frost having set in early, all their turnips and potatoes had been destroyed, and, in some cases, also their grain crops." The condition of the animals is also evidence of the severity of the climate. Sheep and oxen, as seen by me in the months of summer, were mere skin and bone compared with those of Britain, which I attributed, in a great measure, to the cold of winter; and sheep of the Leicester breed, sent from East Lothian, sunk under its effects in the most southerly part of the province.

However much the man of pleasure may extol the winter of Lower Canada for the glorious sleighing it affords-and its boasted advantages seem to be confined to this mode of travelling-the industrious farmer must regard it as an evil, by suspending his operations, and injuring his live-stock. Nature here assists him more sparingly than in warmer latitudes, and he will not live comfortably on cleared land by his own labour, except in the most southerly parts of the province. To clear forest land in most parts by his own exertions, would not reward him for five or six years afterwards, if land was to be had for nothing, and its inferior produce cannot afford good wages to labourers. For the farmer of capital, the neighbourhood of Montreal holds out many advantages. The province is not, however, favourable to farmers who are in search of food and clothing for themselves and families, and still less so for labourers of any description. Both classes must, of necessity, be idle during a considerable portion of the year, and they are not likely to improve their condition by emigrating from Britain to Lower Canada. 


\section{CHAP'TER IV.}

Uyper Canoda-Iuhabilants-Climate-Soil-Mode of Selling Laved, and Prives-Bad Eiffects of Selling on Credit_Situation

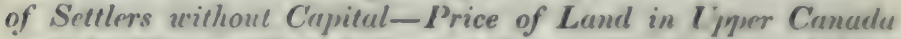
and the Western Linited Stutes-Price of Land, and Mode ni Settlement Injurious to the Province-Suggestions for Improving the State of the Country.

Upper Canada became a separate province in 1791. It is bounded on the east by Lower Canada, and on the south by the river St Lawrence, and the chain of rivers and lakes to the west, the waters of which form the St Lawrence. The boundaries in the north, and in the extreme west towards the Pacific Ocean, are perhaps not accurately definced, and the surface of the province cannot be estimated.

About the time of settling the mouth of the St Lawrence, the French penetrated into Upper Canada, and planted a colony on the river Detroit, where their descendants still reside. At the close of the war, in 1793, when the colonies of North America became independent of Britain, many inhabitants of the United States, who adhered to the government of the mother-country, moved into Upper Canada, where they obtained grants of land. At the same time many disbanded soldiers also received land. In this way parts of the shores of lake Ontario, and lake Erie, and the banks of the Niagara, Detroit, and Thames, were first settled. More recently, many people of Dutch and German extraction have settled in the provinces, as well as subjects of the United States; and there has been a constant stream of emigration from Britain. The population, chiefly found on the lakes and rivers, may amount to about 400,000 , the greater part being of British descent.

Upper Canada differs from the lower province in climate, 
by having a longer summer and a shorter winter; while the extremes of heat and cold, as indicated by the thermometer, are nearly the same in both provinces. The waters of the St Lawrence and lakes, forming the southern boundary of the district, inclining north-east, the climate improves in ascending the waters, till reaching Amherstburgh, in about 42 degrees of latitude. The province, as far as it is accurately known, has not an eminence of sufficient height to affect temperature, and the climate of the different situations may be estimated according to their latitudes. In the most southerly parts, near the head of lake Erie, the length of winter varies from two to three months. Ploughing commences about the first of April; and cattle and horses are allowed to roam in the woods during winter, - a practice which marks the mildness of climate, and also, perhaps, the laziness of the inhabitants.

The climate of Upper Canada is as healthy as the lower province, although the inhabitants are more liable to sickness from the surface not being so well cleared of forest. On my first entry to the country, I thought to judge of the healthiness of situations by the countenances of the inhabitants, and if all of them had been born in the country, this might have been a just criterion. There is something in the climate of America which seems to impart a sallow and seared complexion to the people. It is, however, many years before some natives of Britain lose their florid colour; and I have seen several people retaining their complexion after having resided twenty years in the province, while their children had the general hue of the country. Being unable to judge whether the people had been born in the country, or were lately arrived from Britain, I abandoned the idea of taking the appearance of the inhabitants as an index to healthiness of situation. As I proceeded westward, towards Chatham and Amherstburgh, the complexion of the people became less florid, which I attributed to most of them being natives of the country. I found people afflicted with ague in many places, after having resided years in the district; and from information which I received, deserving of credit, I was led to believe almost every European has a seasoning, or an attack of the ague. The rapidity 
and severity of the attack, however, depends in a great measure on the situation of individuals being aggravated by fatigue, imperfect clothing, bad food, and a damp house."

The surface of Upper Canada is remarkable for want of hills, but much of it is considerably undulating; and where this formation prevailed, I generally found the soil of inferior quality. The soil is variable in all districts; much of it is very bad; and it may generally be termed of medium quality. I could only judge of the soil by its natural appearance, which would be improved by cultivation. In all parts of the coun-

* The fullowing extracts are from the correspondence of my brother Charles, dated Detroit, 7 th August, 1834 :-

" Through how many exciting scenes have I passed since we parted! For two months tossed upon a stormy sea, with a disagreealle captain, in a crazy vessel! - seen the most sublime of nature's works, a stornly sea, and such a storm! - stood on deck when not a soul, from the captain to the cabin-boy, expected to live ten minutes! I have experienced deliyht consequent on deliverance; leaped with joy at the sight of land; anmired the fairy scenery of Long Island and the Hudson when the orchards were in full blossom,-and it is a sight of indescribable heauty? I have travelled up the North river, at the rate of fifteen miles an hour, in the finest steamboats in the world-shot along the rail.roads-crawled on the canals-been shaken in stage-coaches-and crossed lakes Erie and Ontario, which for magnitude deserve the names of inland seas. I have walked since the 7 th of June 210 miles in Upper Canada, 200 in Ohio, 50 in Pennsylvania, 160 in Illinois, and 150 in Indiana and Michigan; in all nearly 800 miles. Some say, the thermometer stood from 95 to 101 degrees in the shade. Often were my elothes as wet with perspiration as if I had waded a river; still I never experienced that lazy, listless feeling I have done during warm weather in Scotland. My appetite was always keen, and it still continues so."

After residing in Upper Canada, on a second visit, for the space of about 20 days, he writes from Cleveland,_-" Do not be astonished at learning I have got the ague. I have had three shaking davs, - my appetite is entirely gone. One day I feel quite well, and the next as helpless as a child; and, altogether, the ague is not a pleasant companion. I shall endeavour to bear it patiently."

From Cincinnati he writes, - "When I wrote about fourteen days ago, I was suffering from fever and ague, and had made up my mind to have it for a companion for some months; but it only stayed with me a week. By medicine and care I sureeeded in banishing it, and now feel quite well. It was brought on by carelessness and a desire to travel cheaply. I have no doubt it will have a good effect in making me more careful in future." 
try, I found sandy soils the least productive; those composed of clay and heavy loam bearing the best crops of every description.

Almost all the writers who have treated of the soil of $\mathrm{Up}$ per Canada have represented the kinds of trees which grow on it an index of its quality; but, after extensive observation, I was unable to trace the connexion generally. From the number of mouldering trees with which the forest is strewed, I was led to imagine, generation hath sueceeded generation since the beginning of time; and it is an admitted fact, that one description of tree hath frequently been succeeded by a different species over a considerable extent of surface. Under these circumstances, the kinds of trees have often more connexion with preceding events and species than the soil; and I regretted time did not admit of my attempting to inveatigate the longevity of the trees, and the kinds which succeed each other, or continue without change of species. It is, however, quite certain, that the oak is found occupying exclusively the best and the worst suils of the province, being that of sand, clay, and loam. Were it necessary, I could point out tracts of country in support of what I have advanced, and districts where a change of species of tree takes place without any apparent difference of soil. If the kind of tree is not a criterion of soil, neither is the size of the trees, which often depends on the number of them on a given space.

The quality of soil can only be ascertained by examination with a spade or some such instrument, and which ought also to embrace the subsoil. By such a mode of proceeding a judge of land cannot be deceived. It is as easy to learn to discriminate soils as trees, and both may be examined with the same facility.

The whole surveyed land of Upper Canada is held by English tenure, with exception, perhaps, of some patches on the banks of the Detroit, occupied by people of French descent. There is a register in every township, in which money mortgaged on land must be entered before it is recoverable, and by consulting which every purchaser may ascertain if good titles to an estate can be obtained.

The lands are in possession of the erown, the Canada 
Company, and private individuals, and may he had at all times to a reasonable extent. The crown lands are disposed of according to the following document:-

\section{" GOVERNMENT LANDS.}

"In conformity to instructions recently received from his Mijesty"s Secretary of State for the Colonies, the following arrangements for dieprosing of the waste lands of the crown in Upper Canada, are made known for the information of emigrants and others.

"Except in the case of U. E. Loyalists, and other persons entitled by the existing regulations of the government to free grants, no person can obtain any of the waste lands of the crown otherwise than by purchasing at the pullic sales, made from time to time under the direction of the commissioner of crown lands.

"These sales will be made on the first and third Tuesday of each month, and will either be continued through the following day or not, as circumstances may appear to the aggent to require.

"They will be held at the following places :-

"At Bytown, for the district of Bathurst.

"At Belleville, for the midland district.

" At Peterborough, for the district of Newcastle.

"At York, for the home district.

"At Hamilton, for the district of Gore.

"At London, for the district of London.

"At Chatham, for the western district.

“ Besides these general periodical sales, there may be occasional sales by auction in other districts, of such town lots, or other lots of land as may remain to be disposed of; and of these sales ample notice will be given.

"The conditions of every sale by public auction will be as follows :One fourth of the purchase money to be paid down, and the remainder in three equal annual instalments, with interest at six per cent on each instalment, payable with the instalment.

"The lands will be put up at an upset price, of which notice will be given at the time of sale, and in the previous advertisements which will be published of the lands intended to be put up at each sale; and in case no offer shall be made at the upset price, the land will be reserved for future sale in a similar manner by auction.

"A patent for the lands will be issued free of charge upon the payment in full of the purchase money and interest.

"The regular periodical sales will be held for the first time as follows :In Peterborough, York, and Hamilton, on the third Tuesday in June next; and in Bytown, Belleville, London, and Chatham, on the first Tuesday in July next; and they will continue to be held at all those places on the first and third Tuesdays in each month, until after the first Tuesday in November next; when such other arrangements as may be made by the government will be announced. 
"Information can be obtained respecting the lands to be disposed of in the several districts, by applying to the following gentlemen, agents for the commissioners of crown lands, viz. :

"In the Bathurst district, Mr John M'Naughton, D.S. Brtown.

"In the eastern district, James Pringle, Esquire, Cornwall.

"In the Newcastle district, Alexander $\mathbf{M}^{\circ}$ Donell, Esquire, Peterborough.

"In the London district, Roswell Mount, Esquire, Delaware.

" In the western district, Henry John Jones, Esquire, Chatham.

"The commissioner for crown lands, acting also as agent for the sale of clergy reserves, requests it to be noticed, that such clergy reserves as have not been hitherto occupied by authority, or leased by the government, will be disposed of, by public auction only, either at the periudical sales of crown lands or at occasional sales, to be duly advertised; and that the terms of payment fur clergy reserves will continue to be as fullows :-Ten per cent to be paid at the time of sale, and the remainder in nine annual instalnents of ten per cent each, with interest on each instalment, to be paid with the instalment.

"Such clergy reserves as have been leased, or occupied by the authority of the govermment, must be applied for by letter to the Commissioner of - Crown Lands, and when disposed of, will be sold by private sale on the same terms of payment as those disposed of by public auction.

"All applications from enigrants, or respecting emigration, not immediately connected with the sale of public lands, are to be addressed to $\mathrm{As}$. Tnovy B. HawкE, Esquire, at York, he being specially appointed by the government to act in that department.

"Commissioner of Crown Lands' Office,

"Peter Robinson.

"York, 27th May, 1833."

By an advertisement dated Taronto, (late York, 10th April, 1834, the upset price of lands in the Newcastle district is fixed at 10s., and the land surrendered by the Six Nations at 15s. per acre. The same advertisement announces clergy reserves, on condition of actual settlement, ten per cent of the price paid at the time of sale, and the remainder at nine annual instalments, with interest of six per cent on each instalment.

Last of Bear Creek-17s. 6d. and the remainder 10s. The township of Chatham, 15s.; Madoc, 7s. 6d.; London, 15s. per acre, Halifax currency.

The mode of disposing of crown lands has been subject of frequent complaint by newly arrived emigrants, and the whole system merits censure. I met individuals who had travelled more than one hundred miles from York to examine lands in 
the west, and returned again to York to petition and make interest with the authorities to get certain lots put up for sale. When they succeeded, they had to live in idleness for a month until the day of sale arrived, and again travel to the place of sale. Sometimes applications to have lands put up for sale are frustrated, and rather than suffer delay and dance attendance on men of influence, many people lave passed into the United States, where a person can go to the land-office of the district and fix on any lot which pleases him. 'There cash is the only interest that can be employed, and its non-payment the only delay to settlement.

Paying the purchase-money by instalments induces people without capital to become purchasers, who, for the interest of themselves and the community, ought to have assisted others in clearing and cultivating land, until they had accumulated sufficient capital, by saving, to purchase without credit. To the system of disposing of land by credit, much of the wretchedness and poverty of the present Canadian landholders may be justly attributed. The experience of the United States government demonstrated this, and a law was passed to abolish credit on the price of land. How difficult it seems to be for Britain to adopt legislation to the existing age of the world!

The Canada Company possess immense tracts of country, and sell land on terms similar to government, giving credit and drawbacks to induce people to purchase. The price of the company's land at Goderich is 7s. 6d. per acre, and equal to the price of crown lands in other parts.

Much land is held by absentee proprietors, or the members of the party who sway the councils of the province. It is commonly in the hands of agents empowered to sell. The prices are generally higher than crown lands, and credit unlimited.

The greater portion of British emigrants, arriving in Canada without funds and the most exalted ideas of the value and productiveness of land, purchase extensively on credit, and take up their abode in the midst of the forest, with the proudest feelings of independence, and in the confident hope of meeting their engagements, and becoming fine gentlemen at the 
end of a few years. Every thing goes on well for a short time. A log-house is erected with the assistance of old settlers, and the clearing of forest is commenced. Credit is obtained at a neighbouring store, and at length it is found necessary to work a day or two in the week for hire to obtain food for the family. The few garden stuftis and field crops, grown the first year, produce little for want of a free circulation of air, and the imperfect manner in which they had been sown. Sloould fever and ague now visit the emigrant, which is frequently the case, the situation of himself and family, enfeebled by disease, is truly wretched. Hope is, however, still bright, and he struggles through the second year, with better crops and prospects than the preceding one. The third year brings him good crops, which furnish a supply of food for his establishment. During this period he has led a life of toil and privation, being poorly fed and most uneomfortably lodged. But the thoughts of owning so many fair acres has been a never-failing source of joy and sweetener of life. On arrival of the fourth harvest, he is reminded by the storekeeper to pay his account with cash, or discharge part of it with his disposable produce, for which he gets a very small price. He is also informed that the purchase-money of the land has been accumulating with interest. The phantom of prosperity, conjured up by his imagination, is now dispelled, and, on calmly looking into his aflairs, he finds himself poorer than when he commenced operations. Disappointment preys on his spirits, and the aid of whisky is perhaps sought to raise them. The hopelessness of his situation renders him indolent and immoral. The land ultimately reverts to the former proprietor, or a new purchaser is found.

To render the situation of an emigrant purchasing without capital more evident, his case shall be illustrated by figures. Suppose 200 acres, which is the common size of lots purchased, at 15s., and that the emigrant has the means of maintaining himself without working for hire, and continues in good health. The three first crops being required to feed the family and obtain necessaries, he may be supposed to have nearly thirty acres in crop the fourth year, if he has been very 
industrious, but making allowance for stumps, fences, and roads, the actual surface in crop will not exceed twenty acres. At this time, near the end of the fifth year, when the fourth crop is reaped, the purchase-money, and interest on it, will amount to about L.200. The interest of this sum at the rate of the country is L.12, and a burden on the land in crop of more than 10s. an acre, which it cannot meet. In this estimate there is no return made for forest land, which is generally as unproductive of grass as the surface of the sea. It is the quantity of land purchased which operates so unfavourably on the settler. If, in the case chosen for illustration, 50 had been purchased instead of 200 acres, the result would have heen very different. It is seldom a person depending on his labour clears and cultivates more than $\mathbf{4 0}$ acres in course of his life. Therefore 50 acres is a sufficient extent for such a character to buy, and under no circumstances ought he to exceed 100 acres.

In the case where the purchase-money has been paid, the settler finds himself but indifferently off, and generally indebted to store-keepers. It must, however, he kept in view, that the land which has been cleared is of considerable value, and at the end of the fifth or sixth year, an industrious man may have his property worth much more money than he paid for it.

There is never any hesitation in selling land to a man without capital, as the rights of it are withheld. Every tree which is cut down enhances the value of the property, which is unproductive while they are standing. When a settler absconds after some years' residence, a case by no means rare, the proprietor derives great advantage from his operations. An agent to a very extensive and wild property, informed me he had sold twenty-five lots of land, consisting of about 6000 acres, and received in all of purchase-money L.300.

If the sketch which I have given of settlers without capital is thought to be overdrawn, from the fact of so many individuals having become prosperous, let it be remembered that land was formerly granted on paying fees of office, and without purchase. The system of selling land on credit, and con- 
tracting debt at stores, hath proved ruinous of late years to settlers without capital, who have no other means of extricating themselves than selling their properties.

In almost every district people are found anxious to sell land, and small farms may be bought on cheaper terms than lands belonging to the crown, Canada Company, or large proprietors, more especially if cash is paid. Indeed the necessities of many people are so urgent, and credit so general, that an individual with cash in his pocket may drive a good bargain at all times.

In a country of such diversity of soil, climate, and situation as Upper Canada, the price of land in its territory must be extremely variable, and will be found to run from 2s. 6 d. to L.6 per acre. On a general view, it is cheapest in the southern part of the western district, when climate and soil are taken into consideration. Few settlers have located themselves of late years in this part of the country, and trade can scarcely be said to have travelled so far west in Canada. Steam-navigation will, however, soon alter the present state of things in this quarter.

When the extent of unoccupied surface, the extent of soil which is occupied and remaining uncleared, and the tens of millions of acres which have never been surveyed, are considered, the price of Canadian land is extravagantly high, and far above its intrinsic value to actual settlers. Land, like other things, is cheap or dear by comparison, government land in the United States being sold at $6 \mathrm{~s}$. 3d. Halifax currency, ready-money, ought to make the British government blush for its policy in Canada. 'The price of land surrendered by the Six Nations, and covered with forest, is fixed at 15s. per acre, which is more than duuble the price of government land in the western United States, superior in quality, situated in a finer climate, elothed with luxuriant grass, and without an obstacle to immediate cultivation. The credit, with accumulating interest on the price of land in Canada, is practically an evil to the purchaser and the country. It is population alone which imparts value to land, and a more effectual method could not be devised for preventing a farther influx of inhabitants to Upper Canada, and draining away many of 
those already settled, than govemment adhering to the present upset prices of land.

The want of information which could be relied on regarding the United States, and the praises lavished on Upper Canada by interested parties, has drawn a number of emigrants to this district of late years. The stream of ernigration has, however, begun to take a different course, and the price of land in Canada will tend to stearly its direction. It is a knowledge of the Western States, joined to their pecuniary difficulties, which makes so many farmers anxious to sell their properties. The late rise in the price of land operates as an inducement for enterprising individuals to leave the province, and already some of them yearly take their departure.

But the whole system of settling land in Canada has been bad for many years. The retention of two-sevenths of the land for erown and clergy reserves, retarked improvement of every description, and granting immense tracts to favourites of government increased the evil. Bestowing grants of 200 acres by favour of government, or private individuals, prevented settlers choosing situations for themselves, and they were often directed to unfavourable parts of the country, with a view perhaps of enhaneing the value of properties in the neighbourhood. A lot of 200 acres of forest land was too great an extent to grant unconditionally to settlers, without capital, as experience proves they seldom clear 50 acres with aid of a family. From these causes the province may be said to be overrun instead of having been settled, - the evils of a forest-covered surface perpetuated, and the good effects which result from concentration and unity of population effectually retarded.

It might now perhaps be difficult to remedy the state of things. A tax ought to be levied on forest-land above a specified extent, to check speculation in land, and induce large landholders to sell or improve their possessions. Land ought to be sold cheap, in small lots, for ready money, on condition of actual settlement and annually clearing a certain extent. The Canada Company ought to be got rid of, or forced to dispose of its land at fixed prices, and on stipulated conditions. Britain, in legislating for Upper Canada, should do justice to 
the colonists and the home subjects who may wish to emigrate. But in all likelihood she does not now possess the power of carrying proper views into effect. The land of the province being held at a monopoly price, operates as a barrier to British emigration, and is a tax on the industrious who reach the province, principally for the benefit of absentees.

Much as Upper Canada appears to me to have been misgoverned, her evils are not likely soon to end. The properties of a great portion of the industrious farmers are either mortgaged to store-keepers or eapitalists, and almost the whole of the influential inhabitants are interested in land. 'The men filling official situations generally having large estates, the managers of the Canada Company, and of other extensive tracts of land, will oppose, from selfishness, the introduction of a better system, and endeavour to perpetuate the present state of things. I had little opportunity of judging if the inbabitants are fit to govern themselves. They will, however, find it a most arduous task to get rid of the present party in power, and a separation from the mother country would, in all probability lessen their chance. Upper Canada is likely to separate from Britain in seeking to retain monopolies. 


\section{CHAPTER V.}

Productions-Ayricultural Societies-Wunt of Pusturage-Prngress of Forest Settlement-First Crops on Forest Lund-Wornout Snil-Mildewed Wheat-Misrepresentations of CunnerleMr Ferguson's Statement-Tounship) of Nickol-Praises and Detractions-Choosing a situation-Advantages and disadventayes of Upper Canada for different Eimigrants_.State of the Inhabitants-Constitution-Game.

The productions of the country are various, and embrace almost every thing that is desirable in life. Wheat is the staple commodity. Indian corn ripens well in the most southerly parts, but is not extensively cultivated any where, and, in the present state of the country, is an uncertain crop beyond $41 \frac{1}{2}$ degrees of latitude. Oats, rye, barley, peas, and millet, number amongst the grains. Tobacco, turnips, potatoes, melons, apples, pears, and peaches, amongst the vegetables and fruits. 'The climate of the southern parts is genial, the industry of man applied to the cultivation of the soil renders it fruitful.

The agriculture of Upper Canada has not been reduced to a system in the oldest cultivated parts, and is carried on in the rudest manner in recently settled districts. The legislature having lately appropriated L.100 to each district for the encouragement of agriculture, societies have been formed for this purpose in Niagara and other districts. I am possessed of a copy of the Niagara District Agricultural Society's rules, and its exertions will, in all likelihood, be directed to the improvement of stock.

In all countries perhaps, and more especially in one covered with dense forests like Upper Canada, the first efforts of the inhabitants are directed to the growing of grain for their own subsistence, and pastural agriculture is introduced at a later 
period. This course of farming must, of necessity, have been followed in Canada, as the forest does not yield a single blade of grass, which is owing, perhaps, to the rays of the sun being excluded from the surface of the earth throughout the whole season, by winter's snow, the foliage of summer, and the fallen leaves of autumn. The severity of winter would also retard the keeping of animals, as an artificial supply of food and shelter is necessary to their existence. So defective is the pastoral farming of $\mathrm{L}^{\prime}$ pper Canada, that almost every town or village of magnitude in the district is dependent on the United States for the sheep and cattle which are slaughtered for the use of the inhabitants. Mr Somerville of Whitby accounted for this, on the ground, that all oxen reared in the country were required by new settlers to plough the soil. It is, however, quite evident, that there is not a sufficient extent of cleared surface on almost any farm to graze breeding stock, and provide them with proper food for winter. The rearing and fatting of animals in Canada must require such a division of labour as did not come under my notice while in the country, and the time has scarcely arrived when it can be successfully adopted. The animals of every kind are of an inferior description, and no great improvement can be effected with them until proper winter food and shelter are supplied. 'The working oxen are chiefly obtained from the States.

Most new settlers find difficulty in providing pasturage for their milch cows; and butter made from the cream of animals roaming in the forest is often of the worst quality. I have been at the residence of settlers who could not produce butter of their own manufacturing at table in the fourth year of their farming. The want of grass is one of the greatest privations of first settlement.

In the old cultivated districts manure is sometimes applied to land. Gypsum is frequently used successfully to clover and Indian corn, and Providence seems to have provided most of the districts composed of sand with an inexhaustible store of gypsum, to which soils it is chiefly applicable. I could not learn that lime had been tried. The robbing sys- 
tem hath long been followed, and its effects are every where apparent.

The progress of bush or forest settlement admits of little choice. After a log-house hath been erected, the trees are cut down with an axe, about three feet from the ground, the branches are lopped off and the trunks chopped into lengths of about fifteen feet, piled together, and burnt. The piling, or logging, as it is called, is by far the most arduous part of the process, requiring the aid of several men and oxen. The burning cannot be effected but in dry weather, and I learned considerable importance was attached to a clean or effectual burning. The ground is then feneed by means of rails, split from logs by an axe, and piled above each other-the whole country being considered common when not properly fenced. The ground is then sown with wheat, or planted with Iudian corn, or some other crop, and the harrow passed over the ground, it being impracticable to use the plough for the stumps and roots of trees. At the expiry of seven years, the stumps are found to be decayed, and the plough may then be employed. From the time of clearing, the land may have been cropped by means of the harrow, or employed in producing grass. There is little room for the display of genius or management, the process being nearly the same in all cases.

From the ashes of the timber a great deal of potash was at one time made, and sent to Britain; but a substitute having been found for this commodity, the ashes are generally spread on the ground, and sometimes, when the land is too rich, they are removed for manure to another part of the farm. When soil is viewed as a workshop, laying prostrate the members of the forest must be a cheering employment to the contemplative landowner. Being of no value in its original state, every sunbeam which darts on the surface, by removal of the trees, is assurance of imparted fertility, and never-ending productiveness; and as the light streams in from heaven, his heart will be filled with gratitude to God, and his arm nerved for new exertion. But the chopping of timber is a most laborious task to one unaccustomed to handle the axe, and the person possessed of a little capital had better pay others for clearing 
land, than attempt it himself on a large scale. To clear a farm out of the midst of the forest, by personal exertion, requires such an iron constitution and strength of arm as few British agriculturists of middle age possess. Many individuals who make the attempt excavate a small space, that may be termed an hospital, which ultimately becomes their graveyard.

I experienced disappointment at erops on newly eleared land being so indliferent, having been led to suppose they were generally too luxuriant. Believing every veretable sulistance to be composed of the same elements, and redueeable by decay, so as to enter into new combinations, I fancied the soil the very essence of fertility, from having been enriched with the decaying leaves of many centuries. If all the woody fibre of the forest and vegetable mould which covers the surface could be at once decomposed, my anticipated fertility would be realized. But in burning the trees, fire passes over the entire surface, and consumes almost every particle of vegetable matter. The agency of fire, joined to the imperfect tilling of the soil, will sufficiently account for the want of luxuriance in first crops, which may generally be considered a fortunate circumstance, when a free circulation of air is prevented.

Settlers have often been cautioned against purchasing what is termed worn-out soil, timbered land being preferable. This appears to me to be one of the many deceptions used to entrap the unwary emigrant into the wilderness. I have already observed the first erops are not luxuriant after clearing the forest. The first wheat crop is, however, the best one until the stumps decay, when the soil will afterwards improve with good management. The most produetive wheat crops, combining quantity and quality, are found on the oldest cultivated soils. Much soil hath been abandoned to nature after being eleared, not owing, however, to its having become exhausted, but to its natural inferiority. It is better to restore the most exhausted soil than clear forest land of the same quality. Nature never becomes exhausted, and the farmer has only to do his part in order to obtain her bounty.

In course of my tour in North America, I was particular in my enquiries regarding mildewed wheat, knowing how destruc- 
tive the disease is to that grain, as well as to others visited by it. Many growing crops and bundles of straw of the previous year's growth were examined, and the result of my observations tended to strengthen the opinions I had formed of the origin and localities of its effects.

Mildew appears to me to result from frost, produced by the radiation of heat, rupturing the sap-vessels, and the moisture which exudes being favourable to the germination of the seeds of the fungus which grows on the straw of the plant, and checks the filling of the grain. It has been established by repeated experiment, that in certain states of the atmosphere, cold, within the limits of freezing, takes place on the surface of the earth when the temperature, at an elevation of a few feet, is ten or twelve degrees warmer. 'This is beautifully explained in "Wells' Essay on Dew," which I recommend to farmers wishing to become acquainted with atmospheric effects on vegetation. The natural agency favourable to the radiation of heat, or production of cold, is a clear sky and still atmosphere. The luxuriance of crops is a predisposing cause to a visitation of mildew, from the breadth, colour, and succulency of the foliage.

In the year 1830, I made an attempt to prove the correctness of my opinions regarding mildew by experiment. My apparatus, which was of the simplest kind, was often exposed; but the difficulty of catching a favourable atmosphere rendered all $\mathrm{my}$ attempts unsatisfactory; but some of my observations with the thermometer were remarkable. On the 19th August, at eight o'clock in the evening, a delicate thermometer, on Fahrenheit's scale, at four feet from the ground, indicated $45^{\circ}$; and a similar one, immediately below the other, exposed on the surface of the grass, $38^{\circ}$; and at half-past eight, respectively, $47^{\circ}$ and $43^{\circ}$, the wind having risen in the interval. Next morning, at four o'clock, the thermometers stood at $38^{\circ}$ and $35^{\circ}$; and another, enclosed in a glass-case, and exposed on the outside of a window, at $45^{\circ}$. At five o'clock, the thermometer, four feet from the ground, indicated $34^{\circ}$, and the one on the grass, $30 \frac{1}{2} \circ$. The thermometer at the window remained unaltered, and, being removed from the case, was placed with the other two on a piece of lodged spring- 
sown wheat. At a quarter past five, all the three indicated $293{ }^{\circ}$. The sun was then a little above the horizon, and olsscured by a small cloud; the sky was clear, the air still, and mild to human feeling. In the same situation, the thermometers, at eight $0^{\prime}$ clock, indicated 55\%, and at two P. .. $755^{\circ}$. At ten in the evening, the thermometer, four feet from the ground, stood at $44^{\circ}$, and the one on the grass, at $42^{\circ}$. At half-past four on the morning of the 21 st, the thermometar, four feet from the ground, stood at $34^{\circ}$, one on the grass, at $28^{\circ}$, and one on the wheat, at $29^{\circ}$. The thermometers on the grass and wheat were thinly coated with ice, and the morning was clear and agreeable. The formation of dew was not very copious on either of the mornings, and my reapers made no remark about cold or frost when handling the grain. The fich of spring-sown wheat, already mentioned, and one of barley, were at this time in a groen state, and very promising; but the grain made no farther improvement, and mildew appeared on both erops in a day or two afterwards.

Although $I$ have not been able to produce mildew by artificial means, the observations made with the thermometers in 1830 almost amount to a demonstration of its origin. Every case of mildew, whether general or partial, in a district, may be accounted for by cold produced by the radiation of heat, coupled with the state of the crops; and the hypothesis has been strongly supported by Scottish writers on practical husbandry, Brown and Aiton, while recording, as the cause of mildew, natural phcnomena which result from or generally accompany the radiation of heat.

But from whatever cause mildew may proceed, there is no question of the wheat crop, throughout a considerable extent of North America, being liable to its effects. Many instances of mildew are recorded in my tour; and I scarcely passed through a district, the surface of which consisted of sudden undulations, or small forest clearances, where the wheat was not seriously injured by it. Some accounts which I have received from parts of Upper Canada for 1834, allude to the destruction of wheat by frost. In all partially cleared parts 
of Upper Canarla, with exception perhaps of situations on the margins of lakes, wheat will suffer from mildew. The want of success which so often attends first crops on small clearances in the midst of the forest, is in all probability owing to the frosts of spring, summer, and autumn, caused by the radiation of heat, and which a free circulation of air will alone prevent. This casualty is a serious evil to first settlers, and ought to form part of their calculations in choosing a situation.

Upper Canada has been much over-rated by some people who have visited the country. Many of the written accounts may be regarded as advertisements; and the statements have been the means of deceiving the unwary. During my sojourn in the province, I frequently heard Mr Adam Fergusson of Woodhill become the subject of reproach; and this season, the clamour is loud against him. A correspondent states in one of his letters,__ Many extravagant notions of America are entertained at home. Some people will form such notions in spitc of any writing; but certainly many absurd things have been published about America by individuals who have travelled through the country without mixing with the people, or whos seem to have written from interested motives. I know not how the Highland Society of Scotland will like to hear of Mr Fergusson's errors. Its patronage certainly tended to mislead many. I have met with people in this part of the world who told me so, and who rail against him at a great rate."

I agree with my correspondent in thinking the patronage which the Highland Society bestowed on Mr Fergusson added weight to his statements, and some of its members will feel disappointed at hearing them called in question. Societies, however, like individuals, often misplace confidence, and spurn the advances of real merit. But his most objectionable matter is contained in " Practical Notes made during a Second Visit to Canada in 1833," with which the Highland Society is not connected.

Mr Adam Fergusson of Woodhill occupied a respectable, 
and perhaps an elevated, place in Scotland. He was understood to be a leading director in one of the first agricultural societies in the world, and acted conspicuously in the public matters of Perthshire, one of the most important counties of his native country. He was considered to have a competent knowledge of agriculture, and to be a person deserving of credit. But his character renders the statements he has put forth more mischievous, and their exposure more necessary. To have censured Mr Fergusson's statements would have been painful to my feelings under any circumstances, and is especially so at present, when he is so far removed. It is, however, a duty I owe my countrymen to be candid, and they shall be allowed an opportunity of judging of our sentiments on Canadian farming.

After stating he has purchased a block of 7000 acres in the township of Nichol, he adds, "In reference to the capabilities of Nichol, I offer with some confidence the following calculations. With a capital of L.500 sterling, which is equal to L.600 currency, a man may purchase and improve 200 acres of wild land in Nichol.

\section{FIRST YRAR.}

The purchase money of 200 acres, at $\$ 4$ per acre, or L.1 currency per acre,

A log-house, $\cdot{ }^{*} \cdot{ }^{\circ}$

Some furniture for log-house, . . .

Barn, including stable and cow-house, .

Household and other expenses till after har-

$$
\text { vest, }
$$

Clear, fence, and sow, 50 acres with wheat, at

L.4 per acre, . . . . . .

L. $200 \quad 0 \quad 0$

$30 \quad 0 \quad 0$

2000

$50 \quad 0 \quad 0$

$50 \quad 0 \quad 0$

$200 \quad 0 \quad 0$

L. $550 \quad 0 \quad 0$

On the 50 acres of wheat he will have 25

bushels per acre, which, at 4s. 6d. per

bushel, . . . . . .

Deduct expense of harvesting, - . . L.35 5 . 0

Household and other expenses, . . . $\quad \begin{array}{llll}46 & 0 & 0\end{array}$

L.281 50

8150

Clears the first year, . . . . L.200 00 


\section{SRCOND YEAR.}

He expends this year as mucil of the L.200 as will clear $37 / 2$ acres more, which, at the same rate as last year, will be The other L.50 he has for purchasing a team of oxen, and household expenses till after harvest,

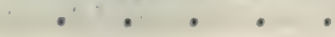

This year he has the original 50 acres and the $37 \frac{1}{2}$ cleared this seawn, all in wheat, the seed for the 50 acres to be debited against the cusuing crop.

$87 \frac{1}{2}$ acres, at 25 bushels at $4 \mathrm{~s} .6 \mathrm{~d}$.

L.492 39

Expense of harvesting, 8cc. ․ . . L.61 10 \&

Sced, as above for 50 acres, at 1 bushet per acre, at $43.6 \mathrm{~d}$

Household and other expenses, . . . 3984

11239

Clears the second year, . . . . L.380 00

THIRD YEAR.

All having been hitherto done by contract, there has now to be charged the expense of stocking the farm, and servants' wages and board, . . .

Wheat seed for $87 \frac{1}{2}$ acres, at 1 busliel per acre, at 48. $6 \mathrm{~d}$.

Grass seed for 25 acres, at 33, per acre, . $\begin{array}{lll}19 & 3 & 9\end{array}$ Assistance during harvest, : $:$, Household and other expenses, :

L. 380000

Has the same crop as last year, but not at so much expense in thrashing, and his own servants assisting.

$87 \frac{1}{2}$ acres in wheat,

Assistance in thrashing, \&c.

Household and other expenses, . . . $37 \quad 39$

L.492 39

Clears this year, . . . . . L.420 00

\section{FOURTU YEAR.}

He clears $62 \frac{1}{2}$ acres more, making in all 150 acres clenared, which is sufficient on a farm of $\mathbf{2 0 0}$ acres.

He this year plants some potatọes, sows turnips, \&c. on that part of the 50 acres, first cleared, not in grass. 
To clear, fence, and sow $62 \frac{1}{2}$ acres, . .

L $250 \quad 0 \quad 0$

Erects a thrashing machine, . . .

$80 \quad 0 \quad 0$

Builds some houses for feeding stock, . .

2000

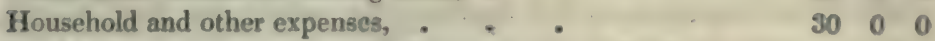

Sundry improvements about the house, .

$40 \quad 0 \quad 0$

L.420 00

Has this year the $37 \frac{1}{2}$ acres formerly cleared, and the $62 \frac{1}{2}$ cleared this year.

In wheat, $\quad 100$ acres at the same rate,

L.562 $10 \quad 0$

$120 \quad 0 \quad 0$

The other 50 acres valued at,

Deduct for household and other expenses, .

L.682 $10 \quad 0$

$82 \quad 10 \quad 0$

L.600 000

At the end of the fourth year he has his farm paid for, stucked, and L.600 eurrency in his pocket."

The result of a stątement depends entirely on the data which have been assumed, and there is no doubt of Mr Fergusson's, in the quoted account, being very erroneous. 'The chief error consists in clearing land, sowing it with wheat, and reaping the crop in the first year, which is an impossibility. The same error is repeated in the fourth year. 'Thus four instead of three crops are reaped in the time specified. I am aware that land has been let to be cleared, on condition of not being paid for until after a crop has been reaped. Mr l'ergusson cannot, however, escape from his error on this account, because he does not mention the circumstance, and the cost of clearing being very low, is entered along with the purchasemoney of the land, the building of the house, and household expenses of the first year. Three successive crops of wheat are taken from the first cleared portion of the ground, without a falling off in the crop, which is an absurdity, and such a mode of cropping is almost never had recourse to. He has omitted the expense of thrashing and marketing his crops, and also, sometimes, seed for sowing, all of which may appear trifles to the writer of "Practical Notes," although of consequence to a farmer. He stocks with animals and servants in the "third year." The former must be valuable creatures, for they live without food, at least the whole produce is charged 
as sold. But the servants are superior to the animals, as they seem to live on air, and refuse wages - the household, harvest, and other expenses in the fourth year, when the crop consists of 100 acres of wheat, do not greatly exceed the same charges in the second year, when there is $87 \frac{1}{2}$ acres in wheat, and no servants engaged. The farm is not stocked until the third year, but a team of oxen is charged in the second, which, perhaps, ought to have been written cows, as these necesiary animals are not mentioned elsewhere.

Mr Fergusson's calculations do not appear accurate, and scarcely intelligible in the way he has given them. They shall, therefore, be arranged, without altering his data, as they would actually occur. The entries marked with asterisks are new, and indispensable in practice.

FIRST YEAR.

$\begin{array}{lllll}\text { Purchase-money of } 200 \text { acres, at } \$ 4, & \text { L. } 200 \quad 0 & 0\end{array}$

A log-house, . . , . . . 500

Some furniture for a $\log$-house, - . . 2000

Barn, including stable and cow-house, $\quad-\quad 50 \quad 0 \quad 0$

Houschold expenses, two entries, - - $76 \quad 00$

Clear, fence, and sow, 50 acres with wheat, at L.4, $200 \quad 0 \quad 0$

\section{SECOND YEAR.}

Clear, fence, and sow $37 \frac{1}{3}$ acres with wheat, at

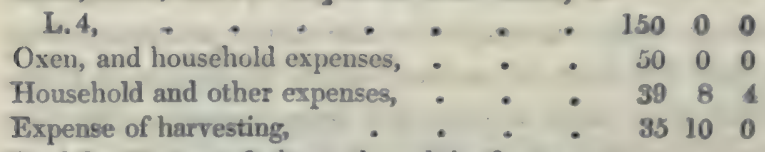

Seed for 50 acres of wheat, cleared the first year, and sown again the second, at 4s.6d. $\quad \begin{array}{lll}11 & 5 & 0\end{array}$

* Harrowing and sowing, . . . . 1210

* Threshing the crop, 1.9th of 1250 bushels, or 140 bushels, at 4s. $6 \mathrm{~d}$. . . . . $\quad 31100$

$\begin{array}{lllll}\text { - Teaming to lake Ontario } 1110 \text { bushels, at 9d. } & 41 & 12 & 6\end{array}$

Crop, 50 acres of wheat will yield 25 bushels per

acre, and sell at 4s. $6 \mathrm{~d}$. per bushel, . .

At the end of the second year L. 967, 15s. 10d.

has been expended, and L. 281 received.

THIRD YEAR.

Stocking the farm, and servants'wages and board, $285 \quad 0 \quad 0$

Grass seeds for 25 acres, at 35 . . . . 3150

Assistance during harvest, . . . $20 \quad 0 \quad 0$

Carried over, 
Brought over,

$$
\text { L. } 1276 \quad 10 \quad 10 \quad \text { L.281 5 } 0
$$

Household and other expenses, two entries,

$\begin{array}{lll}89 & 5 & 0\end{array}$

Assistance in threshing, . . . . 350

* Seed for $37 \frac{1}{2}$ acres, at $4 \mathrm{~s} .6 \mathrm{~d}$. . . . 889

Crop, $87 \frac{1}{2}$ acres of wheat will yield as formerly,

49200

At the end of the third year L.1408, 8s. 9d. has

been expended, and L. 773, 5s. received.

\section{FOURTH YTAR.}

Clears, fences, and sows, $62 \frac{4}{3}$ acres, at L.4, 25000

Erects a thrashing-machine, . . . 8000

Builds some houses for feeding stock, . . $\quad 2000$

Houschold and other expenses, two entries, $11210 \quad 0$

Sundry improvements about the house, $\quad \begin{array}{rlll}40 & 0 & 0\end{array}$

* Seed for 25 acres, in turnip and potatoes, $\quad 1500$

Crop, 37 $\frac{1}{3}$ acres wheat at former rate, .

50 do. grass, valued at . .

$\begin{array}{lll}210 & 18 & 9\end{array}$

12000

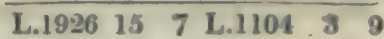

At the end of the fourth year the landowner is minus, - * $*$.

The prospects of the farmer become better after the fourth year, and on the assumed data he would soon become wealthy. At the end of the fourth year, when the land has been cleared, the farm, with buildings, furniture, stocking, and 100 acres of growing wheat, may be valued at L.1200. By the original statement the fourth crop has been reaped, in which case the farm, with buildings, stocking, and furniture, may be valued at L.750. Aceording to my way of arranging $\mathrm{Mr}$ Fergusson's statement, the purchaser of 200 acres of land at the end of the fourth year is only worth L.427, 8s. 2d, or a loser of L.172, 11s. 10d. By the original statement he is worth L.1400, or a gainer of L.800 above his capital of L.600, after maintaining himself and family. Mr Fergusson's statement of Canadian farming, like the Marquis of Londonderry's application to Lord Liverpool, may be marked with the words " too bad!"

With due deference to Mr Fergusson's practical knowledge, I may remark, that he seems to have forgotten the part of the world in which Nichol is situated when framing his statement. How are people to be obtained for thinning turnip in 
the midst of a forest country, and who is to tend his thrashing-machine?

The data of an agricultural statement must be very fluctuating at all times, as the influence of the season affects the quantity and quality of produce, and conseqquently pricess. $\mathrm{Mr}$ Fergusson assumes 25 bushels of wheat per acre as the produce of new cleared land, but the results of my enquiries and observation, including chance of mildew and imperfect cultivation from stumpss, do not warrant their being rated higher than 18 bushels per acre. It appears odd that he should fix the price of wheat in Nichol at 4s. $6 \mathrm{~d}$., when he quotes the Niagara price at $4 \mathrm{~s} .3 \mathrm{~d}$., and it would require 9d. per bushel to bring wheat from Nichol to Lake Ontario, where it would meet the same market as Niagara. At the time he wrote, Nichol wheat could not be worth more than 3s. $6 \mathrm{~d}$. per bushel, Halifax currency. But the price of wheat in Canada is regulated by the prices of Britain. The expense of sending wheat from Nichol to Britain, by way of the St Lawrence, including ensurance, freight, merchant's profit, and many other charges, will amount to nearly 4s. 3d., Halifix currency, per bushel, and it may be worth in London 7s. 3d., which makes wheat worth about 3s. at Nichol.

Having exposed Mr Fergusson's statement, one of my own may perhaps be expected, but nothing satisfactory of the sort can be framed. The expense of elearing, fencing, and sowing, depends on the nature of the timber, and varies from L.3, $10 \mathrm{~s}$. to L.5 per acre. The succeeding wheat crop, also, varies from 12 to 25 bushels per acre, and prices from 1s. $6 \mathrm{~d}$. to $5 \mathrm{~s}$. per bushel. Generally speaking, money is not rapidly made by clearing forest land, while patient industry seldom fails of being ultimately remunerated.

The township of Nichol is not, however, such a situation as I would make choice of, being situated too far to the north, and too distant from water-carriage. Supposing the carriage or teaming of wheat, as it is called in the language of the country, from Nichol to lake Ontario costs 9d. per bushel, and that two successive wheat crops are taken from newlycleared land, yielding 20 bushels each per acre, the carriage 
of the produce to market will amount to 30 s., or double the price of what the land is originally worth, and this charge will operate as a tax, or rent, on every crop that is raised afterwards. The distance from water-conveyance, also, tends to render dear every imported commodity that may be required. When the Ouse or Grand river is made navigable, Nichol will be nearer water-carriage ; but, at present, I would rather pay a high price for land in a good situation and climate in Upper Canada, than take a present of land in Nichol, if I was bound to occupy it.

The writers of private letters, the verbal tales of individuals, and the public journals, are often called into requisition to laud and misrepresent the country, and people of Britain ought to consider the accounts well before giving them credence. In a Montreal newspaper, which lately reached me, I observed a paragraph announcing that a yacht club had been formed at Goderich, of which Captain Dunlop was president. At the time of my visit to Goderich, in the end of August, 1833, the population were chiefly subsisting on flour and salt pork, imported from Detroit. The harbour contained three craft of the smallest size, and I did not see a boat or yacht of any deseription. The youth of Britain, who anticipates displaying at Goderich the uniform of a yacht club, and having the fair sex greeting his triumphant entry into the harbour by the waving of handkerchiefs, may delay his departure for half a century. A steam-boat had appeared off the village in 1833, and could not gain admittance into the harbour for want of water. I did not learn the object of her call, but $I$ am sure all the disposable agricultural produce of the settlement, up to the present time, would not freight a nutshell.

Captain A— in the township of Blenheim, was told by an agent of the Canada Company, that a stage-coach would convey himself and family from Hamilton to the property he had purchased. No such conveyance existed. On representing the imposition which had been practised on him to the managers at York, an abatement of price was offered. I saw the correspondence on the subject.

If Upper Canada has been too much praised on the one 
hand, it has also been unnecessarily cried down by some who are anxious to conceal their want of industry, and endeavour to shift from themselves to the country the cause of their return to Britain. Many people emigrate to America who ought to have remained at home, having been inflated by the representations of others and their own imaginations. I have often heard such characters rail against the province; and, on pressing one of them for the reason of his dislike, was answered, "It could not afford a well-cooked beef-steak." 'They often lounge about villages, and are a moral pest. Iike the fox who lost his tail, they are anxious to involve others in disgrace with themselves; and as most emigrants experience a few weeks' despondency on first arriving in the country, the society of the idle and discontented ought to be avoided.

A person will find considerable difficulty in choosing a lot of land in Canada. Nine-tenths of the population are interested, directly or indirectly, in the sale of land. The accounts he will receive are more likely to mislead than instruct him; and, if possible, he ought to rely on his own judgment in purchasing. When he has decided on the neighbourhood in which he would like to reside, let him look at all the properties for sale, and take the best bargain. Most of the small landowners, being deeply indebted, are anxious to sell partially cleared estates for ready money; and more favourable terms will be obtained from them than the crown, Canada Company, or extensive proprietors.

The wheat of Upper Canada is sown in autumn, and greatly superior in quality to the wheat of the lower province. It embraces, however, a variety of climates, and the quality of wheat improves as the southern boundary is ascended. In Montreal market, the wheat of the upper province sells from 10 to 20 per cent higher than the wheat of the neighbourhood, and what is grown in the extreme west is of most value. The expense of transport from the upper to the lower province is not yet reduced to proper terms, especially from remote quarters. But, in a general view, the improved quality of the wheat may be regarded as covering the expense of sending it by water to Montreal, while the climate will produce a greater quantity than the lower province. This may 
perhaps hold good as far west as the Thames, but on passing that river to the north, both the climate and distance of transport will operate in reducing the value of wheat.

Upper Canada possesses many advantages to the farmer over the lower province. The winter being of shorter duration and less severe, he has more time to prepare the soil. A greater variety of plants can be cultivated, and all of them will attain greater perfection. Animals have a longer summer to fatten, and a shorter winter to pine. Less dry fodder is required for them, and it is more easily obtained. Succulent food might be grown and preserved with greater ease. Still, Upper Canada is not likely soon to become a stock country, both from the limited cleared surface, and severity of winter. Indian corn, too, is not easily grown, except in the southern parts, and it seems to be the ehief winter support of animals in America, where labour is high compared with produce.

Notwithstanding labour is high and prices low in Upper Canada, capital and labour may be better employed in cultivation than in the lower provinee, with exception of the vicinity of Montreal, from the great assistance nature affords. But much capital cannot at present be employed in the cultivation or improvement of land, and perhaps ne portion will yield profit without active personal superintendence and assistance.

A British farmer with eleared land would obtain labour to hire in almost any part of the country, and be enabled to afford good wages from the produce. In many situations, however, he would find difficulty in obtaining a cash price, which is at present one of the greatest drawbacks to the country. Barter is often had recourse to, and the farmer being generally indebted to storekeepers, they make their own terms with him, and prey on his vitals. This state of things is, however, soon likely to change from competition; in the meantime, the needy farmer is sadly imposed on. Labour cannot be divided as in Britain, and cultivation must be carried on in a rude manner. The farmer, however, could find no difficulty in maintaining himself by his own exertions. With two days' labour in the week on an average throughout the season, he may lead a listless life, without domestic com-. 
fort, or care, or anxiety of any kind, and dream of future riches till the close of his existence. With industry, comforts, happiness, and wealth, would be his portion. With forest land the British farmer would be sacrificed, unless in the prime of youth. In chopping, logging, and burning timber, he could not for a time render much assistance, and his previous knowledge would be of little avail. The plough could not be used for seven or eight years. Cultivating merely with the harrow, and mowing with the cradle-scythe amongst blackened stumps, would ill accord with his former habits. In such pursuits he would not, in all probability, find happiness or wealth. 'The young man of ardour and perseverance, whose habits could be changed, is differently situated, and he may enter the forest with every prospect of success. It is the returns from clearing forest land being distant, though certain, which gives youth great advantage over age, independent of his moral pliancy and physical strength.

'The agricultural labourer of Upper Canada finds employment at good nominal wages during summer, but, instead of getting money, he is served with an order on a neighbouring store, from which he obtains goods to the amount, 20 or 30 per cent above real value. In winter his wages are reduced nearly one-half, or he engages in the clearing of forest, on terms of distant payment, and in the interm subsists on store credit. From seldom being paid in money, he sees the hopelessness of raising himself by purchasing land, and the disappointment often leads to drunkenness. At present, it appears to me doubtful if the British agricultural labourer of middle age would greatly better his condition by removing to Upper Canada. It is certain he would obtain more of the good things of life at a sacrifice of some little comfort, and unless he has strong attraction to the country, it is scarcely worth his while to make the change.

It has often been said manufacturers and artisans of all kinds make better Canadian farmers than agriculturists do. This seems to me part of the deception which has been played off on the people of Britain. Knowledge is power in all things, and however prejudiced agriculturists may be, their acquaintance with the time and mode of sowing, harvesting, and 
many etceteras, must give them advantages over other classes. I can conceive few situations more trying than a person without capital, totally unacquainted with farming, placed in the midst of a forest to live by his own exertions.

The man without capital ought to consider well before engaging with forest land, however cheap and advantageous the terms may appear. Almost all who do so can scarcely avoid being ruined, if interest is to be paid on the stipulated price. At page 363, I have supposed a new settler in the forest to have thirty acres in crop the fourth year. But when all things are taken into consideration, it is found that a settler, unaccustomed to chop wood, does not generally clear more than six acres in a year, and attend to other necessary things. Under these circumstances, it will be impossible for him to spare a fraction of money to pay interest or principal for the first five or six years. 'This is rendered evident also by the consideration, that the first crop of wheat does not, by the most favourable calculation, even pay the expense of clearing the forest and cultivating the soil. It is therefore demonstrated, that clearing forest is at first unprofitable to a person without capital, if he had the land for nothing, and that every acre which he clears is at an immediate loss. The cleared land, however, continues productive, and would ultimately reward him, if there was no principal or interest to pay. $\mathrm{By}$ suffering privations, he may wait like the capitalist for distant returns, which, on arriving, would be paid to the real proprietor of the land; and like an over-rented East Lothian farmer, he would not receive the fruits of his own labour. It is overlooking the difficulties of first settlement, which has involved half the recent settlers inextricably in debt, given the storekeeper such influence over the farmer, and prevented the labourer from obtaining cash wages.

In almost all parts of the country, landowners or their agents will urge people to settle on land, well knowing that every yard which is cleared of trees will ultimately become valuable to the estate, although the settler may be ruined by his engagement. Is it from philanthropic or interested mo- 
tives the puffs regarding Upper Canada have been circulated? The unthinking poor two often become the dupes of the designing in all parts of the world.

America has been emphatically styled "the poor man's country;" but Upper Canada does not now merit such a title. The system of store pay, which is so general in the province, operates against the poor man, and does not affect the rich. 'The system of selling land in large lots on credit has a similar effect; while the late rise in the value of land seems to me to be chiefly destructive to the poor man's hopes, by diminishing the demand for labour, and increasing his diffculty of purchasing land.

In stating my belief that the middle-aged agricultural labourer of Britain need not change his residence to Upper Canada, I supposed him to be without capital, having constant employment, and living in some degree of comfort at home. 'The chance of such a person becoming an independent landowner is small, with irregular employment and store pay. The case of the rural inhabitants in many parts of the Highlands of Scotland and Ireland is, however, different, and they would find their condition improved by a change of residence. The sober, the prudent, and the industrious of any country will, however, succeed in Upper Canada, if they can laugh at the hardships of first settlement, and with persevering industry look forward to be ultimately rewarded. It seems to me to be a country chiefly for the young, and those seeking to provide for a family.

Of the unagricultural population of Upper Canada, and their prospects, I am not well qualified to speak. Clergymen, lawyers, and doctors, seem not to be much eared for by the inhabitants, and but indifferently rewarded. Bricklayers find ready employment. Stone-masons are not wanted. Joiners, who can put a great deal of rough work through their hands, are in constant demand at higher wages than other tradesmen, with the advantage of employment in winter. Tailors, shoemakers, and blacksmiths, have good wages in towns and villages. When they commence business on their own account in the country, the thinness of the agricultural population 
does not always furnish regular employment, and their poverty renders cash ditticult to be had. In remote parts of the country, the traffic is carried on chiefly in barter, and many tradesmen in such situations almost never finger money.

The merchants and storekeepers are said to be the most wealthy and influential people in the province, and owe the position they have attained to the situation and character of the inhabitants. 'The settlers being thinly scattered over an immense and almost inaccessible territory, are necessurily unacquainted with traffic and the price of commodities. Their limited produce does not spur them into active exertion to dispose of it; and the state of the roads only admitting of transport for a part of the year, confines the time of sale to the winter months. 1)uring this season, the Sit Lawrence, which is the only channel of trade, being closed by ice, limits the number of merchants, and drives all out of the market but capitalists. The necessities of farmers do not enable them to hold produce from year to year, and they appear to be at the mercy of the merchants, who obtain thousands and tens of thousands of bushels of wheat, at the head of Lake Ontario, in exchange for shoes and other necessaries, without a fraction of eash being paid on either side. The inland storekeeper has still greater advantages over the farmer, and their profits are said to be excessive; 300 per cent on dry goods having been currently obtained at one time. The merchant and storekeeper is, however, distant from the markets of Britain, which regulates the price of Canadian wheat; and the navigation of the St Lawrence, and transport of goods, are so expensive, that profits may not be so great as is reported. Of their influence in the country, there is, however, no doubt; and that it arises from the pecuniary difficulties of landowners is universally admitted, who, in numerous instances, are irretrievably burdened with debt.

'The first settlers, at the close of the war with the colonies, being at too great a distance to admit of much intercourse with each other, and having no outlet for their produce, soon sunk into listless inactivity. Many Germans and Dutch afterwards followed, who commonly settled near each other, and although quiet and industrious people, were altogether 
without enterprise. The greater portion of British emigrants, who first settled in the province, having little capital or education, and obtaining grants of forest in isolated situations, made small progress in a mode of farming so new to them. Having been nurtured in poverty, they had few wants and were not ambitious to improve their condition. From a people so situated, and composed of such materials, little could be expected. Individuals connected with government seem to have been more solicitous about their own than the people's welfare, and little was done to call forth the resources of the country, or to rouse the slumbering energies of the inhabitants. The people, however, formed good subjects for active traders, who still gather a plentiful harvest. Ilow long this state of things may last with traders will depend on competition. Their profits will fall with the opening of communication throughout the country, but capital employed in trade is likely to yield a good return, so long as the necessities of the agricultural population continue urgent.

Every inhabitant of Britain, contemplating the commencement of trade in Upper Canada, must be prepared to do so in a new mode, and, while he views high profits, he ought not to lose sight of transacting business on a limited scale, and in an expensive and disagreeable manner.

If the early inhabitants of Upper Canada sunk into indolence, some of the succeeding settlers were ill fitted to improve them, being blended with the scum and refuse of mankind. For many years the bankrupts in character and fortune, the poor, the idle, and the dissipated, departed from Britain. From the United States the knavish whites, and the runaway blacks found shelter, and after having cheated the Canadians again set off. Such a population receiving grants of forest, separated from each other by clergy reserves and large absentee estates, could not be expected to exert themselves amidst the difficulties of first settlement. People of enterprise, who reached the province, soon made a fortune and retired again.

I found some of the oldest settlers treading out their wheat crop with horses; living in miserable houses, and without a 
particle of sugar to sweeten their tea. This state of things arose from laziness, their possessions being large, their time unoccupied, and the juice of the maple might have been collected a few yards from their residence for the making of sugar.

At the time of my visit nine-tenths of the hotel-keepers and stage-drivers, and most of the active business people, had originally come from the United States. Every horse and $\mathrm{x}$ of size or fatness could be traced to have come from the same territory, and the Canadians appear to me to be much indebted to the people of the United States for any activity and refinement that is to be met with in the province.

The first settlers, the people of business, and almost all travellers for pleasure or health, having come from the United States, their manners and customs have been impressed on the inhabitants of Upper Canada, and I do not think the large influx of British emigrants which has taken place of late years will efface them. I found much less refinement than in the lower province or in the United States, while the coarse manners of the people, and their habits of intemperance, were so prominent, that I heard more oaths and witnessed more drunk people the first few days I was in Canada, than I had met with during my previous wanderings in the States. I must do Upper Canada, however, the justice to say, that such characters appeared to be late importations from Britain and Ireland, and I was sorry to observe intoxication was by no means confined to the lowest class of emigrants.

Knowing that a great deal of moral worth, physical energy, and capital, have lately flowed into Canada, I have no doubt of time producing an important change in the state of the country and people. Indeed, hewing down the forest may be termed mortgaging labour to nature, whose generous returns accumulate like compound interest, and I look on Upper Canada as the germ of a numerously inhabited and wealthy state. Nothing but misgovernment can prevent such a consummation. A number of human beings have, however, been most improperly seduced into the province of late years, and at 
present I regard Upper Canada as a wretched, an immoral, and a misgoverned country.

I found many of the Canadians filled with inveterate prejudice against the inhabitants of the United States, whom they regarded as a band of cheating and lying democrats. Some excuse might have been found for this feeling, had it alone existed amongst the first settlers, who suffered during the late war; but the greatest degree of inveteracy was evinced by persons lately from Britain, whose conduct, in the intercourse of the world, had not been altogether blameless at home. The prosperity of the people of the United States seems to excite the envy of the Canadians. The same feeling does not exist in the State of New York towards the Canadians, who are there considered indolent and dissipated.

The constitution of Upper Canada is modelled after the British one, and there is a council appointed for life by his Britannic Majesty on certain conditions. The House of Assembly is chosen by voters, twenty-one years of age, British subjects, and possessed of 40s. freehold for a county election, and L.5 for a town qualification. The province possesses the power of taxing itself, and the impositions are as little felt as in any country in the world.

There is a general opinion in Britain that Canada is an excellent sporting country, and almost every young emigrant carries out a gun with him to shoot game. Few people however go in quest of it, the winters being so severe, and food so scarce, that game cannot exist in numbers. In every situation deer is difficult to be had, and I only met with one deer-shooter in my travels. The turkey is found only in the western district in limited numbers. Quails are more plentiful, and confined to the west. There are two kinds of pheasants throughout Canada, and not plentiful any where but in the west. The ruffed grouse or prairie hen has never been found in the country. Ducks are particularly numerous in autumn, and at certain seasons so are woodcocks. I have seen more game in half-an-hour in Scotland than I saw in all my wanderings in Canada, and there is no part where good shooting can be obtained but near the River Detroit. 


\section{CHAPTER VI.}

United States-Climate-Diseases-Productions-Agriculture east of the Alleghany Mountuins - Agriculture west of the Mountains-Wages-Choice of Residence-Progress of WeulthWages of the United Stutes and the Canados-Profits of Capital.

The territory of the United States is situated between 24, 27 , and $49^{\circ}$ north latitude, and $10^{\circ}$ east, to $54^{\circ}$ west longitude from Washington. Its mean breadth from north to south is about 830 miles, and mean length from east to west, 2500 miles. The area embraces 2,076,410 square miles, or $1,328,902,400$ acres, consisting of the fullowing states and territories: Maine, New Hampshire, Vermont, Massachusetts, Rhode Island, Connecticut, New York, New Jersey, Pennsylvania, Delaware, Maryland, North Carolina, South Carolina, Georgia, Alabama, Mississippi, Louisiana, Tennessee, Kentucky, Ohio, Indiana, Illinois, Florida, and the Arkansas, Michigan, Missouri, North-west and Western territories.

A territory differs from a state in not sending members to Congress; and the President of the Lnited States, with consent of the senate, appoints the executive officers. Congress has power to make general laws in the territories, which become states on containing a sufticient population.

Many people in Britain have difficulty in forming a conception of the extent of the United States, and imagine each state something like the size of the counties in their own country. But some of the divisions into which the territory is separated are much larger than the whole island of Great Britain. The United States must therefore be considered a union of countries_each state, having its own government and laws, is divided into counties, which are subdivided into townships. 
Having travelled over only a small portion of the United States territory, lying between $37^{\circ}$ and $45^{\circ}$ north latitude, embracing the states of New England, Pennsylvania, New Jersey, New York, Ohio, Indiana, Illinois, and the territory of Michigan, my remarks shall be confined to this region, which might, with propriety, be divided into the eastern, middle, and western states, if particular consideration was intended to be given it.

The climate of that portion of the United States which I travelled over participates of the general character of the continent, having the extremes of heat and cold. 'The length of winter will of course vary with the latitude, which, in the north, will be nearly six months, and in the southern part, about six weeks.

This region is intersected by the Alleghany mountains, commencing in the state of Maine, and passing through New Hampshire, Vermont, Massachusetts, New York, Connecticut, New Jersey, and Pennsylvania, dividing the country longitudinally. Some parts of this range is of considerable height-Mount Washington, in New Hampshire, being 6634 feet above the level of the sea. Monadnock, in the southwest corner of New Hampshire, was the most elevated point which I was near, being 3254 feet in height, and, with the exception of the falls of the Niagara, the only truly sublime object I saw in America. The Alleghany range varies in breadth at different places. Across the mountains in New Hampshire is about 120 miles-in New York, about 150 miles, and in Pennsylvania, 130 miles. In such situations, climate will be affected by altitude as well as latitude.

In the country east of the Alleghanies, north-east winds prevail for a considerable part of the year, especially in the New England states, where they are cold and raw to human feeling in the spring months. To the west of the Alleghanies, the most prevalent wind is from the south-west, and is mild in temperature. The winds blowing chiefly from different directions, on opposite sides of the mountains, have been ingeniously accounted for by Volney and other writers, and thought to be connected with the trade winds, gulf stream, a cold current of air from Davis' Straits, and the configuration 
of the country. There seems to be an opinion amongst the writers on this subject, that the climate of the west is two or three degrees milder than the east, under the same parallel of latitude-the winters of the latter being more severe, and the summers of the former cooler. Judging from human feeling, this may perhaps appear to be the case from the influence of the sea air, in the country bounded by the Atlantic, but the thermometer observations which have been published seem to make the temperature nearly alike at the same altitude on both sides of the Alleghanies. The meteorology of the United States has not, however, been properly investigated, and the most important difference to the farmer, in the climate of the two countries, is a deeper fall of snow in the east than in the west, and a steadier winter.

To the east of the Alleghany mountains, where north-east winds prevail in spring, consumption is a frequent complaint with the human race, and more especially near the sea-coast, the air being particularly keen at certain seasons. 'This disease is most frequent in the New England states, where the cold and dampness of the north-east wind is strongly felt. The inhabitants of New England have not that dark seered complexion so common in other parts of the Union, many of them closely resembling the people of Britain. It is probable the florid complexion of the people, and their proneness to consumption, arise from the dampness of the climate. To the west of the Alleghanies, the most common complaint is bilious fever, in every variety of type, passing by the names of " ague," "chill and fever," and many etceteras. Fever is essentially a disease of the country, and seems connected with the luxuriance and decay of natural vegetation. In every part of inhabited America, fever, originating from this cause, must be frequent, and will be more severe towards the south, as the heat and length of summer increase. It is common on the banks of rivers and on the prairies, from exhalations produced by the rays of the sun; and on first clearing wood lands, the same effects are produced. With the progress of cultivation, fever is likely to abate, and I have no doubt the fatality of the disease in this region is at present heightened by the quantities of animal food consumed by the inhabitants. On 
both sides of the Alleghanies, inflammatory complaints, arising from sudden transitions of temperature, are common. There is no reason, however, to imagine this part of America more unhealthy than the Canadas, unless the prevalence of north-east winds in the east, and the want of culcivation in the west, are more unfavourable than a severe and steady winter.

The agricultural productions are the same as what have been noticed as the growth of the Canadas. A portion of this country may, however, be termed the region of Indian corn, which grows with uneommon luxuriance, and is one of the most important plants in American farming. Mr John Taylor of Virginia called it the "meal, meadow, and manure" of the farm, and it well merits his emphatic description. It is used as human food in a variety of forms; in maintaining and fattening animals during winter it far surpasses every agricultural product, and affords a great quantity of materials for manure. When soil and elimate are adapted to its growth, it furnishes more nourishment for man and beast on a given space, and with less labour, than any other plant. It is the only means of fattening animals during winter in remote parts of the country, and, under present circumstances, no district which I visited in course of my tour can become eminent in breeding and fattening live stock, which is not congenial to the growth of Indian corn. It does not seem to be cultivated with success beyond $43^{\circ}$ north latitude, and an agricultural emigrant, who values the necessaries of life, ought only to settle where this plant can be successfully grown.

Indian corn seems to differ from most other agricultural plants, by growing vigorously for a suecession of years on certain soils without an application of manure. There is much evidence to establish this fact in the Western United States, and amongst the Indians in Upper Canada. I saw it growing luxuriantly on soft prairie soil in Ohio, which farmers assured me could not produce a wheat crop without an application of manure. It is this peculiarity of Indian corn which has given rise to some exaggerated accounts of the fertility of American soil, by producing so many crops without manure. In some parts of the country, Indian corn seems to be like an 
indigenous plant, and its growth for a succession of years is perhaps no greater test of fertility of soil than grass is in Britain.

The soil on the eastern side of the Alleghanies is generally of an inferior description, with exception of the lands on the banks of rivers. The cleared lands have been long cropped under the robbing system, and are far from being productive. The whole of the land that is worth oceupying is owned by private individuals, although a great portion of it is covered with forest; and I was frequently told, that in all situations near a village, or which had ready access to water-carriage, forest land was more valuable than what had been cleared, fuel having became so dear of late years. Much of the land covered with wood is not worth cultivating, and should the forest be removed for fuel, it is likely to remain in pasturage or be suffered to produce trees again. The price of farms varies from L.5 to L.30 sterling per acre, according to quality of soil, buildings, and situation. Labour can at all times be had, and every description of produce finds a ready market. Manures are chiefly employed in growing vegetables, and ean be bought from the stablers of New York at $7 \mathrm{~d}$. sterling a cart-load, similar in shape and size to the carts used in Seotland. Market gardening is the most profitable department of farming, and the growing of grass ranks next.

Notwithstanding the good markets, command of labour, and low price of manure, the cultivation of grain in this part of the country is attended with little profit, which circumstance, joined to a grass erop being more lucrative, illustrates the parts nature and man perform in the production of farm produce which has been so often alluded to. And a Briton who has been aceustomed to pay a high rent will be very apt to overlook, on first reaching America, many circumstances affecting the profits of farming.

Land which has been impoverished by a long succession of erops, under the robbing system, will not yield much grain without a plentiful supply of manure, which the rate of labour may frequently prevent being applied without incurring loss. Suppose an acre of wheat to yield with a moderate applica- 
tion of manure twenty-four bushels of wheat per acre, which is worth $\$ 1$ per bushel. The cost of producing the crop, including twice ploughing, harrowing, seed, sowing, harvesting, and carrying home, thrashing, dressing, and marketing, will amount to $\$ 14$, leaving only $\$ 10$, or L..2, 2 \%. 6d., to meet the interest of capital employed in the purchase and cultivation of the land, taxes, professional profit, and the purchase and application of manure. If the purchase money of the land and capital invested in cultivation amount to $\$ 60$ per acre, the interest may be taken at $\$ 4$, leaving only $\$ 6$, or L.1, 5s. 6d. sterling, for taxes and manure. 'The cost of manure is scarcely worth estimating, but the expense of its carriage and application are so high as often to forbid its use. On the assumed data there will only remain about 18s. sterling per acre to meet the carriage and spreading of manure. 'The expense of labour is strikingly exhibited in contrast with the value of the crop. The wages of a labourer may be stated at seventy-five cents per day, and the value of an acre of wheat would employ a man about thirty-two days. In Britain a wheat crop of similar productiveness, at ordinary prices and rates of labour, would employ a man between eighty and ninety days. The same mode of management is obviously not suited to both countries.

In grass husbandry human labour is but little employed, nature being the chief agent of production, and hence it is remunerating. The difficulty of transporting certain kinds of grass produce from a distance, such as hay and fresh dairy produce, keeps up the price of these commodities, but the small quantity of labour bestowed on their production is the chief cause of their profitableness.

A man with capital may purchase a farm to the east of the Alleghany range, and occupy it with a prospect of having a good return for the capital invested, if he possess prudence and industry. He must not, however, lavish capital on fanciful improvements, or employ much labour on finical operations. Wages are so high that he will require to calculate the value of every day's labour, and render the closest personal superintendence, and perhaps also assistance. Unless this is done farming will be unprofitable, as a great many of 
the workmen are idle and unsteady. Farming cannot, however, be pursued on a large scale with a prospect of success, from the difficulty of superintending the operations and forming a proper division of labour with unskilful and untractable workmen. There is, however, an excellent field for prudent skill and industry near all towns. In short, seience seems scarcely to have been thought of in American farming, and a eautious application of it in draining and other improvements, in particular situations, would be remunerating.

Land may be rented in many parts of the country on fair terms, more especially near towns. In such situations many British emigrants successfully pursue market gardening and dairy husbandry. Native Americans prefer occupying land of their own to paying rent for the use of a farm belonging to others.

The labouring emigrant does not readily find agricultural employment on the east coast, from the country being thickly settled, and the constant influx of emigrants without funds to support them. He should, therefore, lose no time in pushing back into the country, where wages are higher compared with the price of the necessaries of life and land, and where information necessary to a settler on cheap land, can alone be acquired.

'The soil on the western side of the Alleghanies is generally much superior to the eastern, although it is to be found of all descriptions and degrees of fertility. It has not been very long eropped, and the natural composition of a great portion of it will, under any circumstances, render it productive of wheat and Indian corn. Almost all the land in the eastern part of this district is owned by private individuals, but much of it remains uncleared of forest. Towards the west the greater part of the land is held by the United States government, and costs $\$ 1 \frac{1}{4}$ per acre. In every part of the country forest or improved land may be purchased, and the price is governed by local situation and other circumstances. Labour can generally be had, except in the extreme west. Farm produce is in constant demand, and prices are regulated by the markets of the towns on the east coast and New Orleans, to all of which there is access by rivers, canals, or railroads. 
Prices may, therefore, at all times be considered lower than the markets on the east by the expense of transport. Manures are very seldiom used except in the neighbourhood of large towns, where the demand for vegetables and shortness of carriage render it worthy of the farmer's attention.

'The money wages of labour may be stated to be nearly the same from the east to the extreme west, but any difference that exists is towards a rise in the west. In the same direotion a decline in the price of produce takes place. 'Therefore, as the distance from the markets on the coast increases, the farmer pays a greater share of produce to the labourer, and must be remunerated either by the low price of land or its natural fertility. Labourers are of a more unsatisfactory description than in the east, land being 80 cheap that every prudent man is enabled to purchase a farm for himself in the course of a year or two, and it is only the imprudent who continue labourers. The character of the workmen renders labour dearer than is at first apparent.

The country to the west of the Alleghanies is of such extent, and gradually increasing in distance from the seaport towns which regulate the price of the land produce, that farms of equal quality of soil vary from $5 \mathrm{~s}$. $4 \mathrm{~d}$. to $\mathrm{L} .12$ sterling per acre.

A person possessed of capital may purchase a farm in many situations with advantage. But the exercise of prudence and industry in choice of situation and management is particularly called for. The price of produce is so low compared with labour, that only a small portion of capital and labour can be profitably applied to the cultivation of the soil. In almost every instance where cultivation is followed personal assistance will be necessary to obtain profit. It has already been remarked, that money wages in the west are nearly the same as in the east, and as hired men are generally boarded, the western employer has some advantage from the cheapness of provisions. Supposing an acre of ground without an application of manure yields twenty bushels of wheat, which sells at 50 cents per bushel, and a labourer gets $\$ 120$ a-year with board, the value of an acre of wheat will employ a man twenty-six days without including board. To the east of the 
Alleghanies the value of an acre of wheat was stated to pay the wages of a hired man about thirty-two days, including board. In the one case, however, manure is supposed to have been applied, and in the other it had not. But in many parts of the west, wheat generally sells considerably lower than 50 cents a-bushel, and in such situations a hired labourer either obtains a greater share of the produce, or the fertility of the soil is greater. In Sangamon county, in the state of Illinois, the soil of which is very fertile, the price of wheat at Springfield was $37 \frac{1}{2}$ cents when I was there. Supposing wheat to yield twenty-five bushels per acre, its value would employ a labourer about twenty-five days. In every situation the hiring of agricultural labour ought to be determined by calculation. If the farmer obtains a fair profit from the outlay of capital he need not repine at the wages of the labourer, however high they may be.

An emigrant will not always find agricultural employment to the west of the Alleghanies from the low price of farm produce; but there is always a demand for labour in towns and villages, at high wages, and he need not remain idle if he is disposed to work. An industrious and sober man must rapidly accumulate wealth by working for hire, and many perhaps err by purchasing land instead of continuing to work under the direction of others. On leaving New York, a gardener, who was working at Haddington when I left Scotland, gave me ten pounds sterling, which he had saved since his arrival in America, to enable his wife and family to reach him. A young man, whom I, had often employed at spade-work on Mlungoswells farm, at 1s. 6d. a-day without board, was earning, by sawing stones at Cincinnati, $4 \mathrm{~s}$. 3d. a-day with board.

A person cannot purchase and farm land to the east of the Alleghanies without possessing a considerable portion of capital; and to the west of the mountains land is not likely to be cultivated with profit without personal labour. The luxuries of life being prepared in the east, to meet an extensive demand, are cheaper than in the west by the expense of transport from one market to the other. It is the reverse with the necessaries of life ; and the agricultural emigrant ought to be guided 
in his choice of residence on either side of the Alleghanies by his habits, finances, and wants.

All wealth, according to the views I have endeavoured to establish, being the result of nature and labour, the riches of a community must be regulated by the soil and climate of the country, and the skill and industry of the inhabitants. The soil and climate of two countries being equal, the most skilful and industrious people will be the wealthiest - with equal skill and industry the inhabitants of the country most favoured by nature will become the richest. Under a parity of circumstances, with regard to nature and inhabitants, the oldest nation will be the wealthiest, and the progress of new countries in wealth will depend on the facilities of cultivation $-a$ forest-covered surface yielding wealth slower than one clothed with grass. The ratio of extent of territory to the inhabitants of new countries also affects the progress of wealth. With a limited surface capital will rapidly increase, from the cheapness and division of labour that will necessarily ensue, and wealth will be unequally distributed amongst the inhabitants. With an extensive surface capital will accumulate slowly, and all the inhabitants will enjoy an ample share of the necessaries of life, without possessing much tangible capital.

The first settlers in this portion of the United States had to struggle with severe privations. Besides being engaged in warfare with the natives, they settled in insulated situations in the midst of a densely wooded surface, without experience as to the mode of rendering it fruitful, or possessing facilities of communication. They were unable to subsist by their labour, and many perished for want of food. But on every portion of cleared surface nature continued productive, and her exertions being aided by new skill and industry, wealth appeared in the progress of time. There being no rent, and scarcely a burden of any kind to pay, the inhabitants reaped the combined fruits of their own and nature's labour without division. Individuals had as much land as they chose to cultivate ; and having every inducement to render it productive, they rewarded labour with liberal wages. The abundance of land induced labourers to turn landholders, and reward others with high wages, who 
likewise became landholders. Thus there was a constant progression in society, by the prudent and industrious labourers rising into wealth, and receding from the first point of settlement on becoming landholders. These movements continue up to the present time with the existing cause-abundance and cheapness of land, to which many of the peculiarities of the country and its inhabitants may be traced.

Good land being sold by the United states government at $\$ 1 \frac{1}{4}$ per acre, people will not permanently hire themselves for a less reward than can be obtained by cultivating on their own account. When competition depresses wages, operatives commence farming, and wages rise. Thus the wages of labour are regulated by the profits of farming, and will continue to be so until all the good land is oceupied.

The profits of farming do not regulate the wages of labour in the Canadas, because land is there held by monopolists, or sold at a monopoly price. And the late rise in the price of land in Upper Canada not only renders the ultimate prospect of labourers becoming landholders more distant, but also lowers the wages of operatives through competition, by tending to confine them to their professions. But supposing land to be equally abundant and cheap in the Canadas and United States, and the wages of labour to be regulated in both countries by the profits of farming, wages would necessarily be higher in the United States, from possessing superiority of climate. Nature performs more towards the manufacture of agricultural produce in the United States than in the Canadas, and the reward of industry, which is divided between the landholder and labourer, is consequently greater.

This view of the wages of labour in the different parts of North America which I visited, is supported by facts, wages being generally considerably higher in the United States than in the Canadas. During the summer of 1833 the carpenters of New York struck work when getting 5s. sterling per day, and by doing so obtained $6 \mathrm{~s}$. per day. The future prospects of operatives appear to be good, a vast portion of the best land of the country being still unoccupied, a subject which will be afterwards noticed.

The profits of capital employed in farming do not seem 
to affect the profits of capital invested in other fields of pro. duction. Indeed, the high price of labour, and the difficulty of combining systematically and giving proper effect to agricultural labour in most parts of the United States, render the employment of much capital in farming unprofitable. 'The high price of labour affects the investment of capital in other channels, and it will be found difficult to manage a large fortune safely and profitably. On this account wealth is seldom accumulated in large masses, while almost all the inhabitants have it in their power to acquire a competency. The customs of the people are favourable to this degree of wealth-a father's property being generally equally divided at death amongst his children. Capital, however, in many cases, will enter into competition with labour, and its profits in the United States, where the fields of production are so extensive, and its inhabitants so enterprising, cannot be low for many generations to come. 


\section{CHAPTER VII.}

Wealth and refinement of different parts-Writers on American Manners-Plainness - Civility - Aew England CharacterUnfuir dealing-Eimigrant's S'ituation and C'haracter-Givern. ment-United States and Lipper C'anada.

THE comparative wealth and refinement of the eastern parts of the United States, arises from the annual savings of the combined exertions of nature and industry having had time to accumulate and affect the inhabitants ; and the gradual falling off in these attributes, which takes place towards the west, is owing to most of the settlers having originally been operatives in the east, and not having had time to accumulate wealth, or adopt refinements.

Although I did not often witness the domestic manners of the Americans, my opportunities of meeting the inhabitants of the United States in public were frequent, and the impressions imbibed during my intercourse with them were different from what the accounts of others led me to expect. Many travellers who have written on the subject were perhaps ill qualified to form a just estimate of American manners and character, from the sphere of society in which they themselves had previously moved. No scion nor associate of British aristocracy, who has not been brought into familiar intercourse with the middling and lower orders of his own countrymen, is likely to do justice to the Americans, and the tenor of many of the remarks which have been given to the world on the subject is evidence of the writers never having before associated with the class of people to whom they allude. The inhabitants of Britain, in private and public life, being divided into grades, some individuals are altogether unacquainted with the manners and customs of the classes below them. And as Englishmen of high pretensions and refinement, on 
reaching Americn, mingle on terms of equality at public tables and in conveyances with the commonest operatives, they feel disgusted with the manners of the people around them, without considering they belong to a different class from their own associates at home. In Britain, a person of rank is generally regarded with respect by the classes below him. In the United States, rank seldom meets with or expects deference from the people, and the humblest citizen familiarly enters into conversation with every individual who addresses him. This self-possession of the Americans is often mistaken for forwardness, and their unembarrassed conversation for insolence. In Britain, the different classes of population generally remain distinct, and many of their excesses are hid from common gaze. In most parts of the United States, the bar-rooms of hotels form the only scenes of tippling, and, being at all times open to the public, a traveller is apt to consider the people more dissipated than they really are. Were a gentlemanly foreigner to meet the lowest class of the people of England at table, and associate with them in their haunts of vice, his adventures would form a high-coloured picture of British manners and society.

The strictures of British writers on the manners of the people of the United States seem to have created a strong prejudice in the minds of emigrants of every deseription. In the month of May last, a person who had long followed the trade of a country wright in his native village, situated in East Lothian, introduced himself, and asked my opinion regarding the best place of settlement for himself and family in America. He had made up his mind to emigrate, and left me in the determination of residing in the United States. I have just learned, however, that he keeps a spirit store in the village of Niagara, Upper Canada, and assigned as a reason for leaving the States, that he could not endure the manners of the people. The conduct of this Scottish clown is a good satire on the remarks of such refined travellers as Trollope, Hamilton, \&c.

On first reaching the United States, the plainness of the people's manners appeared remarkable. In all classes there 
was a total absence of grimace and corporeal token of respect, with corresponding sounds of address, an expression of obligation or thankfulness seldom being heard. In courteousness the inhabitants appear as far behind the British as the French exceed them. But, on the other hand, vulgarity, rudeness, or insolence, is almost never met with in the humblest walks of life. Mechanies and storekeepers ride in the same vehicle, and sit down at the same table, with the most polished members of society; all seem desirous of behaving well to each other, a rude or indelicate remark never being made, nor a disgusting practice indulged in. On one oceasion only I met with revolting behaviour, at the table of the Washington hotel, during my first residence at New York. On my second visit, I found the individual still an inmate of the house, in which he had lodged for fourteen years. He was an eccentric character, and originally from England.

A general propriety of deportment and softness of manner pervades the lower classes, and that coarseness, which is sometimes met with in Britain, does not appear to exist in the United States; but certain circles of society in Britain seem to have a higher polish than what is to be met with in America, and perhaps the general standard of manners of both countries is not widely different. 'The lower orders of the United States are, however, beyond all question, greatly superior in refinement and intelligence to the lower orders of Britain.

The many classes into which society is divicled in Britain, and the privileges assigned them by the laws and customs of the country, are so distinct, that some individuals, who are jealous of their dignity, endeavour to repulse all beneath them. On the other hand, some people seek distinction by rudeness towards others. And amidst such jarring elements the poor sometimes become servile and debased, the rich contemptuous and overbearing. In America, every individual seems possessed of self-respect, and in the intercourse of life, arrogance is seldom assumed, and never submitted to. Worth is duly appreciated, and hollow pretension exposed.

The civility of all classes in the United States is so universal, that during my intercourse with the inhabitants, I scarcely 
experienced an indication of insolence, and never ohserved that democratic sauciness which I was taught to expect amongst the lower orders. Every individual feels that he is independent, and never alludes to the subject. The case is, however, different in Canada, where some British emigrants seldom let an opportunity escape of telling a well-dressed person, that "this is a free country, and that he does not care a " " " for any man." The emancipated bondsman alone boasts of being free from fetters. A foreigner, however, who arrogates to himself superiority in the States, will be despised by the meanest of the people, and his money will neither purchase their attention nor services. The United States which I visited, seem to me an excellent place for teaching an overweening person a due estimate of himself and hị fellow-mortals. 'Twelve months' intercourse with the people would greatly improve the fagged and fagging youthful aristocracy of Britain. Their haughtiness of demeanour, and acerlity and impatience of temper would be changed, and they would return home with a just sense of the place they occupy in the world, and qualified to discharge the important duties they owe society. Every Briton who has mingled with the people for any length of time, and practised self-examination, will testify to the truth of my remarks.

Whatever may be the state of manners and customs in the United States, the foppish need not desert Britain in search of happiness in the New World, for there such persons are lightly esteemed. The emigrant ought not to vex himself alout having heard that people place their feet on tables, or on the mantel-piece, as nobody will interfere with the position of his on the floor, nor whether they chew tobacco or cheese, as he will be allowed to eat what he pleases. The necessaries of life are generally obtained without much difficulty, and whoever regards mankind as created by the same Being, of the same materials, for the same end, and entitled to the same privileges, need not despair of happiness if he leads a life of virtue and industry.

By far the greater portion of the people I came in contact with were natives of the New England States, who seem to have spread over a considerable portion of the States of New York 
and Illinois, and the territory of Michigan. The character of this people has often been drawn. They have many strong characteristics, and in nine cases out of ten may be recognised in walking into a public room, having an air of confidence and self-esteem above all other people. They form the true Yankees, and are obnoxious over the continent of North America, like the Yorkshiremen in England, and Aberdeenshiremen in Scotland, for their unremitting keenness and industry in business, which may have been engendered by the poverty of the soil, and badness of the climate of New England. They are descended from the first settlers who fled from religious persecution in England, and seem to inherit what may be supposed to have been the prominent dispositions of their forefathers. They faithfully observe all the external forms of decency, and their taciturn, phlegmatic, and calculating disposition, may render them objects of dislike. But their intelligence, self-esteem, enterprise, and perseverance fit them for a young country, and the growing prosperity of the northern section of the ['nited States' territory is in a considerable degree indebted to them.

The Yankees have been generally charged with unfair dealing, and although I had no opportunity of judging of this matter personally, many circumstances induce me to think the charge is to a certain extent well founded. To emigrants the morals of a people are of more consequence than their manners, between which, however, there is no connexion. The Irish are a more polite people than the Scoteh, but greatly inferior in morality; and the Yankees, with all the outward forms of virtue, are considered the most dishonest race in the Union. Yankee knavery is said to consist in overreaching every one with whom they have dealings, if the character of their customer admits of their doing so with impunity. The charge of dishonesty is not applicable to the people of New England generally, and much of the prejudice against them arises from their industry and success in business. In course of conversation I never heard imposition of any kind alluded to in terms of approbation, while honesty of character, and more especially in public men, was inva- 
riably praised. Virtue will ever be respected in civilized society.

In new and extensive territories the restraints of dishonesty seem weaker, and the temptations to overreach stronger than in densely peopled old countries. In new countries, local attachments, family character, and many other feelings which influence conduct, are unfelt. Individuals seldom remain long in one place, and traffic with others similarly situated. The laws are imperfectly put in force, and successful fraud is sometimes considered clear gain, as the parties may never hold farther intercourse, and in the event of exposure, a change of residence obviates disgrace. Most of the people are poor, and grasp at wealth. 'There are few prejulices of birth or station in society, and no barrier in the field of enterprise or ambition to the lowest individual. The reverse of all this takes place in old countries, where other policy than honesty commonly entails ruin in worldly matters. In both situations the degree of moral principle may be the same. But in Britain all is not virtue which appears on the surface of society, and the fear of punishment, resulting from public opinion and effective laws, has perhaps more influence than the dictates of conscience in checking knavery. 'The intercourse of the people of Britain and certain parts of America, seems to arise more from the different circumstances in which they are placed than from religious and moral feeling.

If the view which I have taken of the commercial intercourse of new countries is correct, the emigrant will soon discover that the New Englanders are not the only sharpers in America. A gentleman settled in the township of Hinchinbrooke, Lower Canada, in writing to his friends in East Lothian, states, "although the inhabitants here are not Yankees, yet all act on the Yankee system." And I shall renounce all pretensions to discernment if many of the inhabitants of Upper Canada are not the most accomplished Yankees on the other side of the Atlantic. The change which sometimes takes place in the habits and morals of people on reaching America is not confined to the modes of acquiring property. In some parts of Upper Canada the 
Sabbath was chiefly spent in shooting, and many Scotsmen did so who lived in the vicinity of a church. Every new settler is liable to be beset by all the knaves and cheats of the district on his first arrival. If he defeat their first attempt they seldom make a second, and he may afterwards transact business without much risk of being imposed on. Too much caution cannot, however, be exercised at first settlement, more especially towards old countrymen, who can make advances under more favourable circumstances than a native American, and are equally prone to take adrantage.

The greety and dishonest intereourse which takes place in many parts of North America must be repugnant to honourable feeling, and emigrants ought to guard against being led into the system. But however unpleasant such a state of society may be, the people of Britain need not shun the New World on such grounds. Your experience in life, my dear brother, has not been extensive, but from your knowledge of, and intereourse with, the people of East Lothian, you must be aware that amongst the peers of the realm, their law agents and factors, the tenantry and dealers in horses, catcle, and corn, there are individuals who lay aside morality when transacting business, and are alone guided by the letter of the laws. Their conversation is as little to be depended on as the passing wind, and their writings are sometimes worded with intent to deceive. In short, there are bad characters in every part of the world, and whoever is capable of transacting business with the Tankes of Britain need not be afraid to encounter those in America. I admit the degree of mercantile honour and morality may be higher in Britain than in $\Lambda$ meriea, and imposition less frequent, but contend there are cheats in both countries, and the same caution which is necessary to meet the plans of one knave in Britain will defeat the tricks of twenty in America.

The situation of an emigrant on reaching America must be very different from what it was at home. In the midst of a people whose manners and customs are in some measure new to him, he is an isolated being, without any one in whom he can confide for advice and assistance. If he cannot think for himself, and rely on his own resources in transacting business, 
he will be a helpless mortal, and in all probability becomo the prey of designing persons. It is the dependence of the inhabitants on each other in old countries which unfits so many of them to play their part in the newly settled portions of the United States, where each individual acts independently, and trusts to himself alone. Americans are, therefore, the most acute people in the world in the ordinary intercourse of life, and few foreigners need take up their abode in the country in hope of outstripping them. 'The most essential requisites in an emigrant are energy of mind, stearliness of purpose, and persevering industry. Without possessing these qualifications, no one need expect to mingle successfully in the bustle of life ; although it is possible to exist as a farmer, without being so highly gifted. It is a wrong estimate of themselves which so often gives rise to disappointment and failure on the part of British emigrants. There is nothing in the soil or climate of America which can impart wisdom to the fool, energy to the imbecile, activity to the slothful, or determination to the irresolute. Examination of character should therefore form part of every emigrant's preparation, as his fate will perhaps altogether depend on it. It is folly for the idle and imaginative beings who float in British society to seek an Elysium in the United States, from whence they will again be speedily wafted to their native country. It is the industrious, prudent, and frugal people alone that can calculate on success.

It has already been mentioned that the United States consist of twenty-four separate states, with a general government for defence, commerce, and taxation. Each state has a distinct republican government, for the regulation of its own affairs. The governments of the different states resemble each other, although not precisely alike, and consist of Legislative, Executive, and Judiciary. The mode of electing and the powers of each branch vary in some states, but in all of them the influence of the people is supreme.

With governments, as with almost every thing else, there is a difference of opinion, and many individuals may dislike the republican form and democratic tone which prevail in the states. In such a state of things it is, however, certain, that 
the interests of the many never can be sacrificed for the advantage of the few, and that the laws, taxation, and expenditure of the country must accord with the wishes of the people. Whatever creed emigrants may have adopted, they can live unmolested, without joining in the turmoil of American politics. The field of industry is open to their exertions, and its fruits may be enjoyed in peace and security.

Travellers cannot deny the unspeakable advantages that have accrued to the industry of the United States from the nature of their governments, and many of them, as if stung by envy, dilate on the instability of the Tnion, and by the consequent convulsion see a termination of the happiness and prosperity of the people. It is impossible to say what events may be in the womb of futurity; but there is no rational ground for supposing the dissolution of the I'nion by war is at hand. Almost all the domestic wars which have taken place amongst eivilized men, have either resulted from ambitious chiefs leading deluded and enslaved followers against each other, or from resistance to tyranny. In the region of the United States, to which my remarks are applicable, tyranny in any shape can scarcely be said to exist ; and should ambitious men take the field, where are they to oltain followers? But supposing war to happen, and that the democrats of America copiously shed each other's blood, are the aristocrats and serviles of Europe exempt from such barbarism? The emigrant may calculate on peace from the love the people have for their government, the absence of aristocracy and abject poverty, and unfettered industry. Should he, however, shun the United States, from apprehension of intestine war, in what part of the world will he seek a retreat?

I alluded to the contrast between the United States and Upper Canada, as witnessed near the frontier on each side of the river Niagara. After having had an opportunity of seeing extensively both countries, I consider my first opinions, as expressed at pages 95-96, to be substantially correct, although other causes may have operated in producing the difference than the governments of the countries.

It may be perfectly true " the people, soil, and climate, were originally alike" on both sides of the Niagara, but the 
United States and Upper Canada cannot with propriety be contrasted by those spots alone. The inhabitants of the United States, generally speaking, may be said to have been born in the country, and consequently possessed of the peculiar feelings and qualities of a people suited to a young country. On the other hand, most of the inhahitants of Upper Canada are either the descendants of the Royalists, slothful and unenterprising from the neglect with which they have been treated, or emigrants from Britain, where many of them had acquired notions and habits ill adapted for seteling a wood covered surface. Upper Canarla having also become a place of refuge for the outcasts of other countries, and many of the settlers being composed of the poorest of the Irish and Scotch Ilighlanders, two of the most indolent and unambitious portions of civilized society, there can be no question of the people of the United States being more industrious and energetic than the inhabitants of Upper Canada. The United States sooner became peopled than Upper Canada, and may, consequently, be said to be an older country. The climate of the States is generally also better than Lpper Canada. If the view which I have taken of the source of riches be correct, the United States, being an older country, with a better climate, and a more industrious population than Upper Canada, should also be wealthier. It will accordingly be found that in all external appearances, such as villages, houses in the country, hotels, internal intercourse and trade, and the dress of the people, Upper Canada is about a century behind the United States.

The governments of the several States and Upper Canada are alike in form, consisting of a governor and two deliberative assemblies. In the States persons invested with power are chosen by the people. In Upper Canada the governor, the members of the highest assembly, and of the judiciary, are appointed by the King of Great Britain. The States may be said to have passed the youth of government and attained vigorous manhood. The government of Upper Canada is still in the helplessness of infancy, and cannot, in the nature of things, continue permanent in its present state. Many people give a preference to Upper Canada because it is under the 
British government; but when emigrants reflect on the nature of the two governments, let them ask themselves what the British government has done for them at home? What they expect from it in America? And how long Upper Canada is likely to remain subject to Britain?

Each of the United States forms an integral part of a large confederacy, and the advantages which the population derive from an extensive and unfettered commercial intercourse are great. Upper Canada is insulated. The river St Lawrence forms its only channel of trade, and already disputes have arisen with the Lower province about the imposts collected on foreign commodities. In the event of the Union of the States being dissolved, the interests and feelings of the population would, in all probability, lead to the formation of smaller unions, without disturbing the governments of the separate states. When Upper Canada breaks, or is thrown off from Britain, what will be her situation? While the French interest remains strong in Lower Canada a union of the two provinces will not take place, and all intereourse with foreign nations would be at an end. The inhabitants of the $\mathrm{C}_{\text {pper }}$ province, in such a state of things, would be reduced to the necessity of subduing the Lower Canadians by force of arms, or begging of the United States to be admitted into the Union.

In the United States the expenses of the federal government are impartially levied throughout the Union, and the burdens of the government of each State are paid by its own inhabitants. In every State cheap justice and free education are provided for the people ; and taxation is lighter, compared with the advantages enjoyed, than amongst any other independent people in the world. In C pper Canada a part of the expenses of the country is paid by the people of Great Britain and Ireland, who also bear the expense of defending the province. Free education is not provided for the inhabitants. Taxation is at present almost unfelt, which is owing to the British government. The people of Britain are not, however, likely to be long burdened with the expenses of the province, and when the inhabitants meet the expense of governing themselves, taxation in Upper Canada will be augmented. 
The manners and customs of the people, as witnessed in public, are the same in both countries. In all things there is much less refinement in Upper Canada, and the manners of the people are coarse contrasted with those in the States. Morals seem to correspond with the manners. It was, however, the unfortunate emigrants from Britain and Ireland who imparted such a character to the population. Many individuals seemed to me conscious of self-debasement, and to have left home for the purpose of indulging their vicious propensities without encountering the scorn and censure of their friends and relations. Should it be thought that I have judged harshly of some of my countrymen, let it be remembered I speak only of what was observed in public, and that the harrooms of Upper Canada exhibited the worst part of British society without a releeming feature. The domestic manners and morals of the people of either country did not come properly within the scope of my observation. I may, however, remark, that I was favourably impressed with the manners of the royalist inhabitants of Canada, and it would be ungrateful on my part not to acknowledge the uniform eivility and kindness which $I$ experienced in private from every class of settlers.

In the United States the machinery of government is controlled by the people, who do every thing for the welfare of the country, and political power is invested in worth and talent alone. In Upper Canada government is swayed by an aristocracy, who have never lost sight of their own interest in legislating for the country. A higher and more uniform tone of independence and self-respect pervades the inhabitants in the United States than in Canada. The emigrant who delights in lording over his fellow-mortals, and measures his importance and wealth by the servility and wretchedness of others around him, ought to shun the States. The emigrant who seeks a fair and favourable field for his industry, and aspires to share, in common with his brethren, the just rank and privileges of man, ought to shun Upper Canada.

The United States are rapidly progressing, and their future prosperity seems illimitable. I ascertained there were eighteen 
large steam-boats belonging to the States on lake Erie in 1833 , and a gentleman, who was there in 1834 , assured me they had increased to twenty-four. By the official report of the Postmaster-General to the President of the United States, the annual transportation of the mail was, in $1829,13,700,000$ miles, and in 1832, 23,625,021 miles. There is not one-tenth of the surface yet devoted to the production of human food. The coal-fields of the west are perhaps inexhaustible, the water communication is almost without limits, and the extent of canals and railroads already exceed that of any other nation. The country is great even in its infancy. If its territury, consisting of $1,328,902,400$ acres, were peopled to the same degree as Lingland, containing a great deal of land which eamot be cultivated, the inhabitants would anount to $537,872,383$, while the present population is about $14,000,000$. A vast extent of the best soil, situated in the finest climate, is still unoceupied, and if the views regarding the assistance nature affords the farmer, and his reward affecting wages of other labour, which I have already laid down, be correct, industry eamnot fail of meeting with a rich reward for many centuries yet to come.

The internal and external state of the country is free from molestation, and the prineiples of education and good government are so firmly established, and applicable to every condition that may arise, that nothing is likely to eheck the prosperity of the United States but fancied opposition of interests resulting from extent of territory. A state of things will soon appear, however, to hold the Union together in spite of opposing interests. Between 37 and 45 degrees of north latitude, and beyond 5 degrees of west longitude from Washington, lies the most favoured region of North America. By inspecting a map it will be seen this district is intersected in all directions by navigable rivers and other channels of commerce. The great outlet of the region is by the Mississippi to New Orleans. The river Ohio communicates with Philadelphia and Baltimore by canals and railroads, and by canals and lake Erie with New York. The rivers Wabash, Illinois, Mississippi, and Missouri, will also, in progress of time, communi- 
cate with New York by the Frie canal or other means. For reasons which will be afterwards staterl, population must soon accumulate in this district, which possesses almost every thing within itself which can add to the wealth and greatness of a country. 'The chief power of the States will centre here, and the interests of the inhabitants being interwoven with the mentioned seaports, they will insist on an observance of the Union, whatever may be the views of the northern and southern states.

The inhabitants of the States speak the same language as the English, which may he called the language of commerce. They are made acquainted with the improvements and discoveries of Britain a few months after they become known, and from the freedom of institutions, and energy of the people, greater effect can sometimes be given to them. On a general view of all the circumstances affecting the character and situation of the country and the people, it is scarcely possible to imagine a region promising such unchecked prosperity and future greatness.

Upper Canada has made unparalleled advancement of late years, which is not likely to continue at the present rate, as the causes of prosperity have been altogether artificial. A great number of gallant men, after meritoriously serving Britain in war, were placed on the half-pay list, in prime of life. Seeing no prospect of employment or farther advancement in the profession of arms, many of them retired to Upper Canada, in hope of providing for their families, where they were assigned a grant of land. 'This class of emigrants cannot, however, be much augmented, and the chief source of value to the country of those already settled-their annuities-will terminate with their lives. Of late years, immense sums have been lavished unproductively by the British Grovernment on canals and other works, and in paying public services, which cannot be continued in the existing state of things. A third source of advancement has been the tens of thousands of individuals lured into the country from Britain by devices which will soon lose their influence, in consequence of a rival to the Canada Company having appeared in Lower 
Canada, under the title of the American Land Company. Many of the shareholders reside in Quebee and Montreal, who will employ their influence to prevent strangers proceeding to the Upper province. From these causes, which are temporary, and others formerly stated, there is little reason to expect a continuance of the recent progression in Upper Canada. The country has, however, great advantages in water communication, which, in progress of time, will become useful to trade. 'There is still much unoccupied land, a great part of which, however, lies in an unfavourable climate. From this eireumstance, the monopoly of land, and its consequent high price, the reward of industry and wages of lahour are more likely to diminish than increase.

The position of Cpper Canada in its external relations, which has been stated at page 413 , must be considered unfavourable, and in the internal condition of the country there is much which is unsatisfactory. The province is an appendage to Britain, and seems to have aped many of the frailtie's of the mother country. The principle of government has been patronage; the rule of governing, enriching the few and despising the many. Hence abuses in extensive grants of land, pensions, superfluous offices, an aristocracy, and such an aristocracy! a rapacious church, and the neglect of education. The institutions of Britain are a century behind the intelligence of her inhabitants. Upper Canada is generations behind North America in legislation. I have already said the government of the province is in helpless infancy, and add, it must pass through the slippery paths of youth before attaining strength. There is already discord amongst the inhabitants, who are assailing the oligarehy under a sturdy, though not comprehensive minded, leader. The strife is likely to be tedious, and without bloodshed; the poverty of the country and character of the people being a sufficient guarantee against aggression or envy on the part of the United States, and the scattered condition of the settlers a protection against themselves.

The policy of the movement party ought to be, to seek the aid of the mother country, and steadily but cautiously proceed with measures calculated to cripple the aristocracy, the domi- 
- nant church, and the Canada Company. 'These changes can only be lastingly and beneficially effected by extending the elective franchise, and providing free education for the inbabitants. The ultimate policy of Upper Canada is to court a union with the United States, which would open channels of trade by way of New Orleans and New York.

On a general view of the circumstances affecting the country and people of Upper Canada, much time will be required to develope the resources of the country; and a period of excitement is likely to intervene before a permanent goverument can be established.

Every thing in the C'nited States seems to me to be resting on a natural and sure foundation, with prospect of continued prosperity. In Upper Canadin most things appear to be on an artificial footing, and must consequently experience change. The States present a wider and a better ficld for the exercise of industry than Upper Canada; and the British emigrant, who must live by his own exertions, makes a sacrifice of his immediate interests, and in all probability the interests of his posterity, by preferring Upper Canada to the United States as a place of settlement.

Many people may prefer Canada to the States, from having friends already settled there. Such a reason is not creditable to their friends in Britain, whom they leave behind. The person who makes up his mind to leave the place of his nativity, ought to employ his industry and capital in the best field, and endeavour to bring his friends who may have settled less fortunately to him. 


\section{CHAPTER VIII.}

Illinois-Climute-Face of the country-Prairies-Soil-SillLead-Iron_Coal-Wuter Communication-History-Tourns -Government-Educrtion-Kentuchy Populution-Aime Einglanders-Pioneers-Manwers and Customs.

Some of the western United States, forming part of the extensive and fertile valley of the Mississippi, are so different in character from the Eastern States and the Canadas for agricultural emigration, as to merit particular consideration. 'The region alluded to lies north of latitude $3 x^{\prime}$, and from $7^{\prime}$ of west longitude from Washington to the rocky mountains. Much of this tract is imperfectly known, having never perhaps been trod by civilized man, and embraces the states of Indiana. Illinois, Missouri, and the Michigan, North-west, and Missouri territories. My personal observation extended to a portion of four of the mentioned divisions, which enabled me to form an opinion of their characteristies, which are said to be pretty uniform ; and for the sake of precision Illinois shall be noticed.

The State of Illinois extends from north latitude $37^{\circ}$ to $42 \frac{1}{2}^{\circ}$, and from west longitude $10^{\circ} 35^{\prime}$ to $14^{\circ} 25^{\circ}$. It is bounded on the south by the river Ohio, on the west by the Mississippi, on the north by the north-west territory, and on the east by lake Michigan and Indiana. The length is 382 miles, the area 57,900 square miles, or $37,056,000$ acres, which is nearly the size of England and Wales.

The climate of Illinois partakes of the general character of North America, but from the absence of hills, and small elevation above the level of the sea, this region is milder than any other of the same latitude, The winter in the southern parts seldom exceeds six weeks. At Shawneetown, which is in the southern part of the State, the average temperature of July, in 1819 , was $87^{\circ}$, of December $43^{\circ}$, and the mean annual tem- 
perature $64^{\circ}$. At Prairies des Chiens, which is a few miles beyond the northern boundary of the State, the temperature in July 1820 was $74^{\circ}$, in December $16^{\circ}$, and the average of the year $48^{\circ} 5^{\prime} \cdot{ }^{\circ}$

The diseases in Illinois are such as are common to the upper Mississippi valley, amongst which intermitting and remitting bilious fevers often occur. From the variations of temperature, inflammatory complaints and diseases of the lungs are frequent in this and almost every other part of North America. I met several young men, suffering under consumption, travelling in the steam-boats of the west, although this malady is much more frequent in the eastern states. By an official report of the deaths in the city of New York, from 24th November to 1st December, 1832, in a newspaper lying before me, 14 cases of consumption, out of a total of 92 , are recorded, which is the highest number of any disease on the list; and the same paper states 5 of consumption, out of 62 , at Philadelphia, which occurred during the previous week. Fever, dyspepsia, and consumption, are the maladies of Illinois, the two first being most common in the south, and the latter in the north. The health of an emigrant may, in some measure, be preserved by care. Exposure to sudden changes of temperature without proper clothing, and uncomfortable houses in inclement weather, seldom fail of engendering disease.

The mouth of the Ohio, in the south-west angle of the state, being about 300 feet above the level of the sea, and lake Michigan, in the north-east angle, being 589 feet, while there is no range of hills or elevated ground intervening, the surface of the country must necessarily be level, which is more particularly the case towards the southern part of the state. The rivers, which intersect the country in every direction, have formed deep channels for the conveyance of water, and no great extent of the surface is marshy. The space which I travelled over on foot, between Chicago, on lake Michigan, and the village of Springfield in Sangamon county, a distance of about 200 miles, the surface, with exception of a few miles 
at the commencement and termination of the journey, was undulating, the swells being long and considerable, without a lake, pond, or marsh being visible, except in one instance. On approaching Springfield, the surface became level without being wet, and from this village until I crossed the Mississippi the wettest parts of the surface might have been rendered dry by the ordinary means of ditching.

The feature in the surface of Illinois, which chiefly distinguishes it from the eastern states and the Cauadas, is the prairies, or tracts which are free from timber. I imagine prairies to be natural productions ; they may be termed grass fields, and are of every size and shape, being separated from each other by tracts of forest. Americans, whose ideas of an uninhabited country are associated with interminable forests, have speculated on the origin of prairies, which they regard as an anomaly in nature, and assign their existence to man. A Seotchman, accustomed to the bleak naked mountains, and artificial forests of his own country, may take an oppesite view of a prairie, and support his opinion by the state of the earth's surface after the flood, which would be without trees. But the forest and prairie surfaces of Illinois stand in the relation of water and land on the face of the earth, both being the handiwork of nature, and forming bays, peninsulas, straits, isthmuses, lakes, islands, and every other form of outline which charm the eye and delight the imagination. To the individual who has long been immured in the forest, the effect of prairie scenery is enchanting; and the inhabitant of a cultivated and thickly peopled country, who can gaze on the lovely, the lonely, and the rich prairies of Illinois without emotion towards God and his fellow-creatures must be void of feeling.

The different published accounts of Illinois represent onehalf of the surface of the state to be prairie, but it is probable none of the writers, or any one individual, has had a proper opportunity of forming an opinion on the subject. In the course of my journey, nineteen-twentieths of the country appeared to be prairie; but the forest tract is chiefly in the south, which I did not visit. It is however certain a vast extent of prairie lies north of latitude $39^{\circ}$. An English traveller informed me he found the prairie country unchanged 500 
miles to the west of Illinois. And if such is the case, its brearth in latiturle $40^{\circ}$ will exceed 1000 miles.

There is a considerable extent of the surface thinly covered with tres, interspersed with the same kind of herbage as clothes the prairies, called barrens, or oak-openings, from the wood which grows on them. They may either be considered thin forest, or wooded prairie, as they partake of the nature of both; but in an agricultural point of view, they must he classed as prairie, from the herbage they afford. 'The soil of Illinois, like many other parts of the world which has come under my notice, is variable, and the different halitations of the varieties of sun-flower and other tall-growing plants, often distinctly marked changes of soil on the prairie. 'The prevailing soil between Chicago and Springfield, was black sandy loam, and occasionally considerable tracts of elay or heavy loam intervened. In this distance of nearly $200 \mathrm{miles}, \mathrm{I}$ did not pass over, in all, 10 miles of had soil, which was light coloured sand. The surface, which is forest, oak-openings, or prairie, has no relation to quality of soil, all of which abound with soils of every description.

On no part of the prairie did I observe heath, or nther thriftless vegetation, occupying the entire surface, with exception of a dwarfish species of hazel, in a few instances, to a limited extent. Besides the many beautiful flowering plants which adorn the prairies, they are covered with four or five tall-growing kinds of grass, and the moist and dry soils could be distinguished by the luxuriance of different species. From the grass attaining between three and four feet in height, and being seared by a powerful sun, the surface of the prairies is scorched by fire every autumn, originating by human, and, it is presumed, also occasionally by natural means. The annual burning seems to have destroyed all the grasses which possess fibrous roots, and are propagated by seed; those which at present exist having strong roots, which resist the effects of fire, and propagate themselves without seed. This property of the grasses is illustrative of the economy of nature, by furnishing plants for every situation and circumstance that may arise. The burning is not attended with much danger, as the turning of one or two sods by the plough is deemed a 
sufficient protection against fire for a hay stack in the midst of the prairie; and the inhabitants either save their huildings by this means, or by burning the grass immediately around them, before the general conflagration takes place. The burning, in all probability, is conducive to health, by consuming vegetation, which would otherwise putrify on the surface, and by checking the luxuriance of its growth, which the unconsumed matter would produce by natural decay. There is a ruling Providence in every thing !

The mineral productions of the state have been imperfectly explored. Salt is manufactured in many situations. Near Shawneetown is the most extensive establishment, where about 138,000 bushels are made yearly. Salt is also made in the neighbourhood of Brownsville, in Matison county, and in other parts. The saline reservations given to the state, by the general government, consist of 206,128 acres. One of the most remarkable gifts which bountitul nuture has lavished on the valley of the Mississippi, appears to me to be the inexhaustible supply of salt water. The government of the country seem fully to appreciate the gift, and have wisely macle the springs public property, by which the community will obtain the indispensable article of salt at the cheapest rate.

Lead abounds in the north-east angle of the state, in the neighbourhood of Galena. The mineral is found on both sides of the Mississippi, and supposed to extend over several thousand square miles. The ore is found in detached masses, and not in veins, which renders the digging a matter of chance. The quantity of lead manufactured here, in 1829, was $13,343,150 \mathrm{lbs} . ;$ and the population of the region is stated at 10,000.* 'There are also lead diggings in the State of Missouri, about 70 miles south-west of St Louis, and which were wrought by the French about a century ago. The price of lead, at Galena, is from 2 to 3 cents per lb. When at Springfield, I met a young gentleman from Leith, in Scotland, who had travelled by way of New York, the Erie canal, and lake Michigan, provided with a considerable quantity of shot, which he imagined the country could not furnish. 
Iron ore is said to exist in the southem part of the state; and copper ore in the lead region around (ialena. But I believe neither of them have been manufactured.

Coal, of bituminous quality, has been found on the banks of the principal rivers, in different parts of the state, and, from having been seen on the banks of the river Missouri, it is supposed to extend over the whole of the upper part of the Mississippi valley. But, in the present state of the country, no particular examination of the field has been made. Coal has, however, been wrought in many places on the banks of rivers by quarrying; and is found above the level of the waters. Several steam-mills, at st Louis, use coal for fuel.

Iron is manufactured in Wabash county, and lime-stone is found over the whole State. I observed abundance of sandstone in the chaunel of the Illinois; and perhaps almost every mineral which is useful to man will be found on examination.

Illinois is favourably situated for water communication, the interior of the state being intersected by the Kaskaskia, Rock, and Illinois rivers, which are navigable at all seasons of the year. The State is said to contain between three and fuur thousand miles of boatable waters, a description of navigation which cannot be well defined, as every rill, in so level a country, will float a botut of small size, on melting of the snow in spring. There is no doubt, however, of the water communication being extensive, which will be farther improved by connecting the navigable point of the Illinois with lake Michigan. To the formation of a canal for this purpose, Congress granted the State 480,000 acres of land. The undertaking has not been commenced; and the extent of rock discovered in the intended line, may render a railroad necessary. The navigable rivers Wabash, Ohio, and Mississippi form the boundaries of three sides, and lake Michigan is on the fourth. The external communication is as remarkable as the internal.

The Mississippi connects the State of Illinois with New Orleans to the south; the Ohio opens a communication with Baltimore, Philadelphia, and New York to the west. To the north, lake Michigan communicates with lake Superior and the world of waters which flow into the gulf of St Lawrence. The western communication; by the Missouri, is only limited 
by civilisation, a steam-boat belonging to the American Fur Company having sailed 1400 miles up the river, from its junetion with the Mississippi. So little is known about the western sources of the Missouri, that the limits of navigation, in this direction, must at present be conjectural ; and it does not seem to require a stretch of imagination to conceive, as population advances, a communication opened between the head waters of this river and the Pacific ocean. Should such an event take place, the empires of China, Japan, and Russia will be brought near, and Illinois become one of the most central and favourable trading situatious in the world.

Illinois was originally discovered by the French, who penetrated by way of Canada, in 1673. They founded the villages of Kaskaskia, Cahokia, and others in 1683. When the country became part of the United States, it formed part of the territory north-west of the Ohio. In 1801, it was included with Indiana as a territory. In 1809 , it was made a separate territory. And became one of the United States in 1818.

In so recent a settled country, large towns cannot be expected to be found. Vandalia is the capital, and, like other capitals, situated near the centre of the state. It stands on the western bank of the Kaskaskia, and was founded in 1821. The population is stated at 500 souls.

Shawneetown on the Ohio, alout nine miles below the mouth of the Wabash, is the largest town in the State. A number of thriving villages are rising in every direction, and will acquire population according to their situations for trade. Gialena, situated on Fever river, a few miles above its junction with the Mississippi, and in the northwest corner of the State, will rise into importance, from the manufacture of lead in the neighbourhood. One hundred steam-boat arrivals at this place are said to have occurred within the year. Chicago on lake Michigan, and Ottawa on the Illinois, from being situated at the termination of the communication connecting these waters, will become important places. Alton, situated on the Mississippi, one mile above the mouth of the Missouri, and sixteen below the entrance of the Illinois, is centrically situated for trade, and is soon likely to become the chief shipping port of the State. 
The legrislature of Illinois is vested in a General Assemilly, consisting of a Senate and House of Representatives. The members of Senate are clected for four years, and the reprosentatives for two years. The pay of the members of each branch of the legislature is $\$ 3$ a-day. 'The right of suffrage is vested in all free whites twenty-one years of age, and who have resided six months in the State. The votes are given riva voce."

The executive is vested in a governor and lieutenantgovemor, beth elected for four years. 'The governor's salary is $\$ 1000$, or L.212, 10s. sterling a-year.

The juliciary consists of a chief-justice, and three asenciatejudges, who hold circuit enurts. Their salaries are $\$ 1000$ each.

The taxes are levied by three commissinners in each county. Justices of the peace are elected by the people every four years, and their juriscliction extends over inferior cases. Each county has a juilge of probate, before whom business relating to wills is transacted.

There is no imprisonment for debt, except in case of fraud or refusal on the part of the debtor to deliver up his property for the behoof of his creditors. There are no usury laws. And slavery is not allowed since the adoption of the constitution.

There are fifty-eight counties, and a considerable portion of the northern part of the State has not been surveyed, which was sold by the Indians in 1833. The population, in 1800, consisted of 12,282 . In 1830 , there were 157,445 inhabitants ; and, from the recent emigration, their numbers must now exceed 200,000 .

Congress granted to the State, for the purposes of education, one thirty-sixth part of the public land, or 977,457 acres, and 3 per cent on the sales of land. So there can be no doubt of an efficient system of common free schools being established, wherever the wants of the population require them. Besides the grant for common schools, 46,080 acres of land have been granted for colleges. Such an institution was established at Jacksonville in 1829.

The population of Illinois embraces settlers from almost 
every State in the Union, and every country in Europe. The inhabitants of the south, are understood to have come from Kentucky, a slave-holding State, and were induced to settle in this district from their dislike of slavery. The emigrating Kentuckians approving of slavery, take up their residence in the arjoining State of Missouri, where this bondayge is tolerated. The Kentuckians possess difierent dispositions from the inhabitants of the other States, and, like the New Englanders, they seem to inherit the characters of their forefathers. The first settlers of Kentucky, for a periol of between thirty and forty years, waged a cruel and savage warfare with the Indians. Many thousands perished in the strife, and the features which such a mode of life could not fail of imparting to their characters, have descended, with some modification, to their progeny. The Kentuekians of the present day are men of warm temperament, high-souled, and fearless ; lut, at the same time, generous and hospitable in the extreme. They have been termed the Irishmen of America. With ill-regulated tempers, they can have little medium of character, and will be good or bad members of society, according to the principles they have imbibed. The Kentuckians are said to go armed with knives, a practice which is thought to be on the decline, and which I cannot corroborate from observation. This practice has in all probability descended from the first settlers, and would originate from the unfortunate circumstances in which they were placed. A few boys in Britain, who mistake true honour and courage, provide themselves with pistols and sword-sticks. Perhaps only the fiery youths of Kentucky wear knives.

In the northern part of Illinois almost all the inhabitants appeared to have come from New England, and possessed the characteristics of that people. During my intercourse with them I received some impressions of their dispositions and movements at variance with what I had been led to expect. It has been usual to represent this people void of the best feelings of humanity - the parent with little affection for his offspring - the boy without filial love, impatient of restraint, and scampering off from school to obtain independence in the distant wilderness. But when I found many unmarried young men, after twelve months' residence in Illinois, anxiously 
expecting the arrival of their parents from New England, and had travelled with old people journeying from that country to join their sons in Illinois, I attributed the moving of youth to the western districts to the best of motives, and assigned to both parties the feelings of clomestic affection. The youth of Britain do not engage in the bustle of the world so early as the Americans, and family intercourse is consequently more enduring. But it is the difficulty of earning a subsistence and not affection, which binds the young men of Britain to the roof of their parents, and in all probability the emotions of the heart are the same in both countries.

A class of men are said to precede civilisation in America, called pioneers or squatters, and have been described by travellers as demi-savages, blackened with iniquity, and shunning their fellow mortals by moving to a more remote station, as settlers advance. It is probable such beings did at one time exist, and may still occasionally be met with in the lower part of the Mississippi vallcy. They may he supposed to have originated in such a state of things as occurred at the first settlement of Kentucky, and perhaps were altogether confined to the latitude of this State. In the present day, when the east is densely peopled, and eivilisation in the region of Illinois has reached an open country, desperate characters are more likely to find subsistence and concealment in the crowded city than in the prairie. Be this as it may, there are no such characters in the northern parts of Illinois as the pioneers of old, and I regard the present frontier men of the prairie as one of the best and most enterprising portions of the western population.

The manners and customs of Illinois have been described by Mr Stuart in his "Three Years in North America," in terms and spirit so different from almost any thing that is noticed in the work, that I shall quote part of his remarks.

"I made enquiry on the road from some passengers, as to the hotels at Jacksonville, and was told there were two, neither of them good, but that Bentley's was the best. I found, on going into the house, that the tea and supper were nearly finished; and it was not without some difficulty, and rather uninviting looks from a young lady who was acting as waiter, 
that I procured a fresh supply of coffee and eggs. This was Saturday evening, and the young ladies, after having cleared the table and again covered it with the necessary articles, sat down to their meal with me, on a footing of the most perfect equality. I found them very inquisitive, far more so than any of the New Englanders I ever met with, but I afterwards learned that these people had lately come from a remote part of the country, where probably there were no schools. Such silly conduct, in respect to their own interest, as they were guilty of during the forty-eight hours I remained with them, is generally the offspring of ignorance. I found the hotelkeeper a masterpiece of rudeness, and very soon got a candle and retired to my bedroom. I was told the breakfast hour was half past seven, but I started from my pillow on the following morning at six, when I heard other people stirring so early, and the breakfast had commenced before I was able to get to the parlour. I asked how this happened; but I found from the answer that it was quite unnecessary to have any farther discussion with such a barbarian as Squire Bentley. He did not care for the customs of the British. His forefathers had left England to avoid tyranuy, and they did not care for seeing foreigners here.

"The tea and supper at the hotel in the evening was even a more ridiculously managed meal, than any of those which preceded it. 'The female waiter, it being Sunday evening, was particularly smartly dressed, and sat at the end of the table and at some distance from it, much more intent on placing one leg above the other in a proper position for showing her foot and ankle than in giving the necessary attendance at the tea-table-but she was such a good-humoured ' romp-loving looking Miss,' that though she did any thing rather than attend to her duty, I believe she was the most popular of all the hotel family with the strangers. Every thing was bad, and the hotel people completely lost temper when they noticed that we did not even find fault with them, but laughed at the absurdity of being so treated. Even the bread was execrable- a most uncommon occurrence in the United States. I soon left the supper-table, and when sitting in my thinly boarded room, heard the landlord tell a traveller 
who had recently arrived, at ten minutes past nine in the evening, that he must go to bed-he could not wait longer to show him his room. Candlesticks seemed never to have been cleaned_snuffers were wanting - and as for shoes, there was no one to clean them while I was in the house.

"At an early hour on the following morning, the $\mathbf{3 d}$ May, I left Jacksonville, not without thanking Tom Bentley for bis civility, and telling him how utterly unfit he was for his situation.

"Springfield is a straggling village, somew hat longer than Jacksonville, but the situation is not at all equal to it in point of beauty or interest. The hotel was very nearly as bad as that at Jacksonville. Hornden was the name of the landlord. It was difficult to say whether he, his wife, or his daughter was the sauciest. 'They certainly were as rude untutored Americans as $I$ have seen. The lady undertook to wash some linen for me, and there was no difficulty about it -as I got to her house early in the afternoon-but she delayed and delayed so, that I was obliged to carry them away only half dried next morning after seven o'clock."

It was my fortune to visit Springfield and Jacksonville, without being aware at the time of Mr Stuart's remarks, and my treatment seems to have been very different from what he describes. At Springfield I put up at the hotel in which $\mathrm{Mr}$ Stuart lodged, and refer to page 241 for the particulars of my reception. In the interval between his excursion and mine, the hotel had changed proprietors-and I found no difficulty in getting linens washed and shoes cleaned. Every individual connected with the house was attentive and civil.

My intercourse with Jacksonville was of short duration, and I have no means of ascertaining if I entered Bentley's hotel. The house in which I took coffee was situated on the north side of the square, and in all respects greatly superior to the hotel at Springfield. A smart waiter attended the stage passengers during coffee, and the hotel keeper himself was looking after his business at 2 o'clock in the morning, when the mail started with us.

$\mathrm{Mr}$ Stuart mentions two female waiters having seated themselves at table with him at Jacksonville, " on a footing 
of the most perfect equality." Throughout the whole of my intercourse with the United States, no female waiter or help of any degree seated herself at table, or even in the room of a hotel when I was present, and I am unable to determine whether this was the result of accilent or design. Perhaps the young ladies may have disdained to honour me with their company. Mr Stuart's treatment on his arrival at Jacksonville, admits of easy explanation. By his own aceount, "on going into the house tea and supper were nearly finished," and it was with some difficulty he was admitted to a second table, at which the establishments of western hotels sit down. Mr Stuart had refused to seat himself with the rest of the company at the first table, and in faimess ought to be considered an obtruder at the second one. On his arrival he plainly showed that he considered himself somewhat different from the guests of the hotel, by not sitting down at table. If inferior to them it was right he should mess with the establishment, and if he had assumed superiority over them, it was right so to punish his arrogance. In either case he met with his desert. Travellers in America may derive instruction from his fate. The individual who moves, snail-like, in a foreign land, canopied with the manners and customs of his own country, and marking his route with the slime of prejudice, need not expect civility from the inhalitants.

It is quite evident Mr Stuart had been playing the great man in this part of the country. His demand of fresh coffee and eggs in the evening, his questions about breakfist next morning, his allegation that "the hotel people completely lost temper when they noticed that we did not even find fault with them," and that the female waiter put forth her foot and ankle for his admiration, all denote in a high degree self-importance.

In the seventh chapter of Mr Stuart's work there is the following extract from Professor Silliman, when alluding to an inn in Connecticut.

"This is a peculiarity in the manners of this country not easily understood by a foreigner, and especially by an Englishman. Such a person, if uninstructed in the genius of the country, almost of course presumes that all those he sees in 
public houses are in servile situations. If he adopt towards them imperious and harsh language he gives offence, and produces coldness and possibly resentment, so that the interview ends in mutual dissatisfaction. If the traveller should write a book he of course enlarges on the rudeness of American manners, and it is very possible that even the servants of our inns may give him some oceasion for such remarks, if they are treated as persons of their condition commonly are in Europe." Mr Stuart seems to have forgotten this sensible quotation while in Illinois, and I have no doubt had himself to blame for any rudeness he may have experienced. 'The heart is the source of true politeness, which is often better conveyed by expression of feature or tone of voice, than by words or gestures. The possessor of such civility is incapalle of, and invulnerable to, rudeness, and will be well received in every part of the world. At the time Mr Stuart told Tom Bentley "how utterly unfit he was for his situation," he himself committed a flagrant outrage on decorum, and justly merited any treatment that could have been bestowed on him. There is a ludicrous anecdote related at Springfield of his demands on Hornden, which, if true, shows how unlikely it was any American landlord could comply with them.

The manners and customs of a people, like objects in a landscape, may be coloured by the medium of vision, and they will not only appear different to individuals, but seemingly vary to the same individual according as his feelings may alter. It is evident Mr Stuart was out of humour both at Jacksonville and Springfield, and could not have been a dispassionate judge of what was passing around him. His situation and mine in Illinois must have been very different. He had travelled for some time before in slave-holding countries, where he had fared sumptuously on canvass-backed ducks and other delicacies, attended by crouching and despised creatures. For many weeks I had sojourned in the rudest parts of Upper Canada, Indiana, and Illinois, leading a demi-savage life, and faring, as it were, by the way sides. He was travelling with a carriage and pair, accompanied by a store of venison hams, and whisky. I trudged on foot, quenching my thirst with indifferent water, and occasionally satisfying my hunger with 
nuts. Jacksonville and Springfield must necessarily have presented less refinement, luxury, and humiliation than he had been accustomed to, and more civilisation and comfort than I had for some time experienced. From the state of $\mathrm{my}$ feelings consequent on such a transition, it is possible I may have seen things in too favourable a light, and the truth may perhaps be found to lie somewhere between Mr Stuart's account and mine.

Referring to what has been stated at pages 400,401 , and 403 , regarding the amount of the population of the United States, and the progress of wealth and refinement, it would be unreasonable to expect luxury in so young a country as Illinois, or to subject the manners and customs of its inhabitants to serious criticism. Indeed it will appear evident to every reflecting mind, that such a motley population, scattered over an extensive territory, cannot yet have amalgamated in feeling or custom, and that the manners of the different parts of the state will be as varied as the origin of their population. Rudeness and vulgarity are not attributes of the native popu. lation of the United States; and if found in Illinois, they must be imports from foreign countries. The circumstances of the State with regard to refinement are favourable to young ment entering on life. But every emigrant on leaving Britait must lay his account with a change, to whutever part of the world he proceeds; and if he dislike the manners of the peoples of Illinois, he can live in retirement. 


\section{CHAP'TER IX.}

Protuctions-Animals-Fowls-Country for Sporting-Mode of Selling Land-Unsold Public Land-Number of InutiasuGovernment policy lowards the Indians-War with IndiunsDecrease of Population-Agriculture-Wuges of LabourIllinais and Upper Canada.

'TuE productions of Illinois are numerous, including wheat, Indian corn, tobaceo, Irish and sweet potatoes, and the castor bean from which oil is expressed. Cotton and wine are said to be productions of the southern parts. Almost every kind of fruit attains perfection. Honey is oltained in great quantities both from wild and domesticated bees, which gather sweets from the prairie flowers.

The wild animals include bears; grey, black, and prairie wolves; two varieties of the fox; rabbits, \&c. \&c. Deer are very numerous throughout the state. The hare is not found in North America.

The wild-fowl embrace geese, ducks, turkeys, and quails in endless numbers. The ruffed grouse, or prairie hen, is very plentiful, and one of the finest of game birds. While walking from Chicago I observed them often singly, and seldom more than two or three together. In the neighbourhood of Springfield they were in flocks of from sixty to seventy, scattered over a considerable space while feeding, and, when disturbed, rising on wing without concert, in the mauner of the British pheasant.

The prairies of Illinois seem to me the only good sporting country I saw in America. The ruffed grouse, in size and mode of flying, resemble the black-cock of Britain, and are every where in great numbers. Quails may be as easily shot as sparrows in England, and there are abundance of deer. Fox-hunting might be pursued at a rattling pace over the 
prairie, which does not present an interruption of any description, and would literally form a fox-race. The deer and prairie wolf might be hunted with dogs, or shot, according to fancy. I recommend the upper Mississippi valley to British sportsmen, as a country likely to afford them amusement and instruction. A person may cross the Atlantic with a brace of dogs in one of the best vessels, and travel to the prairies, and devote a year to the excursion, living in the best style the country affords, for the sum of L.200 sterling. If he wiere economical in crossing the ocean, and living with settlers, and serving himself while in Illinois, the expense would be under $\mathrm{L}_{0} 120$.

The mode of selling government land in Illinois, is the same as in the other parts of the Union. When a tract has been surveyed, and brought into the market for settlement, it is advertised, and a day and place of sale fixed. Lots are put up and sold to the highest bidder for ready money. The tracts generally consist of millions of acres, and the sale is continued from day to day while individuals call for particular lots. When purchasers are satisfied, a publie land-office is opened for the sale of the remainder, the price of which is invariably $\$ 1 \frac{1}{4}$, or 5 s. $3 \frac{1}{d} \mathrm{~d}$ sterling per acre. A person wishing land goes to the land-office and selects any lut which pleases him. There is no form of application or interest necessary, title-deeds and possession being immediately obtained on payment of the purchase money. Government land is never sold on credit, and there is no fee of office, nor any other expense, on receiving titles.

Formerly the price of land was $\$ 2$ per acre; one-fourth was paid at the time of purchase, one-fourth at the end of two years, one-fourth at three years, and the remaining fourth at four years. It was, however, found that much of the price of land sold on credit could not be recovered. An act of Congress was passed, limiting the price in future to $S 1 \frac{1}{4}$ per acre, ready money, and the purchasers in arrears were dispossessed of a part of their lands. With this example on record, it may appear somewhat singular that land should continue to be sold on credit in Canada. It seems, however, the policy in that country to enrich the aristocracy at the expense of the poor; 
and selling high-priced land on credit is one of the most effece tual means that could he adopted.

There were $28,237,850$ acres of unsold public land in Illinois in 1832 , and upwards of $3,000,000$ acres recently sold by the Pottowatomy Indians have since come into the market. By far the greater portion of this extensive surface is prairic, on which cattle and sheep might be pastured without challenge, and the whole is open to the selection of settlers.

The following estimate of unoccupied land, belonging to the United States Government, is taken from Mellish's V'iew, published in 1822 .

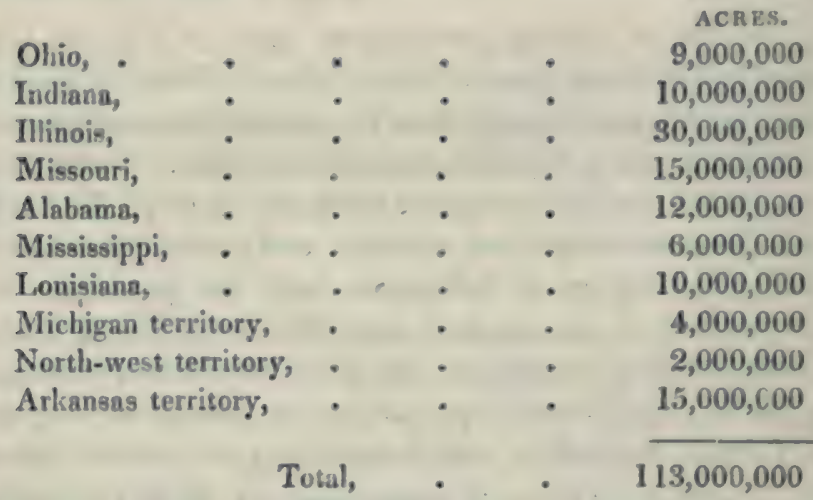

In addition to the pullic lands above stated, the United States hold the preemption right, or exclusive right of purchasing from the Indians tracts lying in several of the States and territories mentioned, and in the immense territory of Missouri, the aggregate extent of which may be stated at not less than $1,000,000,000$ acres.

The number of Indians in the valley of the Mississippi, which includes nearly all that reside on the United States' territory, is not accurately known. The following estimate is taken from a Philadelphia publication of 1832, entitled, "View of the valley of the Mississippi."

Creeks,

Choctaws,

Cherokees,

Seminoles,

Chickasaw's,

22,500
18,000
14,500
4,000
3,500

Sioux

Chippeways, .

Blackfeet,

Assinalooins,

Pottowatemies,
25,000

6,000

5,000

8,000

6,500 


\begin{tabular}{|c|c|c|c|c|c|}
\hline & & & & & \\
\hline Pawnees, & irgeg & $\begin{array}{l}6,500 \\
3180\end{array}$ & Wimelagos, & . & $\begin{array}{l}5,300 \\
6: 300\end{array}$ \\
\hline Oinalias and & Otoes, & 3,180 & Sacs, $\quad:$ & - & 6,300 \\
\hline Delawares, & - & 1,600 & Menomonies, & - & \\
\hline Shawanese, & . & 6,350 & Crows, . & - & 4,500 \\
\hline Kansas, & - & 1,500 & Arriplahas, & . & 4,000 \\
\hline Osages, & v & 6,500 & Crees, : & . & 3,000 \\
\hline Senecas, & . & 400 & Ottawas, & & 4,000 \\
\hline Senecas and & Shawanese, & $3: 0$ & Algonquias, & . & $3,+00$ \\
\hline Miamis, & . & 1,000 & And about tw & enty other & \\
\hline Wyandots, & • & 450 & smal! tribus & , inclutling & \\
\hline Kickapoos, & . & 1,800 & Mandaus, & Arichatres, & \\
\hline $\begin{array}{l}\text { Peorias, Pis } \\
\text { Weas, an }\end{array}$ & $\begin{array}{l}\text { kashaws, } \\
\text { Kaskas- }\end{array}$ & & \&c. \&c. & . & 85,000 \\
\hline kias, & 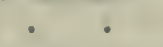 & 1,000 & 'Total, & • & 202,700 \\
\hline
\end{tabular}

As the settlement and future prospects of Illinois are connected with the Indians, the policy of the United States (iovernment towards them may be explained by extracts from a report of the Secretary of War to the President, dated November 25, 1832:- "In the practice of European states," say's President Adams, "before our revolution, the Indians had been considered as children, to be governed as tenants at discretion, to be dispossessed as occasion may require, as hunters to be indemnified by trifling concessions for removal from the grounds upon which their gane was extirpated. In changing the system it would seem as if a fill contemplation of the consequences of the change had not been taken. We have been far more successful in the acquisition of their lands than imparting to them the principles, or inspiring them with the spirit of civilisation. But in apportioning to ourselves their hunting grounds, we have brought on ourselves the obligation of providing them with subsistence; and when we have had the rare good fortune of teaching them the arts of civilisation and the doctrines of Christianity, we have unexpectedly found them forming, in the midst of ourselves, communities, claiming to be independent of ours, and rivals of sovereignty, within the territories of the members of the Union. This state of things requires that a remedy should be provided-a remedy which, while it shall do justice to the unfortunate children of nature, may secure to the members of our confederation their rights of sovereignty and of soil. As an outline of a project to that effect, the views presented in the report of the Secretary of War are recommended to the consideration of Congress. 
65 The most important feature in the present policy of the Government, as connected with this people, is to be foumd in the efforts that are making to remove them beyond the limits of the States and organized territories. A very extensive tract of country, lying to the west and north of the Arkansas territory, has lately leen set apart for the colonization of the Indians.

" Let such of the emigrating Indians as chonse it, continue as heretofore to devote themselves to the chase in a country where their toils will anply be rewarded. Let those who are willing to cultivate the arts of civilisation be formed into a colony, consisting of distinct tribes or communities, but placed contiguous to each other, and connected by general laws, which shall reach the whole. Let the lands be apportioned among families and individuals in severalty, to be held by the same tenures by which we hold ours, with perhaps some temporary and wholesome restraints on the power of alienation. Assist them in forming a code of laws, adapted to a state of civilisation.

"In regard to such Indians as shall still remain within the States and territories, and refuse to emigrate, let an arrangement be made with the proper authorities of the States in which they are situated, for partitioning out to them into severalty as much of their respective reservations as shall be amply sufficient for agricultural purposes. Set apart a tract proportioned in size to the number of Indians, to remain, in common, as a refuge, and subject to all the municipal laws of the state in which they reside. Let the remainder of the reservation be paid for by those who hold the paramount right, at such prices as shall be deemed, in reference to the uses which Indians are accustomed to make of it, reasonable, and the proceeds to be applied for the benefit of those of the tribe who emigrate after their establishment in the colony; or be divided between those who emigrate and those who remain, as justice may require.

"To the views herein presented, of the condition of the Indians, of the prospects which await them, and of the only efficient remedy in their power to seek, or in that of the government to apply, I take the liberty of adding my own testimonial, founded on an intimate intercourse with them for 
eighteen years, both personal and official, under every variety of circumstances, in peace and war, and in very remote regions, as well as within our own settlements. The principles laid down in these extracts, are substantially the same as those which now regulate the government in all their transactions with the Indians, when the question of their permanent establishment, or removal, is brought under discussion. So far as respects the emigrating Indians, this will clearly appear by reference to the instructions of the commissioners now engaged in the adjustment of all the unsettled matters connected with the great plan of colonization.

"With regard, however, to those Indians who refuse to remove, it has not been deemed expedient for the government, by its own act, either to partition out to them the land necessary for their support, or to decide upon the consideration to be allowed for the residue, and to direct its appropriation. This, so far as regards the general government, has been, and continues to be, the sulject of conventional arrangement, in which the parties, by mutual discussion, and compromise of opinion, arrive at a satisfactory result. In these arrangements, where the parties desire it, adequate tracts of land, in fee, with temporary and wholesome restraints upon the right to sell, are secured to all who desire to remain. That this system of guardianship is, however, founded upon a just and intimate knowledge of Indian character, no one acquainted with that character will question. I need not now enquire whether a practical resort to the principles resulting from it will ever become necessary. If it should, no doubt every arrangement which justice and humanity call for, will be liberally made.

"In your message to the Senate, of February 22d, 1830, you explained your views of the question of jurisdiction over the Indian tribes living within the respective States and territories, and stated, that in your opinion, and in the words of the above report, they were subject to the municipal laws of the State in which they reside, in all cases where such laws are extended over them.

"The progress of events, since 1828, has confirmed, if confirmation was wanting, the correctness of these principles, and their adaptation to the actual and prospective condition of 
the Indians. The circle of civilisation and improvement has extended, and various tribes have retired, or are retiring hefore it. 'The experience of the four years which have intervenced, sloes not afford one consolatory hope that the insulated bands who have reserved and occupy tracts surrounded by our settlements can permanently retain these possessions and prosper. There are moral, political, and physical causes all in operation, which cannot be counteracted, and which forlid such an expectation. And, in fact, the whole history of our interconse with our primitive people teaches no one lesson more important than this ; and it will be fortunate for their posterity, and for our responsibility, if, in its practical application, both parties should become satisfied that the system provided loy the act of May $28 \mathrm{th}, 1830$, offers the only rational prospect of a clurable and happly residence for the Indians. A few individuals, almost always half-breeds, and their connexions, engrossing the intelligence and means of these sinall communities, may become assimilated to our institutions, and eventually planted amongst us with safety. But this should never be permitted at the sacrifice of more important interests, and to the utter disregard of the fate which awaits the unfortunate ma.is of these tribes, persuacled or almost compelled to remain where they must rapidly decline, and at length disappear. And the causes which enacted this law are not less obvious in their origin, than they are certain in their operation. 'Their progress is onward, and regret them as we may and must, no human power can arrest their march, or avert their conseruences. These efforts have been made for generations, and in every mode which wisdom and philanthropy could suggest ; and yet, in not one solitary instance has it produced any permanent or general beneficial effect. And we may survey our whole cultivated territory in the vain expectation of discovering one aboriginal community, however small, which has withstood the ceaseless pressure of civilisation, and which holds out the slightest prospect of moral or physical improvement, or even of eventual subsistence, for the great body of the individuals composing it. If such a community exists, it is unknown to me; and, in fact, if one is believed to exist, it is only by those who are 
unacquainted with its actual condition, and with the internal history of its wants, its dissensions, and its oppressions.

"The Choctaw treaty of $18: 30$, allowed that tribe three years to emigrate. In 1831 , about 5000 of them removed to their new possessions between the Canadian and Red rivers. They are highly gratified with the climate and country, and satisfied with the exchange they have made. From the returns which have been received, it is estimated that about 7000 more will cross the Mississippi this season, and the residue of the tribe, amounting to ahout 6000 , will follow the next.

"General Coffee has succeeded in concluding a treaty with the Chickasaws, which will lead to their entire removal, and to their location in the west. The basis of this treaty is different from any heretofore assumed in our negotiations with the Indians. The whole value of the country ceded is assigned to the Clickasaws, and the United States become, in fact, trustees to make the necessary arrangements for their benefit.

"It is stipulated that the ceded territory shall be surveyed and sold, and the whole proceeds, deducting only the actual expenses, applied to the various objects enumerated, connected with the temporary subsistence, removal, and permanent establishment of these Indians. A residuary fund is to be invested in some productive stock, and the income to be annually appropriated for the public and private objects stipulated in the treaty. A country for the residence of the tribe is to be provided by themselves, and it is probable they will be able to make a satisfactory arrangement for that purpose with the Chotaws, a kindred people, who are in possession of a much larger district than is required by their numbers.

"No pecuniary benefit will result to the United States from this treaty ; but should it be ratified, it will constitute an important era in our Indian relations. It will probably lead to the establishment of the principle that, in future cessions of land, the full value shall be secured to the grantors, with such deductions only as may be necessary to carry into effect the - object of the treaties. The advantages to be derived by the United States from these arrangements will be limited to the removal of the Indians from their present unsuitable residences, and to their establishment in a region where we may hope to 
see them prosperous, contented, and improving. And it cannot be doubted but that a course so consistent with the dictatem of justice, and so honourable to the national character, would be approved by public sentiment. Should we hereafter discard all expectation of pecuniary artvantage in our purchases from the Indians, and confine ourselves to the great oljects of their removal and reestablishment, and take care that the proceeds of the cessions are appropriated and applied to their benefit, and in the most salutary manner, we should go far towards discharging the great moral debt which has come down to us as an inheritance from the earlier periods of our history, and which has been unfortunately increased during successive generations by circumstances beyond our control. The policy would not be less wise than just. The time has passed away, if it ever existed, when a revenue derived from such a source was necessary to the government. 'The remnant of our aboriginal race may well look for the value, and that usefully applied, of the remnant of those immense possessions which have passed from them to us, and left few substantial evidences of permanent advantage. One great objection to a removal that has been urged by the more discreet Indians, and by many of our own citizens, who are honestly seeking their improvement, is the prospect, judging by the past, that their location west of the Mississippi would be temporary, as they would be soon pressed for new cessions, and would yield, as they have heretofore yielded, to successive applications for this purpose. Although the nature and objects of their removal, and the spirit of the act of Congress which introduced the system, are opposed to such attempts, still the apprehension is entertained, and has proved injurious. Probably no course would better satisfy them upon this subject than the introduction of a principle which would secure to them the full value of the property, under all circumstances, thus lessening in their view any wish on our part to acquire it, and ensuring to them, if not the power and disposition to retain it, at least the means of converting it to the greatest advantage."

The policy of the United States with regard to the Indians is to place them to the west of the Mississippi, and it has been 
so successful, that a treaty, for the removal of the last body, was concluded at Chicago in September, 1833, and in 1836 there will scarcely be a resident Indian to the east of the Mississippi.

'The Indians are a quiet inoffensive race, and generally conduct themselves well towards the white people. The united tribes of Sacs and Foxes, which inhabit the banks of the Mississippi north of Illinois, are an exception, being a restless fierce people. 'They made war on the $\mathrm{L}$ nited States in 1831, commencing hostilities in the neighbourhood of Prairie des Chien. 'They created a good deal of alarm in the northern part of Illinois and Michigan, but were easily subdued. Their chief, Black Hawk, noticed at page 29, was taken prisoner, and, after two years' confinement, suffered to depart. The Saes and Foxes have retired beyond the Mississippi, and even ceded some territory to the west of the river. The chastisement they got, and the increase of population at (Galena, will keep this tribe in subjection in time to come.

What the ultimate effect will be of removing the Inclians to the west of the Mississippi, I am at a loss to conjecture, and doubt if it will be so beneficial as the 'Inited States' Government seem to contemplate. Not being fully aware of the causes alluted to in the report of the secretary of war, which decrees the poor Indians residing amongst white men to certain annihilation, it is unnecessary to speculate on their removal, or what effects may come into operation in their new territories. I believe, however, it is a fact that the Indians are decreasing in number in the Canadas, as well as in the United States, even after considerable advances in civilisation have taken place, and Christianity obtained a footing amongst them. It is a common opinion that the Indian tribes were extremely numerous in former times, but there is no very good evidence of the fact. The French penetrated from Detroit to New Orleans between 1670 and 1719, establishing trading ports and villages in many parts of the valley of the Mississippi. At the commencement of the eighteenth century the Sacs and Foxes made a desperate effort to take the fort at Detroit from the French, and for forty years subse- 
quent to that period they caused great troulle and embarracemont to them, which was terminated by a successful expedition into the remote regions west of Green Bay."

Ilad the Indians been very numerous in the valley of the Mississippi when it was first discovered, they would int likely have established villages, more especially when ongaged in war with the Sacs and Foxes, who resirle still in the same regions, and are now, perhaps, more powerful than at the time alluded to. The progress of the Indians towards annihilation does not seem to have been rapid for 160 years, and it is a melancholy reflection to think it is connected with civilisation and the intercourse of the whites, and that their removal to the wilderness and exclusion from white peoj,l., has been adopted as the means of preserving the race. Leaving naturalists to determine the properties belonging to colour, I shall simply remark, the dark man of North America, like the dark rat of Britain, seems destined to be exterminated ly the light-coloured species.

- Secretary of War's Report. 


\section{CHAPTIR $\mathrm{X}$.}

Prairie Agriculture-Capital required-Crops and PricesWages of Labour compared with Land and Produce in Illinois and Brituin-Future prospects - Sheep Husbundry-Illinois and L'pper Canada-Illinois and Britain-The Canudas and Illinois estimated by the standard of . Vuture-Emigrant Information.

TнЕ agriculture of forest land in Illinois, is the same as in other parts of America, but is seldom followed, the cultivation of the prairie heing so much more simple and profitable. It has formerly been observed, that the grasses have strong creeping roots, and that six oxen are required to plough the land for the first time. The plough which is used in breaking up the prairie has a very broad share, which cuts a turf seventeen or eighteen inches wide, by two or three in depth. 'The thinner the turf is cut the less grass is found to grow afterwards, which must be owing to the neck, or vital part of the plants, being near the surface. After the first plonghing the soil becomes friable, and is easily cultivated. The breaking up of the prairie is often performed by contract at $\$ 2$ per acre. It is common to drop Indian corn into every thirl furrow of the first ploughing, and the ground is not afterwards operated upon until the crop is reaped, when it is sown with wheat, and simply harrowed. Thus two important crops are obtained by once ploughing and harrowing. A bushel of Indian corn was stated to be sufficient seed for ten acres, and half a bushel of wheat sows one acre. The first crop of Indian corn commonly yields fifty bushels per acre, and the following wheat crop twenty-five bushels. When Indian corn is not sown as a first crop, the ground is sown with wheat, which is covered by the harrow. Grass seldom springs after the land has been 
ploughed, and weeds do not appear for some years afturwards. When Indian corn is grown on land which has been some time cultivated, it is planted on hills four feet square, the intervals heing ploughed in both directions; and a boy with a horse is capalile of manatring the cleaning process of fifty acres. There is but little diversity in prairie agriculture, which is almost entirely confined to the growing of wheat, oats, and Indian corn. Natural herbage affords both hay and pasturage, and the supply is at present inexhaustible. In the tract which I travelled, the seeds of clovers, or artificial grass, never had been sown. But there can be no doult of the soil and climate being capable of producing in abundance almost every description of plant.

$\Lambda$ great many cattle are reared on the prairies which are occupied in common by the inhalitants. The grass was quite withered when I saw it, and the cattle were in good condition, although by no means fat. They are seldom taken under cover during winter, and when snow is on the ground they are foddered with hay. It is customary in some parts to fatten oxen with Indian corn during winter; and the tine animals seen at New York, and alluded to in parge 32, had been fed on Indian corn for two successive winters; it is daily strewed on the ground to the best of the animals; a secondary description succeeds to what the first may have left, and swine are allowed to pick up the refuse. It is by means of the Indian corn of the western states that the people of New Orleans, the cities on the Atlantic, and the Canadas are chiefly supplied with salted beef and pork.

There is perhaps no country in the world where a farmer can commence operations with so small an outlay of money, and so soon obtain a return, as in Illinois. This arises from the cheapness of land, and the facility with which it is cultivated, and will appear more evident from the following statement:$\therefore$ Suppose a settler with sufficient capital to purchase and stock a farm and maintain himself for six months. The farm to consist of two hundred acres, thirty-five of which being forest and the remainder prairie. If the purchase was made in spring, the expense might be thus stated:- 
Purchasing 200 acres of land, at $\$ 1 \frac{1}{4}$. . $\$ 250$

Fencing two fields of 40 acres with an eight rail fence, $\quad 80$

Ploughing by contract 80 acres, at $\$ 2 \quad$. 160

Seed for 80 acres of Indian corn, 10 bushels at 15 cents, $\quad 1.50$

Cutting and harvesting stalks of Indian corn, and harvesting the crop, at $\$ 3$ per acre, . . . . 240

Seed for 80 acres of Wheat, sown after Indian corn, 45 bush. els at 45 cents, . . . . . 20.25

Harrowing Wheat, - $\quad$. $\quad$ - 20

Cows 4, at $\$ 8$, young Cattle 8, at \$5, Pigs $10 \$ \quad$. 82

Buildings and household furniture, . . . 600

Maintenatuce of family for six unonths, and purchasing seeds of vegetables, potatoes, and poultry, $\quad . \quad 13025$

Total, $\$ 1604$

With an expenditure of $\$ 1604$, or $1 . .310,17 \mathrm{~s}$. sterling, is obtained the dairy produce of 4 cows and the improvement of 8 cattle grazing on the prairie, and 3200 lishels of Indian corn, besides vegetables and the improvement of a lot of pigs and poultry.

'The attention of the settler and his family is sujposed to be confined to the cultivation of regetables, tending the cows and pigs, and planting and husking Indian corn.

In the spring of the second year, 80 acres additional would be fenced, ploughed, planted with Indian corn, and harvested at the same expense as the first year o $\$ 481.50$

Harvesting 80 acres of wheat at $\$ 3 \quad 240$

Total

721.50

Supposing the Indian corn of the second year equal to the first crop, the wheat to yield $22 \frac{1}{2}$ bushels per acre, and cost $2 \frac{1}{2}$ bushels in thrashing-the farmer in eighteen months after settling would have expended $\$ 2325.50$, or L.484, 4 s. $6 \mathrm{~d}$. sterling. In the same time he would have reaped 6,400 bushels of Indian corn, and 1600 bushels of wheat, and enjoyed abundance of vegetables, dairy produce, beef, pork, and poultry. With this produce and expenditure the farmer and his family do not perform any laborious work. It is presumed the farm would, with some ploughing, to destroy weeds amongst the Indian com, afterwards continue to yield yearly 3200 bushels of Indian corn, and 1800 bushels of wheat.

The data of the preceding statements are unfavourable for 
industrious and frugal emigrants, being framed for a person disliking to work; and Mr Ferguson's estimate of buildingw, and maintaining a family having been taken, which is tors high for ordinary settlers. The crops are estimated considerably lower than what I was told the land of Illinois generally yields; but from knowing how prone farmers are to speak of good crops, and conceal indifferent ones, I have made considerable deductions from the accounts received, with the view of avoiding exaggeration.

If an industrious man were to purchase the farm, and perform a considerable portion of the work himself, the result would be different. A saving might also be effected on the buildings and living to the extent of $\$ 250$. If to this sum be added $\$ 150$ for work performed personally above the other case, the same produce would be obtained with an outlay of L.389) sterling. A person who would be content at first with cheap houses, little household furniture, and labour with his own hands, might reap the same produce with an outlay of L.300 sterling. The expense of buildings and living until a crop is reaped, must in a great measure depend on the individual himself, and the nature of his family. But the advantages of the country will be best seen by simply viewing the produce of an acre of land for two years, and the cost of obtaining it.

Purchasing an acre of land,

Ploughing,

Seed of Indian corn, .

Harvesting, \&cc.

Seed for Wheut crop,

Harrowing Wheat,

Harvesting Wheat,

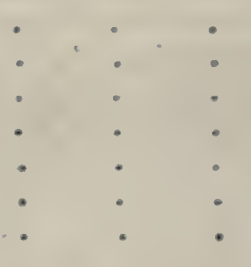

\begin{tabular}{ll}
- & $\$ 1.25$ \\
- & 2 \\
$:$ & 0.02 \\
$:$ & 3 \\
$:$ & 0.50 \\
- & 3 \\
\hline
\end{tabular}

Total, $\$ 10.02$

With an outlay of $\$ 10.02$, or L.2, 2s. 7d. sterling, there is obtained 40 bushels of Indian corn, and $22 \frac{1}{2}$ bushels of wheat.

A person with little capital might commence farming on a sinaller scale than has been taken for illustration; government selling lots of 80 acres. Supposing a farm of this 
extent, consisting of fifteen acres of forest, and the remainder prairie, the expense would stand thus :-

Purchasing 80 acres, at $\$ 1 \frac{1}{4} \quad$. . $\$ 100$

Fencing into two fields of 30 acres, and one of 5 acres for a

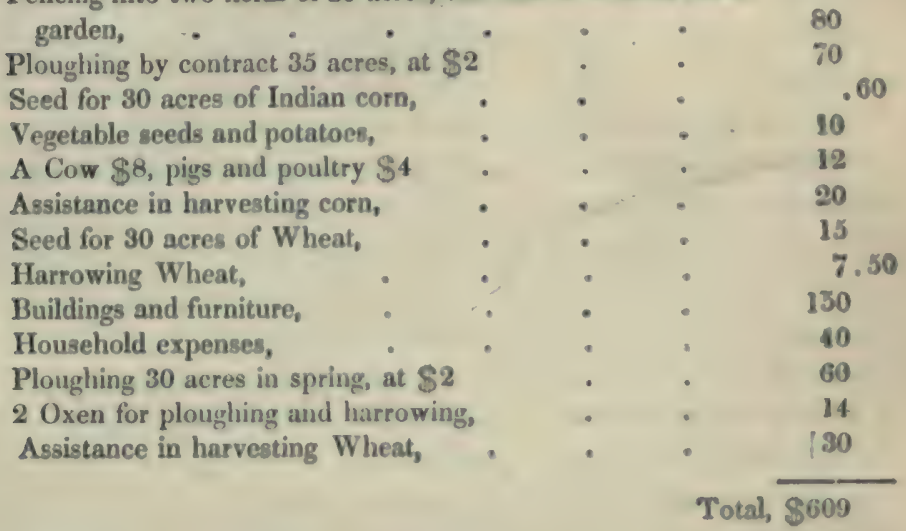

With an expenditure of $\$ 609$, or about L.150 sterling, and the farmer's labour, 2,400 bushels of Indian corn and 675 bushels of wheat would be obtained, besides the produce of a cow, vegetables, pigs, and poultry for family use.

Notwithstanding the enormous quantity of produce exhibited by the preceding statements, high wages and low prices prevent much money being realized. By referring to the statement of the produce of an acre of land for two years, it will be seen the cost is $\$ 10.02$, and Indian corn being estimated at 15 cents per bushel, and wheat at 45 cents, the produce amounts to $\$ 6$ and $\$ 10.12 \frac{1}{2}$ for Indian corn and wheat respectively; or the outlay is L.2, $2 \mathrm{~s} .7 \mathrm{~d}$., and the produce is L.3, 10s. $7 \mathrm{~d}$., subject to the charges of fencing, thrashing, and marketing. Every thing, however, has been done by contract, and in future the purchase of the ground and part of the expense of ploughing would be saved. In the view there is a profit on hired labour, and an industrious man would obtain almost the whole of the produce by labouring himself.

In a country where Nature is so bountiful and land so abundant and cheap, the wages of labour must necessarily be 
high. Accordingly, an ordinary mechanic obtains $\$ 1$ per day, with board, including washing ; and superior workmen, ellgineers, and millwrights, get from \$2 to \$3. Farm labourers are engaged at from $\$ 100$ to $\$ 120$ a-year. Female houseservants obtain $\$ 1$ in private families, and from $\$ 2$ to $\$ 2 \frac{1}{2}$ a-week in hotels. As compared with the prices of produce and land, wages may be stated thus:-

If an ordinary mechanic work five days in the week he will earn throughout the year, besides board, $\$ 260$; or of Indian corn ahout 1733 bushels; or of wheat alont 580 bushels ; or of beef about $13,000 \mathrm{lb}$; or of land about 200 acres.

An ordinary farn labourer will get during the year, besides his board, $\$ 100$; or of Indian corn about 667 bushels; or of wheat about 222 bushels; or of beef ahout $5000 \mathrm{lb}$.; or of land about eighty acres; which is a sufficient extent of surface for any labouring man to possess.

Female house-servants in private families get in the year \$52, which would purchase forty acres of land, and in hotels what would purchase eighty acres of land.

How very different is the situation of farm labourers in England, Scotland, and Ireland, compared with those in Illinois. Supposing the weekly wages of labourers to be $10 \mathrm{~s} .$, 8s., and 3s. 6d., without board, in England, Scotland, and Ireland respectively, and they do not exceed these sums, the Englishman will earn during the year about seventy bushels of wheat, or of beef about $1560 \mathrm{lbs}$.- the Scotchman about sixty-two bushels of wheat, or of beef about $1400 \mathrm{ibs}$. - the Irishman about thirty bushels of wheat, or of beef about $\mathbf{7 5 0}$ lbs. But when the board of the workman, or simply what he himself would consume, is taken from these numbers, they will appear quite insignificant compared with the wages of Illinois.

An ordinary farm labourer in Illinois gets the value of eighty acres of land yearly: In Britain, when due allowance is made for the board of the labourer, he does not get onetenth of an acre of good land. When wages are compared with land, the farm labourer of Illinois is about 800 times better rewarded than in Britain.

The wages of female servants, compared with the price of land, are also remarkable. I am sure there are many of my 
excellent countrywomen who, if they could reach Illinois, would cheerfully earn a farm for their fathers, husbands, or lovers, by engaging in service. Perhaps in almost every case individuals, on their arrival in the country, would act prudently by working for hire for the first twelve months, even if they possess a little eapital. By so doing, the knowlerlge which they would obtain of the country, and the intercourse of the people, would perhaps be of as much importance to them as the increase of funds. In the case of a family without funds, the members might separate entirely or partially, as circumstances admitted, and afterwards again unite when they had obtained the means of purchasing and farming land.

The land in Illinois to which the comparison of wages refers, is of fine quality, situated in the best climate of America, and, considered as a workshop, is not greatly surpassed by any portion of the earth. 'The view which I have taken of the reward of farm labourers in Illinois and Britain may appear excessive, yet it will bear investigation. 'The British labourer's reward of one-tenth of an acre would yield a mere trifle annually; but the Illinois labourer's reward of eighty acres might aftord sustenance for himself and family for ever. The man who gives his services one year for hire in Illinois, and invests his wages in the purchase of land, obtains the services of nature on a large scale in perpetuity, and by leading a life of industry and economy for five or six years, he would be enabled to purchase and sufficiently stock eighty acres of land, which would for ever support himself and family.

Illinois may justly be called " the poor man's country," if any part of the world deserves the title. The extraordinary reward which the labourer receives, and the bountifulness of Nature, are favourable to the poor, and no person who has health and strength, and leads an industrious and a virtuous life, can continue without the means of subsistence in Illinois.

The future prospects of Illinois appear to be highly favourable. Referring to what has been stated regarding the progress of wealth at p. 400, and the channels of trade at p. 424-5, it will be found that almost all the elements of prosperity exist in the country. The soil, grass-covered surface, climate, internal facilities of commerce, cheapness and extent of land, 
and the systems of governing and educating the people, are not surpassed by any other portion of America, and inhabitants are alone wanting to complete its greatness.

The price of Government land being the same over the United States, the prairies of Illinois will be preferred by all judicious settlers to the forests which lie nearer the Atlantic, while the arrangements which have been made with the Indians will tend for a time to check population from proceeding to the west of the districts already surveyed. 'The advantages of the country have only been made public of late years, and less seems to be known regarding it in the eastern portions of the United States and the Canalas than in Britain. Emigrants have, however, been streaming in to Illinois for a year or two from the different parts of Europe and the eastern parts of America, and their number is likely to increase. I have frequently alluded to the anxiety of people in the eastern States and the Canadas to sell their lands. This desire proceeds from the advantages of a prairie country, in which many of the farmers in other portions of America obtain better farms than those which they formerly possessed, and at a twentieth part of the price at which they sell their original ones. There is consequently a class of comparatively wealthy settlers attracted to the west, independent of the natural movement of the United States people, alluded to at p. 400,401. But however great the influx of population may be, there is sufficient room for all who are likely to desire a settlement. Illinois being about the size of England, might furnish a greater supply of food, from the general superiority of its soil, and seems to me to be nearly capable of sustaining the whole inhabitants of England in addition to its present population, or nearly seventy times the inhabitants it now possesses.

The settlement of the prairies in the western parts of the United States will affect the whole population of the Union. The profits of farming in the present state of the country regulate the wages of labour generally, and the facility with which prairie land is cultivated compared to forest land, will attract the operatives of every profession, and thereby have a tendency to keep up wages. Although the price of forest and 
prairie land is the same, the greater productiveness of the latter, and small capital required to bring it into a state of cultivation, will keep down the price of the necessaries of life by furnishing a greater supply. 'Thus the prairies of the west, by attracting population from the eastern States, will have a tendency to keep up the wages of labour there, and prevent a rise in the price of farm produce in the thickly peopled parts of the country.

The inexhaustible supply of coal in Illinois is a strong featture in the future greatness of the country, both as emabling the whole surface to be devoted to the production of human food, and furnishing fuel for culinary and manufacturing purposes. From the natural advantages of the country, and consequent great reward of industry, population will be attracted to it, and manufactures of all kinds will either spring up within the State, or the communication with the cities on the Atlantic will become more accessible than it is at present. The towns of Pittsburg and Buffalo seem likely to become the great depots of produce passing between the eastern and western States. Pittsburg is situated at the head of the steam-boat navigation of the river Ohio-it is the chief seat of hardware manufactures in the United States, and has been termed the Birmingham of America. Pittsburg alrealy communicates with the city of Philadelphia by a railway and canal, and a railway is forming to connect it with Baltimore. There is also, I believe, a canal in progress to open a communication between Pittsburg and the Erie canal, unconnected with lake Erie. Buffalo is situated at the junction of the Erie canal with lake Erie, and is one of the best commercial situations in the United States, being connected with the country to the westward by the great lakes and canals, with New York by the Hudson and Erie canal, and it will also soon communicate with Boston by a railway. These two towns are likely to become the centres of diverging lines of railroads and other modes of communication between the eastern and western States, which form the only means of preventing the depopulation of the countries on the Atlantic, as the abundance and cheapness of food in the west would 
soon induce manufucturers to emigrate and establish themselves there.

It may become a question, at no very remote period, whether the communication between the eastern and western States will he cheaper by water conveyance or railroads. The waters are shut by frost for a portion of the year, the navigation of canals is necessarily slow, and that of rivers often uncertain from want of water, and at all times expensive by the tear and wear of vessels in struggling against the stream. On the other hand, the level surface is admirably fitted for railroads, and the western countries abound in coal and iron. There is no way of so effectually connecting the east and west as by means of railroads. Government commenced a national road, the construction of which has been suspended by President Jackson, to extend from Washington to Jefferson on the Missouri, a distance of nearly 1000 miles, and running through the prairie country. The funds arising from the sale of land might easily form a railroad between Jefferson and Pittsburg, which would be connected with the seaport towns on the Atlantic.

The value of farm produce and land in the different sections of the country will be affected in opposite ways by the opening of the communication between the east and west. By lessening the expense of transport, a greater quantity of produce will flow from the west to the east, and there will be less difference in price, either by produce falling in the east or rising in the west. If prices fall in the east, the value of land will fall there; and if prices rise in the west, the value of land will increase there. Facilitating the intercourse between the countries will extend the market for western produce, and operate like an influx of inhabitants; and the natural effects will be, a rise in the value of produce and land in that quarter.

The west will be farther benefited by the opening of communication lowering the price of the manufactures and luxuries of the east. In a very few years, the prices of Illinois and New York will vary only according to the expense of transport from one place to the other; and the difference will 
annually decrease with an increase of traffic and a facility of communication.

The prices of wheat and Indian corn included in the preceding statements, represent the general prices in Illinuis at the time of my visit; and they were then low from the want of commercial population. A change in this respect was, however, then taking place, which has since progressed. Steam grist-mills have been erected at Jacksonville and other places, and pork-killers from Cincinnati * have established themselves at Alton. Commerce has followed agriculture, and the consequent competition must have the effect of enhancing the price of farm produce. With an unlimited range of pasturage for the rearing of cattle, and Indian corn at fifteen cents, or seven-pence-halfpenny Sterling per bushel, the farmer might comfortably live by stock, without cultivating any portion of his land.

Sheep husbandry has received considerable attention in some parts of the United States of late years, although it is generally imperfectly understood. The chief ohject with flockmasters has been to improve the quality of wool, without regard to the carcass of the animal, wool being much dearer than mutton. Many of the sheep are of the Saxony or Merino blood, or a mixture of these breeds; and their wool is now selling at two shillings and sixpence sterling per pound. This high price is owing to sheep husbandry being foreign to the habits and tastes of American farmers, and the limited funds and cleared surface possessed by forest settlers; and, perhaps, a thorough knowledge of the management of sheep can only be acquired from practice. From these causes, the demand for wool in the United States, with a rapidly increasing population, will, in all probability, long exceed the supply.

There is a general belief in Britain, that the American population dislike mutton, which is, however, certainly not the case. I saw many a leg of mutton discussed at table during my tour; and was often assured that good hind quarters of mutton sold as high as the best beef. Good beef is, however,

* In $1833,300,000$ pigs were killed at Cincinnati. 
to be had in almost every village, while good mutton is a rare commodity, which is partly owing to the breeds of sheep, and their want of food during winter.

In a communication addressed to the State Agricultural Society of New York, by IIenry D. Grove, who resides in Rensseller county, and is a native of Germany, Mr Grove has, by his own account, devoted much attention to woolgrowing in Germany, and for five years in the State of New York. In both countries his flock consisted of full-bloorled Saxon sheep, and he considers his situation in America, in about forty-two and a half degrees of north latitude, superior to Saxony for growing fine wool. I have no means of juilging between the merits of Saxony and the State of New York as wool-growing countries; but from what came under my notice, I think there is no obstacle to sheep-farming in America but what arises from the severity of the winter, which might be obviated by providing shelter and food for the animals.

Mr Grove considers sweet dry pastures, pure water, and pure air, as the chief essentials of wool-growing; and as these exist in many parts of Illinois, and may perhaps be made universal by digging wells, there can be little doubt of its capabilities for sheep husbandry. Not having seen a sheep while in Illinois, I cannot determine if the prairie grasses are calculated to maintain this animal; but as horses and cattle thrive well on them, it is probable sheep will likewise do so. If, however, this should be found not to be the case, it would be an easy matter to convert the prairie into pasturage, composed of clovers and other grasses, by sowing their seeds. The winters in the southern parts of Illinois are so short, that no great quantity of food would be required to maintain sheep while the ground was covered with snow; and the facility with which Indian corn is raised, would render a supply easily attained, if the cultivation of turnip was found unsuitable. There can be no doubt of potatoes and turnips being easily preserved during winter.

I have no certain means of ascertaining the duration of an Illinois winter in latitude 39. Mr Stuart says he found the cattle in this meridian, on reaching the State, fat on the 29 th 
April, but I fear this is too favourable to the climate. I shall, however, assume the ground to be covered with snow for the period of two months, during which it will be necessary to feed sheep artificially. Mr Grove, in the communication formerly alluded to, says, one lb. of oil-cake is equal to two lbs. of good hay; and that for twelve or thirteen years he found his "flock did extremely well whenever he proportioned their food according to nutritiousness, and in such a manner as that two lbs. of good hay would give to each animal." It may be assumed that Indian corn, which weighs about sixty los. per bushel, is as nutritious as oil-cake for feeding sheep. An acre of Indian corn therefore, yielding forty bushels, will maintain forty sheep during winter, with the assistance of straw ; and if hay or potatoes were given, a smaller quantity would suffice. If the Indian corn were bought, and the sheep allowed one lb. daily, each would cost seven-pence halfpenny sterling for two months keeping.

Much of the prairies of Illinois cannot be stocked with sheep until the different varieties of the wolf are extirpated, which will be easily effected with an increase of population, and it is only in the neighbourhood of well-peopled places, and with care during night, that they can be safely kept at present. The time will, however, soon arrive when much of the unsold prairies will be covered with sheep, and then perhaps almost the whole surface of occupied farms will be devoted to providing winter-food for the flocks.

The value of wool is remarkable, compared with land. Suppose the fleece of a Merino sheep weighs three lbs., and sells at sixty cents per lb., the wool of one sheep will nearly purchase an acre and a half of land. Wool could be transported from Illinois to the eastern States for three or four cents apound, and there can be no question that it costs less labour in producing and carrying to market than any other agricultural commodity whatever.

The climate and soil of Illinois seem favourable to every description of agriculture. The luxuriance and productiveness of Indian corn has been noticed at page 394. If this crop were succeeded by wheat, accompanied by clover sown in spring, the herbage of which to be eaten by sheep in autumn after the 
wheat is reaped, and ploughed down for manure to Indian corn in the following spring, I have no doubt alternate crops of wheat and Indian corn might be grown without the aid of manures.

In whatever point of view Illinois is regarded, as adapted for herds and flocks, for wheat and India corn, for manufactures and commerce, or for the abode of population generally, it will be found to be one of the most favoured portions of North America, and with the exception of population, possessing all the elements of future prosperity and greatness. Time will supply inhabitants, which the want of at present, however, forms one of the many advantages of the country for agricultural emigration.

When contrasting Illinois and Upper Canada, I shall not again allude to the governments of the countries, or to their channels of trade, but confine myself chiefly to their agricultural peculiarities.

The most northerly portions of Illinois lie in the same latitude with the most sontherly parts of Upper Canada ; and on a general view of the countries, the one is four degrees to the north of the other. After considering the different published accounts of an American winter, I have been led to conclude, that between thirty-five and fifty degrees of north latitude, the length of winter increases nearly two weeks with each degree of latitude, consequently the winter of Illinois may be stated about two months shorter than that of Upper Canada. Then, in point of climate, Illinois has greatly the advantage in maturing all the valuable products of the soil, and by affording time for cultivating the farm properly. Live stock will also suffer much less during winter, and the artificial supplies of food necessary for this season, are much easier attained.

The settler of Upper Canada has to struggle with the forest before he obtains a site for his house. If he ventures to keep a cow, she must browse on weeds and leaves of trees in summer, and in winter on the boughs of felled trees; the milk and butter which she yields is of the worst quality, and scarcely repays the trouble of roaming after her in the woods. A pig and poultry cannot be maintained at first, and many years 
must pass away before the farm can furnish mutton and wool for family use. Trees must be cut down, chopped into logs, and burned before even a garden can be formed. The first crops suffer both from the effects of frost and the want of a circulation of air. The plough eannot be profitably used until eight years after the forest is cut down; during the greater part of this period the harrow and scythe move amongst blackened stumps, and there is difficulty in growing sufficient food for a family.

The settler of Illinois places his house on the skirts of the forest or on the open field, as fancy may dictate. The prairie furnishes summer and winter-food for any number of cattle and sheep, and poultry and pigs shift for themselves until the crops ripen. With the preliminary of fencing, the plough enters the virgin soil, which in a few months afterwards yields a most abundant crop of Indian corn, and on its removal every agricultural operation may be executed with facility. The first crops are excellent, and seldom suffer from atmospheric effects. Pastoral, arable, or mixed husbandry, may be at once adopted, and produce of all kinds obtained in the utmost profusion.

In Upper Canada the settler is immersed in the forest with roads that are passable for heavy carriages only when frozen. The Illinois settler enjoys a prospect of wood and plain, and the open prairie aftords good roads at all times when the weather is dry. In Upper Canada no part of the surface is productive which has not been cleared. In Illinois the whole of a prairie farm is productive without being cultivated. In Upper Canada the forest settler cannot at first produce his own food, and lives for a time on flour and salt provisions. In Illinois the settler at once raises on his farm almost every thing he can consume. In Upper Canada the farmer is not fully repaid for his first operations until the end of six or seven years. In Illinois the farmer is repaid for his first operations in course of a few months. The farmer's reward in Upper Canada is many years distant, and in Illinois it is almost immediate. In short, the farmer in Upper Canada at first finds difficulty in growing a sufficiency of produce for his own use, and the Illinois farmer difficulty in consuming his produce. 
The positions which I have advanced regarding the farming of the two countries, will appear evident from figures. By consulting pages 117 and 375 , it will be found that the expense of bringing an acre of wheat to maturity in Upper Canada amounts to $\$ .24$, exclusive of harvesting, thrashing, and marketing the crop. The produce cannot be obtained earlier than eighteen months after entering into possession of the land, and will not exceed in general cases eighteen bushels per acre. By referring to page 448 it will be found, that the cxpense of raising a crop of Indian corn and wheat on the prairies of Illinois is stated at $\$ 4.02$, to which $\$ 1$ must he added for fencing, making $\$ 5.02$ for both crops, exclusive of harvesting, thrashing, and marketing. The crops will be ol,tained in eighteen months after entry, and consist of forty bushels of Indian corn and $22 \%$ bushels of wheat, or, in other words, the farmer, with about one-fifth of the labour or outlay on an acre in Illinois, will obtain more than double the produce he could get in the same time in Upper Canada. But if the calculations were extended to the eighth year, the difference of produce would still appear to be greater. During this period an acre in Illinois would, with good management, continue to yield nearly the same produce; while the land in Upper Canada, after yielding two successive wheat crops, would be allowed to produce grass until the stumps rotted. Grass is of little value in Canada, unless near villages where there is a demand for hay, and it would be unfair to allow any thing for the land remaining in pasturage for five years, as in this state it would only be on a footing with the uncultivated prairie. Then, during eight years, an acre of land in Upper Canada would yield thirty-six bushels of wheat, and in Illinois 160 bushels of Indian corn and ninety bushels of wheat.

The result of one acre does not fairly exhibit the real advantages of Illinois. It has formerly been stated that settlers in Canada seldom clear more than six or seven acres in a year; but to place things in a favourable view, I shall suppose ten acres to be cleared, with assistance in logging and burning. In Illinois an industrious settler would have little difficulty, with the occasional assistance of a boy or two, in cultivating fifty acres. On this data, the Upper Canada 
farmer, at the end of eighteen months, would raise 180 bushels of wheat, and the farmer in Illinois 2000 bushels of Indian corn and 1125 bushels of wheat. During this period the Upper Canada farmer would neither have grass for cow nor sheep, and perhaps scarcely food for a pig; while in Illinois stock of all kinds may have been kept.

In assuming wheat in Upper Canada to yield eighteen bushels per acre when land is first cleared, and wheat in Illinois $22 \frac{1}{2}$ bushels, the soil and climate are supposed to be the same in both countries, and twenty per cent has been deducted from the wheat of Upper Canada on account of the surface occupied by stumps. Should it be contended that my estimate of the Upper Canada wheat crop is too low, I would argue my estimate of the Illinois crop is still more so, and maintain, that whatever produce the first wheat crops of $\mathrm{C}$ pper Canada may yield, those of Illinois must be twenty per cent better, from the ground being free from stumps. Indian corn cannot be grown on a large seale amongst stumps; and even after they are removed, the effect of soil and climate will render the crop nearly fifty per cent better in Illinois than in Upper Canada.

Mr Ferguson's calculations seem to me too favourable to Upper Canada; yet if the expenses of harvesting, thrashing, and teaming be added to the expenses of the first wheat crop, as stated by him, the value of the produce, which I think he has greatly overrated, falls L.1, 78. $6 \mathrm{~d}$. short of the expense it has cost in raising; and no statement which I received made the value of the first crop cover the expense of producing it. It is this circumstance which renders the farmers of Upper Canada so poor after first settlement, and time and frugality the only means of escaping from their wretchedness. It is this circumstance, joined to the effects of accumulating interest, which renders inevitable the ruin of every farmer who purchases on credit, and stamps with folly the recent proceedings of government in disposing of land. In Illinois the first crops more than repay the expense of raising them.

The commercial state of the two countries corroborates the nature of the farming. A newly settled district in Upper Canada continues to import flour and salt provisions for many 
years. In Illinois every farmer, soon after establishing himself, sells produce of all deseriptions. The whole population of Upper Canada, with exception of those on the rivers Detroit and Thames, may be said to be fed with fresh or salted animal food from the Cinited States. The difficulties of first settlement in a densely wooded country are so great that the inhabitants of Upper Canada could not have existed without the money of Britain, and the provisions of the western United States.

Viewing soil as a work-shop, the prairie farm of Illinois is superior to the forest one in Upper Canala, not only from containing a better supply of the materials forming climate, as described at pages 327,328 , but from being fitted by nature for immediate operations. Place a prepared workshop, and materials for forming another, before any manufacturer whatever, and ask him whether he would commence his profession in the erected shop, or prepare one with his own hands. Such is the situation of the industrious emigrant farmer with regard to the Illinois prairie and Upper Canada forest. If choice is made of the latter, the farmer is like a manufacturer who would erect a workshop with his own hands. The forest settler, after suffering privations, undergoing much toil, and patiently waiting till the stumps decay, will at length find himself in something like the situation of the prairie farmer on his first settlement. Nay, the first ploughing of forest land after the stumps have decayed, is more expensive than breaking up prairie land, and the succeeding crops greatly inferior. I had no opportunity of forming an opinion of the crops immediately after the stumps decay, but a friend, capable of judging, told me a field which I saw preparing under such circumstances, on the banks of the Otanabee, in the Newcastle district, produced a poor wheat crop in 1834, and that such crops will not average more than fifteen bushels per acre. A person in the township of Hinchinbrook, Lower Canada, prepared and sowed a field of stump land with wheat in 1834, the crop of which did not cover the expense of raising and carrying it to market. The capitalist who clears Canadian forest in preference to farming the prairie of Illinois, makes a sacrifice of property, and the industrious farmer who 
follows the same course throws away ten or twelve years of his labour.

However theoretical the view which I have ventured to take of the first settlers in the two countries may appear to some minds, it will be found to accord with practice. Throughout all my peregrinations in Cpper Canadi, I did not visit or see a settlement of seven or eight years' standing possessing a stack nor a herd of cattle. Ten or twelve acres of wheat, which was put into a barn, formed the utmost extent of that crop on one farm, and the patches of Indian curn selduin exceeded a rood. The tables of the farmers were indifierently stored, fried salt pork from the United States being served $u_{p}$ in many houses twenty-one times a-week. In Illinois the state of things was very different with new settlers. Wheat and Indian corn were seen every where in abundance, and the tables were anply stored with fresh provisions. In Upper Canada salt pork was the standard dish at all meals, and in Illinois salted meat was never placed before me.

A British farmer can have little idea of the Canadian forest from the trees of his own country, which are mere saplings compared with those of Upper Canada; and his notions of drilled crops and rotations will ill accord with the disgusting black stumps which disfigure the fields. In Illinois he may at once pursue any system and perform any operation. 'The best breeds of cattle and sheep will find suitable food in the country, and the most improved implements of husbandry may be employed. A reaping machine was used at Jacksonville in 1834, and it is on the lawned surface of the prairie where this and almost every other description of agricultural machinery can be introduced with advantage. On the forest farm of Cianada machinery cannot be used, nor stock kept.

Since the prairies of Illinois possess such advantages over Upper Canada in the present state of agriculture, what may not be expected from them with the progress of science? Already the crops on nearly one hundred farms in East Lothian are thrashed by means of steam, and its application to other operations will in all probability be soon effected. The coalfield of Illinois is inexhaustible. With steam power to cultivate the prairie, and to reap, collect the crops of grass and of wheat, 
and to separate the grain from the straw, who can set limits to the quantity of human sustenance which Illinois is capable of affording? If ever there is such a place as the granary of the world, it will be the prairies of the western United states of America.

It was difficult for me to form an opinion of the price of wheat in Upper Canada when I was in the country, the accounts being so contradictory, and sometimes stated in cash, and sometimes in store pay. I have stated the expenses and merchants' profit of sending wheat from the township of Nichol to Britain at $3 \mathrm{~s} .7 \mathrm{~d}$. sterling per bushel, and perhaps the average expense of the province will exceed $3 \mathrm{~s}$. 'The wheat of Upper Canada will sell as high in the London market as the best English wheat. The farmer of Upper Canada must, therefore, sell his wheat about 24s. a-quarter below the highest London prices. The Illinois farmer has different markets for his wheat, and can send it to Canada if he pleases. I have no means of calculating the expense of transport from Illinois to Canada, which cannot, however, be very heavy, from the canals being public property, and the dues consequently moderate. The greater produce of land in Illinois will, however, more than pay the expense of sending it to Canada, and I consider myself justified in saying that a farm in Illinois will at all times yield more produce than one in Upper Canada, and that produce realize more money.

The prices of farm produce being high in Upper Canada is disadvantageous to the labouring settler who enters on a forest farm, because, being unable for several years to grow a sufficiency of food for family consumpt, the dearness of what he purchases exhausts his funds. So long as a farmer consumes all the produce which he grows, prices do not in the least affect him, and this is too often overlooked in the Canadas, where it is so difficult at first to grow produce. Fresh beef is said occasionally to fetch twenty-five cents per pound at Quebec, while it can be had in some parts of Illinois at three cents. The settler at Quebec would feel the high price of beef a hardship, and perhaps never reap the benefit of it from the difficulty of fattening cattle in his unfavourable situation. The true value of a crop is expressed by the price and quantity of 
produce, diminished by the expense it costs in raising and marketing.

I also found difficulty in ascertaining the yearly wages of an agricultural labourer in Upper Canada, from the system of cash and store pay, and the difference of summer and winter wages. Mr Somerville of Whitby states the eash wages of the best labourer in Upper Canada at \$80 a-year, while in Illinois they are $\$ 100$. Whether these sums are perfectly atecurate, is of no great consequence, as it is universally admitted over all Canada that wages are lower there than in the United States. Indeed it cannot be otherwise, produce being shared between the farmer and labourer, and land in Upper Canada yielding so much less than in Illinois.

Labour is more easily obtained in Upper Canada than in Illinois, the difficulty with which forest land is cultivated preventing labourers farming on their own account. Whether the agricultural capitalist derives more profit from employing labour in Upper Canada than in Illinois, I cannot satisfactorily determine ; but from what has been formerly stated, the investment of capital in clearing forest in Upper Canada does not in the first instance pay, while farming the prairie is at once remunerating. From the great return of produce, it is probable both the capitalist and labourer are better rewarled in Illinois than in Upper Canada. The higher wages in Illinois, however, bring the farmer and hired labourer nearer each other in the command of the necessaries of life than in Canada. But this circumstance ought to form a source of enjoyment to the capitalist, who should prize the bounty of God the more from knowing it is also amply shared by the labourer. The landholder of Upper Canada, who sets himself down in the forest, toils hard for the first nine or ten years, and cannot command the same comforts and necessaries of life as the labourer in Illinois. I refer to page $\mathbf{4 5 0}$ for evidence of the truth of this remark.

As it is the ambition of every agricultural labourer who leaves Britain for America to become a landholdey there, I shall endeavour to show what are the chances of attaining his object in Upper Canada and Illinois.

Supposing forest land in Upper Canada to be \$3 per acre, $2 \mathrm{G}$ 
and a labourer's wages $\$ 80$ a-year with board, he will get the value of about twenty-seven acres of land. In Illinois, land costs $\$ 1$, and wages being $\$ 100$, the labourer gets the value of eighty acres. But taking into account what has been stated at paye 460 regarding the difference of expense in raising cropss on forest and prairie land, I am justified in asserting the wages of agricultural labour to be about thirty times higher in Illinois than in Upper Canada, when estimated in reference to land and what it can be made to produce in the respective countries.

Purchasing extensive tracts of forest land is a hazardous speculation in Upper Canada, because it is now selling far above its intrinsic value to actual settlers. The soil continues unproductive while the forest remains, and it has been already shown that land does not repay the expense of clearing for years afterwards. Take for illustration a case where a llock of 7000 acres has been purchased at $\$ 4$ per acre, the block would cost L.7000 currency. Suppose the proprietor clears 100 acres yearly for six successive years, at thetermination of which he finds the expense of improvement and his family living has been disbursed by the crops, and I am much mistaken if such an extent of operations and successful issue has ever taken place. The legal interest of the country being 6 per cent, the original purchase money will now amount to L.9520, or a yearly burden on the cleared portion of nearly twenty shillings per acre ; and if the purchase money was only $\$ 2$ instead of $\$ 4$, the yearly burlen would still be ten shillings. Purchasing the prairie of Illinois is very different, because the whole surface is productive without cultivation, and keeping but a single sheep on it per acre, would leave a profit on the outlay. A rise in the value of Illinois land in course of a few years may be held to be certain, and in the mean time it will continue productive. A rise in the value of forest land in Upper Canada for twenty years to come is doubtful, and until then it will remain unproductive. There is no way of escaping from loss in holding a tract of forest land in Canada but by selling it.

A party of friends cannot conveniently settle themselves together in the forest of Upper Canada. Each family would be shut out from the others' occupying a small clearance, with bad 
roads of communication, and the larger the party and the extent of each family's possessions, the greater these and other inconveniences would become. A party may occupy a portion, or the whole, of a prairie in Illinois with the best effects. Each family might settle within sight of the whole party, with good roads of communication, and although the possessions of each might be extensive, circumstances would be the same, with exception of the distance of separation. The skirts of the prairie would afford forest, scattered trees, or lawn for adorning residences, but Upper Canada being an interminable forest, the members of which do not answer to stand when singled out, there is but little choice of natural beauty of situation.

The agriculturists of Britain, who have long been accustomed to obtain high prices for produce, and consequently to finger much cash, may he apt to treat with contempt the idea of farming in a country where prices are so low as they are in Illinois. I have already remarked that the British farmer collects the corn-law tax, the results of nature's assistance, and part of what flows from his own capital, and the operatives' labour, all of which he pays in the name of rent and taxes; so it is only that portion of the cash which sticks to his own pocket that is really valuable to him. When conversing on this subject, a farmer once remarked to me that he paid money away as fast as it was received, and derived no advantage from the cash which resulted from high prices beyond the temporary pleasure of looking at it.

$I_{t}$ is far from my intention to undervalue the advantages enjoyed by the farmers of Britain, or to ridicule them for discharging, through the medium of high prices, just debts, which I consider to be one of the most pleasing employments in life. But while sensible of the general benefits of cash, let me ask British farmers what is the use of money to them beyond the means it affords of purchasing things? The industrious farmer of Illinois may not perhaps be able to accumulate much money, but although not rich in cash, he cannot fail of being rich in things.

The view which $I$ have ventured to describe of cash and things, as affecting the farmer of Britain and Illinois, is not visionary. Take for illustration a favourable case in Britain. 
Suppose a farmer to have rented 300 acres for a periol of thirty years, during which he has maintained and educated a family, and to die worth five thousand pounds. 'This sumiwill do little more than place two sons in a situation similar to what he occupied, that is to say, it will purchase twice the farming apparatus he himself possessed. A farmer occupying the like extent and for the same perior in Illinois, might educate and maintain a family in the fullest abundance, and would find no difficulty during his lifetime in placing a dozen of sons in a similar position with himself by the means of things, whatever might be the state of prices. If a son, on attaining his fifteenth year, were to work for hire, or to be industrious on his father's farm until reaching the age of twenty-one, the results of his own labour would enable him to purchase and stock a farm without assistance from the father. But in a case where the son may not have been industrious, the farmer could have little difficulty in providing him with a farm, when the fleece of a sheep purchases an acre and a half of land. A farm is almost as easily stocked as it is purchased, one ploughing and harrowing being sufficient to procure a crop of Indian corn and one of wheat; while the produce of an acre of the former will furnish seed for 320 acres, and an acre of the latter seed for forty-five acres.

Hitherto the ease of farmers and their sons has only been alluded to. It is unnecessary, however, to notice the shuations of widows, daughters, and infant-children, after what has been stated at pages $336-7$ and $344-5$. When a British tenant, who has farmed on lease, is descending the vale of years, with local attachments for the spot where he was born deeply-seated in his heart, the caprice of land-holder, agent, or factor may uproot the best feelings of his nature, and set him aside to make room for another. But the farmer of Illinois has the assurance of terminating his days on the spot which has been the scene of his operations in manhood, unmolested by any one.

The farmer may change the scene of his operations from Britain to Illinois, and benefit by the transition, but the like prospect cannot be held out to the Illinois farmer. The following is an extract from a letter lately received from my brother 
Charles:- "I do not regret the step which I have taken in settling myself on the banks of the Mississippi, and shall be stimulated to active exertion by the thought, that every tree I cut down, every sod I turn, and every animal I rear, brings me nearer Scotland. I have reason to believe these hopes will be realized. Allowing, however, that they will not-that a livelihood is the most I shall obtain, and that I am compelled to spend and end my days here-what of that? at the longest, life is not so very long, and when accompanied with virtue, it has attractions almost any where. But I still look to Scotland as containing all I truly love in this world, and shall never relinquish the hope of being able to end my days at home." In Britain the state of every thing at present is so different from Illinois, that there is not much prospect of any emigrant farmer realizing such a fortune in Illinois as will enable him to return and live in Britain. The rate of interest in Illinois being nearly three times more, and the price of provisions nearly three times less than in Britain, a change of residence from the former to the latter would be attended with an immense loss of income to the capitalist. On the other hand, a change from Britain to Illinois would greatly augment his income. Britain and Illinois cannot, however, long continue so dissimilar as they are at present. The necessaries of life are likely to approach nearer each other in price, by a rise in the one country and a fall in the other, and ultimately the youthful emigrant of the present day may be enabled to return to Britain in his old age.

Some of the opinions which I have expressed of the Canadas and Illinois, as adapted for agriculture, may be tested by the standard of nature.

From the junction of the north branch of the river Ottawa with the St Lawrence below Montreal, to Goderich in the west of Upper Canada, and from thence to the southern point of Illinois, the eye is only relieved by two inconsiderable eminences in Lower Canada. Lakes Huron and Michigan being situated in the highest parts, and only 589 feet above the level of the sea, this tract of country may be considered an immense valley, the Canadas running from the lakes in a north-easterly direction, and Illinois running south. On a general view, 
there is so little difference of elevation, that the countries may be considered of the same altitude, and their climates affected only by latitude. The medium latitude of Lower Canada may be stated at $46^{\circ}$, of Upper Canada, $44^{\circ}$, and of Illinois, 40. Supposing winter to increase in duration two weeks with each degree of latitude, the winter of the medium of IIlinois may be stated at two months, of Upper Canada at four months, and of Lower Canada at five months. The summers of the countries lengthen inversely with the winters.

Judging from what came under my notice, I am inclined to think the surface of Illinois is superior soil to the Canadas, and the lower province better than Upper Canada. There is, however, much good and bad soil in all the countries, and in order to avoid the semblance of partiality, the soil of the Canadas and Illinois shall be assumed to be similar in quality.

I have formerly denominated soil a workshop; air, moisture, light, and heat, raw materials, termed climate; plants and animals, machinery; certain minerals and labour, oil for the machinery which manufacture farm produce. Nature and man perform distinct parts in the manufacture, and the farmer's success depends on the aid which he is enabled to afford her. Man is subordinate to nature, and a superabundant or a diminished supply of moisture or of heat, which form part of the materials she supplies, may arrest the manufacture, and impair or destroy the machinery furnished by man.

The workshop or soil of the Canadas and Illinois has been assumed to be similar, but the raw materials of nature are not at all times furnished to the workshops of these countries in the same proportions, and this variation of supply or difference of climate, affects the manufacturing results of the farms, both with regard to the quantity and quality of fabrics.

The winters of Lower Canada, Upper Canada, and Illinois being respectively five, four, and two months in length, manufacturing will be altogether suspended in the countries for corresponding periods. The effects of suspended heat, or presence of cold, on animal machinery, is increased by intensity as well as duration, and labour or furnishing of oil is impracticable in winter. Manufacturing proceeds only when winter is absent, and is increased by the intensity and length 
of summer, when oil can be supplied. Winter being a!sent seven months in Lower Canada, eight in Upper Canada, and ten in Illinois, the relative quantities of fabrics manufactured in the workshops are not truly represented by these numbers; and when all the effects of climate and of labour on animal and vegetable machinery are duly considered, the average farming results, as regard quantity, may be stated in Lower Canada at six, in Cpper Canada at seven and a half, and in Illinois at ten. But farming depends greatly on the aid afforded nature, and the stated results of the countries are supposed to arise from similar management.

Climate not being alike congenial to all plants and animals, the results of the farm will be affected in quantity and quality by the machinery which is employed and the care bestowed on it. It is almost unnecessary to illustrate this position. The north of Scotland yields finer oats than the south of England, but falls far short in the growth of wheat. The wheat of Lower Canada is inferior to the wheat of the upper province, and the growth of Illinois is sujerior to the wheat of Upper Canada. Lower Canada does not produce autumn sown wheat, and I Pper Canala is not, like Illinois, congenial to the growth of Indian corn, the "meal, meadow, and manure" of the farm. Taking into consideration the winters and summers of the countries, the qualities of their wheat, and the importance of Indian corn, the average farming results, combining the quantity and quality of human sustenance, may be stated in Lower C'anada at five, in L'pper Canada at eight, and in llinuis at twelve. This calculation is meant to apply to soil under cultivation, and to embrace the results of nature, capital, and labour.

I formerly assumed the results of nature in American farming to be represented by the number 3. They will, however, necessarily vary with the climate of the different parts of the country and the system of management. pursued. From what has been already stated regarding the agriculture of the Canadas and Illinois, nature's part in the produce arising from cultivation may be stated thus-

Nature in Lower Canada produce will be represented by

- in Upper Canada by

- in Illinois by 
It has already been mentioned, that a person possessing his own land has nature for his servant; and if the estimates of her assistance in the different countries approximate to accuracy, the farmer in Illinois receives from nature double the assistance of the Lower Canada farmer, and upwards of thirty per cent more than the farmer in Upper Canada.

The assistance which farmers in the different countries derive from nature on first settlement is not fully displayed by the numbers two, three, and four. It has formerly been assumed that a person in the Canadas may clear ten acres of forest land in a year, and reap from it a crop of wheat at the end of eighteen months, and that a person in Illinois may reap, in the same time a crop of Indian corn and a crop of wheat from fifty acres. But the stumps of trees in the Canadas will occupy two acres out of the ten, and thereby limit nature's assistance to eight acres. Nature's assistance to the farmer in eighteen months after settlement may be thus expressed:-

In Lower Canada, 8 multiplied by 2 on a wheat crop, 16

In Upper Canada, 8 multiplied by 3 on a wheat crop,

In Illinois, 50 multiplied ly 4 on an Indian corn crop, 200 \}

$$
50 \text { multiplied by } 4 \text { on a wheat crop, } 200\}
$$$$
24
$$

From the preceding statement, the farmer in Illinois receives from nature twenty-five times the assistance of the Lower Canada farmer, and nearly seventeen times the assistance of the farmer in Upper Canada. But if nature's contribution to the advantages which the Illinois settler derives from the prairie be estimated, he may be said to receive from nature thirty, and twenty times the assistance of the farmer in Lower and Upper Canada respectively. It is the assistance which the farmer derives from nature in degree, as well as in extent, which gives the prairies of Illinois such advantages over the forests of Canada.

The British emigrant reaches Lower Canada by the river St Lawrence, the navigation of which is closed by ice from November till May. Upper Canada may be reached by the St Lawrence, or by way of New York and the Erie canal. When the emigrant has a delicate family, and is encumbered with heavy luggage, the route by New York is the best, more especially if the place of his destination communicates 
with lakes Erie, St Clair, or Huron. The routes to Illinois are by the St Lawrence and New York, through the western lakes to Chicago on lake Michigan, or by New York and the canal communicating with the river Ohio and lake lisie. Illinois may also be reached by way of New York, Philadelphia, and from thence to Wheeling on the Ohio, or by way of Baltimore and Wheeling. But the most economical way for a family and luggage to proceed is by way of New Orleans and the Mississippi, navigation seldom being interrupted by this route, and steamboats leaving New Orleans every two or three days for the town of St Louis and the Ohio.

The expense of the best cabin passage from Liverpoul to New Orleans, including bedding and wine, is from L.30 to L.35 sterling, and the passage from New Orleans to St Louis, L.5, 6s. A steerage passage from Liverpool to New Orleans is from I.4 to I..5, exclusive of bedding and pryvisions, and from New Orleans to St Louis, L.1, 14s.

'The agricultural implements of Britain are ill adapted for the forest settler; and as a general rule, the implements of the country are suitable for what is required of them. Cotton goods are nearly as cheap in the United States as in Britain, but woollens are higher.

The household furniture of Britain is unsuitable for agricultural emigrants. Cooking apparatus adapted for the country can be had every where. Crockery, glass, and hardware may be taken, and bedding materials, with exception of feathers.

THE END. 



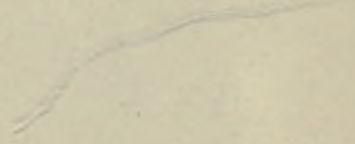




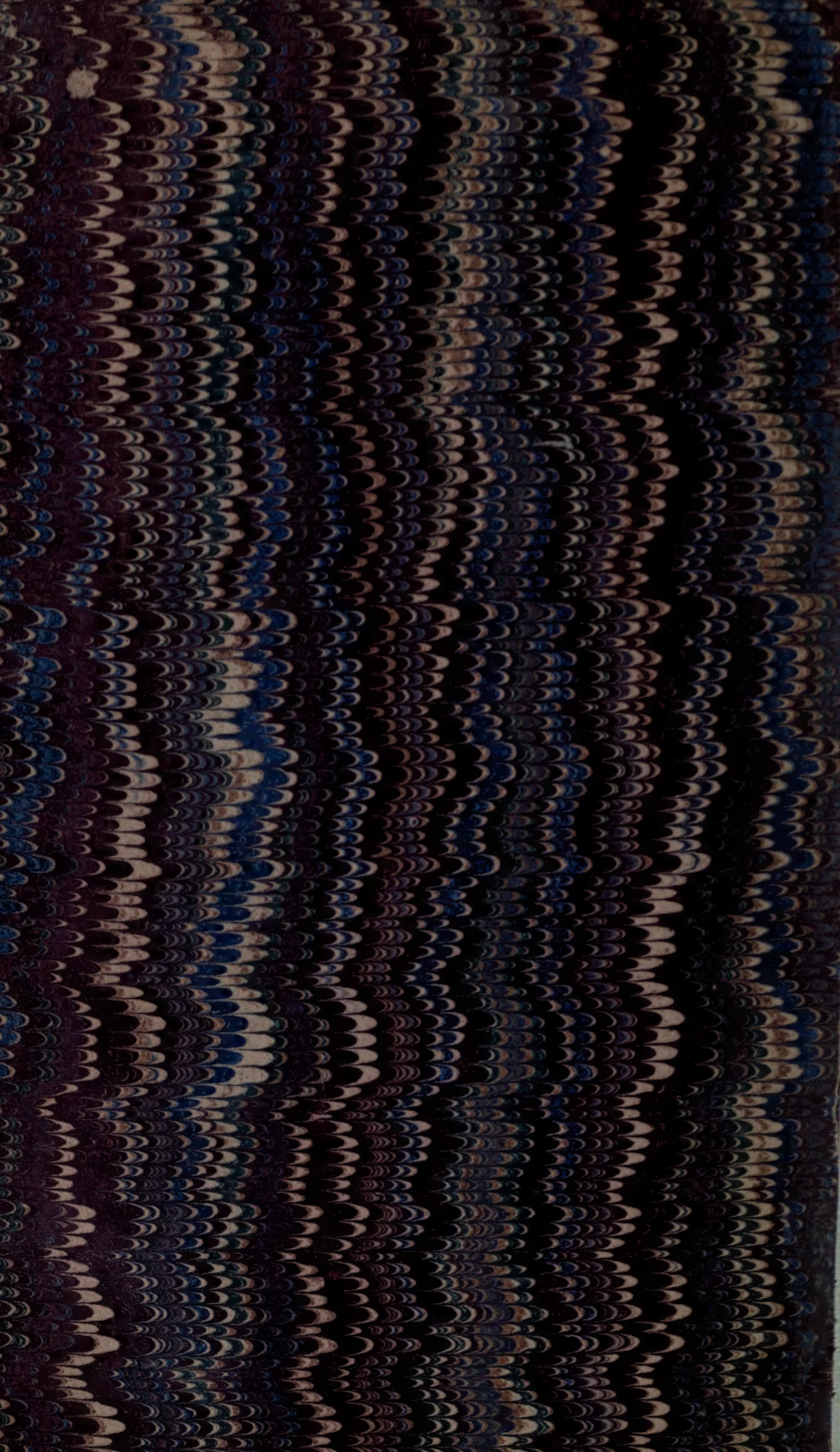


